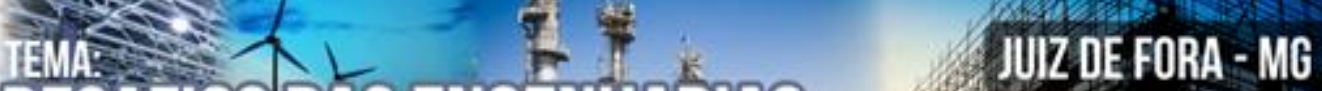

\section{Trabalhos Científicos}

\section{TEMA IX - GESTÃO AMBIENTAL E SUSTENTABILIDADE \\ Total: 29 trabalhos}

\begin{tabular}{|c|c|}
\hline IX-034 & $\begin{array}{l}\text { Análise de potencialidades para produção de energia renovável na região norte do estado do rio de janeiro } \\
\text { Wallan Azevedo dos Santos } \\
\text { Milton Erthal Junior } \\
\text { Luiz Fernando Rosa Mendes } \\
\text { Fábio Barbosa Batista } \\
\text { Hevilmar Carneiro Rangel }\end{array}$ \\
\hline IX-033 & $\begin{array}{l}\text { Garrafas em PET e Vidro: um estudo bibliográfico e comparativo de suas propriedades e características relacionadas à } \\
\text { produção e consumo sustentável } \\
\text { Ana Luiza Cordeiro Pereira } \\
\text { Thainá Alves de Melo Ferreira } \\
\text { Ana Flávia Faria Paiva } \\
\text { Camila Gonçalves Castro }\end{array}$ \\
\hline IX-032 & $\begin{array}{l}\text { Aplicação de Engenharia de Produção - Sociedade Beneficente Mão Amiga - Juiz de Fora } \\
\text { CLEULLER CAMILO DA COSTA VIEIRA SILVA } \\
\text { Larissa Christina Vale de Paiva }\end{array}$ \\
\hline IX-031 & $\begin{array}{l}\text { Avaliação da matriz elétrica da região Norte Fluminense por meio estimativa do índice de renovabilidade } \\
\text { Wallan Azevedo dos Santos } \\
\text { Milton Erthal Junior }\end{array}$ \\
\hline IX-029 & $\begin{array}{l}\text { Compras públicas e governo eletrônico: um estudo bibliométrico com foco na sustentabilidade } \\
\text { Fernando Cerutti Aguiar } \\
\text { Cláudio Luiz Melo de Souza } \\
\text { Milton Erthal Junior }\end{array}$ \\
\hline IX-028 & $\begin{array}{l}\text { Utilização de Resíduos de Serragem de Jequitibá Rosa para a Produção de Briquetes } \\
\text { Beatriz Cristina Ferreira Machado } \\
\text { Matheus Hernesto Mendes Alves } \\
\text { Rodolfo de Souza Cunha } \\
\text { Tiago Bittencourt Nazaré }\end{array}$ \\
\hline IX-027 & $\begin{array}{l}\text { Vantagens da implementação da energia solar em uma escola de pequeno porte na cidade de Maripá de Minas } \\
\text { Híngred Ferraz Pereira } \\
\text { Daniela Fonseca Costa } \\
\text { José Carlos Miranda Grizendi }\end{array}$ \\
\hline IX-026 & $\begin{array}{l}\text { Análise de estabilidade transitória em uma unidade de geração com inserção de sistemas SMES } \\
\text { Vanessa Carla Silva Melo } \\
\text { Clara Bustamante Fonseca Barbosa } \\
\text { Marlon José do Carmo }\end{array}$ \\
\hline IX-025 & $\begin{array}{l}\text { Fontes Renováveis de Energia Elétrica e Impactos Ambientais: Uma Revisão Bibliográfica } \\
\text { Vander Luiz da Silva } \\
\text { Jaqueline de Matos Silva }\end{array}$ \\
\hline IX-024 & $\begin{array}{l}\text { Análise da Utilização do SGA na Eficácia de Auditorias Ambientais } \\
\text { Beatriz Cristina Ferreira Machado } \\
\text { Josiane Aparecida Cardoso de Souza } \\
\text { Bruno Carlos Alves Pinheiro } \\
\text { Tiago Bittencourt Nazaré }\end{array}$ \\
\hline IX-022 & $\begin{array}{l}\text { Estudo de caso em uma associação de coleta de resíduos sólidos } \\
\text { Adna Amorim dos Santos } \\
\text { Lucas Marcos Silva Queiroz } \\
\text { Lo-Ruana Karen Amorim Freire Sanjulião } \\
\text { Thales Volpe Rodrigues } \\
\text { Carlos Henrique Fagundes }\end{array}$ \\
\hline IX-021 & $\begin{array}{l}\text { Administração Pública voltada à Gestão Ambiental: uma revisão da legislação brasileira } \\
\text { Samanta de Lima Alonso } \\
\text { Fernando Queiroz de Lira Alexandrino } \\
\text { José Artur Moraes Vieira } \\
\text { Renan André Barbosa dos Santos } \\
\text { Luiz Alfredo Evelyn Simas }\end{array}$ \\
\hline IX-019 & $\begin{array}{l}\text { Bairros Sustentáveis } \\
\text { Sávio Amaral Avidago }\end{array}$ \\
\hline
\end{tabular}




\begin{tabular}{|c|c|}
\hline & $\begin{array}{l}\text { Rafaela Nunes } \\
\text { Carlos Augusto Ramos dos Reis } \\
\text { Livia Souza de Oliveira } \\
\text { Paulo Roberto Mendes da Silva }\end{array}$ \\
\hline IX-018 & $\begin{array}{l}\text { A análise da colaboração dos usuários com descarte responsável de móveis usados } \\
\text { Brigitte Rodriguez Castaneda } \\
\text { Carlos Eduardo Gavilán } \\
\text { Cristian Xavier Cruzado Alvarez } \\
\text { PAULO SERGIO PEREIRA SALCEDO } \\
\text { Victor Zavaleta Rodriguez }\end{array}$ \\
\hline IX-017 & $\begin{array}{l}\text { Pavimentos permeáveis } \\
\text { Rafael de Moura } \\
\text {-Iorrana Vasconcelos Coimbra } \\
\text { Israel lasbik } \\
\text { Iracema Mauro Batista } \\
\text { José Damato Neto }\end{array}$ \\
\hline IX-016 & $\begin{array}{l}\text { Iluminação em pátios ferroviários: Um estudo de caso sobre redução de consumo de energia elétrica } \\
\text { Jussara Fernandes Leite } \\
\text { Luciano José Vieira Franco } \\
\text { Alexandre Horta Tourinho } \\
\text { Bruno Dias Moreno }\end{array}$ \\
\hline IX-015 & $\begin{array}{l}\text { Comparativo entre processos de produção de carvão } \\
\text { Gilvan Dos Santos Gaudereto } \\
\text { Luara Ferreira Alves } \\
\text { William José Lopes } \\
\text { Liliane Souza Oliveira Moni } \\
\text { EriKa Maria Carvalho Silva Gravina }\end{array}$ \\
\hline IX-014 & $\begin{array}{l}\text { CONSTRUÇÕES SUSTENTÁVEIS } \\
\text { Mateus Oliveira Costa } \\
\text { Mirella Gomes de Lima Andrade } \\
\text { Alexandre Siqueira de Silva } \\
\text { Eunice Singulane }\end{array}$ \\
\hline IX-013 & $\begin{array}{l}\text { Resíduos da Construção Civil } \\
\text { Larissa Do Santos Ferrari } \\
\text { Luara Ferreira Alves } \\
\text { Liliane Souza Oliveira Moni } \\
\text { William José Lopes } \\
\text { EriKa Maria Carvalho Silva Gravina }\end{array}$ \\
\hline IX-011 & $\begin{array}{l}\text { A IMPORTÂNCIA DO REÚSO DE ÁGUAS CINZAS PARA FINS RESIDENCIAIS } \\
\text { Diogo Roman } \\
\text { Mirella Gomes de Lima Andrade } \\
\text { Alexandre Siqueira de Silva } \\
\text { Eunice Singulane }\end{array}$ \\
\hline IX-010 & $\begin{array}{l}\text { Tecnologia de Bioprocessamento aplicada à Gestão de Resíduos em Agroindustriais: Um Estudo Teórico } \\
\text { Vitor Hugo dos Santos Filho } \\
\text { Vander Luiz da Silva } \\
\text { Maria Helene Giovanetti Canteri }\end{array}$ \\
\hline IX-009 & $\begin{array}{l}\text { Análise comparativa de viabialidade ambiental e econômica de três métodos de contenção em encostas em uma área } \\
\text { situada no munícipio de Pará de Minas/MG } \\
\text { Leonardo Gonçalves Almeida } \\
\text { ULISSES DOMINGOS PEREIRA JUNIOR } \\
\text { Deny Figueiredo Alves } \\
\text { Lázaro César Rita } \\
\text { Jocilene Ferreira da Costa }\end{array}$ \\
\hline IX-007 & $\begin{array}{l}\text { Logística Reversa e Reciclagem de pilhas e baterias no Brasil: geração de vantagem competitiva baseada no estudo de } \\
\text { caso de uma indústria metalúrgica } \\
\text { Caroline Brasileiro Pena } \\
\text { Aleson Lameck Pinheiro } \\
\text { Júlia Moreira Santos Teixeira } \\
\text { Taynara Polyanna Rocha Costa }\end{array}$ \\
\hline
\end{tabular}




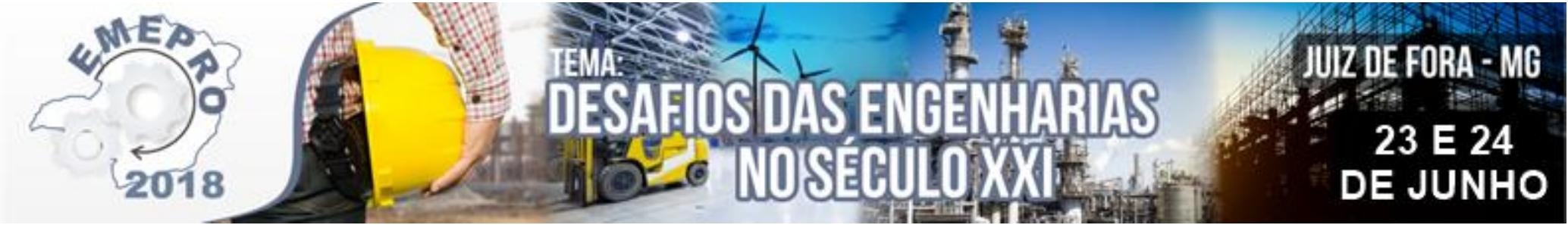

\begin{tabular}{|c|c|}
\hline IX-006 & $\begin{array}{l}\text { Produção Mais Limpa como vantagem competitiva: estudo de caso em uma indústria de meias } \\
\text { Caroline Brasileiro Pena } \\
\text { Aleson Lameck Pinheiro } \\
\text { Taynara Polyanna Rocha Costa } \\
\text { Júlia Moreira Santos Teixeira }\end{array}$ \\
\hline IX-005 & $\begin{array}{l}\text { Aquecedores Solares: alternativa para redução do consumo de energia elétrica } \\
\text { Eliziane Medeiros Santos } \\
\text { Jéssica de Almeida Rocha }\end{array}$ \\
\hline IX-004 & $\begin{array}{l}\text { A tecnologia LED e sua economia energética } \\
\text { Eliziane Medeiros Santos } \\
\text { Jéssica de Almeida Rocha }\end{array}$ \\
\hline IX-003 & $\begin{array}{l}\text { Biomassa: alternativa eficaz de produção e distribuição de energia } \\
\text { Eliziane Medeiros Santos } \\
\text { Jéssica de Almeida Rocha }\end{array}$ \\
\hline IX-002 & $\begin{array}{l}\text { Impactos econômicos e ambientais da substituição de lâmpadas fluorescentes por lâmpadas de LED em uma instituição } \\
\text { de ensino } \\
\text { RAFAEL RODRIGUES BENELLI } \\
\text { RENATA RODRIGUES TEIXEIRA } \\
\text { Lucas Scavariello Franciscato } \\
\text { Vanessa Moraes Rocha De Munno }\end{array}$ \\
\hline IX-001 & $\begin{array}{l}\text { Materiais de construção: seus impactos ambientais } \\
\text { Eliziane Medeiros Santos } \\
\text { Jéssica de Almeida Rocha }\end{array}$ \\
\hline
\end{tabular}




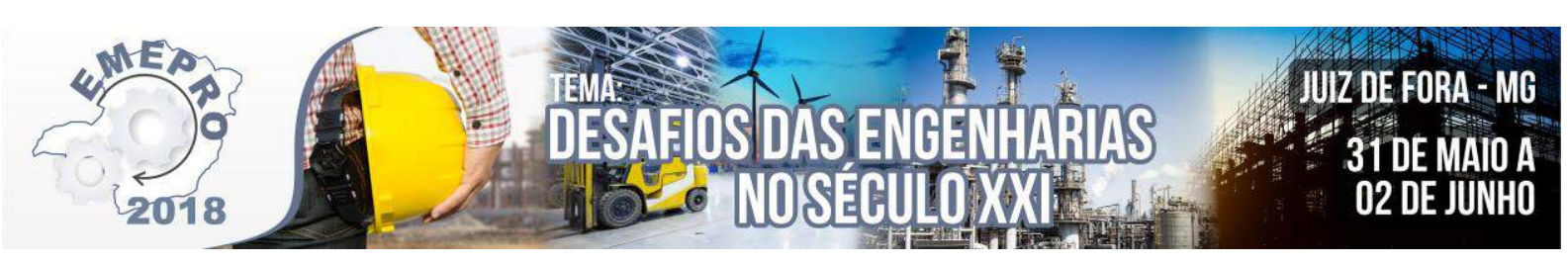

\title{
Análise de potencialidades para produção de energia renovável na região norte do estado do rio de janeiro
}

\author{
Wallan Azevedo dos Santos (IFFluminense) wallan.azevedo@hotmail.com \\ Milton Erthal Junior (IFFluminense/UCAM) miltonerthal@hotmail.com \\ Luiz Fernando Rosa Mendes (IFFluminense) lfmendes@iff.edu.br \\ Fábio Barbosa Batista (UNIG) fbarbosa@unig.com.br \\ Hevilmar Carneiro Rangel (IFFluminense) hcrangel@gmail.com
}

\begin{abstract}
Resumo: Neste trabalho foi realizado um estudo das principais fontes de geração de eletricidade, considerando as matrizes da geração de eletricidade no Brasil, no Estado do Rio de Janeiro, em especial a região Norte Fluminense (NF). Para tanto, se buscou fazer um levantamento das potencialidades de aproveitamento de fontes renováveis de geração de energia elétrica na região NF para o ano de 2017, a partir da aplicação de um questionário destinado a especialistas da área de energia. Na análise foram considerados os seguintes tipos de geração de eletricidade: Hidrelétricas, Biomassa, Eólica, Fotovoltaica e Híbrida (Eólica+Fotovoltaica). Como resultado, verificou-se que as características naturais da região possibilitam um alto potencial de aproveitamento de fontes renováveis. Dentre essas características destacaram-se a presença de diversos rios, alto nível de insolação, longa extensão de costa marítima com potencial para uso de energia eólica, elevada produção de biomassa, sendo esta principalmente devido aos resíduos produzidos pela produção de açúcar na região, que gera uma grande quantidade de bagaço de cana-de-açúcar. A cogeração é apresentada como uma solução de geração distribuída de energia bastante atrativa para região. Essa pesquisa permitiu por meio dos questionários, conhecer a visão de especialistas do setor energético quanto ao aproveitamento de fontes alternativas de energia no NF, podendo servir de subsídio para novos estudos que permitam avaliar mais detalhadamente a aplicação dos recursos naturais renováveis para geração de eletricidade na região.
\end{abstract}

Palavras-chave: Fontes renováveis; Matriz elétrica; Sustentabilidade.

\section{Introdução}

O uso de energia elétrica está presente em todos os setores da sociedade, desde a moradia, saúde, transporte, economia, passando pelo trabalho, com implicações ao meio ambiente e influenciando nas relações internacionais (HINRICHS et al.,2010). O consumo de energia está relacionado com a evolução tecnológica. Isso pode ser constatado com uma análise da Revolução Industrial, quando houve um acentuado incremento na utilização de recursos naturais energéticos, principalmente os combustíveis fósseis, inicialmente o carvão mineral e em seguida o petróleo (HOFFMANN, 1998; SANTOS et al., 2017).

Este fato associa o setor energético a responsabilidade pelas altas taxas de emissões de poluentes na atmosfera, colocando em risco a sustentabilidade deste setor (GOLDEMBERG; LUCON, 2007). Assim, as fontes de energias renováveis para geração de eletricidade são componentes fundamentais para o desenvolvimento sustentável dos países, contribuindo para 


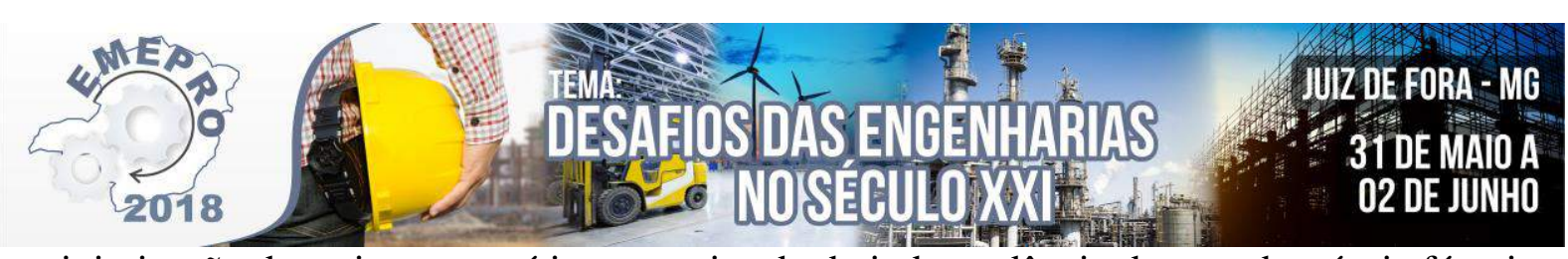

a minimização das crises energéticas em virtude da independência dos combustíveis fósseis e da melhoria da utilização dos recursos naturais (BALTA; DERVOS, 2012).

O estado do Rio de Janeiro é o principal produtor de petróleo e gás natural do Brasil, responsável por $66 \%$ da produção nacional, desempenhando um importante papel na economia e desenvolvimento do país. Além disso, é o terceiro estado que mais contribui com a geração de energia elétrica no país (cerca de 10\%), ficando atrás apenas do estado de São Paulo $(12,67 \%)$ e Paraná $(18,98 \%)$. O estado apresenta caracteristicas naturais favoraceis ao desenvolvimento de tecnologias para aproveitamento de fontes renováveis como a energia fotovoltaica, eólica e biomassa. Entretanto, o estado apresenta um índice de renovabilidade de apenas $15,08 \%$. Uma das regiões do estado do Rio que merece um olhar mais atento é a Mesorregião do Norte Fluminense (NF), seja devido às características climáticas da região vinculado ao alto potencial renovável ou à sua importância econômica, social, cultural e ambiental que esta região desempenha no estado. Entretanto, o NF apresenta uma depêndencia de combustíveis fósseis, como o gás natural, que compoe um pouco mais de $90 \%$ de sua matriz elétrica. (ERTHAL; MENDES, 2015).

Desse modo, este estudo se propõe realizar uma avaliação das potencialidades e viabilidades para aproveitamento dos potenciais de geração de energia elétrica por meio de fontes renováveis na região NF do Estado do Rio de Janeiro para o ano de 2017. A metodologia deste trabalho foi baseada na aplicação de um questionário à especialistas do setor de energia, que atuam na região, com a finalidade de efetuar uma avaliação destas potencialidades. Dentre as energias disponíveis e abundantes na região, serão consideradas as energias renováveis, mais adaptáveis às características geográficas da região, sendo estas: hidrelétricas, eólica, fotovoltaica, biomassa e híbrida (eólica e fotovoltaica).

O trabalho é constituído das seguintes etapas: pesquisa exploratória dos artigos, livros e documentos técnicos; elaboração e aplicação de questionário e tratamento dos dados obtidos. Com base em artigos e livros da área de energia foi possível elaborar a revisão de literatura deste artigo e estabelecer as vantagens e desvantagens das principais fontes geradoras de energia elétrica localizadas no Estado do Rio de Janeiro.

\section{Revisão da literatura}

Essa seção descreveu uma breve explicação sobre os tipos de energias renováveis estudados nesse trabalho baseada em Relatórios de Órgãos Públicos do setor energético e em artigos publicados nas bases científicas Scopus, Science Direct e Scielo.

\subsection{Hidrelétricas}

No Estado do Rio de Janeiro, esse potencial hidrelétrico concentra-se na bacia hidrográfica do rio Paraíba do Sul. De acordo com Tolmasquim (2012), dentre todas as formas de geração de eletricidade, a hidráulica é a única que reúne simultaneamente quatro atributos absolutamente relevantes: é renovável; praticamente não emite gases de efeito estufa; é extremamente competitiva; e, no caso do Brasil, a construção das usinas pode ser feita praticamente com $100 \%$ de fornecimento e serviços nacionais, o que significa geração de emprego e renda no país.

A geração de hidroeletricidade apresenta baixo custo de operação (menor custo entre as demais fontes de energia), promove o armazenamento de água doce facilmente explorada e contribui para a estabilidade do sistema elétrico como um todo. Por outro lado, requer alto custo de implementação, gera fortes impactos socioambientais durante sua para sua construção e pode ser influenciada por aspectos climáticos (CORRÊA DA SILVA et. al, 


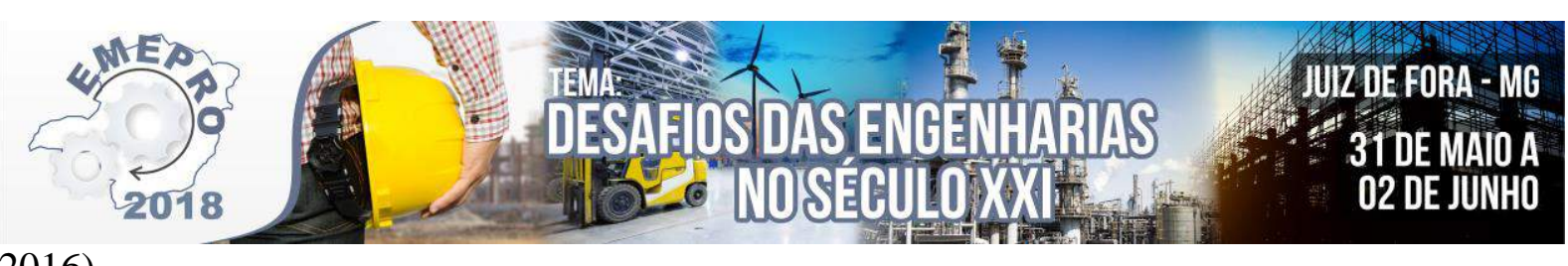

2016).

A questão de sua contribuição nas emissões dos Gases de Efeito Estufa - GEEs é contraditória, pois se por um lado emite pouco $\mathrm{CO}_{2}$ durante sua operação, acaba emitindo $\mathrm{CH}_{4}$ nos lagos gerados pelo represamento. A emissão de $\mathrm{CH}_{4}$ pode ser minimizada nas usinas a fio d’água, que utilizam pouco, ou quase nenhum alagamento.

Devido a ciclos climáticos com intensos períodos de estiagem por alguns anos, os níveis dos reservatórios diminuíram drasticamente, prejudicando a capacidade de geração nos anos de 2013 a 2016. Isto causou um aumento na necessidade de diversificação da matriz elétrica prevista no planejamento do setor elétrico a fim de se assegurar seu abastecimento (ANEEL, 2016).

\subsection{Biomassa - Cogeração}

Segundo a ANEEL (2008), a biomassa é qualquer matéria orgânica que possa ser transformada em energia mecânica, térmica ou elétrica, podendo ser de origem: florestal, agrícola, rejeitos urbanos e industriais. É considerada uma das fontes de energia com maior potencial de crescimento para os próximos anos, se tornando uma das principais alternativas para a diversificação da matriz energética diante da necessidade em diminuir a utilização de combustíveis fósseis.

De acordo com Goldemberg; Lucon (2008), as formas mais comuns de se produzir de eletricidade a partir da biomassa são: rejeitos agrícolas, cogeração com bagaço de cana-deaçúcar, "fazendas" energéticas (capim elefante), incineração de lixo urbano, biogás de esgotos domésticos, biogás de efluentes industriais e biogás de aterro sanitário.

No Brasil a cogeração é frequente nas usinas de açúcar e álcool com a queima do bagaço da cana-de-açúcar. A biomassa proveniente do bagaço da cana-de-açúcar apresenta um enorme potencial de geração de eletricidade. No estado do Rio de Janeiro esta produção está concentrada na região NF (BALANÇO ENERGETICO RJ, 2014).

A cogeração de biomassa em sistemas baseados em bagaço de cana-de-açúcar pode proporcionar diversos benefícios ao meio ambiente e ao setor energético, podendo ser utilizada de forma complementar na rede convencional de geração de energia elétrica, diminuindo assim a utilização de combustíveis fósseis e contribuindo efetivamente em períodos de seca, já que os reservatórios de água tendem a diminuir drasticamente.

\subsection{Energia eólica}

O Brasil possui um dos maiores potenciais eólicos do mundo, que excede em três vezes as necessidades atuais de eletricidade no país (GWEC, 2016). O território brasileiro possui uma vantagem em termos de ventos, caracterizado por uma presença duas vezes superior à média mundial e pela volatilidade de 5\% (oscilação da velocidade), o que dá maior previsibilidade ao volume a ser produzido. A velocidade costuma ser maior em períodos de estiagem, possibilitando operar as usinas eólicas em sistema complementar com as usinas hidrelétricas, de forma a preservar a água dos reservatórios em períodos de poucas chuvas (ANEEL, 2008).

A geração eólica caracteriza-se principalmente por não emitir Gases de Efeito estufa GEEs, para atmosfera, descartar a dependência de utilização de combustíveis fósseis, além de apresentar alta modularidade, baixo custo de operação e contribuir com a economia local. Por outro lado, depende das condições meteorológicas da região, requer alto custo de 


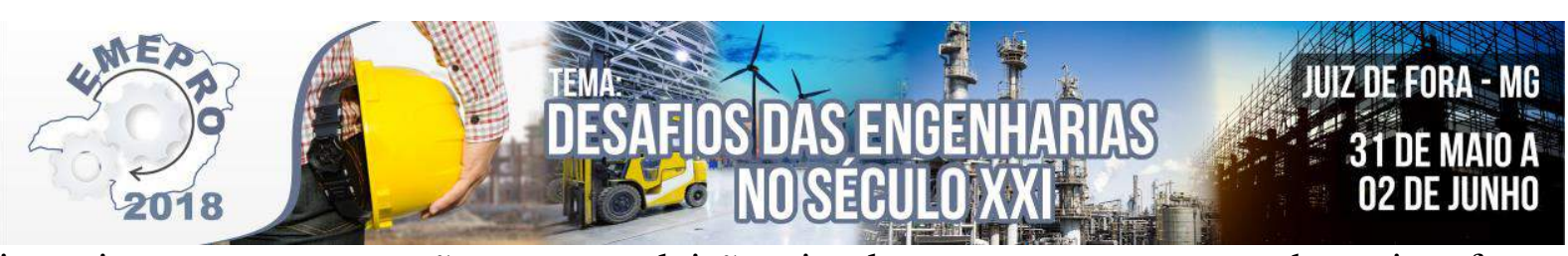

investimento e manutenção, causa poluição visual e sonora, os aerogeradores interferem negativamente no habitat de pássaros e animais voadores, além de possíveis interferências eletromagnéticas podem atrapalhar os meios de comunicação na região de instalação.

As regiões com ventos médios anuais mais intensos situam-se no litoral NF, principalmente nos municípios de São Francisco de Itabapoana, São João da Barra e Campos dos Goytacazes. Essa região apresenta alto potencial de aproveitamento eólico, com velocidades médias anuais de $6,5 \mathrm{~m} / \mathrm{s}$. Essa região possui uma extensa planície costeira de baixa rugosidade e intensos regimes de vento na maior parte do ano (a $50 \mathrm{~m}$ de altura) (CRESESB, 2002). Apesar do alto potencial apresentado, esse tipo de energia ainda é muito pouco explorado na região. Atualmente, há somente uma usina eólica implantada no NF, localizada em Gargaú no munícipio de São Francisco de Itabapoana, a Central de Geração Eólica de Gargaú (CGE Gargaú) com uma capacidade instalada de 28,1 MW.

\subsection{Geração Fotovoltaica (FV)}

O país possui um grande potencial para gerar eletricidade a partir da energia solar. Segundo o Atlas Brasileiro de Energia Solar (2006), diariamente incide entre $4.500 \mathrm{Wh} / \mathrm{m} 2$ a $6.300 \mathrm{Wh} / \mathrm{m} 2$ de radiação solar no Brasil, mostrando que esta fonte é favorável para produção de energia elétrica, ainda que este recurso represente menos do que $0,1 \%$ da Matriz Energética Brasileira. (PINTO; AMARAL; JANISSEK, 2016).

No Brasil, a Região Sudeste é a região dentre as demais regiões que apresenta o maior potencial solar. No estado do Rio de Janeiro, a região NF, parte da Região dos Lagos e o litoral Sul do estado são as áreas com o maior potencial para produção de energia solar fotovoltaica. A radiação solar nessa região é superior à verificada na Alemanha - um dos países que lideram a expansão da energia solar fotovoltaica no planeta. No NF a incidência da radiação solar varia entre 4,1 e 5 quilowatts-hora/metro quadrado por dia (AMÉRICA DO SOL, 2016).

Apesar de não possuir usinas fotovoltaicas de grande porte no estado do Rio de Janeiro, constata-se que a participação de 461 unidades consumidoras com geração distribuída fotovoltaica, correspondendo a uma potência total de $2.489,41 \mathrm{~kW}, 8,51 \%$ da potência fotovoltaica nacional. A energia solar fotovoltaica poderia ser integrada de forma complementar na matriz energética, já que sua introdução deste tipo de geração e contribuiria para a redução das perdas com transmissão e aproximando a relação entre geração e consumo.

Além disso, o território nacional possui uma das maiores reservas de silício do mundo, tornando- se um local privilegiado para se desenvolver indústrias locais de produção de células solares (AMÉRICA DO SOL, 2016).

De acordo com a Resolução Normativa ANEEL n ${ }^{\circ} 482 / 2012$, o consumidor brasileiro pode gerar sua própria energia elétrica a partir de fontes renováveis ou cogeração qualificada e possibilita ainda fornecer o excedente para a rede de distribuição de sua localidade, aliando assim a economia financeira, consciência socioambiental e autosustentabilidade. A geração distribuída proporciona diversos potenciais benefícios ao sistema elétrico, como o adiamento de investimentos em expansão dos sistemas de transmissão e distribuição, o baixo impacto ambiental, a redução no carregamento das redes, a minimização das perdas e a diversificação da matriz energética (ANEEL, 2016).

Segundo Grossmann et. al (2012), a geração FV para produção de energia elétrica apresenta a maior taxa de crescimento entre as fontes renováveis de energia, sendo inserida nas redes elétricas convencionais em algumas regiões do mundo. A geração FV não gera 


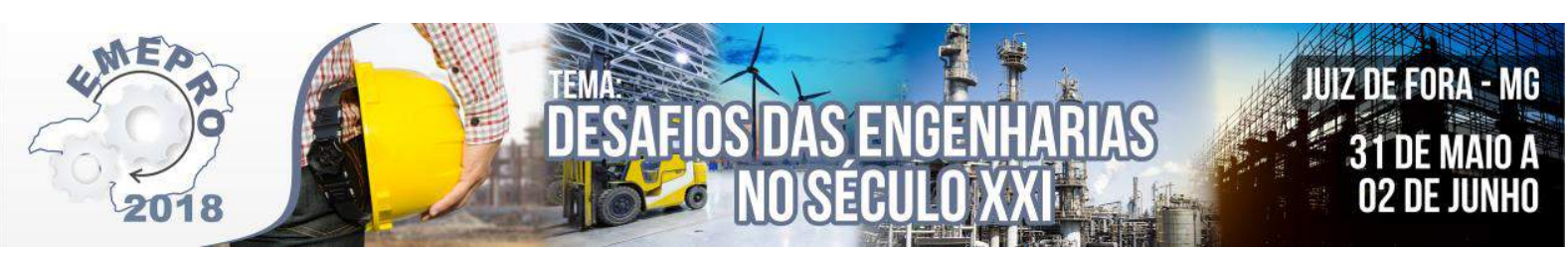

Gases de Efeito Estufa - GEEs em sua operação apresenta baixo custo de operação e manutenção, rápida instalação, elevada vida útil de painéis e modularidade, além de contribuir para universalização do acesso a eletricidade, podendo ser utilizado de forma complementar ou isolada em locais de difícil acesso. Em contrapartida, esse tipo de energia depende fortemente da intensidade de radiação solar, apresenta um alto custo de implantação, necessita de equipamentos auxiliares para gerar e armazenar energia elétrica. Uma das razões desse tipo de energia ainda não ser fortemente explorada no Brasil é devido escassez de mão de obra qualificada para lidar com essa tecnologia.

\subsection{Geração híbrida para produção de energia elétrica: eólico-fotovoltaico}

Um sistema renovável híbrido consiste na utilização diversificada de fontes de energia, incluindo a eólica e a solar, para maximizar a utilização dos recursos naturais de forma sustentável. Esses sistemas são introduzidos como solução alternativa para lidar com as limitações meteorológicas que alguns dos tipos de fontes renováveis apresentam. Sistemas híbridos de energia trazem um maior rendimento e retornos econômicos e ambientais do que sistemas independentes de geração de energia eólica, solar, hídrica e biomassa. A combinação funciona de forma eficiente com a geração de mais energia durante o dia com os painéis solares e coletores aproveitando a radiação solar, e no período noturno com os aerogeradores contribuindo na universalização do serviço de eletricidade em comunidades isoladas. Esse fato é comum de acontecer na região NF no período de inverno, já que, os ventos são mais intensos, assim como no verão quando é atingido o pico de incidência solar (RIBEIRO et $a l ., 2012)$.

\section{Metodologia}

Para avaliar a potencialidade e viabilidade da implantação de energias renováveis na região NF no ano de 2017, foi elaborado e aplicado um questionário (ver Apêndice) à especialistas da área de energia, que atuam na região. Considerando as particularidades da Região Norte-Fluminense, foram consideradas as fontes de energia que mais se adequariam a uma implantação na região, sendo os seguintes tipos: hidrelétrica, biomassa, eólica, fotovoltaica e híbrida (eólica + fotovoltaica).

Quanto aos atributos a serem pesquisados, foram considerados o aproveitamento atual, potencialidade, estabilidade na geração, viabilidade econômica, viabilidade técnica, impactos ambientais e impactos sociais. Para avaliação de cada atributo, foram pontuados os quesitos: muito alto (5), alto (4), médio (3), baixo (2), muito baixo (1) e não quero opinar (0). Para cada tipo de geração foi elaborado um gráfico que demonstrasse os resultados obtidos nas respostas dadas pelos especialistas no questionário. Estes opinaram sobre o aproveitamento do tipo de energia, possibilitando que pudéssemos efetuar uma análise do potencial de aproveitamento das energias renováveis com alto potencial de aproveitamento na região norte do Estado do Rio de Janeiro.

\section{Resultados}

\subsection{Hidrelétrica}

Quanto à pesquisa que efetuamos para avaliar a potencialidade da implantação de sistemas renováveis de geração de energia elétrica na região norte-fluminense do estado do Rio de Janeiro, identificamos os resultados para hidrelétrica apontados no gráfico da Figura 1. 


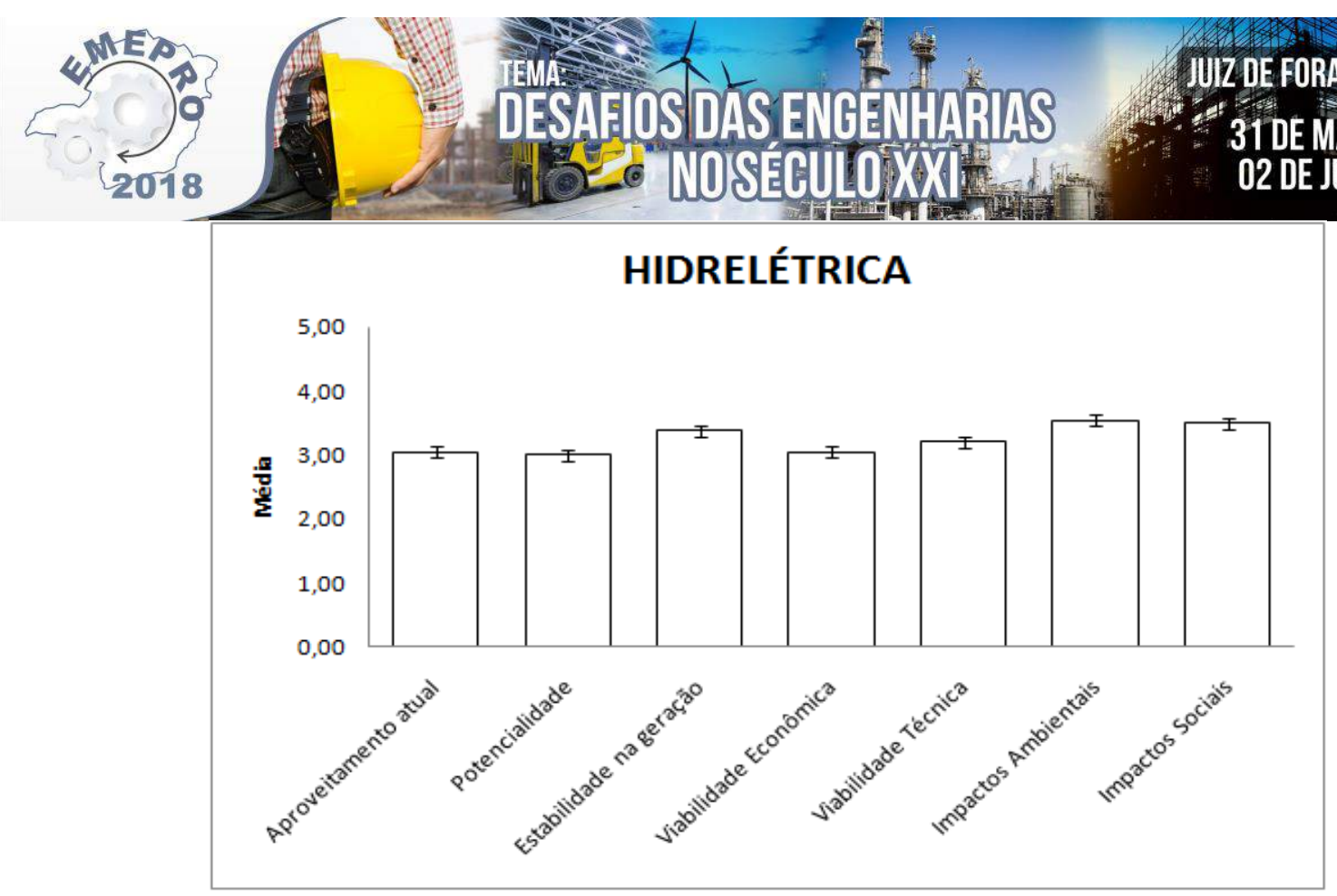

FIGURA 1 - Aproveitamento atual, potencial e os possíveis impactos socioambientais da geração de energia por hidrelétricas na região Norte-Fluminense. Fonte: Autores (2017).

Verifica-se que a amostra apontou que apesar de gerar grandes impactos socioambientais, a hidrelétrica proporciona uma alta estabilidade na geração de energia, alta viabilidade técnica e econômica, mas um médio potencial e aproveitamento.

Considerando que grande parte da região Norte-Fluminense se encontra em uma planície sedimentar, com pequenas quedas d'água em seus rios, o aproveitamento realmente não é muito bom, tendo apenas como alternativa a construção de Pequenas Centrais Hidrelétricas - PCHs, ou geração que aproveite o a energia contida no fluxo hídrico dos rios. Há, portanto, potencialidade de aproveitamento, no entanto, deve-se estudar como fazê-lo, dentro das técnicas possíveis na engenharia.

\subsection{Biomassa}

Na pesquisa efetuada, identificamos através da Figura 2, a opinião dos pesquisados sobre a Biomassa, com o respectivo resultado.

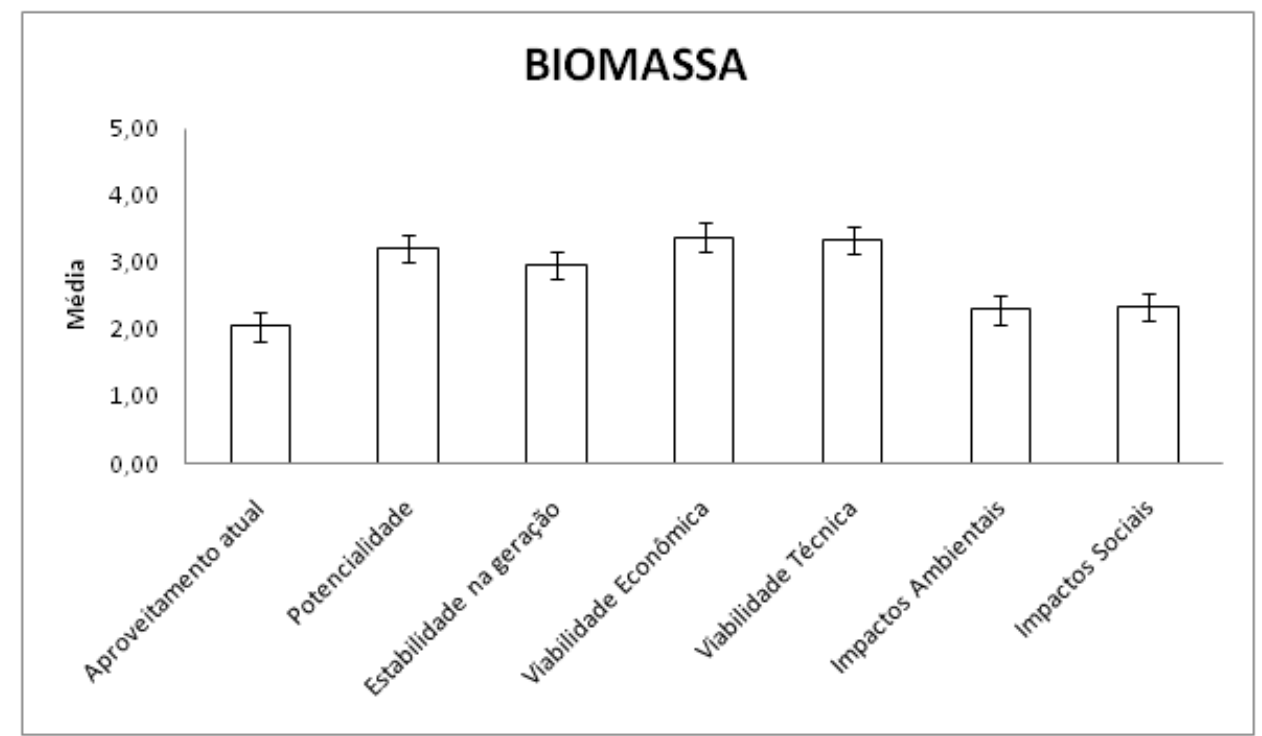

FIGURA 2 - Gráfico de aproveitamento de biomassa para a região Norte-Fluminense. Fonte: Autores (2017). 


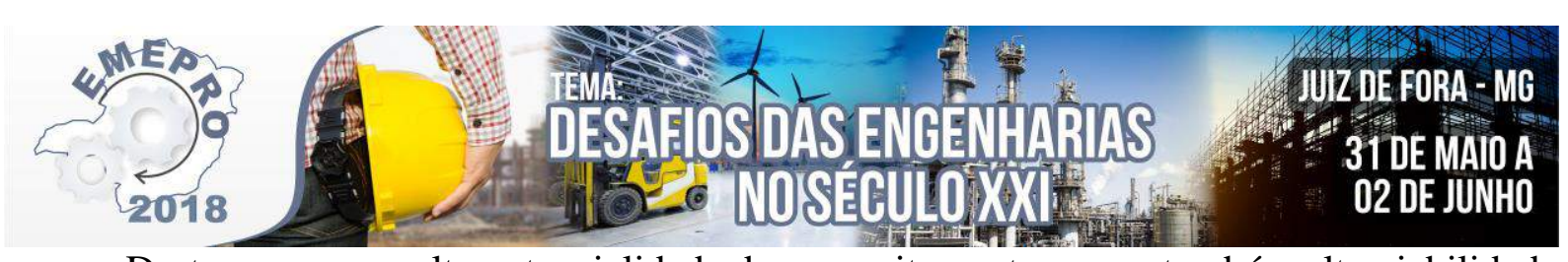

Destaca-se que a alta potencialidade de aproveitamento, como também alta viabilidade econômica e técnica, com mediana estabilidade na geração. Entretanto, é registrado um baixo aproveitamento atual deste tipo de geração na região, ainda que cause baixos impactos ambientais e sociais. Apesar das usinas de açúcar da região serem auto-geradoras a partir do bagaço de cana-de-açúcar, a co-geração é pouco explorada, assim como a utilização de biodigestores que praticamente não existe na região Norte-Fluminense. Este equipamento poderia ser utilizado nos lixões, nas fossas coletivas e nas estações de tratamento de esgoto, o que aproveitaria grande parte dos gases gerados no processo.

\subsection{Eólica}

Já o Gráfico da Figura 3, representa o resultado da pesquisa sobre o aproveitamento da energia eólica na região NF.

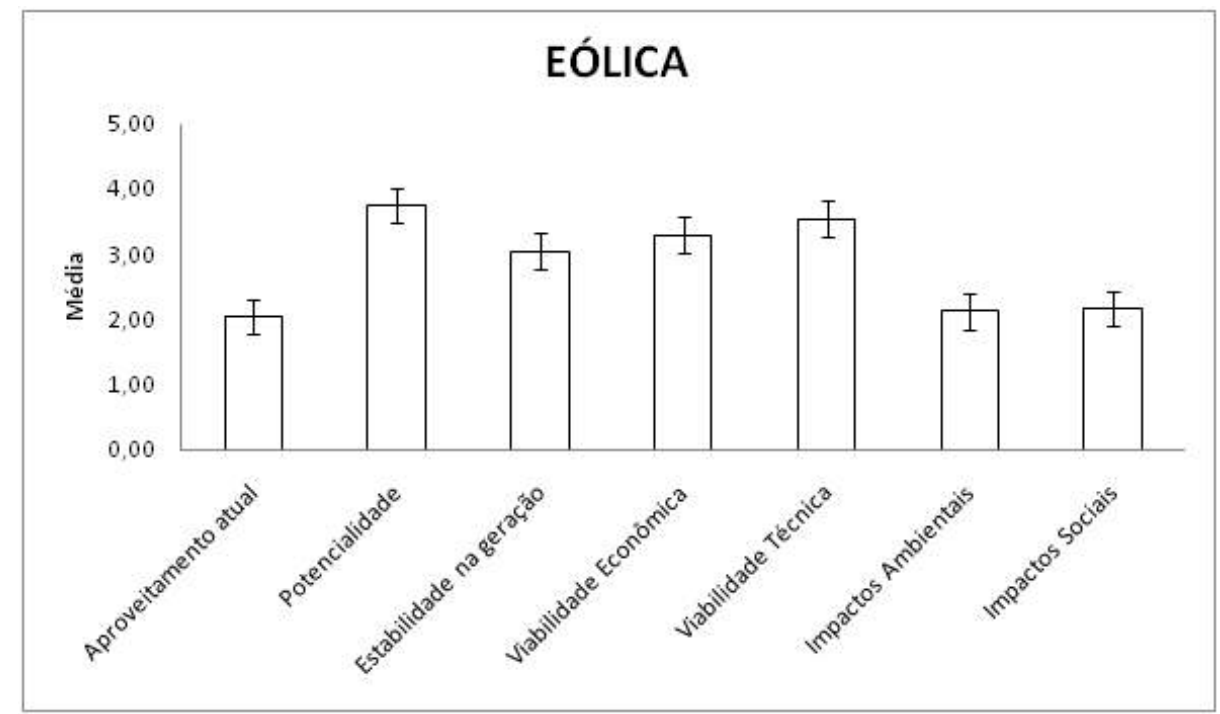

FIGURA 3 - Gráfico de aproveitamento de energia eólica para a região Norte-Fluminense. Fonte: Autores (2017).

Na opinião dos técnicos especializados, a geração eólica tem alta potencialidade, viabilidade técnica e econômica, com menor nível de estabilidade na geração, baixo aproveitamento atual, assim como baixo impactos ambientais e sociais.

Existe instalado na localidade Gargaú, no litoral do município de São Francisco de Itabapoana, um parque eólico. Há um alto potencial eólico que ainda não é explorado na região, que possui uma longa região costeira que vai da praia do Açu até Barrra de Itabapoana, numa extensão de cerca de $100 \mathrm{~km}$, onde poderiam ser instalados outros parques eólicos, assim como o aproveitamento individual em forma de co-geração de energia com a concessionária local. As regiões com ventos médios anuais mais intensos no Estado situam-se no litoral NF, na região dos lagos, Cabo Frio e Búzios, e também na região serrana, polígono Piraí-Vassouras- Petrópolis. O território do litoral NF consiste em uma extensa planície costeira com baixa rugosidade e regimes de vento propícios a aproveitamentos eólicos com velocidades médias anuais em torno de $6,5 \mathrm{~m} / \mathrm{s}$ (a $50 \mathrm{~m}$ de altura) (CRESESB, 2002).

\subsection{Fotovoltaica}

Quanto à pesquisa efetuada, podemos constatar no gráfico da Figura 4, a opinião técnica especializada sobre o aproveitamento da energia fotovoltaica na região nortefluminense. 


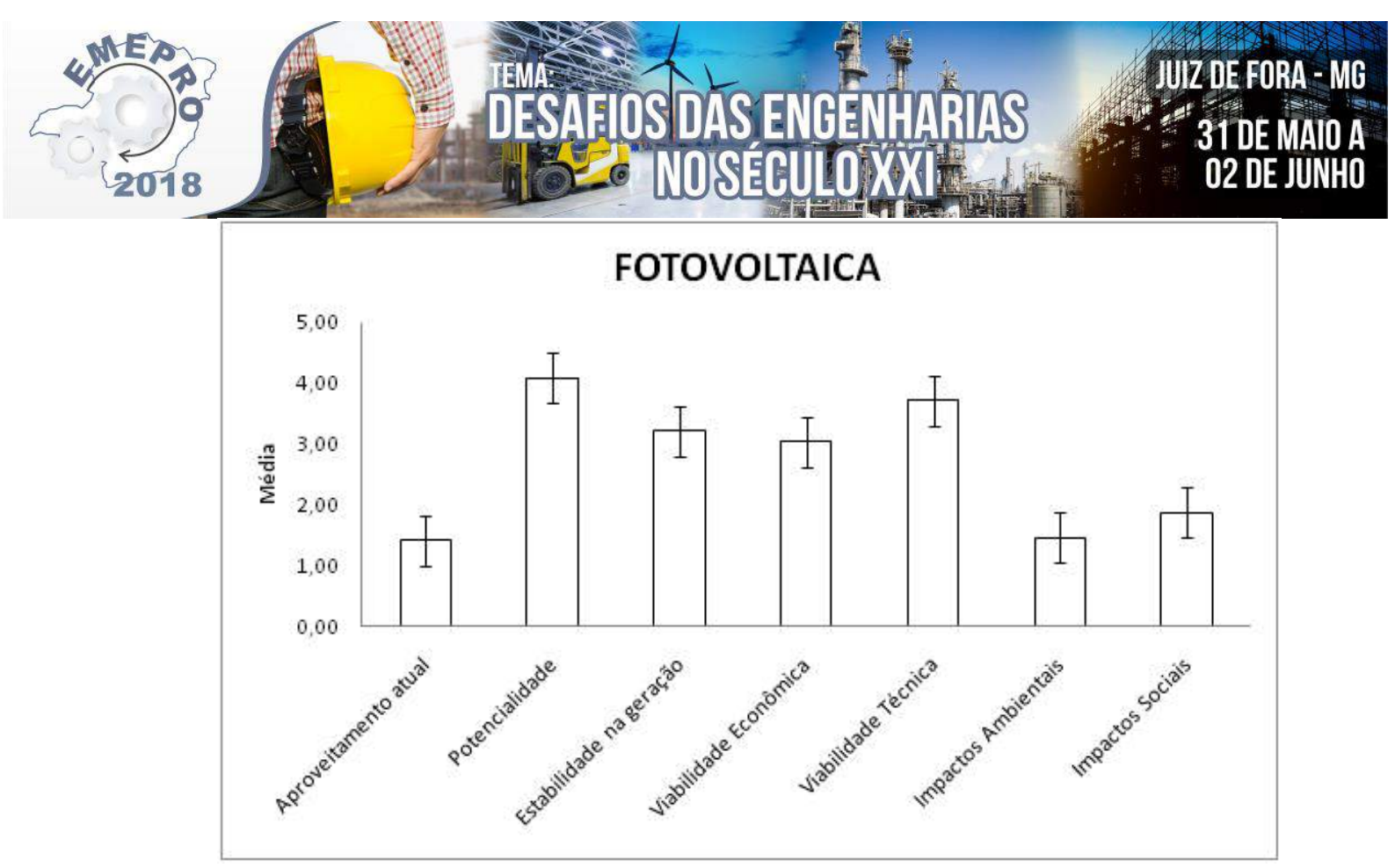

FIGURA 4 - Gráfico de aproveitamento de energia fotovoltaica para a região Norte Fluminense. Fonte: Autores (2017).

Verifica-se que a potencialidade é bastante alta, assim como a viabilidade técnica, com menor estabilidade na geração e viabilidade econômica. No entanto, foi considerado que o aproveitamento atual é muito baixo, assim como os impactos ambientais e sociais. Atualmente, não há registros de uma participação efetiva da energia fotovoltaica na matriz elétrica do estado fluminense. Entretanto, este cenário pode ser alterado, visto que o estado tem buscado desenvolver novas tecnologias que visem o aproveitamento de fontes renováveis de energia, o que pode ser comprovado pela publicação do novo Atlas Solarimétrico do estado do Rio de Janeiro (2016). Conhecer o potencial solar do estado do Rio de Janeiro e em especial da região NF, representa um importante referencial para atrair projetos de usinas fotovoltaicas de grande porte e desenvolver a mini e micro geração de energia fotovoltaica (Rio de Janeiro, 2016).

\subsection{Híbrida (Eólica - Fotovoltaico)}

Quanto à pesquisa, verificou-se o resultado para a geração híbrida é apresentado no gráfico da Figura 5 . 

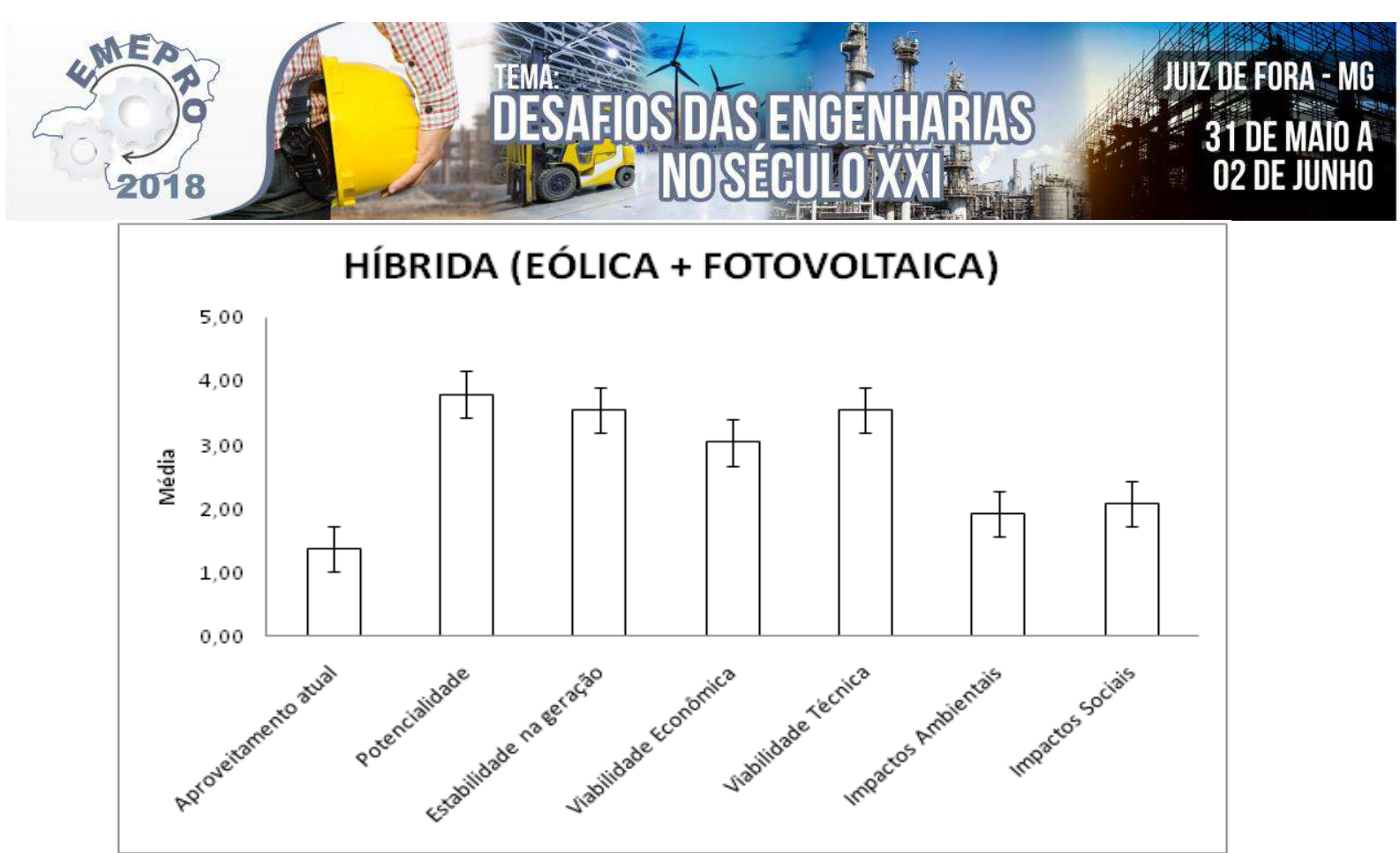

FIGURA 5 - Gráfico de aproveitamento de energia híbrida (eólica + fotovoltaica) para a região Norte Fluminense. Fonte: Autores (2017).

Considerando que a região Norte-Fluminense apresenta alta incidência solar e ventos intensos em maior parte do ano, principalmente em suas regiões litoraneas, esse tipo de geração de energia seria muito interessante para reduzir o consumo de gás natural na sua matriz elétrica. Dessa forma, seria possível mitigar os impactos socioambientais causados pela queima dos combustiveis fósseis com menores custos de consumo final para o consumidor.

\section{Condiderações Finais}

A região NF apresentou condições climáticas favoráveis ao aproveitamento das energias fotovoltaicas e eólicas, visto que as incidências solar e eólica apresentou altos potenciais energéticos em sua extensão territorial, principalmente na região litorânea. Entretanto esses tipos de geração de energia são altamente influenciadas pelas interferências meteorológicas sendo sugerido seu uso em conjunto com outras fontes convencionais. A cogeração é apresentada como uma solução de geração distribuída de energia bastante atrativa e dependendo de incrementos tecnológicos suas fontes de geração poderiam suprir os picos de demanda de energia, contribuindo para a estabilização das redes de distribuição e diminuição das perdas.

Essa pesquisa permitiu por meio dos questionários, conhecer a visão de especialistas do setor energético quanto ao aproveitamento de fontes alternativas de energia no NF, o que evidenciou a possibilidade do aproveitamento desse potencial energético da região. Entretanto, a visão destes merece ser aprofundada quanto às questões econômicas da região junto aos órgãos públicos e privada.

\section{Referências}

AGÊNCIA NACIONAL DE ENERGIA ELÉTRICA. Banco de Informações da Geração (BIG) - Capacidade de Geração do Brasil. $2016 . \quad$ Disponível em: <http://www.aneel.gov.br/aplicacoes/capacidadebrasil/capacidadebrasil.asp>. Acessado em: 02 de dezembro de 2016.

AGÊNCIA NACIONAL DO PETRÓLEO. Dados Técnicos, 2016. Disponível em:<http://www.anp.gov.br/wwwanp/exploracao-e-producao-de-oleo-e-gas/dados tecnicos/acesso-aos-dados- 


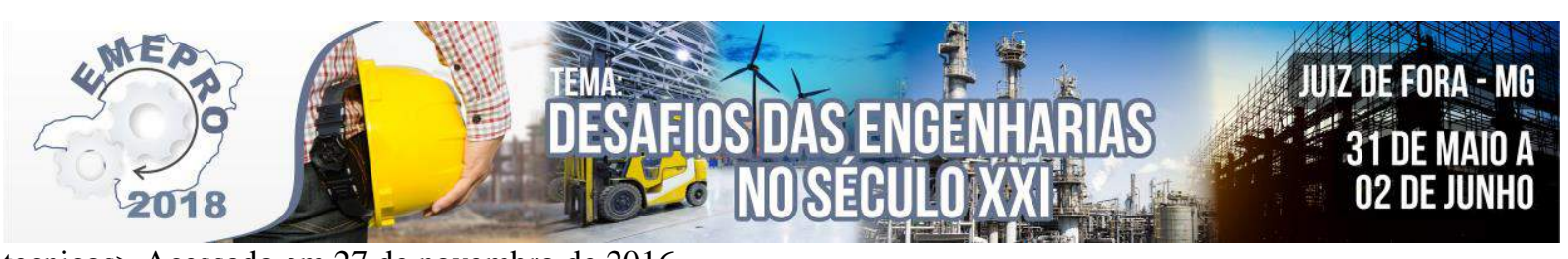

tecnicos>.Acessado em 27 de novembro de 2016.

AMÉRICA DO SOL. Conhecimento em Energia Fotovoltaica, 2016. Disponível em: <http://www.cresesb.cepel.br/publicacoes/download/atlas_eolico/Atlas\%20do\%20Potencial\%20Eolico\%20Brasi leiro.pdf $>$. Acessado em: 01 de dezembro de 2016.

Atlas Rio Solar. Atlas Solarimétrico do Estado do Rio de Janeiro. IEPUC - Instituto de Energia da PUC-Rio. Rio de Janeiro : Ed. PUC-Rio, 2016.

BALTA, A. E.; DERVOS, A. N. Special framework for the spatial planning \& the sustainable development of renewable energy sources. Renewable Energy. Elsevier, 2012. Disponível em: <http://www.sciencedirect.com/science/article/pii/ S0960148112003369>. Acessado em 01 de dezembro de 2016.

BIRESSELIOGLU, M. E.; KARAIBRAHIMOGLU, Y. Z. The government orientation and use of renewable energy: Case of Europe. Journal Renewable Energy. n. 47, p. 29-37, 2012.

CENTRO DE REFERÊNCIA PARA ENERGIA SOLAR E EÓLICA SÉRGIO DE SALVO BRITO CRESESB- Estado do Rio de Janeiro - Atlas Solar e Eólico, 2012. Disponível em: http://www.cresesb.cepel.br/publicacoes/download/atlas_eolico/AtlasEolicoRJ.pdf>. Acessado em 03 de Dezembro de 2016

CORRÊA DA SILVA, R.; DE MARCHI NETO, I.; SILVA SEIFERT, S. Electricity supply security and the future role of renewable energy sources in Brazil. Renewable and Sustainable Energy Reviews, v. 59, p. 328341, jun. 2016.

EMPRESA DE PESQUISAS ENERGÉTICAS. Balanço Energético Nacional (BEN), 2016. disponível em: $<$ https://ben.epe.gov.br/>. Acessado em 16 de novembro de 2016.

ERTHAL, M.; MENDES, L. F. R..Considerações sobre a matriz elétrica do estado do Rio de Janeiro sob a ótica do índice de renovabilidade. In: I EINEPRO - Encontro Interestadual de Engenharia de Produção, 2015, São João da Barra - RJ. Considerações sobre a matriz elétrica do estado do Rio de Janeiro sob a ótica do índice de renovabilidade, 2015.

HINRICHS, R. A.; KLEINBACH, M.; REIS, L. B. Energia e Meio Ambiente. São Paulo: Thomson, 2010. 590p.

HOFFMANN, V. E. Estratégia e ecologia: um estudo de caso. In: Revista Produção [online]. 1998, v.8, n.2, p. 187-200. ISSN: 0103-6513.

GROSSMANN, W. et al. Investment and employment from large-scale photovoltaics up to 2050. In: Revista Empirica [online]. 2012, v. 39, p. 165-189.

GOLDEMBERG, J. Biomassa e energia. Revista Química Nova. v.32, n.3, p. 582-587, 2009.

GOLDEMBERG, J.; LUCON, O. Energia e meio ambiente no Brasil. In: Revista Estudos Avançados [online]. 2007, v.21, n.59, p. 7-20. ISSN: 0103-4014.

GOLDEMBERG, J.; LUCON, O. Energia, Meio Ambiente e Desenvolvimento. São Paulo: EDUSP. 2008, 400p.

MENDES, L.F.R.; HOSKEN, L.A.L.; GOMES, G.R.R. Estudo de viabilidade para implantação de energias renováveis no distrito de Farol de São Thomé - Campos dos Goytacazes/ RJ utilizando mineração de dados. In: Simpósio de Engenharia de Produção (18). Anais. Bauru/SP, 2011. ISSN: 1809-7189.

MINISTÉRIO DAS MINAS E ENERGIA. Programa de Incentivo às Fontes Alternativas de Energia Elétrica (PROINFA). Disponível em : <http://www.mme.gov.br/programas/ proinfa/>. Acessado em 20/11/2016

PAUliSTA, C. R. ; CAVADAS, L. S. ; ERTHAL JUNIOR, M. ; SANTOS, R. A. ; SANTOS, W. A.; HORA, H. R. M. . Desenvolvimento de metodologia para cálculo da Pegada Ecológica de discentes de pós-graduação em 


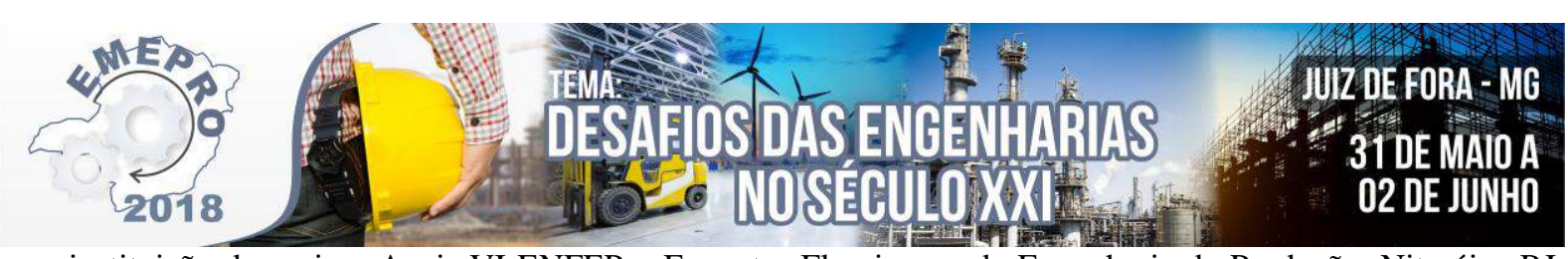

uma instituição de ensino. Anais VI ENFEPro Encontro Fluminense de Engenharia de Produção, Niterói - RJ, 2016.

RIBEIRO, L. A. S. et al. Making isolated renewable energy systems more reliable. Journal Renewable Energy. 2012, n. 45, p. 221-231. ISSN: 0960-1481.

RIO DE JANEIRO. Balanço Energético do Estado do Rio de Janeiro 2014. Governo do Estado do Rio de Janeiro, 2016. Disponível em: www.rj.gov.br/ Acessado em 08 de Dezembro de 2016.

SANTOS, W. A.; PAUliSTA, C. R. ; PESSANHA, D. C. ; ERTHAL JUNIOR, M. ; REIS, A. C. Uma Breve Análise Da Utilização Da Liga De Alumínio 6061 Em Carrocerias Automotivas. Anais do $13^{\circ}$ Congresso Iberoamericano de Engenharia Mecânica, Lisboa, Portugal, 2017.

TOLMASQUIM, M. T. Perspectivas e planejamento do setor energético no Brasil. Revista Estudos Avançados. vol.26, n.74, p. 247-260, 2012.

\section{APÊNDICE - QUESTIONÁRIO DE PESQUISA}

\section{QUESTIONÁRIO}

Esta pesquisa tem como objetivo fornecer dados para elaboração de Artigo Científico, com a finalidade de avaliar a potencialidade da implantação de sistemas renováveis de geração de energia elétrica na Região Norte do Estado do Rio de Janeiro.

\begin{tabular}{|c|c|c|c|c|c|c|c|}
\hline $\begin{array}{c}\text { TIPO DE } \\
\text { GERAÇÃO }\end{array}$ & ATRIBUTOS & $\begin{array}{l}\text { MUITO } \\
\text { ALTO }\end{array}$ & ALTO & MEDIO & BAIXO & $\begin{array}{l}\text { MUITO } \\
\text { BAIXO }\end{array}$ & $\begin{array}{c}\text { NÃO } \\
\text { QUERO } \\
\text { OPINAR }\end{array}$ \\
\hline \multirow{6}{*}{ Hidrelétrica } & $\begin{array}{l}\text { Aproveitamento } \\
\text { atual }\end{array}$ & & & & & & \\
\hline & Potencialidade & & & & & & \\
\hline & $\begin{array}{l}\text { Viabilidade } \\
\text { Econômica }\end{array}$ & & & & & & \\
\hline & $\begin{array}{l}\text { Viabilidade } \\
\text { Técnica }\end{array}$ & & & & & & \\
\hline & $\begin{array}{l}\text { Impactos } \\
\text { Ambientais }\end{array}$ & & & & & & \\
\hline & $\begin{array}{l}\text { Impactos } \\
\text { Sociais }\end{array}$ & & & & & & \\
\hline \multirow{6}{*}{ Biomassa } & $\begin{array}{l}\text { Aproveitamento } \\
\text { atual }\end{array}$ & & & & & & \\
\hline & Potencialidade & & & & & & \\
\hline & $\begin{array}{l}\text { Viabilidade } \\
\text { Econômica }\end{array}$ & & & & & & \\
\hline & $\begin{array}{l}\text { Viabilidade } \\
\text { Técnica }\end{array}$ & & & & & & \\
\hline & $\begin{array}{l}\text { Impactos } \\
\text { Ambientais }\end{array}$ & & & & & & \\
\hline & $\begin{array}{l}\text { Impactos } \\
\text { Sociais }\end{array}$ & & & & & & \\
\hline \multirow[t]{2}{*}{ Eólica } & $\begin{array}{l}\text { Aproveitamento } \\
\text { atual }\end{array}$ & & & & & & \\
\hline & Potencialidade & & & & & & \\
\hline
\end{tabular}




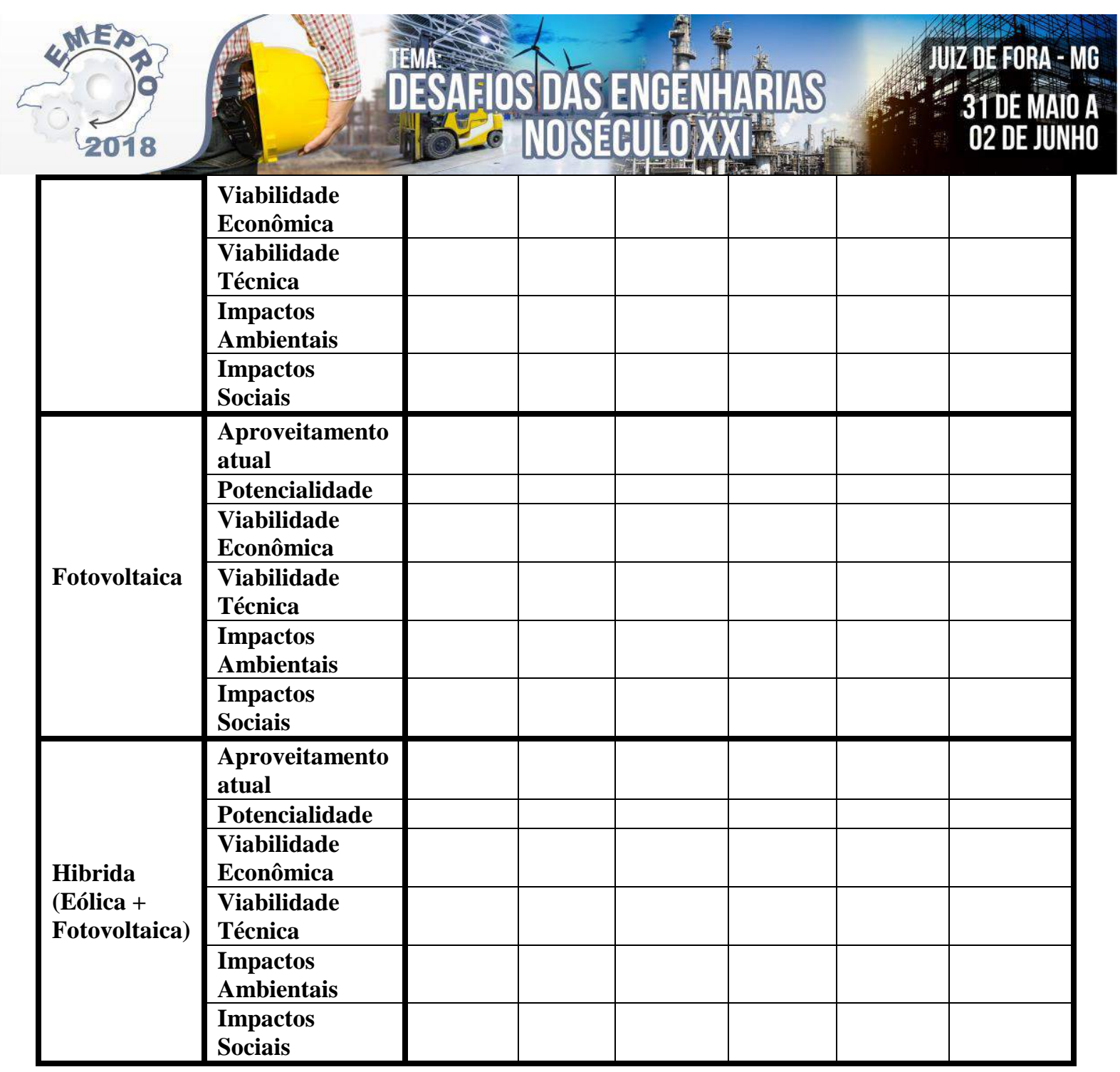




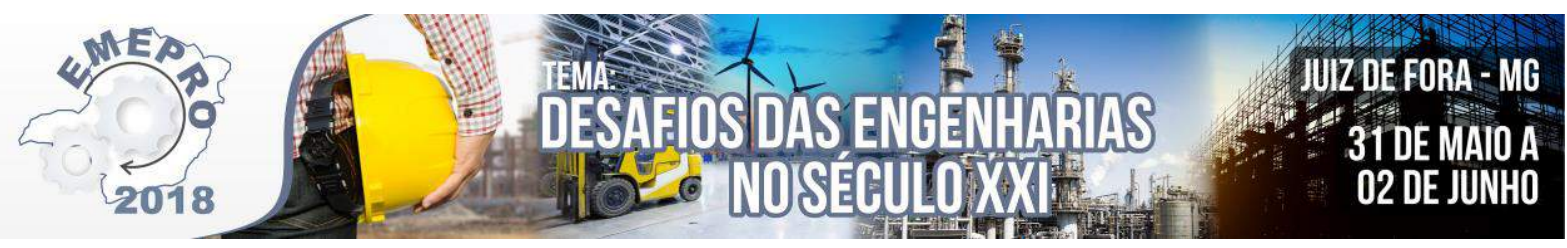 \\ Garrafas em PET e Vidro: um estudo bibliográfico e comparativo de suas propriedades e características relacionadas à produção e consumo sustentável
}

\author{
Ana Luiza Cordeiro Pereira (IFMG) - analuizacordeiro96@gmail.com \\ Thainá Alves de Melo Ferreira (IFMG) - thainaaalves25@ hotmail.com \\ Ana Flávia Faria Paiva (IFMG) - ana.ffpaiva1@ gmail.com \\ Camila Gonçalves Castro (IFMG) - camila.castro@ifmg.edu.br
}

Resumo: Os materiais apresentam diferentes propriedades, formas de processamento e efeitos sobre o meio ambiente o que deve ser analisado para melhor escolha entre os mesmos para fabricação de um produto. Nesse aspecto, o presente estudo busca por meio de uma revisão da literatura e análise documental comparar a utilização do PET (Polietileno Tereftalato) e Vidro na produção de garrafas com o intuito de analisar as propriedades de ambos, bem como suas possibilidades quanto à sustentabilidade, assunto este que com o crescente consumismo e respectivos danos a natureza tornou-se debate constante na atualidade, bem como diferencial competitivo entre as organizações. Além das principais vantagens e desvantagens quanto às propriedades, o estudo aborda a biodegrabilidade, reciclagem, reutilização, bem como a emissão de poluentes, demanda de recursos naturais, entre outros temas relacionados a consumo e produção sustentável. Pôde-se perceber que há grande ineficiência no que diz respeito ao saneamento básico, o que dificulta a reciclagem e reuso dos materiais, bem como incentivo e investimento para ambas as atividades, as quais são importantes para redução de lixo, necessidade de matéria prima e como conseqüência danos ao ambiente. Inferiu-se também lacunas para estudos futuros, que abordem a logística reversa dos materiais analisados e apresentem testes práticos sobre os mesmos. Palavras chave: Polietileno Tereftalato (PET); Vidro; Propriedades dos Materiais; Sustentabilidade

\section{Introdução}

Diante do cenário atual, caracterizado pela competitividade entre as organizações, é necessário que para que se mantenham no mercado as instituições busquem formas de aprimorar e otimizar seus processos e produtos (DEITOS, 2002). Silva (2002) afirma que com o emprego da tecnologia é possível que as empresas implementem novas formas de processamento e matérias-primas para confecção de seus produtos. Leite (2009) acrescenta que o desenvolvimento e competitividade do mercado atual, foram responsáveis pelo surgimento de um maior portfólio de produtos com preços reduzidos, obsolescência acelerada e, desta forma, com ciclo de vida menor.

Outro fato que merece atenção é a crescente preocupação com a produção e consumo sustentável, uma vez que a intensa modificação ambiental gerada pelo desenvolvimento das sociedades mostra-se como fator de risco para o planeta e toda a humanidade (NASCIMENTO, 2012). O consumismo atual agrava consideravelmente os danos gerados ao meio ambiente, uma vez que percebe-se o aumento da poluição, o que torna necessário a reciclagem e reutilização dos materiais (MANZINI; VEZZOLI, 2005). 


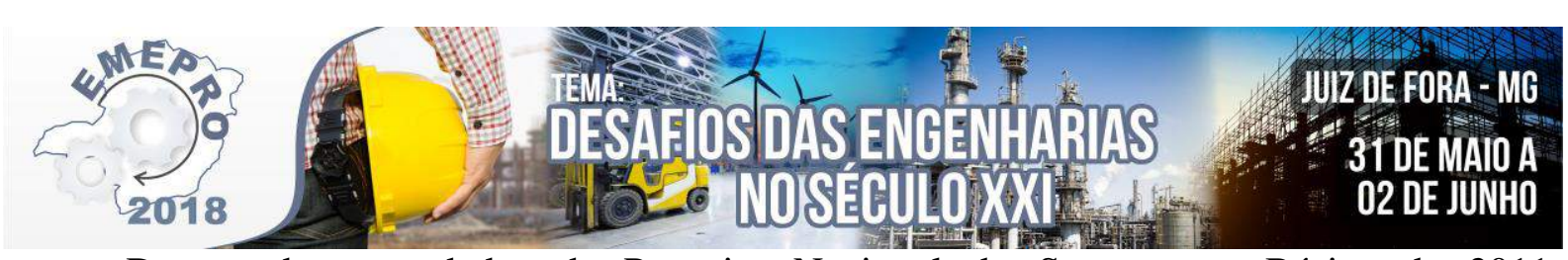

De acordo com dados da Pesquisa Nacional do Saneamento Básico de 2011, aproximadamente $63,6 \%$ das cidades brasileiras não utilizavam um método adequado de disposição final dos resíduos gerados, constituindo-se um sério problema ambiental, social, econômico e político. Segundo o Instituto Sócio Ambiental (2008) 20\% do lixo produzido no Brasil ainda é simplesmente jogado nos rios e várzeas.

Nesse aspecto, surge a necessidade da análise dos materiais que podem ser utilizados para fabricação de um mesmo produto, uma vez que de acordo com suas propriedades, formas de processamento, bem como facilidade de reutilização, pode ser verificado quais vantagens e desvantagens apresentam para os consumidores, produtores e para o meio ambiente (MIRANDA, 2012). Assim, o presente artigo visa por meio de uma revisão da literatura e análise documental comparar dois materiais utilizados na fabricação de garrafas de refrigerantes: o PET (um polímero) e o vidro (uma cerâmica), a fim de analisar as propriedades e peculiaridades quanto à sustentabilidade que ambos apresentam.

\section{Referencial teórico}

\subsection{PET}

De acordo com Chen (2003) e Karayannidis e Achilias (2007) o PET (Polietileno Tereftalato) é um poliéster termoplástico caracterizado por excelentes propriedades térmicas e mecânicas, ressaltam ainda que trata-se de um material semicristalino, com estrutura parcialmente alifática e aromática, com alta resistência, transparência e segurança. Segundo Valle (1995), o PET foi criado por volta de 1941 por Win Field e Dickson, no entanto seu uso industrial iniciou-se somente após a $2^{\text {a }}$ Guerra Mundial através de fibras têxteis conhecidas como Tergal.

De acordo com a ABIPET (Associação Brasileira da Indústria do PET) o PET chegou ao Brasil em 1988, o qual foi utilizado primeiramente na indústria têxtil. Segundo ROMÃO et al. (2009) somente a partir de 1993 ganhou forte expressão no mercado de embalagens, principalmente para os refrigerantes. Conforme ABIQUIM (Associação Brasileira das Indústrias Químicas), atualmente o PET é utilizado em diversos produtos como recipientes de refrigerantes e água mineral, produtos alimentícios, farmacêuticos e de limpeza, mantas de impermeabilização, fibras têxteis, entre outras. Ao analisar aspectos econômicos, caracterizase por ser um produto barato, seguro e moderno.

Segundo Piatt e Rodrigues (2005), o PET é um polímero, mais precisamente um plástico. Sobre a produção dos polímeros, eles explicam que do petróleo obtem-se uma fração denominada nafta, da qual retiram-se o monômeros, que por sua vez são unidos a fim de formar as grandes cadeias poliméricas, processo este chamado de polimerização. Conforme Solomons (2009) o PET pode ser produzido industrialmente de duas formas, ambas vias químicas. A primeira é a esterificação direta do ácido tereftálico purificado (PTA) com etileno glicol (EG) e a segunda seria a transesterificação do dimetil tereftalato (DMT) com etileno glicol (EG). Soares Junior (2010) acrescenta que com o acréscimo de cargas e aditivos, o uso de métodos para orientação das cadeias (uni e biaxial) e a aplicação de tratamento térmico, o PET pode ser fabricado com várias propriedades distintas, de acordo com as necessidades específicas das máquinas de transformação e do produto final.

Garcia (2007) e Odian (2004) afirmam que a grande e crescente utilização do PET advêm de suas vantagens em relação aos demais termoplásticos, como: excelente facilidade de processamento, alta resistência química, alta estabilidade hidrolítica (devido à presença de anéis aromáticos), estabilidade térmica, propriedades mecânicas atrativas a altas temperaturas, 


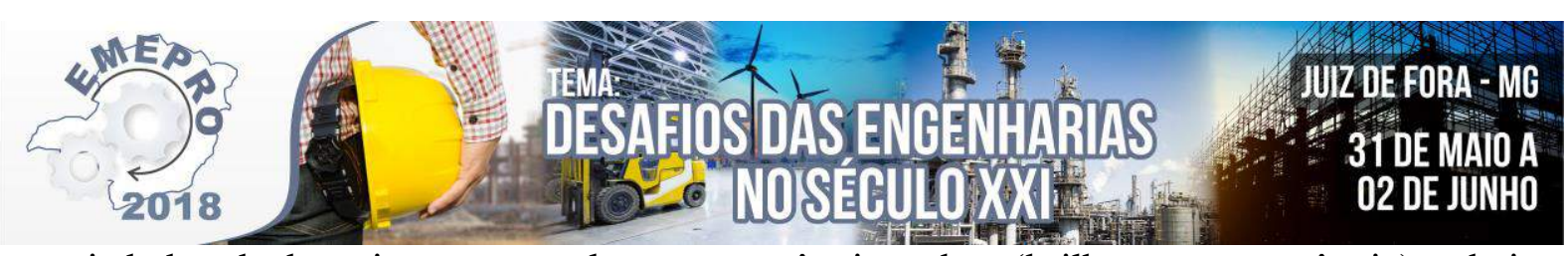

propriedades de barreira a gases, leveza, aparência nobre (brilho e transparência) e baixo custo de produção.

\subsection{Vidro}

A história mais popular da origem do vidro diz que ele foi descoberto ocasionalmente há mais de 4 mil anos por navegadores fenícios. Ao fazerem uma fogueira na praia, o calor fez com que a areia, o salitre e o calcário das rochas reagissem formando o vidro. (VALT, 2004). Para Dudas (2003) no Brasil, a indústria do vidro teve início no século XVII com as invasões holandesas em Olinda e Recife, em Pernambuco. Em 1810, foi instalada a primeira indústria de vidro no Brasil, com produção através de processos de sopro e de prensagem.

Os vidros consistem em silicatos não cristalinos que também contêm outros óxidos, notavelmente $\mathrm{CaO}, \llbracket \mathrm{Na} \rrbracket \_2 \mathrm{O}, \mathrm{K} \_2 \mathrm{O}$ e $\llbracket \mathrm{Al} \rrbracket \_2 \mathrm{O}$, os quais influenciam suas propriedades, sendo os mais importantes são a base de sílica [SiO]_2 (CALLISTER, 1999). De acordo com Callister (1999) as duas principais características dos materiais vítreos são a sua transparência e a relativa facilidade com a qual eles podem ser fabricados.

Segundo Navarro (1991) o vidro é um produto inorgânico de fusão que passou por um resfriamento numa condição rígida sem cristalização. Para Pinheiro (2007) o vidro trata-se de um material inorgânico, homogêneo e amorfo, obtido através do resfriamento de uma massa em fusão que apresenta como principais qualidades a transparência e a dureza. Akerman (2000) afirma que o vidro é um sólido, não cristalino, que apresenta o fenômeno de transição vítrea. De acordo com Alves (2001), a temperatura de transição vítrea, refere-se a uma temperatura característica para os vidros que define a passagem do estado vítreo para o estado viscoelástico, por meio da relaxação estrutural. Paul (1990) acrescenta que a temperatura de transição vítrea não é um ponto fixo, mas sim uma faixa de temperatura, sendo que dentro dessa faixa pode assumir diversos valores de temperatura de acordo com a velocidade de resfriamento do material.

\subsection{Produção de Vidro e de PET e de suas respectivas garrafas}

A fabricação do vidro pode ser dividida em duas fases, a preparação da composição e a fusão (SAINT GOBAIN, 2003). Segundo Valt (2004) na primeira fase as matérias-primas, extraídas da natureza, são pesadas e enviadas ao misturador para a homogeneização da massa, que passa a ser chamada de composição ou mistura vitrificável, já na segunda etapa a composição é conduzida ao forno de fusão, transformando-se em vidro, que após elaborado é conduzido às máquinas de conformação.

No processo de fusão forma-se um elemento viscoso, que acima de $1000{ }^{\circ} \mathrm{C}$ se torna uma massa transparente e homogênea. Uma vez retirada do forno, essa mistura poderá ser trabalhada de diversas maneiras, em função da forma pretendida. (Villela, 2007). Callister (1999), acrescenta que existem quatro diferentes métodos de conformação que podem ser usados para fabricar produtos à base de vidro: prensagem, insuflação, estiramento e conformação das fibras.

A fase inicial de produção de garrafas de vidro é a conformação. Nesta fase, a massa de vidro fundido é soprada contra moldes de ferro, tomando a forma de garrafa. O método de conformação depende do tipo de produto, da quantidade que se pretende produzir e dos recursos disponíveis (VALT, 2004). A fase final de produção de garrafas é o recozimento. Nesta fase, as garrafas percorrem fornos tipo túnel onde ocorre o resfriamento gradual da garrafa até a temperatura ambiente, com o objetivo de aliviar as tensões que normalmente 


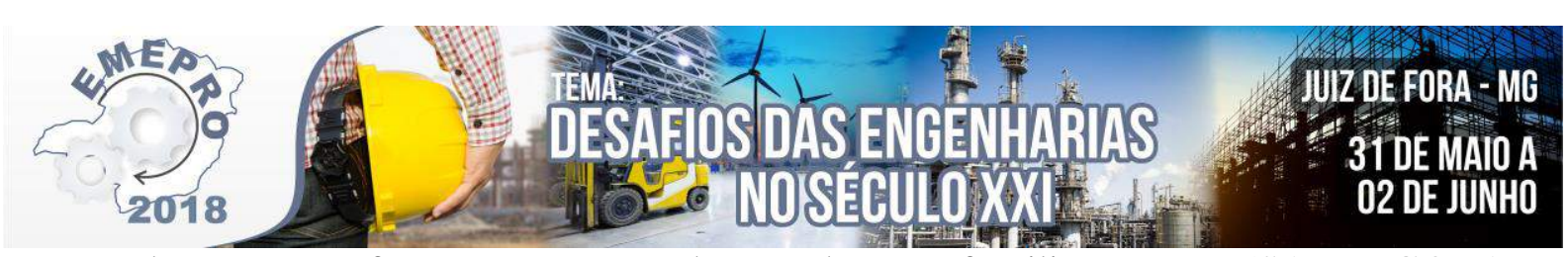

surgem durante a conformação e que podem quebrar ou fragilizar a peça (SAINT GOBAIN, 2003).

O processo de produção do PET, por sua vez tem início na extração do petróleo que, após ser destilado e refinado, é separado em diversos compostos, entre os quais a nafta. A partir da nafta, são obtidos outros produtos como o etileno e o pxileno, estes são matériasprimas para a fabricação do monoetilenoglicol (MEG) e do dimetiltereftalato (DMT), respectivamente. $\mathrm{O}$ polímero $\mathrm{PET}$ é obtido à partir desses dois materiais, na forma de flocos (VALT, 2004).

Segundo a ABIPET a transformação da resina PET em garrafas, ocorre em 7 etapas distintas, sendo as três últimas referentes à produção da garrafa propriamente dita: secagem, alimentação, plastificação, injeção, condicionamento, sopro, ejeção do produto. No processo de condicionamento a pré-forma recebe um tratamento térmico diferenciando, aquecendo-se mais onde for necessário, depois disso, no sopro a pré-forma é colocada, geralmente com o auxílio de robôs, dentro do molde, cuja cavidade tem a forma final da embalagem, e finalmente a embalagem soprada é retirada ou ejetada da máquina, pronto para o envase. Valt (2004) acrescenta, que as garrafas de refrigerante seguem então para os centros consumidores e, após serem usadas, são descartadas. Parte das garrafas descartadas é recolhida e encaminhada para a reciclagem e o restante segue para disposição em aterros.

\subsection{Sustentabilidade}

Segundo Rosa (2007) sustentabilidade é o fruto de um movimento histórico relativamente novo que questiona a sociedade quanto ao modo de desenvolvimento. De acordo com Ferreira (2005), em uma sociedade sustentável o progresso é medido pela qualidade de vida, ou seja, pela saúde, longevidade, maturidade psicológica e ambiente limpo, não pelo consumo e desenvolvimento material. Conforme Mendes (2009) as ações só podem ser consideradas sustentáveis quando estas procuram garantir o futuro de um local, com qualidade de vida, respeito às pessoas e sua cultura, conservação do meio ambiente, manutenção da biodiversidade, e adequação ao território.

Sachs (1993) ressalta seis dimensões de sustentabilidade: sustentabilidade ecológica, que relaciona-se a preservação dos recursos naturais, produção de recursos renováveis, limitação de uso dos recursos não-renováveis, redução do volume de resíduos e poluição e utilização de tecnologias limpas; sustentabilidade econômica, caracterizada pela efícácia econômica avaliada em termos macrossociais, desenvolvimento econômico entre os setores de forma equilibrada, capacidade de modernização e autonomia em pesquisas e desenvolvimento; sustentabilidade social que abrange a necessidade de recursos materiais e não-materiais, com o objetivo de maior equidade na distribuição da renda, de modo a melhorar os direitos e as condições da população; sustentabilidade espacial ou territorial, a qual busca o equilíbrio e a preservação rural-urbana ; sustentabilidade cultural:, que refere-se ao respeito à cultura de cada local; garantindo continuidade e equilíbrio entre a tradição e a inovação. E por fim a sustentabilidade política, que em no âmbito nacional baseia-se na democracia, apropriação universal dos direitos humanos, e em âmbito internacional relacionase a prevenção de guerras, garantia da paz e na promoção da cooperação internacional e na aplicação do princípio da precaução na gestão do meio ambiente e dos recursos naturais; prevenção da biodiversidade e da diversidade cultural; gestão do patrimônio global como herança da humanidade; cooperação científica e tecnológica entre as nações.

\section{Metodologia}




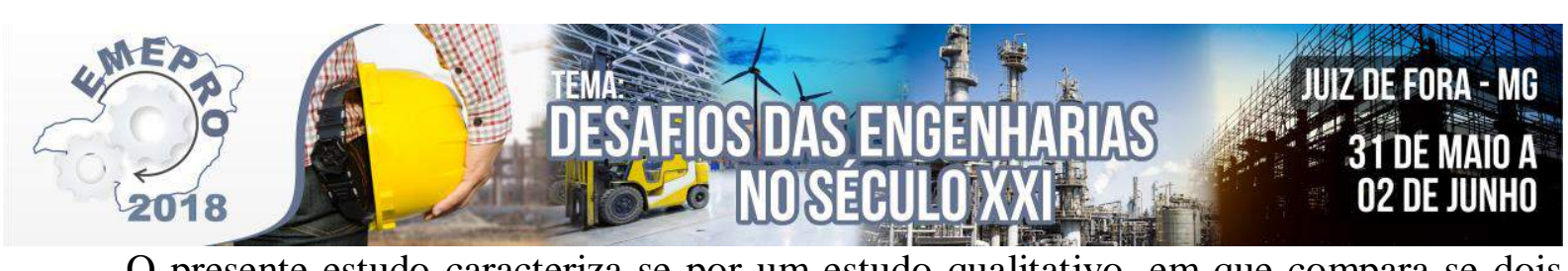

O presente estudo caracteriza-se por um estudo qualitativo, em que compara-se dois materiais distintos com base em suas propriedades, sendo eles um polímero e uma cerâmica, quando utilizados na fabricação de garrafas de refrigerantes. Para realização do estudo foram utilizadas inferências feitas por autores que tratam sobre a temática, a partir de uma revisão da literatura. Para obtenção dos dados foi utilizada a análise documental, que segundo Semensato (2013) consiste na busca por informações registradas em documentos, referentes à um determinado objeto de pesquisa e pertinentes ao objetivo da pesquisa, em que a coleta de dados é realizada a partir do levantamento de documentos acessíveis ao pesquisador, a fim de satisfazer as questões de pesquisa para o cumprimento do objetivo proposto. As comparações e discussões foram embasadas nas informações fornecidas pelos autores utilizados como referência.

\section{Discussão e Resultados}

\subsection{Propriedades}

Ao considerar a utilização do PET na produção de garrafas e os estudos de Montenegro et al. (2000), percebe-se que a temperatura de transição vítrea do material encontra-se bem acima da temperatura ambiente (cerca de $74^{\circ} \mathrm{C}$ ), o que garante maior confiabilidade ao produto quando submetido a condições normais de temperatura. A densidade do mesmo (cerca de 1,33) confere leveza e como conseqüência facilidade quanto a armazenagem e manuseio. Por tratar-se de um polímero, e como já exposto por Callister (2008), pode-se dizer que apresenta boa ductibilidade e considerável resistência mecânica.

Com relação ao vidro e conforme Barros (2010) percebe-se que tal material por tratarse de uma cerâmica possui elevada resistência a compressão $\left(1000 \mathrm{~N} / \mathrm{mm}^{2}\right)$, no entanto no que diz respeito a tração apresenta índices menos consideráveis (300 a $700 \mathrm{daN} / \mathrm{cm}^{2}$ ). Além disso, percebe-se mensurável dureza $(6,5)$, e como consequiência fragilidade. Outro aspecto a ser analisado é a densidade do material, a qual mostra-se mais de duas vezes superior a do PET $(2,5)$, o que confere maior dificuldade quanto a manuseio do produto.

Ashby e Johnson (2011) também analisam algumas características dos materiais, em sua análise ela considera o vidro separadamente e o PET como pertencente ao grupo dos poliésteres como é mostrado na tabela 1:

TABELA 1: Características do vidro e poliésteres

\begin{tabular}{|c|c|c|}
\hline Característica & Vidro & Poliéteres (PET, PBT) \\
\hline Densidade & $2,44-2,5 \mathrm{Mg} / \mathrm{m}^{3}$ & $1,19-1,81 \mathrm{Mg} / \mathrm{m}^{3}$ \\
\hline Módulo de Elasticidade & $68-72 \mathrm{Gpa}$ & $1,6-4,4 \mathrm{Gpa}$ \\
\hline Alongamento & $0 \%$ & $1,3-5 \%$ \\
\hline Tenacidade a fratura & $0,55-0,7 \mathrm{Mpa} \cdot \mathrm{m}^{1 / 2}$ & $1,05-9,16 \mathrm{Mpa} \cdot \mathrm{m}^{1 / 2}$ \\
\hline Dureza & $440-480 \mathrm{Hv}$ & $11-40 \mathrm{Hv}$ \\
\hline Condutividade Térmica & $0,7-1,3 \mathrm{~W} / \mathrm{m} . \mathrm{K}$ & $0,28-0,58 \mathrm{~W} / \mathrm{m} . \mathrm{K}$ \\
\hline Dilatação Térmica & $9-9,5 \times$ microK & $115-170 \times \mathrm{microK}$ \\
\hline
\end{tabular}

Por meio da tabela 1, percebe-se que o vidro apresenta maior condutividade térmica, que no caso de embalagens de bebidas frias como refrigerantes não é uma característica desejável (CRUZ, 2012). No entanto, sua dilatação térmica mostra-se inferior quando 


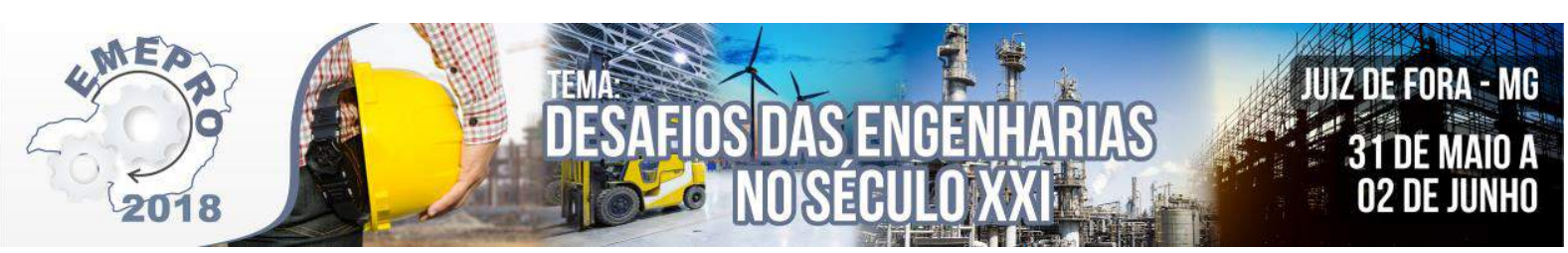

comparado ao PET, logo este é mais resistente quando submetido a altas temperaturas. Além disso, segundo Lima e Afonso (2009) a embalagem de vidro impede a passagem de gás, ou seja, evita que o gás do refrigerante se perda e desse modo altere suas características organolépticas. Pode-se perceber também que o vidro, como já é característico das cerâmicas e enfatizado por Ashby e Jones (2007), não apresenta capacidade de alongamento, como consequência, tende a propagar trincas com maior facilidade.

\subsection{Sustentabilidade e Meio Ambiente}

Doratiotto et al. (2011) ressalta que o PET é produzido do petróleo, um combustível fóssil não-renovável, altamente poluente quando queimado ou derramado, e tóxico, quando inalado ou ingerido. Além disso, a biodegradabilidade do PET é muito lenta. Segundo Neiman (1991), uma garrafa de PET pode demorar até 500 anos para se desfazer na natureza, por isso deve ser reciclada. Weinar (1992) acrescenta que o PET é um material 100\% reciclável, no entanto para utilização em produtos alimentícios não pode ser utilizado após reciclagem devido a contaminação que estes produtos geralmente apresentam. Em contrapartida, Guelbert et al. (2007) afirmam que caso a coleta seletiva fosse realizada de forma devida, conseguiria-se mais PET com menos contaminação.

De acordo com Zanin e Mancini (2000) a reciclagem mecânica de plásticos é a forma mais comum de se recuperar o valor agregado do PET. Conforme Dias e Teodósio (2006), nesse processo mecânico, os produtos plásticos são moídos, lavados, submetidos à secagem e reprocessados, dando origem a novos produtos. Nunes et al (2005) ressaltam que os transformadores utilizam PET reciclado para diversos tipos de produtos, e é possível fabricar desde fibra de poliéster para a fabricação de roupas até novas embalagens para produtos não alimentícios. Petry (2012) acrescenta ainda que são inúmeros os produtos que podem substituir a matéria prima virgem pelo material gerado pela reciclagem de garrafas PET, podendo ser utilizados nos mais diversificados segmentos, como a construção civil e produção de automóveis.

Ao tratar da reciclagem do vidro, Lemos (2012) afirma que dentre os materiais de embalagens, o vidro apresenta maior potencial de reuso e de reciclagem, uma vez que pode ser reprocessado infinitamente sem perder suas propriedades. Segundo a UBV (União Brasileira de Vidros) o vidro é um material $100 \%$ reciclável, pois sua composição não se altera durante o processo de fusão e não existe perda das suas características químicas ou mecânicas. Tal possibilidade de reciclagem constitui uma grande vantagem do ponto de vista ambiental, não só pela economia de matérias-primas, bem como pela menor geração de resíduos.

De acordo com Dias e Cruz (2009) o vidro, quando descartado no meio ambiente, apresenta um tempo de decomposição extremamente alto, mais de um milhão de anos, o que torna importante seu reaproveitamento. Consoante a UBV existem duas formas em que o vidro pode ser reciclado: como caco e grão. O terceiro formato, ou seja, o pó de vidro, ainda não pode ser reciclado, o que gera despesas para as beneficiadoras que precisam custear seu descarte. A associação acrescenta ainda que as empresas que reciclam o vidro preferem os cacos, uma vez que, no processo de fusão, ele derrete com facilidade, o que economiza energia. Oliveira et al. (2008) apresentam como principais vantagens da reciclagem do vidro o baixo custo no processos, economia na aquisição da matéria prima, geração de emprego e renda para a população de baixa renda e por fim, a mensurável contribuição ambiental. 


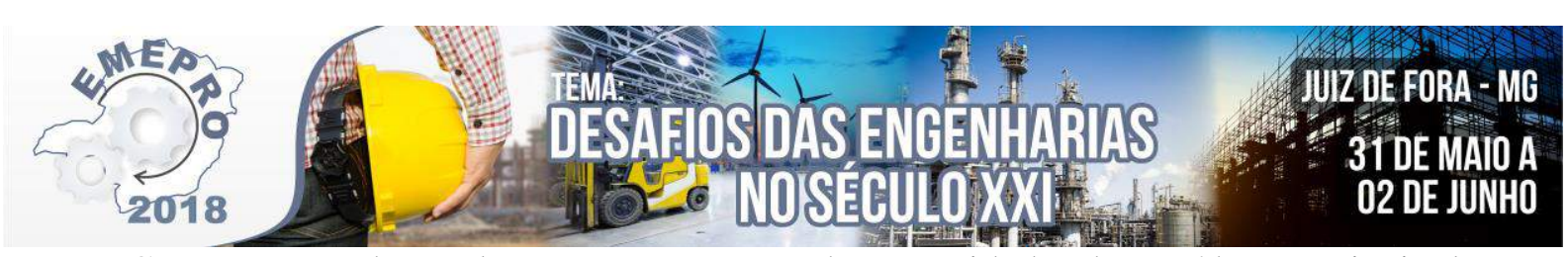

Como umas das soluções para a grande quantidade de resíduos, principalmente garrafas, faz-se uso da reutilização das mesmas. Segundo a ABIVIDRO (Associação Técnica Brasileira das Indústrias Automáticas de Vidro) o vidro é o constituinte de embalagem mais antigo utilizado pela sociedade, sendo totalmente reutilizável para a produção de novas embalagens. No entanto, seu manuseio é mais delicado tanto para o fabricante, quanto para o comerciante e para o consumidor. De acordo com Nardi (2013), a versão retornável de garrafas de vidro vem perdendo mercado de forma significativa no Brasil, pois os comerciantes de produtos que fazem uso desse tipo de embalagem, com a criação de embalagens plásticas do tipo PET, optaram pela utilização do segundo, com o objetivo de redução de custos, facilidades na cadeia de transporte e pela não necessidade de tratamento para a limpeza das garrafas para reuso e reembalagem do produto.

Como meio de incentivar a reutilização das garrafas, a Coca-Cola lançou a garrafa retornável de PET, conhecida como REF PET. A criação do REF PET foi uma estratégia para recuperar e atingir as classes mais baixas de consumidores, que passaram a consumir marcas de pequenos produtores (GUERRA; et al., 2013). Segundo a ABIR (Associação Brasileira das Indústrias de Refrigerantes e de Bebidas não alcoólicas), o REF PET caracteriza-se como um tipo de PET retornável que pode ser reutilizado pela indústria até 25 vezes, sendo o mesmo confeccionado em um tipo de PET mais resistente, que traz economia e segurança para o consumidor.

\section{Considerações Finais}

Com o objetivo de comparar a utilização do PET e do Vidro para produção de garrafas de refrigerantes, o presente artigo demonstrou que o PET apresenta maior leveza e ductibilidade, o que facilita o manuseio dos produtos. $\mathrm{O}$ vidro por sua vez, apresenta maior resistência quando exposto a altas temperaturas, maior condutividade térmica, além de impedir de maneira satisfatória a passagem de gases.

Com base nas inferências feitas por meio da literatura e ao considerar que o presente estudo diz respeito à produção de garrafas, pode-se dizer que no que tange à sustentabilidade o vidro apresenta maiores benefícios, sendo que o mesmo pode ser fundido e reutilizado infinitamente, uma vez que mantém suas propriedades. Apesar do PET ser um termoplástico e poder ser amolecido pelo calor sem perder suas propriedades, poderá ser reutilizado, em maior parte, somente para fabricação de outros produtos, devido a contaminação a que está sujeito. Ademais, ao analisar as garrafas como produtos retornáveis, pode-se concluir que o vidro pode ser utilizado diversas vezes, até sua danificação física, enquanto que o REF PET pode retornar a fábricas de refrigerantes no máximo 25 vezes. É importante ressaltar que na natureza o vidro demanda um período maior até sua degradação, porém, o PET gera maior volume de resíduos poluentes.

Outro fator que merece atenção é a necessidade de maior desenvolvimento no setor de saneamento básico e reciclagem, uma vez que segundo dados do IBGE (Instituto Brasileiro de Geografia e Estatística) apenas uma pequena parcela dos resíduos sólidos é reaproveitada no Brasil e estes muitas vezes, apresentam alto grau de contaminação devido o mau descarte. Além disso, torna-se necessário o maior incentivo a reutilização de produtos e embalagens, que reduziria a quantidade de lixo gerado, a necessidade de matéria-prima e energia e ampliaria a vida útil destes produtos.

Como principal dificuldade para realização do estudo aponta-se a falta de recursos para realização de testes práticos em laboratório a fim de analisar as propriedades mecânicas 


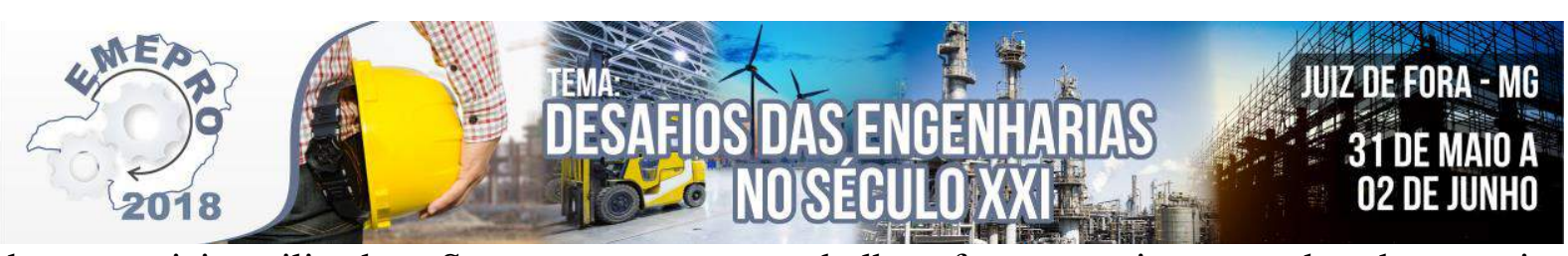

dos materiais utilizados. Sugere-se que em trabalhos futuros, sejam testadas de maneira prática e posteriormente apresentadas tais propriedades, bem como a análise acerca do impacto das característica de cada um dos materiais sobre as atividades logísticas, e por fim um estudo sobre o processo de logística reversa das garrafas de ambos os materiais.

\section{Referências}

ABIPET - ASSOCIAÇÃO BRASILEIRA DA INDÚSTRIA DO PET. Disponível em: <http://www.abepet.com.br >. Acesso em: 02 de março de 2018.

ABIQUIM - Associação Brasileira das Indústrias Químicas. Disponível em: http://www.abiquim.org.br/resinastermoplasticas/principais.asp. Acesso em: 13 de fevereiro de 2018.

AKARMAN, M. Natureza, Estrutura e Propriedades do Vidro. CETEV - Centro Técnico de Elaboração do Vidro, 2000.

ALVES, O. L. Modernas Aplicações dos Vidros. LQES . Instituto de Química, UNICAMP, SP, Brasil, 2001.

ASHBY, M. E.; JOHNSON, K. Materiais e designe: arte e ciência da seleção de materiais no designe de produtos. Rio de janeiro: Elsevier, 2011.

Associação Brasileira das Indústrias de Refrigerantes e de Bebidas não alcoólicas (ABIR). COCA-COLA lança em Santa Catarina embalagem retornável. 2012. Disponível em: http://abir.org.br/2012/06/18/coca-colalanca-em-santa-catarina-embalagem-retornavel/. Acesso em: 20 de julho de 2016.

Associação Técnica Brasileira das Indústrias Automáticas de Vidros (ABIVIDRO). Disponível em: http://www.abividro.org.br/ . Acesso em: 10 de março de 2018.

BARROS, C. Apostila de vidros. Instituto Federal De Educação, Ciência E Tecnologia Sul Rio Grandense, 2010.

Callister Jr., W.D. Ciência e Engenharia dos Materiais, uma Introdução. $7^{a}$ Ed. Ed. Guanabara, 2008.

CALLISTER, W. D. Ciência e Engenharia de Materiais: Uma Introdução. 5. ed. Rio de Janeiro: LTC Editora, 2000.

CHEN, C. Study of Glycolysis of Poly(ethylene terephthalate) recycled from postconsumer soft-drink bottles. III. Further Investigation. Journal of Applied Polymer Science, v. 87, p. 2004-2010, 2003.

CRUZ, G. F. B. Fabricação de Refrigerantes. Rede de Tecnologia e Inovação do Rio de Janeiro - REDETEC, 2012.

DEITOS, M. L. M. S. A Gestão da Tecnologia nas Pequenas e Médias Empresas. Trabalho de Conclusão de Curso. Edunuoeste. Cascavel, 2012.

DIAS, G.; CRUZ, T. M. S. Plano de gerenciamento integrado de resíduos vítreos - PGIRV. Belo Horizonte: Fundação Estadual do Meio Ambiente : Fundação Israel Pinheiro, 2009.

DIAS, S. L. F. G.; TEODÓSIO, A. S. S. Reciclagem do PET: desafios e possibilidades. In: ENEGEP - Encontro Nacional de Engenharia de Produção,25, Fortaleza 2006.

DORATIOTTO, C. P.; NASCIMENTO, A. P. B.; GOZZI, M. P.; FERREIRA, M. L. Reciclagem de Pet (Polietileno Tereftalato) no Brasil. XIV Encontro Latino Americano de Iniciação Científica e X Encontro Latino Americano de Pós-Graduação - Universidade do Vale do Paraíba, 2011.

DUDAS, L. Educação ambiental: o ciclo do lixo. Curitiba: 3R’s Educação ambiental, 2002.

FERREIRA, L C. Sustentabilidade: uma abordagem histórica da sustentabilidade. In: BRASIL. Encontros e Caminhos: Formação de Educadoras(es) Ambientais e Coletivos Educadores. Brasília: Ministério do Meio Ambiente, 2005.

GARCIA, E.E.C.Você Conhece o Lado Químico do PET?. Boletim de Tecnologia e Desenvolvimento de Embalagens, v. 9, n. 4, pp. 1-3, 1997.

GUELBERT, T. F.; GUELBERT, M.; CORREA, M.; LESZCZYNSKI, S. A. C.; GUERRA, J. C. C. A Embalagem PET e a Reciclagem: Uma Visão Econômica Sustentável para o Planeta. Engep, 2007. 


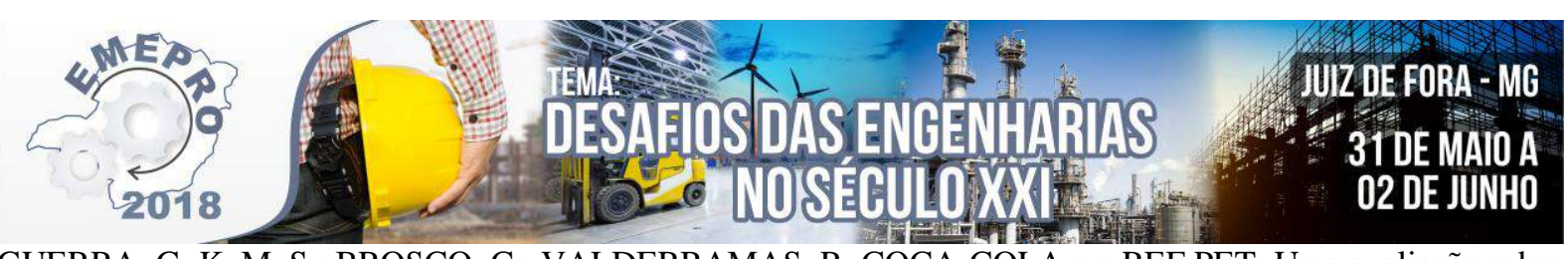

GUERRA, G. K. M. S.; BROSCO, C.; VALDERRAMAS, R. COCA-COLA e o REF PET: Uma avaliação sobre a concepção do consumidor em relação à sustentabilidade e seus hábitos de compra na cidade de Bauru. In: Congresso de Ciências da Comunicação na Região Norte, 12 , Manaus-AM, 2013

INSTITUTO BRASILEIRO DE GEOGRAFIA E ESTATÍSTICA (IBGE). Pesquisa Nacional de Saneamento Básico 2011: Limpeza Urbana e Coleta de Lixo. Disponível em: http://www.ibge.gov.br. Acesso em: 10 de março de 2018.

INSTITUTO SÓCIO AMBIENTAL. Almanaque Brasil Socioambiental: 2008. 2 ed. São Paulo, SP, 2008.

KARAYANNIDIS, G. P.; ACHILIAS, D. S. Chemical recycling of Poly(ethyleneterephthalate). Macromol. Mater. Eng, v. 292, p. 128-146, 2007.

LEITE, P. R. Logística Reversa: meio ambiente e competitividade. São Paulo: Pearson Prentice Hall, 2009.

LEMOS,E. Diagnóstico da Cadeia de Reciclagem de Embalagem de Vidro em Santa Catarina. Florianópolis, 2012. 110p. Trabalho de Conclusão de Curso (Graduação) - Universidade Federal de Santa Catarina. Departamento de Engenharia Sanitária e Ambiental.

LIMA, A. C. S; AFOnSO, J. C. A. A Química do Refrigerante. Química Nova na Escola, São Paulo, 2009.

MANZINI, E.; VEZZOLI,C. O Desenvolvimento de Produtos Sustentáveis. São Paulo: Editora da Universidade de São Paulo, 2005.

MENDES, J. M. G. Dimensões da Sustentabilidade. Revista das Faculdades Santa Cruz, v. 7, n. 2, 2009.

MIRANDA, P. E. V. Materiais e Meio Ambiente. Revista Matéria, v. 17. n. 4, 2012.

MONTENEGRO, R. S. P.; PAN S. S. K.; RIBEIRO, M. C. M. Resina PET para Recipientes. [S.1.:s.n]. 2000.

NARDI, P. C. C. Logística Reversa: proposta de um modelo para acompanhamento da sustentabilidade de um processo produtivo de Ref PET. Ribeirão Preto, 2013. Tese de Doutorado apresentada a Faculdade de Economia, Administração e Contabilidade de Ribeirão Preto/USP.

NASCIMENTO, E. P. Trajetória da sustentabilidade: do ambiental ao social, do social ao econômico. Estudos avançados, vol. 26, n. 74, 2012

NUNES, J. R. A.; ALVEZ, J. D.; FERREIRA, O. M. Reciclagem De Pet: Potencial Para Aproveitamento Na Fabricação De Novos Produtos. Artigo apresentado como requisito para conclusão de curso - Universidade Católica de Goiás - Departamento de Engenharia - Engenharia Ambiental , 2005.

ODIAN, G. Principles of Polymerization. 4 Ed. New Jersey, USA, John Wiley \& Sons, 2004.

OLIVEIRA, F. R.; SILVEIRA, R. M. C. F. Utilização de resíduo de vidro para fabricação de novos produtos agregando valor e design. In: Simpósio de Engenharia de Produção, Simpep, 15, São Paulo, 2008.

PETRY, Jéssica. Estudo de Caso: Responsabilidade ambiental: reciclagem e reutilização de garrafas pet. Revista Interdisciplinar Científica Aplicada, Blumenau, v.6, n.3, 2012.

PIATTI, T. M., RODRIGUES, R. A. F. Plásticos : características, usos, produção e impactos ambientais . Maceió: EDUFAL, 51p, 2005.

PINHEIRO, F. C. Evolução do uso do vidro como material de construção civil. Itatiba, 2007. Monografia de conclusão do Curso de Engenharia Civil da Universidade São Francisco.

ROSA, A. Rede de governança ambiental na cidade de Curitiba e o papel das tecnologias de informação e comunicação. Dissertação de mestrado. Gestão Urbana. Pontifícia Universidade Católica do Paraná, 2007.

SACHS, I. Estratégias de transição para o século XXI: desenvolvimento e meio ambiente. São Paulo: Nobel, 1993.

SEMENSATO, B. I. Análise Comparativa entre as Metodologias de Pesquisa Científica e as Metodologias da Ação Ergonômica a Partir de um Constructo Teórico. Ação Ergonômica, v. 8, n. 1, 2013.

SILVA, J. C. T. Tecnologia: Conceitos e Dimensões. In: Enegep - Encontro Nacional de Engenharia de Produção, 22, Curitiba-PR, 2002. 


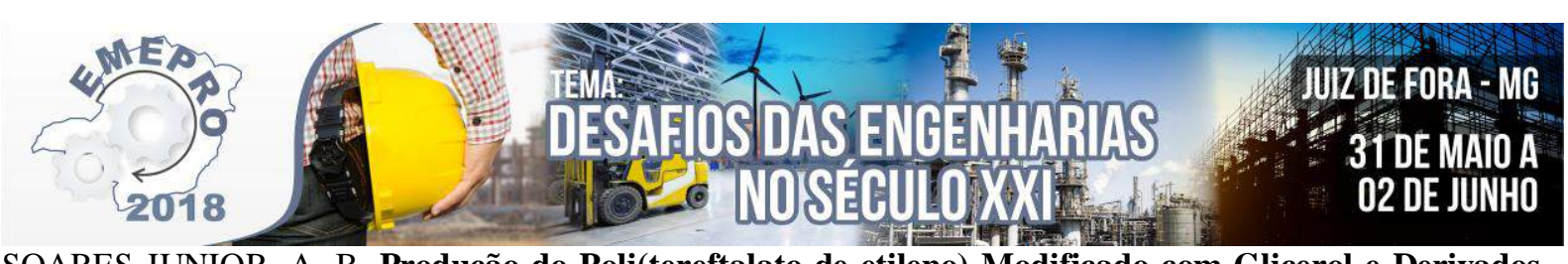

SOARES JUNIOR, A. B. Produção do Poli(tereftalato de etileno) Modificado com Glicerol e Derivados . Dissertação (mestrado) - UFRJ COPPE - Programa de Engenharia Química. Rio de Janeiro: UFRJ/COPPE, 2010.

SOLOMONS, T. W. G. Química Orgânica. 9. ed. São Paulo: LTC (Grupo GEN), 2009.

União Brasileira de Vidros (UBV). Disponível em: http://abravidro.org.br/vidros/uniao-brasileira-de-vidros-ubv/. Acesso em: 28 de jul. 2016.

VALle, C. E. Reciclagem no Brasil: O Desafio de Ser Competitivo Protegendo o Meio Ambiente. 1. ed. São Paulo: Pioneira, 1995.

Valt, R. B. G. Analise do ciclo de vida de embalagens de PET, de alumínio e de vidro para refrigerantes no Brasil variando a taxa de reciclagem dos materiais. Tese de Mestrado: Universidade Federal do Paraná, Curitiba, 2004.

Weinar, JOnAthan. Os Próximos Cem Anos: Em nossas Mãos o Destino da Terra. 2. ed. Rio de Janeiro: Campus, 1992.

ZANIN, M.; MANCINI, S. D. Resíduos Plásticos e reciclagem: aspectos gerais e tecnologia. São Carlos: Edusfcar, 2004. 


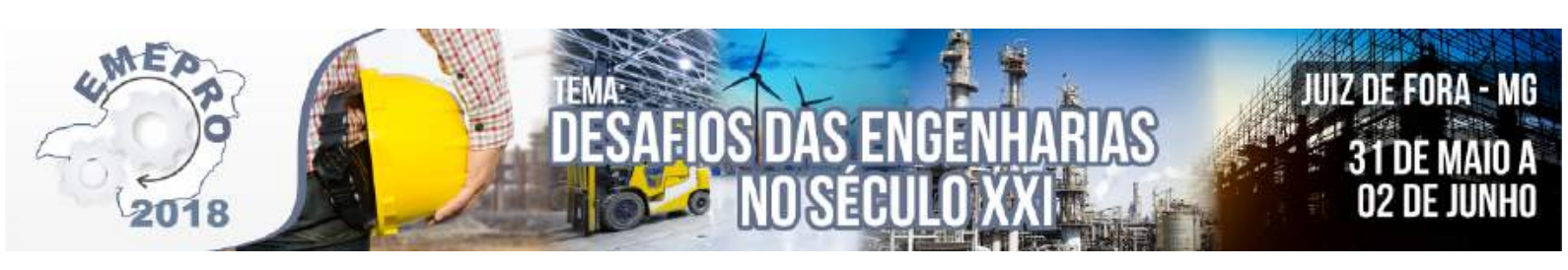

\title{
Aplicação de Engenharia de Produção - Sociedade Beneficente Mão Amiga - Juiz de Fora
}

\author{
Cleuller Camilo da Costa Vieira Silva - UFJF - cleuller.camilo@engenharia.ufjf.br \\ Larissa Christina Vale de Paiva - UFJF - larissa.paiva@engenharia.ufjf.br
}

Resumo: O projeto a seguir foi desenvolvido como modelo a ser executado com gerência de membros do curso de Engenharia de Produção do Departamento de Projetos do Engenheiros Sem Fronteiras - Núcleo Juiz de Fora. A aplicação deste projeto em especifico é focada em melhorias organizacionais e estratégias de marketing associadas à imagem institucional do local de execução. Realizado seguindo as etapas de prospecção da instituição, planejamento, execução, finalização e ações de retorno para avaliação do andamento e correções. A eficiência, viabilidade e o impacto são constatados devido à cultura de melhoria contínua, baixo custo de execução e expressivo número de pessoas atingidas direta e indiretamente. A instituição prospectada para a realização do projeto foi a Sociedade Beneficente Mão Amiga, a instituição fundada por Maria Aparecida da Silva, realiza um trabalho de amparo a mais de 250 familias com vulnerabilidade social no bairro Ipiranga em Juiz de Fora desde 1982.

Palavras-chave: organização, melhoria contínua, engenharia social.

\section{INTRODUÇÃO}

Uma instituição social ter um potencial são necessárias três coisas: a) precisa gerenciar a si mesma tão bem quanto as melhores; b) aprender a captar dinheiro; e, c) precisa de mudança na atitude do governo e das suas burocracias. (VIEIRA apud DRUCKER (1996))

As aplicações do marketing são muitas: bens, serviços, eventos, experiências, pessoas, lugares, propriedades, organizações, informações e ideias. O marketing transpôs a sua atuação comercial para se tornar uma atividade aliada das funções sociais e culturais, apoiando ações humanitárias e ambientais. Sendo assim, o presente trabalho irá focar especialmente no marketing de organizações, em que ONGs elaboram estratégias para melhorar sua imagem pública e competir por recursos, e no marketing de ideias, que influencia o comportamento para o bem. (BARROS apud Richers (2000)) 


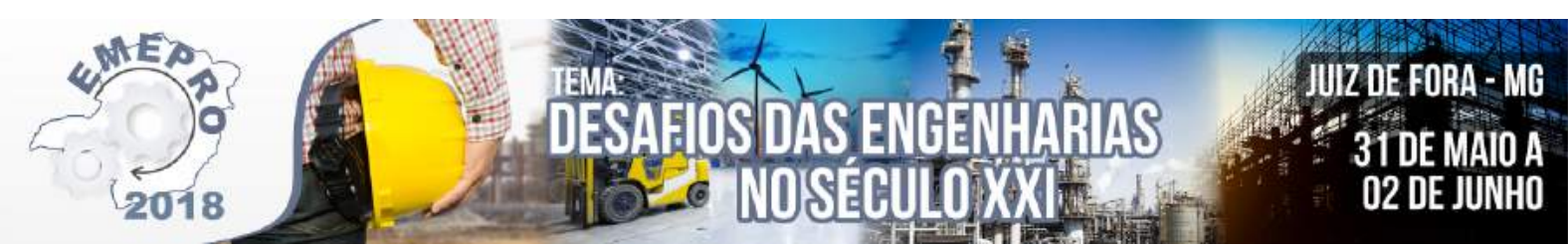

Considerando como base inicial essas referências é possível compreender a aplicação desse projeto e sua relação direta com o curso de Engenharia de Produção. O projeto além disso contribui diretamente para a formação dos alunos participantes da ONG Engenheiros Sem Fronteiras, pois gera uma aproximação direta deles com o seu curso através de atividades práticas, vivência de planejamento e controle de projetos e uma grande aproximação de realidades diferentes.

\section{OBJETIVO}

A realização do projeto de aplicação de Engenharia de Produção na Sociedade Beneficente Mão Amiga teve como objetivo aprimorar e padronizar os documentos utilizados para cadastro dos apoiados, introduzir a cultura de controle financeiro no bazar da instituição, criar um método de controle das doações realizadas por parte da instituição, aprimorar as estratégias de marketing nas redes sociais para que assim tivessem um maior alcance na região de Juiz de Fora. As estratégias de marketing fariam com que a instituição fosse conhecida por mais pessoas propensas a doarem materiais necessários, bem como mais pessoas iriam conhecer o trabalho da instituição e procuraria auxílio nela, ou seja, atingiram em dois âmbitos diferentes uma parcela maior da sociedade. Essas ações buscam alcançar após sua implementação uma cultura de trabalho em equipe, melhoria contínua e organização na Sociedade Beneficente Mão Amiga. Além disso, esse projeto era o primeiro de Engenharia de Produção realizado no Engenheiros Sem Fronteiras- Núcleo Juiz de Fora, então tinha como objetivo interno criá-lo como modelo dentro núcleo para que conseguíssemos reproduzi-lo e captar e ajudar mais pessoas e instituições nessa área.

\section{MATERIAIS E MÉTODOS}

A Sociedade Beneficente Mão Amiga, fundada em 1982, localizada no bairro Ipiranga em Juiz de Fora, é uma organização não governamental que atende mais de 250 famílias em situação de risco no bairro e entorno. As atividades incluem doações de alimentos, roupas, doações de leite para recém- nascidos, enxoval para gestantes, aulas de reforço para crianças e atendimento de psicólogos e fonoaudiólogos. O orçamento que permite o funcionamento da instituição é oriundo do bazar de roupas e de doações de terceiros.

A instituição foi prospectada inicialmente através de uma doação de leite já planejada pelo Engenheiros Sem Fronteiras - Núcleo Juiz de Fora, a arrecadação ocorreu num período de 15 dias no mês de maio de 2017, alcançando um número expressivo de 1300 litros de leite, batendo a meta de 1001 litros em 30\%. Essa arrecadação era necessária visto que a instituição atendia diretamente a 30 crianças recém nascidas e além disso várias famílias com filhos menores, antes da arrecadação a instituição estava a mais de 2 meses sem poder atender a essas famílias e crianças. Outra motivação com a realização da arrecadação é a aproximação que essa gera com a instituição, sendo um forma de motivar os membros a realizar a arrecadação, além de demonstrar para a instituição assistida o 


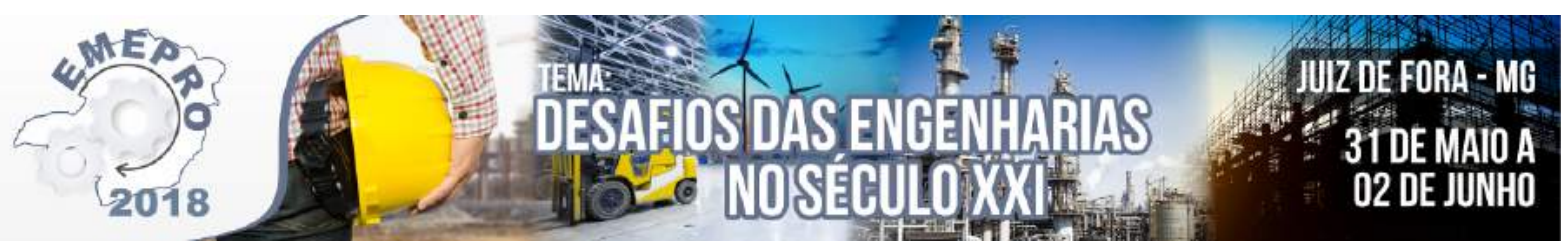

interesse e disposição a ajudar. Abaixo imagens do projeto:

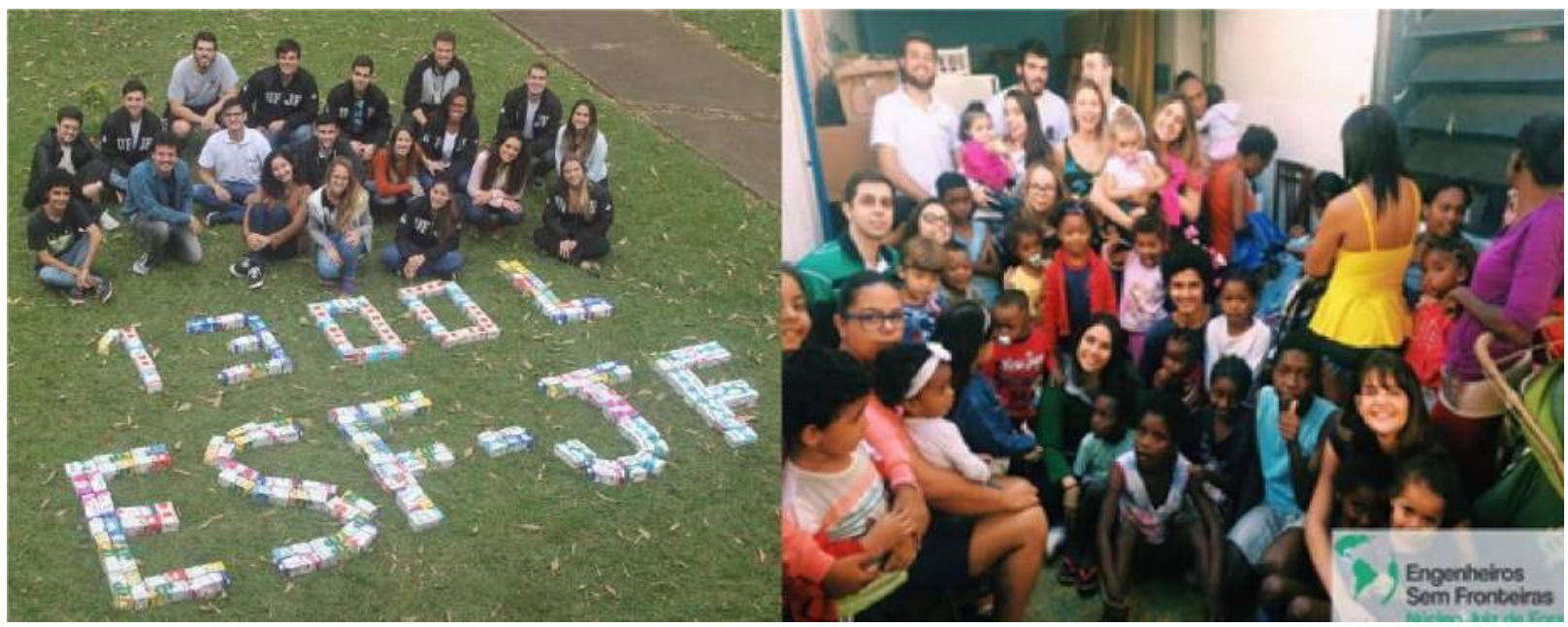

FIGURA 1: Projeto de Arrecadação de Leite - Sociedade Beneficente Mão Amiga - Arrecadação e Entrega.

Fonte: arquivo Engenheiros Sem Fronteiras - JF (2017).

Durante a visita de entrega da doação de leite na instituição foi identificado por alguns membros da diretoria de projetos e de engenharia de produção à necessidade de uma ação de melhoramento na organização interna no local, inicialmente foram constatados os seguintes pontos de melhoria:

- Falta de padrão e organização no cadastramento de famílias;

- Falta de controle das doações entregues às famílias cadastradas;

- Falta de um controle de caixa no bazar social;

- Pouca atratividade das páginas em suas redes sociais.

Uma equipe foi formada para o desenvolvimento do novo projeto para a aplicação de técnicas relacionadas a Engenharia de Produção, para corrigir os pontos de melhorias identificados, sendo a equipe formada por três alunos do curso de Engenharia de Produção e por membro do Departamento de Marketing do ESF-JF. A equipe foi montada dessa maneira com o intuito de aproveitar os conhecimentos de cada um em sua área de expertise para serem entregues os resultados esperados.

O projeto foi dividido conforme o fluxograma abaixo:

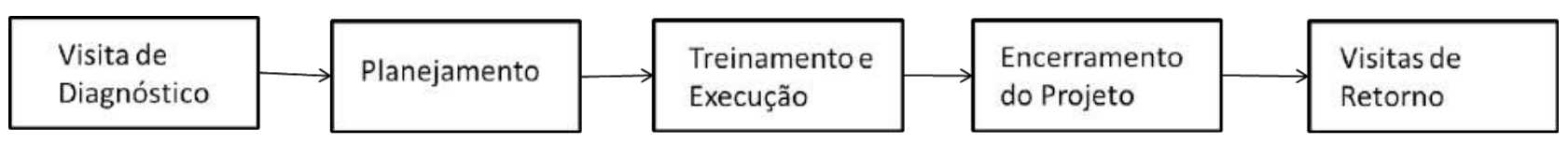

FIGURA 2: Fluxograma de etapas do Projeto Aplicação de Engenharia de Produção - Sociedade Beneficente

Mão Amiga. Fonte: Elaborado pelos autores (2017).

1) Visita de Diagnóstico: Visita realizada por todos os membros da equipe do projeto para identificação das correções necessárias, utilizando para tal uma 


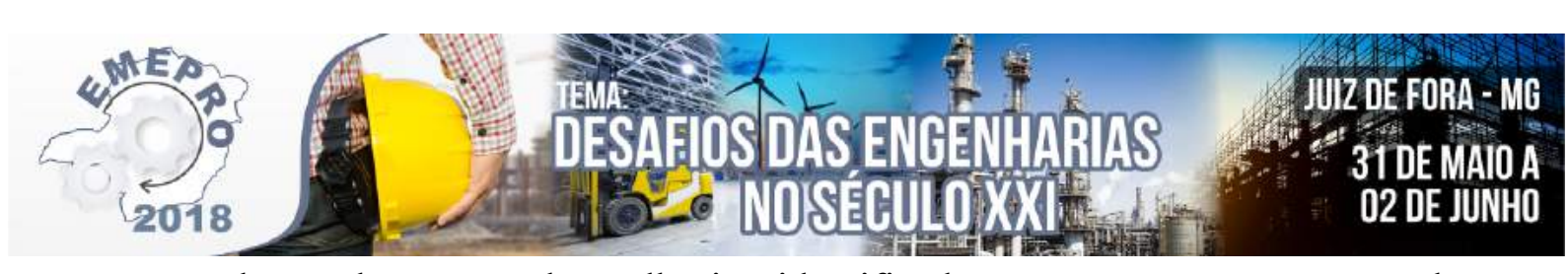

relação de pontos de melhorias identificados na prospecção versus soluções possíveis;

2) Planejamento: Período de duas semanas em junho focadas na criação dos documentos que seriam implementados, bem como de visitas na instituição para obtenção de feedbacks acerca das modificações que seriam implementadas e da maneira que eram executadas antes do projeto. Enquanto isso, o Marketing já avaliava as mídias sociais e começava a criar um guia de melhorias e sugestões para gerar uma maior atratividade;

3) Treinamento e Execução: Período de quatro semanas em julho e agosto, com quatro visitas na instituição onde houve o treinamento dos voluntários do local sobre o preenchimento dos novos documentos de cadastro de famílias e controle de doações criados, além de aplicação dos novos formulários com as famílias cadastradas;

4) Encerramento do Projeto: Visita para conclusão e obtenção de feedback da instituição, além de agendamento de futuras visitas de retorno para avaliar o andamento das mudanças.

5) Visitas de retorno: Foram realizadas três visitas de retorno no projeto com objetivo verificar a utilização e aproveitamento das novas metodologias implementadas, bem como caso necessário adequar a realidade/dificuldades da instituição. As visitas de retorno no departamento de Projetos, são realizadas conforme um período após a finalização do projeto, a frequência utilizada para tal foram 1 mês, 3 meses e 6 meses após o término do projeto.

É importante ressaltar que a execução do projeto baseou-se no ciclo PDCA (Planejar - Executar - Verificar - Agir), metodologia que proporciona uma melhoria contínua dos processos. As duas primeiras etapas citadas acima: visita de diagnóstico e planejamento corresponde a planejar o projeto, uma vez que nelas foram identificadas os pontos de melhoria, a partir disso foi traçado caminho que deveria ser percorrido para solucionar os pontos observados. A etapa de Treinamento e Execução corresponde ao fazer, caracterizado por colocar em prática o que foi planejado e preparar os voluntários para a melhor execução da nova metodologia de trabalho, buscando a melhoria contínua da gestão interna da instituição.Na etapa de Encerramento do Projeto equivale a etapa de verificar, pois ocorre análise dos resultados alcançados com as melhorias realizadas e combinado as visitas de retorno que teve como objetivo continuar verificando os resultados e caso necessário seria realizadas ações corretivas para corrigir falhas encontradas. Além disso, o projeto foi realizado utilizando o PDCA para que essa metodologia entrasse cultura da instituição para que ela aproveite do ciclo PDCA e em todo o processo foi incentivado a participação dos responsáveis pela instituição para que eles consiga manter essa cultura mesmo após o término do projeto pelo Engenheiros Sem Fronteiras.

Além de todas as atividades realizadas dentro da instituição foram feitas também muitas atividades internas de planejamento para que o projeto acontecesse conforme o esperado e desse o resultado almejado. Com isso, segue abaixo o cronograma com todas as atividades realizadas tanto interna quanto externamente: 


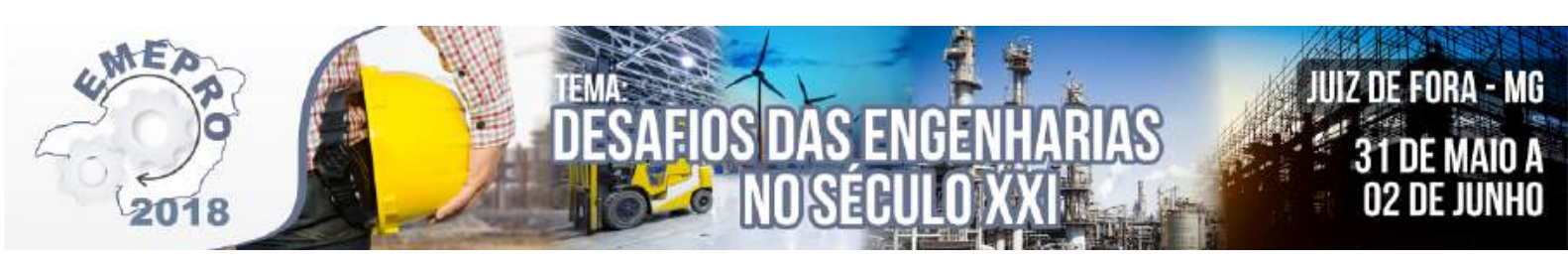

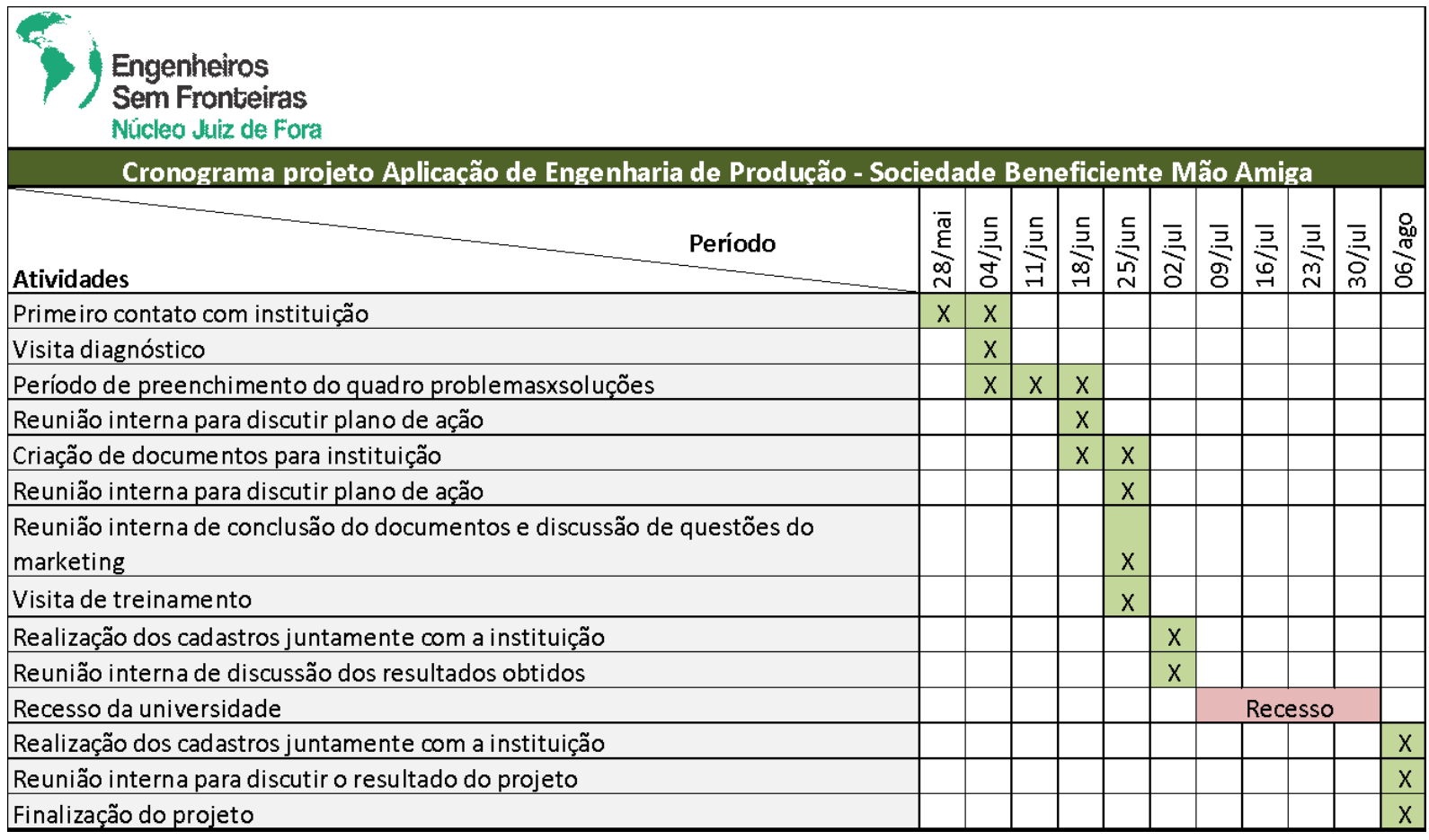

FIGURA 3: Cronograma do Projeto Aplicação de Engenharia de Produção - Sociedade Beneficente Mão Amiga. Fonte: Elaborado pelos autores (2017).

Os métodos utilizados para a realização do projeto incluíram o uso do pacote Office para a criação e adequação dos novos documentos, visitas de treinamento e cadastro inicial de um número expressivo de famílias para dessa forma já trazer essa cultura para a instituição e analisar as ações.

\section{RESULTADOS E DISCUSSÃO}

O projeto obteve a criação de três documentos principais na instituição, sendo estes adequados a realidade do local e baseados em feedbacks contínuos realizados com os funcionários do local, ou seja, foram documentos mais simples que fossem viáveis a serem mantidos pela instituição, foram criados os seguintes documentos:

- Formulário de cadastro: Dados do responsável e dependentes da família, endereço, renda familiar e projetos que participavam na instituição e associado as doações recebidas por cada família;

- Lista de presença mensal: Listagem com o nome dos responsáveis e marcação de entrega realizada no mês vigente. Essa lista auxiliaria a instituição a ter controle de quais famílias foram atendidas em cada mês, além de conseguir priorizar melhor seu foco de atendimento a famílias menos beneficiadas. Antes a instituição não tinha um controle específico acabando por realizar doações desproporcionais a algumas famílias;

- Controle financeiro do bazar: Formulário de entradas e saídas de valores da instituição. O Bazar da Sociedade Beneficente Mão Amiga, é a principal fonte de renda de funcionamento do local, e não possuía um controle anteriormente, dessa forma conseguiríamos ter um controle de caixa efetivo. 


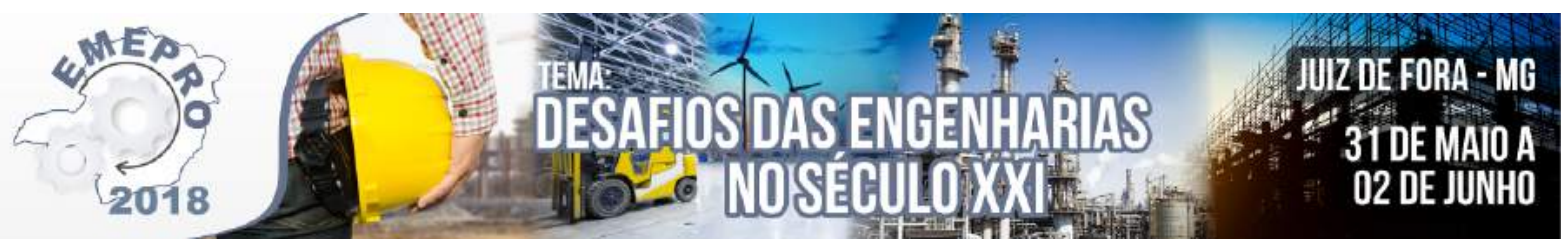

As visitas para treinamento e execução fluíram com bastante facilidade sendo cadastrados 57 núcleos familiares diretamente, 173 dependentes indiretamente e 5 funcionários treinados com o formato novo de cadastro. O projeto teve um alcance de 235 pessoas impactadas. Abaixo seguem imagens do treinamento e execução dos formulários com as famílias.

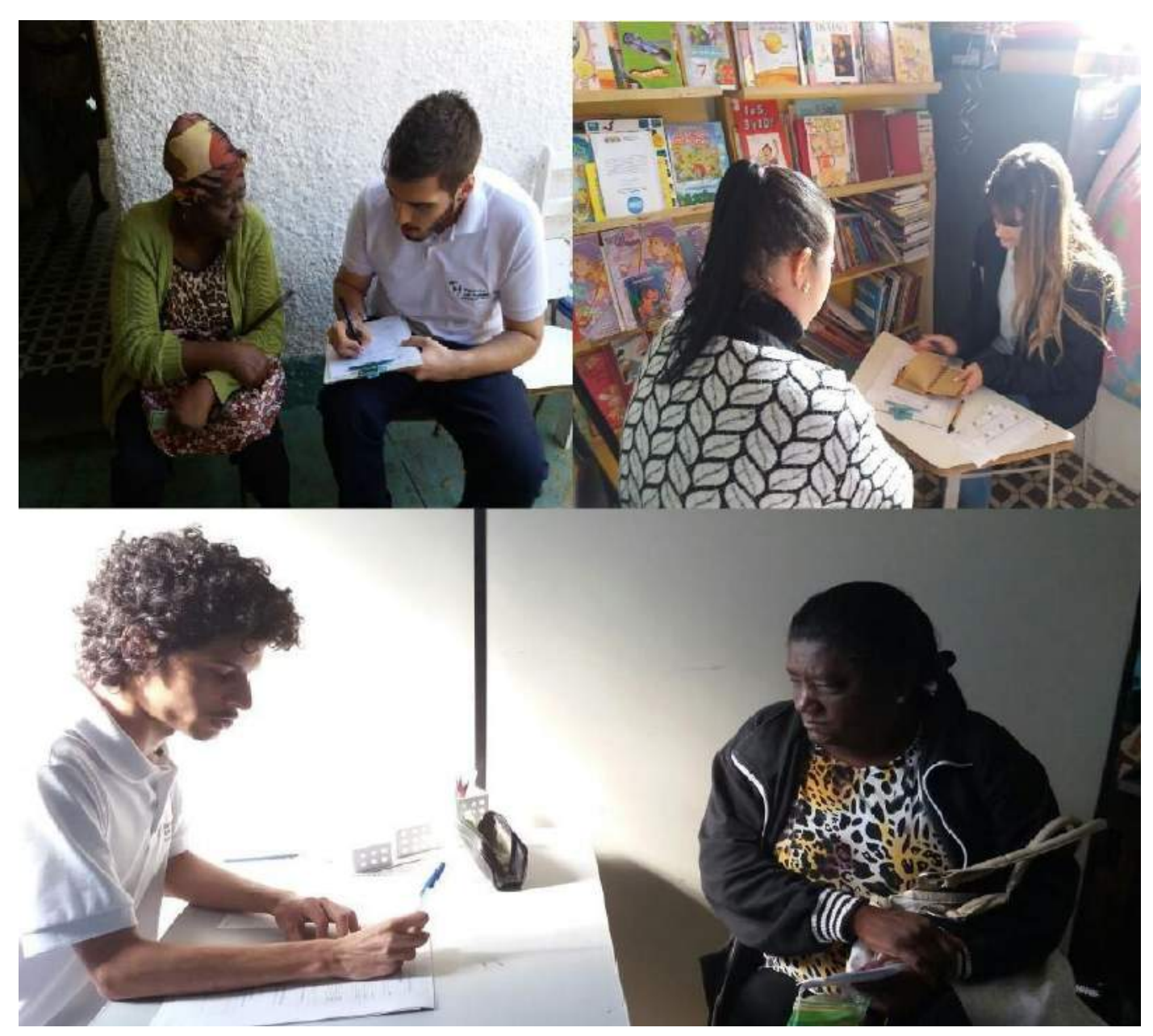

FIGURA 4: Projeto de Aplicação de Engenharia de Produção - Sociedade Beneficente Mão Amiga -

Treinamento e Execução. Fonte: Arquivo Engenheiros sem Fronteiras - JF (2017)

Com relação ao marketing das mídias sociais da instituição, criamos um guia de "Planejamento das Mídias Sociais" esse foi repassado para a responsável pela página do Facebook da instituição. Neste guia foi estruturada uma estratégia para a realização das postagens, melhores horários e periodicidade para as postagens, ideias para serem aplicadas nos aniversários de fundação além de formas de captação de parceiros.

O Engenheiros Sem Fronteiras - Núcleo Juiz de Fora realiza em alguns de seus projetos após uma análise de necessidade visitas de retorno, essas visitas têm por objetivo verificar o andamento dos resultados do projeto, além de avaliar possíveis correções a serem implementadas. As visitas ocorrem por preferência com o gerente original do 


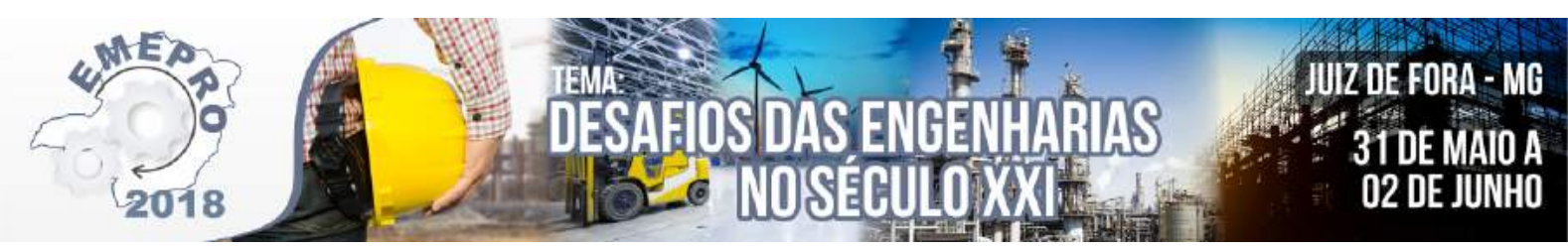

projeto, este confere o relatório de encerramento para verificar quais etapas foram concluídas e realiza um feedback com a instituição dessa forma identificando se há alguma ação corretiva ou de melhoria a ser realizada. $\mathrm{Na}$ instituição as visitas já foram concluídas em março de 2018, com 3 visitas realizadas, nelas foram constatadas o aproveitamento das correções realizadas, sendo elas o dobro de famílias cadastradas no formulário, utilização do controle de caixa e diversas sugestões implementadas nas redes sociais.

\section{CONSIDERAÇÕES FINAIS}

Por fim, o presente projeto foi executado como modelo e gerou uma continuidade dentro do Engenheiros Sem Fronteiras - Núcleo Juiz de Fora, atualmente, já estamos na terceira instituição com o modelo desse projeto sendo reproduzido. $\mathrm{O}$ alto impacto, o baixo custo associado, e acompanhamento com as visitas de retorno são o que impulsionam e geram o bom aproveitamento deste trabalho. Com a finalização do projeto foi alcançado a maior organização e padronização dos documentos referentes ao cadastro, bem como nas visitas de retorno foram observadas a utilização por parte da instituição desses métodos. Com relação às estratégias de marketing, a instituição no início do projeto possuía duas páginas do Facebook o que dificulta as suas estratégias de marketing, com a finalização do projeto a instituição utilizou apenas uma página e procura atualmente divulgar suas ações e necessidades de doações na página, para que mais pessoas tenham conhecimento acerca do trabalho da instituição e realizado de acordo com o guia "Planejamento das Mídias Sociais". Além disso, a realização do projeto nessa instituição foi satisfatório tanto para a Sociedade Beneficente Mão Amiga quanto para o Engenheiros sem Fronteiras, pois criou uma maior aproximação entre as duas e foi conseguindo maior divulgação de ambas, atingindo assim uma parcela da sociedade e criando uma parceria entre elas.

\section{REFERÊNCIAS BIBLIOGRÁFICAS}

ANDRADE, F. F. O Método de Melhorias PDCA. 2003. 157 p. Dissertação (Mestrado em Engenharia de Construção Civil e Urbana) - Escola Politécnica, Universidade de São Paulo, 2003

BARROS, Raissa B., Marketing Social aplicado a ONGs, Brasília, 2013. VIEIRA, Renata M. F., Elaboração de Projetos Sociais: Uma Aplicação, Florianópolis, 2001.

PEDROSA, Antônio C. G.,; CABRAL, Augusto C. A.; PESSOA, Maria N. M.; PARENTE, Tobias C.; PENHA, Emanuel D. S; ALVES, Rafael A., Competência Gerencial No Terceiro Setor: Um Estudo em Organizações Não Governamentais na Cidade de Fortaleza-Ceará, São Paulo, 2009, XXXIII EnANPAD 


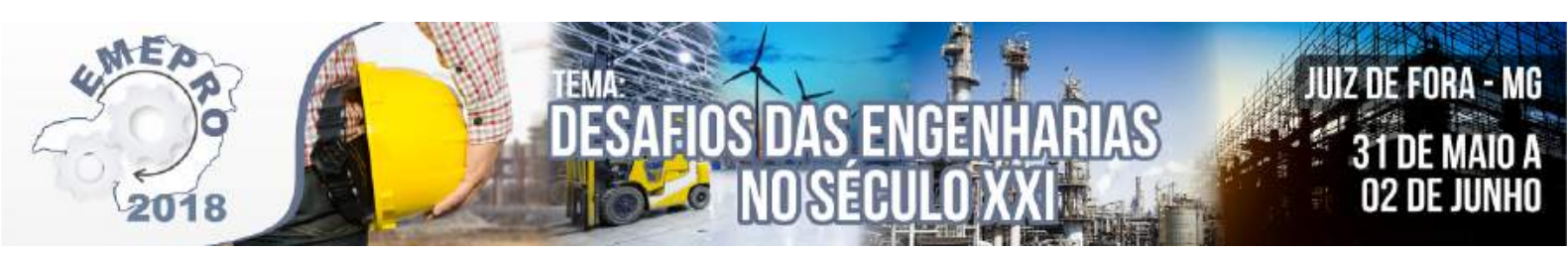

Antonio Celso Gonçalves Pedrosa, Augusto Cézar de Aquino Cabral, Maria Naiula Monteiro Pessoa, Tobias Coutinho Parente, Emanuel Dheison dos Santos Penha, Rafael de Almeida Alves 


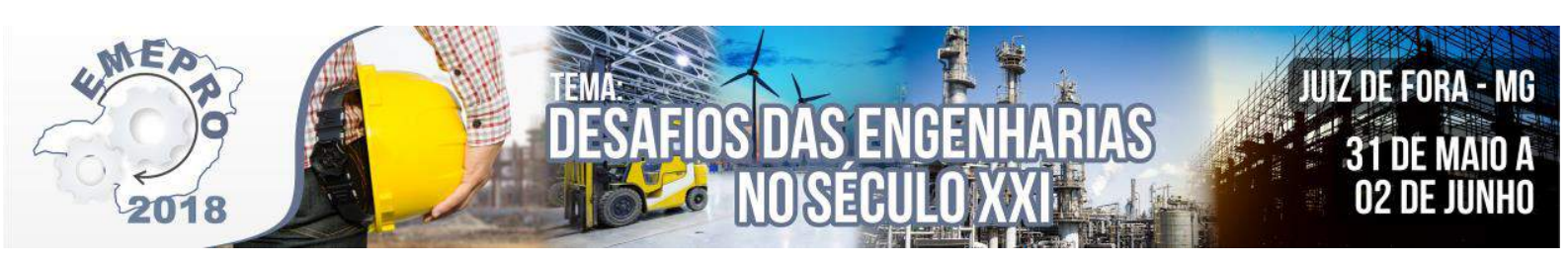

\title{
Avaliação da matriz elétrica da região Norte Fluminense por meio estimativa do índice de renovabilidade
}

\author{
Wallan Azevedo dos Santos (IFFluminense) wallan.azevedo@hotmail.com \\ Milton Erthal Júnior (IFFluminense/UCAM) miltonerthal@hotmail.com
}

\begin{abstract}
Resumo: O uso de combustíveis fósseis para geração de eletricidade produz quantidades significativas de Gases do Efeito Estufa como o dióxido de carbono $\left(\mathrm{CO}_{2}\right)$, dióxido de enxofre $\left(\mathrm{SO}_{2}\right)$, óxidos de nitrogênio $\left(\mathrm{NO}_{x}\right)$. A Bacia de Campos localizada na Mesorregião Norte Fluminense do estado do Rio de Janeiro é considerada a maior produtora de petróleo e gás natural do Brasil, fato que levanta discussões acerca da sustentabilidade do setor energético da região. Assim, este trabalho tem como objetivo de avaliar o grau de sustentabilidade da matriz elétrica da Região Norte do Estado do Rio de Janeiro através da utilização do Índice de Renovabilidade. Como resultado a região Norte Fluminense apresentou um índice de Renovabilidade na geração de energia elétrica de 5\%. Esse baixo valor indicou a necessidade do desenvolvimento de políticas públicas quanto ao incentivo do uso de fontes renováveis na geração de energia elétrica em substituição de combustíveis fósseis. Apesar da predominância do gás natural (95\%) da matriz elétrica da região, esta apresentou um alto potencial fotovoltaico, eólico e de biomassa que poderiam ser mais explorados de forma sustentável, mitigando os impactos negativos gerados pelas fontes não renováveis.
\end{abstract}

Palavras-chave: Índice de renovabilidade; Fontes Renováveis; Matriz Elétrica; Sustentabilidade.

\section{Introdução}

A Região Sudeste é uma das regiões mais importantes do Brasil, possuindo um grande destaque industrial e econômico (cerca de 50\% do PIB Nacional), e nela localiza-se o Estado do Rio de Janeiro. O Estado Fluminense possui forte participação na matriz energética do País, contribuindo com $10 \%$ da geração total de eletricidade nacional e $31 \%$ da capacidade nacional instalada na região (cerca de $44.112 \mathrm{MW}$ ). Além disso, é considerado o maior produtor de petróleo e gás natural do país, concentrado na Bacia de Campos, localizada na Mesorregião Norte Fluminense do estado (EPE, 2016).

A Mesorregião Norte Fluminense (NF) é uma das seis mesorregiões pertencentes ao estado do Rio de Janeiro, caracterizado pela união entre nove municípios, sendo esses: Campos dos Goytacazes, Carapebus, Cardoso Moreira, Conceição de Macabu, Macaé, Quissamã, São Fidélis, São Francisco de Itabapoana e São João da Barra. Destaca-se por possuir uma área de $9.730 .443 \mathrm{~km}^{2}$ e apresentar o maior PIB per capita entre as demais mesorregiões do estado. A economia da região é sustentada principalmente por atividades petrolíferas em Macaé e pela economia agroindustrial de Campos dos Goytacazes. Nesta região se encontram os maiores investimentos na Indústria de Petróleo no Brasil, fazendo com que o Brasil seja reconhecido como um dos líderes mundiais em exploração e produção em águas profundas. Em 2013, a produção de petróleo e gás natural da Bacia de Campos foi responsável por 99,2\% da produção estadual de energia primária (ANP, 2015). 


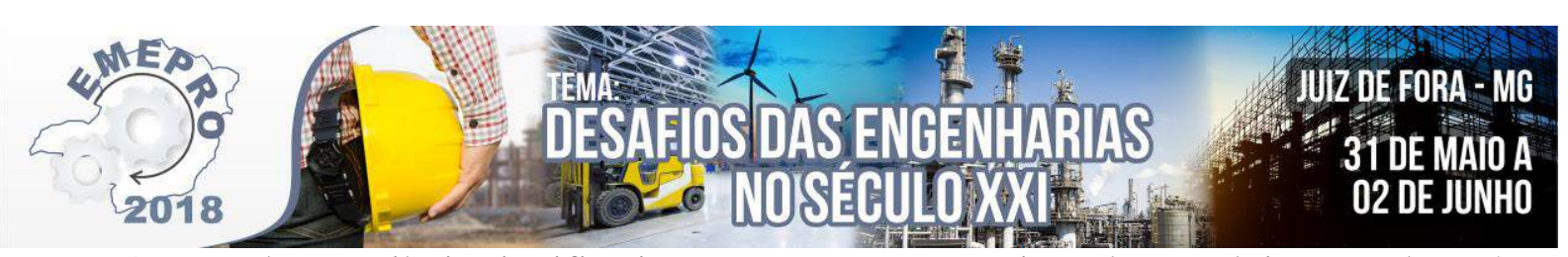

Apesar de contribuir significativamente para economia e desenvolvimento do país, a região NF apresenta forte predominância de combustiveis fósseis na geração de energia elétrica, o que intensifica as discussões acerca das questões ambientais que norteiam o setor energético. $\mathrm{O}$ uso de combustíveis fósseis para geração de eletricidade produz quantidades significativas de Gases do Efeito Estufa como o dióxido de carbono $\left(\mathrm{CO}_{2}\right)$, dióxido de enxofre $\left(\mathrm{SO}_{2}\right)$, óxidos de nitrogênio $\left(\mathrm{NO}_{\mathrm{x}}\right)$. Atualmente, as preocupações ambientais se tornaram um dos mais importantes pilares da segurança energética, refletindo diretamente nas políticas deste setor (BIRESSELIOGLU; KARAIBRAHIMOGLU, 2012).

Tendo em vista aspectos técnicos, econômicos, sociais e ambientais, as energias renováveis são consideradas as opções mais interessantes para quebrar o paradoxo atual do setor de energia já que as fontes de energias renováveis são parâmetros fundamentais para o desenvolvimento sustentável de um país, contribuindo para a minimização das crises energéticas em virtude da diminuiçao do uso dos combustíveis fósseis e da melhoria da utilização dos recursos naturais (BALTA; DERVOS, 2012; SANTOS et al. 2017). Torna-se fundamental avaliar e monitorar a sustentabilidade do setor elétrico de determinada região.

Os princípios do desenvolvimento sustentável estão baseados na ideia de possuir um modelo de desenvolvimento capaz de utilizar os recursos naturais de forma racional e sustentável a fim de atender as necessidades da geração atual, sem comprometer as possibilidades de atender as necessidades das gerações futuras. Nas últimas duas décadas, uma lista em contínuo crescimento de índices e indicadores de sustentabilidade foram introduzidas na comunidade científica com o objetivo de sensibilizar a opinião pública quanto as pressões exercida pelo homem sobre o ambiente. Atualmente, os índices e indicadores de sustentabilidade mais utilizados cientificamente são: a Pegada Ecológica (do inglês Ecological Footprint); o Índice de Sustentabilidade Ambiental ou ESI (do inglês Environmental Sustainability Index); Análise Emergética e o Índice de Renovabilidade (MENDES, 2013; PAULISTA et al., 2016).

O índice de renovabilidade é uma ferramenta útil para avaliar o percentual de recursos renováveis na geração de eletricidade de uma região fornecendo informações sobre a sustentabilidade no uso dos recursos locais (ERTHAL; MENDES, 2013). Este índice constitui-se na razão entre o somatório das energias renováveis utilizadas em um sistema pela energia total utilizada no mesmo sistema. Tendo em vista a importância energética e econômica da região do NF em nível Nacional, este estudo se propõe em avaliar o grau de sustentabilidade da matriz elétrica da Região Norte do Estado do Rio de Janeiro utilizando o Índice de Renovabilidade.

\section{Metodologia}

A metodologia utilizada neste trabalho foi realizada a partir da efetivação de duas etapas sequenciais e complementares: Coleta e Tratamento dos dados e Interpretação dos resultados.

Os dados utilizados para avaliação da matriz elétrica da região NF e a estimativa do índice de renovabilidade (REN) foram obtidos a partir dos dados do Banco de Informações de Geração da (BIG) da Agência Nacional de Energia Elétrica em Novembro de 2016 (ANEEL, 2016).

Para determinação deste índice, classificaram-se previamente os sistemas de geração de eletricidade da região, em fontes renováveis e não renováveis de energia a partir de uma 


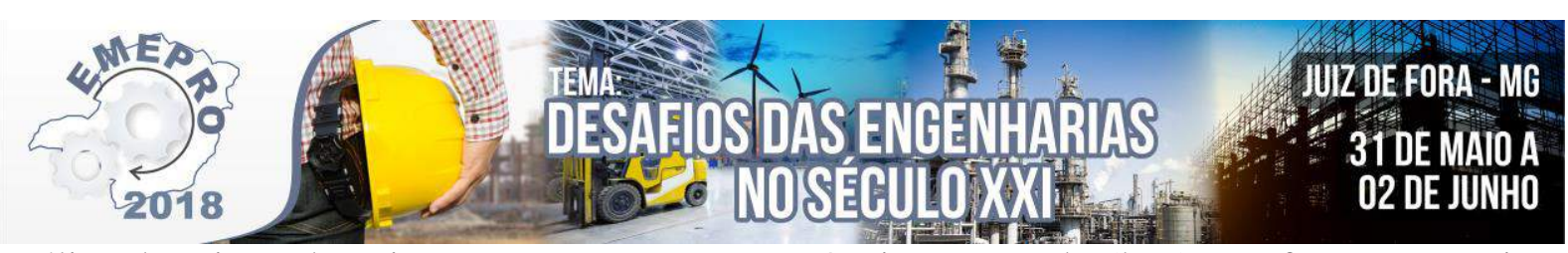

análise dos tipos de usinas em operação e a potência outorgada $(\mathrm{kW})$, conforme a seguinte Equação 1 .

$$
R E N(\%)=\Sigma \frac{P R}{P T} \times 100
$$

Onde:

REN $(\%)=$ Renovabilidade da geração de eletricidade a partir das fontes primárias;

$\Sigma \mathrm{PR}=$ Somatório da $(\mathrm{kW})$ de potência elétrica outorgada da geração de eletricidade a partir das fontes primárias renováveis

$\Sigma \mathrm{PT}=$ Somatório da potência elétrica total outorgada da geração de eletricidade a partir de todas as fontes primárias $(\mathrm{kW})$.

O resultado da Equação 1 indica que quanto mais próximo de 100\%, mais renovável é a matriz elétrica, encontrando-se em um estado de harmonia ambiental. Um resultado abaixo de $50 \%$ indica a necessidade de mudanças na matriz elétrica.

\section{Resultados e Discussão}

A partir da coleta de dados no BIG e classificação das fontes primárias de energia, foi obtido para a região NF um valor de $91.050 \mathrm{~kW}$ de potência elétrica outorgada da geração de eletricidade a partir das fontes primárias renováveis, e $1.872 .617 \mathrm{~kW}$ potência elétrica total outorgada da geração de eletricidade a partir de todas as fontes primárias. Foi obtido a partir da Equação 1, o nível de renovabilidade da matriz elétrica do da região NF do Estado do Rio de Janeiro.

$$
\operatorname{REN}(\%)=\frac{91.050}{1.872 .617} \times 100=5 \%
$$

A região Norte Fluminense apresentou um índice de renovabilidade de apenas 5\%, traduzidos na necessidade de se melhorar a sustentabilidade do parque gerador de eletricidade da região. Isso pode ser explicado devido a predominância da utilização de recursos de origem não renovável para geração de eletricidade, como a expressiva participação de $95 \%$ do gás natural em sua matriz elétrica (Figura 1).

O gás natural é, sem dúvida, um dos elementos energéticos de maior flexibilidade no consumo, no mundo atual. As políticas econômicas de incentivo ao seu uso, adotadas nos últimos anos no Brasil, contribuíram bastante para a penetração desse combustível na matriz energética nacional. O Estado do Rio de Janeiro, especialmente a região Norte Fluminense, concentra a maior parte das Unidades de Processamento de Gás Natural (UPGN) existentes no Brasil. 


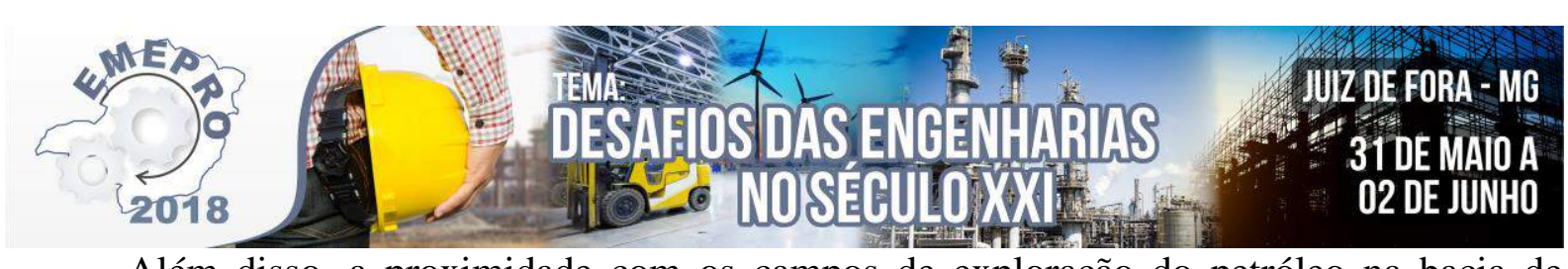

Além disso, a proximidade com os campos de exploração do petróleo na bacia de Campos que facilita a logística do transporte de gás natural, o que possibilitou a construção de 2 (duas) termelétricas no município de Macaé, a termoelétrica Mário Lago (antiga Macaé Merchant) e Norte Fluminense. Sua participação hoje no consumo final e nas centrais termoelétricas é considerada essencial e indispensável para a geração elétrica na região Norte Fluminense e no Estado do Rio de Janeiro (RIO DE JANEIRO, 2016).

Apesar do gás natural ser considerado uma fonte estratégica de produção para o estado fluminense, do ponto de vista ambiental a utilização de gás natural para produção de energia elétrica é negativa, já que este é proveniente de combustível fóssil, gerando gases que contribuem para intensificação do efeito estufa no planeta. Além disso, a utilização do gás natural em termoelétricas aumenta o custo tarifário $(\mathrm{kWh})$ para o consumidor final, visto que essa fonte consisite em uma matéria prima de custo elevado quando comparado por exemplo com a geração hidrelétrica. A utilização de fontes alternativas de energia para geração de eletricidade, é uma das principais saídas para mitigação dos problemas ambientais referentes a intensificação do Efeito Estufa, sendo o Norte Fluminense um dos vetores de contribuição para este tipo de problema ambiental

\section{Matriz Elétrica do Norte Fluminense}

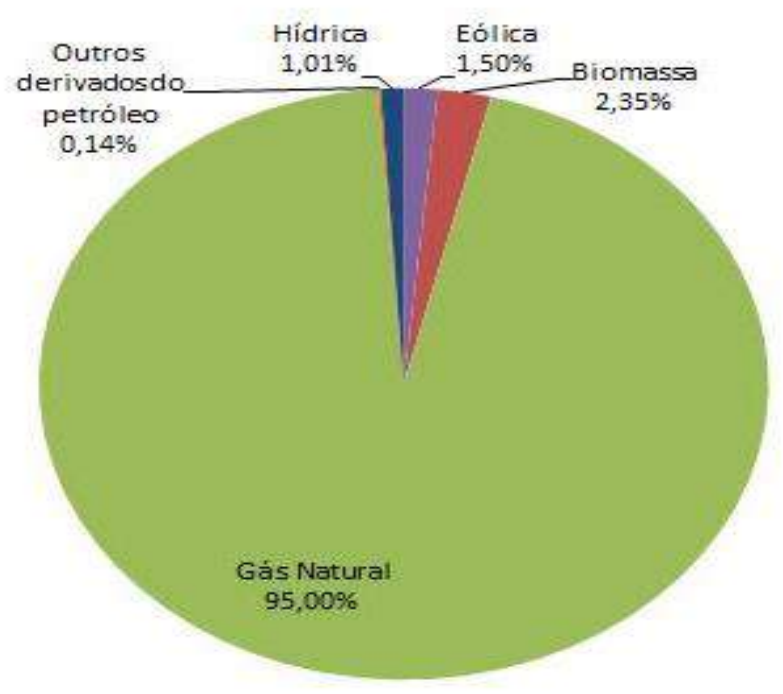

FIGURA 1 - Matriz elétrica da Região Norte Fluminense. Fonte: ANEEL (2016)

O cenário da geração de eletricidade por fontes renováveis na região Norte Fluminense apresentou uma participação de apenas $4,86 \%$, se contrastando com a matriz elétrica brasileira que possui por sua vez uma participação das fontes renováveis de aproximadamente $81 \%$.

Apesar de historicamente, a região NF apresentar uma abundância no cultivo e produção de cana-de-açúcar, esta ainda é pouco utilizada na geração de energia elétrica de forma complementar. $\mathrm{O}$ aumento de sua participação na matriz elétrica poderia proporcionar diversos benefícios ao meio ambiente e ao setor energético, podendo ser utilizada de forma 


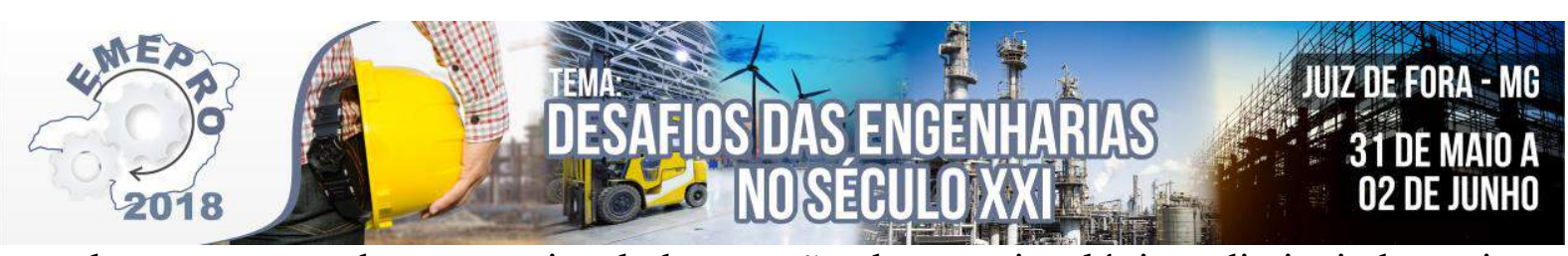

complementar na rede convencional de geração de energia elétrica, diminuindo assim a utilização de combustíveis fósseis e contribuindo efetivamente em períodos de seca, já que os reservatórios de água tendem a diminuir drasticamente (GOLDEMBERG, 2009). Além do uso da cana de açucar, o mesmo poderia ser feito quanto ao incentivo de produção de energia elétrica a partir de resíduos sólidos e líquidos em lixões, nas fossas coletivas e nas estações de tratamento de esgoto, mitigando a poluição ambiental causado por estes fatores.

A discussão pode ser estendida a geração de energia solar, que apesar de não possuir atualmente usinas solares no estado fluminense, a radiação solar anual média incidente neste território varia entre 1,75 e $4,25 \mathrm{kWh} / \mathrm{m}^{2}$ dia, sendo a região $\mathrm{NF}$ uma das áreas com o maior potencial para produção de energia solar fotovoltaica no estado, destacando a cidade de Campos dos Goytacazes (Figura 2) (AMÉRICA DO SOL, 2016).

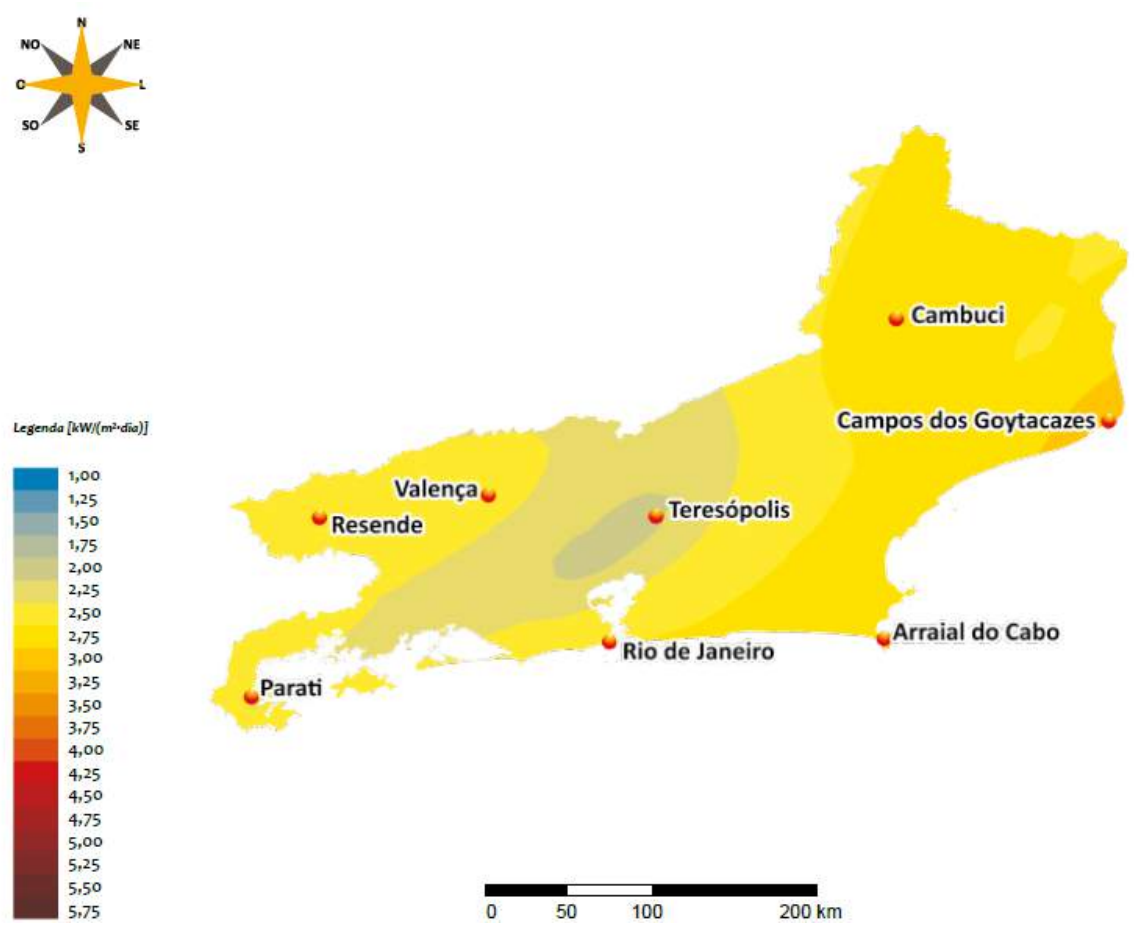

FIGURA 2 - Potencial de energia solar na região sudeste do Brasil. Em destaque a cidade de Campos dos Goytacazes localizada na região Norte Fluminense. Fonte: Atlas Rio Solar (2016).

Quanto a energia eólica, o território do litoral norte fluminense consiste em uma extensa planície costeira com baixa rugosidade e regimes de vento propícios a aproveitamentos eólicos com velocidades médias anuais em torno de $6,5 \mathrm{~m} / \mathrm{s}$ (a $50 \mathrm{~m}$ de altura) (CRESESB, 2002). Segundo o Atlas da Energia Eólica do estado do Rio de Janeiro (2002), conforme Figura 3, as regiões com ventos médios anuais mais intensos situam-se no litoral Norte Fluminense, nos municípios de São Francisco de Itabapoana, São João da Barra e Campos dos Goytacazes (região 1); na Região dos Lagos, os municípios de Cabo Frio e Búzios (região 2), e também na região serrana, no polígono Piraí-Vassouras-Petrópolis (região 3). 

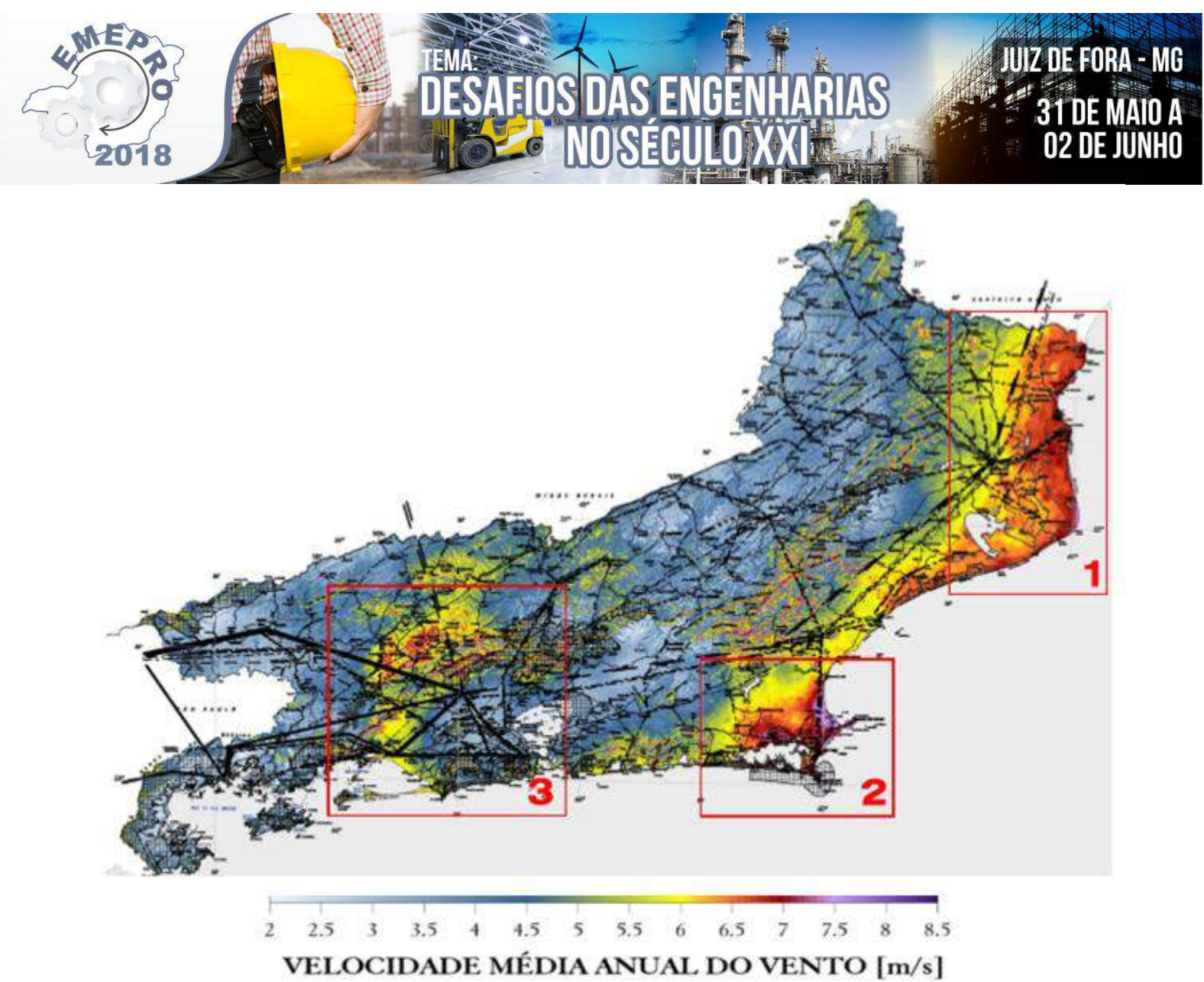

FIGURA 3- Regiões com Potencial Eólico no Estado do Rio de Janeiro. Fonte: Atlas Eólico do Estado do Rio de Janeiro (2002)

Iniciativas que visem o aproveitamento desta fonte na região já vêm sendo tomadas como o Programa de Incentivo às Fontes Alternativas de Energia Elétrica (PROINFA) do Ministério das Minas e Energia do governo brasileiro. Nesse contexto, foi construída em 2010 a Central de Geração Eólica de Gargaú (CGE Gargaú) administrada pela empresa Omega Energia que possui 17 aerogeradores de 1,653 MW, totalizando 28,1 MW.

Em vista da região NF ser bastante ensolarada o ano inteiro e com ventos constantes na sua região costeira, seria muito interessante o desenvolvimento e a introdução da geração híbrida de forma, na qual há uma combinação da geração eólica e fotovoltaica. Esse tipo de geração é muito atrativa, em vista dos diversos benefícios proporcionados por cada fonte isoladamente,podendo ser aplicado em regiões de díficil acesso à eletricidade, como comunidades rurais e isoladas. Sistemas híbridos de energia trazem um maior rendimento e retornos econômicos e ambientais do que sistemas independentes de geração de energia eólica, solar, hídrica e biomassa.

Considerando que grande parte da região Norte-Fluminense se encontra em uma planície sedimentar, com pequenas quedas d'água em seus rios, o aproveitamento de energia para construção de hidrelétricas não é muito bom, o que justifica a pequena participação de $1,01 \%$ na matriz elétrica da região. Como alternativa frente a essa situação, seria a construção de Pequenas Centrais Hidrelétricas - PCHs, ou aproveitamento dentro das técnicas possíveis na engenharia dos fluxos hídricos dos rios que norteiam a região.

O incentivo da utilização destas fontes energéticas renováveis poderiam auxiliar gestores dos setores públicos e privados a gerarem sua própria energia elétrica e ainda vender 


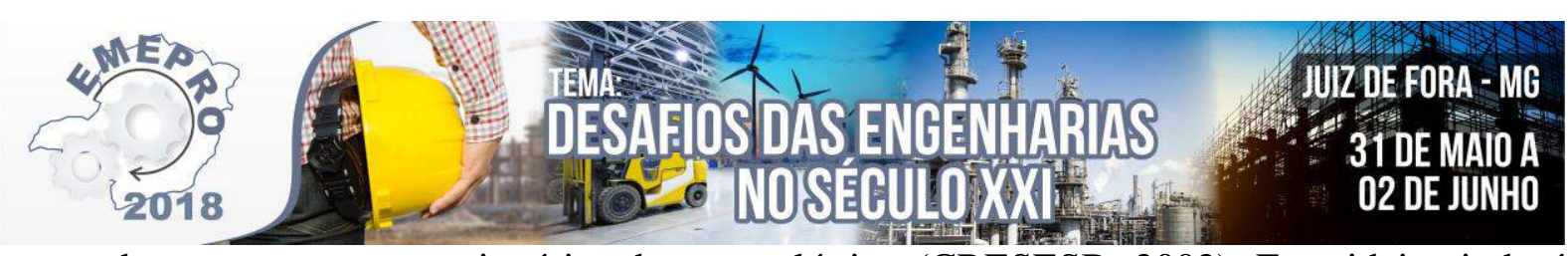

o excedente para as concessionárias do setor elétrico (CRESESB, 2002). Essa ideia ainda é mais interessante do ponto de vista ambietal, visto que reduziria a emissão de GEEs derivados da geração de energia por combustíveis fósseis, aproveitamento de resíduos sólidos lançados de forma incorreta na natureza, preserva a capacidade de suporte dos ecossistemas e mitiga os efeitos do aquecimento global.

\section{Considerações Finais}

Devido a forte predominância da utilização de gás natural na geração de eletricidade, a região Norte Fluminense apresentou um índice de renovabilidade de apenas 5\%. Entretanto, a região apresentou possuir condições propícias para a implementação de fontes de energia alternativa, visto que as incidências solar, eólica e a biomassa apareceram de forma abundante no território analisado. Essas fontes apresentam altos potenciais energéticos que poderiam ser mais bem aproveitados, inclusive de forma combinada como na geração híbrida. Os resultados encontrados neste trabalho poderá servir de ferramenta auxiliar no avanço do estudo de geração elétrica a partir de fontes alternativas, o que mitigaria os impactos ambientais causados pela produção de energia elétrica derivado de combustíveis fósseis.

\section{Referências}

AGÊNCIA NACIONAL DE ENERGIA ELÉTRICA. Banco de Informações da Geração (BIG) - Capacidade de Geração do Brasil. $2016 . \quad$ Disponível em: <http://www.aneel.gov.br/aplicacoes/capacidadebrasil/capacidadebrasil.asp>. Aces-sado em: 02 de dezembro de 2016.

AGÊNCIA NACIONAL DE ENERGIA ELÉTRICA. Resolução Normativa n ${ }^{\circ} 235$ de 14/11/2006. Estabelece os requisitos para a qualificação de centrais termelétricas cogeradoras de energia e dá outras providências. 2016 Disponível em: <http://www2.aneel.gov.br/cedoc/ren2006235.pdf>. Acessado em 27 de novembro de 2016.

AGÊNCIA NACIONAL DO PETRÓLEO. Dados Técnicos, $2016 . \quad$ Disponível em:<http://www.anp.gov.br/wwwanp/exploracao-e-producao-de-oleo-e-gas/dados tecnicos/acesso-aos-dadostecnicos $>$.Acessado em 27 de novembro de 2016.

AMÉRICA DO SOL. Conhecimento em Energia Fotovoltaica, 2016. Disponível em: <http://www.cresesb.cepel.br/publicacoes/download/atlas_eolico/Atlas\%20do\%20Potencial\%20Eolico\%20Brasi leiro.pdf $>$. Acessado em: 01 de dezembro de 2016.

Atlas Rio Solar. Atlas Solarimétrico do Estado do Rio de Janeiro. IEPUC - Instituto de Energia da PUC-Rio. Rio de Janeiro : Ed. PUC-Rio, 2016.

BALTA, A. E.; DERVOS, A. N. Special framework for the spatial planning \& the sustainable development of renewable energy sources. Renewable Energy. Elsevier, 2012. Disponível em: <http://www.sciencedirect.com/science/article/pii/ S0960148112003369>. Acessado em 01 de dezembro de 2016.

BIRESSELIOGLU, M. E.; KARAIBRAHIMOGLU, Y. Z. The government orientation and use of renewable energy: Case of Europe. Journal Renewable Energy. n. 47, p. 29-37, 2012.

CENTRO DE REFERÊNCIA PARA ENERGIA SOLAR E EÓLICA SÉRGIO DE SALVO BRITO CRESESB- Estado do Rio de Janeiro - Atlas Solar e Eólico, 2012. Disponível em: http://www.cresesb.cepel.br/publicacoes/download/atlas_eolico/AtlasEolicoRJ.pdf $>$. Acessado em 03 de Dezembro de 2016

EMPRESA DE PESQUISAS ENERGÉTICAS. Balanço Energético Nacional (BEN), 2016. disponível em: 


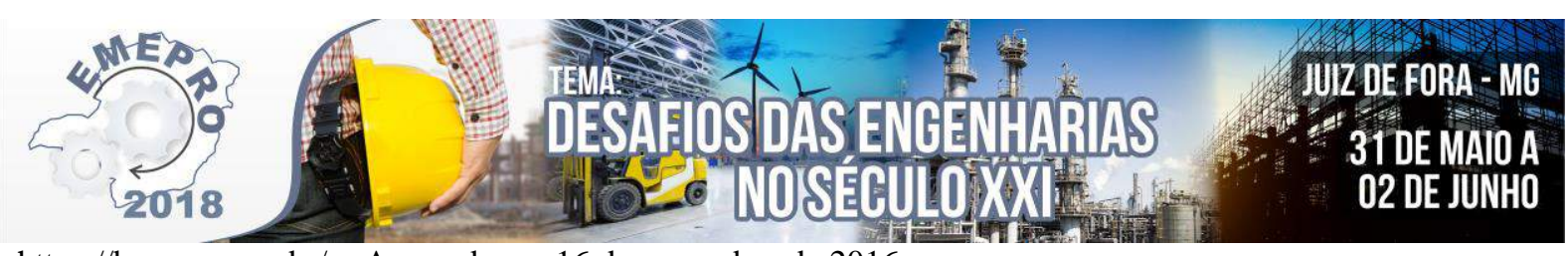

<https://ben.epe.gov.br/>. Acessado em 16 de novembro de 2016.

ERTHAL, MILTON; MENDES, L. F. R..Considerações sobre a matriz elétrica do estado do Rio de Janeiro sob a ótica do índice de renovabilidade. In: I EINEPRO - Encontro Interestadual de Engenharia de Produção, 2015, São João da Barra - RJ. Considerações sobre a matriz elétrica do estado do Rio de Janeiro sob a ótica do índice de renovabilidade, 2015.

RIO DE JANEIRO. BALANÇO ENERGÉTICO DO ESTADO DO RIO DE JANEIRO 2014. GOVERNO DO ESTADO DO RIO DE JANEIRO, 2016 Disponível em: www.rj.gov.br/ Acessado em 08 de Dezembro de 2016.

GOLDEMBERG, J. Biomassa e energia. Revista Química Nova. v.32, n.3, p. 582-587, 2009.

MENDES, L.F.R.; HOSKEN, L.A.L.; GOMES, G.R.R. Estudo de viabilidade para implantação de energias renováveis no distrito de Farol de São Thomé - Campos dos Goytacazes/ RJ utilizando mineração de dados. In: SIMPÓSIO DE ENGENHARIA DE PRODUÇÃO (18). Anais. Bauru/SP, 2011. ISSN: 1809-7189.

MINISTÉRIO DAS MINAS E ENERGIA. Programa de Incentivo às Fontes Alternativas de Energia Elétrica (PROINFA). Disponível em : <http://www.mme.gov.br/programas/ proinfa/>. Acessado em 20/11/2016

PAULISTA, C. R. ; CAVADAS, L. S. ; ERTHAL JUNIOR, M. ; SANTOS, R. A. ; SANTOS, W. A.; HORA, H. R. M. . Desenvolvimento de metodologia para cálculo da Pegada Ecológica de discentes de pós-graduação em uma instituição de ensino. Anais VI ENFEPro Encontro Fluminense de Engenharia de Produção, Niterói - RJ, 2016.

SANTOS, W. A.; PAUliStA, C. R. ; PESSANHA, D. C. ; ERTHAL JUNIOR, M. ; REIS, A. C. Uma Breve Análise Da Utilização Da Liga De Alumínio 6061 Em Carrocerias Automotivas. Anais do 13º Congresso Iberoamericano de Engenharia Mecânica, Lisboa, Portugal, 2017.

TOLMASQUIM, M. T. Perspectivas e planejamento do setor energético no Brasil. Revista Estudos Avançados. vol.26, n.74, p. 247-260, 2012. 


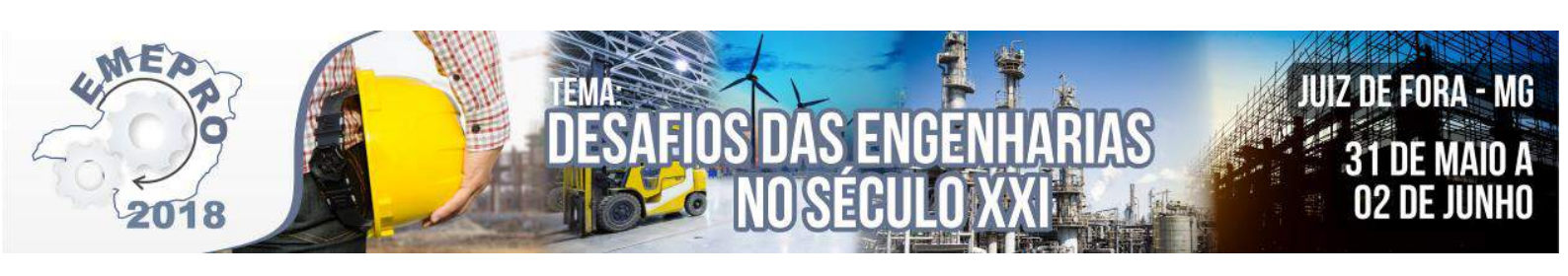

\title{
Compras públicas e governo eletrônico: um estudo bibliométrico com foco na sustentabilidade
}

\author{
Fernando Cerutti Aguiar - Universidade Candido Mendes - fernandocerutti@gmail.com \\ Cláudio Luiz Melo de Souza - Universidade Candido Mendes - claudiomelo.edu@ gmail.com \\ Milton Erthal Junior - Universidade Candido Mendes - miltonerthal@hotmail.com
}

Resumo: A gestão pública tende a utilizar, cada vez mais, ferramentas eletrônicas que visam otimizar os processos de contratação no ambiente governamental. Este trabalho tem como objetivo realizar uma análise bibliométrica da "Nova Gestão Pública" e o denominado "Governo Eletrônico" e a sua relação com o tema "Sustentabilidade". Para isso, foram realizadas buscas nas bases Scopus e Web of Science utilizando-se as palavras-chaves "sustainable AND public procurement" e "sustainable AND "e-government". Refinando o resultado para artigos publicados somente em periódicos na última década, 2008 à 2018, totalizando 183 registros na base Scopus e 175 na base Web of Science. Ao final da análise foram selecionados 28 artigos relevantes para compor a base da pesquisa. Demonstrou-se através deste trabalho que existe uma crescente relação entre governo eletrônico e seus processos de contratação, cada vez mais, compromissados com as questões ambientais e o desenvolvimento sustentável.

Palavras-chave: Contratação pública; Compras sustentáveis; E-gov.

\section{Introdução}

A sustentabilidade e a otimização de processos são temas que vêm ganhando destaque na agenda política da administração pública, principalmente na última década. Diante dessa nova realidade, o setor público está mais consciente sobre a relevância do seu papel indutor de transformações estruturais nos principais setores produtivos e de consumo sustentáveis (BRASIL, 2018).

Conforme o Guia de Compras Públicas Sustentáveis para Administração Federal, as contratações públicas sustentáveis representam uma solução para integrar fatores sociais e ambientais em todas as fases do processo de contratação ou compra do governo, visando à redução de impactos sobre a saúde humana, o meio ambiente e os direitos humanos (SOUZA; QUELHAS e GOMES, 2015).

De acordo com Alencastro, Silva e Lopes (2014), as compras públicas sustentáveis têm sido apontadas como um relevante instrumento de gestão ambiental nos órgãos governamentais, haja vista objetivarem inserir critérios de sustentabilidade nos procedimentos destinados a adquirir bens e contratar serviços, além de estimular os governos a adotarem comportamentos que usualmente são exigidos de particulares e de pessoas jurídicas de direito privado, melhorando a imagem da autoridade pública.

Para García-Sánchez et al. (2013), por meio das TICs (Tecnologias de Informação e Comunicação), as atividades de gestão pública estão sendo aprimoradas, proporcionando enormes avanços em termos de eficiência, transparência e utilização de recursos. Assim, 


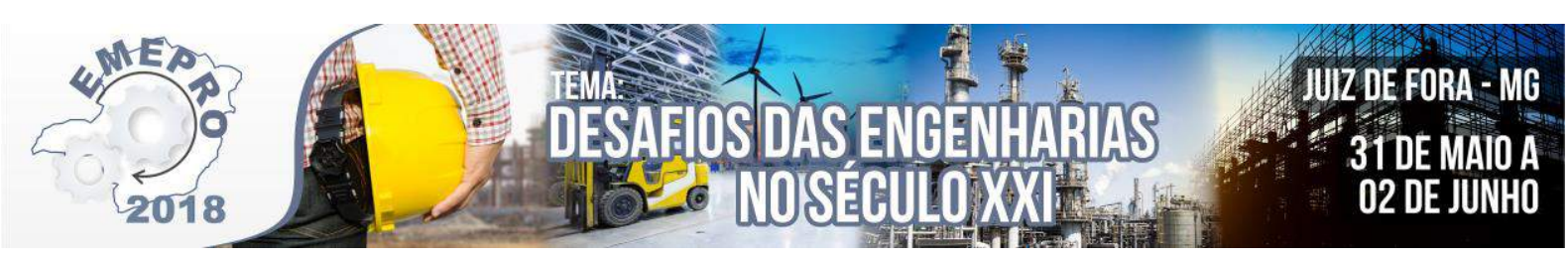

aliado à sustentabilidade e aos sistemas de contratações públicas está o "Governo Eletrônico" ou "e-gov".

De acordo com Schuppan (2008), com o desenvolvimento de sistemas de comunicação e de legislações bem formuladas e atualizadas, o e-gov tem grande potencial para ser uma ferramenta propulsora do desenvolvimento sustentável ao redor do mundo.

O Governo Eletrônico para o Desenvolvimento Sustentável é o uso das tecnologias de informação com a finalidade de apoiar os serviços públicos, a administração pública e a interação entre o governo e o público, possibilitando a participação pública na tomada de decisão do governo, promovendo a equidade social, o desenvolvimento socioeconômico e protegendo recursos naturais para as futuras gerações (ESTEVEZ; JANOWSKI, 2013).

Segundo Cunha, Duclós e Barbosa (2006), a adoção de recursos tecnológicos e de programas de e-gov são fundamentais para promover o desenvolvimento econômico e social sustentável em um ambiente de alta complexidade e de rápidas mudanças, transformando a administração pública e afetando todos os níveis e funções governamentais.

Sendo assim, este trabalho tem como objetivo identificar a produção científica sobre o tema "Sustentabilidade" e sua relação com as contratações públicas e o governo eletrônico, através de um estudo bibliométrico, visando apontar os principais autores que contribuem para o tema, países onde são publicados, período das publicações e principais periódicos.

\section{Metodologia}

O método utilizado baseia-se na metodologia proposta por Costa (2010), que utiliza ferramentas de busca de dados bibliográficos "online". O modelo propõe a sequência de algumas etapas que permitem mapear os estudos já realizadas sobre o tema e facilitar a identificação dos principais artigos para formulação de um conjunto de referências que servirão de núcleo de partida para uma determinada pesquisa.

A busca foi realizada na base SCOPUS e WEB OF SCIENCE através do acesso pelo portal de periódicos da Capes. Essas bases foram selecionadas por terem grande credibilidade e abrangência no meio acadêmico.

A pesquisa foi realizada no mês de março de 2018, utilizando-se os termos "sustainable AND public procurement" OR "sustainable AND "e-government". A ideia principal é relacionar o tema "sustentabilidade" com "contratos públicos" e "governo eletrônico", para que se possa ter uma dimensão da relação entre eles. Primeiramente, os termos foram pesquisados individualmente (A- sustainable, B- public procurement e C- egovernment) e depois em conjunto. A partir dessas combinações foram elaborados os diagramas de Venn apresentados na Figura 1. A pesquisa foi realizada no idioma Inglês, visando alcançar o maior número de artigos possível. O afinamento dos resultados foi por seleção de apenas artigos de periódicos, publicados desde 2008 a 2018.

Na Figura 1, destaca-se que os artigos a serem utilizados nas próximas etapas são aqueles que fazem intercessão entre os termos "A e B", "A e C" e "A e B e C", sendo que não se faz relevante para a pesquisa aqueles cuja intercessão está entre "B e C", pois o que se pretende aqui é analisar o tema principal " $A$ " em relação aos demais.

Importante também mencionar que embora os termos "B e C" não sejam o foco desta pesquisa, percebe-se que, em comparação com as outras intercessões, o tema "governo eletrônico" está sendo pouco explorado em conjunto com o tema "contratos públicos", determinado que, embora os temas estejam relacionados, eles normalmente não são estudados 


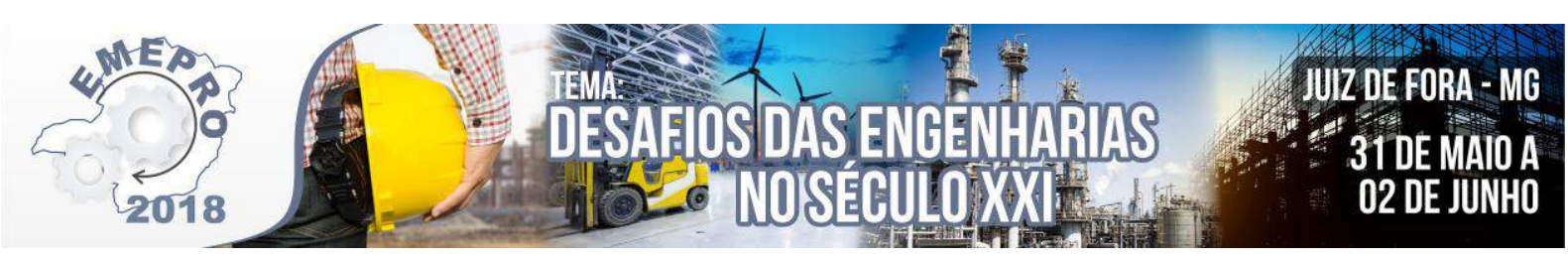

conjuntamente, o que provavelmente ocasionou a ocorrência de apenas 01 registro na intercessão dos três termos.

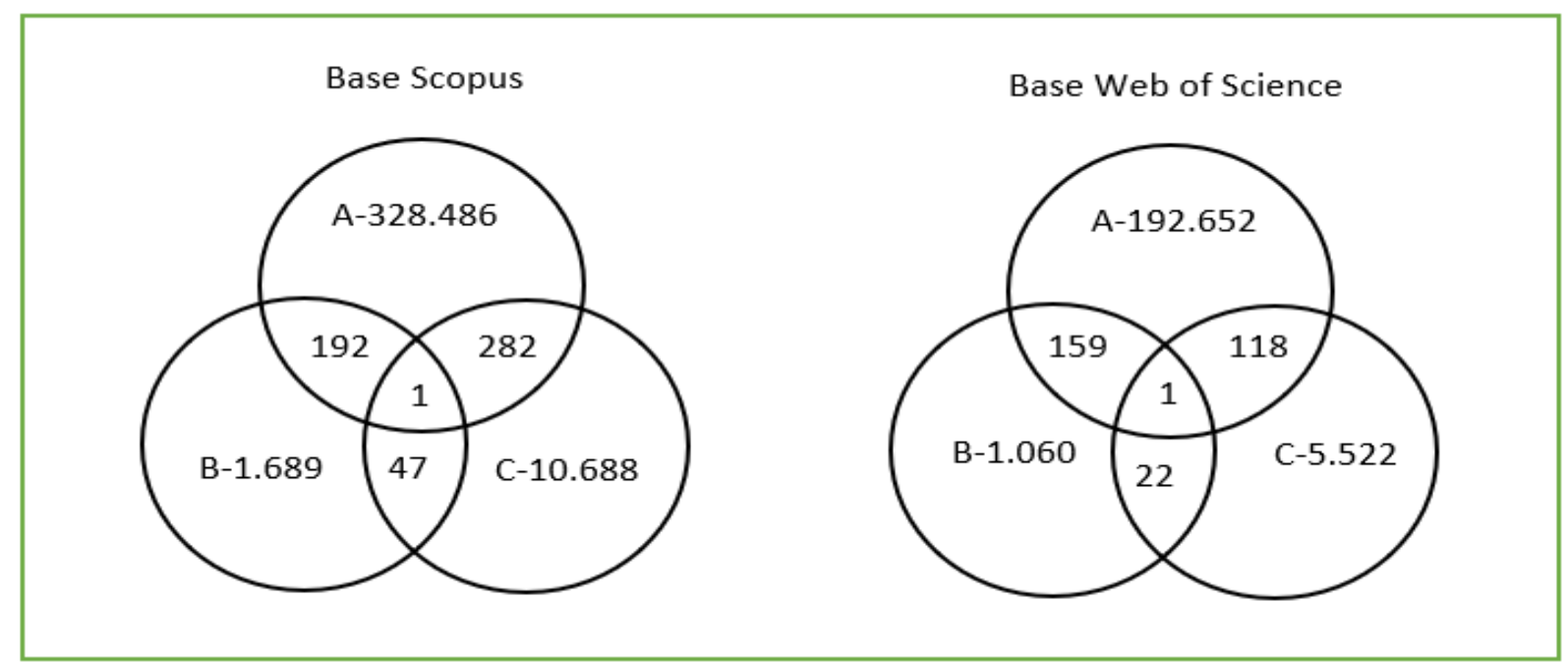

Figura 1 - Publicações identificadas na Base Scopus e Web of Science. Fonte: Elaborado pelos autores

A partir da pesquisa principal que utilizou os termos "sustainable AND public procurement" OR "sustainable AND "e-government", refinou-se os resultados para os artigos publicados apenas em periódicos e durante o período de 2008 à março de 2018, de modo obter as publicações mais recentes sobre o tema, que por tratar de inovações tecnológicas que estão em constante evolução, deve-se ter mais atenção aos trabalhos recentes.

\section{Resultados e Discussão}

Chegou-se ao resultado de 183 artigos na base Scopus e 175 na base Web of Science, dentre 2008 e 2018. Percebe-se que a quantidade de publicações sobre o tema tem aumentado consideravelmente entre 2010 e 2017, identificando-se que o tema está em ascensão. O crescimento provavelmente está associado ao desenvolvimento de novas tecnologias, a expansão da Internet em nível mundial, a adoção destas inovações em ambiente governamental e ao aumento da preocupação com o desenvolvimento sustentável ao longo dos anos (Figura 02).

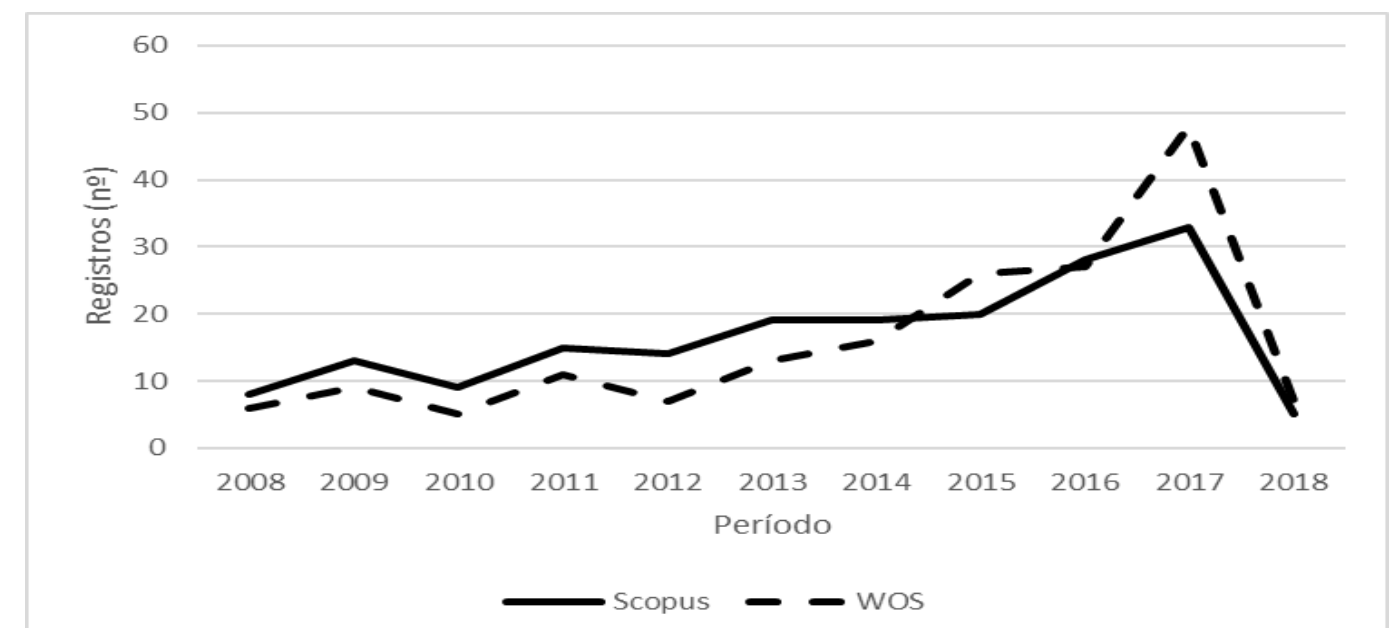

Figura 2 - Registros de publicações na Base Scopus e Web of Science. Fonte: Elaborado pelos autores 


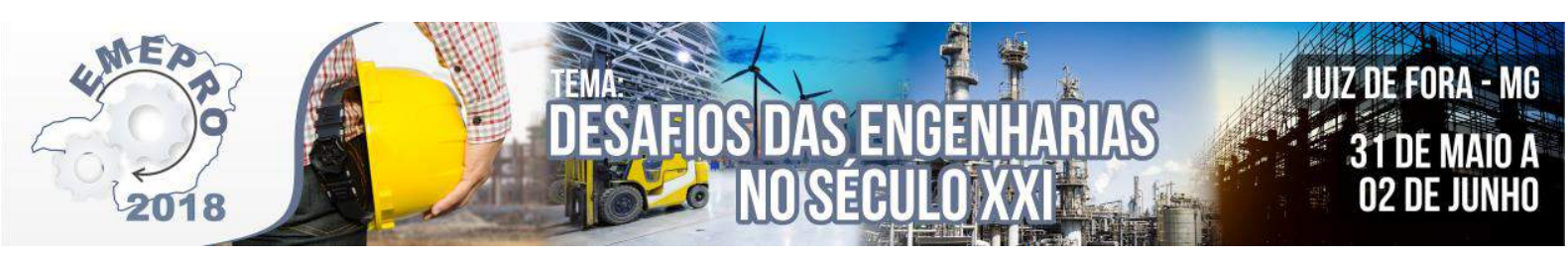

Os artigos mais antigos de 2008 a 2010 tratavam em sua maioria de questões relacionadas à implantação de governo eletrônico em países emergentes e a adequação destes às novas tecnologias, enquanto que posteriormente os artigos começaram a ter uma proximidade maior entre o desenvolvimento de tecnologias e sua relação direta com o desenvolvimento sustentável.

Os primeiros artigos de e-gov deste período abordavam funções cujo o objetivo era a redução de problemas administrativos em áreas como a de processos estatísticos e de informação, gestão financeira, sistemas tributários e formalização. Já os artigos mais recentes, em grande parte, tratam de questões relacionando o e-gov com a participação pública nas tomadas de decisão governamental, assim como na utilização de ferramentas eletrônicas para o desenvolvimento sustentável, sobretudo em relação ao aspecto social, melhorando a prestação de serviços públicos.

Em relação aos processos de contratações sustentáveis, observa-se nos registros mais antigos diversas análises acerca da adoção de critérios de sustentabilidade em compras públicas em determinados países ou universidades, já nos artigos mais atuais, é possível observar vários exemplos de modelagem de processos de compras sustentáveis, sugeridos como forma de orientar e facilitar a implantação destes critérios.

Em relação a 2018, o baixo número de publicações justifica-se pela pesquisa ter sido realizado em março deste ano.

Os principais autores e periódicos que publicaram o tema, ou seja, com no mínimo 03 artigos, constam nas Tabela 1 e 2, respectivamente. Quanto aos autores, destaca-se Virginijus Kanapinskas, doutora em direito, natural da república da Lituânia, servidora pública e membro do Ministério do Interior do seu país de origem. A autora é pesquisadora filiada à Universidade Mykolas Romeris com quatro registros na Base Scopus e nenhum na Web of Science.

\begin{tabular}{llll}
\multicolumn{2}{c}{ Tabela 1 Autores com maior número de publicações sobre o tema entre 2008 e 2018.} \\
\hline \multicolumn{1}{c}{ Autores } & \multicolumn{1}{c}{ Base Web of Science } \\
\hline Kanapinskas, V. & $\mathbf{N}^{\mathbf{0}}$ & \multicolumn{1}{c}{ Autores } & $\mathbf{N}^{\mathbf{0}}$ \\
Brammer, S. & 4 & Brammer, S. & 3 \\
Grandia, J. & 3 & Frey, M. & 3 \\
Jakaitis, J. & 3 & Grandia, J. & 3 \\
Plytnikas, Ž. & 3 & Sonnino, R. & 3 \\
Sonnino, R. & 3 & Testa, F. & 3 \\
Testa, F. & 3 & Walker, H. & 3 \\
Tvaronavičiene, A. & 3 & - & - \\
Walker, H. & 3 & - & - \\
\end{tabular}

Fonte: Elaborado pelos autores 


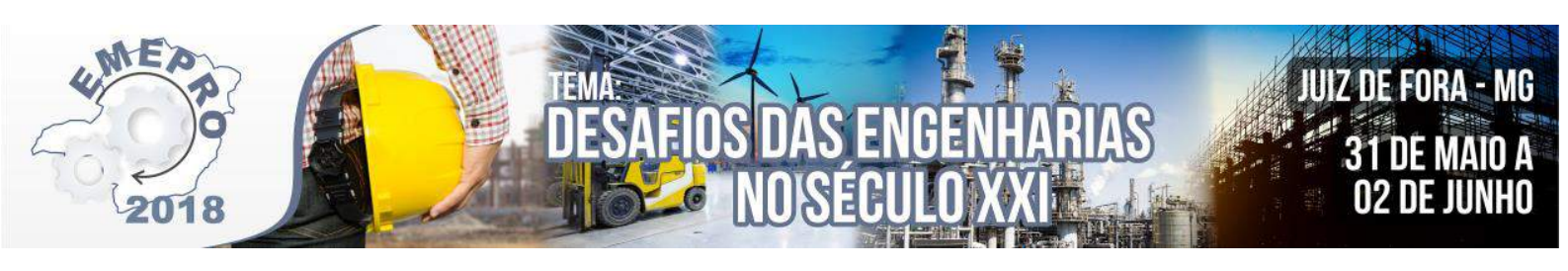

Tabela 2 - Periódicos com maior número de publicações sobre o tema entre 2008 e 2018.

\begin{tabular}{|c|c|c|c|}
\hline Base Scopus & $\mathbf{N}^{\mathbf{0}}$ & Base Web of Science & $\mathbf{N}^{\mathbf{0}}$ \\
\hline Journal of Cleaner Production & 18 & Journal of Cleaner Production & 23 \\
\hline $\begin{array}{l}\text { International Journal of Procurement } \\
\text { Management }\end{array}$ & 4 & Sustainability & 8 \\
\hline Natural Resources Forum & 4 & Government Information Quarterly & 7 \\
\hline Revista de Administração Pública & 4 & Natural Resources Forum & 4 \\
\hline Sustainability Switzerland & 4 & $\begin{array}{l}\text { Environment Development and } \\
\text { Sustainability }\end{array}$ & 3 \\
\hline $\begin{array}{l}\text { Ciriec Espana Revista de Economia Publica } \\
\text { Social y Cooperativa }\end{array}$ & 3 & Journal of Environmental Management & 3 \\
\hline Government Information Quarterly & 3 & Public Money Management & 3 \\
\hline Journal of Environmental Management & 3 & $\begin{array}{l}\text { Supply Chain Management an } \\
\text { International Journal }\end{array}$ & 3 \\
\hline Journal of Security and Sustainability Issues & 3 & $\begin{array}{l}\text { Technological and Economic } \\
\text { Development of Economy }\end{array}$ & 3 \\
\hline Supply Chain Management & 3 & & \\
\hline $\begin{array}{l}\text { Technological and Economic Development of } \\
\text { Economy }\end{array}$ & 3 & & \\
\hline
\end{tabular}

Fonte: Elaborado pelos autores

O periódico "Journal of Cleaner Production" se destaca por um número muito acentuado de artigos em relação aos demais e ainda, por ter a maioria de seus artigos indexados em ambas as bases.

Importante ressaltar também que alguns registros encontrados na base Scopus são os mesmos encontrados na base Web of Science, ou seja, artigos que foram indexados às duas bases.

O levantamento também abordou as principais áreas do conhecimento em que são produzidos os trabalhos relacionados ao tema. As áreas que mais se destacam são Ciências Sociais e Ciências Ambientais, representando, em conjunto, pouco mais de $40 \%$ das publicações, seguidas pelas áreas de Gestão de Negócios, Engenharia e Energia. 

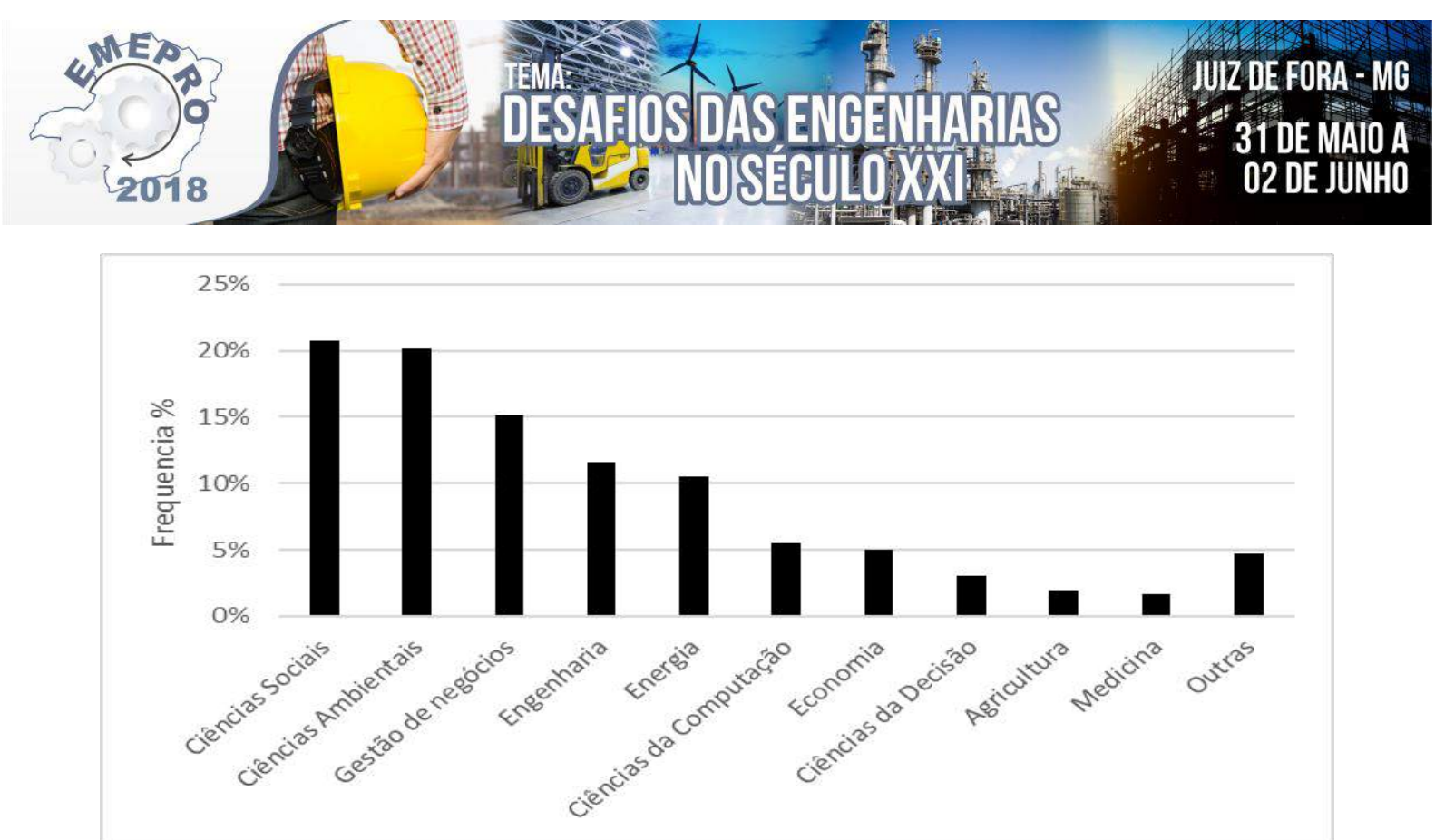

Figura 3. Frequência relativa por área de concentração das publicações na base Scopus. Fonte: Elaborado pelos autores

Seguiu-se então para análise dos países com maior quantidade de publicações. O Reino Unido é a região onde é publicado o maior número de artigos sobre o tema, levando grande vantagem em relação aos demais. Isto pode ser entendido pela diversidade de programas de mestrado e doutorado que a região oferece em estudos de sustentabilidade. Destaca-se também que o Brasil, apesar de contribuir com apenas 7 publicações, está com número igual a países considerados mais desenvolvidos, como Noruega, Bélgica e Dinamarca.

Tabela 3 - Países com maior número de publicações com o tema entre 2008 e 2018.

\begin{tabular}{lcc}
\hline \multicolumn{1}{c}{ Países } & No & (\%) \\
\hline Reino Unido & 30 & $18,87 \%$ \\
Itália & 16 & $10,06 \%$ \\
Espanha & 13 & $8,18 \%$ \\
Estados Unidos & 13 & $8,18 \%$ \\
Alemanha & 11 & $6,92 \%$ \\
Suécia & 11 & $6,92 \%$ \\
China & 10 & $6,29 \%$ \\
Lituânia & 10 & $6,29 \%$ \\
Holanda & 9 & $5,66 \%$ \\
França & 8 & $5,03 \%$ \\
Bélgica & 7 & $4,40 \%$ \\
Brasil & 7 & $4,40 \%$ \\
Dinamarca & 7 & $4,40 \%$ \\
Noruega & 7 & $4,40 \%$ \\
\hline
\end{tabular}

Fonte: Elaborado pelos autores

Após a análise estatística destes registros, procedeu-se a leitura dos títulos e resumos dos trabalhos, selecionando-se, por fim, 28 artigos que irão compor o núcleo de partida para pesquisa.

Estes trabalhos foram selecionados com base em critérios de relevância e afinidade com a dissertação a ser realizada. Analisou-se a proximidade com temas como cadeia de suprimentos, compras públicas sustentáveis, gestão ambiental, administração pública, governo digital, entre outros. 


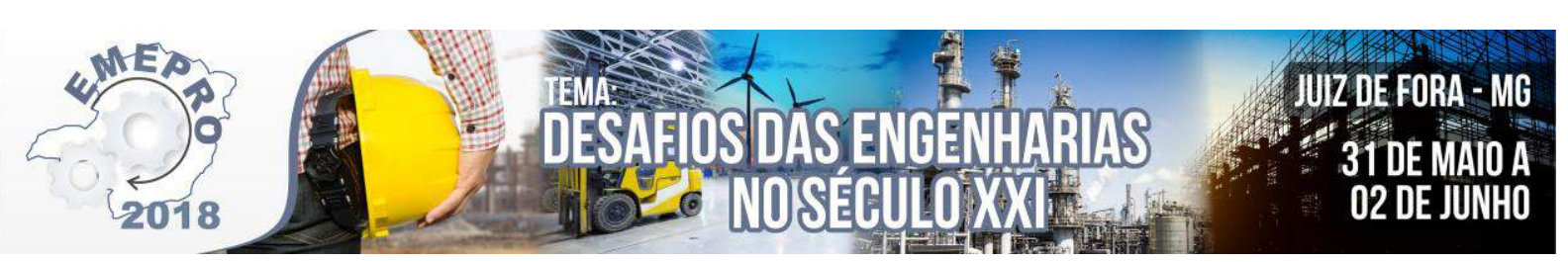

№

Tabela 3 - Artigos selecionados na base Scopus e Web of Science.

№ AUTOR PERIÓDICO ANO Citações Base Adoption of e-government in three Latin American countries: T. Lau, M. Aboulhoson, C. Lin,

D. Atikin

1 Argentina, Brazil and Mexico

C. Bratt, S. Hallstedt, K. Robèrt, Assessment of criteria development for public procurement G. Broman, J. Oldmark

Telecommunications Policy

2 from a strategic sustainability perspective

Contratações Públicas Sustentáveis: Uma Análise do Perfil das

3 Licitações de Instituições Públicas Brasileiras

Educação e Tecnologia Ambiental

Journal of Cleaner Production SCOPUS/

Contratações sustentáveis na administração pública brasileira: a M. Alencastro, E. da Silva, A

4 experiência do Poder Executivo federal

Lopes

Santa Maria

Cost-effectiveness, domestic favouritism and sustainability in

5 public procurement

Demand-pull and environmental innovations: Estimating the

6 effects of innovative public procurement

S. Keulemans, S. Walle

Revista de Administração Pública

International Journal of Public

Sector Management

C. Ghisetti

Technological Forecasting and Social

Development of a framework for the implementation of green T. Akenroye, A. Oyegoke, A.

Change

Eyo

International Journal of

Procurement Management

Driving sustainable supply chain management in the public

M. Amann, J. Roehrich, M. Eßig, Supply Chain Management: An

8 sector

C. Harland International Journal

Electronic Governance for Sustainable Development -

9 Conceptual framework and state of research

Environmental Criteria of Public Procurement as a Tool of

10 Development Sustainability

Evolutions in E-governance: Evidence from Spanish Local

11 Governments

Exploring the collective actions of public servants in e-

12 government development

Finding the missing link: examining the mediating role of

13 sustainable public procurement behaviour

Green Public Procurement as an initiative for Sustainable

E. Estevez, T. Janowski

L. štofová, P. szaryszová Environmental Management Government Information Quarterly

I. García-Sánchez, L. Rodríguez- Environmental Policy and

Domínguez, J. Frias-Aceituno Governance

T. Chou, J. Chen, C. Pu

Decision Support Systems

J. Grandia

Journal of Cleaner Production

B. Pacheco-Blanco, M.

14 Consumption. An exploratory study of Spanish public universities Bastante-Ceca

15 Green public procurement in practice - The case of Norway

t is not easy being green: increasing sustainable public

16 procurement behaviour

A. Fet, O. Michelsen, L. Boer

Journal of Cleaner Production

wos

scopus

\begin{tabular}{lll}
2014 & 0 & SCOPUS \\
\hline & SCOPUS/
\end{tabular}

\begin{tabular}{ccc}
2017 & 1 & WOS \\
\hline & & SCOPUS/
\end{tabular}

$2017 \quad 0 \quad$ WOS

WOS

$2013 \quad 3 \quad$ SCOPUS

$2014 \quad 30 \quad$ WOS

2013 SCOPUS/

SCOPUS/

20160 WOS

NOS

$\begin{array}{lll} & & \text { SCOPUS } \\ 2013 & 7 & \text { WOS }\end{array}$

SCOPUS/

200819 WOS

$2016 \quad 5 \quad-\quad$ WOS

WOS

Society and Economy

Fonte: Elaborado pelos autores

Social Science Research

$\begin{array}{lll}2011 & 6 & \text { WOS } \\ \end{array}$

$2015 \quad 23 \quad$ SCOPUS




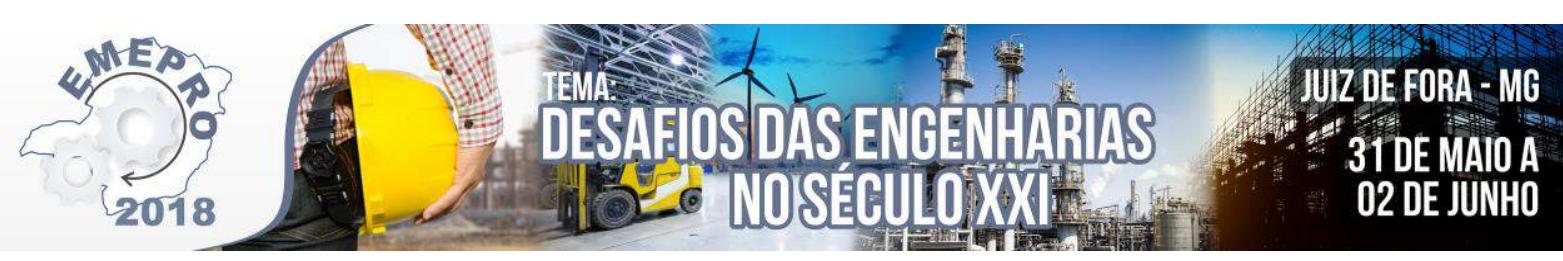

Tabela 4 - Artigos selecionados na base Scopus e Web of Science (2)

\begin{tabular}{|c|c|c|c|c|c|c|}
\hline \multirow[b]{2}{*}{17} & \multirow[b]{2}{*}{ Modelling the Process of Green Public Procurement } & \multicolumn{4}{|l|}{ M. Majerník, N. Daneshjo, J. } & \multirow{2}{*}{$\begin{array}{c}\text { SCOPUS/ } \\
\text { wOS }\end{array}$} \\
\hline & & Chovancová, G. Sančiová & TEM Journal & 2017 & 0 & \\
\hline & Municipal Contact Centres: A Slower Approach Towards & & & & & SCOPUS/ \\
\hline 18 & Sustainable Local Development by E- government & I. Bernhard, E. Wihlborg & European Planning Studies & 2015 & 1 & WOS \\
\hline & Objetivos e desafios da política de compras públicas & & & & & \\
\hline 19 & sustentáveis no Brasil: a opinião dos especialistas & H. Couto, F. Ribeiro & Revista de Administração Pública & 2016 & 0 & SCOPUS \\
\hline & Operacionalização das compras públicas sustentáveis na & & Revista Metropolitana de & & & \\
\hline 20 & secretaria de administração penitenciária do estado de SP. & G. Araujo, C. Teixeira & Sustentabilidade & 2016 & 0 & WOS \\
\hline & Repoliticising and scaling-up ethical consumption: Lessons from & & & & & SCOPUS/ \\
\hline 21 & public procurement for school meals in Brazil & D. Kleine, M. Brightwell & Geoforum & 2015 & 2 & WOS \\
\hline & SPP Toolbox: Supporting Sustainable Public Procurement in the & P. Trindade, P. Antunes, P. & & & & SCOPUS/ \\
\hline 22 & Context of Socio-Technical Transitions & Partidário & Sustainability & 2017 & 0 & WOS \\
\hline & Sustainable E-Governance: The Relationship among Trust, Digital & & & & & SCOPUS/ \\
\hline 23 & Divide, and E-Government & S. Myeong, Y. Kwon, H. Seo & Sustainability & 2014 & 9 & WOS \\
\hline & The conceptual model for the effect of technology on the & & & & & SCOPUS/ \\
\hline 24 & political and social aspects of Iran's e-government & F. Saghaf, B. Zarei, M. Fadaei & Quality \& Quantity & 2016 & 2 & WOS \\
\hline & The relationship between sustainable procurement and e- & & International Journal of Production & & & SCOPUS/ \\
\hline 25 & procurement in the public sector & H. Walker, S. Brammer & Economics & 2012 & 61 & WOS \\
\hline & The role of change agents in sustainable public & & & & & SCOPUS/ \\
\hline 26 & procurement projects & J. Grandia & Public Money \& Management & 2015 & 5 & WOS \\
\hline & Towards a more Circular Economy: Proposing a framework & & & & & \\
\hline & linking sustainable public procurement and sustainable business & & Resources, Conservation and & & & SCOPUS/ \\
\hline 27 & models & S. Witjes, R. Lozano & Recycling & 2016 & 32 & WOS \\
\hline 28 & $\begin{array}{l}\text { Two-dimensional approach to governmental excellence for } \\
\text { human development in developing countries: Combining policies } \\
\text { and institutions with e-government }\end{array}$ & $\begin{array}{l}\text { H. Choi, M. JaePark, J. Jeung } \\
\text { Rho }\end{array}$ & Government Information Quarterly & 2017 & 0 & $\begin{array}{l}\text { SCOPUS/ } \\
\text { wOS }\end{array}$ \\
\hline
\end{tabular}




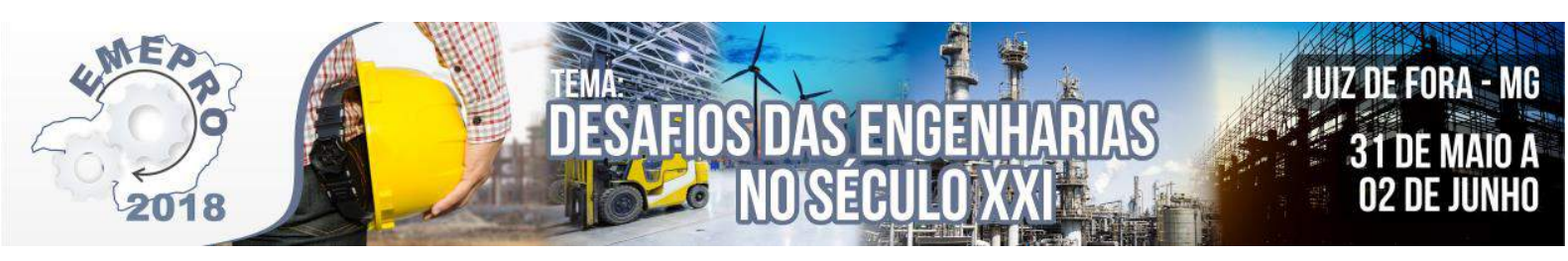

Por último, destaca-se ainda os 3 principais artigos, dentre os 28 descritos nas tabelas 3 e 4 , que possuem ainda mais proximidade com a pesquisa a ser desenvolvida.

Estevez e Janowski (2013), realizaram uma importante pesquisa bibliográfica envolvendo os temas governo eletrônico e desenvolvimento sustentável com o intuito de identificar o estado de pesquisa da intercessão entre os dois temas. $\mathrm{O}$ artigo revelou que, apesar do crescente interesse na pesquisa do EGOV e do Desenvolvimento Sustentável e um forte potencial para aplicar a pesquisa do EGOV a objetivos de sustentabilidade adicionais, a pesquisa na interseção de ambos os domínios é escassa. Os autores sugerem que estes temas deveriam ser estudos em conjunto, de forma interdisciplinar, e que isto poderia levar a contribuições mais significativas, beneficiando principalmente grupos mais vulneráveis.

Souza et al. (2012) fizeram uma análise do perfil das licitações de instituições públicas brasileiras. $\mathrm{O}$ artigo mapeou a produção acadêmica referente ao tema "contratações públicas sustentáveis" e traçou um perfil das licitações "verdes" realizadas pela Administração Pública Brasileira. Por meio de dados do Portal de Compras do Governo Federal os autores identificaram o percentual de licitações sustentáveis nas diversas regiões do Brasil, determinando quais regiões possuem maior índice de contratações sustentáveis. Também foram identificados os principais itens adquiridos como sustentáveis. Verificou-se que $89 \%$ das licitações visavam à compra de materiais de consumo e exigiam fabricação com material reciclado. Outras licitações estabeleciam certificação de bom manejo florestal e selo PROCEL de eficiência de gasto energético.

Alencastro et al. (2014) fizeram uma análise do processo de implementação das Compras Públicas Sustentáveis no âmbito do Poder Executivo federal brasileiro, levando em consideração os objetos, normas, potencialidades e limitações. Analisou-se a inserção de critérios de sustentabilidade nos procedimentos licitatórios realizados pelos órgãos integrantes de uma amostra de 12 ministérios considerando os aspectos sociais, econômicos e ambientais presentes nos procedimentos realizados através do portal de compras governamentais. A pesquisa também compreendeu a análise dos mecanismos utilizados pela administração pública federal para especificação dos produtos sustentáveis adquiridos e as alternativas para inserção de critérios de sustentabilidade nessas aquisições. O estudo revelou que apesar do aumento no percentual de aquisições sustentáveis desde o início da vigência da Instrução Normativa $\mathrm{n}^{\mathbf{0}} 1$, em janeiro de 2010, mais da metade dos órgãos do Poder Executivo Federal tem participação inexpressiva nesse processo, devendo o Ministério do Planejamento identificar e corrigir as causas do problema.

\section{Conclusões}

Com este trabalho, atingiu-se o objetivo de definir uma base de artigos para a revisão bibliográfica da pesquisa. Possibilitou-se também analisar estatisticamente o tema em questão, avaliando sua evolução ao longo do tempo e mapeando as principais áreas de pesquisa e países onde são estudados.

Observou-se que as áreas que abrigam a maior parte das pesquisas são as áreas de ciências sociais e ambientais, que representam aproximadamente $40 \%$ dos estudos, seguidas por Gestão de Negócios, Engenharia e Energia, que também representam boa parte dos registros. 


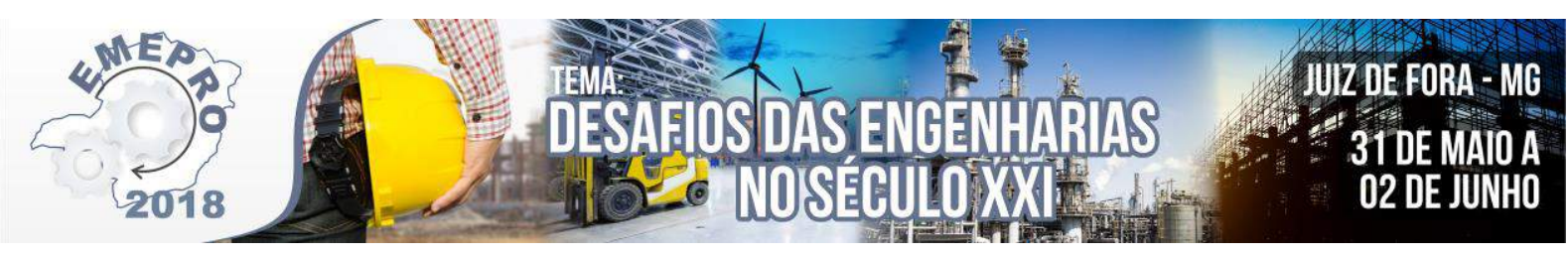

Identificou-se que o periódico "Journal of Cleaner Production" apresenta quantidade de registros muito superior aos demais periódicos, sendo que na base Scopus, a quantidade de registros é 4,5 vezes maior que o segundo periódico com mais publicações.

Foi possível visualizar que o Reino Unido é a região onde se encontram a maior parte dos registros, aproximadamente 19\%, demonstrando que a região se destaca nos estudos que envolvem sustentabilidade, seguido por Itália, Espanha e Estados Unidos. No Brasil observou-se apenas apenas $4,4 \%$ dos registros.

Conclui-se que a pesquisa identificou uma crescente evolução do número de artigos a partir de 2010, demonstrando o aumento da preocupação dos órgãos governamentais, ao redor do mundo, com o desenvolvimento sustentável no âmbito das contratações públicas e do governo eletrônico. 


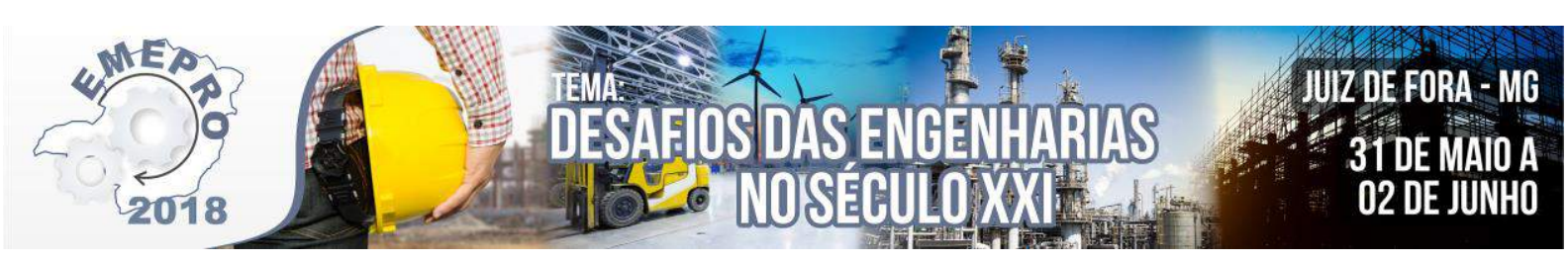

Referências:

AKENROYE, T. O.; OYEGOKE, A. S.; EYO, A. B. Development of a framework for the implementation of green public procurement in Nigeria. International Journal of Procurement Management v. 6, n. 1, p. 1, 2013.

ALENCASTro, M. A. C.; SILVA, E. V.; LOPES, A. M. D.. Contratações sustentáveis na administração pública brasileira: a experiência do Poder Executivo federal. Revista de Administração Pública v. 48, n. 1, p. 207-235, fev. 2014.

AMANN, M. et al. Driving sustainable supply chain management in the public sector. Supply Chain Management: An International Journal v. 19, n. 3, p. 351-366, 6 maio 2014.

ARAUJO, G. C.; TEIXEIRA, C. E.. Operacionalização das compras públicas sustentáveis na secretaria de administração penitenciária do Estado de São Paulo. Set./Dez v. 6, n. 3, p. 63-86, 2016.

BERnHARD, I.; WIHLBORG, E.. Municipal Contact Centres: A Slower Approach Towards Sustainable Local Development by E-government. European Planning Studies v. 23, n. 11, p. 2292-2309, 2 nov. 2015.

BRASIL, Ministério do Planejamento, Orçamento e Gestão, Contratações públicas Sustentáveis. Disponível em: https://www.comprasgovernamentais.gov.br/index.php/sustentabilidade>. Acesso: 23 jan. 2018

BRATT, C. et al. Assessment of criteria development for public procurement from a strategic sustainability perspective. Journal of Cleaner Production v. 52, p. 309-316, ago. 2013.

CAYOLLA TRINDADE, P.; ANTUNES, P.; PARTIDÁRIO, P.. SPP Toolbox: Supporting Sustainable Public Procurement in the Context of Socio-Technical Transitions. Sustainability v. 10, n. 2, p. 67, dez.2017.

CHOI, H.; PARK, M.; RHO, J. Two-dimensional approach to governmental excellence for human development in developing countries: Combining policies and institutions with e-government. Government Information Quarterly v. 34, n. 2, p. 340-353, 1 abr. 2017.

CHOU, T.; CHEN, J.; PU, C. Exploring the collective actions of public servants in e-government development. Decision Support Systems v. 45, n. 2, p. 251-265, maio 2008.

COSTA, H. G. Modelo para webibliomining: proposta e caso de aplicação. Revista FAE, Curitiba, v. 13, n.1, p. 115-126, 2010.

COUTO, H. L. G.; RIBEIRO, F. L. Objetivos e desafios da política de compras públicas sustentáveis no Brasil: a opinião dos especialistas. Revista de Administração Pública v. 50, n. 2, p. 331-343, 1 abr. 2016.

CUNHA, M. A. V. C.; DUCLÓS, L.C.; BARBOSA, A. F. Institucionalização do e-governo como Instrumento de Legitimidade da Governança Eletrônica no Setor Público no Brasil, Chile e Peru. Encontro da Associação Nacional de Pós-graduação e Pesquisa em Administração. Salvador: EnANPAD, 2006.

ESTEVEZ, E.; JANOWSKI, T. Electronic Governance for Sustainable Development — Conceptual framework and state of research. Government Information Quarterly v. 30, p. S94-S109, jan. 2013. FET, A.

M.; MICHELSEN, O.; BOER, L. Green public procurement in practice - The case of Norway. Society and Economy v. 33, n. 1, p. 183-198, 1 abr. 2011.

GARCÍA-SÁNCHEZ, I.; RODRÍGUEZ-DOMÍNGUEZ, L.; FRIAS-ACEITUNO, J. Evolutions in Egovernance: Evidence from Spanish Local Governments. Environmental Policy and Governance v. 23, n. 5, p. 323-340, set. 2013.

GHISETTI, C. Demand-pull and environmental innovations: Estimating the effects of innovative public procurement. Technological Forecasting and Social Change v. 125, p. 178-187, dez. 2017.

GRANDIA, J. Finding the missing link: examining the mediating role of sustainable public procurement behaviour. Journal of Cleaner Production v. 124, p. 183-190, 15 jun. 2016.

GRANDIA, J. The role of change agents in sustainable public procurement projects. Public Money \& Management v. 35, n. 2, p. 119-126, 4 mar. 2015.

GRANDIA, J.; STEIJN, B.; KUIPERS, B. It is not easy being green: increasing sustainable public procurement behaviour. Innovation: The European Journal of Social Science Research v. 28, n. 3, p. 243-260, 3 jul. 2015. 


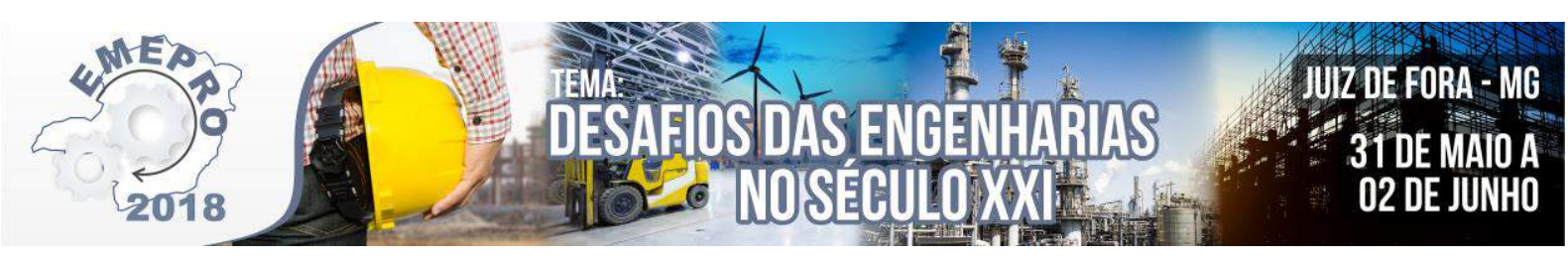

KEULEMANS, S.; VAN DE WALLE, S. Cost-effectiveness, domestic favouritism and sustainability in public procurement. International Journal of Public Sector Management v. 30, n. 4, p. 328-341, 8 maio 2017.

KLEINE, D.; DAS GRAÇAS BRIGHTWELL, M. Repoliticising and scaling-up ethical consumption: Lessons from public procurement for school meals in Brazil. Geoforum v. 67, p. 135-147, 1 dez. 2015.

LAU, T.Y. et al. Adoption of e-government in three Latin American countries: Argentina, Brazil and Mexico. Telecommunications Policy v. 32, n. 2, p. 88-100, mar. 2008.

MAJERNÍK, M. et al. Modelling the process of green public procurement. TEM Journal v. 6, n. 2, p. 272 278,1 maio 2017.

MYEONG, S.; KWON, Y.; SEO, H. Sustainable E-Governance: The Relationship among Trust, Digital Divide, and E-Government. Sustainability v. 6, n. 12, p. 6049-6069 , 5 set. 2014.

PACHECO-BLANCO, B.; BASTANTE-CECA, M. J. Green public procurement as an initiative for sustainable consumption. An exploratory study of Spanish public universities. Journal of Cleaner Production v. 133, p. 648-656, 1 out. 2016.

SAGHAFI, F.; ZAREI, B.; FADAEI, M.. The conceptual model for the effect of technology on the political and social aspects of Iran's e-government. Quality \& Quantity v. 50, n. 4, p. 1765-1780 , 10 jul. 2016.

DE SOUZA, T. F.; QUELHAS, O. L. G.; GOMES, C. F. S. Contratações públicas sustentáveis: uma análise do perfil das licitações de instituições públicas brasileiras. Revista Eletrônica em Gestão Educação e Tecnologia Ambiental v. 19, p. 477-492, 2015.

STOFOVÁ, L.; SZARYSZOVÁ, P. Environmental Criteria of Public Procurement as a Tool of Development Sustainability. Environmental Management v. 17, 2016.

WALKER, H.; BRAMMER, S. The relationship between sustainable procurement and e-procurement in the public sector. International Journal of Production Economics v. 140, n. 1, p. 256-268, nov. 2012.

WITJES, S.; LOZANO, R. Towards a more Circular Economy: Proposing a framework linking sustainable public procurement and sustainable business models. Resources, Conservation and Recycling v. 112, p. 37$44,2016$. 


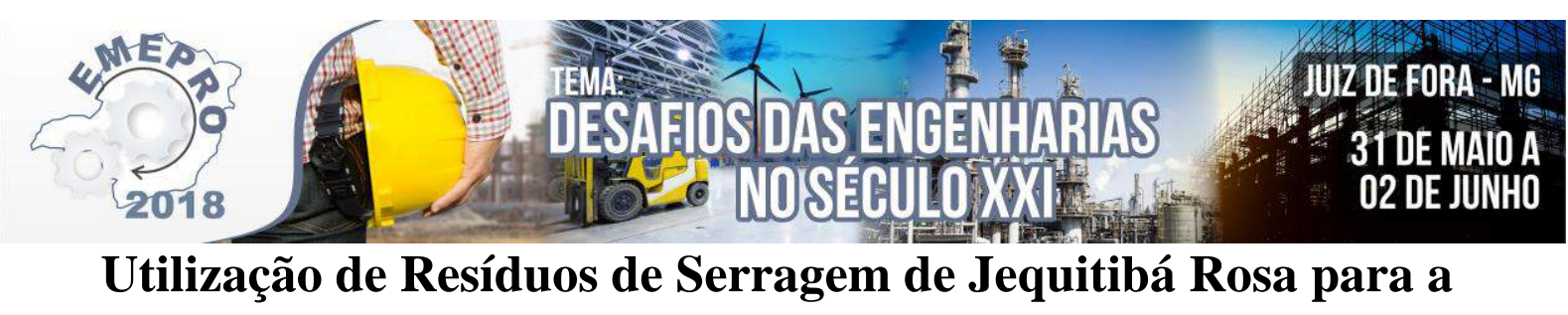

Produção de Briquetes

\author{
Beatriz Cristina Ferreira Machado - FIC/UNIS - biacfmachado@ gmail.com \\ Matheus Hernesto Mendes Alves - FIC/UNIS - matheushernesto@ hotmail.com \\ Rodolfo de Souza Cunha - FIC/UNIS - rodolfocunhaeng@ gmail.com \\ Tiago Bittencourt Nazaré - FIC/UNIS - tiago_bit@yahoo.com.br
}

Resumo: A transformação de resíduos florestais em biocombustíveis sólidos por meio do processo de briquetagem é uma maneira de viabilizar sua utilização energética. O presente estudo discorre sobre o potencial de reaproveitamento energético dos resíduos de serragem de madeira de Cariniana legalis (Jequitibá rosa), oriundos de uma indústria de móveis. A produção de briquetes além de contribuir para uma geração de energia térmica limpa propõe uma forma alternativa de descarte sustentável para resíduo de madeira. Tendo como objetivo inicial verificar a viabilidade energética dos briquetes como fonte de energia, e a utilização consciente dos resíduos de madeira pelas empresas. Por meio da confecção de vinte e cinco corpos de prova, foram realizados testes de queima em diferentes prensagens para verificação do briquete mais adequado como fonte de energia térmica. Foram realizadas pesquisas bibliográficas, e foi diagnosticado um baixo índice de fontes ligadas ao tema, o mesmo no que diz respeito à destinação final de resíduos de madeira.

Palavras-chave: Briquete; Resíduos de madeira; Destinação; Energia.

\title{
1. Introdução
}

O Brasil detém uma matriz elétrica de origem predominantemente renovável. Segundo o Balanço Energético Nacional (BEN, 2017), as fontes renováveis representam 81,7\% da oferta interna de eletricidade no Brasil, que é a resultante da soma dos montantes referentes à produção nacional mais as importações, que são essencialmente de origem renovável. A matriz energética mantém cerca de $45,3 \%$ de sua produção proveniente de fontes como recursos hídricos, etanol e biomassa, além de energia eólica e solar. Cabe destacar que a matriz energética mundial corresponde a cerca de $13 \%$ de fontes renováveis referente aos países desenvolvidos, recuando para 6\% em nações subdesenvolvidas (BRASIL, 2010). Segundo Farage et al. (2013), os resíduos sólidos são um desafio, visto o aumento expressivo de sua geração e a preocupação com a sua disposição final ou reaproveitamento e se justifica pela falta de soluções sanitárias e ambientalmente adequadas. O Brasil possui grande potencial para o reaproveitamento desses resíduos, porém pouco difundido no país.

Conforme Feitosa (2007), os resíduos de madeira são, por muitas vezes, associados à palavra problema, pois geralmente seu descarte, transporte e armazenamento causam transtornos tanto financeiros quanto logísticos. Devido ao resíduo permanecer em seus depósitos gerando custos e consequentemente reclamações de clientes internos e órgãos regulamentadores, as empresas devem manter um planejamento eficiente e eficaz de sua cadeia produtiva. 


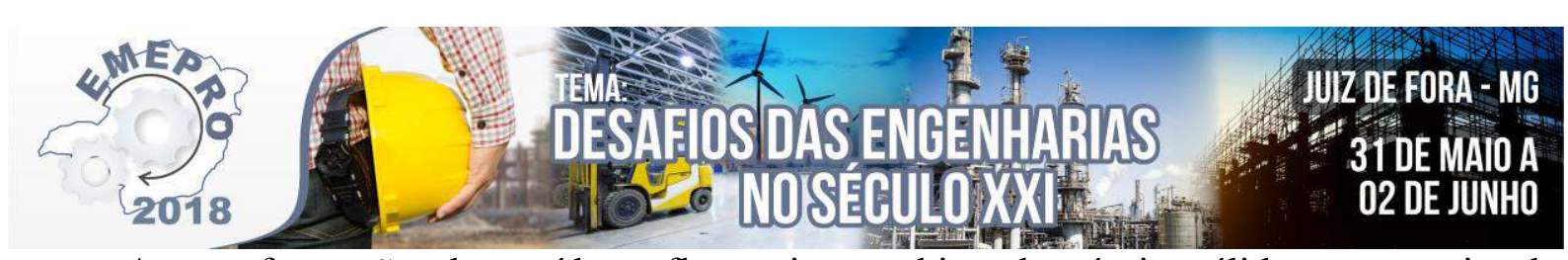

A transformação de resíduos florestais em bicombustíveis sólidos por meio da briquetagem é uma maneira de viabilizar sua utilização energética (AMORIM et al., 2015). A briquetagem é um processo de reconstrução, ou seja, é a reconsolidação de material particulado por meio da aplicação de temperatura e pressão a uma massa de partículas, com ou sem adição de ligantes (QUIRINI \& BRITO, 1991). O aproveitamento dos resíduos é uma das formas de minimizar o desperdício e aumentar o aproveitamento da madeira (PAULA et al., 2011).

O uso da matéria-prima necessária para a produção do briquete tem como resultado a diminuição dos resíduos florestais, contribuindo para uma grande redução do risco de incêndios e queimadas. (Revista da Madeira, 2010).

O estudo e desenvolvimento de biomassa para a geração de energia pode apresentar grandes benefícios no que se refere à qualidade de energia, nos impactos na vida humana e meio ambiente. $\mathrm{O}$ aproveitamento térmico de biomassa é uma maneira barata e tecnologicamente viável de produzir energia (CHRISOSTOMO, 2011). Perante o cenário atual, é necessário desenvolver alternativas que objetivem mitigar os impactos ambientais gerados pela disposição inadequada dos resíduos madeireiros, buscando a sua utilização como fonte sustentável para a produção.

O objetivo deste trabalho é produzir briquetes a partir de serragem de madeira gerada por uma fábrica de móveis localizada na zona da mata mineira, visando a viabilidade como fonte energética para geração de energia térmica através da queima, além de ressaltar a importância do uso de briquetes, mostrando as vantagens ambientais em se substituir o carvão vegetal pelos briquetes de resíduos de madeira.

\subsection{O Briquete e o Processo de Briquetagem}

O briquete é uma fonte concentrada e comprimida de material energético, podendo ser resultante de biomassa vegetal, ou fino de carvão misturado a algum tipo de adesivo (Revista da Madeira, 2010). A densidade energética do briquete é equivalente a cerca de sete vezes mais que a da madeira, e consequentemente maior poder calorífico, o que caracteriza uma maior geração de energia por massa do produto (Revista da Madeira, 2014).

Segundo Zorzan et al (2011), a briquetagem é um dos processos aplicados para o aproveitamento de resíduos de madeira na forma de combustível.

A briquetagem consiste na densificação dos finos (pequenas partículas de materiais sólidos). Esses resíduos são prensados, geralmente com ligante adequado, e obtêm-se um produto compacto, com forma e tamanho adequado à necessidade de utilização e possuem maior valor comercial, e são chamados de briquetes (FAAIJ, et al. 2005).

Os briquetes que necessitam de aglutinantes são aqueles que o material a ser aglomerado não apresenta resistência à compressão e ao impacto após a compactação. $\mathrm{O}$ resíduo de madeira contém lignina em sua composição, descartando a utilização de aglutinantes naturais ou químicos (CARVALHO e BRINCK, 2004).

Alves Júnior e Santos (2002) comprovam que o processo de briquetagem ou a transformação de madeira em briquetes consiste na trituração da madeira (moagem) e posterior compactação a elevadas pressões, o que pode causar a elevação da temperatura do processamento na ordem de $100^{\circ} \mathrm{C}$. 


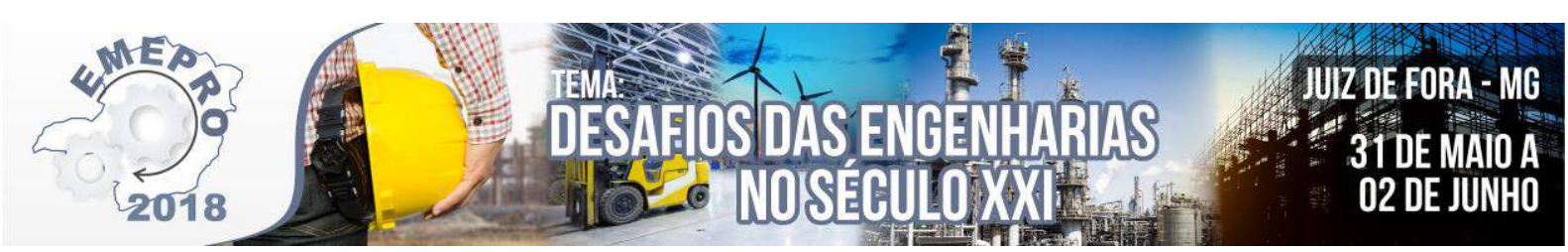

Para definição do material a ser estudado, foi realizada uma pesquisa para comparação da composição química de outras biomassas. Conforme o Quadro 1, a análise imediata é o processo feito na descrição de uma biomassa, pelo teor de umidade, porcentagem de voláteis e teor de cinzas.

QUADRO 1 - Análise imediata de outras biomassas (MIRANDA, F.; TANNOUS, K, 2012)

\begin{tabular}{|l|r|r|r|}
\hline \multicolumn{1}{|c|}{ Cadinho } & \multicolumn{1}{|c|}{$\begin{array}{c}\text { (\%) } \\
\text { Umidade }\end{array}$} & $\begin{array}{c}\text { (\%) } \\
\text { Voláteis }\end{array}$ & \multicolumn{1}{c|}{$\begin{array}{c}\text { (\%) Teor de } \\
\text { Cinzas }\end{array}$} \\
\hline Casca de Arroz & 5,96 & 68,79 & 16,71 \\
\hline $\begin{array}{l}\text { Bagaço de cana de } \\
\text { açúcar }\end{array}$ & 2,33 & 86,77 & 1,00 \\
Fibra de coco verde & 9,27 & 76,59 & 3,07 \\
\hline Jequitibá rosa & 5,4 & 83,95 & 0,55 \\
\hline
\end{tabular}

Fonte: MIRANDA, F.; TANNOUS, K, 2012. Adaptado pelo autor (2018).

Segundo MIRANDA, F.; TANNOUS, K, (2012), comparando os resultados obtidos com outras biomassas (Quadro 1) é possível observar que o teor de cinzas de Jequitibá rosa possui baixa porcentagem de resíduo, o que está diretamente ligado ao poder calorífico do mesmo, evidenciando sua eficiência energética. $O$ teor de umidade é um fator muito importante na utilização de biomassa como combustível, pois apresenta relação inversa com o poder calorífico.

O briquete apresenta vantagens, por alcançar grande poder calorífico sendo um ótimo substituto da lenha convencional, por ser um produto ecologicamente correto, já que utiliza resíduos de madeira de pouco ou nenhum valor agregado, tornando-os um produto de elevado valor combustível para diversas outras aplicações. Como alternativa para agregar valor e reduzir os impactos causados pelos resíduos, os briquetes podem ser usados na produção de energia.

A utilização do briquete ainda não faz parte da cultura brasileira, sendo esta a principal barreira à sua inserção no mercado.

\subsection{Resíduos de Serragem}

Ao se desdobrar uma tora de madeira, a geração de resíduos é inevitável, sendo que o volume e tipos de pedaços e fragmentos resultantes são dependentes de vários fatores. Como exemplos destes fatores, destacam-se o diâmetro das toras e o uso final das peças serradas (IPEA, 2012).

Segundo Moraes (2002), a indústria de móveis pode ser segmentada em função da matéria-prima que utiliza ou do uso final dos móveis que produz. Como existem diferentes tipos de matérias-primas à base de madeira utilizada na fabricação de móveis, as empresas moveleiras apresentam diferentes características e produzem diversos resíduos de madeira e seus derivados. Em geral, estes resíduos se apresentam na forma de serragem e de retalhos e seu aproveitamento tem sido principalmente para geração de energia.

Hillig et al (2006) analisando a caracterização e aproveitamento dos resíduos de madeira, propõe uma classificação, sendo caracterizados como insumos da cadeia produtiva da indústria madeireira, conforme o quadro abaixo: 


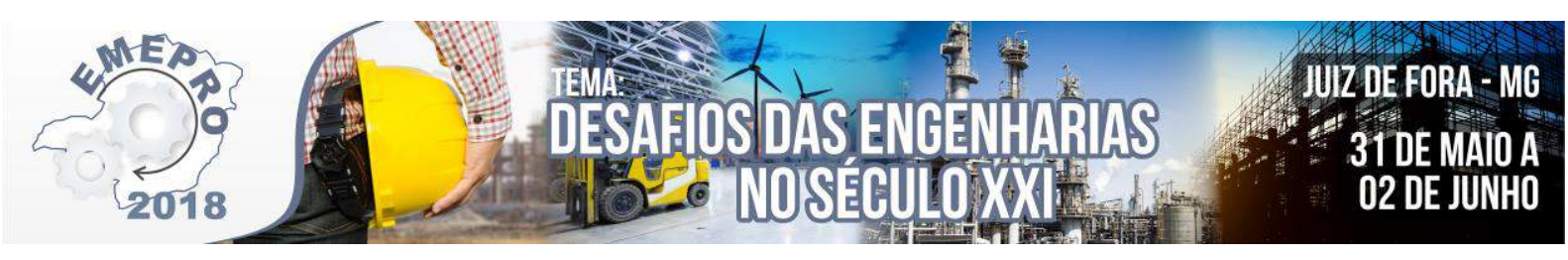

QUADRO 2- Insumos da cadeia produtiva da indústria madeireira (Hillig et al ,2006)

\begin{tabular}{|c|l|}
\hline SERRAGEM & $\begin{array}{l}\text { Resíduo originado da operação de serras, encontrado em todos os } \\
\text { tipos de indústria, à exceção das laminadoras }\end{array}$ \\
\hline CEPILHO & $\begin{array}{l}\text { Conhecido também por maravalha, resíduo gerado pelas plainas nas } \\
\text { instalações de serraria/beneficiamento e beneficiadora (indústrias } \\
\text { que adquirem a madeira já transformada e a processam em } \\
\text { componentes para móveis, esquadrias, pisos, forros, etc.); }\end{array}$ \\
\hline LENHA & $\begin{array}{l}\text { Resíduo de maiores dimensões, gerado em todos os tipos de } \\
\text { indústria, composto por costaneiras, aparas, refilos, resíduos de topo } \\
\text { de tora, restos de lâmina }\end{array}$ \\
\hline
\end{tabular}

Fonte: Hillig et al ,2006. Adaptado pelo autor (2018).

Com a utilização dos resíduos da madeira podem ser gerados os briquetes, que são produzidos a partir da compactação de resíduos lignocelulósicos, utilizando pressão e temperatura e são considerados lenha de qualidade (SILVA, 2007).

\subsection{Política Nacional dos Resíduos Sólidos}

O Licenciamento Ambiental é uma exigência legal e uma ferramenta do Poder Público para o controle ambiental. De acordo com a Resolução CONAMA no 237, de 19 de dezembro de 1997, temos: A Lei no 12.305/10, que institui a Política Nacional de Resíduos Sólidos (PNRS), prevê a prevenção e a redução na geração de resíduos, tendo como proposta a prática de hábitos de consumo sustentável e um conjunto de instrumentos para garantir o aumento da reciclagem e da reutilização dos resíduos sólidos, e a destinação ambientalmente adequada dos rejeitos. Institui a responsabilidade compartilhada dos geradores de resíduos: dos fabricantes, importadores, distribuidores, comerciantes, o cidadão e titulares de serviços de manejo dos resíduos sólidos urbanos na Logística Reversa dos resíduos e embalagens pósconsumo.

Segundo relatório EMBRAPA (2012), no Brasil, não há normas específicas para análise de propriedades de biomassa compactada, embora a produção de briquetes e pelletes exista há muitos anos. Como forma explícita de ampliar o uso de briquetes e pelletes no país, são necessárias normas, leis e políticas de incentivos aos produtores e aos consumidores desses produtos. Como exemplo, a utilização de políticas de certificação e padronização dos produtos, adotados por países desenvolvidos.

Atualmente os resíduos de madeira são destinados principalmente para queima, portanto é necessária a valorização do resíduo por meio da reciclagem com a perspectiva da criação de uma identidade própria com objetivo de alcançar maior colocação junto ao mercado consumidor, tendo em vista a justificativa da sustentabilidade.

\section{Materiais e Métodos}

Para descrever e abordar sobre o tema escolhido para este trabalho, foi necessário realizar uma pesquisa em livros e artigos científicos disponíveis na internet. Mediante a esses 


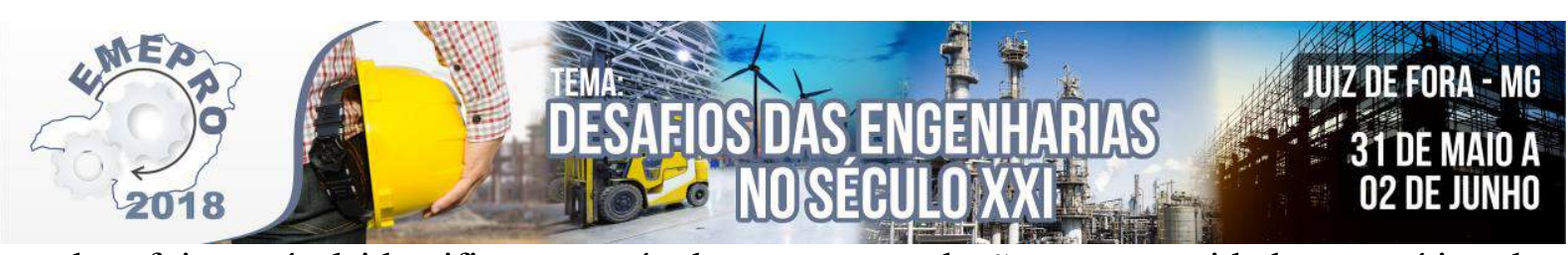

estudos, foi possível identificar os métodos para a produção e a capacidade energética dos briquetes, bem como os benefícios por eles gerados.

Com o material científico relatado nas pesquisas, foram encontrados artigos que fazem uso do briquete como forma alternativa no reaproveitamento de resíduos e com fins para geração de energia térmica.

O presente estudo visa desenvolver de forma prática um meio de utilizar os resíduos de serragem de Cariniana legalis (Jequitibá-rosa) de uma madeireira, demonstrando por meio de testes uma possível fonte de geração de energia. Os materiais e equipamentos utilizados para o estudo foram:

- Serragem de Cariniana legalis extraída de uma fábrica de móveis;

- Peneira de espessura 2,5mm;

- Bacia para armazenamento de Cariniana legalis;

- Balança Eletrônica BG400;

- Copo dosador modelo csn400 ml (com o objetivo de medir a quantidade de Cariniana legalis a ser utilizada na composição do Briquete);

- Prensa Hidráulica RIBEIRO 15 TON com Moldes do formato cilíndrico de diâmetro interno de $30 \mathrm{~mm}$ e altura de $7 \mathrm{~cm}$;

- Paquímetro digital Digimess® 200 mm 8 Pol;

- Secador profissional TAIFF Turbo 6000 - $1.700 \mathrm{~W}$;

- HS-3V Cronômetro de mão Digital CASIO uso Profissional 1/100;

- Bico de Bunsen;

- Microsoft Word 2007 para a escrita deste;

- Microsoft Excel 2007 para lançamento e análise de dados.

Para a realização deste trabalho foram confeccionados, no laboratório de materiologia da Faculdade, vinte e cinco corpos de prova, sendo cinco conjuntos de briquetes, cada um com cinco briquetes, com as seguintes propriedades:

- Prensados à 3 ton, sem processo de secagem manual.

- Prensados à 5 ton, sem processo de secagem manual.

- Prensados à 5 ton, com processo de secagem manual.

- Prensados à 7 ton, com processo de secagem manual.

- Prensados à 7 ton, sem processo de secagem manual.

No caso em estudo, não foi utilizado aglutinante devido ao poder plástico da lignina que, com a pressão, se molda em nova forma. No processo de compactação, as forças de atração molecular de Van der Waals atuam na união das partículas, tornando efetivas quando a distância entre elas diminui pela ação de uma elevada força externa. 


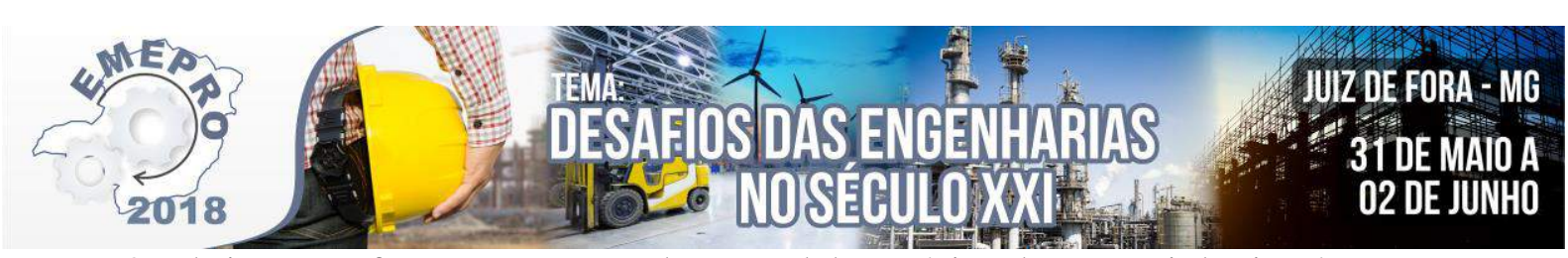

Os briquetes foram armazenados no laboratório de materiologia, à temperatura ambiente após prensagem, por um período de 10 dias. A secagem manual, foi realizada utilizando o secador profissional TAIFF Turbo $6000-1.700 \mathrm{~W}$, para estudos e análise de teor de umidade.

A fabricação dos briquetes foi dividida em partes, conforme descritas abaixo:

Foi realizado o peneiramento da serragem de Cariniana legalis, utilizando uma peneira de granulometria 2,5mm, para separação do pó da serragem e preparação da prensagem do material. Foi definido como peso ideal de 14,87 gramas do material para cada briquete produzido, utilizando uma balança eletrônica modelo BG400, pesados após processo de peneiramento. Todos os corpos de prova possuem quantidades iguais de material a ser trabalhado. $\mathrm{O}$ molde de prensagem possui formato cilíndrico com dimensões de $30 \mathrm{~mm}$ de diâmetro e $7 \mathrm{~cm}$ de altura.

Depois de alocado o material ao molde, foi realizado a prensagem em uma prensa hidráulica do modelo RIBEIRO $15 \mathrm{TON}$, submetidos a um peso equivalente às toneladas para cada conjunto de briquetes, sendo 3, 5 e 7 ton respectivamente. Após retirado do molde, foram realizadas medidas de massa e dimensões (Altura e diâmetro) dos corpos de amostra, para que fosse possível elaborar estudos relacionados com as propriedades descritas acima antes e após a secagem. Para realizar medidas referentes à massa foi utilizada a balança eletrônica BG400 e as dimensões foram avaliadas com o auxílio do equipamento paquímetro digital Digimess ${ }^{\circledR} 200 \mathrm{~mm} 8$ Pol.

Com os corpos de prova produzidos e amostrados, os mesmos foram armazenados no laboratório de materiologia, em temperatura ambiente, com intuito para que não houvesse intervenção externa em sua formação.

Após dez dias de secagem a temperatura ambiente, foi efetuada novas medições e pesagens dos briquetes para verificar possíveis mudanças em suas estruturas. Os corpos de amostra de secagem manual foram feitos com a utilização do secador profissional TAIFF Turbo 6000 - $1.700 \mathrm{~W}$, e expostos a temperatura máxima do secador por um período de cinco minutos, cronometrados com a utilização do HS-3V Cronômetro de mão Digital CASIO uso Profissional $1 / 100$, à uma distância aproximada de $15 \mathrm{~cm}$ para evitar qualquer combustão ou perda estrutural da serragem já peneirada.

Foram utilizados cálculos de variação de umidade de material seco e úmido por meio de uma planilha Microsoft Excel, para definir qual a porcentagem de água foi perdida no processo de secagem.

Para o cálculo da porcentagem de perda de água, comparou-se o briquete em estado inicial (massa úmida) com o mesmo material, porém após secagem (massa seca). O cálculo foi realizado através da Equação 01:

\section{Perda de Peso: Peso Inicial (massa úmida) - Peso Final (massa seca)}

Umidade: Perda de Peso $* 100$ 


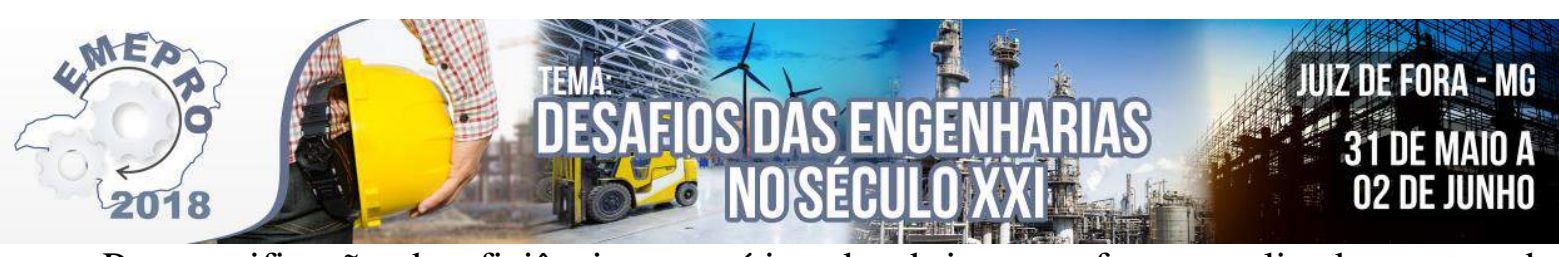

Para verificação da eficiência energética dos briquetes, foram realizados testes de queima no laboratório de Química. Durante o teste, foram observados o tempo de chama ao queimar o briquete e o tempo referente à brasa. Ambos foram cronometrados a partir do HS3 V Cronômetro de mão Digital CASIO uso Profissional 1/100.

\section{Resultados e Discussões}

Através dos dados obtidos após a confecção dos briquetes, foi possível analisar as dimensões, a massa úmida e a massa seca, a porcentagem de perda de água após um período de secagem em temperatura ambiente e de secagem manual, o tempo de queima de cada briquete e a densidade média dos resíduos da queima, conforme figuras 1 e 2 .

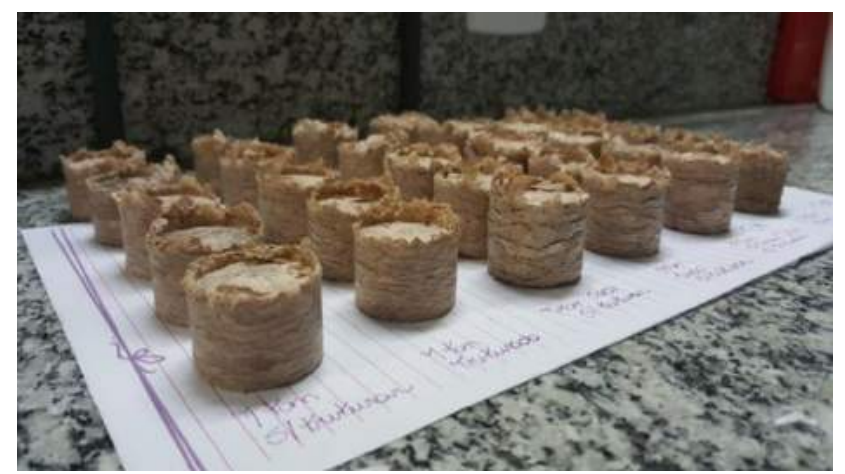

FIGURA 1 - Briquetes Confeccionados. Fonte:Próprio autor (2018).

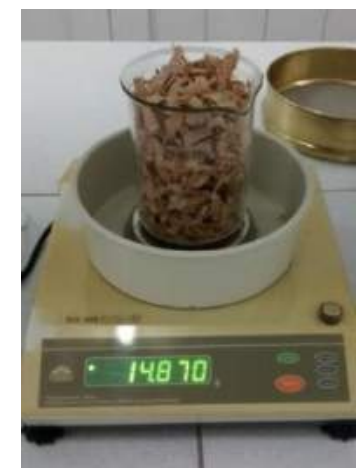

FIGURA 2 - Pesagem dos Briquetes. Fonte:Próprio autor (2018).

$\mathrm{Na}$ figura 1, foram apresentados os briquetes confeccionados de acordo com a metodologia aplicada à prensagem do material. A figura 2 representa o peso ideal de 14,87 gramas do material para cada briquete produzido. amostra.

Abaixo o Quadro 3, com os dados referentes às medições obtidas dos corpos de 


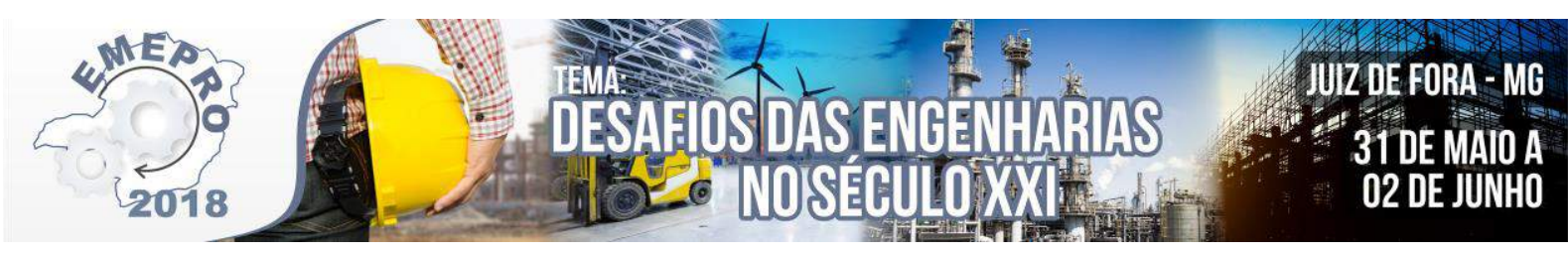

QUADRO 3- Análise de dimensão, massa e perda de água referente aos briquetes

\begin{tabular}{|c|c|c|c|c|c|}
\hline \multicolumn{6}{|c|}{ Briquetes 3 Ton Sem Secar } \\
\hline & Dimensões (mm) & Massa Úmida (g) & Massa Seca (g) & Perda de Massa (g) & \% de Perda de Água \\
\hline B1 & $30,42 \times 21,04 \mathrm{~mm}$ & 14,883 & 14,378 & 0,505 & 3,39 \\
\hline B2 & $30,46 \times 21,07 \mathrm{~mm}$ & 14,871 & 14,549 & 0,322 & 2,17 \\
\hline B3 & $30,33 \times 21,08 \mathrm{~mm}$ & 14,83 & 14,551 & 0,279 & 1,88 \\
\hline B4 & $30,40 \times 21,09 \mathrm{~mm}$ & 14,823 & 14,681 & 0,142 & 0,96 \\
\hline B5 & $30,42 \times 21,09 \mathrm{~mm}$ & 14,847 & 14,356 & 0,491 & 3,31 \\
\hline \multicolumn{6}{|c|}{ Briquetes 5 Ton Sem Secar } \\
\hline & Dimensões (mm) & Massa Úmida (g) & Massa Seca (g) & Perda de Massa (g) & \% de Perda de Água \\
\hline B1 & $30,60 \times 21,07 \mathrm{~mm}$ & 14,852 & 14,738 & 0,114 & 0,77 \\
\hline B2 & $30,40 \times 20,92 \mathrm{~mm}$ & 14,888 & 14,647 & 0,241 & 1,62 \\
\hline B3 & $30,35 \times 21,09 \mathrm{~mm}$ & 14,873 & 14,715 & 0,158 & 1,06 \\
\hline B4 & $30,36 \times 21,08 \mathrm{~mm}$ & 14,854 & 14,635 & 0,219 & 1,47 \\
\hline B5 & $30,39 \times 20,48 \mathrm{~mm}$ & 14,876 & 14,678 & 0,198 & 1,33 \\
\hline \multicolumn{6}{|c|}{ Briquetes 5 Ton Seco } \\
\hline & Dimensões (mm) & Massa Úmida (g) & Massa Seca (g) & Perda de Massa (g) & \% de Perda de Água \\
\hline B1 & $31,25 \times 23,65 \mathrm{~mm}$ & 14,801 & 13,395 & 1,406 & 9,50 \\
\hline B2 & $30,71 \times 22,40 \mathrm{~mm}$ & 14,873 & 13,406 & 1,467 & 9,86 \\
\hline B3 & $30,60 \times 22,45 \mathrm{~mm}$ & 14,828 & 13,786 & 1,042 & 7,03 \\
\hline B4 & $30,69 \times 22,60 \mathrm{~mm}$ & 14,878 & 13,86 & 1,018 & 6,84 \\
\hline B5 & $30,55 \times 20,94 \mathrm{~mm}$ & 14,867 & 13,81 & 1,057 & 7,11 \\
\hline \multicolumn{6}{|c|}{ Briquetes 7 Ton Seco } \\
\hline & Dimensões (mm) & Massa Úmida (g) & Massa Seca (g) & Perda de Massa (g) & \% de Perda de Água \\
\hline B1 & $30,53 \times 21,09 \mathrm{~mm}$ & 14,886 & 13,795 & 1,091 & 7,33 \\
\hline B2 & $30,60 \times 20,98 \mathrm{~mm}$ & 14,856 & 13,731 & 1,125 & 7,57 \\
\hline B3 & $30,35 \times 20,49 \mathrm{~mm}$ & 14,878 & 13,715 & 1,163 & 7,82 \\
\hline B4 & $30,46 \times 21,07 \mathrm{~mm}$ & 14,866 & 13,706 & 1,16 & 7,80 \\
\hline B5 & $30,39 \times 20,38 \mathrm{~mm}$ & 14,877 & 13,78 & 1,097 & 7,37 \\
\hline \multicolumn{6}{|c|}{ Briquetes 7 Ton Sem Secar } \\
\hline & Dimensões (mm) & Massa Úmida (g) & Massa Seca (g) & Perda de Massa (g) & \% de Perda de Água \\
\hline B1 & $30,52 \times 21,09 \mathrm{~mm}$ & 14,883 & 14,51 & 0,373 & 2,51 \\
\hline B2 & $30,39 \times 20,49 \mathrm{~mm}$ & 14,712 & 14,457 & 0,255 & 1,73 \\
\hline B3 & $30,46 \times 21,00 \mathrm{~mm}$ & 14,96 & 14,688 & 0,272 & 1,82 \\
\hline B4 & $30,61 \times 20,05 \mathrm{~mm}$ & 14,827 & 14,382 & 0,445 & 3,00 \\
\hline B5 & $30,43 \times 20,73 \mathrm{~mm}$ & 14,833 & 14,469 & 0,364 & 2,45 \\
\hline
\end{tabular}

Fonte:Elaborada pelo autor (2018).

Para realização do teste de queima, foram escolhidos aleatoriamente, dois corpos de prova de cada conjunto de briquete com prensagens variadas. Conforme os quadros 4 e 5, foram verificadas as diferenças nos tempos de chama e brasa, e a geração de resíduos dos mesmos, figuras 3 e 4 . Após a cronometragem da queima de cada um dos corpos de prova, foi possível verificar uma diferença nos tempos de queima entre os briquetes que tiveram secagem manual. 


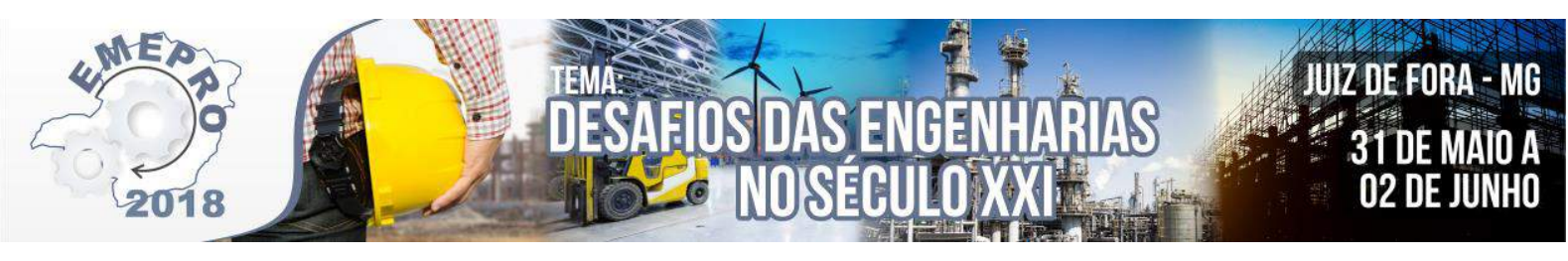

QUADRO 4 - Análise de queima e a geração de resíduos sem secar

\begin{tabular}{|c|c|c|c|}
\hline \multicolumn{4}{|c|}{ Briquetes 3 Ton Sem Secar } \\
\hline \multirow{3}{*}{ Queima/Chama } & Briquete & Tempo & $\begin{array}{c}\text { Resíduo } \\
\text { (g) }\end{array}$ \\
\hline & B1 & 00:06:19 & B1 - \\
\hline & B5 & 00:06:38 & 0,569 \\
\hline \multirow{2}{*}{ Queima/Brasa } & B1 & 00:30:21 & B5 - \\
\hline & B5 & $00: 31: 57$ & 0,673 \\
\hline \multicolumn{4}{|c|}{ Briquetes 5 Ton Sem Secar } \\
\hline \multirow{3}{*}{ Queima/Chama } & Briquete & Tempo & $\begin{array}{c}\text { Resíduo } \\
\text { (g) }\end{array}$ \\
\hline & B3 & 00:06:50 & B3 - \\
\hline & B5 & 00:07:03 & 0,461 \\
\hline \multirow{2}{*}{ Queima/Brasa } & B3 & $00: 22: 23$ & B5 - \\
\hline & B5 & $00: 33: 36$ & 0,543 \\
\hline \multicolumn{4}{|c|}{ Briquetes 7 Ton Sem Secar } \\
\hline \multirow{3}{*}{ Queima/Chama } & Briquete & Tempo & $\begin{array}{c}\text { Resíduo } \\
\text { (g) }\end{array}$ \\
\hline & B4 & 00:06:30 & B4 - \\
\hline & B5 & 00:06:24 & 0,682 \\
\hline \multirow{2}{*}{ Queima/Brasa } & B4 & $00: 31: 42$ & B5 - \\
\hline & B5 & 00:30:57 & 0,712 \\
\hline
\end{tabular}

QUADRO 5 - Análise de queima e a geração de resíduos secos.

\begin{tabular}{|c|c|c|c|}
\hline \multicolumn{4}{|c|}{ Briquetes 7 Ton Seco Manual } \\
\hline \multirow{3}{*}{ Queima/Chama } & Briquete & Tempo & $\begin{array}{c}\text { Resíduo } \\
\text { (g) }\end{array}$ \\
\hline & B1 & 00:07:30 & B1 - \\
\hline & B3 & 00:08:03 & 0,387 \\
\hline \multirow{2}{*}{ Queima/Brasa } & B1 & $00: 34: 37$ & B3 - \\
\hline & B3 & 00:34:23 & 0,427 \\
\hline \multicolumn{4}{|c|}{ Briquetes 5 Ton Seco Manual } \\
\hline \multirow{3}{*}{ Queima/Chama } & Briquete & Tempo & $\begin{array}{c}\text { Resíduo } \\
\text { (g) }\end{array}$ \\
\hline & B2 & 00:07:59 & B2 - \\
\hline & B4 & 00:08:22 & 0,228 \\
\hline \multirow{2}{*}{ Queima/Brasa } & B2 & $00: 36: 17$ & B4 - \\
\hline & B4 & $00: 36: 20$ & 0,377 \\
\hline
\end{tabular}

Fonte:Elaborada pelo autor (2018).

Fonte:Elaborada pelo autor (2018).

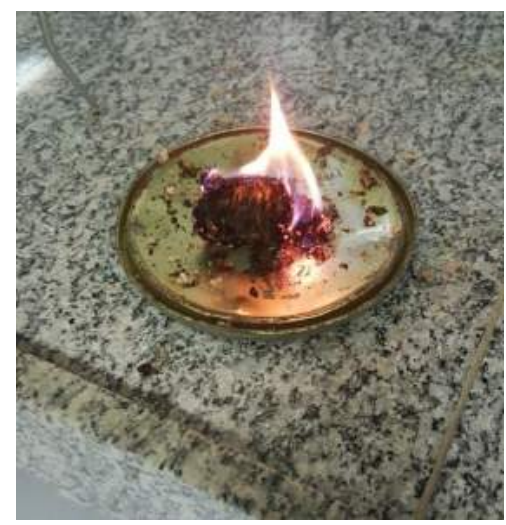

FIGURA 3 - Queima dos Briquetes. Fonte:Próprio autor (2018). 

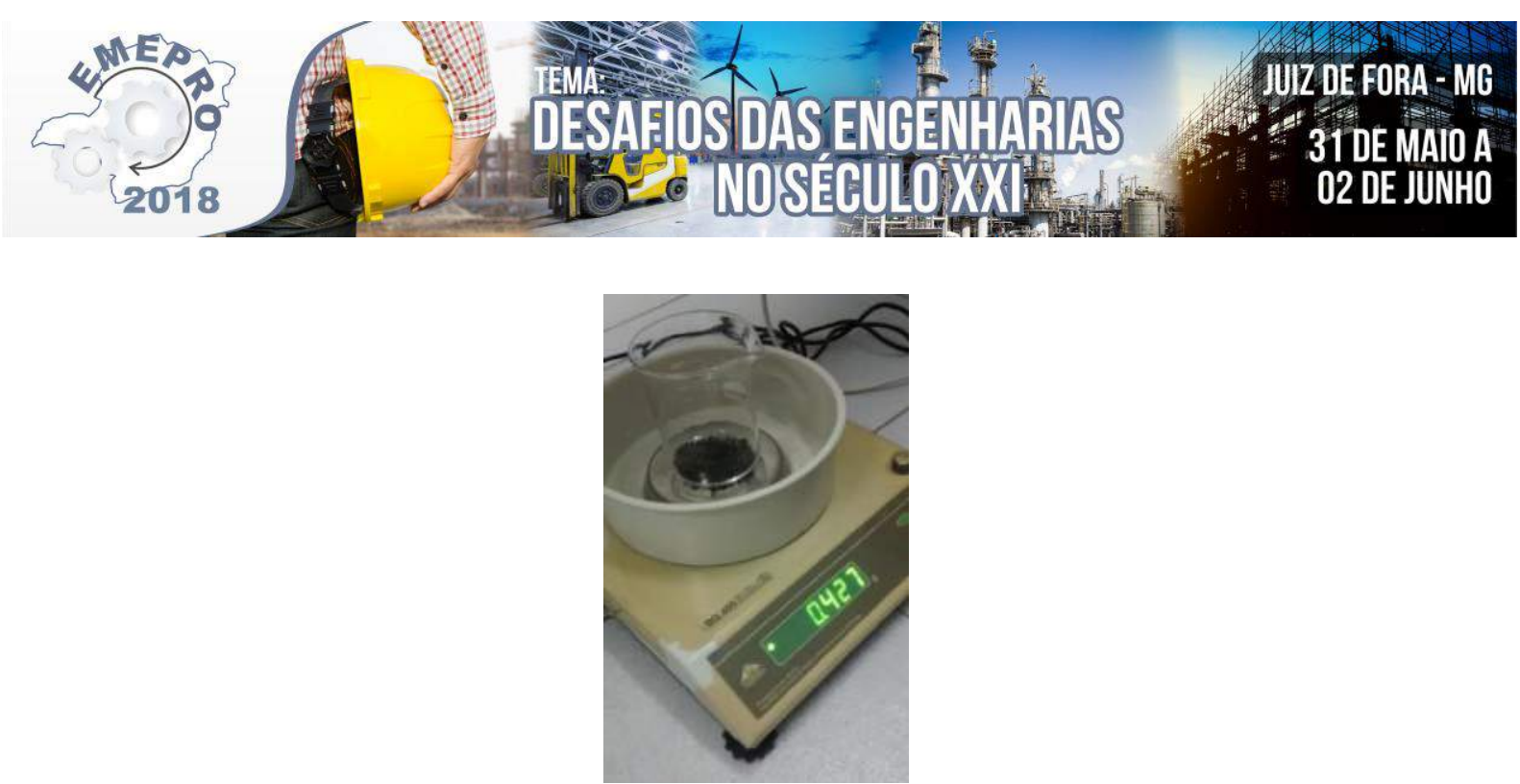

FIGURA 4 - Geração resíduo pós queima. Fonte:Próprio autor (2018).

De acordo com a análise, observou-se que os briquetes que passaram por secagem manual, tiveram uma perda de água significativa com relação aos briquetes que passaram apenas pelo processo de secagem em temperatura ambiente, garantindo assim maior tempo de queima chama/brasa, principalmente nos briquetes com prensagem de 5 ton., evidenciando a eficiência energética para combustão de serragem de Cariniana legalis (Jequitibá-rosa). Conforme a Resolução $\mathrm{N}^{\mathrm{0}}$ 382, Anexo IV, de 26 de dezembro de 2006, os derivados de madeira em forma de lenha, cavacos, serragem, pó de lixamento, casca, compensado ou MDF e assemelhados, que não tenham passado por processos químicos, como tintas ou outros revestimentos, poderão ser utilizados como combustível em processo de geração de calor por combustão externa, em caldeiras e fornos.

\section{Considerações Finais}

Os resíduos sólidos são considerados um desafio visto o aumento expressivo de sua geração, e a preocupação com a sua disposição final ou reaproveitamento, se justifica pela falta de soluções ambientalmente adequadas. O Brasil possui grande potencial para o reaproveitamento desses resíduos, porém pouco difundido no país. A produção de briquetes a partir desses resíduos é vista como uma alternativa sustentável para o reaproveitamento e também para geração de energia térmica através da queima dos briquetes.

Foram confeccionados, no laboratório de materiologia da Faculdade, vinte e cinco corpos de prova, sendo cinco conjuntos de briquetes com prensagens de 3, 5 e 7 ton., com secagem à temperatura ambiente e secagem manual. Após um período de 10 dias de secagem em temperatura ambiente, observou-se que os briquetes que passaram por secagem manual, tiveram uma perda de água significativa com relação aos briquetes que passaram apenas pelo processo de secagem em temperatura ambiente, garantindo assim maior tempo de queima chama/brasa, principalmente nos briquetes com prensagem de 5 ton., evidenciando a eficiência energética para combustão de serragem de Cariniana legalis (Jequitibá-rosa).

Conclui-se, após os testes realizados, que os briquetes com secagem manual prensados a 5 ton., são mais adequados à geração de energia térmica, vistos os resultados obtidos. Para um estudo mais aprofundado, a pesquisa bibliográfica sugere testes de granulometria dos materiais, pois quanto menor a granulometria maior a capacidade energética. 


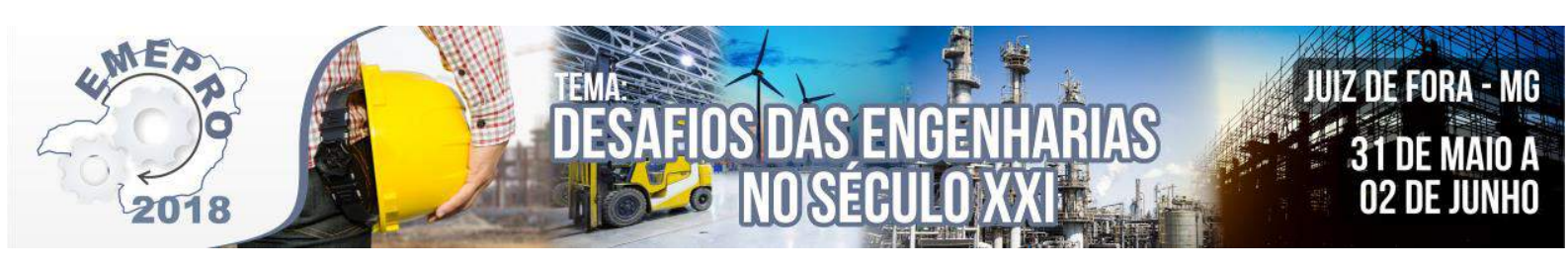

\section{Referências}

ALVES JÚNIOR, F.T.; SANTOS, G.A. Potencial de geração de biomassa para briquetagem e o perfil do mercado consumidor deste insumo na região do Cariri-CE. In: CONGRESSO IBEROAMERICANO DE PESQUISA E DESENVOLVIMENTO DE PRODUTOS FLORESTAIS, 2.; SEMINÁRIO EM TECNOLOGIA DA MADEIRAS E PRODUTOS FLORESTAIS NÃO-MADEIRÁVEIS, 1., 2002, Curitiba. Anais... Curitiba: FUPEF, 2002. 1 CD-ROM

AMORIM, F. S.; RIBEIRO, M. X.; PROTÁSIO, T. P.; BORGES, C. H. A.; COSTA, R. M. C. Produção de briquetes a partir de espécies florestais. Revista Verde de Agroecologia e Desenvolvimento Sustentável, v.10, n.4, p.34-41, 2015. https://doi.org/10.18378/ rvads.v10i4.3779

BALANÇO ENERGÉTICO NACIONAL 2017: Ano base 2016 / Empresa de Pesquisa Energética. - Rio de Janeiro : $\quad$ EPE, $2017 . \quad$ Disponível em: <https://ben.epe.gov.br/BENRelatorioFinal.aspx?anoColeta=2017\&anoFimColeta=2016>. Acessado em: $15 \mathrm{de}$ set. de 2017.

CARVALHO,E.A.,BRINCK,V.Briquetagem,capítulo15.Comunicação técnica elaborada para a $4^{\mathrm{a}}$ edição do livro.In:LUZ,A.B. da, SAMPAIO,J.A.,ALMEIDA,S.L.M. de. (CETEM- Centro de Tecnologia Mineral Ministério da Ciência e Tecnologia). Tratamentos de Minérios. Rio de Janeiro,2004.p.613-636.

CHRISOSTOMO, Walber.Estudo da compactação de resíduos lignocelulósicos.para a utilização de combustível sólido. Universidade de São Carlos.Dissertação.80fls.Sçao Carlos. Disponível em: <http://www.bdtd.ufscar.br/htdocs/tedeSimplificado//tde_busca/arquivo.php?codArquivo=5173> Acesso em: 27 de set. de 2017. Acesso em: 25 de setembro de 2017.

DOCUMENTOS, 13. PRODUÇÃO DE BRIQUETES E PÉLETES A PARTIR DE RESÍDUOS AGRÍCOLAS, AGROINDUSTRIAIS E FLORESTAIS,2012 - Embrapa Agroenergia Brasília, DF 2012. Disponível em: <https https://ainfo.cnptia.embrapa.br/digital/bitstream/item/78690/1/DOC-13.pdf>. Acessado em: 12 de set. de 2017.

EMBRAPA. Produçao de briquetes e péletes a partir de resíduos agrícolas, agroindustriais e florestais / José Manuel Cabral de Sousa Dias ... [et al.]. - Brasília, DF: Embrapa Agroenergia, 2012. Disponível em: http://www.infoteca.cnptia.embrapa.br/infoteca/handle/doc/952626. Acessado em: 25 de outubro de 2017.

FAAIJ, A. et al. Novas tecnologias para os vetores modernos de energia de biomassa. In: ROSSILO-CALLE, F.; BAJAY, S. V.; ROTHMAN, H (Org). Uso da biomassa para produção de energia na indústria brasileira. 1 ed. Campinas, SP 2005. p 339-417.

FARAGE, Rogério Machado Pinto et al . AVALIAÇÃO DO POTENCIAL DE APROVEITAMENTO ENERGÉTICO DOS RESÍDUOS DE MADEIRA E DERIVADOS GERADOS EM FÁBRICAS DO POLO MOVELEIRO DE UBÁ - MG. Ciênc. Florest., Santa Maria , v. 23, n. 1, p. 203-212, Mar. 2013 . Disponível em: <http://www.scielo.br/scielo.php?script=sci_arttext\&pid=S1980-50982013000100203\&lng=en\&nrm=iso>. Acessado em: 15 de setembro de 2017. http://dx.doi.org/10.5902/198050988454

FEITOSA, C. B. Aproveitamento Econômico Dos Resíduos De Madeira Como Alternativa Para Minimização De Problemas Sócio-ambientais No Estado Do Pará, 2007. Disponível em: < http://webartigos.com/artigos/aproveitamento-economico-dos-residuos-de-madeira-como-alternativa-paraminimizacao-de-problemas-socio-ambientais-no-estado-do-para/1175\#ixzz4uOGbxLVZ>. Acessado em: 22 de set. de 2017.

HILLIG, Everton et al. Resíduos de madeira da indústria madeireira - caracterização e aproveitamento.Anais... XXVI ENEGEP - Fortaleza, CE, Brasil, 9 a 11 de Outubro de 2006

IPEA, INSTITUTO DE PESQUISA ECONÔMICA APLICADA. Diagnóstico dos Resíduos Orgânicos do Setor Agrossilvicultural e Agroindustria Associadas. Brasília, 2012, 129 p.

JUNQUEIRA, Karina Gavião. PRODUÇÃO DE GÁS DE SÍNTESE A PARTIR D CAMA DE FRANGO COLETADO NO DIS FEDERAL POR MEIO DE PROCESSOS, 2014 - Universidade de Brasília - UnB Faculdade UnB Gama - FGA Curso de Engenharia de Energia. Disponível em: < https://fga.unb.br/articles/0000/7653/TCC2_KarinaJunqueira_1045989.pdf>. Acessado em: 12 de set. de 2017. 


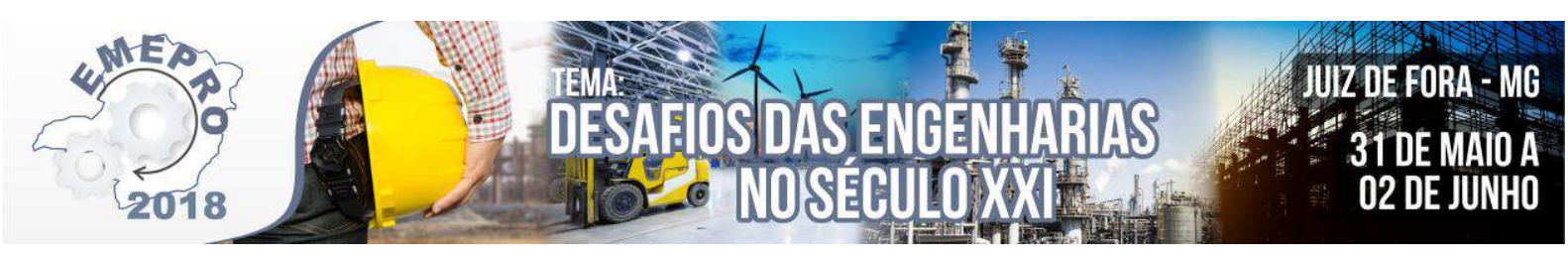

MINISTÉRIO DO MEIO AMBIENTE. Brasil, 2006.

Disponível em: < http://www.mma.gov.br/port/conama/res/res06/res38206.pdf>. Acessado em: 20 de out. de 2017.

MINISTÉRIO DO MEIO AMBIENTE. Brasi1,2010.

Disponível em: <http://www.brasil.gov.br/meioambiente/2010/11/matriz-energetica>. Acessado em: 20 de set. de 2017

MIRANDA, F.; TANNOUS, K. Avaliação do potencial energético de biomassas vegetais. Rev. de Ci. Exatas, RJ, EDUR, v. 27/31, n. 2, jul-dez., p. 97-109, 20122012.

MORAES, M. A. F. D. Estudo da competitividade de cadeias integradas no Brasil: imactos das zonas de livre comércio. Cadeia: madeira e móveis. Nota técnica final, Campinas UNICAMP-IE-NEIT, 2002

PAULA, L. E. de R.; TRUGILHO, P. F.; REZENDE, R. N.; DE ASSIS, C. O.; BALIZA, A. E. R. Produção e avaliação de briquetes de resíduos lignocelulósicos. Pesquisa Florestal Brasileira, Colombo, v.33, n.66, p.103112, 2011. Disponível em: 〈https://doi. org/10.4336/2011.pfb.31.66.103〉. Acessado em: 20 de set. de 2017.

REVISTA DA MADEIRA. O Briquete. Briquetes são alternativas para aproveitamento energético da madeiraRevista da Madeira.Edição nº 124, julho 2010.

REVISTA DA MADEIRA, Guia Brasileiro de Biomassa, Briquete: Lenha Ecologia, edição No ${ }^{\circ}$ 138, janeiro 2014.

QUIRINO, W. F; BRITO, J. O. Caracteristicas de combustão de briquetes de carvão vegetal. Brasília, DF: IBAMA, Laboratório de Produtos Florestais, 1991. 16 p. (IBAMA-LPF. Série Tecnica, n.13).

SILVA, C.A. Estudo técnico-econômico da compactação de resíduos madeireiros para fins energéticos. 2007. 68p. Dissertação (Mestrado em Engenharia Mecânica)-Universidade Estadual de Campinas, Campinas.

ZORZAN, F., PINTO, J. P., PAZ, J. M., PASA, M. E., MANTOVANI, C. A. Desenvolvimento da concepção de uma máquina compactadora de resíduos vegetais para produção de briquetes.SIEF - Semana Internacional das Engenharias da FAHOR, 2011.Disponível em: Acessado em: 20/10/2017. 


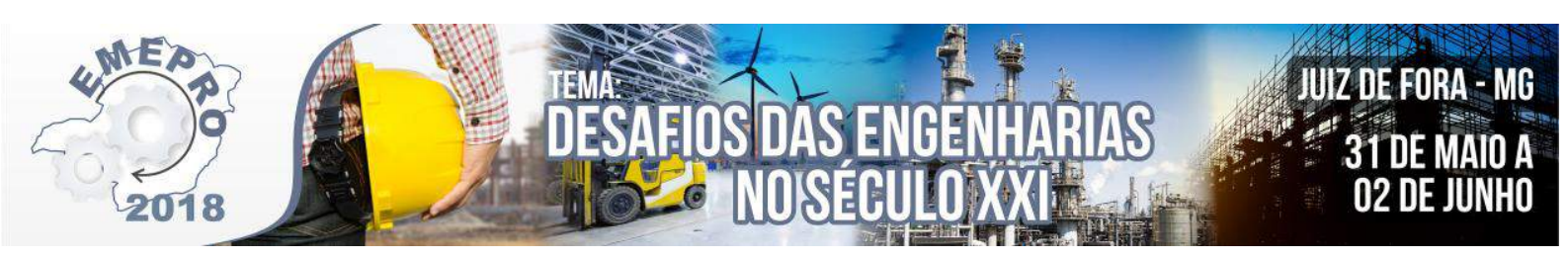

\title{
Vantagens da implementação da energia solar em uma escola de pequeno porte na cidade de Maripá de Minas
}

\author{
Híngred Ferraz Pereira (Faculdade Machado Sobrinho) - hingred_ferraz@live.com \\ Daniela Fonseca Costa (Faculdade Machado Sobrinho) - dnfonseca3@ gmail.com \\ José Carlos Miranda Grizendi (Faculdade Machado Sobrinho) - josecarlos@ grizendi.com.br
}

Resumo: O presente trabalho teve por objetivo realizar uma pesquisa sistemática que trata das vantagens da implementação da energia solar em uma escola de pequeno porte, na cidade de Maripá de Minas/MG. Dessa forma, iniciou-se com uma breve explanação sobre as novas fontes de energia sustentável, visando integrar a sociedade ao tripé da sustentabilidade, perpassando pela evolução da mesma desde os primórdios, até os dias atuais, ressaltando a finitude das reservas. Posteriormente, foram apresentados os diversos tipos de energia solar, abordando suas características e benefícios. Assim, este trabalho utiliza das variáveis independentes e dependentes, apresentando uma pesquisa quantitativa, das quais serão traduzidas as informações obtidas, com a finalidade de analisá-las $e$ classificá-las, além da pesquisa experimental. Os estudos realizados mostraram que a escola possui relativamente um controle mensal de consumo de $\mathrm{kWh}$, sendo favorável a implementação de um projeto de energia solar. Para tanto, foi solicitado um projeto orçamentário para a implantação do sistema solar fotovoltaico na referida escola. Pode-se concluir que o investimento terá retorno em menos de seis anos, mostrando-se viável para um patrimônio público. Assim, a utilização da energia solar fotovoltaica permite uma redução de custos, redução de recursos naturais, sendo uma energia renovável e sustentável.

Palavras-chave: Energia solar; Sustentabilidade; Economia

\section{Introdução}

Sabendo que o Sol é fonte de energia renovável e o seu aproveitamento tanto como fonte de calor, quanto de luz é uma das alternativas energéticas mais promissoras para o futuro, o principal objetivo desse trabalho é exibir os benefícios revelados em um estudo de uma possível implementação de um projeto de energia solar na Escola Municipal "Professora Hilda Lobão Rezende”, uma escola de pequeno porte, localizada em Maripá de Minas, uma pequena cidade da Zona da Mata mineira.

No mundo contemporâneo onde a demanda energética aumentou consideravelmente para atender as necessidades da humanidade - hoje estimada em mais de seis bilhões de pessoas - o homem tem se voltado para a natureza, buscando nos seus elementos as alternativas energéticas capazes de lhe proporcionar a energia de que tanto necessita para a manutenção de um nível de vida adequado. Fontes de energia como a hidrelétrica, nuclear, termelétrica, dentre outras atualmente vêm sendo mais escolhida por diversos motivos. Porém os problemas causados por tais escolhas atingem a todos. Essas fontes de energia acabam com o meio ambiente, poluem a atmosfera, alteram os lugares onde são produzidas as respectivas fontes de energia e muitos outros.

Assim, Bermann (2003) afirma que atualmente, há uma necessidade urgente da busca por novas fontes de energia sustentável. Essa procura visa integrar a sociedade ao tripé da 


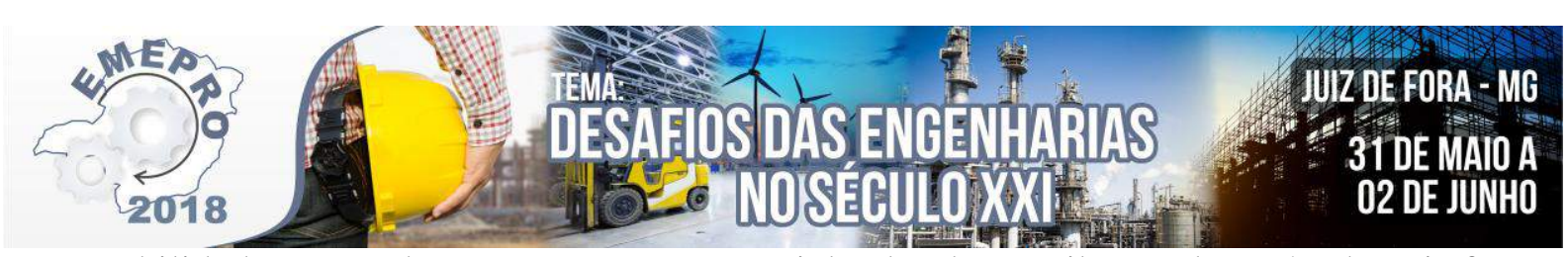

sustentabilidade. Levando-se em conta o potencial solar do Brasil em relação às demais fontes energéticas, as vantagens se destacam, pois, seu benefício é em curto prazo. Apesar de ser uma fonte nova e custosa, seu payback ${ }^{1}$ é rápido.

Dessa forma, desde os primórdios da humanidade já era necessário à utilização de alguma fonte energética para sobrevivência. Segundo Palz (2002) os primatas utilizavam como fonte quase que exclusivamente o Sol, onde obtinham principalmente aquecimento através da combustão da madeira e transporte com energia dos animais.

Com passar dos anos, houve a evolução do ser humano e com ela a mudança de suas necessidades. O autor Chaves (2014) explica que no século XVIII, com a primeira Revolução Industrial, a demanda de energia teve um substancial aumento, levando a população a buscar novos métodos para obtenção da mesma.

Em função disso, com a incessante busca atrás de novas fontes, foram desenvolvidas as convencionais conhecidas até hoje, como por exemplo, as hidrelétricas e os combustíveis fósseis (carvão mineral, gás natural e o petróleo).

Dessa perspectiva, entende-se o cenário energético segundo Lopez (2012, p. 23), ao propor que

a demanda de energia mundial nos próximos 50 anos, conforme estudos realizados pelo United Nations Solar Energy Group for Environment and Development (Uneged), mostra que a participação das energias solar e eólica será superior a 30\% na demanda global.

Contudo, como relatado por José Goldemberg (2010, p. 22) “as reservas de petróleo, gás natural e carvão são finitas e devem se esgotar dentro de 42, 64 e 241 anos respectivamente" e a água do planeta também está se tornando escassa com o passar dos anos. Com esse esgotamento das fontes, tem-se falado sobre a energia provida do Sol e de outras possíveis energias com fontes renováveis.

Com base nesses estudos, acredita-se que estudos acadêmicos e científicos como o caso deste artigo possuem uma relevância atual e por isso, imprescindível se faz discutir sobre a importância da Energia Solar.

Além deste estudo de campo, este trabalho é, também, fruto de uma pesquisa sistemática, que segundo Sampaio e Mancini (2007, p.84), "é uma forma de pesquisa que utiliza como fonte de dados a literatura sobre determinado tema".

Para tanto, a partir de uma análise anual das contas de energia da referida escola, foi solicitado um orçamento para a implementação da energia solar, verificando ser uma vantajosa fonte de economia, além da preservação do meio ambiente.

Assim, este artigo está estruturado em quatro tópicos.

\section{Embasamento teórico}

Neste trabalho, abordaremos temas ligados à fonte de energia solar, que segundo Lopez (2012, p.21) "é a energia menos poluente e menos finita conhecida até o momento". Nesse sentido, serão apresentados às diferenças entre a energia solar com as demais fontes, as características do consumo de energia, os benefícios gerados por ela, um projeto de

\footnotetext{
${ }^{1}$ É um indicador que determina o prazo de recuperação de um investimento, também chamado de payout.
} 


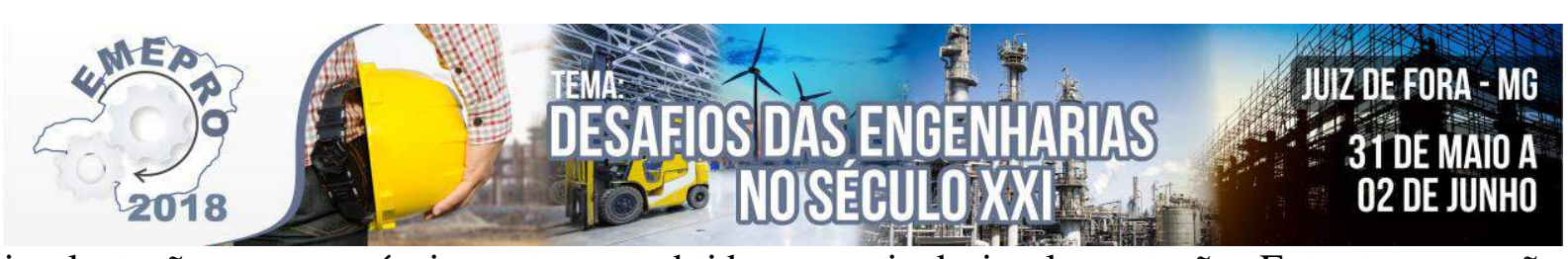

implantação e as possíveis vantagens obtidas a partir da implementação. Estes temas serão base para o estudo do caso apresentado, abarcados na leitura de diversos autores.

\subsection{Fontes de energia}

Atualmente existem diversas fontes de energia, sendo que elas dividem em dois tipos: fontes renováveis e fontes não renováveis.

As fontes renováveis são aquelas inesgotáveis e pode-se manter e aproveitadas ao longo do tempo. Como exemplos são citados a eólica e a solar, que são obtidas através dos ventos e do sol respectivamente.

As fontes não renováveis são aquelas derivadas de produtos esgotáveis, como por exemplo, petróleo e carvão mineral.

Existem hoje no mundo, conhecidamente, onze fontes de energias, sendo, hidráulica, gás natural, derivados do petróleo, carvão, nuclear, biomassa, eólica, solar, geotérmica, marítima e biogás.

O Brasil é um país em que sua maior parte da geração de eletricidade é proveniente de usinas hidroelétricas. Apesar disso, também possui um grande potencial com a produção a partir de combustíveis fósseis. Além destes dois potenciais, segundo Bronzatti e Neto (2008) também há uma grande exploração de urânio para utilização em novas usinas nucleares. No entanto este processo é mais complexo devido aos altos custos de investimento e de tecnologia, bem como as questões ambientais.

Bronzatti e Neto (2008, p.4) afirmam que,

no ano de 1970, a principal matriz energética era a lenha, representando $48 \%$ das necessidades brasileiras no uso final de energia. O petróleo, no mesmo ano, já representava 36\% da demanda. Entre 1970 e 1990, o consumo de lenha reduziu para uma taxa de $2,9 \%$ ao ano. Com a crise energética dos anos 70, o Brasil investiu nas fontes energéticas hidráulicas e de cana-de-açúcar, que tiveram um ritmo de crescimento de $6,6 \%$ ao ano, entre os anos de 1970 e 2005.

\subsection{Energia Solar}

A energia solar pode ocorrer de duas maneiras: ativa e passiva, sendo sua principal diferença o processo de transformação da geração de energia.

Segundo a Lopez (2012) quase todas as fontes de energia, abrangendo biomassa, eólica, energia dos oceanos, combustíveis fosses e hidráulica, são formas indiretas de energia solar, também chamada forma passiva.

Da forma ativa existem duas representações práticas de aproveitamento da energia solar, sendo geração por sistema térmico e sistema elétrico. Atualmente, esses sistemas são utilizados em sua maioria em aquecimento residencial passivo e fornecimento de energia elétrica para equipamentos autônomos remotos.

Goldemberg (2010, p.22) afirma que "a energia solar é totalmente dominante na superfície da Terra".

A Energia Solar Fototérmica caracteriza-se conforme Lopez (2012, p.25) "pelo surgimento de uma diferença de potencial, provocada pela junção de dois metais, em condições específicas".

Segundo Silva (2015, p.6), 


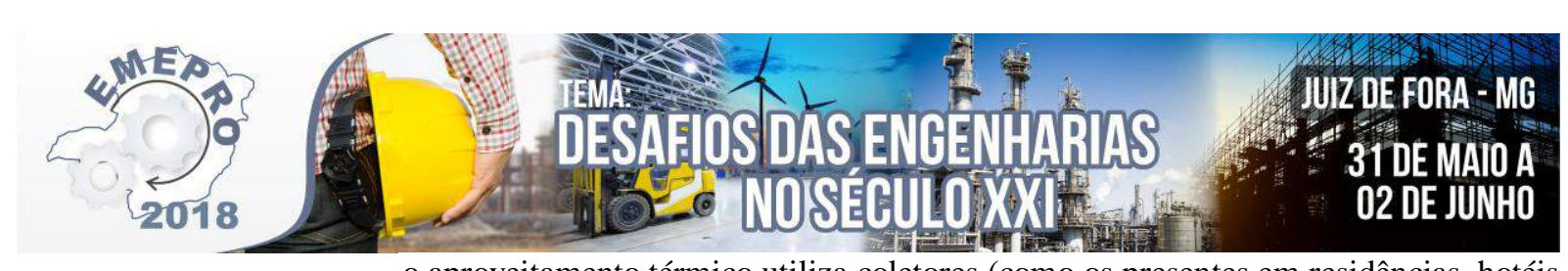

o aproveitamento térmico utiliza coletores (como os presentes em residências, hotéis etc.) para o aquecimento de água ou concentradores solares (para atividades que requerem temperaturas elevadas, tais como secagem de grãos e produção de vapor). Nesse caso, a radiação solar é captada por coletores, transformada em calor e utilizada para aquecimento. São os chamados Sistemas de Aquecimento Solar (SAS).

A abundância de energia solar na superfície da Terra modifica de acordo com o local e a época do ano. Conforme Lopez (2012) a disponibilizada média incidente sobre uma superfície plana de um metro quadrado, no período de um dia é de $0,2 \mathrm{kWh} / \mathrm{m}^{2}$. Esta intensidade, quando comparado com as outras fontes conhecidas, não é muita.

A principal vantagem do sistema fototérmico é que sua tecnologia é similar à utilizada nas usinas térmicas convencionais, suprindo o combustível fóssil por energia solar concentrada.

A Energia Solar Fotovoltaica é transmitida pelo sol na forma de radiação eletromagnética. De acordo com Silva (2015, p.6),

a radiação solar incide sobre materiais semicondutores e é transformada diretamente em corrente contínua; para transformar a corrente contínua em corrente alternada, são utilizados aparelhos chamados inversores.

Lopez (2012, p.86) diz que "o efeito fotovoltaico tem relação com os modelos de condução da eletricidade". No sistema elétrico relata a conversão direta da radiação solar em corrente elétrica contínua.

No cenário atual brasileiro, a usina solar ainda não é viável devido principalmente à inexistência de incentivos significativos, altos custos para os equipamentos e leilões de energia sem sinal locacional e diferenciação por fonte.

Com a tendência de aumentos nos custos de combustíveis fósseis e com as restrições ao seu uso, fontes tradicionais devem perder competitividade e dar espaço as fontes alternativas como a solar.

\section{Metodologia}

Os estudos encontrados nesta pesquisa são frutos de estudos empíricos ${ }^{2}$, sendo estes observados em campo juntamente com documentos ${ }^{3}$ cedidos pela Escola Municipal "Professora Hilda Lobão Rezende", da cidade de Maripá de Minas, e com uma abordagem quantitativa.

Fonseca (2002, p.20) esclarece que,

diferentemente da pesquisa qualitativa, os resultados da pesquisa quantitativa podem ser quantificados. Como as amostras geralmente são grandes e consideradas representativas da população, os resultados são tomados como se constituíssem um retrato real de toda a população alvo da pesquisa. A pesquisa quantitativa se centra na objetividade. Influenciada pelo positivismo, considera que a realidade só pode ser compreendida com base na análise de dados brutos, recolhidos com o auxílio de instrumentos padronizados e neutros. A pesquisa quantitativa recorre à linguagem matemática para descrever as causas de um fenômeno, as relações entre variáveis,

\footnotetext{
${ }^{2}$ É construído por meio de tentativas e erros num agrupamento de ideias. É caracterizado pelo senso comum, pela forma espontânea e direta de entendermos.

${ }^{3}$ Contas de energia elétrica, planta baixa da Escola Municipal "Professora Hilda Lobão Rezende" - Maripá de Minas e um orçamento de um projeto de implantação de energia solar.
} 


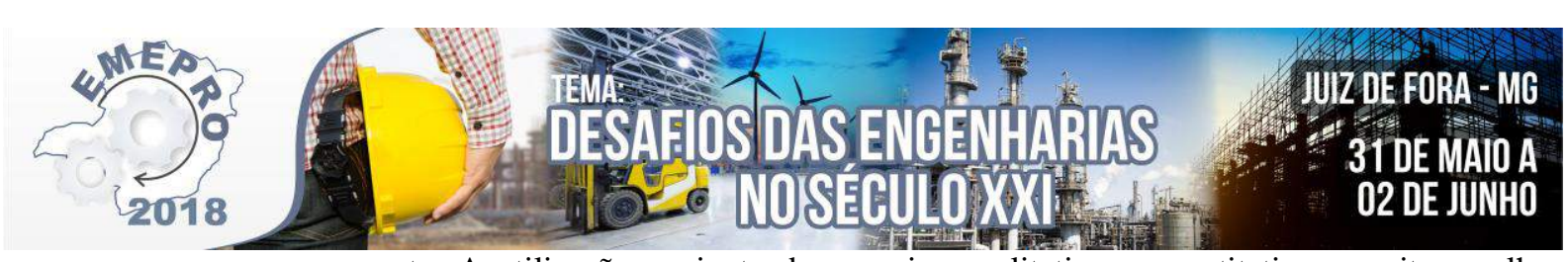

etc. A utilização conjunta da pesquisa qualitativa e quantitativa permite recolher mais informações do que se poderia conseguir isoladamente.

O presente trabalho utiliza das variáveis independentes e dependentes, apresenta uma pesquisa quantitativa, das quais serão traduzidas as informações obtidas com a finalidade de analisá-las e classificá-las, além da pesquisa experimental.

A pesquisa quantitativa foi realizada de modo documental, com a análise de contas de energia elétrica cedidas pela Prefeitura Municipal de Maripá de Minas e de um projeto orçamentário feito empresa ESolar ${ }^{4}$.

\section{Resultados}

A partir da coleta documental fornecida pela Prefeitura Municipal de Maripá de Minas, através do Prefeito Municipal, foi possível aferir os dados coletados durante o período de junho de 2016 a junho de 2017, relacionados ao consumo de Energia.

A tabela 1 e o gráfico 1 apresentam um resumo das contas de energia da Escola Municipal "Professora Hilda Lobão Rezende" no período relatado.

Tabela 1: Resumo das contas de energia elétrica

\begin{tabular}{ccccc}
\hline $\begin{array}{c}\text { Mês/Ano } \\
\text { Referente }\end{array}$ & $\begin{array}{c}\text { kWh } \\
\text { Utilizados }\end{array}$ & Valor/kWh & $\begin{array}{c}\text { Encargos e } \\
\text { cobranças }\end{array}$ & Total \\
\hline Jul/2016 & 720 & $\mathrm{R} \$ 0,6910$ & $\mathrm{R} \$ 15,02$ & $\mathrm{R} \$ 512,55$ \\
Ago/2016 & 640 & $\mathrm{R} \$ 0,6825$ & $\mathrm{R} \$ 13,48$ & $\mathrm{R} \$ 450,29$ \\
Set/2016 & 800 & $\mathrm{R} \$ 0,6952$ & $\mathrm{R} \$ 10,72$ & $\mathrm{R} \$ 566,88$ \\
Out/2016 & 1.040 & $\mathrm{R} \$ 0,7052$ & $\mathrm{R} \$ 9,58$ & $\mathrm{R} \$ 742,95$ \\
Nov/2016 & 760 & $\mathrm{R} \$ 0,7104$ & $\mathrm{R} \$ 12,23$ & $\mathrm{R} \$ 552,14$ \\
Dez/2016 & 800 & $\mathrm{R} \$ 0,6894$ & $\mathrm{R} \$ 0,00$ & $\mathrm{R} \$ 551,56$ \\
$\mathrm{Jan} / 2017$ & 480 & $\mathrm{R} \$ 0,6817$ & $\mathrm{R} \$ 0,00$ & $\mathrm{R} \$ 327,22$ \\
Fev/2017 & 680 & $\mathrm{R} \$ 0,6868$ & $\mathrm{R} \$ 12,15$ & $\mathrm{R} \$ 479,18$ \\
$\mathrm{Mar} / 2017$ & 1.160 & $\mathrm{R} \$ 0,7194$ & $\mathrm{R} \$ 0,00$ & $\mathrm{R} \$ 834,45$ \\
Abr/2017 & 1.080 & $\mathrm{R} \$ 0,6905$ & $\mathrm{R} \$ 9,51$ & $\mathrm{R} \$ 755,20$ \\
Mai/2017 & 800 & $\mathrm{R} \$ 0,6912$ & $\mathrm{R} \$ 0,00$ & $\mathrm{R} \$ 552,97$ \\
$\mathrm{Jun} / 2017$ & 880 & $\mathrm{R} \$ 0,6605$ & $\mathrm{R} \$ 0,00$ & $\mathrm{R} \$ 581,25$ \\
$\mathrm{Ju} / 2017$ & 800 & $\mathrm{R} \$ 0,6758$ & $\mathrm{R} \$ 0,00$ & $\mathrm{R} \$ 540,66$ \\
\hline
\end{tabular}

Fonte: Documentos coletados pelos autores na Prefeitura Municipal de Maripá de Minas

\footnotetext{
${ }^{4}$ Empresa de engenharia de sustentabilidade.
} 


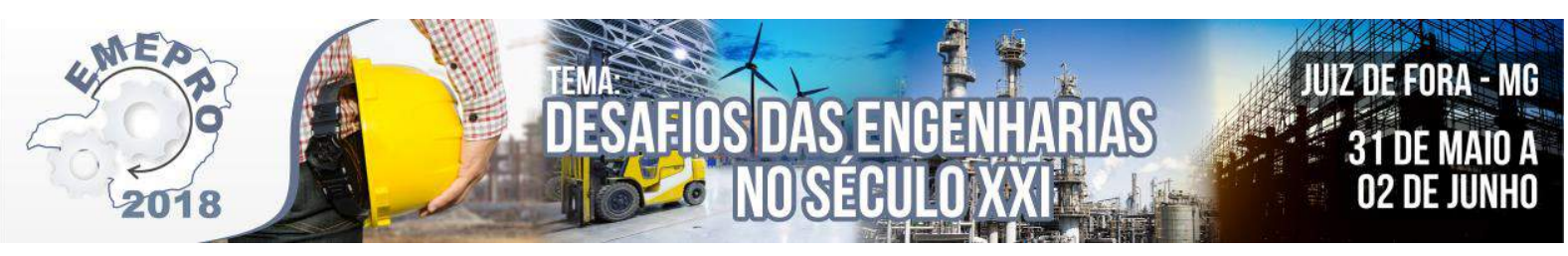

KWh/Mês

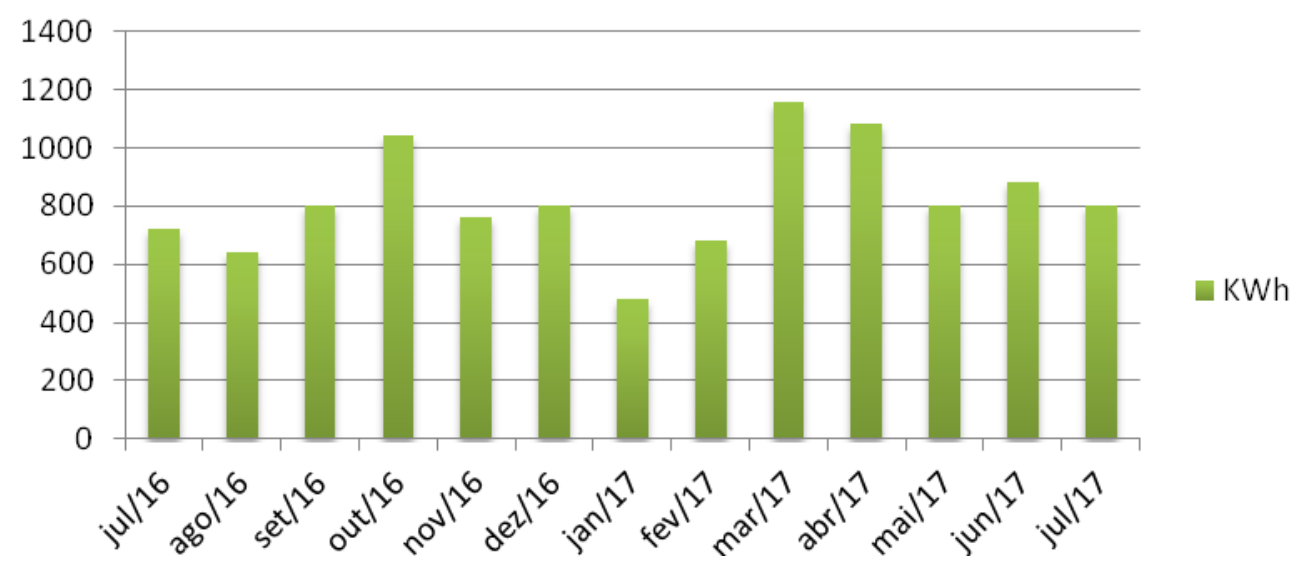

Gráfico 1: Consumo de energia em relação aos meses

Fonte: Os autores

A partir dos dados coletados, foi possível perceber que a escola possui relativamente um controle mensal de consumo de $\mathrm{kWh}^{5}$, exceto no mês de janeiro de 2017 , que teve uma queda resultante das férias escolares e nos meses de outubro de 2016, março e abril de 2017 que teve um aumento sem justificativa aparentemente.

A empresa ESolar, uma empresa de Serviço de Engenharia de Sustentabilidade, que trabalha com projetos nas áreas de elétrica, automação e mecânica, abrangendo toda uma área voltada por consumidores industriais, comerciais e residenciais, sediada à Rua: São Geraldo, 287 - Costa Carvalho, na cidade de Juiz de Fora, Minas Gerais, foi solicitada e fez um projeto orçamentário para a implantação do sistema solar fotovoltaico na Escola Municipal "Professora Hilda Lobão Rezende".

Para este orçamento a empresa só teve acesso ao anexo 3 que é referente à conta de luz do mês de Setembro/2016. Sendo assim, o projeto pode requerer alterações após uma visita técnica, quando será feita uma avaliação mais detalhada.

O projeto está descrito na tabela 2, com seus respectivos investimentos:

\footnotetext{
${ }^{5}$ Quilowatt-hora.
} 


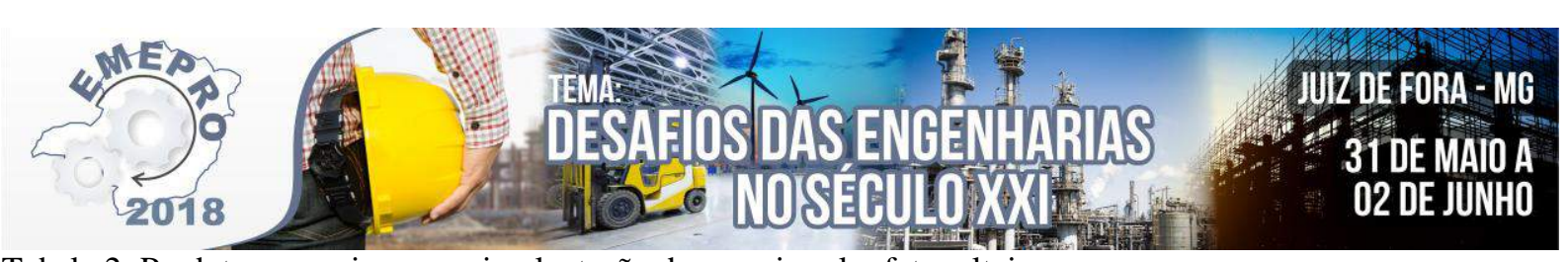

Tabela 2: Produtos e serviços para implantação da energia solar fotovoltaica

\begin{tabular}{ccc}
\hline Item & Investimento & Custo \\
\hline 20 Módulos Fotovoltaicos & \\
Inversor Fotovoltaico & Cabo Solar & \\
Kit Fotovoltaico & Estrutura para instalação & \\
Conectores & String Box & \\
Serviço de & Frete estimado $\$ 829,05$ \\
Transporte & Elaboração de Memorial e projeto & \\
elétrico & \\
Serviço de & Emissão de Art & \\
Engenharia & Tramites junto a Cemig & \\
& Serviço de instalação & \\
&
\end{tabular}

Fonte: Empresa Esolar

Totalizando um valor de $\mathrm{R} \$ 35.154,74$. Sendo a potência do sistema de $6,5 \mathrm{KWp}^{6}$, obtém um valor de $\mathrm{R} \$ 5.408,42$ por $\mathrm{KWp}$.

Segundo a empresa Solar Volt ${ }^{7}$, os painéis solares têm vida útil de 30 a 40 anos como um todo. Os fabricantes comprovam um funcionamento de forma eficiente, com potencial de produção em pelo menos $80 \%$ durante um período de 25 anos.

Com os dados da energia solar utilizada na Escola Municipal "Professora Hilda Lobão Rezende" e com o valor do projeto orçado, calculou-se o payback do mesmo em 5,2 anos.

\section{Considerações finais}

O problema da escassez dos recursos energéticos tem sido há anos um importante tópico de pesquisa na área e este artigo ilustra uma possível solução eficiente com o uso da energia solar.

Foi possível demonstrar, através de um caso real, a importância e os benefícios de se fazer a implantação de um sistema solar fotovoltaico. O estudo feito na Escola Municipal "Professora Hilda Lobão Rezende", demonstrou que apesar de ter um gasto relativamente pequeno de consumo de energia elétrica em relação aos órgãos públicos, será possível obter ganhos com a utilização estratégica da energia solar.

Conclui-se que o investimento terá retorno em menos de seis anos, o que é significativamente viável para um patrimônio público. Sendo assim, a utilização da energia solar fotovoltaica permite uma redução de custos e redução de recursos naturais, sendo esta uma energia renovável e sustentável.

\footnotetext{
${ }^{6}$ Citado no projeto

${ }^{7}$ Empresa de desenvolvimento de soluções e projetos de energia solar fotovoltaica.
} 


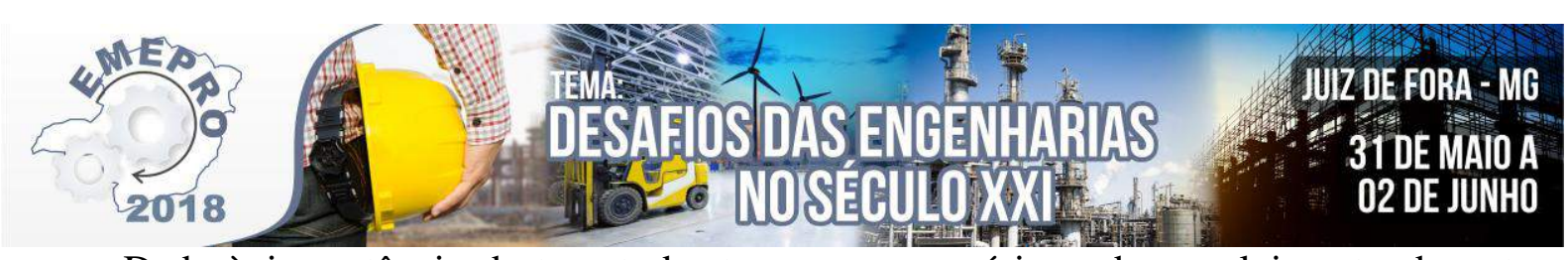

Dada à importância deste estudo, torna-se necessário o desenvolvimento de outras formas de geração de energia e aperfeiçoamento das técnicas e custos das mesmas. Podendo assim economizar, não só dinheiro, mas também os recursos naturais, que estão cada vez mais escassos.

Portanto, em situações de limitações financeiras de patrimônios públicos, a utilização de energia solar fotovoltaica se mostra eficiente no ponto de vista econômico. Contudo, sugerem-se novas investigações sobre as vantagens e desvantagens do uso da energia hidrelétrica em comparação com a energia solar fotovoltaica em patrimônios públicos de diferentes naturezas (como por exemplo: Postos de saúde; Prefeituras; Creches; Hospitais, entre outros).

\section{Referências}

BERMANN, Célio. Energia no Brasil: Pra quê? Pra quem? Crise e Alternativas para um país sustentável. 2. Ed. São Paulo. Editora Livraria da Física, 2003.

BRONZATTI, F. Luiz; NETO, A. Iarozinski. Matrizes energéticas no Brasil: cenário 2010-2030. IN: ENCONTRO NACIONAL DE ENGENHARIA DE PRODUÇÃO, 2008, Rio de Janeiro. A integração de cadeias produtivas com a abordagem da manufatura sustentável. Disponível em:

8TTP://www.abepro.org.br/biblioteca/enegep2008_TN_STO_077_541_11890.pdf. Acesso em: 12 jun. 2017.

CHAVES, Lázaro Curvêlo. A Energia Solar. Disponível em:

8TTP://www.culturabrasil.org/revolucaoindustrial.html. Acesso em: 24 abr. 2017.FONSECA, João José Saraiva da. Metodologia da pesquisa científica. Fortaleza-CE, 2002.GOLDERMBERG, José. Energia e Desenvolvimento Sustentável. Vol. 4, São Paulo. Editora Edgard Blucher Ltda., 2010.LOPEZ, Ricardo Aldabó. Energia Solar para produção de eletricidade. São Paulo; Artliber Editora Ltda., 2012.

PALZ, Wolfgang. Energia Solar e fontes alternativas. Curitiba: Hermus Livraria, 2002.

SAMPAIO, Rosa Ferreira; MANCINI, Marisa Cotta. Estudos de revisão sistemática: um guia para síntese criteriosa da evidência científica. Revista Brasileira de Fisioterapia. Disponível em: http://www.scielo.br/pdf/\%0D/rbfis/v11n1/12.pdf. Acesso em: 20 set. 2017. Vol. 11, No 01, p. 83-89, São Carlos-SP; Bimestral, 2007.

SILVA, R. M. Energia Solar no Brasil: dos incentivos aos desafios. Brasília: Núcleo de Estudos e Pesquisas/CONLEG/Senado, Fevereiro/2015 (Texto para Discussão nº 166). Disponível em: www.senado.leg.br/estudos. Acesso em: 09 nov. 2017. 


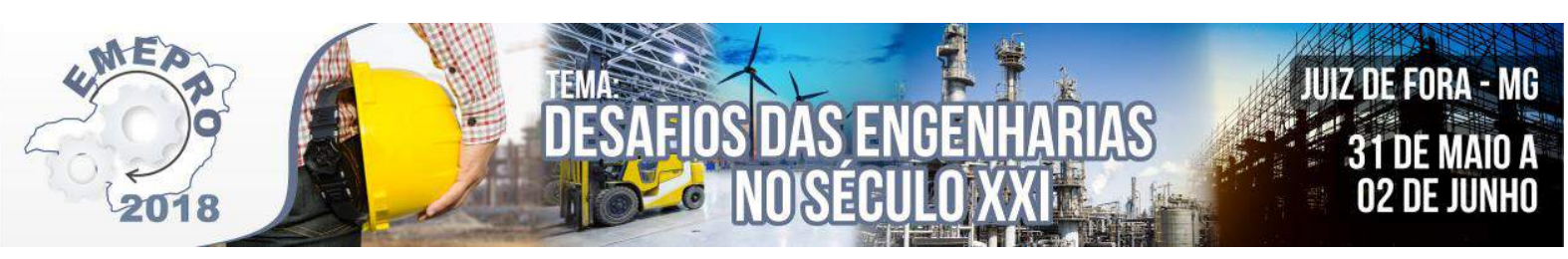

\title{
Análise de estabilidade transitória em uma unidade de geração com inserção de sistemas SMES
}

\author{
VANESSA CARLA SILVA MELO - CEFET-MG - vanessacsm91@ gmail.com
}

CLARA BUSTAMANTE FONSECA BARBOSA - CEFET-MG - clarabfb@ gmail.com

MARLON JOSÉ DO CARMO - CEFET-MG - marloncarmo@iee.org

Resumo: Este trabalho apresenta a análise da inserção de Armazenadores Supercondutores de Energia Magnética (SMES - Superconductor Magnetic Energy Storage) para melhoria da estabilidade transitória e qualidade de energia em um sistema elétrico de potência de pequeno porte. $O$ assunto é de fundamental importância e bastante discutido atualmente. Uma análise da estabilidade transitória em uma unidade de geração com a inserção de micro SMES é o objetivo do trabalho, e está relacionado à utilização de SMES para a melhoria da qualidade da energia e o impacto desta sobre uma geração realizada por máquina síncrona. Para a simulação foi utilizado o software Matalb/Simulink e posteriormente foram apresentados e analisados os resultados obtidos. Verificou-se que em alguns casos a utilização de unidades SMES foram factíveis para os problemas propostos.

Palavras-chave: Qualidade da Energia, Estabilidade Transitória, Sistemas Elétricos de Potência, Supercondutividade, SMES.

\section{Introdução}

A disponibilidade da energia elétrica representa uma expansão da qualidade de vida das populações. Assim que se implanta um sistema de distribuição de energia elétrica, a população local passa a constar com inúmeros benefícios, tais como um maior conforto doméstico e melhores possibilidades de emprego e produção. À medida que os benefícios da energia elétrica passam a fazer parte do dia-a-dia das pessoas, é natural que se inicie um processo de discussão quanto à qualidade desse produto (MEHL, 2001). O termo Qualidade da Energia Elétrica (QEE) tornou-se uma palavra-chave no contexto do setor elétrico nacional, uma vez que as concessionárias de energia e os fabricantes, preocupam-se todos os dias com a sua qualidade. Embora, largamente utilizado, ainda não existe um consenso no emprego desse termo, podendo ter diferentes significados para grupos distintos dependendo do ponto de vista de cada um deles, ou seja, cada um vai necessitar de um índice de qualidade de energia de uma forma diferente (MARTINHO, 2010). Diante de um mercado globalizado, crescentemente competitivo, o assunto da qualidade da energia tem se tornado de fundamental importância, uma vez que os modernos processos industriais podem sofrer curtas interrupções de tensão elétrica, o que implica em significativas perdas econômicas a longo prazo. Muitos desses problemas, que não eram comuns no passado, ocorrem atualmente devido ao crescente uso de equipamentos que fornecem características não lineares à rede, e estes são cada vez mais sensíveis à qualidade da tensão de alimentação (GAMA, 2006). 


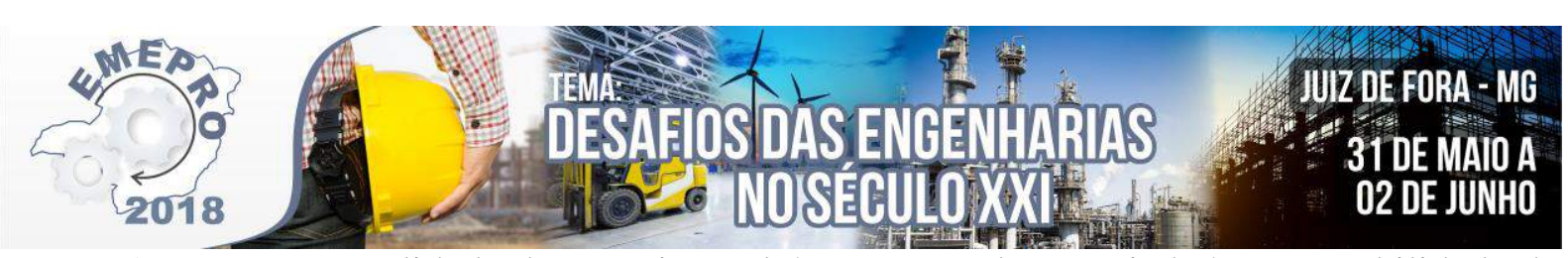

A expressão qualidade da energia também vem sendo associada à sustentabilidade do planeta, pois em alguns casos o problema causado por uma má gestão desta, pode ocasionar o desperdício da mesma. Isso colabora com as atuais preocupações de excesso na demanda versus escassez de energia, já que com o desperdício é preciso gerar mais para suprir essa demanda. (MARTINHO, 2010). Sempre que ocorre um problema no sistema elétrico, seja um desvio na forma de onda da tensão de alimentação, corrente ou frequência, dizemos que existe um problema de qualidade da energia. Tais problemas podem resultar na falha ou má operação de equipamentos dos consumidores. A estabilidade de um sistema está relacionada com a condição de equilíbrio entre forças opostas. As máquinas síncronas interconectadas mantêm-se sincronizadas através de forças chamadas "forças restauradoras". Quando estão no estado de regime permanente, existe um equilíbrio entre o torque de carga elétrica e o torque mecânico motriz em cada máquina, fazendo com que o rotor permaneça com a sua velocidade constante. Se o sistema é perturbado, esse equilíbrio se desfaz, causando uma aceleração ou desaceleração dos rotores das máquinas (MATA, 2005). Os distúrbios nos sistemas elétricos podem provocar variações na frequência, e estas podem ocasionar interrupções no fornecimento. A maior parte das cargas podem operar em faixas amplas de frequência, o que não acontece com os geradores sincronizados.

Um sistema elétrico de potência é formado basicamente por geradores síncronos e cargas interligados por linhas de transmissão. Um sistema interligado com um grande número de máquinas está sujeito a pequenas perturbações, como por exemplo, a variação de cargas no barramento. A essas pequenas perturbações, denomina-se estabilidade dinâmica. Quando o sistema é afetado por grandes perturbações, denomina-se estabilidade transitória (DIAS; PILONI, 2010). Nos últimos anos, muito tem se falado na qualidade da energia, que é a base para que os equipamentos funcionem bem. Os problemas de qualidade da energia não são recentes, mas o crescente interesse por esse assunto deve-se ao uso de equipamentos eletroeletrônicos cada vez mais sensíveis, o que faz com que os distúrbios como o afundamento de tensão e outras perturbações associadas à qualidade de energia sejam cada vez mais frequentes. Com isso, ocorre um aumento das pesquisas objetivando minimizar os danos causados por esses distúrbios, inclusive sobre os elementos geradores nas usinas, pois estes podem ser afetados por esses problemas. Portanto, a situação problema a ser resolvida neste trabalho, está relacionada à utilização de SMES para a melhoria da qualidade da energia e o impacto desta sobre uma geração realizada por máquina síncrona. Para tanto, utilizar-se-á duas linhas de transmissão que conectam a máquina síncrona a um sistema de grande porte representado por uma barra infinita. A análise sistêmica por motivo de simplicidade foi utilizada em sistema três fios e não se utilizou modelo de sequência positiva. Produziu-se uma falta em uma fase e verificou-se as tensões e correntes de linha, bem como as características transitórias da máquina. A inserção do SMES tem como objetivo melhorar a qualidade de energia sobretudo nos aspectos de estabilidade transitória, o qual será o foco deste trabalho.

O trabalho está organizado em seções, conforme sumarizados a seguir: na seção 2 , apresenta-se o funcionamento do SMES; a seção 3 descreve a metodologia e são apresentados os resultados de simulação, bem como a análise destes resultados; por último apresentam-se as conclusões e sugestões para trabalhos futuros.

\section{O Armazenador Supercondutor de energia magnética}

O SMES é conhecido por ser um excelente dispositivo de armazenamento de energia. Existem outras formas de se armazenar energia como os capacitores e as baterias, porém os armazenadores supercondutores de energia vêm se destacando. $\mathrm{O}$ armazenamento de energia 


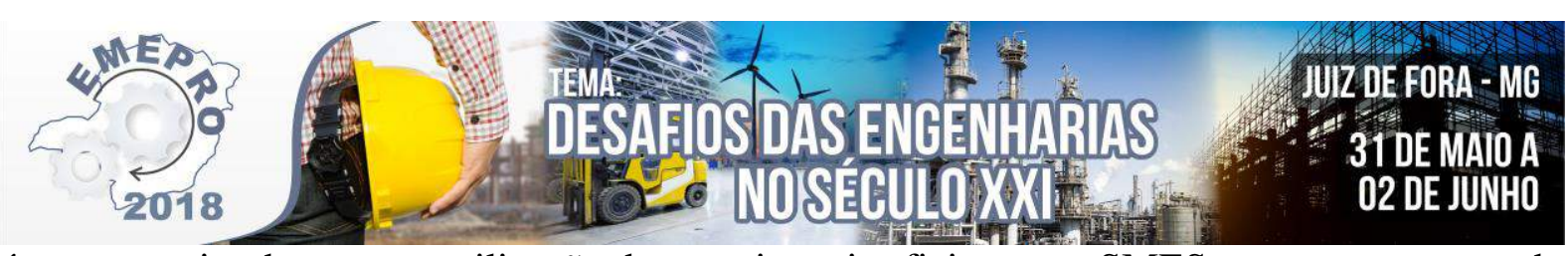

é uma maneira de tornar a utilização da energia mais eficiente e o SMES vem se apresentando como um sistema promissor e com um vasto campo de aplicação, das quais pode-se destacar o nivelamento de carga, a estabilidade de tensão e o melhoramento da qualidade de energia.

\subsection{Definição de um SMES}

O armazenador supercondutor de energia magnética é uma das aplicações da supercondutividade. Especificamente, SMES é um armazenador de energia elétrica contínua que excita um campo magnético de corrente contínua. Para transportar essa corrente, o condutor opera a temperaturas criogênicas, ou seja, muito baixas e se comporta como um supercondutor produzindo um campo magnético, portanto não há perdas resistivas. Assim, a energia pode ser armazenada de um modo persistente, até que seja solicitada (Xue et al, 2006). A atual tecnologia da criogenia e da supercondutividade, faz com que sejam definidos os componentes do dispositivo de SMES. Em geral, um sistema SMES consiste em quatro partes: a bobina supercondutora com o imã (SCM), o sistema de condicionamento de energia (PCS), o sistema criogênico (CS) e a unidade de controle (CU). A função de cada parte é descrita a seguir:

Superconducting Coil with the Magnet (SCM): É composto pela bobina supercondutora, o imã, e a proteção da bobina. Ele é usado para armazenar a energia elétrica contínua. A bobina supercondutora e o imã devem ser fortes o suficiente para resistirem à grande força de Lorentz (força sobre uma carga pontual devido a campos eletromagnéticos) quando energizados. A proteção da bobina é necessária para proteger a bobina supercondutora contra falhas, o que pode causar sérios danos aos sistemas SMES.

Power Conditioning System (PCS): Consiste nos conversores e circuitos de disparo. Ele é a interface entre a rede e o SCM. Através do PCS, a energia em corrente alternada pode ser transformada em energia em corrente contínua, e assim pode ser armazenada no SCM. Inversamente, a energia em corrente contínua armazenada no SCM também pode ser transformada em energia em corrente alternada, que será entregue à rede.

Cryogenic System (CS): É necessário para resfriar e colocar o SMES na temperatura de operação. É composto por refrigeradores, bomba de vácuo, tanques e tubulações de Hélio e um Dewar (conhecido como garrafa térmica, é um objeto projetado para fornecer um isolamento térmico quase perfeito, dificultando as trocas de calor com o meio externo).

Control Unit (CU): É uma parte essencial no sistema SMES. Várias funções do sistema SMES e da proteção da bobina supercondutora são controladas pelo CU. Não importa o que o SMES irá implementar, ele depende principalmente do CU para executar várias funções. Ele é composto de um microcontrolador ou DSP (Processador digital de sinais do inglês: Digital Signal Processor) e um circuito de interface. A Figura 1, apresenta um sistema SMES com as suas partes resumidamente:

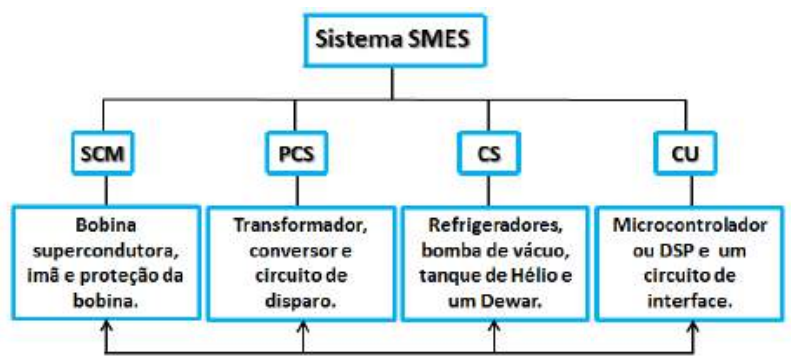

FIGURA 1 - Partes constituintes de um SMES. Fonte: Adaptado de (ALI \& DOUGAL, 2010). 


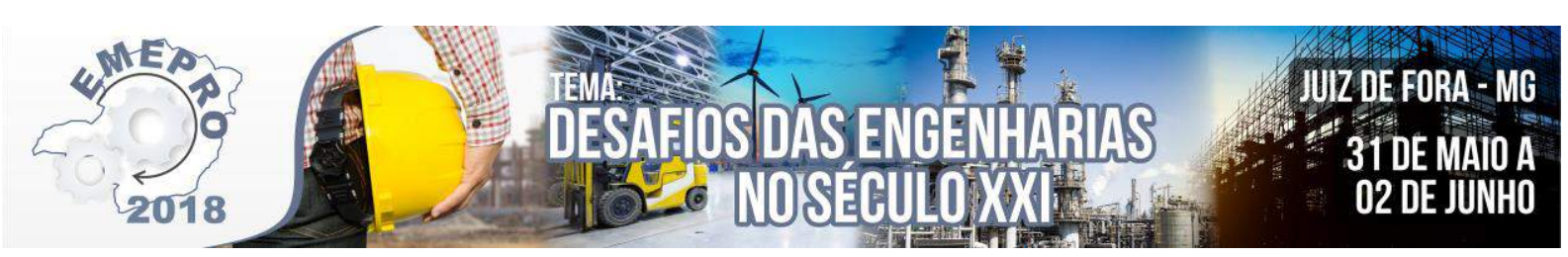

\subsection{Topologias de sistemas SMES}

$\mathrm{O}$ armazenador supercondutor de energia magnética armazena energia no campo magnético criado a partir da corrente que flui em uma bobina supercondutora. A potência ativa bem como a potência reativa podem ser absorvidas ou liberadas no sistema pela bobina quando necessário. No SMES, o sistema de condicionamento de energia (PCS) que é responsável por essa transferência de energia entre a bobina e o sistema (Ali et al, 2010). Existem três tipos de PCS aplicados ao SMES:1- PCS Thyristor; 2- PCS Voltage Source Converter (VSC); 3- PCS Current Source Converter (CSC).

A primeira topologia é formada por um transformador do tipo estrela-delta, uma ponte conversora AC-DC com seis tiristores e uma bobina supercondutora. A ponte conversora imprime uma tensão positiva ou negativa na bobina supercondutora. As cargas e descargas são controladas alterando o ângulo de atraso que controla o disparo sequencial dos tiristores. Quando esse ângulo é menor que $90^{\circ}$, o conversor opera no modo retificador, carregando a bobina. Quando ele é maior que $90^{\circ}$, o conversor opera no modo inversor, descarregando a bobina. Sendo assim, a energia pode ser absorvida ou liberada para o sistema quando necessário. A Figura 2 apresenta a topologia 1.

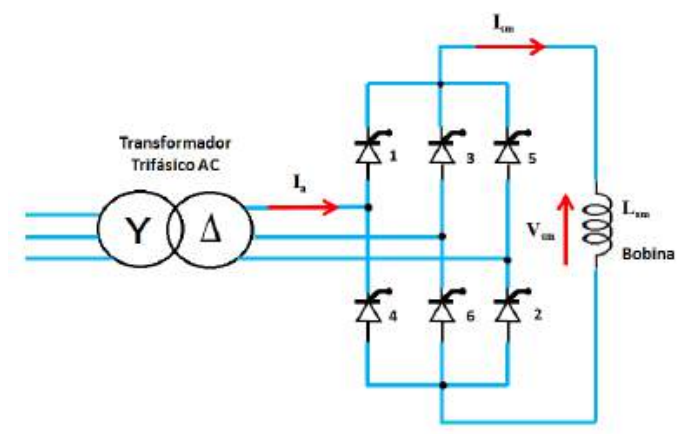

FIGURA 2 - Topologia PCS-SMES. Fonte: Adaptado de (ALI \& DOUGAL, 2010).

A topologia 2 mostrada é formada por um transformador do tipo estrela-delta, um inversor/retificador com modulação por largura de pulso (PWM) usando transistores bipolares de portas isoladas (IGBT), um chopper DC-DC de dois quadrantes usando IGBT e uma bobina supercondutora. O conversor PWM e o chopper DC-DC estão ligados por um capacitor DC de ligação. O conversor PWM fornece uma interface entre o sistema de alimentação AC e a bobina supercondutora. O sistema de controle utilizado é o controle proporcional - integral (PI) que compara a tensão nos terminais da bobina e no capacitor com valores de referência. O sinal PWM é gerado pela comutação do IBGT e a tensão DC sobre o capacitor é mantida constante em todos os seis pulsos do conversor PWM.A bobina supercondutora é carregada ou descarregada pelo chopper DC-DC. Isso é feito de acordo com o ajuste de tensão média nos terminais da bobina, determinado pelo ciclo de trabalho do chopper. Se esse ciclo for maior que 0.5, ela é carregada e se for menor que 0.5, ela é descarregada (Ali et al, 2010). A Figura 3 apresenta a topologia 2. 


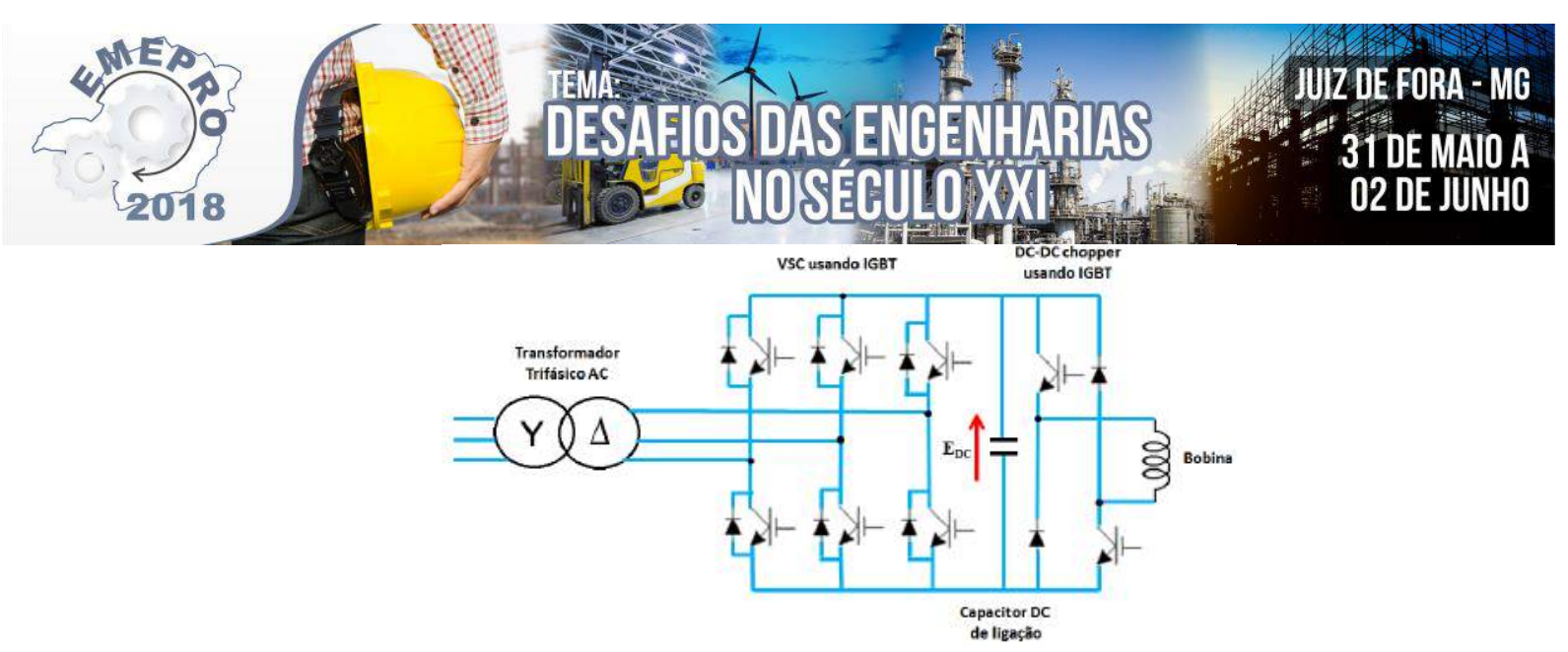

FIGURA 3 - Topologia VSC-SMES. Fonte: Adaptado de (ALI \& DOUGAL, 2010).

Na topologia 3, o lado DC está ligado diretamente na bobina supercondutora e o lado AC está ligado diretamente na linha de alimentação. Os capacitores podem filtrar os harmônicos de alta ordem da corrente AC de linha. Através da regulação dos pulsos de gatilho dos dispositivos de comutação, a corrente na bobina pode ser modulada para gerar corrente controlável trifásica PWM. A Figura 4 ilustra a topologia CSC-SMES.

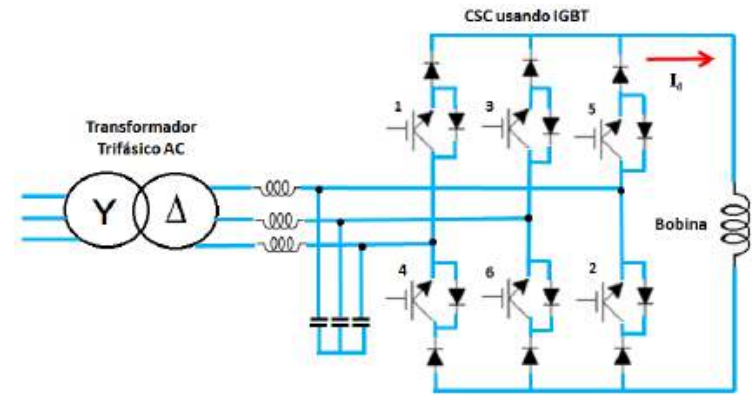

FIGURA 4 - Topologia CSC-SMES. Fonte: Adaptado de (ALI \& DOUGAL, 2010).

\subsection{Projetos utilizando SMES}

Os projetos desenvolvidos primeiramente utilizaram os materiais supercondutores de baixa temperatura (LTS) Low Temperature Superconductor e mais tarde, com a descoberta dos materiais supercondutores de alta temperatura (HTS) High Temperature Superconductor, estes também foram sendo utilizados. A seguir serão descritos alguns projetos que foram feitos, utilizando os LTS SMES e os HTS SMES.

\section{LTS SMES}

Em 1972 iniciou-se o primeiro projeto utilizando o SMES. Foi usada uma unidade de 30 MJ projetada pelo Los Alamos National Laboratory (LANL) juntamente com a Bonneville Power Administration (BPA). O projeto foi instalado em 1979 na subestação de Tacoma, nos Estados Unidos e possuia um conversor de $10 \mathrm{MW}$, que tinha como objetivo fornecer amortecimento às oscilações de baixa frequência da rede. Com o sucesso dessa instalação inicial, foram iniciados os estudos sobre o SMES.

Em 1991, foi finalizado um projeto da Kyosho Eletric Power Co., cujo objetivo era compensar as flutuações das cargas e fazer o controle da tensão da rede. Foi instalado um SMES de $36 \mathrm{MJ}$ para isso. Este projeto foi seguido pela construção de uma unidade de $20 \mathrm{MJ}$ na Alemanha, em 2000, pela Accel Instruments. Foram instaladas seis unidades de SMES na rede, em Wisconsin, nos Estados Unidos, no mesmo ano pela companhia American Superconductor com a finalidade de resolver problemas de instabilidade de tensão e depressões de tensão da rede. 


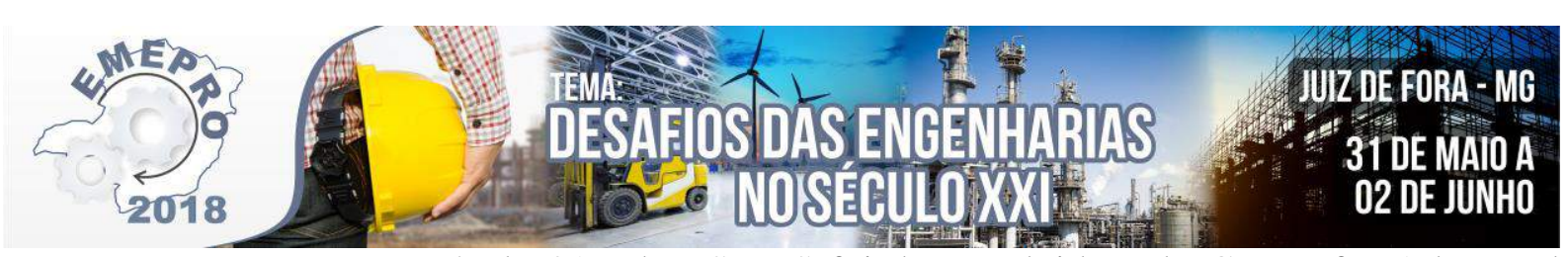

Um programa no século 21 sobre SMES foi desenvolvido pelo Center for Advanced Power System (CAPS) na Florida, nos Estados Unidos, juntamente com o Eletric Power Research Institute (EPRI) e tem a capacidade de armazenar até $100 \mathrm{MJ}$ e fornecer $50 \mathrm{MW}$ de potência.

\section{HTS SMES}

Logo que os supercondutores HTS foram descobertos, inicialmente eles não foram aplicados no desenvolvimento dos SMES. Porém, com a grande disponibilidade da fita HTS, iniciaram-se os estudos para descobrirem se esta nova tecnologia poderia ser usada nos projetos SMES. Em 1993, foi instalado um SMES de 1,4 MVA/2,4 MJ pelo Brookhaven National Laboratory, nos Estados Unidos com a finalidade de oferecer alta qualidade de energia, protegendo a rede das interrupções de tensão.

Em 1997, foi construído pela American Superconductor Corporation (ASC) um projeto de um dispositivo HTS SMES de $5 \mathrm{KJ}$, com capacidade para transportar até $100 \mathrm{~A}$.

Em 2001, o Korean Electrotechnology Research Institute (KERI) projetou um dispositivo SMES de $200 \mathrm{KJ}$, com capacidade para transportar até $200 \mathrm{~A}$.

Os projetos mais recentes foram iniciados em 2005: no Japão, um dispositivo SMES de 10 MVA para a compensação de flutuações de cargas e na Austrália, pela Universidade de Wollongong, foi projetada uma unidade de SMES de $20 \mathrm{KJ}$ utilizando fita BSCCO-2223 para pequenas interrupções de tensão.

Após o desenvolvimento e os estudos dos projetos citados, verificou-se que a tecnologia LTS SMES é mais vantajosa nas instalações de alta potência tais como produção e transporte de energia, enquanto a HTS SMES é mais vantajosa para pequena e média potência como a distribuição de energia.

\subsection{Futuras aplicações do SMES nos Sistemas Elétricos}

A tecnologia SMES pode ser aplicada para melhorar a estabilidade do sistema de potência corrigindo os distúrbios causados nas redes, por exemplo. Os estudos recentes com os supercondutores estão fazendo do SMES uma solução viável para corrigir alguns problemas encontrados nos sistemas elétricos. A seguir serão descritas algumas aplicações do SMES nesses sistemas.

\section{SMES para Reduzir as Oscilações do Sistema}

As oscilações de baixa frequência $(0,5$ a $1 \mathrm{~Hz})$ da rede, surgem logo após a ocorrência de uma maior perturbação como falhas na linha de transporte e perdas nas unidades de geração. O amortecimento dessas oscilações é uma maneira de melhorar a capacidade de transmissão da rede. O SMES pode reduzir essas oscilações através da modulação das potências ativas e reativas, como pode ser visto na Figura 5 (XUE et al, 2006).

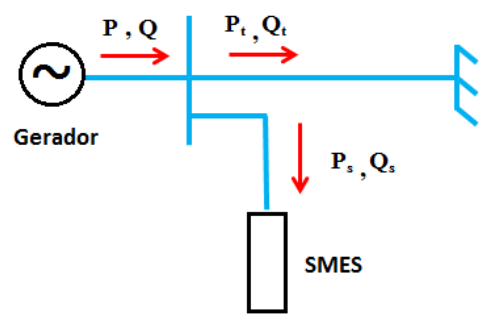

FIGURA 5 - SMES para reduzir oscilações no sistema. Fonte: Adaptado de (XUE et al., 2006). 


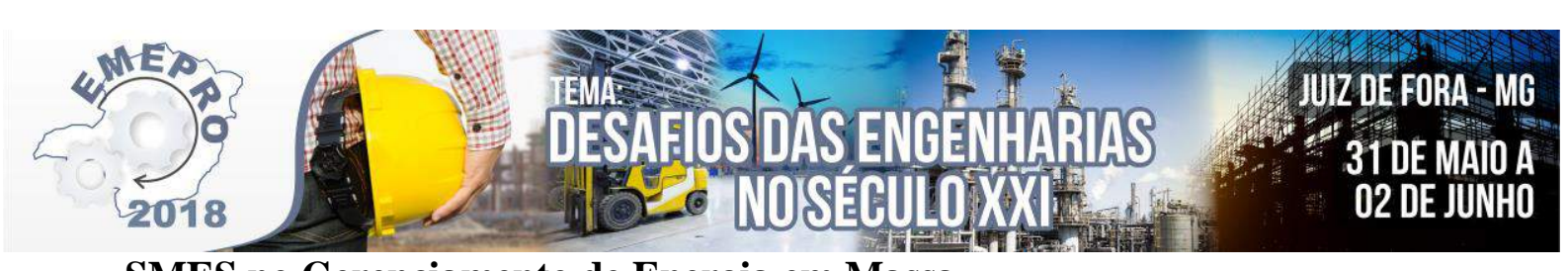

SMES no Gerenciamento de Energia em Massa

Uma unidade de SMES tem a capacidade de armazenar e transferir grandes quantidades de energia. Essa energia armazenada que não é utilizada em um determinado local pode ser transferida para outro ponto onde a demanda é maior. Isso pode reduzir o custo da eletricidade (ALI et al, 2010).

\section{SMES para aumentar a Estabilidade da Tensão}

A instabilidade da tensão existirá quando ocorrer uma grande perda de produção de energia ou quando não houver potência reativa dinâmica para manter as tensões. Isso pode provocar um decaimento da tensão em um período de 5 a $15 \mathrm{~min}$, ou até mais rápido, provocando assim uma interrupção da tensão. O SMES é eficiente para diminuir essas instabilidades, uma vez que ele fornece potência ativa e reativa simultaneamente, de forma a anular essa perturbação devido à perda de produção de energia (Xue et al, 2006).

\section{SMES no Controle da Flutuação de Cargas}

A Figura 6 apresenta um sistema com unidade SMES para o controle da flutuação de cargas. O SMES possui uma característica de resposta rápida às demandas de potência ativa e reativa, a qual pode ser usada para o controle da flutuação das cargas, fazendo o nivelamento dessas flutuações e melhorando a estabilidade das redes de energia.

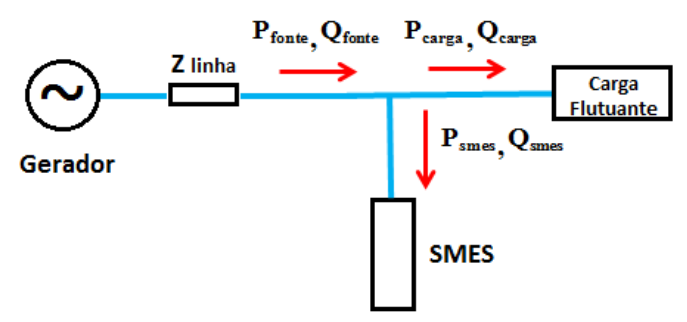

FIGURA 6 - SMES no controle de flutuação de cargas. Fonte: Adaptado de (XUE et al., 2006).

\section{SMES como Reserva Girante}

No caso de uma grande unidade de produção ser forçada a sair de serviço, um número específico de dispositivos de geração, devem ser mantidos fora de serviço, mas ligados, como reserva girante. Essa reserva girante deverá ser cerca de $7 \%$ da carga do sistema. Uma vez que o SMES pode armazenar uma quantidade de energia significativa, é possível que este forneça energia suficiente de forma a satisfazer o pedido de reserva girante, até que as turbinas sejam colocadas em serviço. Fornecer reserva girante utilizando o SMES é mais eficiente e rentável do que com turbinas, visto que o SMES é uma tecnologia praticamente sem perdas de armazenamento, enquanto manter as turbinas em rotação tem perdas significativas e custos operacionais elevados (XUE et al, 2006).

Nesta seção apresentou-se uma breve introdução sobre SMES e na próxima desenvolve-se a metodologia e os resultados a partir da aplicação da mesma, utilizando uma das topologias descritas nessa seção.

\section{Metodologia e resultados}

A rede a ser simulada é constituída por um gerador síncrono trifásico com tensão eficaz igual a $315 \mathrm{kV}$ e potência aparente igual a $1000 \mathrm{MVA}$, frequência igual a $60 \mathrm{~Hz}$ e velocidade igual a $1800 \mathrm{rpm}$. Um gerador síncrono opera com uma velocidade de rotação constante sincronizada com a frequência da tensão elétrica alternada aplicada a ele. A rede é 


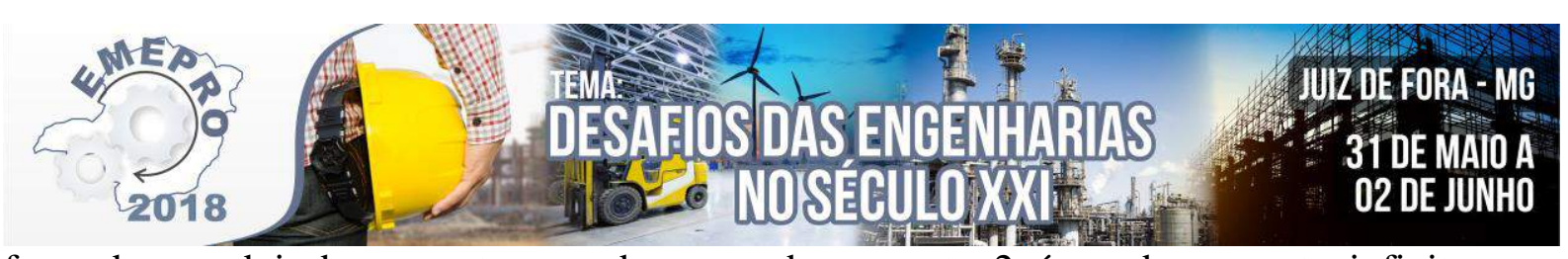

formada por dois barramentos, sendo que o barramento 2 é um barramento infinito, que representa outro sistema de grande porte.

Ela possui duas linhas de transmissão trifásicas divididas em duas partes. Cada linha é composta por uma resistência equivalente igual a $1,2 \Omega$ e uma indutância equivalente igual a 93,37 mH, como pode ser observado na Figura 7.

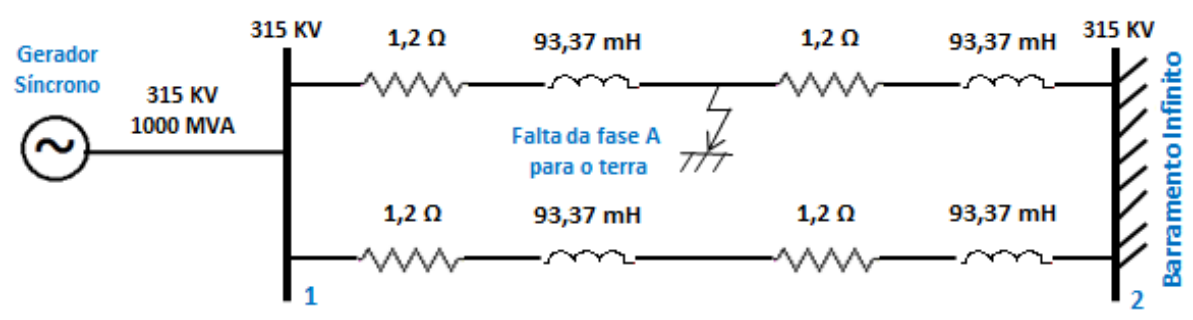

FIGURA 7 - Rede a ser simulada no Software Matlab/Simulink. Fonte: os autores

\subsection{Problemas a serem investigados}

Foi analisado um distúrbio de tensão na barra 1 na falta entre o período de 3.6 e $3.8 \mathrm{~s}$. Secundariamente, foi analisada e discutida a estabilidade transitória da rede, que diz respeito aos fenômenos que ocorrem após uma súbita perturbação em um sistema elétrico de potência e seus impactos no ângulo de carga da máquina síncrona, a sua velocidade e a potência fornecida.

\subsection{Topologia do SMES}

A topologia SMES escolhida neste trabalho, foi o modelo PCS Thyristor. Essa topologia é formada por um transformador do tipo estrela-delta, uma ponte conversora ACDC com seis tiristores e uma bobina supercondutora, como já foi apresentada na seção 2.

\subsection{O Controlador do SMES}

O sistema de controle adotado foi o controlador PI, por ser um sistema de controle simples, robusto e confiável.

O controle PI (Figura 8) irá calcular o valor do ângulo de disparo $\alpha$ dos tiristores através da variação da velocidade angular $\Delta \omega$ da máquina síncrona e dos parâmetros $\mathrm{Kp}$ (ganho proporcional) e Ti (constante de tempo). Será usado um valor do $\mathrm{Kp}=180$ e Ti $=0.2$, os quais foram ajustados manualmente (ALI et al, 2010).

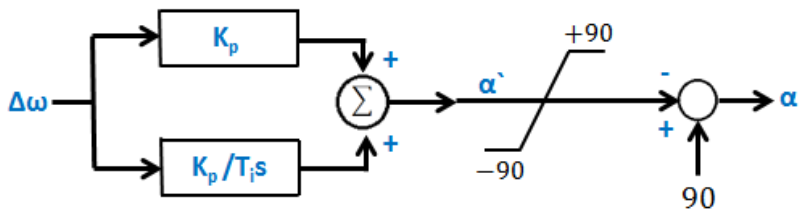

FIGURA 8 - Modelo de controle PI. Fonte: os autores

Quando o valor do ângulo de disparo $\alpha$ é menor que $90^{\circ}$, o conversor do SMES opera no modo retificador, carregando a bobina. Quando $\alpha$ é maior que $90^{\circ}$, o conversor opera no modo inversor, descarregando a bobina. Assim, a energia do SMES pode ser absorvida ou liberada para o sistema quando necessário.

\subsection{Resultados para 1 Unidade SMES inserida na Barra 1}

A Figura 9 mostra a topologia da rede utilizada para uma unidade ligada a Barra 1. 


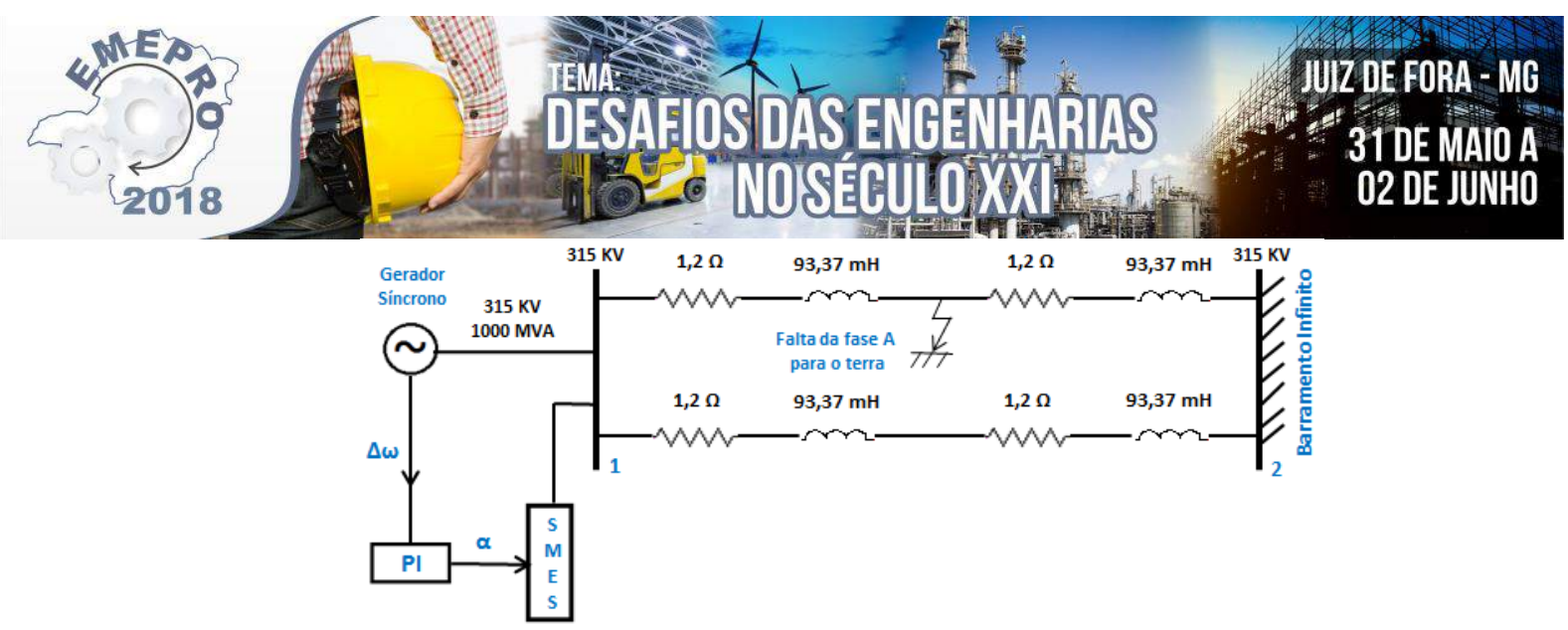

FIGURA 9 - Topologia utilizada na simulação. Fonte: os autores

Embora a topologia apresentada é para um sistema modelado em sequência positiva, a simulação é realizada utilizando medições um sistema trifásico convencional.

\section{SEM SMES}

Considerando a rede da Figura 9, sem o SMES, a falta foi inserida da fase A para a terra em 300 ohms, o que provoca uma queda da tensão de linha Vab e Vca somente, enquanto a Vbc não é alterada. As Figuras 10 a 12 apresentam o comportamento das tensões de linha da rede.

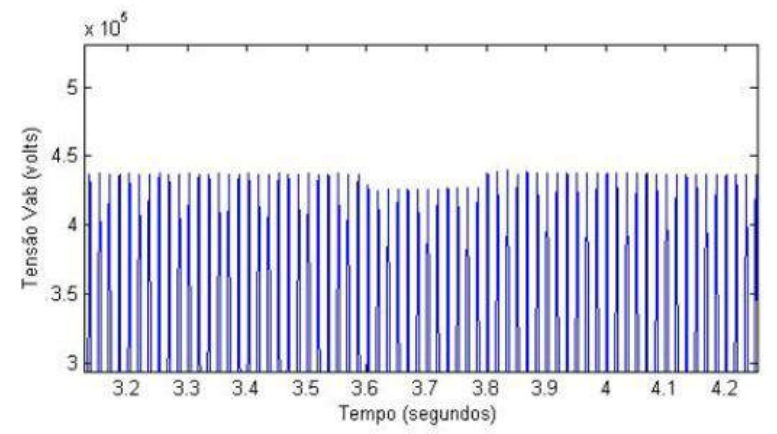

FIGURA 10 - Tensão de Linha Vab em parte do seu ciclo. Fonte: os autores.

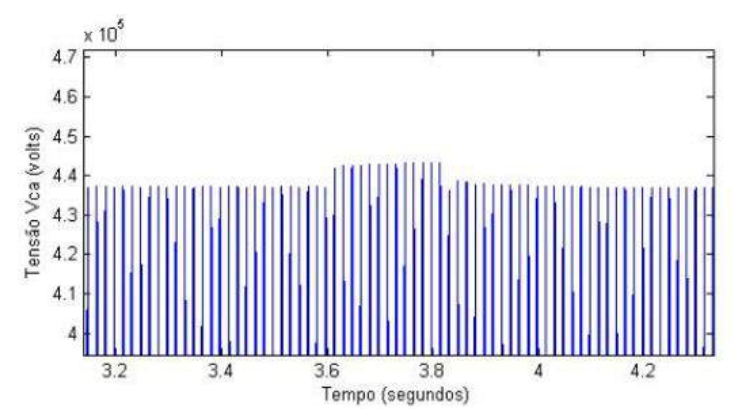

FIGURA 12 - Tensão de Linha Vca em parte do seu ciclo. Fonte: os autores.

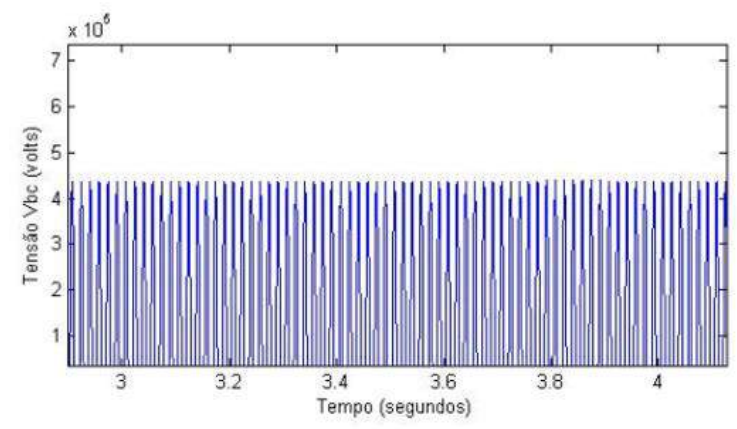

FIGURA 11 - Tensão de Linha Vbc em parte do seu ciclo. Fonte: os autores.

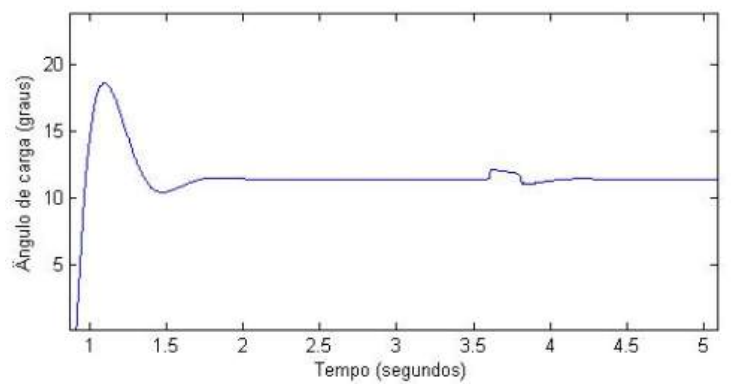

FIGURA 13 - Ângulo de carga da máquina síncrona. Fonte: os autores.

A tensão alternada $\mathrm{Vab}$ atinge um valor de pico igual a $440 \mathrm{kV}$ mas, entre o tempo de 3.6 e $3.8 \mathrm{~s}$, tempo e que a falta é aplicada, a tensão reduz e passa a ter valor de pico igual a 426 $\mathrm{kV}$. Isso representa uma queda de $3.18 \%$ da tensão. Depois ela retorna ao seu valor inicial, no tempo a partir de 3.8s. Observa-se que a tensão alternada $\mathrm{Vca}$ atinge um valor de pico igual a $437 \mathrm{kV}$ mas, entre o tempo de 3.6 e $3.8 \mathrm{~s}$ a tensão aumenta e passa a ter valor igual a $440 \mathrm{kV}$. 


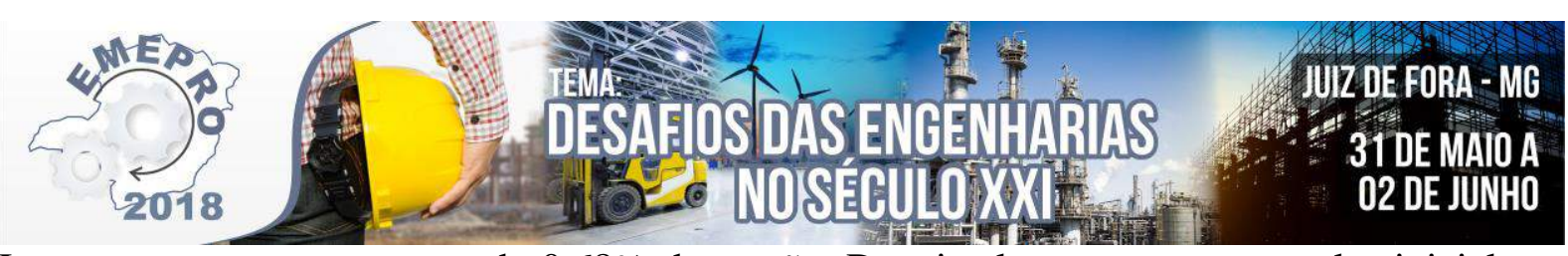

Isso representa um aumento de $0.68 \%$ da tensão. Depois ela retorna ao seu valor inicial, no tempo a partir de $3.8 \mathrm{~s}$.

Observa-se ainda a questão da estabilidade transitória durante a falta. Há uma incursão no ângulo de carga no período da falta, causando um deslocamento em regime. Pode-se observar tal fato na Figura 13. A variação angular inicial deve-se ao regime transitório. $\mathrm{O}$ ângulo de carga sofre uma sobre-elevação nos primeiros instantes da simulação e depois estabiliza em um valor igual a $11.4^{\circ}$. No intervalo de tempo entre 3.6 e $3.8 \mathrm{~s}$, ele sofre uma oscilação e depois retorna ao seu valor inicial de $11.4^{\circ}$. O ângulo de carga aumenta durante 0 distúrbio e atinge um valor entre 12 e $12.5^{\circ}$ e vai decrescendo até o momento em que a falta é retirada. Logo após a falta, ele retorna ao seu valor de $11.4^{\circ}$.

\section{COM SMES}

As Figuras 14 a 16 apresentam as tensões de linha com a inserção do SMES na barra 1.

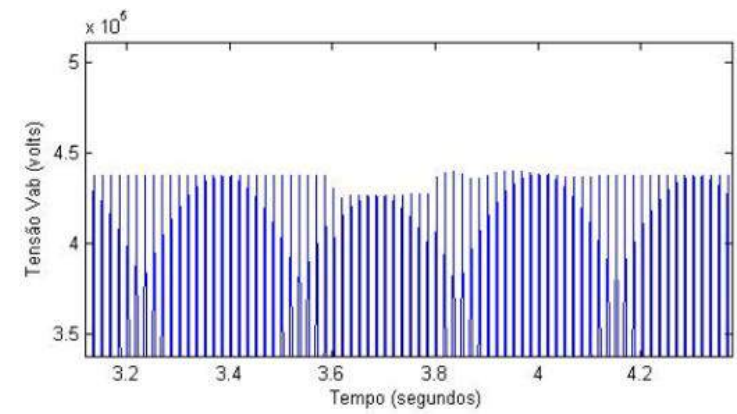

FIGURA 14 - Tensão Vab com uma unidade SMES na Barra 1. Fonte: os autores.

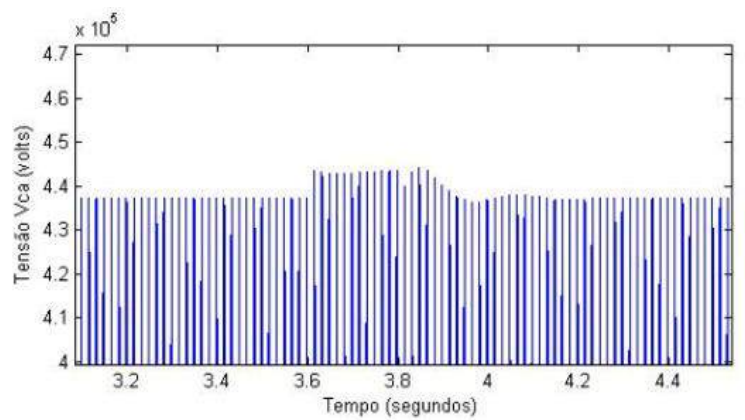

FIGURA 16 - Tensão Vac com uma unidade SMES na Barra 1. Fonte: os autores.

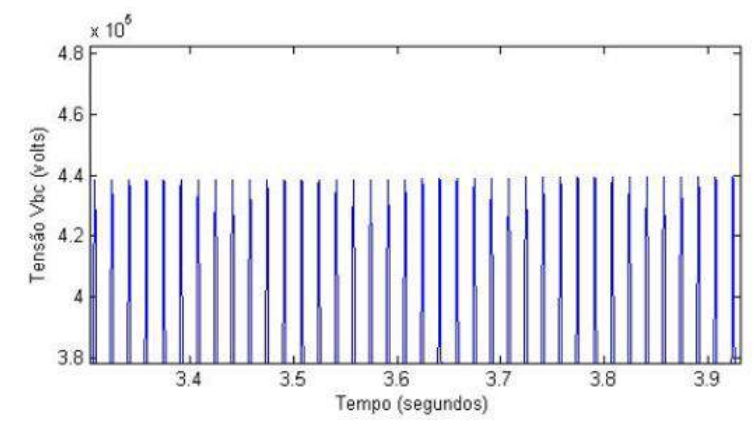

FIGURA 15 - Tensão Vbc com uma unidade SMES na Barra 1. Fonte: os autores.

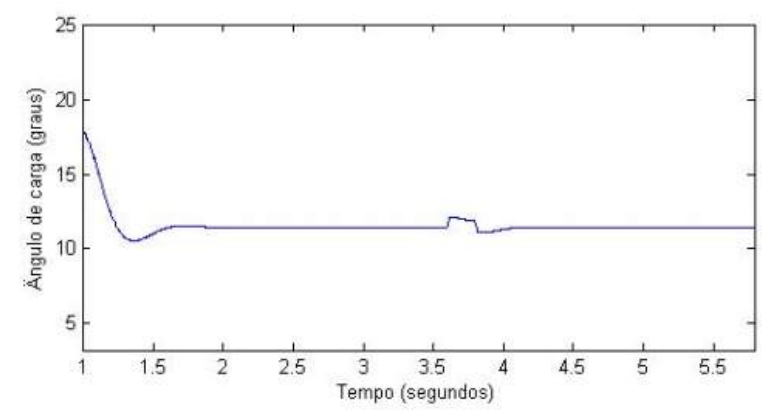

FIGURA 17 - Ângulo de carga da máquina sincrona com SMES na Barra 1. Fonte: os autores.

Observa-se que a tensão alternada Vca atinge um valor de pico igual a $437 \mathrm{kV}$ mas, entre o tempo de 3.6 e 3.8 s a tensão aumenta e passa a ter valor igual a $443 \mathrm{kV}$. Isso representa um aumento de $1.35 \%$ da tensão. Depois ela retorna ao seu valor inicial, no tempo a partir de 3.8s. A Figura 17 apresenta o ângulo de carga da máquina síncrona.

Observa-se que o ângulo de carga sofre uma sobre-elevação nos primeiros instantes da simulação e depois estabiliza em um valor igual a $11.4^{\circ}$. No intervalo de tempo entre $3.6 \mathrm{e}$ $3.8 \mathrm{~s}$, ele sofre uma oscilação e depois retorna ao seu valor inicial de $11.4^{\circ}$. Foi medido o valor da incursão angular, e o ângulo de carga aumenta durante o distúrbio e atinge um valor entre 


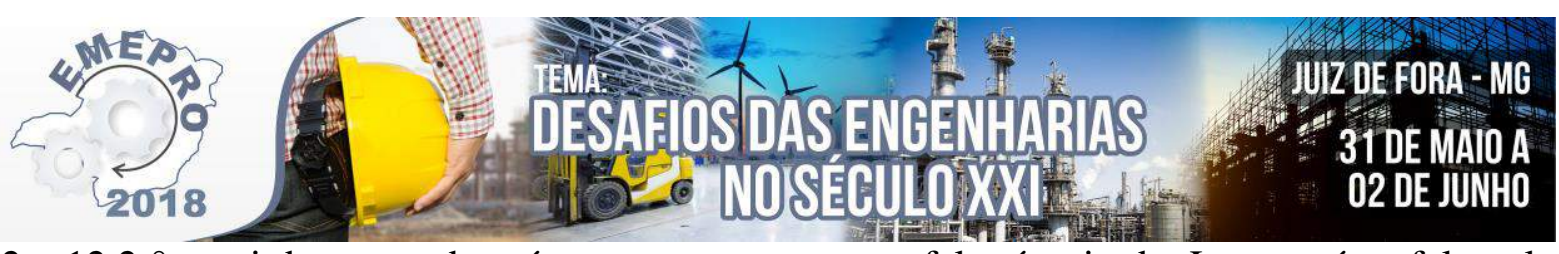

12 e $12.2^{\circ}$ e vai decrescendo até o momento em que a falta é retirada. Logo após a falta, ele retorna ao seu valor de $11.4^{\circ}$. Observa-se uma queda discreta. Contudo, a instalação do SMES na Barra 1 não foi o suficiente para produzir uma estabilidade transitória maior aceitável. Entretanto, neste trabalho foi investigado a instalação do SMES em outros pontos da rede, bem como a variação da quantidade de unidas SMES instaladas.

A Tabela 1 demonstram os resultados. Analisando-se a Tabela 1, observa-se que as três primeiras configurações com SMES são factíveis em relação à rede sem SMES, mostrando, para tanto uma melhora na estabilidade transitória, conforme as porcentagens. Houve um aumento da potência ativa fornecida no sistema tanto na falta quanto fora da falta utilizando o SMES, pois o mesmo está inserindo potência ativa no sistema, aumentando assim a confiabilidade neste quesito. Em relação às outras três configurações utilizando o SMES, apresentaram melhoras em relação à questão da estabilidade transitória, mas não atenderam no tocante a tensão, ou melhoria desta no momento da falta já que houve um afundamento da tensão durante todo o período analisado.

Tabela 1 - Resumo dos resultados obtidos nas simulações (preto - sem falta; vermelho - na falta. As tensões e correntes medidas representam valores de pico).

\begin{tabular}{|c|c|c|c|c|c|c|c|c|c|}
\hline & $\begin{array}{l}\mathbf{V}_{\mathrm{ab}} \\
(\mathrm{kV})\end{array}$ & $\begin{array}{l}\mathbf{V}_{\mathbf{b e}} \\
(\mathbf{k V})\end{array}$ & $\begin{array}{r}\mathbf{V}_{\text {ca }} \\
(\mathbf{k V})\end{array}$ & $\begin{array}{l}\mathbf{I}_{\mathrm{a}} \\
(\mathrm{A})\end{array}$ & $\begin{array}{l}\mathbf{I}_{\mathbf{b}} \\
(\mathrm{A})\end{array}$ & $\begin{array}{l}\mathbf{I}_{\mathrm{c}} \\
(\mathrm{A})\end{array}$ & $\begin{array}{l}\text { Variação do } \\
\text { Ângulo de } \\
\text { carga } \\
\text { (Percentual) }\end{array}$ & $\begin{array}{c}\text { Variação da } \\
\text { Velocidade } \\
\text { da máquina } \\
\text { (Percentual) } \\
\text { e duração } \\
\text { transitório } \\
\text { (segundos) }\end{array}$ & $\begin{array}{c}\text { Potência } \\
\text { Média } \\
\text { (MW) }\end{array}$ \\
\hline Sem SMES & 440426 & $\begin{array}{l}440 \\
440\end{array}$ & $\begin{array}{l}437 \\
440\end{array}$ & $\begin{array}{l}2600 \\
2750\end{array}$ & 2600 & $\begin{array}{l}2600 \\
2650\end{array}$ & 10,53 & $0,044 / 0,7 \mathrm{~s}$ & $\begin{array}{l}1000 \\
1070\end{array}$ \\
\hline $\begin{array}{c}\text { SMES no } \\
\text { barramento } \\
1\end{array}$ & $\begin{array}{l}440 \\
426\end{array}$ & $\begin{array}{l}440 \\
440\end{array}$ & $\begin{array}{l}437 \\
443\end{array}$ & $\begin{array}{l}2700 \\
2820\end{array}$ & $\begin{array}{l}3200 \\
3150\end{array}$ & $\begin{array}{l}1850 \\
1900\end{array}$ & 8,77 & $0,056 / 0,6 \mathrm{~s}$ & $\begin{array}{l}1200 \\
1220\end{array}$ \\
\hline $\begin{array}{c}\text { SMES na } \\
\text { falta }\end{array}$ & $\begin{array}{l}440 \\
428\end{array}$ & $\begin{array}{l}440 \\
440\end{array}$ & $\begin{array}{l}438 \\
444\end{array}$ & $\begin{array}{l}2570 \\
2740\end{array}$ & 2475 & $\begin{array}{l}2740 \\
2800\end{array}$ & 7,89 & $0,056 / 0,6 \mathrm{~s}$ & $\begin{array}{l}1060 \\
1090\end{array}$ \\
\hline $\begin{array}{l}\text { SMES na } \\
\text { outra linha } \\
\text { de } \\
\text { transmissão } \\
\end{array}$ & $\begin{array}{l}438 \\
426\end{array}$ & $\begin{array}{l}438 \\
438\end{array}$ & $\begin{array}{l}437 \\
443\end{array}$ & $\begin{array}{l}2600 \\
2750\end{array}$ & $\begin{array}{l}2455 \\
2380\end{array}$ & $\begin{array}{l}2730 \\
2800\end{array}$ & 7,89 & $0,05 / 0,5 \mathrm{~s}$ & $\begin{array}{l}1060 \\
1090\end{array}$ \\
\hline $\begin{array}{c}\text { SMES no } \\
\text { barramento } \\
1 \text { e na falta }\end{array}$ & $\begin{array}{l}270 \\
262\end{array}$ & $\begin{array}{l}270 \\
270\end{array}$ & $\begin{array}{l}268 \\
271\end{array}$ & $\begin{array}{l}6400 \\
6450\end{array}$ & $\begin{array}{l}6160 \\
6110\end{array}$ & $\begin{array}{l}6850 \\
6915\end{array}$ & 1,59 & 0,028 & $\begin{array}{l}1014 \\
1021\end{array}$ \\
\hline $\begin{array}{c}\text { SMES no } \\
\text { barramento } \\
1 \text { e na outra } \\
\text { linha de } \\
\text { transmissão } \\
\end{array}$ & $\begin{array}{l}270 \\
262\end{array}$ & $\begin{array}{l}270 \\
270\end{array}$ & $\begin{array}{l}268 \\
271\end{array}$ & $\begin{array}{l}6400 \\
6450\end{array}$ & $\begin{array}{l}6160 \\
6110\end{array}$ & $\begin{array}{l}6850 \\
6915\end{array}$ & 1,59 & 0,028 & $\begin{array}{l}1014 \\
1021\end{array}$ \\
\hline 3 SMES & $\begin{array}{l}272 \\
265\end{array}$ & $\begin{array}{l}272 \\
272\end{array}$ & $\begin{array}{l}270 \\
272\end{array}$ & $\begin{array}{l}6370 \\
6415\end{array}$ & $\begin{array}{l}\mathbf{5 8 4 0} \\
\mathbf{5 7 8 0}\end{array}$ & $\begin{array}{l}7190 \\
7260\end{array}$ & 1,6 & 0,028 & $\begin{array}{l}1028 \\
1030\end{array}$ \\
\hline
\end{tabular}

Fonte: os autores. 


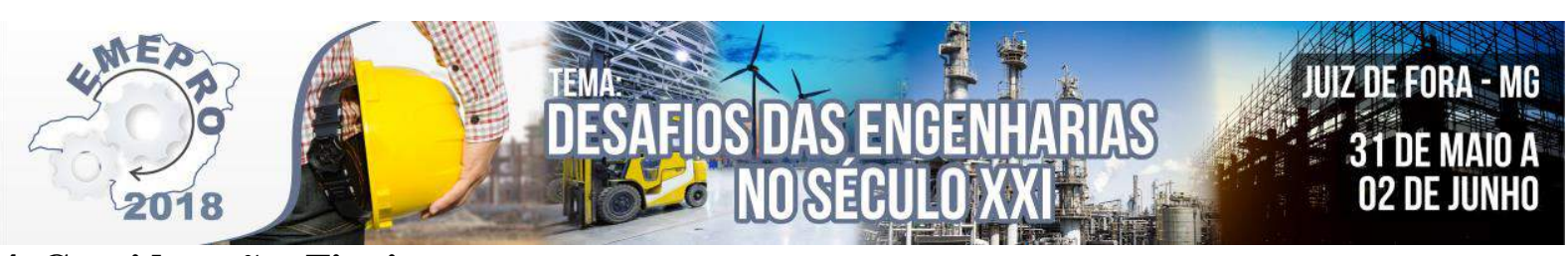

\section{Considerações Finais}

Apresentou-se neste trabalho uma análise preliminar da inserção do SMES para correção de problemas em sistemas de geração e transmissão de energia elétrica no tocante à qualidade da energia sob a estabilidade transitória. De forma sucinta, delimitou-se, logo após a apresentação da metodologia, as simulações e resultados de forma a deixar o trabalho pouco extenso, dado a complexidade do tema. Os resultados se mostraram satisfatórios para três topologias estudadas, melhorando a estabilidade transitória, sobretudo às variações do ângulo de carga da máquina. Estas variações devem ser mantidas dentro de certos limites para que não propaguem problemas para o sistema elétrico tais como variação de frequência, tensão e em casos extremos desligamento de unidades de geração por questões de proteção. Quanto à quantidade de unidades SMES, bem como a instalação em redes maiores e que representam situações mais reais dependerá de modelagem a sequência positiva, bem como investigação utilizando metaheurísticas.

\section{Referências}

ALI, M. H.; Wu, B.; DOUGAL, R. A. An Overview of SMES Applications in Power and Energy Systems, IEEE Transactions on Sustainable Energy, Vol. 1, $\mathrm{n}^{\circ}$ 1, Abril, 2010.

DIAS, F. F. G.; PILONI. F. C. Análise de Estabilidade Transitória em Sistemas Elétricos de Potência, Universidade de Brasília, Brasília - DF, 2010.

GAMA, P. H. R. P. Conservação de Energia: Eficiência Energética de Equipamentos e Instalações, Cap. 15 Qualidade da Energia Elétrica p. 325 - 589, 3ª ed., Itajubá - MG, 2006.

MARTINHO, E. Distúrbios da Energia Elétrica, Editora Érica, 2a ed., São Paulo - SP, 2010.

MATA, C. G. Uma Contribuição na Análise da Estabilidade Transitória dos Sistemas Elétricos de Distribuição na Presença de Geração Distribuída, Tese de Mestrado, UFJF, Juiz de Fora - MG, 2005.

MEHL, E. L. M. Qualidade da Energia Elétrica, UFPR, Curitiba - PR, 2001.

XUE, X. D.; CHENG, K. W. E.; SUTANTO, D. A Study of the Status and Future of Superconducting Magnetic Energy Storage in Power Systems, Superconductor Science and Technology, Vol. 19, n6, 2006. 


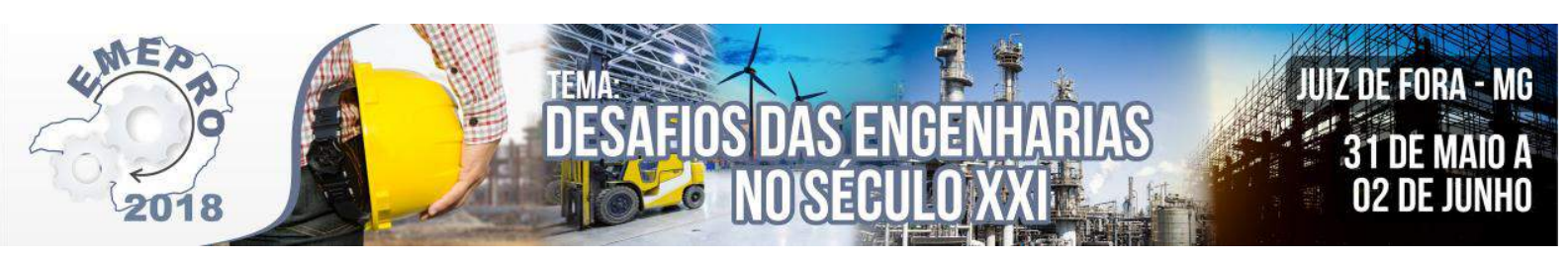

\title{
Fontes Renováveis de Energia Elétrica e Impactos Ambientais: Uma Revisão Bibliográfica
}

\author{
Vander Luiz da Silva - Universidade Tecnológica Federal do Paraná - vander-luiz@ hotmail.com \\ Jaqueline de Matos Silva - Universidade Tecnológica Federal do Paraná - \\ jaqueline.mattos94@hotmail.com
}

\begin{abstract}
Resumo: Em estabelecimentos comerciais e indústrias, a seleção e usos de fontes renováveis para geração de energia elétrica e a implementação de práticas sustentáveis auxiliam na redução de certas categorias de impactos ambientais. Neste contexto, o presente estudo teve por objetivo discutir sobre usos de fontes alternativas e renováveis de energia elétrica e suas aplicações no contexto organizacional. Para alcance do objetivo proposto foi elaborada uma revisão sistemática de literatura nas bases de dados Science Direct, Web of Science e Scopus, seguindo os protocolos de qualificação e seleção de artigos. Nota-se que as discussões relativas às fontes renováveis de energia e impactos ambientais são focos centrais de muitos pesquisadores. Discussões mais detalhadas e multidisciplinares sobre experimentos, desenvolvimento e aplicações de fontes de energia renováveis nas indústrias tendem a se intensificar com o decorrer dos anos, de modo a reduzir impactos ambientais e beneficiar o meio ambiente e sociedade.
\end{abstract}

Palavras-chave: Engenharia da sustentabilidade; Impactos ambientais; Energia renovável.

\section{Introdução}

De maneira geral, os estabelecimentos comerciais e as indústrias dos diversos setores geram impactos ao ambiente, seja pela geração de efluentes, emissão de gases poluentes na atmosfera, disseminação de lixos, entre outras causas.

Diante da necessidade de minimizar os impactos no ambiente, uma infinidade de práticas sustentáveis é aplicada nos estabelecimentos comerciais e nas indústrias. Uma questão discutida em contexto global é a adoção de práticas, sistemas e usos de recursos para produção que resultem em menores impactos ambientais.

Em estabelecimentos comerciais e indústrias, a seleção e usos de fontes renováveis para geração de energia elétrica e a implementação de práticas sustentáveis, como usos de equipamentos ecoeficientes, auxiliam na redução de certas categorias de impactos ambientais.

No Brasil, usos e consumo de energia elétrica advinda da integração de fontes renováveis, em uma mesma indústria ou em estabelecimento comercial, não é uma prática muito difundida, pois, ainda predominam-se os usos de energia elétrica de hidrelétricas.

A proposta de usos de fontes alternativas de energia elétrica foram mencionadas nos estudos de Varun, Prakash e Bhat (2009), Berrill et al. (2016), entre outros estudos. Tal proposta é sugerida como uma possível prática de redução de categorias de impactos ambientais, a partir de princípios de Avaliação de Ciclo de Vida de produtos e estudos de sustentabilidade organizacional. 


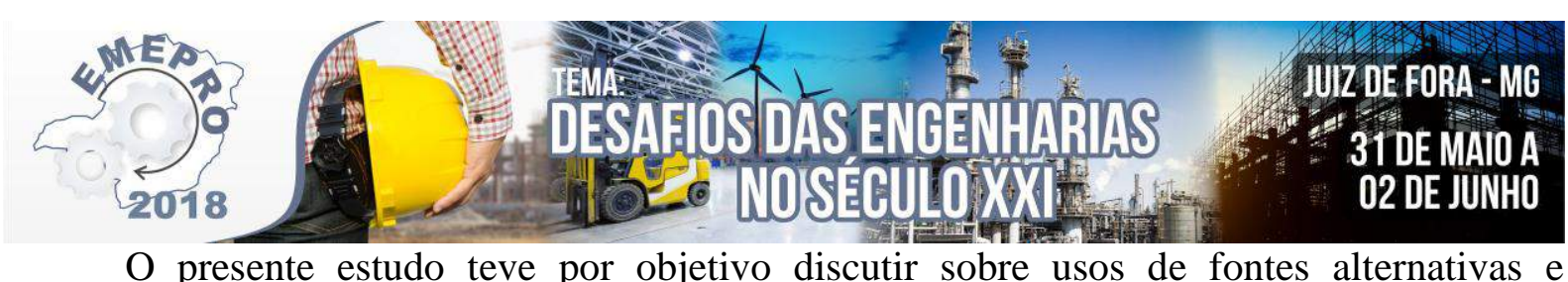

O presente estudo teve por objetivo discutir sobre usos de fontes alternativas e renováveis de energia elétrica e suas aplicações no contexto organizacional.

Para alcance do objetivo proposto foi elaborada uma revisão sistemática de literatura nas bases de dados Science Direct, Web of Science e Scopus, seguindo os protocolos de Pagani, Kovaleski e Resende (2015).

O estudo está estruturado em quatro seções. Na primeira seção, a pesquisa é contextualizada e o seu objetivo é apresentado. Na segunda seção, apresenta-se o procedimento metodológico empregado no estudo. Posteriormente, os resultados são discutidos. Por fim, na quarta seção encontram-se as considerações finais.

\section{Procedimento metodológico}

Para realização do estudo, foi elaborada uma revisão sistemática de literatura, de modo a identificar estudos relevantes que tratassem de fontes de energias renováveis, suas aplicações e principais resultados. As etapas utilizadas para alcance de tais fins foram adaptadas de Pagani, Kovaleski e Resende (2015), a destacar: i) Selecionar bases de dados bibliográficos; ii) Estabelecer palavras-chave e combinações de palavras-chave; iii) Definir critérios de buscas nas bases de dados; iv) Executar as buscas nas bases de dados; v) Definir e aplicar critérios de filtragem; vi) Qualificar artigos a partir do cálculo e análise de valores de InOrdinatio, e; vii) Analisar os artigos selecionados.

Primeiramente, foram selecionadas bases de dados bibliográficos, realizada uma combinação de palavras-chave e estabelecido um procedimento básico para as buscas, conforme apresentados no Quadro 1.

\begin{tabular}{|c|c|c|c|}
\hline \multirow{2}{*}{ Palavras-chave } & \multicolumn{3}{|c|}{ Base de dados } \\
\cline { 2 - 4 } & Science Direct & Scopus & Web of Science \\
\hline $\begin{array}{c}\text { "Environmental impact" AND } \\
\text { "Renewable energy" }\end{array}$ & \multicolumn{2}{|c|}{ Procedimento: i) Keywords in Title, e; ii) AllYears. } \\
\hline
\end{tabular}

Após a execução de buscas nas bases selecionadas, os estudos obtidos foram agrupados no Zotero ${ }^{\circledR}$ versão 4.0, onde foram aplicados critérios de filtragem (eliminar duplicidades, capítulos de livros e artigos de conferências).

Os artigos resultantes foram submetidos à Methodi Ordinatio de Pagani, Kovaleski e Resende (2015), a partir do cálculo e análise de valores de InOrdinatio da Methodi Ordinatio, visando qualifica-los, de acordo com os elementos fator de impacto, ano de publicação e número de citações de cada artigo.

Posteriormente, os melhores artigos, categorizados de acordo com os valores obtidos de InOrdinatio e a relevância do tema em estudo, foram selecionados para análises e, destes, foram extraídas informações relevantes.

Para elaboração do estudo utilizou-se o método de abordagem qualitativo, de acordo com a classificação de Silva e Menezes (2005).

A pesquisa classifica-se quanto aos fins, como descritiva e explicativa, e quanto aos meios, como bibliográfica (GIL, 2008). 


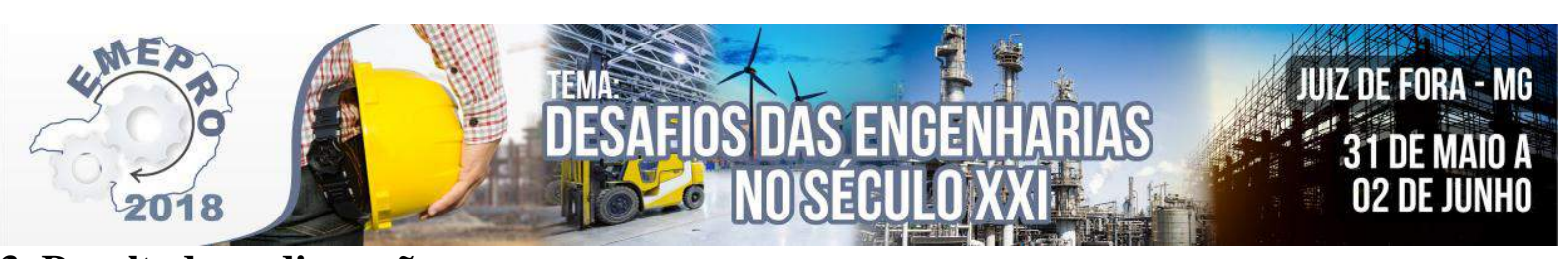

3. Resultados e discussão

\subsection{Análises do portfólio de artigos}

Os resultados obtidos nas bases de dados bibliográficos estão descritos na Tabela 1.

Tabela 1: Resultados brutos obtidos nas bases de dados selecionadas.

\begin{tabular}{ccccc}
\hline \multirow{2}{*}{ Palavras-chave } & \multicolumn{3}{c}{ Base de dados } & \multirow{2}{*}{ Total } \\
\cline { 2 - 3 } & Science Direct & Scopus & Web of Science & \\
\hline $\begin{array}{c}\text { "Environmental } \\
\text { impact" AND } \\
\text { "Renewable energy" }\end{array}$ & 9 & 23 & 10 & 42 \\
\hline Fonte: Elaborado pelos autores (2017) a partir de dados de Science Direct, Scopus e Web of Science.
\end{tabular}

Os 42 estudos teóricos e empíricos foram submetidos a alguns procedimentos de filtragem, descritos na Tabela 2. Cabe ressaltar que o número de artigos obtidos está limitado às palavras chave definidas, e à priorização de palavras chave nos títulos de artigos. Deste modo, foi possível obter artigos com maior compatibilidade com o tema em estudo.

Tabela 2: Filtragem de estudos.

\begin{tabular}{ccc}
\hline Procedimento de filtragem & Total bruto de artigos & Total de artigos após filtragem \\
\hline Eliminação de duplicidade & 42 & 28 \\
Capítulo de livros & 28 & 25 \\
Artigos de conferência & 25 & 22 \\
\hline
\end{tabular}

O portfólio de 22 artigos foi submetido à Methodi Ordinatio para selecionar os estudos mais relevantes. As justificativas de seleção deste número de artigos estão descritas na Tabela 3.

Tabela 3: Justificativas de seleção de artigos.

\begin{tabular}{lc}
\hline \multicolumn{1}{c}{ Justificativa } & Total \\
\hline Total de artigos submetidos à Methodi & 22 \\
Artigos com melhores resultados de InOrdinatio da Methodi Ordinatio & 17 \\
Artigos não analisados devido aos baixos resultados de InOrdinatio (artigos publicados & 5 \\
em anos passados e com poucas citações na literatura, predominantemente). & 5 \\
\hline
\end{tabular}

Fonte: Autores (2017).

As informações básicas dos 17 artigos e resultados de InOrdinatio da Methodi Ordinatio estão descritos no Apêndice 1.

Um dado importante a ser abordado é o ano de publicação de cada artigo. A Figura 1 apresenta o período de publicações dos artigos analisados. 

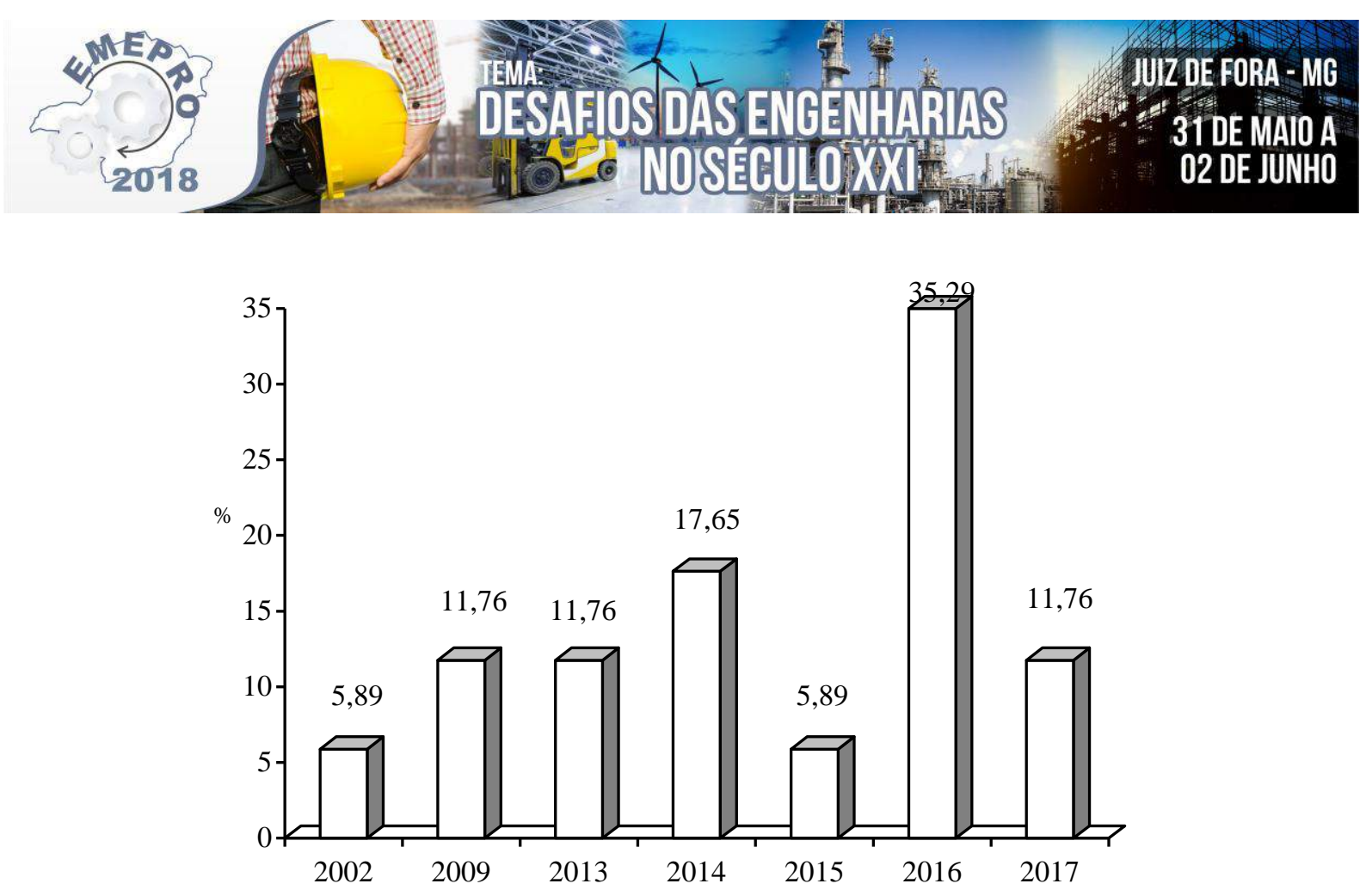

Figura 1: Distribuição de artigos conforme os respectivos anos de publicações. Fonte: Autores (2017).

Por meio da Figura 1 é possível verificar a atualidade do tema, com maiores índices de estudos publicados nos anos de 2016 (35,29\%) e outros anos como 2014 (17,65\%).

Os 17 artigos analisados foram publicados nos periódicos: Renewable and Sustainable Energy Reviews (3 artigos), Environmental Impact Assessment Review (2 artigos) e Ocean \& Coastal Management (2 artigos). Outros periódicos apresentaram uma publicação de artigo e, portanto, não foram explicitados.

O Quadro 2 apresenta os respectivos focos de estudos e os principais resultados discutidos em cada um dos artigos selecionados e analisados.

\begin{tabular}{|c|c|c|}
\hline Código & Foco de estudo & Principais resultados \\
\hline 001 & $\begin{array}{c}\text { Discutir sobre a evolução de usos de } \\
\text { sistemas renováveis na Îndia, focando-se } \\
\text { em problemas de caráter ambiental, } \\
\text { principalmente. }\end{array}$ & $\begin{array}{l}\text { Importantes fontes renováveis de energia são } \\
\text { eólica, biomassa e solar, respectivamente. } \\
\text { Tendências de redução de emissões de } \\
\text { poluentes na atmosfera aumentaram-se ao } \\
\text { longo dos anos, conforme sistemas de energia } \\
\text { renováveis foram instalados em áreas remotas } \\
\text { do país. }\end{array}$ \\
\hline 002 & $\begin{array}{l}\text { Avaliar o impacto ambiental e o custo para } \\
\text { geração de energia elétrica considerando } \\
\text { fontes de energia renováveis, como } \\
\text { fotovoltaica, solar e eólica. }\end{array}$ & $\begin{array}{c}\text { No estudo, a energia eólica foi constatada } \\
\text { como uma das fontes de energia elétrica mais } \\
\text { sustentáveis. }\end{array}$ \\
\hline 003 & $\begin{array}{l}\text { Apresentar um modelo com análises de } 44 \\
\text { cenários de fontes de energia elétrica, } \\
\text { relacionando fontes renováveis e não } \\
\text { renováveis, no contexto Europeu. }\end{array}$ & $\begin{array}{l}\text { Sistemas baseados em energias renováveis, } \\
\text { que integram fontes eólica e solar geram } \\
\text { menores impactos de aquecimento global, se } \\
\text { comparados aos cenários com usos de gás } \\
\text { natural, carvão, bem como outras fontes não } \\
\text { renováveis e/ou renováveis de energia } \\
\text { elétrica. }\end{array}$ \\
\hline
\end{tabular}

Quadro 2: Focos e principais resultados identificados no portfólio de artigos analisados. Fonte: Elaborado pelos autores (2017) a partir das análises de artigos. 


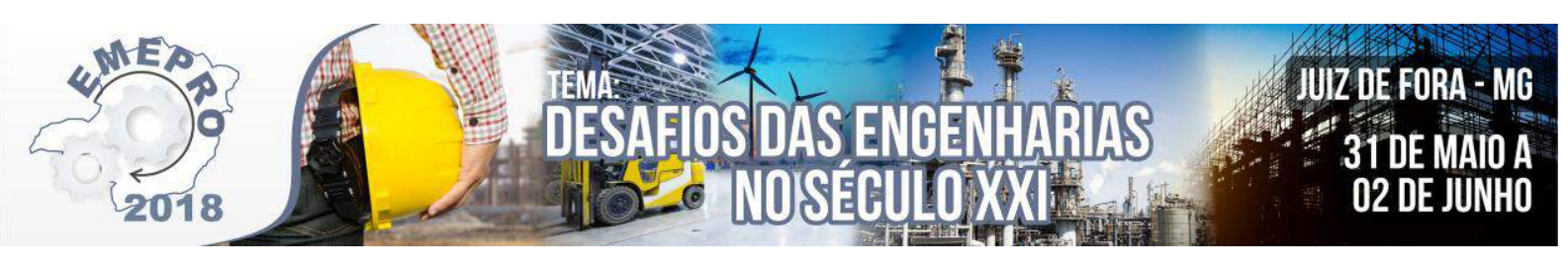

\begin{tabular}{|c|c|c|}
\hline Código & Foco de estudo & Principais resultados \\
\hline 004 & $\begin{array}{l}\text { Discutir sobre um modelo metodológico } \\
\text { para extração de energia por meio de } \\
\text { ondas de maré. }\end{array}$ & $\begin{array}{l}\text { São incorporadas quatro questões principais } \\
\text { no modelo, e listados objetivos para } \\
\text { respondê-las: i) Qual a melhor maneira de } \\
\text { avaliar os recursos de ondas de maré, e os } \\
\text { efeitos na extração de energia?; ii) Quais são } \\
\text { as consequências físicas na extração de } \\
\text { energia de ondas de maré?; iii) Quais são as } \\
\text { consequências ecológicas para extração de } \\
\text { energia de ondas de maré?; iv) Como avaliar } \\
\text { as diversas mudanças na extração de energia?. } \\
\text { Foi possível integrar metodologias em um } \\
\text { mesmo modelo. } \\
\end{array}$ \\
\hline 005 & $\begin{array}{c}\text { Avaliar os impactos ambientais } \\
\text { relacionados à geração e distribuição de } \\
\text { fontes renováveis de energia na Finlândia, } \\
\text { a partir de uma revisão sistemática de } \\
\text { literatura. }\end{array}$ & $\begin{array}{l}\text { Na Finlândia, os principais impactos } \\
\text { ambientais têm relação com o uso de energia } \\
\text { de biomassa florestal, que causa desequilíbrio } \\
\text { de nutrientes no solo e eutrofização. As usinas } \\
\text { hidrelétricas teriam potencialmente grandes } \\
\text { impactos nas mudanças climáticas, uso do } \\
\text { solo e biodiversidade. Já com relação à } \\
\text { energia eólica, a principal preocupação tem } \\
\text { sido relacionada ao ruído e uso do solo. Outra } \\
\text { possível preocupação para os próximos anos é } \\
\text { a disponibilidade de metais para fabricação de } \\
\text { painéis solares e sistemas de hidrelétricas, } \\
\text { gerando outros impactos ambientais. }\end{array}$ \\
\hline 006 & $\begin{array}{c}\text { Avaliar os principais benefícios } \\
\text { econômicos e ambientais no uso de } \\
\text { energia renovável para abastecimento de } \\
\text { veículos elétrico. }\end{array}$ & $\begin{array}{l}\text { A substituição de gasolina por energia elétrica } \\
\text { de fonte renovável (eólica) demonstrou-se } \\
\text { viável à indústria em estudo, ao consumidor e } \\
\text { ao meio ambiente. Para indústria pública de } \\
\text { estações de abastecimento, a renda bruta teve } \\
\text { aumento de até } 655 \% \text {. No transporte de } \\
\text { passageiros, o preço estimado de } 30 \text { milhas de } \\
\text { viagem era de US \$ } 3,80 \text { (gasolina) e de US \$ } \\
1,27 \text { (energia eólica). Já para meio ambiente, } \\
\text { a energia eólica reduziu expressivamente as } \\
\text { emissões de Gases do Efeito Estufa. }\end{array}$ \\
\hline 007 & $\begin{array}{c}\text { Identificar requisitos de Avaliação de } \\
\text { Impacto Ambiental, dispostos na } \\
\text { legislação japonesa, que afetam o processo } \\
\text { de desenvolvimento de projetos de energia } \\
\text { renovável. }\end{array}$ & $\begin{array}{c}\text { Sistemas de energia renováveis em larga } \\
\text { escala exigem o desenvolvimento adicional } \\
\text { de requisitos, além daqueles dispostos na } \\
\text { legislação japonesa. Os esforços de reforma } \\
\text { do país ainda são limitados por certas áreas } \\
\text { políticas. Outra questão é a falta de } \\
\text { gerenciamento de barreiras administrativas } \\
\text { dispostas em leis ambientais, bem como } \\
\text { deficiências regulatórias do mercado japonês } \\
\text { de energia elétrica. }\end{array}$ \\
\hline
\end{tabular}

Quadro 2: Focos e principais resultados identificados no portfólio de artigos analisados. Fonte: Elaborado pelos autores (2017) a partir das análises de artigos. 


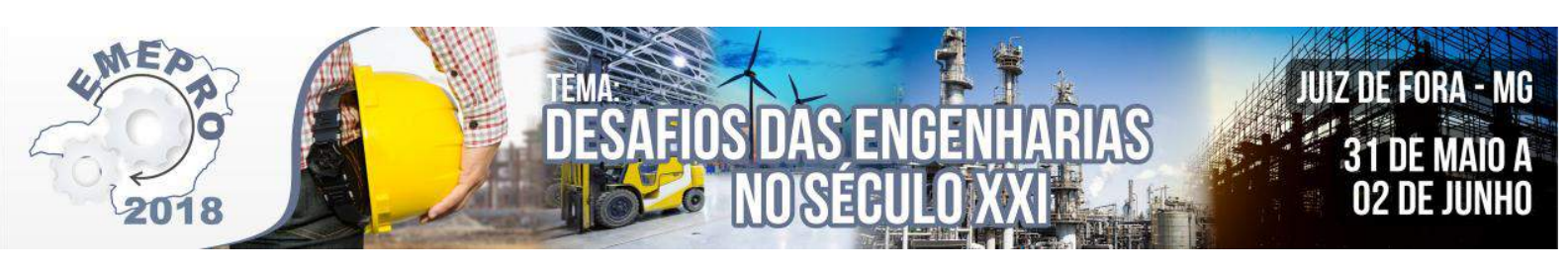

\begin{tabular}{|c|c|c|}
\hline Código & Foco de estudo & \begin{tabular}{|c|} 
Principais resultados \\
\end{tabular} \\
\hline 008 & $\begin{array}{l}\text { Apresentar o cenário mercadológico de } \\
\text { energia elétrica na Grécia, no período } \\
\text { estudado, e informações acerca de } \\
\text { legislação energética, emissões de gases de } \\
\text { efeito estufa, e tendências de consumo e } \\
\text { perspectivas futuras de desenvolvimento } \\
\text { energético sustentável no País. }\end{array}$ & $\begin{array}{l}\text { Observou-se que na Grécia as condições } \\
\text { climáticas e a topografia contribuem para a } \\
\text { geração de energia renovável (RES). A } \\
\text { energia solar apresentou crescimento de } 47 \% \text {, } \\
\text { entre um período de } 18 \text { anos. As fontes } \\
\text { renováveis de energia elétrica são importantes } \\
\text { para redução de impacto ambiental. Já com } \\
\text { relação às barreiras que inibem o avanço de } \\
\text { RES no país, estão: falta de investimentos; } \\
\text { falta de estrutura adequada; falta de } \\
\text { envolvimento da sociedade, e; falta de } \\
\text { estratégias e políticas nacionais. }\end{array}$ \\
\hline 010 & $\begin{array}{l}\text { Discutir sobre os impactos ambientais } \\
\text { resultantes de sistemas e tecnologias de } \\
\text { energia renovável, focando-se na produção } \\
\text { de eletricidade em larga escala. }\end{array}$ & $\begin{array}{l}\text { Por meio de análises de relatórios de } \\
\text { Instituições de Pesquisas Internacionais, } \\
\text { muitas das tecnologias disponíveis trazem } \\
\text { benefícios ao ambiente, incluindo a redução } \\
\text { de impactos ambientais e usos de recursos } \\
\text { naturais, contudo, mais estudos de Avaliação } \\
\text { de Ciclo de Vida devem ser realizados. }\end{array}$ \\
\hline 011 & $\begin{array}{c}\text { Explorar as diretrizes de análises de } \\
\text { impacto e de estética de paisagem na } \\
\text { Avaliação de Impacto Ambiental (EIA), } \\
\text { com referência aos projetos italianos de } \\
\text { energia renovável. }\end{array}$ & $\begin{array}{l}\text { Salienta-se que diretrizes de EIA para as } \\
\text { energias renováveis continuam a falhar, pois, } \\
\text { abordam a questão de estética e percepção de } \\
\text { impactos de forma exaustiva. É necessário } \\
\text { integrar a avaliação de impactos ambientais e } \\
\text { perceptivos, e melhorar as abordagens } \\
\text { metodológicas da EIA para este propósito. }\end{array}$ \\
\hline 012 & $\begin{array}{c}\text { Explorar o papel da Avaliação de Impacto } \\
\text { Ambiental (EIA) no avanço de energia } \\
\text { renovável marinha. }\end{array}$ & $\begin{array}{l}\text { Constatou-se que reformas simples aos } \\
\text { processos de EIA facilitam a inovação, e } \\
\text { conduzem a preservação do meio ambiente. É } \\
\text { necessário que novas tecnologias sejam } \\
\text { apoiadas por diretrizes complementares, e que } \\
\text { iniciativas amplas governamentais } \\
\text { apresentem-se como um canal de } \\
\text { disseminação de conhecimento. }\end{array}$ \\
\hline 013 & $\begin{array}{l}\text { Discutir os efeitos da redução do uso de } \\
\text { eletricidade de hidrelétricas de grande } \\
\text { potencial (RES-E) sobre os custos de } \\
\text { energia elétrica no mercado Espanhol. }\end{array}$ & $\begin{array}{l}\text { A } R E S-E \text { implicou na redução expressiva de } \\
\text { economia de custos no país, tanto com relação } \\
\text { à geração e distribuição de eletricidade como } \\
\text { minimização de impactos ambientais. O } \\
\text { vento, biomassa e hidrelétricas de menor } \\
\text { potencial apresentam-se como fontes } \\
\text { promissoras para geração de energia elétrica. }\end{array}$ \\
\hline 014 & $\begin{array}{c}\text { Destacar as carências de contribuições } \\
\text { claras associadas à Avaliação de Impacto } \\
\text { Ambiental (EIA) de energia renovável } \\
\text { marítima. }\end{array}$ & $\begin{array}{l}\text { Observou-se que as abordagens existentes não } \\
\text { quantificam explicitamente a magnitude e } \\
\text { a probabilidade de impacto. A avaliação dos } \\
\text { efeitos de impacto sobre uma população } \\
\text { requer uma modelagem demográfica } \\
\text { detalhada. No geral, é necessária uma } \\
\text { abordagem mais sistemática e estratégica de } \\
\text { abordagens EIA. }\end{array}$ \\
\hline
\end{tabular}

Quadro 2: Focos e principais resultados identificados no portfólio de artigos analisados. Fonte: Elaborado pelos autores (2017) a partir das análises de artigos. 


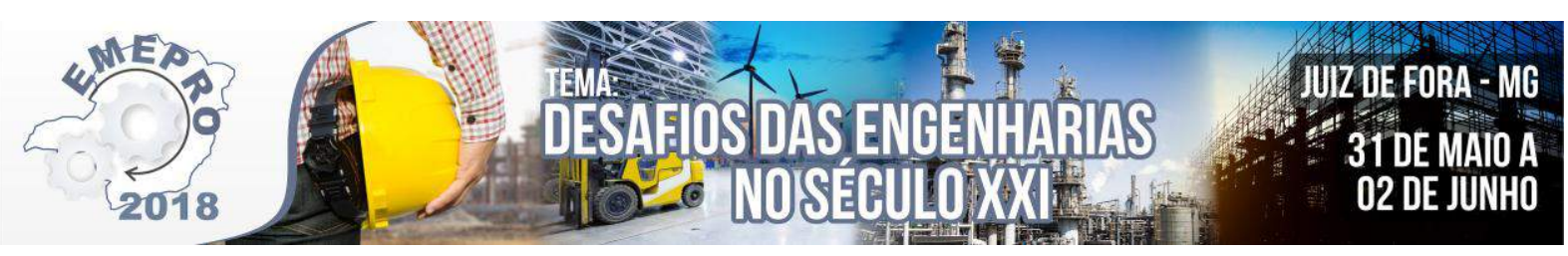

\begin{tabular}{|c|c|c|}
\hline Código & \begin{tabular}{|c|} 
Foco de estudo \\
\end{tabular} & Principais resultados \\
\hline 015 & $\begin{array}{l}\text { Realizar a avaliação de impactos } \\
\text { ambientais de uma versão híbrida de } \\
\text { sistema de eletricidade de fontes } \\
\text { renováveis de energia (eólica e solar). }\end{array}$ & $\begin{array}{l}\text { O índice de sustentabilidade da turbina eólica } \\
\text { é superior a do sistema fotovoltaico ( } 60 \mathrm{~g} \mathrm{CO}_{2} \\
\left.\text { / Mês e } 75 \mathrm{~g} \mathrm{CO}_{2} / \text { Mês, respectivamente }\right) \text {. }\end{array}$ \\
\hline 016 & $\begin{array}{c}\text { Abordar questões acerca de avaliação de } \\
\text { impactos ambientais relacionados aos } \\
\text { projetos de sistemas e tecnologias de } \\
\text { energia renovável. }\end{array}$ & $\begin{array}{l}\text { Entre o total de } 19 \text { relatórios analisados, de } \\
\text { Avaliação de Impacto Ambiental }(E I A), 18 \\
\text { citam prováveis ganhos quanto à minimização } \\
\text { de impactos ambientais a partir de usos de } \\
\text { energias renováveis, principalmente } \\
\text { relacionados às mudanças climáticas. Nesses } \\
\text { relatórios há uma maior ênfase em impactos } \\
\text { positivos das energias renováveis, se atuantes } \\
\text { enquanto substitutas de fontes de energia } \\
\text { fósseis. }\end{array}$ \\
\hline 017 & $\begin{array}{l}\text { Discutir aspectos relacionados à utilização } \\
\text { de energia renovável, eficiência } \\
\text { energética, meio ambiente e } \\
\text { desenvolvimento sustentável na Turquia. }\end{array}$ & $\begin{array}{l}\text { Recursos de energia renovável são } \\
\text { promissores para redução de impactos } \\
\text { ambientais e alcance de vantagens } \\
\text { econômicas. A Turquia importa energia, pois } \\
\text { as reservas nacionais de fósseis são limitadas. } \\
\text { Observou-se que Turquia há condições } \\
\text { favoráveis para geração de fontes renováveis } \\
\text { de energia elétrica, embora, são necessários } \\
\text { investimentos e estratégias no país. }\end{array}$ \\
\hline
\end{tabular}

Quadro 2: Focos e principais resultados identificados no portfólio de artigos analisados. Fonte: Elaborado pelos autores (2017) a partir das análises de artigos.

Nota-se que as discussões relativas às fontes renováveis de energia e impactos ambientais são focos centrais de muitos pesquisadores, auxiliando na disseminação de tecnologias, sistemas e práticas sustentáveis, redução de impactos e aperfeiçoamento contínuo de processos industriais.

O foco da maior parcela de artigos está centrado nas abordagens de estudos de impactos ambientais com usos de fontes de energias renováveis e não renováveis, e métodos para redução de categorias de impactos ambientais, como aquecimento global.

\section{Considerações finais}

O presente estudo buscou identificar e apresentar discussões atuais sobre usos de energias renováveis e impactos ambientais (redução de impactos ambientais pelos usos de fontes renováveis de energia elétrica, ou estudos de impactos considerando fontes diversas de energia).

O estudo fornece discussões interessantes sobre usos de fontes de energia renováveis. Nota-se que discussões mais detalhadas, completas e multidisciplinares sobre experimentos, desenvolvimento e aplicações de fontes de energia renováveis tendem a se intensificar com o decorrer dos anos, de modo a reduzir impactos ambientais e beneficiar o meio ambiente e a sociedade.

\section{Referências}

AKELLA, A.; SAINI, R.; SHARMA, M. Social, economical and environmental impacts of renewable energy systems. Renewable Energy, v. 34, n. 2, p. 390-396, 2009. 


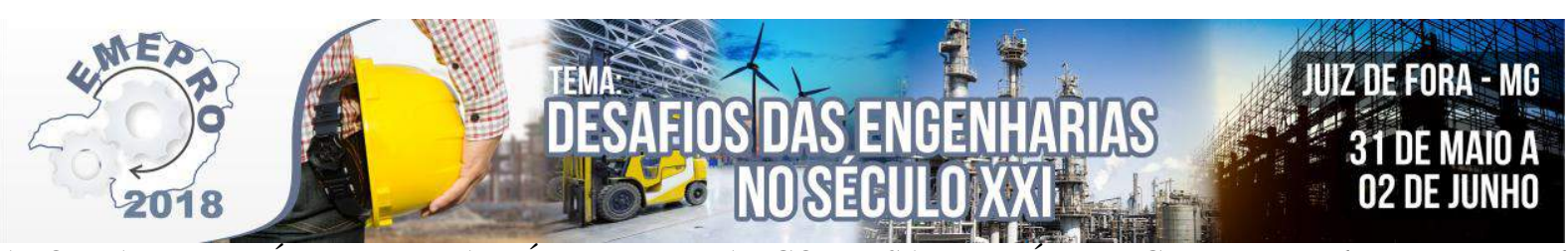

AZOFRA, D.; JIMÉNEZ, E.; MARTÍNEZ, E.; BLANCO, J.; SAENZ-DIEZ, J. C. Economical-environmental impact of subsidised renewable energy sources for electricity (RES-E) in the Spanish system. Energy for Sustainable Development, v. 29, p. 47-56, 2015.

BERRILL, P.; ARVESEN, A.; SCHOLZ, Y.; GILS, H.; HERTWICH, E. Environmental impacts of high penetration renewable energy scenarios for Europe. Environmental Research Letters, v. 11, n. 1, 2016.

BUCHSPIES, B.; KALTSCHMITT, M. Life cycle assessment of bioethanol from wheat and sugar beet discussing environmental impacts of multiple concepts of co-product processing in the context of the European Renewable Energy Directive. Biofuels, v. 7, n. 2, p. 141-153, 2016.

CALISKAN, H.; DINCER, I.; HEPBASLI, A. Exergoeconomic and environmental impact analyses of a renewable energy based hydrogen production system. International Journal of Hydrogen Energy, v. 38, n. 14, p. 6104-6111, 2013.

GIL, A. C. Como elaborar projetos de pesquisa. São Paulo: Atlas, 2008.

KAYGUSUZ, K. Environmental impacts of energy utilisation and renewable energy policies in Turkey. Energy Policy, v. 30, n. 8, p. 689-698, 2002.

LARSEN, S. V. Is environmental impact assessment fulfilling its potential? The case of climate change in renewable energy projects. Impact Assessment and Project Appraisal, v. 32, n. 3, p. 234-240, 2014.

MACLEAN, I. et al. Resolving issues with environmental impact assessment of marine renewable energy installations. Frontiers in Marine Science, v. 1, 2014.

MONDOL, J.; KOUMPETSOS, N. Overview of challenges, prospects, environmental impacts and policies for renewable energy and sustainable development in Greece. Renewable and Sustainable Energy Reviews, v. 23, p. 431-442, 2013.

NIENHUESER, I.; QIU, Y. Economic and environmental impacts of providing renewable energy for electric vehicle charging: A choice experiment study. Applied Energy, v. 180, p. 256-268, 2016.

PAGANI, R. N.; KOVALESKI, J. L.; RESENDE, L. M. Methodi ordinatio®: a proposed methodology to select and rank relevant scientific papers encompassing the impact factor, number of citation, and year of publication. Scientometrics, Springer, v. 105, n. 3, p. 2109-2135, 2015.

POTOCNIK, J.; KHOSLA, A. Examining the Environmental Impact of Demand-Side and Renewable Energy Technologies. Journal of Industrial Ecology, v. 20, n. 2, p. 216-217, 2016.

SCHUMACHER, K. Large-scale renewable energy project barriers: Environmental impact assessment streamlining efforts in Japan and the EU. Environmental Impact Assessment Review, v. 65, p. 100-110, 2017.

SIDE, J.; GALLEGO, A.; JAMES, M.; DAVIES, I.; HEATH, M.; KARUNARATHNA, H.; VENUGOPAL, V.; VOGLER, A.; BURROWS, M. Developing methodologies for large scale wave and tidal stream marine renewable energy extraction and its environmental impact: An overview of the TeraWatt project. Ocean \& Coast Management, v. 147, p. 1-5, 2017.

SILVA, E. L.; MENEZES, E. M. Metodologia de pesquisa e elaboração de dissertação. Florianópolis: UFSC, 2005.

SOKKA, L.; SINKKO, T.; HOLMA, A.; MANNINEN, K.; PASANEN, K.; RANTALA, M.; LESKINEN, P. Environmental impacts of the national renewable energy targets - A case study from Finland. Renewable and Sustainable Energy Reviews, v. 59, p. 1599-1610, 2016. 


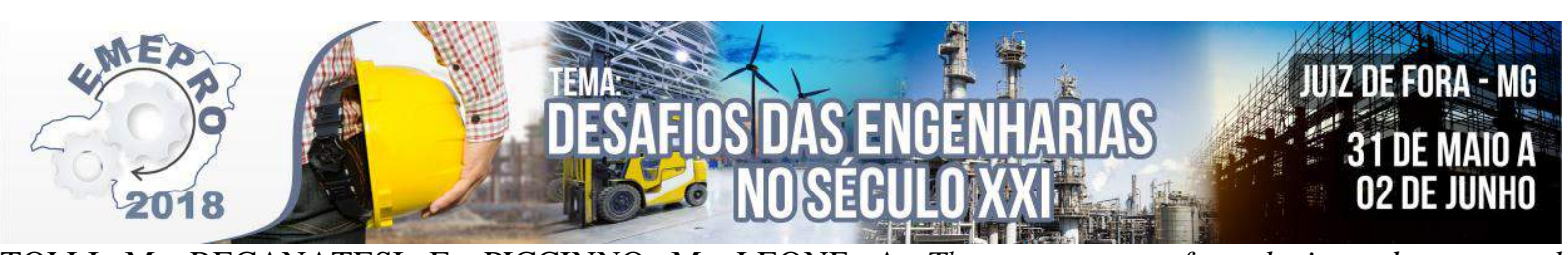

TOLLI, M.; RECANATESI, F.; PICCINNO, M.; LEONE, A. The assessment of aesthetic and perceptual aspects within environmental impact assessment of renewable energy projects in Italy. Environmental Impact Assessment Review, v. 57, p. 10-17, 2016.

VARUN; PRAKASH, R.; BHAT, I. K. Energy, economics and environmental impacts of renewable energy systems. Renewable and Sustainable Energy Reviews, v. 13, n. 9, p. 2716-2721, 2009.

WRIGHT, G. Strengthening the role of science in marine governance through environmental impact assessment: A case study of the marine renewable energy industry. Ocean and Coastal Management, v. 99, p. 23-30, 2014.

\section{Apêndice 1}

Tabela 4: Informações básicas de artigos e valores de InOrdinatio da Methodi Ordinatio.

\begin{tabular}{|c|c|c|c|c|c|c|}
\hline Código & Ranking & Autores & Título do artigo & Ano & N. Citações & InOrdinatio \\
\hline 001 & 1 & $\begin{array}{l}\text { Akella, A., } \\
\text { Saini, R. and } \\
\text { Sharma, M. }\end{array}$ & $\begin{array}{l}\text { Social, economical } \\
\text { and environmental } \\
\text { impacts of } \\
\text { renewable energy } \\
\text { systems }\end{array}$ & 2009 & 269 & 289,00 \\
\hline 002 & 2 & $\begin{array}{c}\text { Varun, } \\
\text { Prakash, R., } \\
\text { Bhat, I. K. }\end{array}$ & $\begin{array}{c}\text { Energy, economics } \\
\text { and environmental } \\
\text { impacts of } \\
\text { renewable energy } \\
\text { systems } \\
\end{array}$ & 2009 & 167 & 187,01 \\
\hline 003 & 3 & $\begin{array}{l}\text { Berrill, P., } \\
\text { Arvesen, A., } \\
\text { Scholz, Y., } \\
\text { Gils, H. and } \\
\text { Hertwich, E. }\end{array}$ & $\begin{array}{l}\text { Environmental } \\
\text { impacts of high } \\
\text { penetration } \\
\text { renewable energy } \\
\text { scenarios for } \\
\text { Europe }\end{array}$ & 2016 & 17 & 107,01 \\
\hline 004 & 4 & $\begin{array}{c}\text { Side, J., } \\
\text { Gallego, A., } \\
\text { James, M., } \\
\text { Davies, I., } \\
\text { Heath, M., } \\
\text { Karunarathna, } \\
\text { H., Venugopal, } \\
\text { V., Vogler, A. } \\
\text { and Burrows, } \\
\text { M. }\end{array}$ & $\begin{array}{c}\text { Developing } \\
\text { methodologies for } \\
\text { large scale wave } \\
\text { and tidal stream } \\
\text { marine renewable } \\
\text { energy extraction } \\
\text { and its } \\
\text { environmental } \\
\text { impact: An overview } \\
\text { of the TeraWatt } \\
\text { project }\end{array}$ & 2017 & 3 & 103,00 \\
\hline 005 & 5 & $\begin{array}{c}\text { Sokka, L., } \\
\text { Sinkko, T., } \\
\text { Holma, A., } \\
\text { Manninen, K., } \\
\text { Pasanen, K., } \\
\text { Rantala, M. } \\
\text { and Leskinen, } \\
\text { P. }\end{array}$ & $\begin{array}{l}\text { Environmental } \\
\text { impacts of the } \\
\text { national renewable } \\
\text { energy targets - A } \\
\text { case study from } \\
\text { Finland }\end{array}$ & 2016 & 12 & 102,01 \\
\hline \multicolumn{7}{|r|}{ Continua } \\
\hline
\end{tabular}

Fonte: Elaborado pelos autores (2017) a partir dos dados e informações básicos dos artigos selecionados. 


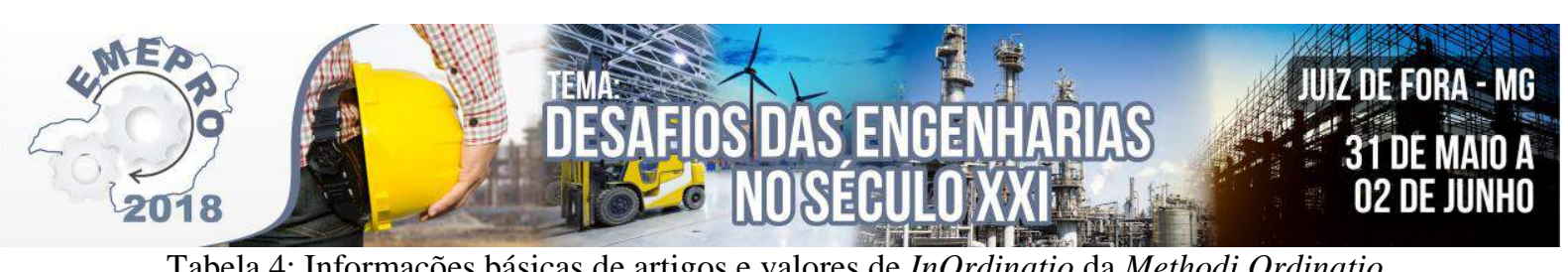

Tabela 4: Informações básicas de artigos e valores de InOrdinatio da Methodi Ordinatio.

\begin{tabular}{|c|c|c|c|c|c|c|}
\hline Código & Ranking & Autores & Título do artigo & Ano & N. Citações & InOrdinatio \\
\hline 006 & 6 & $\begin{array}{l}\text { Nienhueser, I. } \\
\text { and Qiu, Y. }\end{array}$ & $\begin{array}{l}\text { Economic and } \\
\text { environmental } \\
\text { impacts of providing } \\
\text { renewable energy } \\
\text { for electric vehicle } \\
\text { charging - A choice } \\
\text { experiment study }\end{array}$ & 2016 & 10 & 100,01 \\
\hline 007 & 7 & $\begin{array}{c}\text { Schumacher, } \\
\text { K. }\end{array}$ & $\begin{array}{l}\text { Large-scale } \\
\text { renewable energy } \\
\text { project barriers: } \\
\text { Environmental } \\
\text { impact assessment } \\
\text { streamlining efforts } \\
\text { in Japan and the EU }\end{array}$ & 2017 & 0 & 100,00 \\
\hline 008 & 8 & $\begin{array}{c}\text { Mondol, J. and } \\
\text { Koumpetsos, } \\
\text { N. }\end{array}$ & $\begin{array}{c}\text { Overview of } \\
\text { challenges, } \\
\text { prospects, } \\
\text { environmental } \\
\text { impacts and policies } \\
\text { for renewable } \\
\text { energy and } \\
\text { sustainable } \\
\text { development in } \\
\text { Greece }\end{array}$ & 2013 & 35 & 95,01 \\
\hline 009 & 9 & $\begin{array}{c}\text { Buchspies, B. } \\
\text { and } \\
\text { Kaltschmitt, } \\
\text { M. }\end{array}$ & $\begin{array}{c}\text { Life cycle } \\
\text { assessment of } \\
\text { bioethanol from } \\
\text { wheat and sugar } \\
\text { beet discussing } \\
\text { environmental } \\
\text { impacts of multiple } \\
\text { concepts of co- } \\
\text { product processing } \\
\text { in the context of the } \\
\text { European } \\
\text { Renewable Energy } \\
\text { Directive }\end{array}$ & 2016 & 4 & 94,00 \\
\hline 010 & 10 & $\begin{array}{c}\text { Potocnik, J. } \\
\text { and Khosla, A. }\end{array}$ & $\begin{array}{c}\text { Examining the } \\
\text { Environmental } \\
\text { Impact of Demand- } \\
\text { Side and Renewable } \\
\text { Energy } \\
\text { Technologies }\end{array}$ & 2016 & 1 & 91,00 \\
\hline 011 & 11 & $\begin{array}{c}\text { Tolli, M., } \\
\text { Recanatesi, F., } \\
\text { Piccinno, M. } \\
\text { and Leone, A. }\end{array}$ & $\begin{array}{c}\text { The assessment of } \\
\text { aesthetic and } \\
\text { perceptual aspects } \\
\text { within } \\
\text { environmental } \\
\text { impact assessment } \\
\text { of renewable energy } \\
\text { projects in Italy }\end{array}$ & 2016 & 1 & 91,00 \\
\hline \multicolumn{7}{|r|}{ Continuando. } \\
\hline
\end{tabular}

Fonte: Elaborado pelos autores (2017) a partir dos dados e informações básicos dos artigos selecionados. 


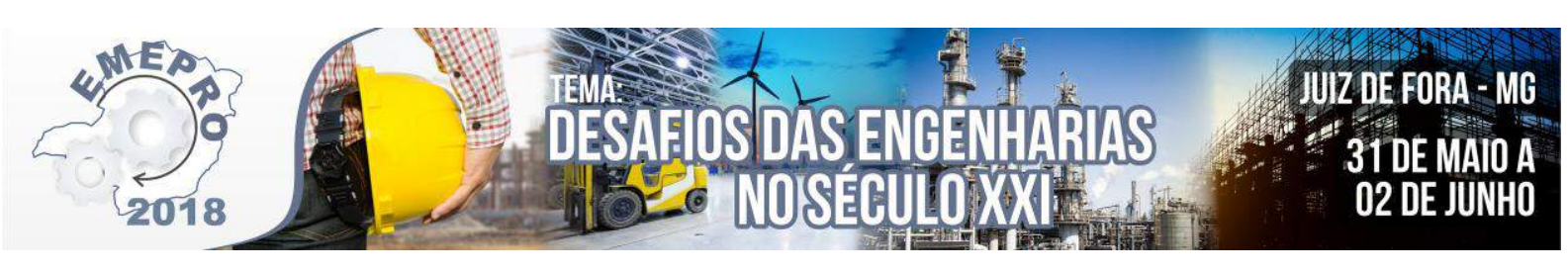

Tabela 4: Informações básicas de artigos e valores de InOrdinatio da Methodi Ordinatio.

\begin{tabular}{|c|c|c|c|c|c|c|}
\hline Código & Ranking & Autores & Título do artigo & Ano & $\begin{array}{c}\text { N. } \\
\text { Citações }\end{array}$ & InOrdinatio \\
\hline 012 & 12 & Wright, G. & $\begin{array}{l}\text { Strengthening the } \\
\text { role of science in } \\
\text { marine governance } \\
\text { through } \\
\text { environmental } \\
\text { impact assessment: } \\
\text { A case study of the } \\
\text { marine renewable } \\
\text { energy industry }\end{array}$ & 2014 & 19 & 89,00 \\
\hline 013 & 13 & $\begin{array}{l}\text { Azofra, D., } \\
\text { Jiménez, E., } \\
\text { Martínez, E., } \\
\text { Blanco, J. and } \\
\text { Saenz-Díez, } \\
\text { J.C. }\end{array}$ & $\begin{array}{c}\text { Economical- } \\
\text { environmental } \\
\text { impact of subsidised } \\
\text { renewable energy } \\
\text { sources for } \\
\text { electricity (RES-E) } \\
\text { in the Spanish } \\
\text { system } \\
\end{array}$ & 2015 & 6 & 86,00 \\
\hline 014 & 14 & $\begin{array}{c}\text { Maclean, I. et } \\
\text { al. }\end{array}$ & $\begin{array}{c}\text { Resolving issues } \\
\text { with environmental } \\
\text { impact assessment } \\
\text { of marine } \\
\text { renewable energy } \\
\text { installations } \\
\end{array}$ & 2014 & 12 & 82,00 \\
\hline 015 & 15 & $\begin{array}{l}\text { Caliskan, H., } \\
\text { Dincer, I. and } \\
\text { Hepbasli, A. }\end{array}$ & $\begin{array}{l}\text { Exergoeconomic } \\
\text { and environmental } \\
\text { impact analyses of } \\
\text { a renewable energy } \\
\text { based hydrogen } \\
\text { production system }\end{array}$ & 2013 & 21 & 81,00 \\
\hline 016 & 16 & Larsen, S.V. & $\begin{array}{c}\text { Is environmental } \\
\text { impact assessment } \\
\text { fulfilling its } \\
\text { potential? The case } \\
\text { of climate change in } \\
\text { renewable energy } \\
\text { projects }\end{array}$ & 2014 & 5 & 75,00 \\
\hline 017 & 17 & Kaygusuz, K. & $\begin{array}{l}\text { Environmental } \\
\text { impacts of energy } \\
\text { utilisation and } \\
\text { renewable energy } \\
\text { policies in Turkey }\end{array}$ & 2002 & 87 & 37,00 \\
\hline \\
\hline
\end{tabular}

Fonte: Elaborado pelos autores (2017) a partir dos dados e informações básicos dos artigos selecionados. 


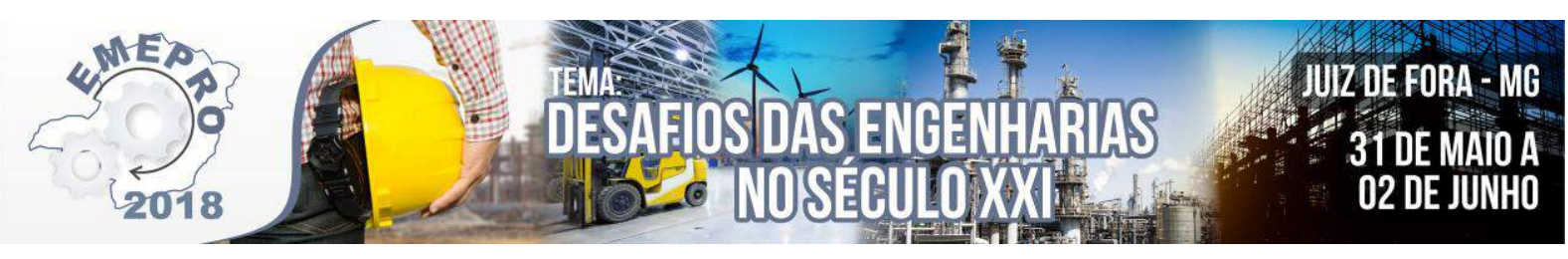

\title{
Análise da Utilização do SGA na Eficácia de Auditorias Ambientais
}

\author{
Beatriz Cristina Ferreira Machado, FIC-UNIS/Cataguases, biacfmachado@gmail.com \\ Josiane Aparecida Cardoso de Souza, FIC-UNIS/Cataguases, josisouzakta@hotmail.com \\ Bruno Carlos Alves Pinheiro, UENF/ Campos de Goytacazes, bruno.pinheiro@uemguba.edu.br \\ Tiago Bittencourt Nazaré - FIC/UNIS/Cataguases, tiago_bit@yahoo.com.br
}

\begin{abstract}
Resumo: Tendo em vista o aumento da exploração dos recursos ambientais, na busca pelo desenvolvimento dos setores industriais, uma forma de tentar minimizar e mitigar os impactos ambientais gerados na produção, seria a implantação de um Sistema de Gestão Ambiental (SGA). O presente trabalho é uma revisão da literatura sobre as vantagens de se implantar um SGA, mostrando conformidades apontadas pelas auditorias ambientais, instrumento este de suma importância na avaliação do desempenho ambiental das empresas. Foi constatado que a utilização de auditorias ambientais se mostram importantes como ferramentas da gestão ambiental, contribuindo para o bom funcionamento do SGA, onde permitem a reduzir as repercussões sobre o meio ambiente, assim como o cumprimento de leis ambientais e do aperfeiçoamento da imagem da empresa frente ao ambiente externo.

Palavras-chave: Auditoria Ambiental. Sistema de Gestão Ambiental.
\end{abstract}

\section{Introdução}

Tendo em vista o aumento desenfreado da exploração dos recursos ambientais, na busca pelo desenvolvimento dos setores industriais, é visível a problemática ambiental acerca desse tema. Garantir um futuro sustentável às futuras gerações hoje em dia é ponto chave para as discussões e planejamentos ambientais. Conforme Seifert (2011, p.45), a preservação do meio ambiente converteu-se em um dos fatores de maior influência dos anos 90 e da primeira década de 2000. As empresas começaram a apresentar soluções e alternativas para alcançar o desenvolvimento sustentável e, ao mesmo tempo, a aumentar a lucratividade de seus negócios.

Segundo Alencar et. al (2015, p.577), a gestão ambiental visa a auxiliar a administração e o gerenciamento dos aspectos ambientais, econômicos e sociais de uma organização de forma a utilizar de maneira racional os recursos naturais, a preservação do meio ambiente e a continuidade do negócio. $\mathrm{O}$ uso de boas práticas garante a preservação e a conservação da biodiversidade por meio da redução, reutilização e reciclagem de insumos produtivos e, como consequência, a minimização dos possíveis impactos ambientais.

Visto a necessidade de se desenvolver de forma sustentável, a implantação de medidas de controle ambiental nas atividades do processo industrial, é fundamental.

Autores como Valle, 2004; Instituto Nacional de Normalização e Metrologia, 2013; Haden; Oyler; Humphreys, 2009 definem a gestão ambiental de maneira similar, onde:

“A gestão ambiental em uma organização compreende um conjunto de procedimentos para desenvolver e implementar a política ambiental, que permita gerenciar os aspectos ambientais e reduzir os impactos das suas atividades. Esta gestão pode contribuir também para a promoção da responsabilidade social e de vantagem competitiva." 


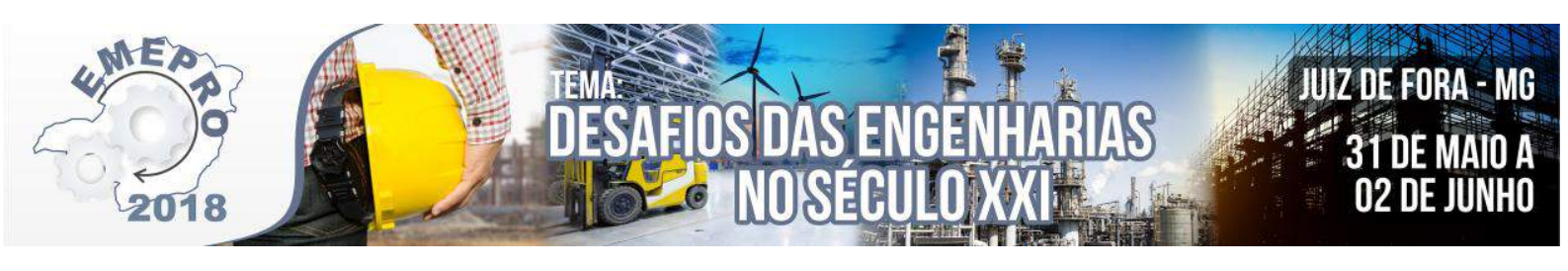

Com a implantação de um Sistema de Gestão Ambiental (SGA), temos a auditoria ambiental diretamente ligada à gestão. De acordo com Rodrigues (2011), a auditoria ambiental consiste em um instrumento hábil na definição da natureza e da extensão das áreas de impacto ambiental de uma atividade pública ou privada. A auditoria identifica, analisa e informa a situação real em que a empresa se encontra, quanto à conformidade e ao atendimento aos controles existentes. Aliado a isso, fundamenta as medidas necessárias para reduzir as áreas de impacto, estima-se o custo dessas medidas e indica um cronograma para sua execução.

O objetivo deste trabalho é evidenciar que o uso de auditorias ambientais, sejam elas internas, externas ou independentes, contribuem de forma direta para o sucesso e a melhoria contínua dos processos do SGA nas organizações.

\section{Metodologia}

O presente trabalho foi elaborado através de revisão de literatura fundamentada em artigos científicos, revistas online, legislações e livros referentes ao assunto. Procurou-se levantar informações sobre a importância das auditorias ambientais como base para avaliação do desempenho ambiental, a obtenção e garantia de certificações para as organizações e a relação existente entre o SGA e as auditorias como um todo.Através da pesquisa bibliográfica, foi possível apresentar as vantagens ao se implantar um SGA dentro das organizações.

\section{Referencias Teóricos}

Com o passar dos anos, é visto a crescente necessidade de se implantar a gestão ambiental nas organizações. A preocupação com as questões ambientais colocam as empresas em um ponto de benefício estratégico, onde é possível desfrutar dos ganhos obtidos a partir das ações sociais e ambientais aplicadas corretamente. Segundo Oliveira et al (2012), foi registrado um agravamento nas questões voltadas para a concentração de riquezas, desemprego, prejuízos ambientais que estimularam diversas correntes de pensamentos, tendo em vista aliar a forma atual de desenvolvimento financeiro e industrial com a melhoria da qualidade de vida, o que engloba as interações entre a sociedade, e desta com o ambiente.

"A problematização das relações entre a sociedade e o meio ambiente e a nova consciência daí resultante atribuíram um novo significado e estatuto ao meio ambiente, constituindo uma 'questão ambiental' onde antes ela não existia". (LIMA, 2015, p. 27)

Para garantir a minimização dos impactos ambientais gerados pelas empresas potencialmente poluidoras, são desenvolvidas alternativas que contribuem e auxiliam de forma a atingir os objetivos e metas desejados através do uso consciente dos recursos naturais. De acordo com Jabbour e Jabbour (2013), gestão ambiental envolve a adoção de práticas gerenciais de planejamento e organização, com o intuito de melhorar a relação entre a organização e o meio ambiente, reduzindo os impactos ambientais.

A Resolução CONAMA no 306/2002, define gestão ambiental como "a condução, direção e controle do uso dos recursos naturais, dos riscos ambientais e das emissões para o meio ambiente, por intermédio da implementação de um Sistema de Gestão 


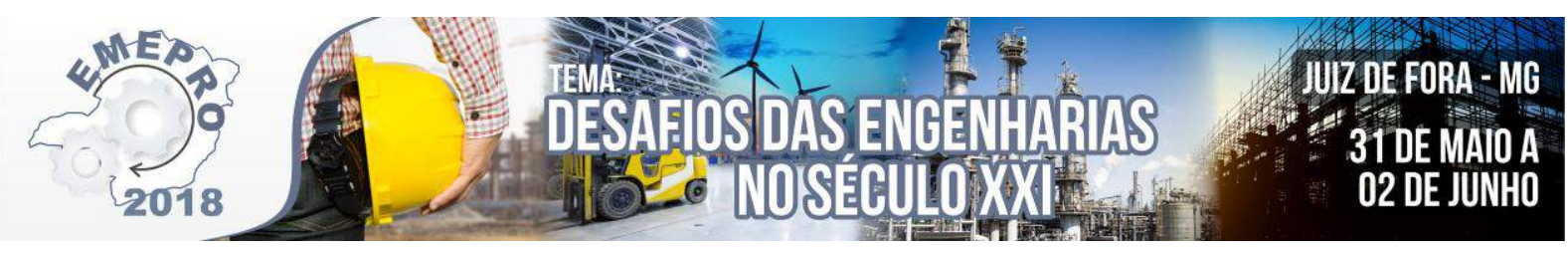

Ambiental". Ainda de acordo com o CONAMA n ${ }^{\circ}$ 306/2002, define SGA como:

"A parte do sistema de gestão global que inclui estrutura organizacional, atividades de planejamento, responsabilidades, práticas, procedimentos, processos e recursos para desenvolver, implementar, atingir, analisar criticamente e manter a política ambiental da instalação.( Resolução do CONAMA n. 306, de 05 de julho de 2002).”

O SGA tem sido fortemente implantado pelas organizações no que se refere ao gerenciamento ambiental, pois ele fornece às atividades um equilíbrio entre a produção e a sustentabilidade. "Os instrumentos de gestão ambiental são responsáveis por agrupar as práticas de gestão ambiental adotadas pelas organizações e, por meio da sinergia entre elas, influenciar positivamente o desempenho ambiental das organizações" (JABBOUR; JABBOUR, 2013, p.57).

O uso de boas práticas garante o desenvolvimento econômico, social e ambientalmente sustentável, por meio da redução, reutilização e reciclagem dos insumos da produção e, consequentemente, a minimização dos impactos ambientais.

Conforme a figura 1, o processo de implementação do SGA é baseado no ciclo da melhoria contínua, que busca atingir melhorias no desempenho ambiental em conformidade com a política ambiental da empresa. De acordo com a ABNT (2004), esse ciclo, também conhecido como PDCA, estabelece as metas e objetivos, executa os processos; verifica e monitora ações corretivas e age para garantir a melhoria no desempenho do sistema de gestão ambiental (ABNT, 2004).

Figura 1 - Representação do ciclo da melhoria contínua (PDCA).

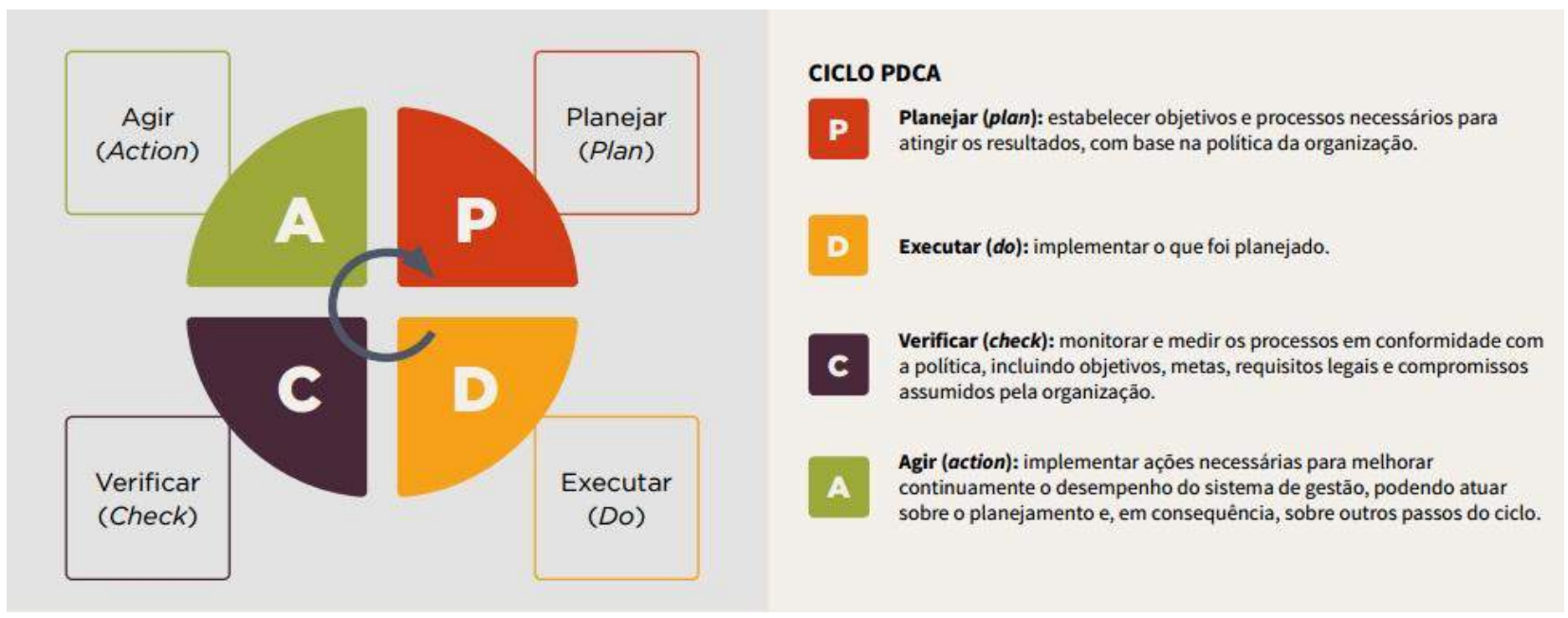

Fonte: ISO 14001:2015. FIESP/CIESP (2015)

As possibilidades oferecidas pela implantação de Sistemas de Gestão Ambiental vão ao encontro das necessidades das organizações, principalmente em virtude da multiplicidade de contextos socioeconômico-ambientais que elas enfrentam (SEIFFERT, 2011).

Conforme Oliveira, Serra e Salgado (apud TRIERWEILLER, A. C. et al. 2013), a gestão ambiental é uma alternativa utilizada pelas organizações ao redor do mundo para a 


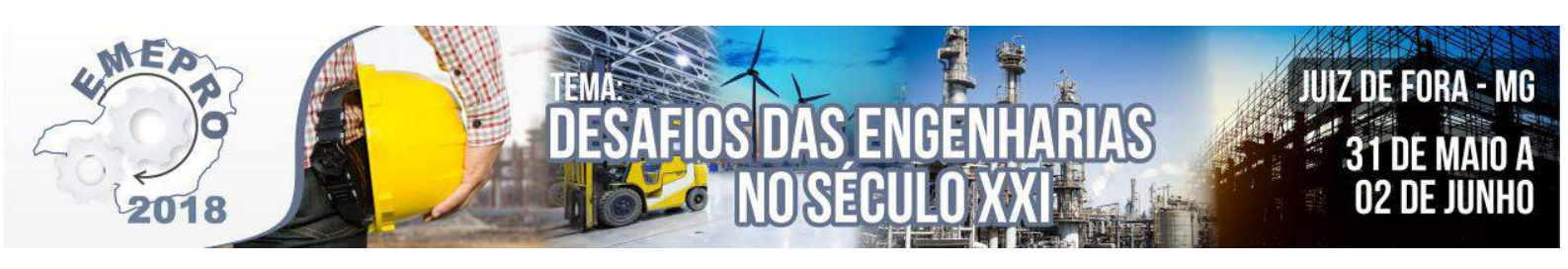

melhoraria e controle de suas atividades no sentido de agredir menos o meio ambiente, gerando economia e, com isso o aumento de competitividade como decorrência do processo de modernização, redução de desperdícios, emissões de resíduos e diminuição de multas.

Com o emprego do SGA, as empresas possuem auxilio na administração e no gerenciamento dos aspectos ambientais, sociais e econômicos da organização. De acordo com NBR ISO 14001(1996), o SGA é parte do sistema de gestão integrada de uma estrutura organizacional que abrange atividades de planejamento, práticas, procedimentos, responsabilidades, processos e recursos para desenvolver, implementar, atingir, analisar criticamente e manter a política ambiental.

\title{
3.2 Licenciamento e Certificação Ambiental
}

O Licenciamento Ambiental é uma exigência legal e uma ferramenta do Poder Público para o controle ambiental. De acordo com a Resolução CONAMA $n^{\circ} 237$, de 19 de dezembro de 1997, temos:

\footnotetext{
"Licenciamento Ambiental: procedimento administrativo pelo qual o órgão ambiental competente licencia a localização, instalação, ampliação e a operação de empreendimentos e atividades utilizadoras de recursos ambientais, consideradas efetiva ou potencialmente poluidoras ou daquelas que, sob qualquer forma, possam causar degradação ambiental, considerando as disposições legais e regulamentares e as normas técnicas aplicáveis ao caso (Resolução do CONAMA n. 237, de 19 de dezembro de 1997)".
}

É obrigação do empreendedor, prevista em lei, buscar o licenciamento ambiental junto ao órgão competente, desde as etapas iniciais de seu planejamento e instalação até a sua efetiva operação. E para que ocorra o licenciamento dos empreendimentos, o Poder Público, no exercício de sua competência de controle, em razão da Resolução CONAMA nº 237/97, expedirá três tipos de licenças:

\begin{abstract}
"I - Licença Prévia (LP) - concedida na fase preliminar do planejamento do empreendimento ou atividade aprovando sua localização e concepção, atestando a viabilidade ambiental e estabelecendo os requisitos básicos e condicionantes a serem atendidos nas próximas fases de sua implementação;

II - Licença de Instalação (LI) - autoriza a instalação do empreendimento ou atividade de acordo com as especificações constantes dos planos, programas e projetos aprovados, incluindo as medidas de controle ambiental e demais condicionantes, da qual constituem motivo determinante;

III - Licença de Operação (LO) - autoriza a operação da atividade ou empreendimento, após a verificação do efetivo cumprimento do que consta das licenças anteriores, com as medidas de controle ambiental e condicionantes determinados para a operação (Resolução do CONAMA n. 237, de 19 de dezembro de 1997)."
\end{abstract}

A licença ambiental, de acordo com a Resolução CONAMA n²37/97, é o documento com prazo de validade definido, em que o órgão ambiental estabelece regras, condições, restrições e medidas de controle ambiental a serem seguidas pelas empresas. As empresas que funcionam sem a Licença Ambiental estão sujeitas às sanções previstas em lei, incluindo as punições relacionadas na Lei de Crimes Ambientais, instituída em 1998: advertências, multas, embargos, paralisação temporária ou definitiva das atividades. 


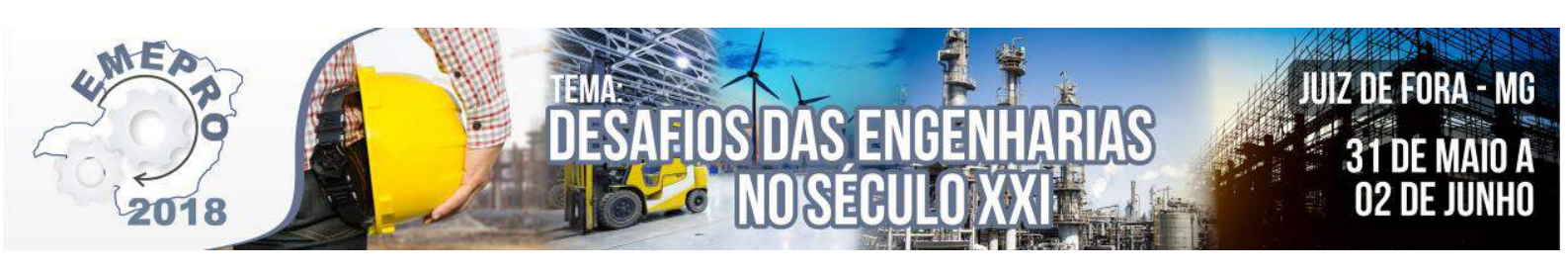

A Avaliação do Impacto Ambiental (AIA) é fundamental para a análise do Licenciamento Ambiental, que exige a avaliação do "relatório ambiental, planos e projeto de controle ambiental, relatório ambiental preliminar, diagnóstico ambiental, plano de manejo, plano de recuperação de área degradada e a análise preliminar de risco (art. $1^{\circ}$, III, Res. 237/97, CONAMA)". A avaliação do impacto ambiental se interrelaciona com outros processos, como estudos de viabilidade, de usos e de ocupação do solo e de incorporação dos efeitos cumulativos das mudanças dos ecossistemas, monitoramente e experiência adquirida (FIORILLO; MORITA; FERREIRA, 2011). A figura 2 mostra os passos necessários para o requerimento da licença.

O CONAMA, fazendo uso de suas atribuições, estabelece definições, responsabilidades, critérios e diretrizes para uso e implementação da Política Nacional do Meio Ambiente. Para a realização do Licenciamento Ambiental no Brasil, em concordância ao exposto pelos autores e resoluções citadas, o CONAMA define como documentos indispensáveis: a) o EIA/RIMA - Estudo de Impactos Ambientais acompanhado do Relatório de Impacto Ambiental - para empreendimentos e atividades com significativo impacto ambiental; b) o PCA/RCA - Plano de Controle Ambiental acompanhado do Relatório de Controle Ambiental - para empreendimentos ou atividades com grande potencial poluidor; c) o PRAD - Plano de Recuperação de Áreas Degradadas - deve ser apresentado, juntamente com o EIA/RIMA, quando um empreendimento se destina à exploração de recursos minerais.

O EIA/RIMA é uma exigência legal, instituída pela Resolução CONAMA 001/86, na implantação de projetos com o significativo impacto ambiental. Consiste em realizar o diagnóstico ambiental da área de influência do projeto, análise dos impactos ambientais e definição de medidas mitigadoras para redução desses impactos além de programas de acompanhamento e monitoramento ambiental.

Em síntese, a realização da avaliação e o cumprimento das documentações exigidas pelo órgão ambiental, norteiam a necessidade da realização de auditorias para que seja evidenciada a conformidade durante a execução das atividades dos empreendimentos. Para a obtenção de uma licença é necessária a identificação do tipo de licença requerida e do órgão fiscalizador competente, e depois de obtido o requerimento da licença é iniciado o processo de licenciamento ambiental. A figura 2 representa um fluxograma do processo de licenciamento ambiental, para o requerimento de licenças ao órgão competente. 


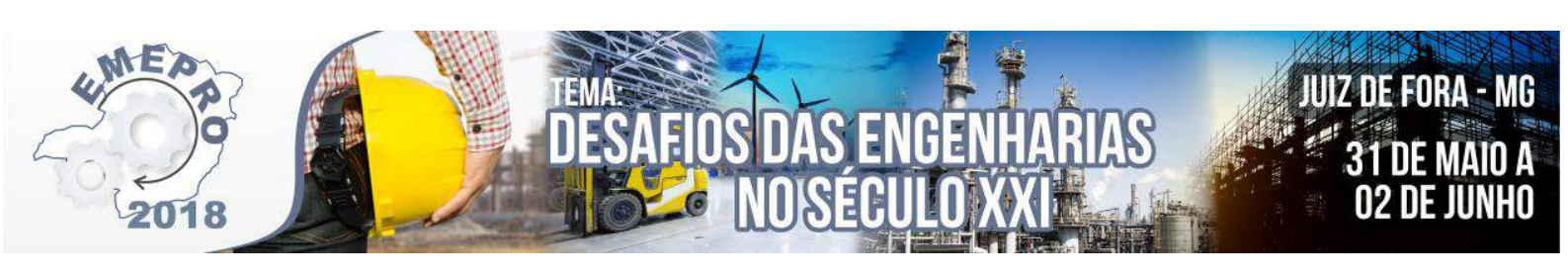

Figura 2 - Passos Necessários para o Requerimento da Licença

PASSOS NECESSÁRIOS PARA O REQUERIMENTO DA LICENÇA

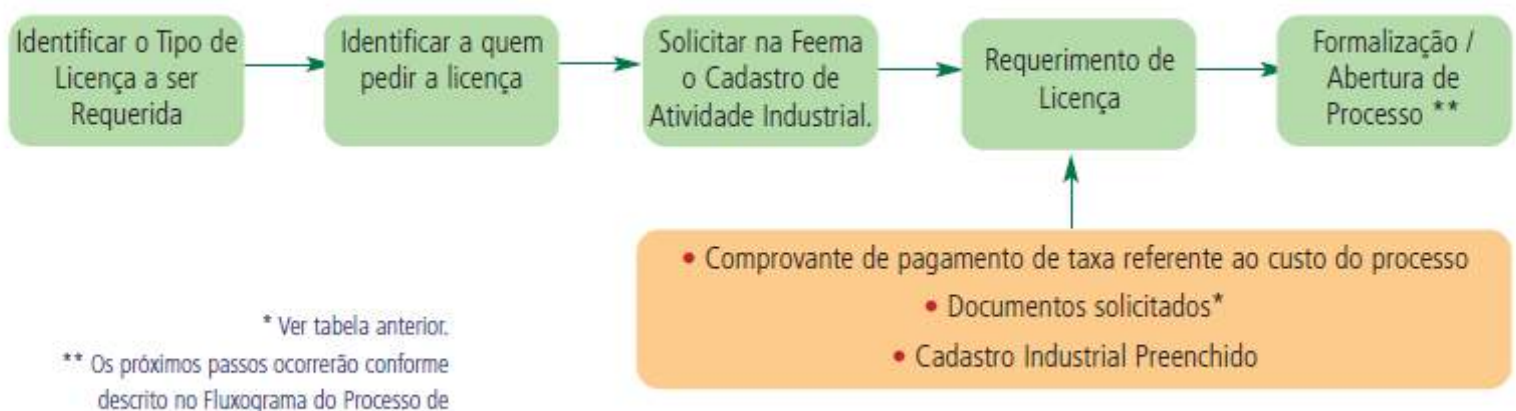

Licenciamento Ambiental (mais adiante)

Fonte: Manual de Licenciamento ambiental: guia de procedimento passo a passo. Rio de Janeiro: GMA, 2004.

Os estudos e o acompanhamento das atividades evidenciam como são importantes os diagnósticos realizados pelos empreendimentos na implantação de seus projetos, visto que a preocupação com as questões ambientais aumentam gradativamente, submetendo as empresas a desenvolverem uma gestão voltada para a consciência ambiental.

\subsection{Auditoria Ambiental}

A auditoria ambiental representa uma ferramenta eficaz na caracterização da natureza e do tamanho das áreas impactadas por uma atividade, seja pública ou privada. Segundo Rodrigues (2011), "a auditoria detecta, analisa e informa a situação real em que se encontra a empresa quanto à conformidade e ao respeito aos controles existentes". Ainda sobre o conceito de auditoria ambiental, La Rovere (2011) define como "um instrumento usado por empresas para auxiliá-las a controlar o atendimento a políticas, práticas, procedimentos e/ou requisitos estipulados com o objetivo de evitar a degradação ambiental". Seguindo as opiniões citadas, podemos dizer que a auditoria é um instrumento que auxilia no controle e segurança do desempenho ambiental, na adoção de medidas adequadas para a redução dos impactos e indicação de condicionantes a serem cumpridas pelas empresas.

O objetivo principal da auditoria ambiental é "avaliar o grau de conformidade do estabelecimento com a legislação e com a política ambiental da organização, incorporada ao Sistema de Gestão Ambiental, se a empresa o tiver implantado" (NBR ISO 14001), ou de acordo com Peno A. Juchem (apud LIMA, 2011, p. 3), é a "busca permanente da melhoria da compatibilidade ambiental das ações, processos, produtos e serviços de empresas e instituições". Analisando esses conceitos, são apontadas para a auditoria ambiental as metas legais, políticas, econômicas e gerenciais da organização.

Um conceito mais amplo relacionado à auditoria ambiental é disponibilizado pela NBR ISO 14010 (ABNT, 1996) e disposto pela Resolução CONAMA 306/2002, onde informa que, auditoria ambiental é um: 


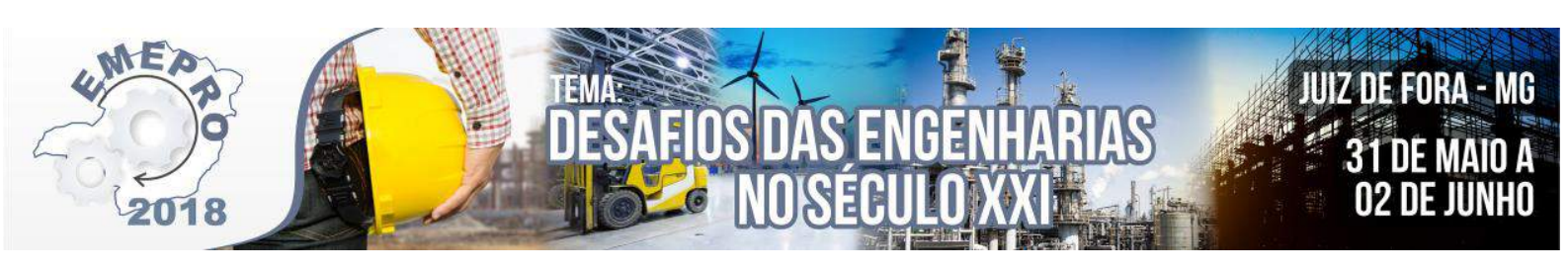

"Processo sistemático e documentado de verificação, executado para obter e avaliar, de forma objetiva, evidências que determinem se as atividades, eventos, sistemas de gestão e condições ambientais especificados ou as informações relacionadas a estes estão em conformidade com os critérios de auditoria estabelecidos nesta Resolução, e para comunicar os resultados desse processo (Resolução do CONAMA n. 306, de 5 de julho de 2002).”

De acordo com Alcântara et al (2015), para a realização da auditoria ambiental primeiramente é necessário que o auditor conheça a realidade ambiental da empresa, para que possa tomar as devidas providências em ocorrência de irregularidades, e, além disso, para não ser pego de surpresa por problemas ambientais.

A norma ABNT NBR ISO 14001: 2004 aponta os requisitos inerentes a um SGA, permitindo a uma organização desenvolver e implementar uma política e objetivos que considerem os requisitos legais e outros requisitos por ela subscritos e informações referentes aos aspectos ambientais significativos (ABNT, 2004).

O SGA está diretamente ligado com a auditoria ambiental, a partir de seus resultados que se obtêm a melhoria contínua. Perante a legislação ambiental em vigor no Brasil, o auditor, certifica que a organização está de acordo com as exigências emitidas pelos órgãos fiscalizadores e prevê medidas mitigadoras para minimização de seus impactos ambientais. A legislação exige cada vez mais das empresas, e procura conduzir suas atividades com respeito e preocupação ambiental. De acordo com o Manual de auditoria ambiental (2011, p.3):

\begin{abstract}
"A gestão ambiental nas empresas pode ser definida como aquela parte da função gerencial global que trata, determina e implementa a política de meio ambiente estabelecida para a própria empresa. De maneira mais específica, o dicionário de vocabulário básico de meio ambiente define gestão ambiental como: "tentativa de avaliar valores e limites das perturbações e alterações que, uma vez excedidos, resultam em recuperação demorada do meio ambiente, de modo a maximizar a recuperação dos recursos do ecossistema natural para o homem, assegurando sua produtividade prolongada e de longo prazo (MANUAL DE AUDITORIA AMBIENTAL, 2011, p.3).”
\end{abstract}

De acordo com Moraes (2014), "com a inserção do contexto da sustentabilidade nas empresas, e a obrigatoriedade de se cumprir as leis ambientais, surgiu a série de normas ISO 14000, como um marco de auxílio na busca da implantação de uma gestão ambiental efetiva nas empresas (MORAES, 2014)". A serie ISO 14000 trata sobre alguns assuntos voltados para área ambiental como SGA, a avaliação de desempenho ambiental, as auditorias, entre outros.

No Brasil a ISO é representada pela ABNT - Associação Brasileira de Normas Técnicas. Segundo Alves (2015), as empresas que buscam credibilidade no mercado têm desenvolvido seu SGA baseado nas normas da ISO, pois têm como objetivo à certificação de seus processos, uma vez que, a NBR ISO 14001 é a única norma certificável desse conjunto, e empresas que possuem esse certificado garantem além da credibilidade, a sua positiva reafirmação em sua área de atuação.

“A implementação de um sistema de gestão ambiental (SGA) baseado nas normas ISO 14000 agrega valor as empresas, conferindo qualidade aos processos e produtos e garantindo a observância das leis ambientais vigentes como prérequisito essencial para a obtenção da certificação. Desse modo, as empresas não 


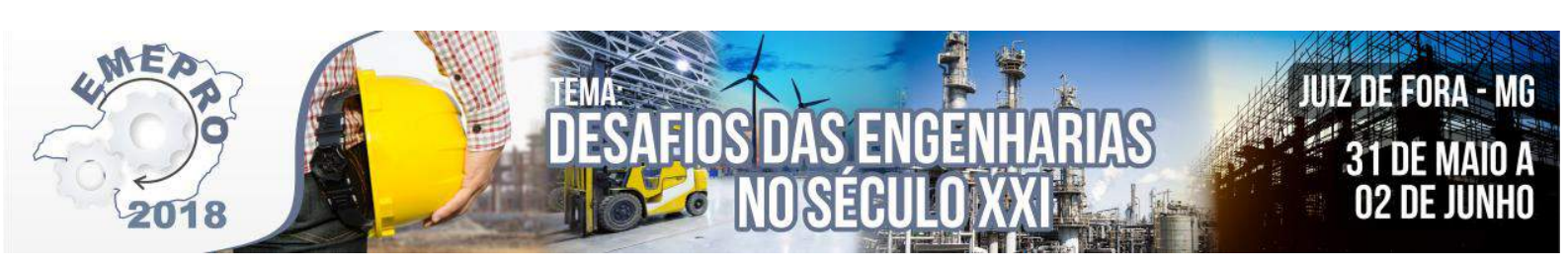

podem considerar essas normas como barreira, mas sim como um valioso instrumento de gestão ambiental. (SILVA e PRZYBYSZ, 2014, p. 96)"

A implantação da norma ISO 14001 deve servir como um importante fator determinante na realização de negócios, tornando-se um pré-requisito para transações entre clientes e fornecedores tanto domésticos quanto internacionais (SEIFFERT, 2010).

Todas as normas da ISO passam por revisões em um determinado tempo, para melhor se adequarem às exigências do mercado e às mudanças na busca pela melhoria contínua. A NBR ISO 14001:2004 passou por um processo de revisão (NBR ISO 14001:2015), e de acordo com CIESP/FIESP (2015) é possível destacar as principais mudanças no PDCA, por exemplo, na fase Planejar foram inseridos a contextualização da organização, liderança e comprometimento com a política ambiental. Na fase executar foi inserido o planejamento e controle operacional; na fase de verificar foi incluída a avaliação de desempenho e na fase de agir, foi proposta a melhoria com foco em melhoria contínua.

O processo de auditoria passa pelas etapas de planejamento, de preparação, de execução e de emissão do relatório, para que, ao final do processo, sejam verificadas as possibilidades de melhoria e a solução de eventuais não conformidades apontadas, para a garantia da melhoria contínua de seus processos (RODRIGUES, 2011).

De acordo com Seiffert (2006), frente à legislação e as diversas normas aplicáveis à fiscalização ambiental no país, a implantação da norma ISO 14001 configura uma forma de redução do ônus associado ao processo de fiscalização ambiental do governo, pois a empresa passa a vistoriar suas áreas e processos, uma vez que o não atendimento às condicionantes impostas pela legislação pode acarretar a perda da certificação.

\subsection{Natura como modelo de Carbono Neutro}

A Natura é uma multinacional brasileira do setor de cosméticos, higiene e beleza, fundada em 1969, atuando além do Brasil, em países como Argentina, Chile,Colômbia, Estados Unidos, França, México e Peru e, na Bolívia, atua-se por meio de um distribuidor local. Tem o compromissode desenvolver produtos que expressam os valores e os comportamentosmais sustentáveis a toda a redede relações.

É considerada pioneira em sustentabilidade, onde lançou em 2014 a Visão de Sustentabilidade 2050, assumindo compromissos para gerar menos impacto, ou seja, garantir melhores condições entre sociedade e meio ambiente de forma a reduzir e mitigar impactos (NATURA, 2016). Dentre os objetivos a serem atingidos até 2030, estão iniciativas relacionadas com resíduos, empoderamento feminino, educação, água, biodiversidade e Amazônia e carbono.

Cientes das questões ambientais voltadas para as emissões de gases efeito estufa (GEE), a Natura criou em 2007 o Programa de Carbono Neutro, que visa reduzir os impactos das emissões das operações, em todasas etapas - desde a extração de matériasprimas,osprocessos da cadeia produtivaaté a destinação das embalagensdos produtos pósconsumo, aliandoganhos econômicos e socioambientais. As emissões que não podem ser evitadas são $100 \%$ compensadas. A figura 3 apresenta o total de emissões de $\mathrm{CO}_{2}$, dos últimos três anos, de acordo com o relatório anula da Natura, 2016: 


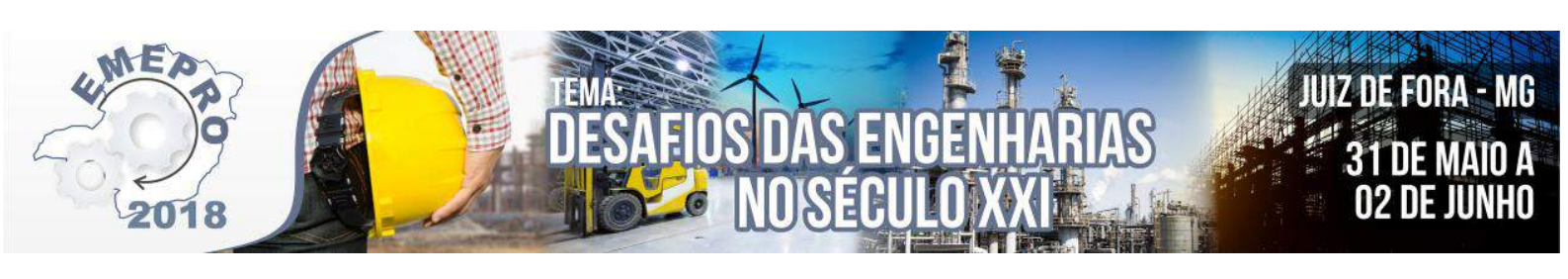

FIGURA 3: Total de emissões na cadeia de valor.

\begin{tabular}{|c|c|c|c|}
\hline $\begin{array}{l}305-2 / 305-4 \\
\text { Emissões relativas de } \mathrm{CO}_{2}(\mathrm{~kg} \\
\text { de } \mathrm{CO}_{2} \mathrm{e} / \mathrm{kg} \text { de produto faturado) }\end{array}$ & $\begin{array}{c}\text { Total de } \\
\text { emissões } \\
\text { de } \mathrm{CO}_{2} \mathrm{e}(\mathrm{t})^{12}\end{array}$ & $\begin{array}{l}\text { Emissões relativas } \\
\text { (kg de } \mathrm{CO}_{2} \mathrm{e} / \mathrm{kg} \text { de produ- } \\
\text { to faturado) }\end{array}$ & $\begin{array}{l}\text { Redução acumulada } \\
\text { de emissões relati- } \\
\text { vas desde } 2012(\%)\end{array}$ \\
\hline 2014 & 332.208 & 3,00 & 6,9 \\
\hline 2015 & 321.267 & 3,17 & 1,4 \\
\hline 2016 & 303.424 & 3,17 & 1,3 \\
\hline
\end{tabular}

1. $\mathrm{CO}_{z}$ (ou $\mathrm{CO}_{2}$ equivalente): medida utilizada para expressar as emissôes dos gases de efeito estufa, baseada no potencial de aquecimento global de cada um. 2. Inclui escopos $1,2 \mathrm{e} 3$ do GHG Protocol.

Fonte: Relatório Anual (Natura; 2016)

Em 2016, foi alcançado o objetivo de compensar localmente as emissões de cada um dos países das Operações Internacionais, com a contratação de créditos no México e no Chile. Entre os destaques foram a obtenção de 26.000 créditos de carbono no Chile e 62.420 créditos de carbono no Peru, sendo a maior iniciativa florestal do país e a maior transação do tipo por uma empresa privada no país.

Por estes e outros motivos relacionados a Sustentabilidades, a Natura é a quarta maior empresamundial no mercado voluntáriode créditos de carbono.

\section{Considerações Finais}

Os resultados obtidos, mediante ao estudo desta pesquisa, evidenciam que cada vez mais a auditoria ambiental vem sendo utilizada como forma de efetivar a eficiência do SGA nas organizações. A busca pela certificação ambiental traz vantagens não só para organização, que por meio da NBR ISO 14001 se adequada à legislação pertinente quanto à utilização dos recursos naturais, criando credibilidade em seu mercado de atuação e trazendo métodos de prevenção aos impactos ambientais.

A utilização da ISO 14.000 trata de recursos para a implantação de um SGA eficaz, focando na mitigação de possíveis impactos ambientais, proporcionando mecanismos fundamentais para o desempenho ambiental e garantia de um crescimento econômico alinhado à gestão racional dos recursos naturais.

Perante aos dados da pesquisa, é possível afirmar que a certificação ambiental proporciona um melhor desempenho dos processos de gestão ambiental, e que as empresas certificadas possuem uma maior preocupação com o meio ambiente, reproduzindo esse conceito em suas ações gerenciais. A realização das auditorias ambientais certifica essas ações, e comprovam a eficácia do SGA dentro das organizações, contribuindo para a melhoria contínua.

Diante aos apontamentos realizados pelos autores e tendo a Natura como modelo de comprometimento ambiental, conclui-se que as realizações de auditorias ambientais levam as empresas a assumirem uma responsabilidade ambiental de suas atividades, criando credibilidade com o seu mercado de atuação, e aprimoramento do seu SGA com as evidências 


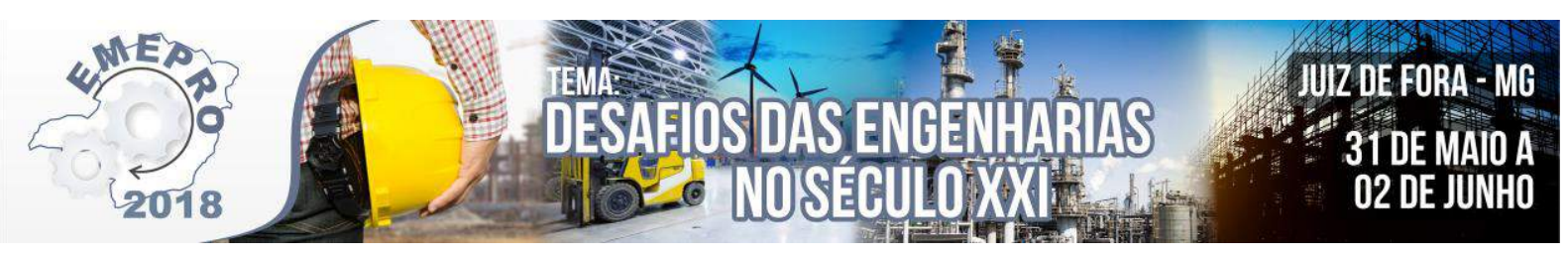

dos relatórios finais de auditoria, fazendo com que os resultados futuros sejam mais satisfatórios não só para a organização, mas também para o meio ambiente.

\section{Referências}

ASSOCIAÇÃO BRASILEIRA DE NORMAS TÉCNICAS. NBR ISO14010: Diretrizes para Auditoria Ambiental: princípios gerais. Rio de Janeiro: 1996.

ASSOCIAÇÃO BRASILEIRA DE NORMAS TÉCNICAS. NBR ISO 14001: Sistema de gestão ambiental Requisitos com orientações para uso. Rio de Janeiro - RJ/2004.

FIORILLO, C. A. P.; MORITA, D. M.; FERREIRA, P. Licenciamento Ambiental. São Paulo: Saraiva, 2011.

JABBOUR, A.B. L. S.; JABBOUR, C. J. C. Gestão ambiental nas organizações: fundamentos e tendências. São Paulo: Atlas, 2013. 104 p.

LA ROVERE, E. L. (Coord.). Manual de auditoria ambiental. . 3. ed.. Rio de Janeiro: Qualitymark, 2011.

LIMA, G. F. C. Educação Ambiental no Brasil: formação, identidades edesafios [livro eletrônico]. Campinas, SP: Papirus, 2015.

MORAES, C.S.B.; PUGLIESI, E.; Auditoria e certificação ambiental [livro eletrônico]. Curitiba: InterSaberes, 2014. PDF.

OLIVEIRA, L. R. et al. Sustainability: the evolution of concepts to implementation as strategy in organizations. Productionv. 22, n. 1, p. 70-82, 2012. Acesso em: 15 abr. 2017.

SEIFFERT, M.E.B. Gestão Ambiental: Instrumentos, esferas de ação e educação ambiental. 2.ed. São Paulo: Atlas,2011.

SEIFFERT, M. E. B. ISO 14001. Sistemas de gestão ambiental. Implantação objetiva e econômica. 4. ed. São Paulo: Atlas, 2011.

SILVA, C.; PRZYBYSZ, L.C.B.; Sistema de Gestão Ambiental [livro eletrônico]. Campinas: InterSaberes, 2014.

Ministério do Meio Ambiente. Conselho Nacional do Meio Ambiente. Resolução n. 306, de 5 de julho de 2002, 19 jul. 2002, Seção 1, páginas 75-76. Disponível em: <http://www.mma.gov.br/port/conama/legiabre.cfm?codlegi=306>. Acesso em: 16 abr. 2017.

NATURA. Relatório Anual - Natura 2016. Disponível em: <http://www.natura.com.br/sites/default/files/ra_natura_2016_1_3.pdf>. Acesso: 28 abr. 2017

ALENCAR et al. Sistema De Gestão Ambiental E ISO 14000 Na Indústria Têxtil - A Sustentabilidade Como Tendência, Revista do Centro de Ciências Naturais e Exatas - UFSM. V. 19, n. 2, mai-ago. 2015, p. 575-586

ISO 14001:2015 - Saiba o que muda na nova versão da norma. CIESP/FIESP, 2015. Disponível em: < http://www.ciesp.com.br/wp-content/uploads/2015/09/dma-iso-14001-2015-v4.pdf>. Acessado em: 15 mai. 2017.

Manual de Licenciamento ambiental: guia de procedimento passo a passo. Rio de Janeiro: GMA, 2004. Março, 2004.

OLIVEIRA, R. O Licenciamento Ambiental e o Desafio Do Desenvolvimento Sustentável No Brasil, 2012. Disponível em: <http://www.publicadireito.com.br/artigos/?cod=6df182582740607d〉. Acessado em: 10 mai. 2017.

Resolução CONAMA. $N^{o} \quad 306 / 2002 . \quad$ Disponível em: <http://www.mma.gov.br/port/conama/res/res05/res35805.pdf>. Acessado em: 02 mar. 2017.

RODRIGUES, L. A. Auditoria ambiental e sua contribuição no Processo de gestão, 2011. Revista de Administração do Unisal. v. 4, n. 5, 1-23. (2014) 


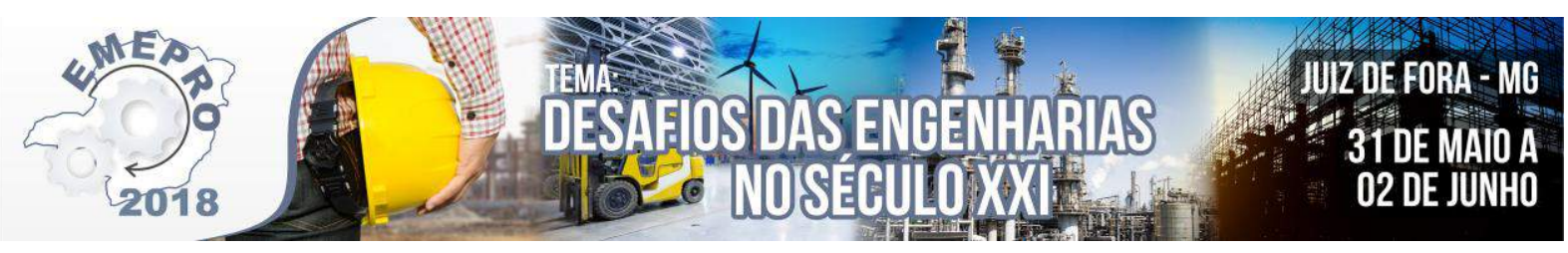

TRIERWEILLER, A. C. et al. Gestão ambiental: levantamento da produção científica brasileira em periódicos de Engenharia de Produção. Production Journal, v. 24, n. 2, p. 435-450, 2013. 


\title{
紫 \\ Estudo de caso em uma associação de coleta de resíduos sólidos
}

\author{
Adna Amorim dos Santos - UEMG - Unidade Passos - adnaamorim@ yahoo.com.br \\ Lucas Marcos Silva Queiroz - UEMG - Unidade Passos - lucasmsq@ hotmail.com \\ Lo-Ruana Karen Amorim Freire Sanjulião - UEMG - Unidade Passos - loruanna@yahoo.com.br \\ Thales Volpe Rodrigues - UEMG - Unidade Passos - thales.volpe@ hotmail.com \\ Carlos Henrique Fernandes - UEMG - Unidade Passos - carloshenrique.tim2@gmail.com
}

Resumo: Este artigo descreve características de associações de catadores em especifico de Minas Gerais ressaltando problemas de produtividade, e através de um estudo específico mostra as dificuldades que impedem a melhoria na produtividade no setor de coleta de resíduos sólidos. É composto por uma revisão bibliográfica e logo após um estudo realizado em uma associação de Itaú de Minas - MG, identificando os principais problemas que afetam a melhoria, o grupo teve acompanhamento de uma assessoria onde foram desenvolvidos trabalhos para fortalecimento do grupo, incentivo à importância de tomarem decisões juntos. Uma das necessidades identificadas é um local apropriado para destinar os materiais que muitas vezes se encontram armazenados nas residências dos catadores para o benefício da saúde, higiene, aumento da qualidade de vida além de possibilitar a execução de outros projetos futuramente o que contribuiria com o crescimento da renda gerada pela atividade. Palavras-chave: Coleta Seletiva; Associação; Catadores de reciclados.

\section{Introdução}

A geração de resíduos sólidos gerados através de diversas atividades humanas é um grande desafio aos poderes públicos, e consequentemente à administração municipal. Na metade do século XX, com novos padrões industriais a alta produção de resíduos vem crescendo em ritmo acelerado e a capacidade de absorção dos mesmos pela natureza não tem sido proporcional. Podemos ver mediante a alta produção (velocidade que é gerado) e concepção de produtos (na descartabilidade) e além de tudo isso a diversidade de materiais de difícil degradação e maior toxidade. De acordo com Silva, Donel e Cuellar (2003) resíduo é a matéria criada pelo próprio homem resultados das atividades diárias humanas e consumismo, que após ser utilizada não é absorvida pelo meio ambiente, gerando inevitavelmente o aumento dos resíduos e materiais estranhos ao meio natural.

A falta de planejamento e praticidade em técnicas de descarte, tem ocasionado inadequação, como passivos do meio ambiente capazes de comprometer a qualidade de vida e os recursos naturais. De acordo com pesquisa realizada pela Revista da Lata, seis anos após a aprovação da Política Nacional de Resíduos Sólidos no Brasil, apenas 18\% dos municípios possuem coleta seletiva de resíduos (REVISTA DA LATA, 2017).

Com o advento das cooperativas de catadores, foi elevado o número de postos de trabalho e para os que conseguem organizar-se nestas cooperativas ou empresas, há um crescimento em sua remuneração e sua situação de semiclandestinidade tende a ser superada com o crescimento do mercado e da consciência social (CALDERONI, 1998). A implantação de uma associação, executaria a coleta seletiva, a conscientização da sociedade e a diminuição de materiais desapropriados para os aterros, e ajudando na eliminação do lixão. 


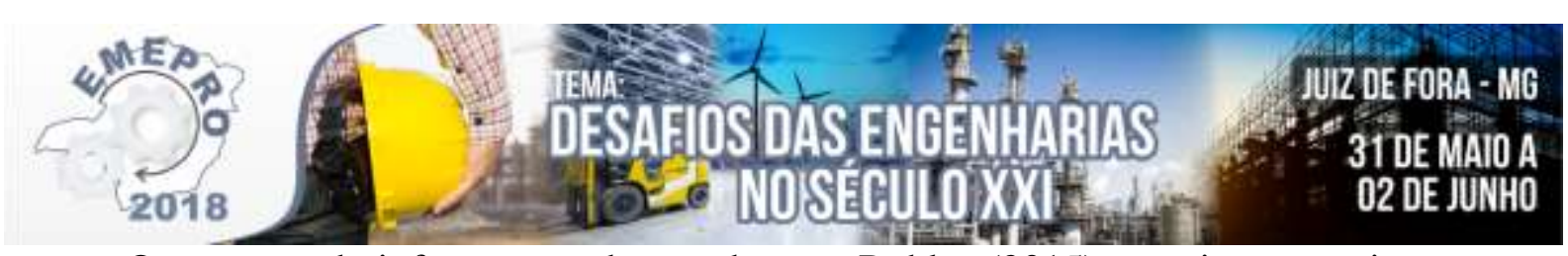

O aumento de informações de acordo com Robles (2015), a rotina exaustiva, com as novas tendências, cenários de transformação constante, torna impossível um resultado de sucesso para a associação se não atuarem de forma colaborativa, a solução e superação dos desafios estão na rede de conhecimento e não mais em uma ou duas pessoas esforçadas e talentosas. É preciso preocupar-se com a gestão de pessoas, pois é fundamental para a força e continuidade do projeto, propondo que precisam atuar juntos e dividirem as responsabilidades, e os desafios. É um processo de autoconhecimento do grupo, precisa-se de orientações e lideranças, que pratiquem o que falem, possuindo inteligência emocional e empatia sincera, criando um ambiente harmonioso e de confianças onde as experiências e novas ideias, sejam encorajadas e reconhecidas pela equipe.

O objetivo deste artigo é por meio do estudo da logística reversa da coleta resíduos sólidos em conjunto com as características de uma associação em Itaú de Minas, identificar os problemas que dificultam a melhoria da produtividade neste setor e promover $\mathrm{o}$ fortalecimento no trabalho com o grupo de catadores de Itaú de Minas visando um trabalho em equipe, uma forma de estarem prontos e capacitados, com uma visão unanime em sentido aos seus direitos e deveres de levar uma associação ou cooperativa à diante. Propor medidas para melhor qualidade de vida e bem-estar dos catadores, além disso, identificar as principais necessidades para aumento de capacidade da coleta em grupo e geração de renda em trabalhos sociais no município.

Esse trabalho é justificado pela falta de execução de gerenciamento dos resíduos no município, onde os catadores executam um trabalho independente, autônomos, e sem amparo. Sua qualidade de vida é totalmente atingida devido ao acumulo de recicláveis em suas casas até a venda para empresas do ramo, com perigo de doenças, proliferação de animais peçonhentos e transmissores de doenças, e pela incansável rotina diária de coleta.

Portanto deve-se estudar melhor o processo de execução da logística de reversa dos resíduos sólidos no município. Pois a falta de trabalho com a sociedade traz grande dificuldade para os mesmos na incansável rotina diária de coleta, e não é obtido ganho favorável e seus direitos de amparo ao catador não são executados.

\section{Revisão Bibliográfica}

\subsection{Logística reversa}

O conceito de logística reversa está presente a tempos, mas é de grande dificuldade datar o surgimento deste termo com exatidão, em dias atuais as definições da logísticas reversa revelam conceitos ainda em construção à novos negócios e pesquisas revelando-se em processo de fusão apresentando um vasto campo (BRITO e DEKKER, 2002).

Logística reversa, segundo Gonçalves e Martins 2006, inclui-se a preocupação dos governos e a necessidade de sua realização também decorre de crescentes números de leis que incentivam a reciclagem de recipientes e materiais de embalagens e que proíbem o descarte indevido. A logística reversa condiz com a área da logística empresarial, que planeja, controla e opera as informações logísticas, dos bens de pós-venda e pós consumo, por meios de canais de distribuição reversos, não só agregando valores financeiros, mas ecológicos, legal entre outros (LEITE, 2003). A Figura 1 apresenta-o processo simples da logística reversa do material reciclável como um todo. 

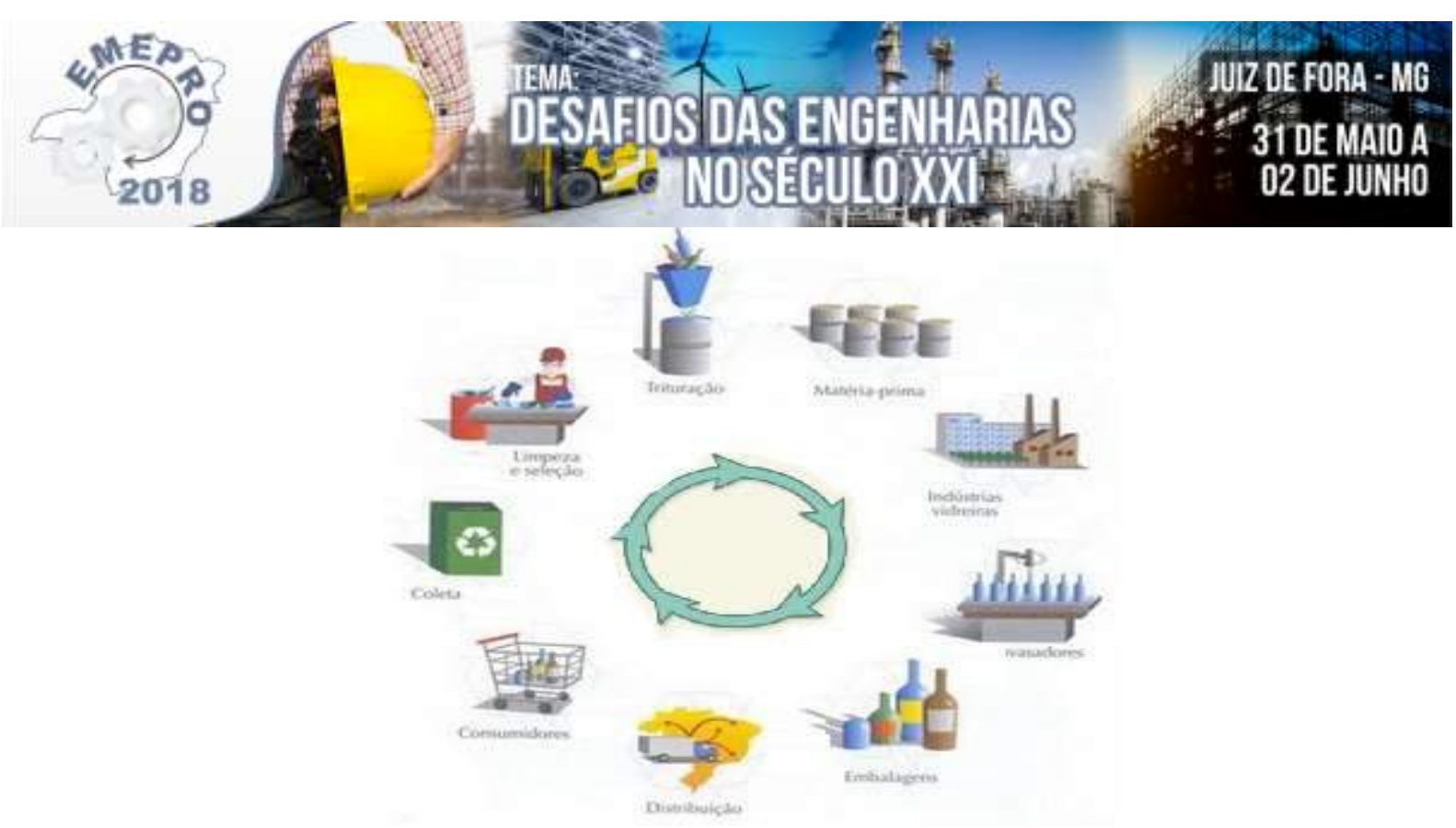

FIGURA 1 - Fluxo da logística reversa de resíduos sólidos. Fonte: Santos (2011, p. 1).

\subsection{O processo de coleta de resíduos sólidos e a logística reversa}

De acordo com as informações do IPEA (2010), com o passar dos anos e com o propósito de reverter a exclusão social os catadores de materiais recicláveis vêm buscando coletivamente a superação que impedem de apropriarem um maior valor por seu trabalho, com as estimativas divulgadas pelo IPEA, apenas $2.4 \%$ da coleta de resíduos sólidos no Brasil, são de forma seletiva o restante são coletas regulares às quais se misturam com outros materiais, a quais sofrem contaminação, dificultando ou até mesmo impossibilitando a reciclagem dos materiais.

Com incentivo ao consumismo, a quantidade e a variabilidade de materiais descartáveis avolumam inesperadamente. Diante disto, o poder público tem como dever buscar e executar alternativas que minimizam os impactos sobre o meio ambiente, causado por estes resíduos sólidos e entre as alternativas uma das mais favoráveis é a coleta seletiva e a qual possibilita posteriormente a realização da reciclagem dos materiais (SILVA et al.,2013).

Esta coleta de materiais recicláveis com a destinação dos resíduos sólidos corretamente tem o sentido de logística reversa, pois há o envolvimento das operações no transporte, no planejamento, e no monitoramento de rotas. O planejamento de uma logística reversa proporciona resultados e benefícios à sociedade, sendo ele bem estruturado como em melhor rota, frota, e localização e também com a finalidade de minimizar o tempo e custo.

Os aspectos legais que conduzem a implantação e a gestão de resíduos sólidos nos municípios tem como fundamento a legislação brasileira, sendo ela federal, estadual e municipal, a Tabela 1 apresenta a jurisdição que rege mediante aos resíduos sólidos.

TABELA 1- Aspectos Legais

\section{Legislação Federativa}

$\begin{array}{lll}\text { ABNT 8.419/1894 } & \text { Gerenciamento de Resíduos Sólidos. } \\ \text { Lei n 9.605/1998 } & \begin{array}{l}\text { Dispõe sobre as sanções penais } \\ \text { administrativas derivadas de condutas e }\end{array}\end{array}$




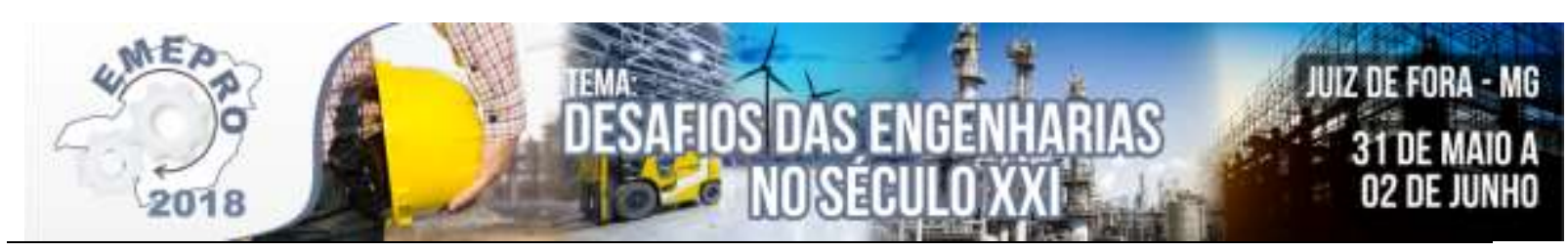

atividades lesivas ao meio ambiente, e dá outras providências.

Resolução CONAMA nº 275/2001

NBR 10.004/2004

Lei $\mathrm{n}^{\mathrm{o}} 11.107 / 2005$

Decreto Federal N5.940/2006

Lei n 11.445/2007

Lei $\mathrm{n}^{\circ} 12.305 / 2010$

CBO - Classificação Brasileira de Ocupações
Estabelece o código de cores para os diferentes tipos de resíduos, a ser adotado na identificação de coletores e transportadores bem como nas campanhas informativas para a coleta seletiva.

Classificação dos resíduos sólidos.

Dispõe sobre normas gerais de contratação de consórcios públicos e dá outras providencias.

Institui a separação dos resíduos recicláveis descartados pelos órgãos e entidades da administração pública federal direta e indireta, na fonte geradora, e a sua destinação as associações e cooperativas dos catadores de materiais recicláveis.

Lei Nacional de Saneamento Básico.

Política Nacional de Resíduos sólidos.

Catador de material reciclável é profissão reconhecia pelo ministério do trabalho $\mathrm{e}$ emprego.

\section{Legislação Estadual}

Lei $\mathrm{n}^{\mathrm{o}}$ 11.720/1994

Lei $n^{\circ} 13.766 / 2000$

Lei $\mathrm{n}^{\circ} 18.031 / 2009$

Decreto $\mathrm{n}^{\circ} 45.181 / 2009$

DN Copam no 172 de 2011

\section{Legislação Municipal}

Lei $n^{\circ} 1.709 / 2004$

Lei $n^{\circ} 31 / 2010$

Lei $n^{\circ} 791 / 2010$ seletiva de lixo. Minas Gerais
Política Estadual de Saneamento Básico.

Política Estadual de apoio e incentivo a coleta

Política Estadual de Resíduos sólidos.

Regulamenta a lei $\mathrm{n}^{\mathrm{o}} 18.031$, de 12 de janeiro de 2009, e dá outras providencias.

Institui o Plano estadual de coleta Seletiva de

Dispõe sobre o sistema de limpeza urbana no município de Itaú de Minas.

Considerando as disposições dos art.182 da Constituição Federal, do Capítulo III da Lei Federal $\mathrm{n}^{\circ} 10.257$, de 10 de julho de 2001 Estatutos das Cidade e dos artigos 227 a 234 do título III, Capitulo VIII, Capitulo BII - da Política Urbana da Lei Orgânica do Município de Itaú de Minas.

Dispõe sobre o uso de papel reciclado e implantação de coleta seletiva por parte dos 


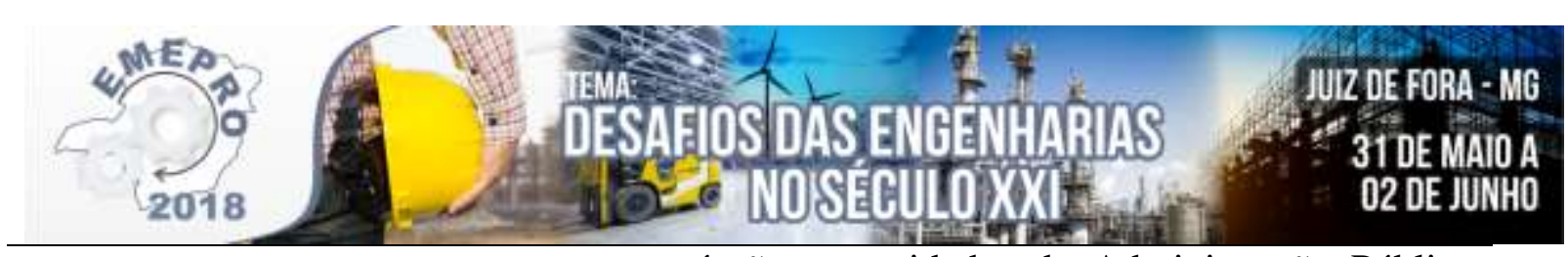

órgãos e entidades da Administração Pública Municipal Direta e indireta e poder legislativo.

Dispões sobre o uso de sacolas plásticas biodegradáveis para acondicionamento de Lei $n^{\circ} 817 / 2011$ produtos e mercadorias a serem utilizados nos estabelecimentos comerciais em todo o município de Itaú de Minas.

Fonte: Da autora

\subsection{Casos de associações de coleta seletiva em Minas Gerais}

A associação como todos os outros empreendimentos tem suas características e tributos, mas para que efetivamente possa realizar o trabalho de melhorias em organizações é imprescindível tomar conhecimento dos fatores que participam da cultura de trabalho, os ambientes que o envolvem e suas implicações como um todo (OLIVEIRA, LIMA, LIMA, 2009).

Lima e Oliveira (2008) fizeram estudos das atividades de coleta seletiva em outros municípios, e muitos deles enfrentam a escassez de recursos. Com o estudo verificaram que os maiores obstáculos para as associações de catadores, são:

- Relações institucionais extra organização: logística de coleta, relações com a administração municipal, qualidade do material proveniente da coleta seletiva e de doadores, relação com grandes doadores;

- Organização do trabalho e gestão interna à organização: organização do trabalho (divisão de tarefas, jornada de trabalho, rotatividade, qualificação) e disciplina (ritmo de trabalho, absenteísmo), conflitos internos, regras de distribuição dos ganhos (por produção, coletiva...);

- Organização física do processo de produção: postos de triagem, fluxo de produção; dimensões dos galpões; economia de movimentos na separação: deslocamentos das pessoas, movimentação de material, fases e movimentos de triagem.

Os autores identificaram que as dificuldades para ganhos da produtividade, em se tratando de dificuldades técnicas enfrentadas pelas associações são resultados não somente de características da organização e pessoais, mas ao processo de catação e ao setor de reciclagem como um todo. A implantação de infraestrutura para a triagem é um impasse para melhorias e reivindicações na pesquisa de Dias (2002), os problemas são decorrentes de uma série de fatores de ausência de estudos, fluxo de tarefas, localização e participação da população.

Em Associações de Catadores presentes nos municípios mineiros de Barroso, Campo Belo e São João Del-Rei, Oliveira e Abreu (2008) realizaram uma pesquisa e detectaram que apesar do avanço já conquistado pelos catadores ainda há a presença de obstáculos prejudiciais a eficiência deste canal reverso. Em Campo Belo, por exemplo, existe a coleta e o obstáculo principal é a baixa adesão da população na separação dos resíduos que podem ser reciclados. Nos outros dois municípios a coleta seletiva existe, porém somente em alguns bairros por conta dos catadores. O Quadro 1 mostra comparativos a respeito da pesquisa sobre as associações de coleta seletiva nas cidades de mencionadas. No município de Barroso, 


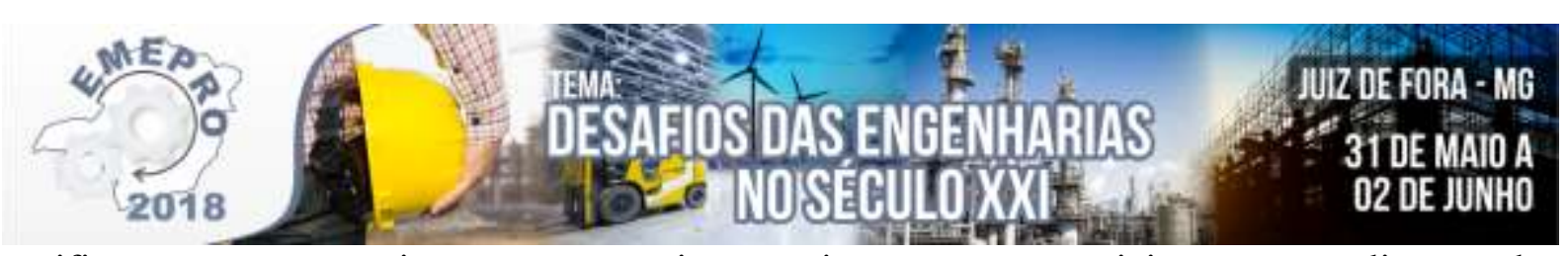

verifica-se que a associação não possui os equipamentos essenciais para a realização das atividades operacionais, impossibilitando o planejamento logístico e a eficiência da produção.

\begin{tabular}{|c|c|c|c|}
\hline & BARROSO & CAMPO BELO & SÃO JOÃO DEL-REI \\
\hline $\begin{array}{l}\text { MOTIVO DE CRIAÇÃO } \\
\text { DAS ASSOCIAÇÕES }\end{array}$ & $\begin{array}{l}\text { Deliberação Normativa } \\
\text { COMPAM 52/2001; } \\
\text { Assinatura de Termos de } \\
\text { Ajustamento de Conduta } \\
\text { (TAC) }\end{array}$ & $\begin{array}{l}\text { Deliberação Normativa } \\
\text { COMPAM 52/2001; } \\
\text { Adequação pra } \\
\text { recebimento de fundos do } \\
\text { ISMS ecológico }\end{array}$ & $\begin{array}{l}\text { Impulsionado por } \\
\text { projeto da UFSJ }\end{array}$ \\
\hline $\begin{array}{l}\text { PARTICIPAÇÃO EM } \\
\text { INCUBAÇÃO }\end{array}$ & ITCP/UFSJ & Não participa & ITCP/UFSJ \\
\hline $\begin{array}{l}\text { ATUAÇÃO DA } \\
\text { PREFEITURA NA } \\
\text { ASSOCIAÇÃO }\end{array}$ & $\begin{array}{l}\text { Campanhas de educação } \\
\text { ambiental; } \\
\text { Fornece o galpão e } \\
\text { pagamento das despesas }\end{array}$ & $\begin{array}{l}\text { Serviço terceirizado para } \\
\text { a prefeitura; } \\
\text { Fornece local, transporte, } \\
\text { equipamentos, } \\
\text { alimentação; } \\
\text { Campanhas de educação } \\
\text { ambiental }\end{array}$ & $\begin{array}{l}\text { Fornece o depósito e } \\
\text { pagamento das } \\
\text { despesas; } \\
\text { Campanhas de educação } \\
\text { ambiental }\end{array}$ \\
\hline $\begin{array}{l}\text { ACONDICIONAMENTO } \\
\text { DOS RESÍDUOS }\end{array}$ & Aterro Controlado & Aterro Sanitário & Aterro controlado \\
\hline $\begin{array}{l}\text { RESTRIÇÕES PARA A } \\
\text { ASSOCIAÇÃO }\end{array}$ & $\begin{array}{l}\text { Falta de equipamentos para } \\
\text { a operacionalização do } \\
\text { trabalho; } \\
\text { Implantação efetiva da } \\
\text { coleta seletiva na cidade }\end{array}$ & $\begin{array}{l}\text { Baixa adesão da } \\
\text { população na coleta } \\
\text { seletiva }\end{array}$ & $\begin{array}{l}\text { Implantação efetiva da } \\
\text { coleta seletiva na cidade }\end{array}$ \\
\hline $\begin{array}{l}\text { ABRANGÊNCIA DA } \\
\text { COLETA SELETIVA }\end{array}$ & Restrita à alguns bairros & Em todos os bairros & Restrita à alguns bairros \\
\hline
\end{tabular}

QUADRO 1 - Informações e comparativos entre associações. Fonte: Oliveira e Abreu (2008) apud Oliveira, Lima, Lima (2009).

Em um estudo desenvolvido por Ribeiro e Lima (2000), os autores mencionam um problema enfrentado por catadores em Uberlândia, onde a coleta seletiva dos resíduos sólidos não produziu efeitos, pois a qualidade do material era baixa, devido à presença de resíduos orgânicos observados na separação da esteira da usina de triagem.

A participação dos catadores, segundo Cruz (2002), como agente ambiental que fazem o recolhimento de materiais recicláveis tem papel fundamental e muito importante para o mercado de recicláveis.

Calderoni (1998), define o catador como “...o agente da reciclagem que retira os materiais recicláveis diretamente dos lixões ou aterros ou materiais descartados pelas calçadas, destinando-os a sucateiros." É de grande benefício todo esse trabalho para a limpeza urbanística, mas muitas das vezes passam despercebidos e até sofrem um prejulgamento negativo, estes materiais são encaminhados para empresas do ramo e poupam recursos da natureza, exercendo um papel muito importante, bem como uma alternativa de renda (ABREU, 2001).

\section{Método de Pesquisa}

Miguel et al. (2010) destacam diversos métodos de pesquisa, tais como a pesquisa bibliográfica, o estudo de caso, o levantamento (survey), o experimento, a modelagem e simulação e a pesquisa-ação. Uma vez que esta pesquisa conta com a participação ativa nas pesquisas literárias, e também presente no acompanhamento, desenvolvimento do projeto e análise minuciosa do grupo dos catadores, o método que mais se compatibiliza é o estudo de campo. Também chamada de pesquisa-ação, é uma forma qualitativa na qual o participante 


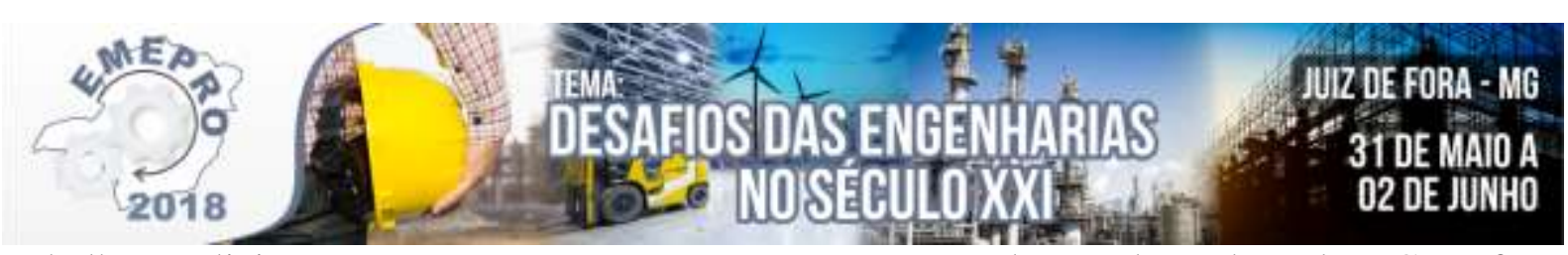

trabalha explicitamente com, para e por pessoas em vez de estudar sobre elas. Com foco maior na geração de soluções para problemas do cotidiano (POPE, MAYS, 2009).

De acordo com Lopes (2006) esse tipo de pesquisa faz com que o autor entre em contato direto com o ambiente onde o problema ocorre. Muito empregado em levantamentos sobre as partes mais baixas da comunidade. A Figura 2 representa o ciclo da pesquisa-ação, sendo que o mesmo se repete até que se alcancem os objetivos propostos ou seja determinado o fim do projeto.

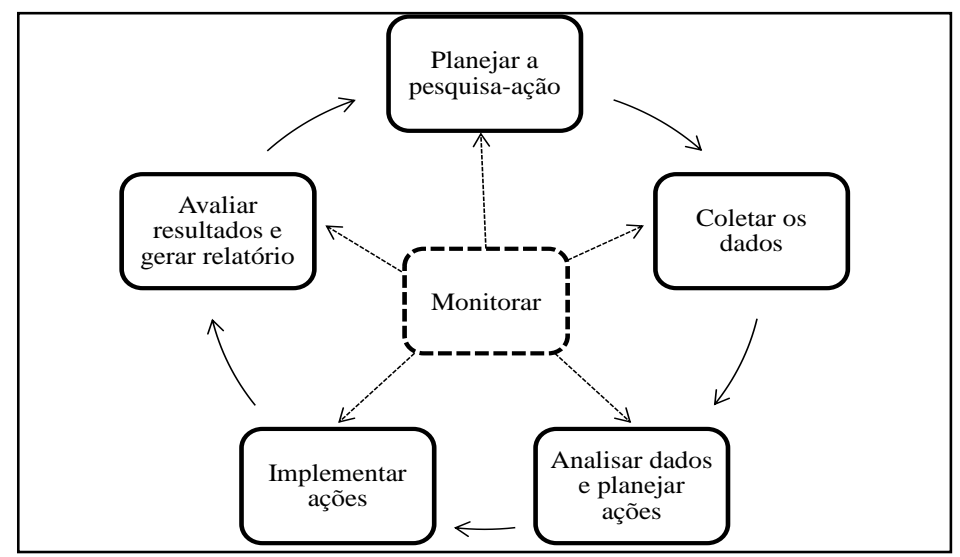

FIGURA 2 - Estrutura padrão para condução da pesquisa-ação. Fonte: Adaptado de Miguel et al. (2010) e Thiollent (2011)

Foram realizadas pesquisas bibliográficas para enfatizar as teorias e embasamento do estudo, e feito um período de realização de pesquisas e acompanhamento junto ao grupo, um período de 24 meses. Dentre os instrumentos e técnicas usados para a coleta dos dados foram coletados dados documentais, em relatórios fornecidos pela associação, e por meio de observação in loco, com participação nas reuniões e promoção de discussão direcionada realizadas mensalmente com o grupo onde era possível identificar seu modo de pensar e forma com as decisões eram tomadas, além de participação nos eventos sociais elaborados pelos mesmos. Após a análise qualitativa dos dados a fim de atingir o objetivo da pesquisa foram traçadas as ações, a intervenção ocorreu por meio de uma assessoria realizada pela pesquisadora, que trazia orientações, treinamentos para promoção de aprendizados no propósito de reaproxima-los focando o trabalho em equipe, sempre ressaltando a importância e os benefícios de se trabalhar associados, e destacando os interesses mútuos do grupo.

\section{Desenvolvimento}

\subsection{Associação dos catadores de Itaú de Minas}

O estudo foi desenvolvido na cidade de Itaú de Minas o município conta com 16.082 habitantes de acordo com o IBGE (2017). Por meio dos dados coletados diferente da maioria das cidades brasileiras, a associação de catadores foi criada mediante ao projeto NRDC Núcleo Rotary Desenvolvimento Comunitário - Itaú Recicla que é a base de apoio para o crescimento da associação que tem sido desenvolvida em Itaú de Minas fundada em julho de 2013, contendo hoje 16 associados ao projeto. A mesma, tem como objetivo a inclusão social, união dos catadores para melhor geração de renda, demonstração de sua importância na sociedade, conservação e execução de seus direitos mediante as leis federais, estaduais e municipais, e o plano diretor do município.

Analisando o Gráfico 1, é possível notar que houve uma diminuição no número de associados, desde a fundação até o presente momento. 

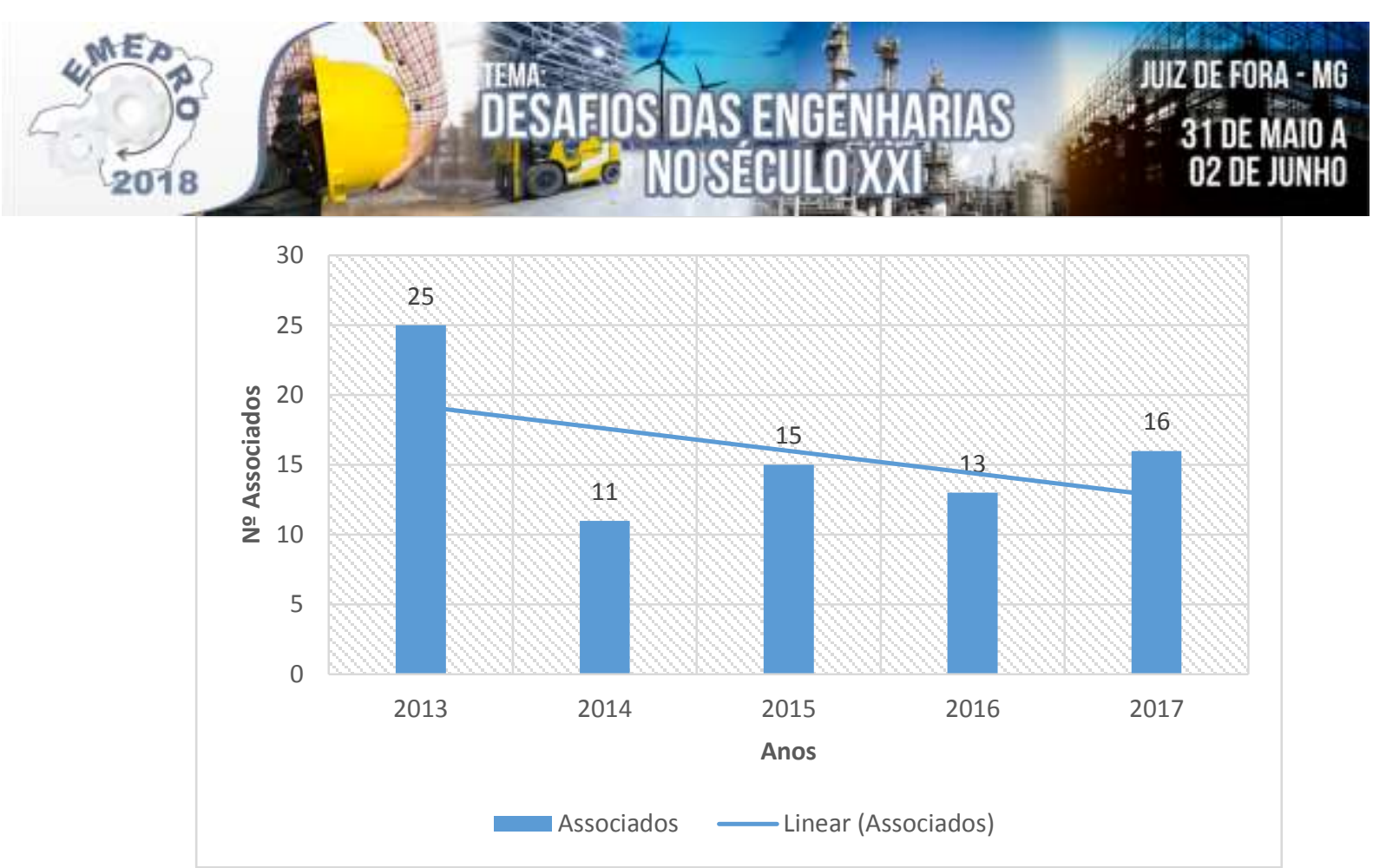

GRÁFICO 1- Número de Associados. Fonte: Da Autora.

Durante a realização da pesquisa foi observado que a associação de Catadores do município enfrenta alguns obstáculos que prejudicam a produtividade e eficiência deste canal reverso. Por exemplo, a coleta seletiva dos resíduos sólidos vem sendo trabalhada com a sociedade, porém, um dos principais problemas que é enfrentado é a baixa adesão da população na separação dos resíduos que podem ser reciclados visto que somente em alguns bairros acontece estas separações de materiais recicláveis e orgânicos, e a coleta seletiva é realizada através dos catadores, o que ocasiona perdas de material, de qualidade e de tempo. Pois na maioria das vezes a coleta seletiva não é realizada de forma efetiva e os materiais não podem ser reciclados, pois apresentam contaminação de outros resíduos orgânicos, problema vivenciado por outras associações em outros municípios como em Uberlândia citado por Oliveira, Lima, Lima (2009).

A associação não possui os materiais ou equipamentos de coleta para a realização das atividades operacionais, impossibilitando o planejamento logístico e a eficiência da produção. Mas esta situação é visualmente identificada em vários outros municípios do estado de Minas Gerais de acordo com Lima e Oliveira (2008).

Segundo informações de Borderô (2017) os somatórios de resíduos sólidos de lixo/ano recolhidos na cidade de Itaú de Minas são de $44.892,4 \mathrm{Kg}$, subdivido em $996.2 \mathrm{~kg}$ de alumínio, 30.982,2 $\mathrm{Kg}$ de papelão, 8.411,1 Kg de plástico, 4.499,2 $\mathrm{Kg}$ de Ferro e 3,8 Kg de cobre, o Gráfico 2 apresenta os valores computados do ano de 2017. 


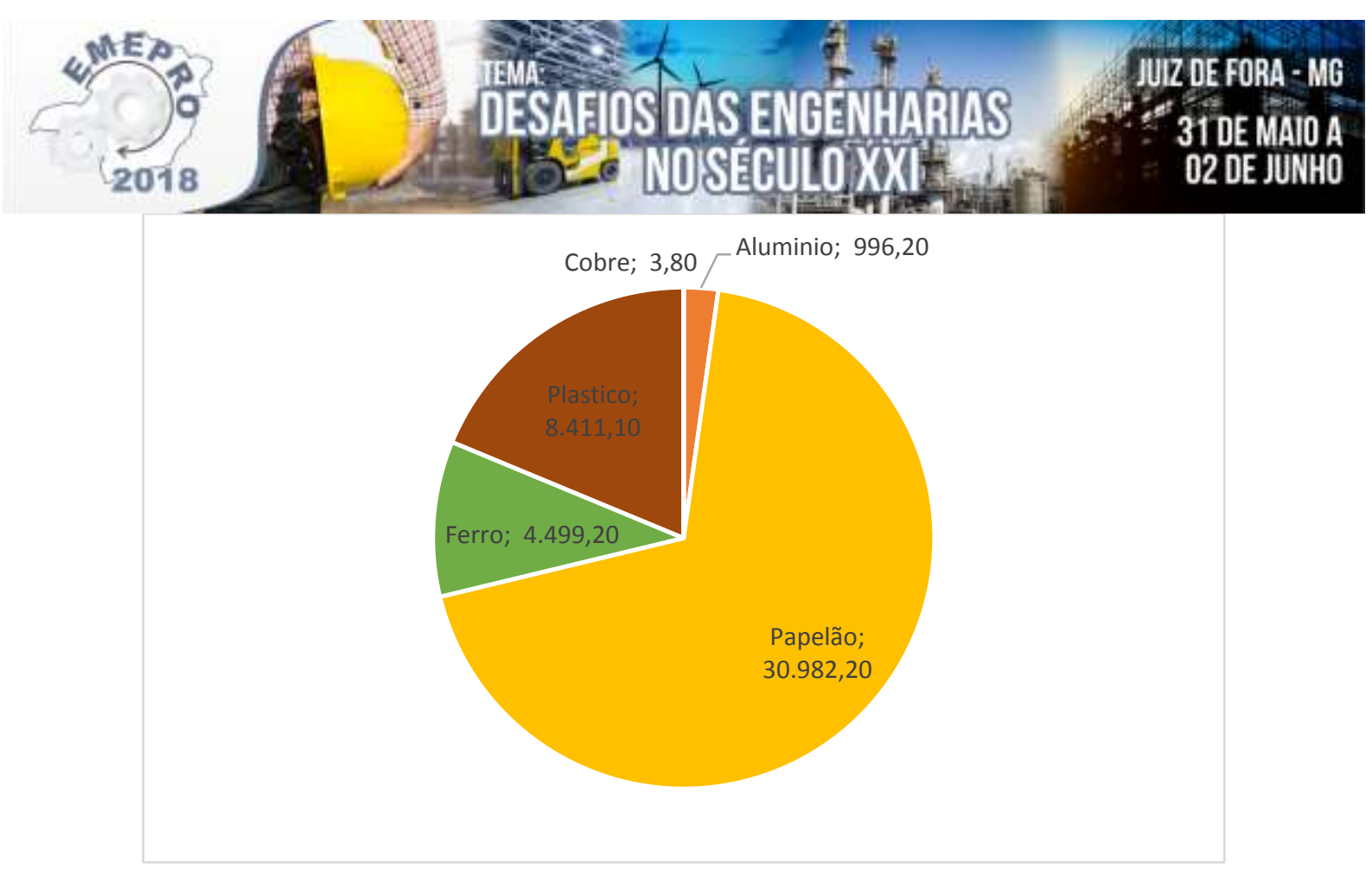

GRÁFICO 2- Quantidade de material computada no ano 2017. Fonte: Da autora

Com relação às condições de trabalho os catadores de reciclados vivem em condições precárias, com exposição à contaminação presente em lixos. Desde o início de 2016, este grupo vem sendo assessorado por uma consultoria externa, e recebendo apoio da Prefeitura Municipal de Itaú de Minas. O grupo aprovou seu Estatuto social, elegendo o seu corpo diretor responsável por condução do mesmo. As empresas colaboram com a coleta diária e com as atividades desenvolvidas pelos catadores, separando os materiais para que posteriormente possa ser coletado. No município há dois bairros que incentivam todo o trabalho fazendo a junção dos materiais reciclados, nos quais o catador faz a coleta uma vez por semana. Em suas atividades diárias no final de seu expediente os catadores seguem com seus carrinhos para a venda nos sucatões. O percurso de coleta não é bem definido, cada um faz sua própria rota, logo após recolherem o material até o limite que suportam, e cada catador segue para a venda.

$\mathrm{Na}$ fundação da associação os catadores eram completamente dispersos, com seus trabalhos individuais, nas reuniões realizadas mensalmente foram detectadas muitas faltas dos associados, mas atualmente o grupo se fortalece mediante à trabalhos sociais, e através das reuniões com aplicação de dinâmicas direcionadas (Figura 3) o grupo tem apresentado grande interesse nesta nova jornada, executando trabalhos colaborativos que resultou no destaque dentro da comunidade onde despertou a atenção de empresários que fizeram a doação de novos carrinhos, EPI's e uniformes. Anteriormente a relação entre eles eram de competitividade, posteriormente à criação da associação passou-se a desenvolverem um trabalho colaborativo tornando o ambiente onde passam um tempo juntos melhor. 

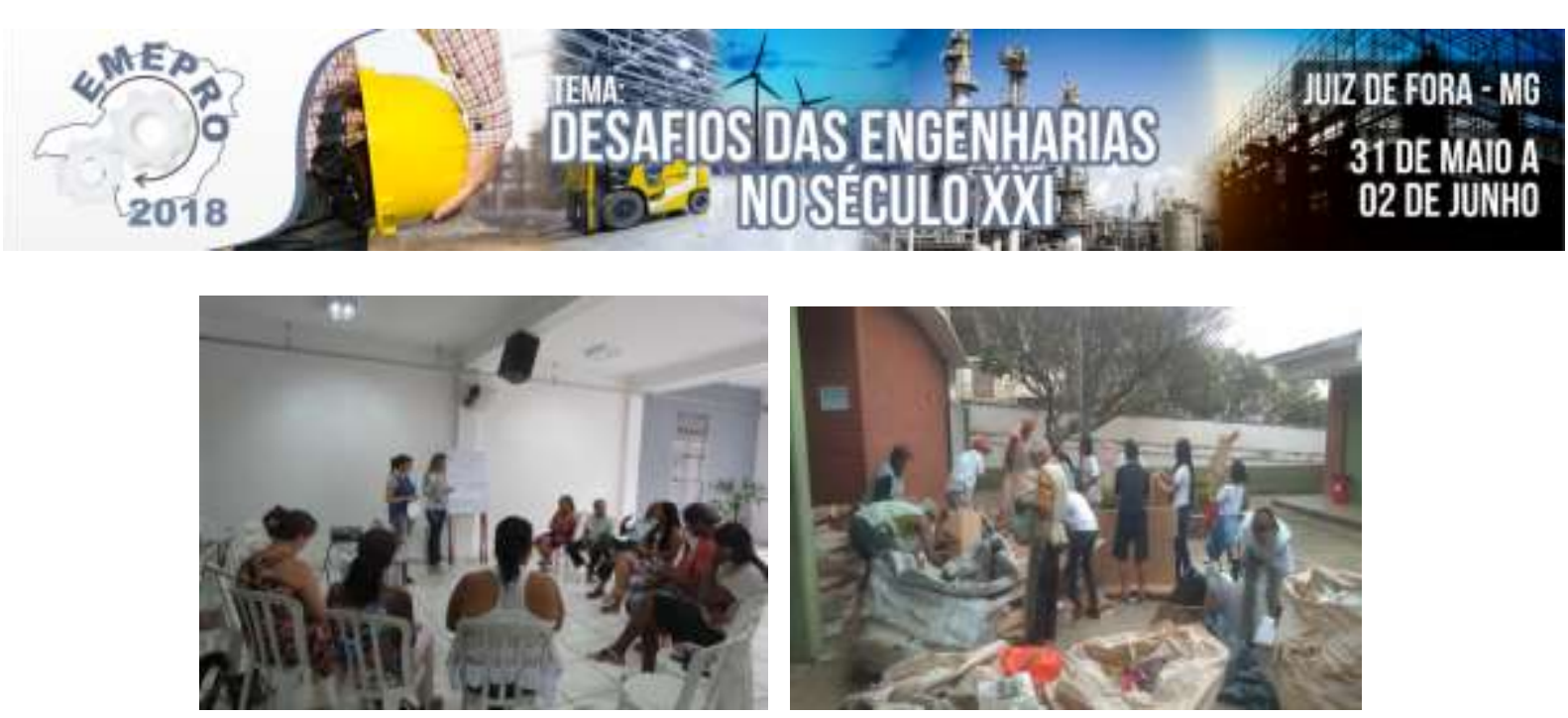

FIGURA 3 - Ações do grupo de catadores. Fonte: Da Autora

\subsection{Principais problemas enfrentados pela associação}

Com base nas observações realizadas, foi possível observar e apontar os principais problemas e questões que dificultam o crescimento da associação em produtividade, gestão humana, entre outros.

Durante a coleta de dados foi identificada a necessidade de maior envolvimento por parte da comunidade itauense para colaboração com os serviços dos catadores. Também é perceptível que a participação da sociedade só será possível a medida que a associação tenha equipamentos e espaço suficiente para trabalhar com outros bairros, o que ainda não acontece. Além disso a associação é carente de equipamentos e um local amplo que poderia melhorar as condições de trabalho dos catadores, como por exemplo, esteiras e baias para separação do material e organização do material coletado, na Tabela 2 são mencionados alguns fatores que dificultam o progresso da mesma.

TABELA 2 - Problemas identificados, que impedem melhoria da associação.

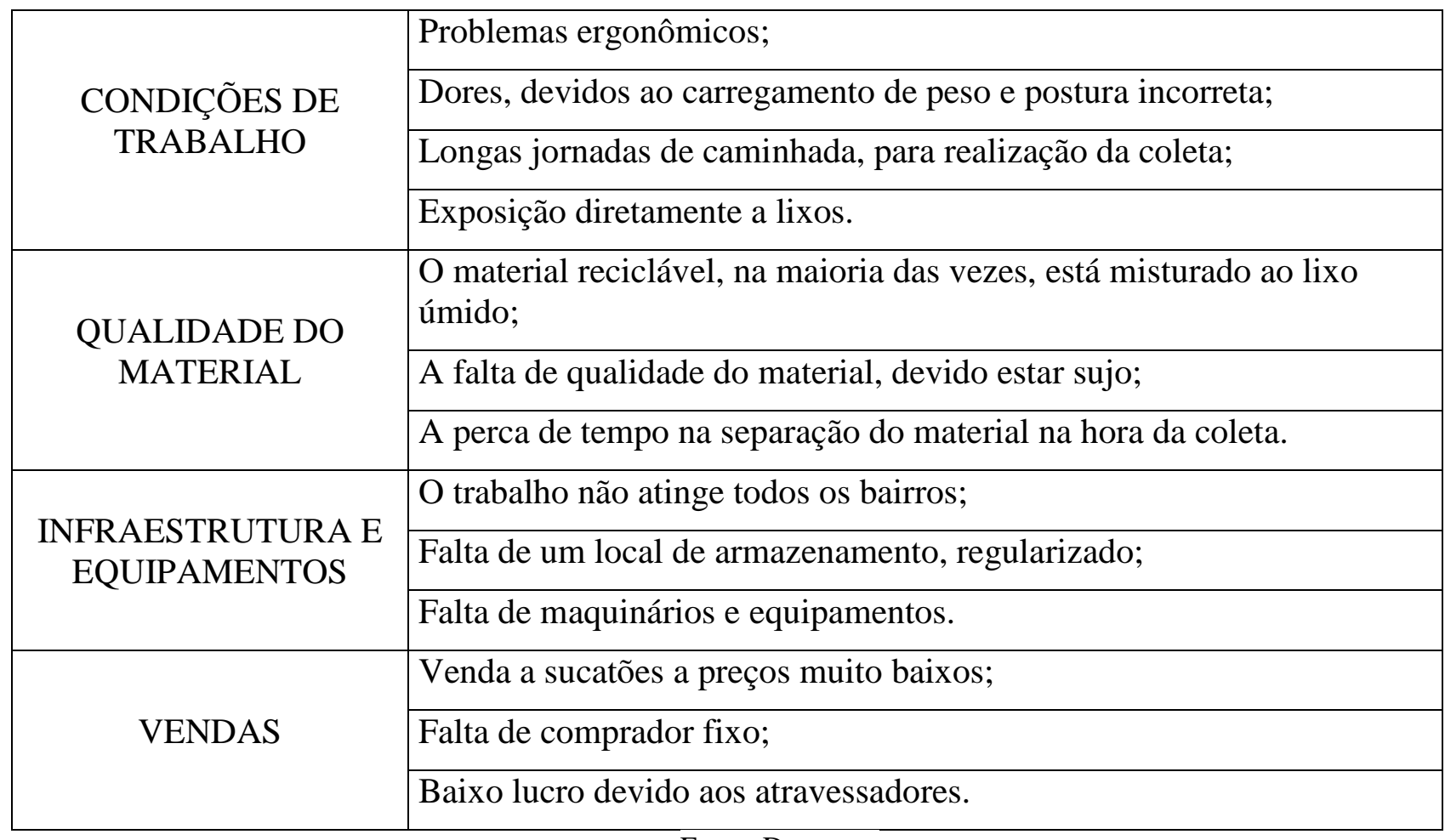




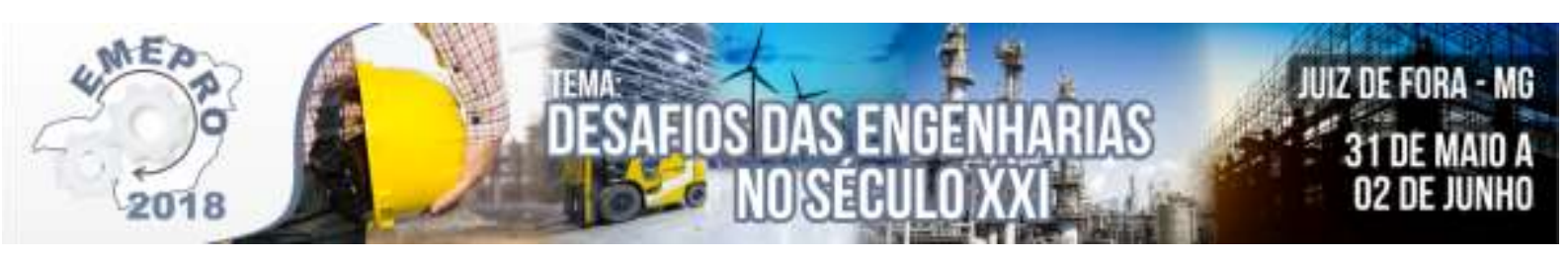

Apesar de palestras repassadas para a população poucas pessoas separam o lixo reciclável o que dificulta o trabalho dos catadores. Campanhas eficientes de conscientização na população do município poderiam trazer bons resultados e deveriam ser realizadas mais frequentemente, até que a comunidade tenha como hábitos benéficos a separação dos resíduos que necessita da participação e apoio poder público.

\section{Considerações Finais}

A coleta de resíduos sólidos tem um grande papel como um todo, se forem destinados adequadamente pode resultar em empregos e geração de renda, além de contribuir para um desenvolvimento sustentável, mas para isso faz-se necessário um planejamento para que este projeto de associação siga por muitos anos.

Por meio do estudo foi identificado um problema logístico da coleta seletiva de materiais recicláveis, e foram listados os problemas que dificultam a melhoria da produtividade no setor de coleta dos mesmos.

O Brasil carece de modelos para implantação de programas de coleta seletiva que sejam autossustentáveis, pois as existentes são muito dependentes de recursos do poder público, impossibilitando um crescimento maior. Através dos estudos abordados referente a revisão bibliográfica juntamente com o estudo em questão, nota-se que os mesmos problemas se repetem em várias cidades, e são assuntos de muita importância tanto para comunidade quanto ao poder público, e também a qualidade de vida dos catadores.

O estudo identificou um dos gargalos para o crescimento da associação, que é a falta do local apropriado para triagem e armazenamento do material, para melhoria e andamento do processo de coleta dos resíduos sólidos da mesma, este local, poderá abrir oportunidades para estudos futuros, como a gestão logística de rotas e frotas da associação. Tal fato é bastante dependente do poder público municipal para o qual futuramente será de grande benefício, por reduzirem os gastos públicos com a coleta, transporte e destinação dos resíduos sólidos urbanos, aumentando a vida útil de seus aterros sanitários, pela diminuição dos resíduos descartados pelo processo comum.

É importante ressaltar a necessidade do apoio da sociedade, os atores fundamentais para o sucesso da coleta, precisando esta ser sensibilizada para que possam compreender a importância desta separação dos materiais recicláveis, que ocorre através da educação ambiental que conduz a transformação de suas ações.

Dessa forma, o trabalho realizado no presente estudo, atingiu seu objetivo em realizar um estudo sobre a associação de catadores do município, e promover o fortalecimento da mesma, além de identificar os obstáculos existentes e oportunidades de melhoria. Uma das sugestões para trabalho futuro seria conseguir um local apropriado para o armazenamento que resultara na continuidade dos trabalhos melhorando a qualidade de vida dos catadores e grande aumento da geração de renda. Foi uma experiência extremamente importante para os associados, e para a pesquisadora, ter a oportunidade de discutir os problemas relacionados ao funcionamento desta organização, e trazer contribuições tanto para gestão dos resíduos recicláveis e ressaltar a responsabilidade do poder público municipal, quanto a qualidade de vida dos membros da associação.

\section{Referências}

ABREU, M. F. Do lixo à Cidadania: Estratégias para a Ação. Brasília: Caixa, 2001. 


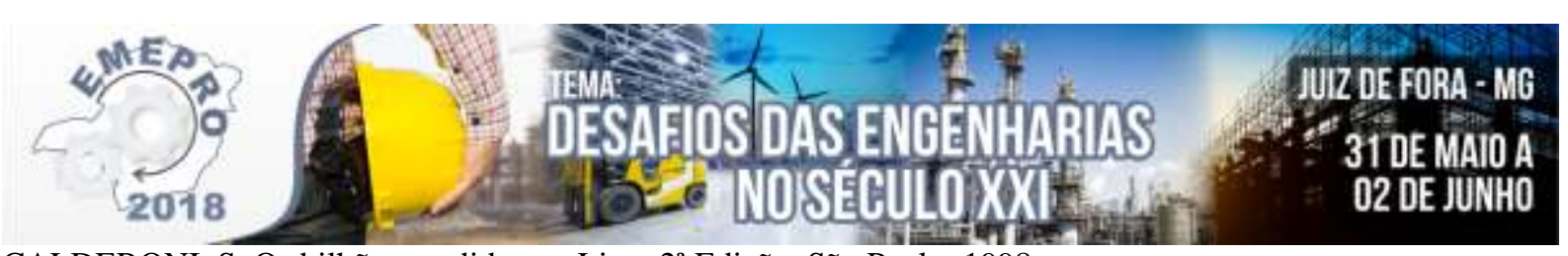

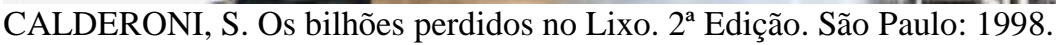

CRUZ,A.L.M; A reciclagem dos resíduos sólidos urbanos: um estudo de caso. Florianópolis. 2002. Disponível em: <https://repositorio.ufsc.br/bitstream/handle/123456789/82430/227599.pdf?sequence=1>. Acesso em: 29/12/2017.

BRITO, M. P. \& DEKKER, R. Reverse logísticos: a framework. Econometric Institute. Report EI 2002-38, Erasmus University Rotterdam, The Netherlands, 2002.

DIAS, S. M. Construindo a cidadania: avanços e limites do projeto de coleta seletiva em parceria com a ASMARE. Dissertação. Instituto de Geociências da UFMG. Belo Horizonte, 2002.

GONÇALVES, M. E. \& MARINS, F. A. S. Logística Reversa numa empresa de laminação de vidros: um estudo de caso. Revista Gestão \& Produção, Vol.13, n.3, p.397-410, 2006.

IPEA - INSTITUTO DE PESQUISA ECONÔMICA APLICADA. Pesquisa sobre pagamento por serviços ambientais urbanos para gestão de resíduos sólidos. Brasília: Ipea, 2010. Disponível em: 〈http:// goo.gl/tTVr〉.

LEITE, P. R. Logística Reversa: meio ambiente e competitividade. São Paulo: Pearson Prentice Hall, 2003

LIMA, F.P.A. \& OLIVEIRA, F. G. Produtividade técnica e social das associações de catadores: por um modelo de reciclagem solidáira. In: KEMP, V. H. \& CRIVELLARI, H. M. T. (orgs.). Catadores na cena urbana: construção de políticas socioambientais, p. 225-248. Belo Horizonte: Autêntica Editora, 2008

LOPES, J.E.G.; RIBEIRO F.J.F.; PEDERNEIRAS, M. M. M.; RIBEIRO, I. B.; Pesquisa-Ação: Uma Abordagem para a Produção. RCO - Revista de Contabilidade e Organizações - FEA-RP/USP, v. 3, n. 7, p. 125 126, set-dez 2009.

MIGUEL, P.; FLEURY, A.; MELLO, C.; NAKANO, D.; TURRIONI, J.; LEE HO, L.; MORABITO, R.; MARTINS, R.; PUREZA, V. Metodologia de pesquisa em engenharia de produção e gestão de operações. 2 ed. Rio de Janeiro: Elsevier, 2010.

OLIVEIRA, R. L. \& ABREU, J. C. de. Políticas de apoio à gestão ao empreendimento coletivo dos catadores de materiais recicláveis em três municípios. VII Congresso de produção científica UFSJ - São João Del-Rei, MG, Brasil, 11 a 14 de novembro, 2008.

OLIVEIRA, R. LIMA, J. LIMA, R. LOGÍSTICA REVERSA: O CASO DE UMA ASSOCIAÇÃO DE OLETA SELETIVA DE MATERIAIS RECICLÁVEIS EM ITAJUBÁ - MG, 2009.

POPE, C. Mays, N. Pesquisa qualitativa na atenção à saúde. $3^{\text {a }}$ ed. Porto Alegre: Artmed; 2009

Revista online da lata. A reciclagem do Brasil em Numeros. Publicado em 09/2017, disponivel em http://www.abralatas.org.br/a-reciclagem-do-brasil-em-numeros/ acessado em 20/01/2018.

RIBEIRO, T.F.\& LIMA, S.C. Coleta Seletiva de Lixo Domiciliar - Estudo de Casos. Caminhos de Geografia Revista on Line Programa de Pós-Graduação em Geografia UFU. 2000.

ROBLES, R. Da competitividade a colaboração - o caminho para o engajamento para as empresas. Inovando na gestão de pessoas.2015. Disponível em: https://pt.linkedin.com/pulse/da-competitividade-\%C3\%A0colabora\%C3\%A7\%C3\%A3o-o-caminho-do-para-empresas-robles acessado em 19/01/2018.

SANTOS, T. Politica nacional de resíduos sólidos, 2011. Disponível em: https://maesso.wordpress.com/2011/06/21/politica-nacional-de-residuos-solidos/ acessado em: 22/03/2018.

SILVA, E. M. T.; DONEL, F.; WOLLMANN, A. R., CUELLAR, J. O planejamento como instrumento de implementação da coleta seletiva de resíduos sólidos urbanos. XXIII Encontro Nacional de Engenharia de Produção - ENEGEP - Ouro Preto, MG, Brasil, 21 a 24 de outubro, 2003. 


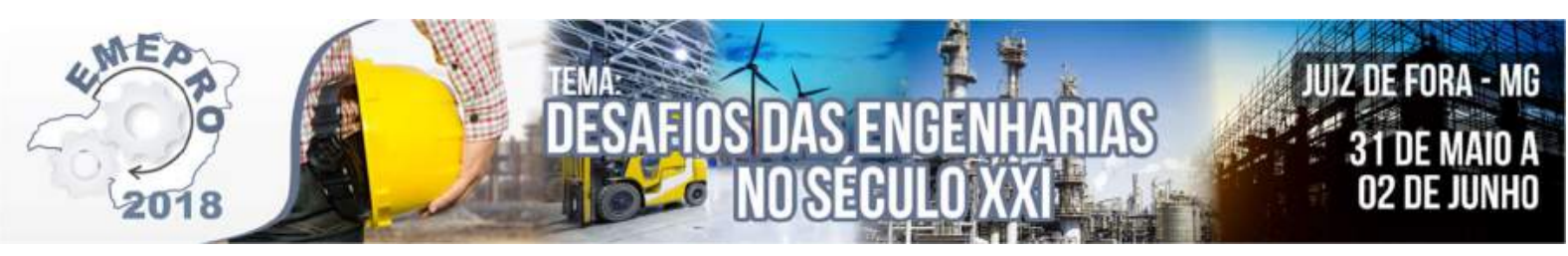

Administração Pública voltada à Gestão Ambiental: uma revisão da legislação brasileira

\author{
Samanta de Lima Alonso (CEFET/RJ) samanta.cefet@gmail.com \\ Fernando Queiroz de Lira Alexandrino (IFRJ) fernando.hnd@gmail.com \\ José Artur Moraes Vieira (UFF) josearturmv@gmail.com \\ Renan André Barbosa dos Santos (CEFET/RJ) renanprod@yahoo.com.br \\ Luiz Alfredo Evelyn Simas (UFF) luiz.simas.uff@gmail.com
}

Resumo: Estudos recentes sobre a degradação ambiental mostram a urgência em reverter os efeitos negativos da atuação humana no planeta. Para que essa mudança aconteça, o papel da Administração Pública é fundamental, visto que ela é responsável por defender e preservar o meio ambiente no processo de formulação das suas políticas públicas. A proposta deste trabalho é analisar a legislação brasileira quanto à responsabilidade ambiental, discutindo os principais instrumentos normativos da esfera federal que tratem deste tema e apresentando alguns projetos sustentáveis em destaque. A coleta de dados será realizada junto aos sites oficiais do governo, onde leis e relatórios informativos, em particular aqueles que tratam das questões relativas ao meio ambiente, estão disponíveis a todos os cidadãos.

Palavras-chave: Desenvolvimento Sustentável; Administração Pública; Melhores Práticas A3P

\title{
1. Introdução
}

A necessidade de redução dos impactos ambientais decorrentes da ação humana é uma urgência, visto que os dados e as estatísticas sobre degradação ambiental são alarmantes. De acordo com o Painel Intergovernamental de Mudanças Climáticas (IPCC, 2014), em seu $5^{\circ}$ Relatório de Avaliação do Clima, a concentração de gases de efeito estufa na atmosfera aumentou a níveis sem precedentes nos últimos 800 mil anos, sendo que aproximadamente $30 \%$ das emissões de CO2 têm sido absorvidas pelo oceano, causando um decréscimo de 0,1 no $\mathrm{pH}$ da água.

Outro dado do $5^{\circ}$ Relatório de Avaliação do Clima é que o nível do mar aumentou, em média, nas seguintes proporções: $1,7 \mathrm{~mm}$ ao ano entre 1901 e $2010 ; 2,0 \mathrm{~mm}$ ao ano entre 1971 e 2010; e 3,2 $\mathrm{mm}$ ao ano entre 1993 e 2010. Além disso, nas últimas duas décadas, as camadas de gelo da Groenlândia, da Antártida e do mar Ártico sofreram reduções. Com relação à temperatura média global da terra e do oceano, o relatório indica um aumento de $0,85^{\circ} \mathrm{C}$ no período entre 1880 e 2012 .

Para reverter esse cenário, é preciso o envolvimento de todos os setores, principalmente o Poder Público, que deve incluir a responsabilidade ambiental no processo de formulação das suas políticas públicas. De fato, o papel da Administração Pública é fundamental, visto que ela é responsável por defender e preservar o meio ambiente para as presentes e futuras gerações, conforme disposto no artigo 225 da Constituição Federal promulgada em 1988 (BRASIL, 1988).

De acordo com Carlos Minc na Cartilha A3P (MMA, 2009), a Administração Pública 


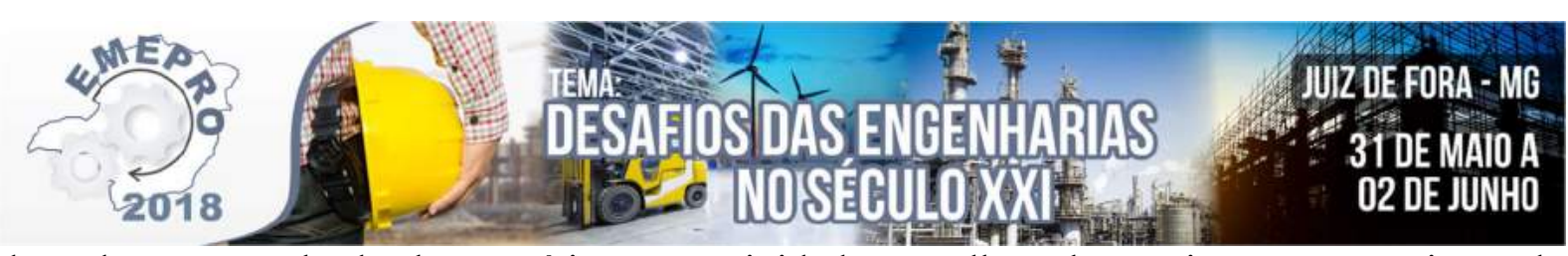

deve dar o exemplo das boas práticas nas atividades que lhe cabem, visto que possui grande poder de compra através das licitações e principalmente a atribuição de cumprir as políticas públicas. Essas boas práticas devem abranger o conceito de desenvolvimento sustentável, expressão definida pelo Relatório Brundtland, em 1987, como uma proposta de desenvolvimento que visa compatibilizar o desenvolvimento econômico com a utilização racional dos recursos naturais, visando garantir a mesma qualidade de vida às presentes e futuras gerações.

Este conceito, segundo Mikhailova (2004), após a Conferência das Nações Unidas sobre Meio Ambiente e Desenvolvimento, conhecida como Rio-92, passa a ser o alvo principal da política ambiental. Silva (2009) afirma que, a partir do surgimento do conceito de desenvolvimento sustentável, a questão ambiental passou a ser associada à gestão e ao pensamento estratégico das organizações. Dessa forma, ainda segundo Silva (2009), a variável ambiental passa a incorporar as políticas organizacionais, não sendo apenas uma preocupação temporária ou um assunto da moda.

Diante da problemática supracitada, o objetivo deste trabalho é discutir a legislação vigente no Brasil sobre a responsabilidade ambiental do Poder Público a nível federal. Para isto, é necessário examinar os principais normativos, além de apresentar projetos que sejam referência na prática sustentável. Com relação à forma de abordagem do problema, esta será uma pesquisa qualitativa e, no que tange aos procedimentos técnicos, trata-se de uma pesquisa documental.

A pesquisa será realizada com base no levantamento e estudo da documentação legal disponível que embasa a atuação do Poder Público, como a lei 8.666/1993 que institui normas para licitações e contratos da Administração Pública, a lei 12.187/2009 que rege a Política Nacional de Mudança do Clima, a lei 12.305/2010 que define a Política Nacional de Resíduos Sólidos e a cartilha A3P sobre a Agenda Ambiental na Administração Pública. As diretrizes ambientais definidas em tais documentos nortearão a busca por exemplos de práticas sustentáveis executadas pelo Poder Público. Para a apresentação desses exemplos, serão realizadas consultas em relatórios informativos do prêmio anual de "Melhores Práticas na A3P" para a identificação de políticas públicas relacionadas ao tema.

A partir da pesquisa desenvolvida neste trabalho, espera-se obter uma análise sobre a legislação de responsabilidade ambiental voltada à Administração Pública, traçando um perfil da atuação da Administração através de exemplos de políticas públicas em conformidade com as leis ambientais vigentes.

\section{Referencial Teórico}

A lei 8.666 de 1993 define normas para a execução de licitações e contratos pelos órgãos públicos (BRASIL, 1993). Em seu artigo $3^{\circ}$ estabelece que a licitação pública deve promover o desenvolvimento nacional sustentável, ou seja, nos processos de aquisições de bens e contratações de serviços é necessário inserir critérios sociais, ambientais e econômicos. Assim, o poder de compra dos setores públicos irá estimular a geração de benefícios econômicos e socioambientais para o país.

Outra norma é a Política Nacional de Mudanças do Clima (PNMC), estabelecida pela lei 12.187 de 2009, que define objetivos, diretrizes e instrumentos para que o Brasil alcance o objetivo de reduzir o aquecimento global e as suas consequências (BRASIL, 2009). Esta legislação conceitua gases de efeito estufa como substâncias gasosas da atmosfera que absorvem e emitem radiação térmica emitida pela superfície da terra, pela atmosfera e pelas 


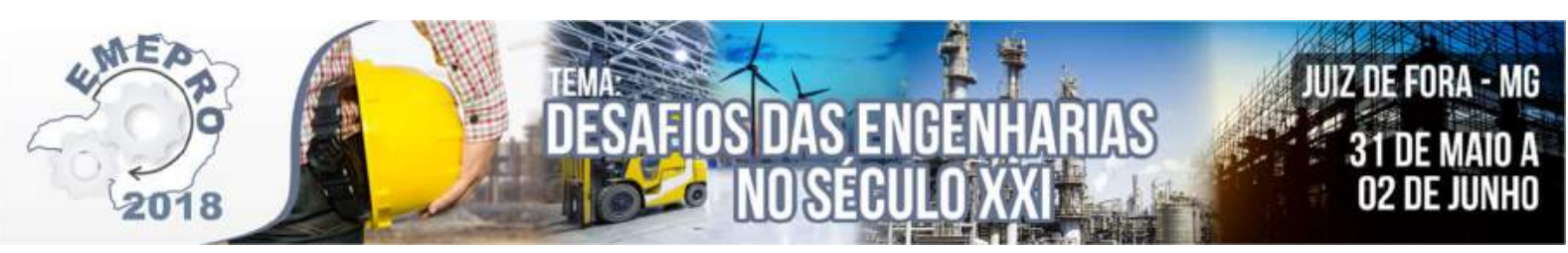

nuvens, acarretando o efeito estufa.

O Protocolo de Quioto não estabeleceu metas de redução de emissões de gases de efeito estufa para o Brasil. Entretanto, o país assumiu um compromisso voluntário de adotar ações de mitigação das emissões de gases de efeito estufa com o objetivo de reduzir suas emissões projetadas até o ano de $2020 \mathrm{em}$ um percentual entre 36,1\% e 38,9\%. Essa meta foi estabelecida de forma voluntária, mesmo o país não tendo essa obrigação.

Já a lei 12.305, sancionada em 2010, estabelece a Política Nacional de Resíduos Sólidos (PNRS), definindo princípios, objetivos e instrumentos a serem seguidos, além de estabelecer diretrizes referentes à gestão integrada e ao gerenciamento ambientalmente adequado dos resíduos sólidos (BRASIL, 2010). As normas da PNRS devem ser seguidas por pessoas físicas e jurídicas, de direito público ou privado. Essa lei define a seguinte ordem de prioridade no Gerenciamento de Resíduos Sólidos: não geração, redução, reutilização, reciclagem, tratamento e disposição final ambientalmente adequada.

Existe ainda uma cartilha da Agenda Ambiental na Administração Pública (A3P), criada em 1999 pelo Ministério do Meio Ambiente com o intuito de revisar os padrões de produção e de consumo nas instituições públicas, de modo que passem a seguir padrões de sustentabilidade ambiental em atividades rotineiras (MMA, 2009). Essa mudança de comportamento promoverá a economia de recursos naturais e a redução de gastos, já que haverá o uso racional e responsável dos bens públicos.

A A3P tornou-se o principal programa de gestão socioambiental voltado à Administração Pública e vem sendo implementada por diversos órgãos públicos das três esferas de poder e também pela iniciativa privada. O seu principal objetivo é estimular a reflexão e a mudança de atitude dos servidores públicos em suas atividades do dia a dia, as quais devem incorporar critérios de gestão socioambiental.

As ações da A3P devem ser norteadas pelo princípio dos "5 R's": Repensar a necessidade de consumo e os padrões de produção e descarte; Reduzir desperdícios, consumindo menos produtos e priorizando os que gerem menos resíduos e que tenham maior durabilidade; Reaproveitar, reutilizando ao máximo os materiais antes de descartá-los; Reciclar, transformando materiais usados em matérias primas para novos produtos; Recusar consumos desnecessários e produtos que gerem impactos ambientais significativamente negativos.

\section{Prêmio A3P e Gestão Pública Socioambiental}

De modo a incentivar o cumprimento de práticas sustentáveis na Administração Pública foi criado o Prêmio A3P que visa reconhecer instituições públicas que implementaram, voluntariamente, políticas públicas relacionadas à Gestão Socioambiental. O evento divulga as iniciativas públicas com relação ao tema e desde a sua primeira edição, em 2009, vem incentivando todos os entes que compõem a Administração Pública a participarem. A seguir são apresentados alguns exemplos de projetos premiados.

- Selo Casa Azul

Em 2009 a Caixa Econômica Federal (CEF) criou o Selo Casa Azul, através do qual se observa um avanço no planejamento das habitações, que trará como consequências uma moradia planejada e melhor construída, além da redução das despesas dos moradores com a economia de água e energia. Este selo é uma metodologia de classificação socioambiental para projetos de construção civil habitacional que são financiados pela CEF. Os tipos de selo 


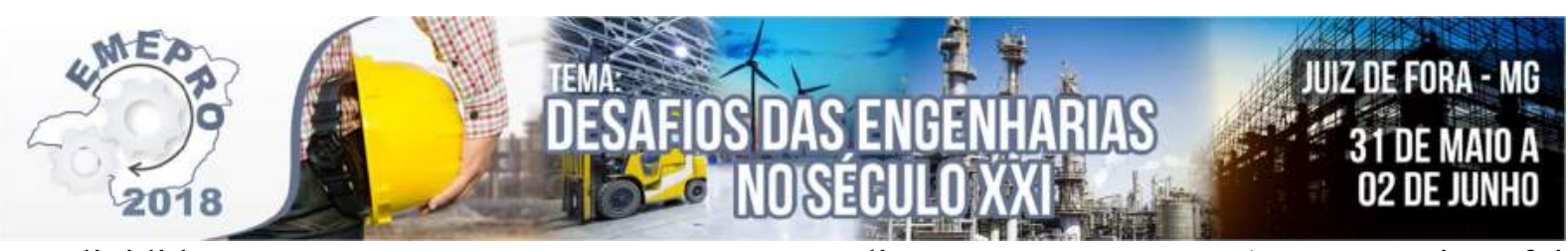

são divididos em: Ouro, Prata ou Bronze, como disposto na FIGURA 1. Esse projeto foi vencedor do $3^{\circ}$ lugar na categoria "Inovação na Gestão Pública" no $3^{\circ}$ Prêmio Melhores Práticas A3P, em 2011.

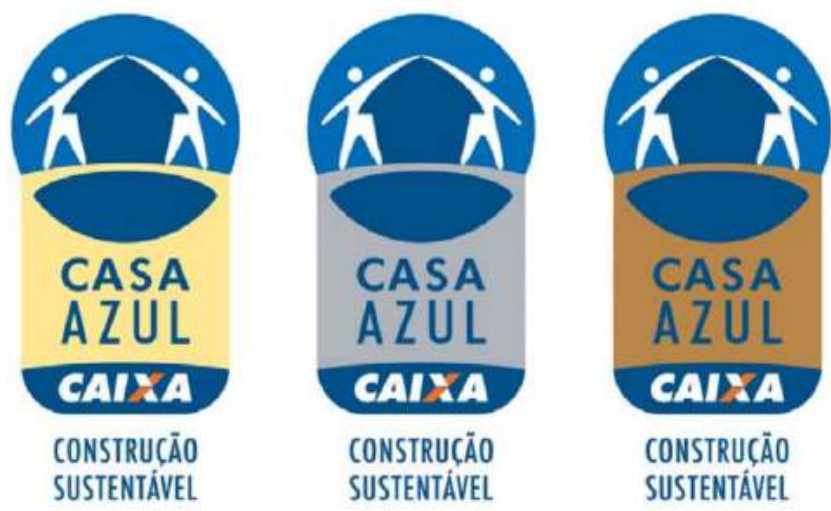

FIGURA 1 - Tipos de Selo Casa Azul. Fonte: CEF (2010).

- Implantação de centro de produção de mudas de árvores para reflorestamento e compensação de carbono no Haiti

Desde 2004, o Exército Brasileiro atua no programa das Nações Unidas que promove ações de segurança interna e de apoio humanitário ao Haiti. Além dos problemas sociais, este país também apresenta graves problemas ambientais, visto que a sua cobertura vegetal nativa já foi destruída em $98 \%$, além da alta probabilidade de catástrofes naturais na região. Diante dessas vulnerabilidades ambientais, o Exército Brasileiro elaborou um projeto de implantação de um centro de produção de mudas de árvores para reflorestamento da região e compensação do carbono emitido durante as operações militares brasileiras no Haiti. A FIGURA 2 mostra a presença dos militares junto aos residentes.

Os resultados desse projeto incluem a geração de renda para 300 trabalhadores haitianos, a compensação de, aproximadamente, 2.600 toneladas de $\mathrm{CO} 2$ e a plantação de 12.000 mudas de árvores para reflorestamento. Esse projeto foi vencedor do $1^{\circ}$ lugar na categoria "Inovação na Gestão Pública" no $4^{\circ}$ Prêmio Melhores Práticas A3P, em 2012.

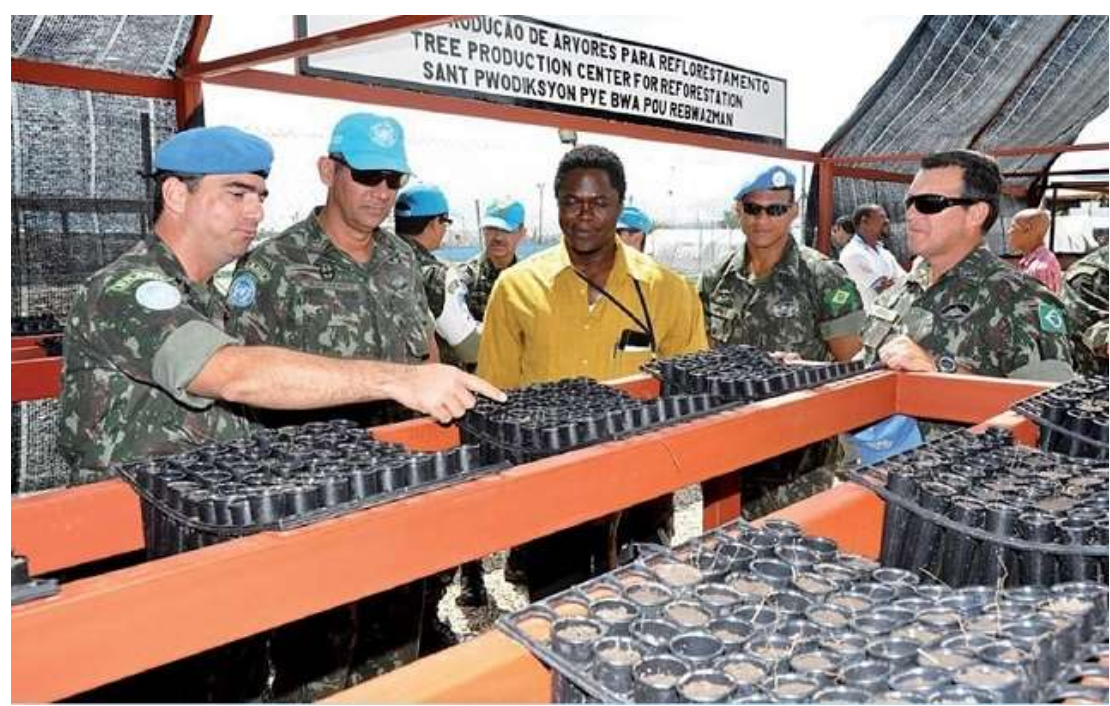

FIGURA 2 - Centro de produção de mudas de árvores no Haiti. Fonte: EB (2017). 


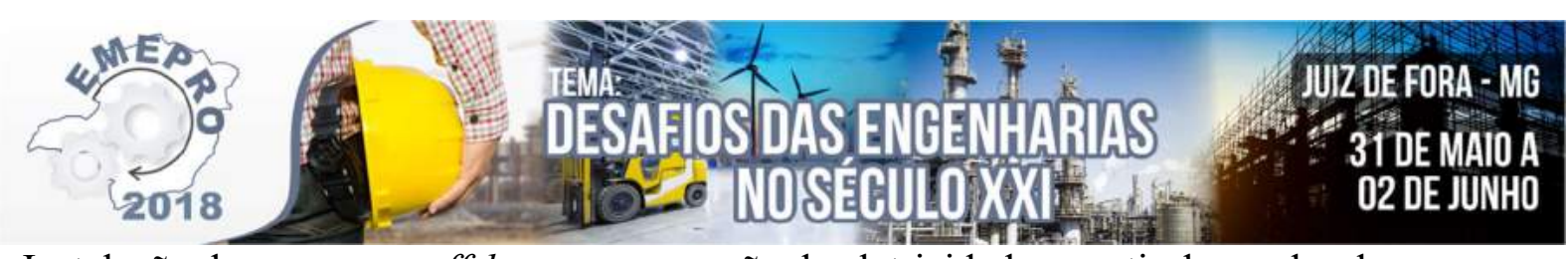

- Instalação de conversor offshore para geração de eletricidade a partir das ondas do mar

O projeto foi idealizado pela Eletrobrás Furnas - Centrais Elétricas S/A com o objetivo de instalação e operação de um protótipo conversor offshore que gere eletricidade a partir das ondas do mar, ou seja, esse protótipo possui uma tecnologia de conversão das energias das ondas em energia elétrica. A localização do protótipo é em uma base da Marinha na Ilha Rasa, situada a $10 \mathrm{~km}$ da praia de Ipanema, na cidade do Rio de Janeiro.

Essa tecnologia apresenta baixos impactos ao meio ambiente e grande capacidade de geração de energia renovável, já que uma usina é capaz de gerar $100 \mathrm{KW}$ de energia, o que é suficiente para abastecer 200 residências com 4 moradores em cada uma delas. Como o Brasil possui a maior extensão de litoral oceânico livre do mundo, a previsão é que a capacidade de geração de eletricidade chegue a $20 \mathrm{GW}$ de potência.

Esse projeto foi vencedor do $3^{\circ}$ lugar na categoria "Uso/Manejo Sustentável dos Recursos Naturais" no $5^{\circ}$ Prêmio Melhores Práticas A3P, em 2014. Na FIGURA 3 é encontrado um esquema sobre a tecnologia desenvolvida neste projeto.

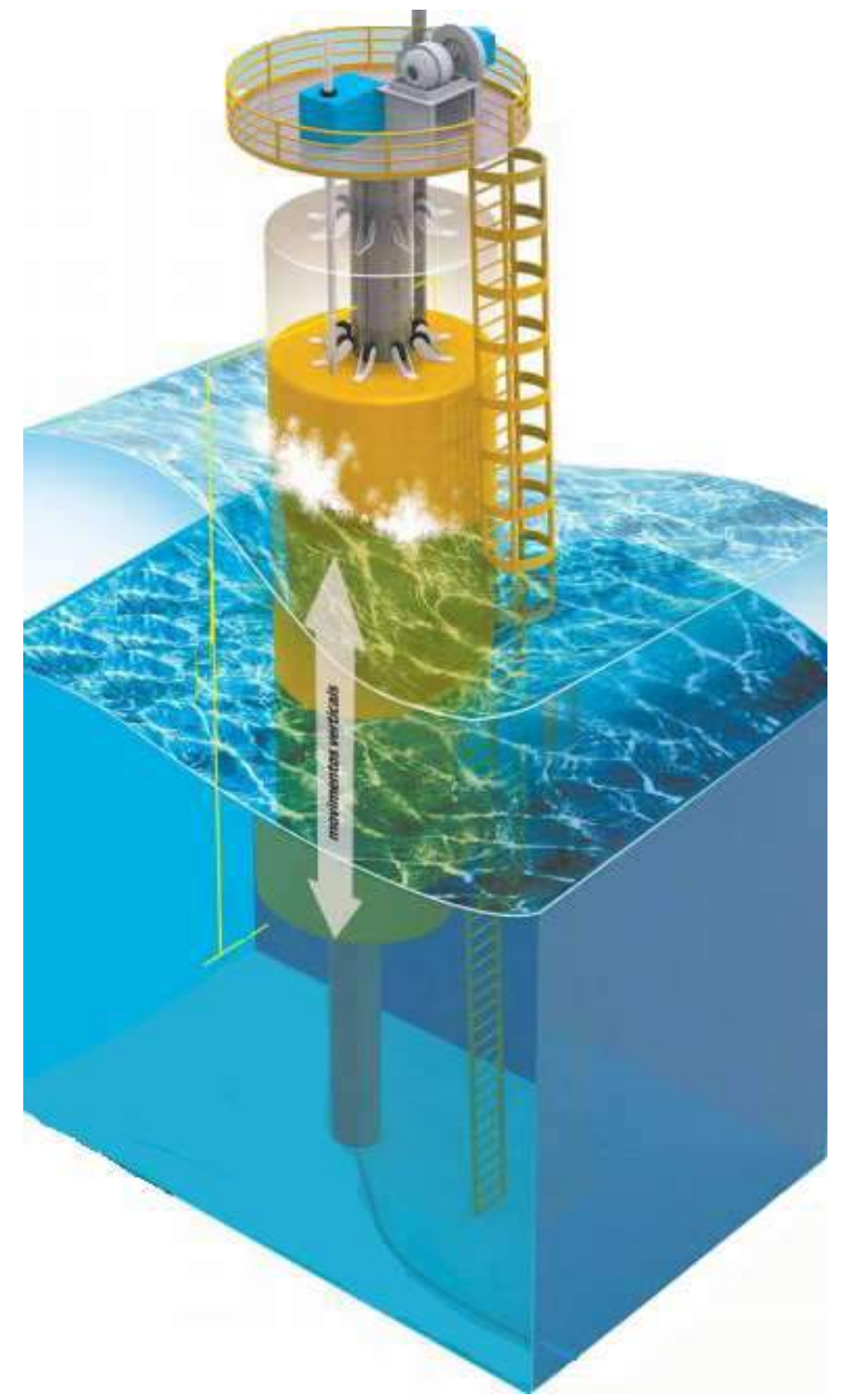

FIGURA 3 - Visão esquemática do gerador de energia elétrica offshore. Fonte: O DIA (2013). 


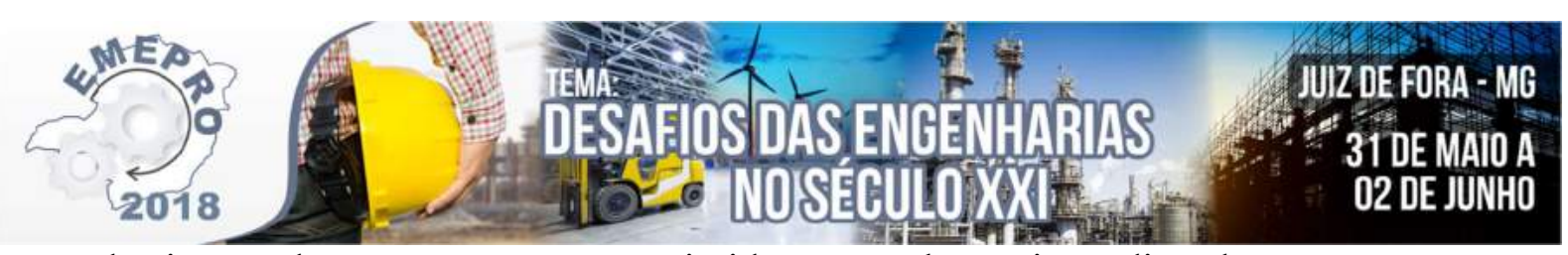

- Uso do sistema de espuma por ar comprimido, no combate a incêndios classe A e B

O Corpo de Bombeiros Militar do Distrito Federal (CBMDF) iniciou em 2007 pesquisas para a elaboração de uma espuma ambientalmente correta a ser utilizada nas operações de combate a incêndio da corporação. As pesquisas resultaram na criação de um sistema de espuma por ar comprimido que foi incorporado em 2013 às viaturas do CBMDF para combate a incêndios das classes A e B. Esse projeto foi vencedor do $1^{\circ}$ lugar na categoria "Uso/Manejo Sustentável dos Recursos Naturais" no $6^{\circ}$ Prêmio Melhores Práticas A3P, em 2016.

As principais vantagens obtidas com esse novo sistema envolvem: utilização de 6 vezes menos água do que o processo anterior devido à otimização do resfriamento na operação; a espuma é 100\% biodegradável, decompondo-se em menos de 30 dias; não há liberação de gases tóxicos e há redução da poluição pluvial.

\section{Discussão acerca das Políticas Públicas}

Conforme apresentado, nota-se uma tendência do Poder Público em incorporar a preocupação socioambiental em seus programas de governo, aplicando as práticas sustentáveis em diversas esferas de poder e ramos de atuação. Esse fato pode ser comprovado pela quantidade de legislações criadas especificamente sobre o tema nos últimos anos. Além disso, a A3P foi incluída, inicialmente, por meio de Plano Plurianual e atualmente, devido a sua relevância, integra o Departamento de Produção e Consumo Sustentáveis (DPCS) do Ministério do Meio Ambiente.

Diferentemente do que ocorria no passado, quando tais práticas eram usualmente utilizadas como um modismo ou tentativas de marketing positivo para os negócios, o tema hoje é, de fato, preocupante e necessário, sendo incorporado em ações que trazem benefícios diretos para a sociedade, não apenas brasileira como também haitiana. Os benefícios para o meio ambiente são expressivos e facilmente identificáveis, além disso, nota-se que os programas implementados buscam também garantir uma questão primordial da Constituição Federal de 1988, que é a garantia da dignidade da pessoa humana.

Isso pode ser notado desde o financiamento pela CEF de moradias planejadas e melhor construídas que significam a conquista da casa própria para muitas famílias e ainda reduzem as despesas dos moradores com consumo de água e de energia, até a contribuição para a reconstrução da cobertura vegetal de uma nação amiga, que acarreta geração de renda para 300 trabalhadores de classe baixa que anteriormente ao projeto viviam à margem da sociedade no Haiti.

\section{Considerações Finais}

A partir deste estudo é possível concluir que a Poder Legislativo no Brasil tem avançado com relação à criação de normas que norteiam o comportamento socioambiental da Administração Pública. Observa-se que nas últimas décadas houve a elaboração de leis relacionadas aos resíduos sólidos, à preocupação com as mudanças climáticas e à Agenda Ambiental voltada ao poder público, pois este é responsável por defender e preservar o meio ambiente para as presentes e futuras gerações.

Como consequência do aumento das legislações vigentes relacionadas ao tema e com a importância deste assunto para a sociedade, houve a criação de um prêmio voltado a boas práticas de ações sustentáveis executadas pela Administração Pública. Esse prêmio reforça a necessidade de que as leis sejam executadas na prática com mais adeptos dispostos a 


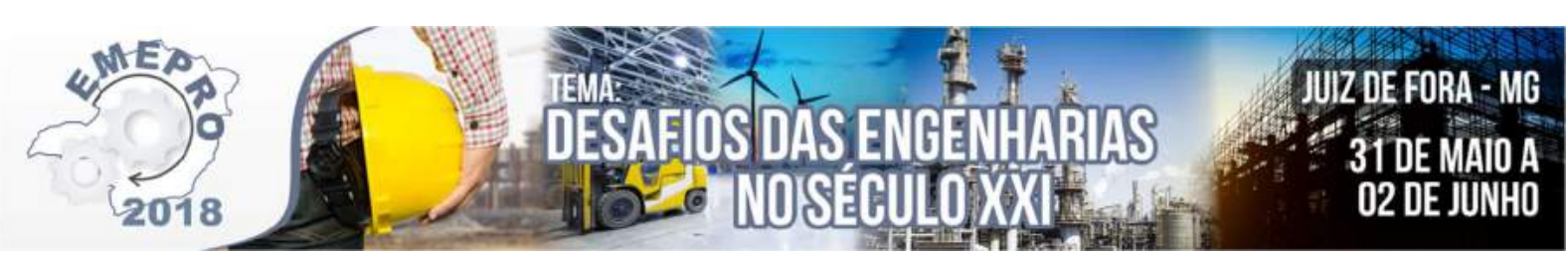

implementar projetos para além do papel, reforçando a necessidade de que o desenvolvimento econômico e tecnológico da atualidade ocorra de modo a garantir a preservação do meio ambiente e dos seus recursos naturais para as próximas gerações.

O objetivo deste trabalho foi alcançado, visto que com a apresentação das legislações estudadas e dos exemplos de políticas públicas citados foi possível traçar um perfil da atuação da Administração. Tal perfil é norteado não apenas pela redução de impactos ambientais em diversos setores e esferas do poder pública como também pela garantia de direitos sociais que impactam diretamente a vida dos cidadãos. Esse último é um ponto chave deste estudo, pois atrelar questões ambientais com sociais é necessário para que a população sinta o impacto real no seu cotidiano e, assim, percebam as melhorias geradas na sua própria qualidade de vida.

A falta de dados sobre os gastos especificamente com as políticas públicas apresentadas limita uma possível avaliação do custo/benefício de tais medidas, o que enriqueceria mais o estudo se fosse uma informação acessível e divulgada amplamente e detalhadamente por cada projeto implementado. Como forma de complementar o trabalho, sugere-se o prosseguimento do estudo com a adição de variáveis como continuidade dos programas e impacto na credibilidade dos gestores públicos através de índices de aceitação ou rejeição da população para com os governantes responsáveis.

\section{Referências}

BRASIL. Constituição da República Federativa do Brasil. 1998. Disponível em:

$<$ http://www.planalto.gov.br/ccivil 03/constituicao/constituicaocompilado.htm>. Acesso em: 25 jan. 2017.

BRASIL. Lei $n^{\circ}$ 8.666, de 21 de Junho de 1993: Licitações e Contratos da Administração Pública. 1993. Disponível em:

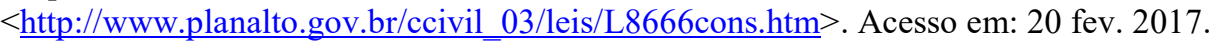

BRASIL. Lei $\mathrm{n}^{\circ}$ 12.187, de 29 de Dezembro de 2009: Política Nacional sobre Mudança do Clima. 2009. Disponível em:

$<$ http://www.planalto.gov.br/ccivil_03/ ato2007-2010/2009/lei/112187.htm>. Acesso em: 20 fev. 2017.

BRASIL. Lei $\mathrm{n}^{\circ}$ 12.305, de 2 de Agosto de 2010: Política Nacional de Resíduos Sólidos. 2010. Disponível em: <http://www.planalto.gov.br/ccivil_03/_ato2007-2010/2010/lei/112305.htm>. Acesso em: 20 fev. 2017.

CEF. CAIXA ECONÔMICA FEDERAL. Guia Caixa de Sustentabilidade Ambiental. 2010. Disponível em: $<$ http://www.caixa.gov.br/Downloads/selo_casa_azul/Selo_Casa_Azul.pdf $>$. Acesso em: 3 mar. 2017.

EB. EXÉRCITO BRASILEIRO. Exército brasileiro em revista. Disponível em:

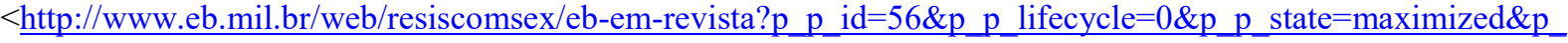
p_mode $=$ view\&p_p_col_id=118_INSTANCE_h4N2sC0AU28O_column-1\&p_p_col_count=1\&_56_groupId $=11425 \& 56$ articleId $=5964027>$. Acesso em: 3 mar. 2017.

IPPC. Intergovernmental Panel on Climate Change. 2014. Disponível em: <http://www.ipcc.ch/report/ar5/syr/>. Acesso em: 12 de janeiro de 2017.

MIKHAILOVA, I. Sustentabilidade: evolução dos conceitos teóricos e os problemas da mensuração prática. Revista Economia e Desenvolvimento, n. 16, pp. 22-41, 2004.

MMA. MINISTÉRIO DO MEIO AMBIENTE. Agenda Ambiental na Administração Pública. 2009. Disponível em: <http://www.mma.gov.br/estruturas/a3p/_arquivos/cartilha_a3p_36.pdf > . Acesso em: 19 set. 2016.

MMA. MINISTÉRIO DO MEIO AMBIENTE. Banco de projetos premiados pelo Prêmio Melhores Práticas A3P. Disponível em: <http://www.mma.gov.br/pol\%C3\%ADtica-de-res\%C3\%ADduos-s\%C3\%B3lidos/ item $/ 520>$. Acesso em: 26 fev. 2017.

O DIA. Ondas do mar vão se transformar em energia no Rio. 2013. Disponível em: < http://odia.ig.com.br/201311-11/ondas-do-mar-vao-se-transformar-em-energia-no-rio.html>. Acesso em: 28 de fevereiro de 2017.

SILVA, O. R. Empresários Ausentes, Cidadãos Presentes: Um Ensaio Sobre Ética Ambiental no Mundo 


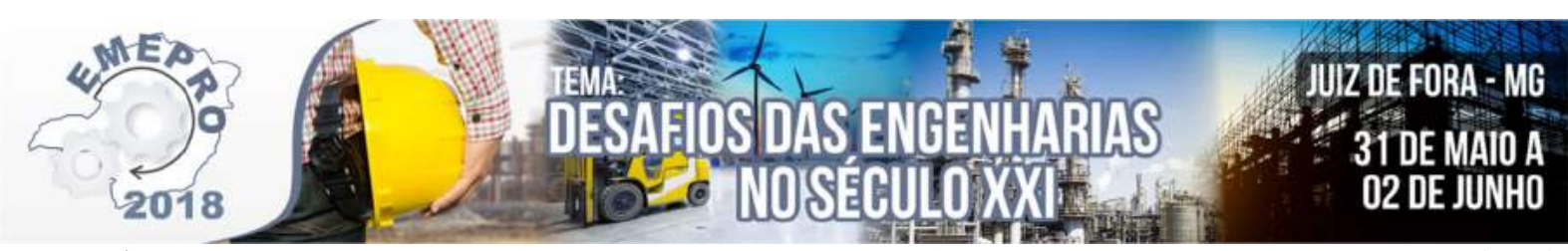

Corporativo. In: ROSINI, A. M.; HOYOS GUEVARA, A. J.; RODRIGUES, M. C.; SILVA, J. U. (Org.). Consciência e desenvolvimento sustentável nas organizações. Rio de Janeiro: Elsevier, 2009. 


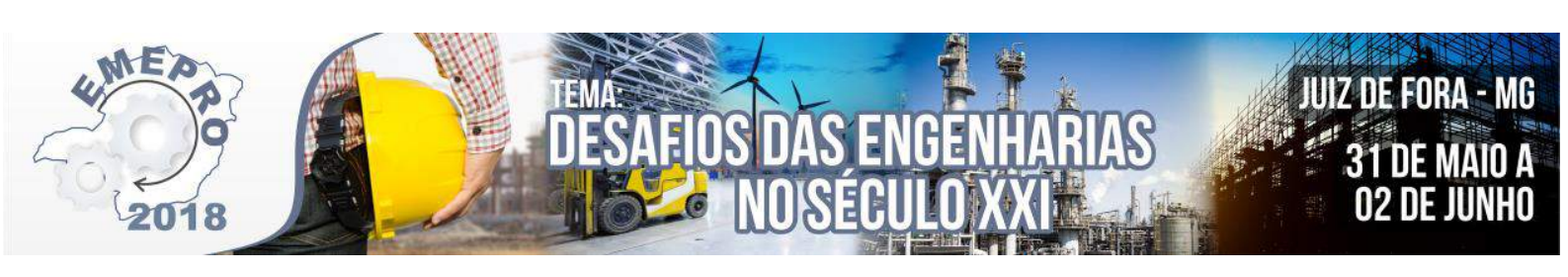

Bairros Sustentáveis

\author{
Sávio Amaral Avidago (FUPAC - Ubá) svioamaral@yahoo.com.br \\ Rafaela Nunes (FUPAC - Ubá) rafah.nunes01@ gmail.com \\ Carlos Augusto Ramos dos Reis (FUPAC - Ubá) gutounipac@gmail.com \\ Livia Souza de Oliveira (FUPAC - Ubá) livia_soliveira@yahoo.com.br \\ Paulo Roberto Mendes da Silva (FUPAC - Ubá) prmendesilva62@ gmail.com
}

Resumo: O trabalho em questão foi desenvolvido com o intuito de demonstrar a importância da sustentabilidade implantada ao desenvolvimento de área urbana, objetivando a melhora relacionado a condição de vida nessas regiões. Foram apresentadas as principais características para se alcançar a metodologia de um bairro sustentável, assim como também as vantagens aos envolvidos em seu desenvolvimento. Os dois principais processos de certificação hoje que atuam no cenário LEED ND (Leadership in Energy Enviromental Desing for Neighborhood Development) e AQUA BAIRROS, foram citados como métodos importantes no controle e desenvolvimento sustentável na área urbana.

Palavras-chave: Bairro; sustentabilidade; AQUA BAIRROS.

\title{
1. Introdução
}

Com o passar do tempo a relação entre o homem e seu habitat mudou conforme a concepção do que é bom, passou-se a pensar em relações sustentáveis. O homem passou a ter mais consciência das atividades humanas sobre o meio ambiente, a ameaça de escassez dos recursos naturais, a poluição ambiental e sonora e o aumento demográfico, fizeram com que ele criasse um novo pensamento e unisse as melhores condições de vida sem comprometer o seu habitat.

Com a necessidade de conviver com essas condições, o termo sustentabilidade tem aparecido constantemente em propagandas e descrição de produtos, ofertas de serviços ou empreendimentos. Exemplo disso são os bairros sustentáveis, definidos como um novo vetor estratégico da sustentabilidade, que visa desenvolver o bairro com usos mistos, reuso de recursos finitos, preocupações ambientas na implantação e execução do bairro. Mas, esses locais são realmente sustentáveis ou é apenas uma jogada de marketing para vender uma nova tendência de mercado imobiliário.

O trabalho em questão tem o objetivo de apresentar os conceitos de sustentabilidade no âmbito urbano, sua importância no desenvolvimento de melhores espaços nas cidades e mostrar a viabilidade da aplicação desses conceitos em grandes centros. O estudo focará em compreender o conceito de bairro sustentável, onde através de analises será verificado se o conceito de bairro sustentável está bem aplicado ou se é mais uma estratégia dos empreendedores imobiliários.

A definição de "desenvolvimento sustentável”, publicada no Relatório Brundtland, como o "desenvolvimento que satisfaz as necessidades presentes, sem comprometer a capacidade das gerações futuras de suprir suas próprias necessidades" (WCED, 1987), é a que ficou consagrada. (ARANHA, 2006).

Por essa definição, o desenvolvimento deve considerar o equilíbrio entre a economia 


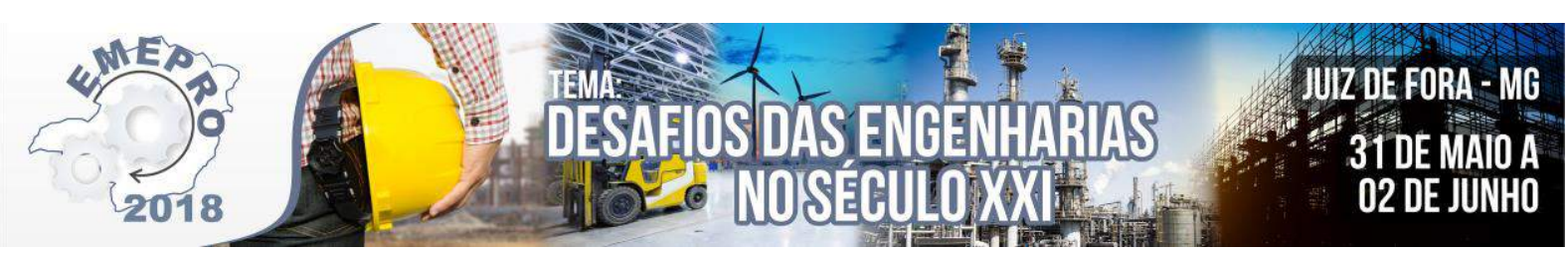

e os recursos do meio ambiente, num sistema global interdependente. (WCED, 1987). Em meio a outros insumos, este também contribuiu para elevar a consciência de que conservação e desenvolvimento não poderiam mais continuar a serem tratados como polos opostos e devem ser metas permanentes da humanidade. Desenvolvimento sustentável pode ser definido como o desejo de manter a realização de aspirações sociais desejáveis. (FRANZ, 2011).

\section{Desenvolvimento}

\subsection{Bairro sustentável}

Os bairros sustentáveis partem dos princípios do proveito no uso de recurso e diminuição de impactos ambientais ao desenvolvimento do projeto. A diretriz sustentabilidade instrui o planejamento e desenvolvimento dos projetos buscando alcançar o conceito de um bairro que faz uso dos recursos naturais de forma eficiente, unindo as questões relacionadas à conscientização dos habitantes à tecnologia, conforto e bem-estar em relação ao meio ambiente, seguindo as necessidades dos usuários atuais e garantindo em ocasiões futuras o bem-estar e necessidades dos mesmos. Mesmo tendo opiniões diversas quanto à melhor definição do que é qualificado com sustentabilidade, existe um ponto de equilíbrio em opiniões de que bairros sustentáveis devem acolher soluções práticas que visam reduzir os impactos globais ao meio ambiente. Apesar de ser um novo conceito encontrado em áreas urbanas, tais conceitos já são bem aplicados em países desenvolvidos.

Com um conhecimento avançado em desenvolvimento de diretrizes sustentáveis, grandes empresas estrangeiras atuam hoje no Brasil como consultoras e certificadoras. O Bairro de Pedra Branca localizado em Palhoça - SC, por adotar essas diretrizes sustentáveis, recebeu vários prêmios e reconhecimento internacional.

A Fundação Vanzolini, certificadora e criadora do processo AQUA de certificação, concedeu ao condomínio Residencial Damba Golf I da Damba Incorporadora, localizada em São Carlos, interior de São Paulo, o primeiro certificado de bairro sustentável em território brasileiro.

\subsubsection{Conceito de Bairro Sustentável}

O conceito de bairro sustentável, gira em torno da ideia de que o bairro seja totalmente autossustentável; por exemplo, ele deveria gerar a própria energia consumida, gerar alimento para a população, gerar todos os recursos que ali são consumidos. No desenvolvimento de empreendimentos sustentáveis, as considerações econômicas, técnicas e ambientais, devem ser tratadas de forma que estas ficam em perfeita concordância com o objetivo de obter um projeto que seja viável aos seus usuários atuais e futuros. Algumas questões que são tratadas com extrema delicadeza quando se refere à sustentabilidade é a gestão de resíduos sólidos em relação à forma como são tratos e armazenados, a eficiência energética de acordo com a forma com esta é obtida, o reaproveitamento dos recursos naturais de forma que não a afete e a degrade, assim como a mobilidade interna e a integração com a infraestrutura do entorno.

A questão do conceito de sustentabilidade pode ser dividida em três grupos distintos de áreas de conhecimento, que precisam estar em harmonia para o desenvolvimento do produto, buscando o equilíbrio ideal, que são eles: sustentabilidade ecológica, sustentabilidade social e economia ecológica.

A parte que cabe à Sustentabilidade ecológica corresponde à preservação da natureza 


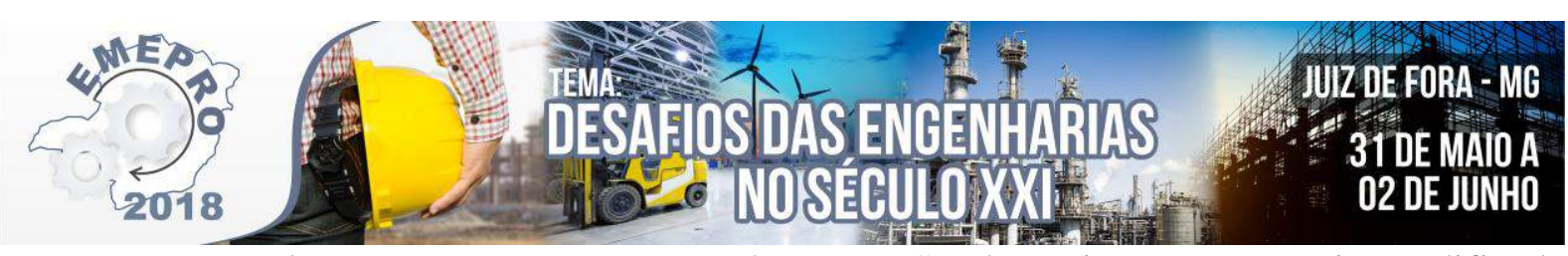

no que se trata da natureza externa ao ser humano. Sendo assim, quanto mais modificada esteja a natureza menor sustentabilidade ecológica encontramos. (FOLADORI, 2004).

Para se atingir de maneira mais eficiente o assunto da economia ecológica, bastaria alinhar os processos produtivos, e com isso obter um desenvolvimento capitalista sustentável. O melhor caminho para isso, seria o caso de substituição dos recursos naturais não-renováveis por renováveis, e de reduzir a emissão de poluentes (FOLADORI, 2004). Quanto ao que se trata do tema sustentabilidade social, o aumento da qualidade de vida deve ser o foco a ser obtido e não o meio para se obter uma natureza mais sustentável.

O desenvolvimento humano se é colocado em primeiro plano, com o objetivo de se favorecer, mais a medida que esse desenvolvimento vai sendo buscado, haveria um melhor relacionamento com o ambiente externo (FOLADORI, 2004). Para uma melhor sustentabilidade social, o ideal seria algumas atitudes serem tomadas, para que a desigualdade social diminua, a ampliação dos direitos e garantir acessos aos serviços como educação e saúde, objetivando o acesso pleno à cidadania.

\subsubsection{Características de um bairro sustentável}

Há várias características que diferenciam os bairros sustentáveis de bairros convencionais. Partes destes elementos estão bem visíveis, outros passam desapercebidos aos seus residentes, porém todos têm a mesma finalidade, que é contribuir para a qualidade de vida dos que neles vivem.

\subsubsection{Meio ambiente e sociedade - Acessibilidade}

Para a execução de um projeto onde há uma melhor acessibilidade de pessoa com necessidades especiais, deve ser aplicado um conceito de desenho universal, onde se satisfaz os diferentes tipos de deficiências, visual e auditiva, mobilidade, pensando também nas necessidades de idosos e crianças.

É sugerida a colocação de faixas de pedestres livres de quaisquer obstáculos que dificultem a mobilidade do pedestre, de perigo minimizando acidentes e passando mais segurança para os pedestres e elementos. Para uma melhor visualização a faixa deverá tem uma cor que contraste com a da calçada e para pessoas com necessidade material especial para que seja facilitada a detecção por bengala.

Pisos táteis direcionais devem ser utilizados em circulações amplas quando houver caminhos preferenciais de circulação assim como a sua sinalização. Devendo ser colocados tanto em áreas públicas como em particulares, seguindo algumas normas como distância das guias das calçadas (em locais externos), inclinação do solo, trajeto facilitado, evitando qualquer tipo de obstáculo, entre outras normas.

\subsubsection{Eficiência Energética}

Um projeto de eficiência energética tem como prioridade o conforto dos habitantes, e preza pela economia de recursos. Portanto, é de extrema importância para o sucesso do empreendimento, analisar cuidadosamente todas as intervenções que possam dificultar o residente de alcançar tal objetivo (PIMENTEL, 2013).

De acordo com Pimentel (2013), a posição como são executadas a residências influencia de forma indireta na questão da eficiência energética, de forma que essas edificações devem acompanhar as principais variáveis climáticas. Estas são: ventos, radiação solar, precipitações, temperatura e umidade relativa do ar. As duas primeiras variáveis, ventos e sol, 


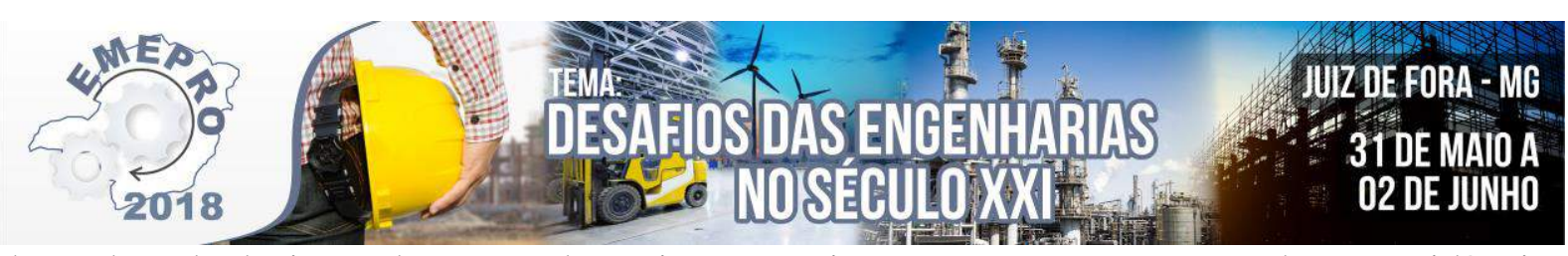

dependem de decisões do macro de projeto, a posição em que serão executadas as residências interfere de maneira positiva ao conforto térmico do projeto.

Há algumas estratégias adotas para que a geometria das edificações consiga uma eficiência energética, como o escalonamento das alturas das edificações, espaçamentos adequados entre os edifícios e disposição adequada em planta. Deve ser realizado estudo de insolação sobre o entorno de forma a garantir acesso solar aos terrenos e edifícios vizinhos.

Os ambientes externos devem possuir um tratamento de microclima, alcançando um ambiente mais agradável relacionado à temperatura, proporcionando espaços mais abertos que podem ser usados em várias condições meteorológicas. Com a implantação de diversos tipos de vegetação proporcionam um sombreamento, tornando-se de extrema importância para locais onde há grande exposição à insolação, não reduzindo apenas a incidência de radiação solar direta à pele, mas também pelo sombreamento ocorre o resfriamento da superfície e que irá acarretar uma redução na temperatura do ar.

\subsubsection{Consumo de energia}

No contexto de Duarte (2004), projetos que apresentem soluções para lidar com as condições ambientais locais, envolvendo temperatura do ar, temperatura superficial, umidade, radiação solar, ventos, ruídos e, ainda, qualidade do ar, aliadas a um bom aproveitamento da luz natural, estão contribuindo para a realização de uma residência de menor impacto ambiental, no que tange à questão da energia.

A partir da busca por um menor consumo de energia e da importância da satisfação e da boa produtividade dos usuários, o conforto ambiental (ergonômico, térmico, luminoso e acústico) tem um papel central nas decisões de projeto. Em termos de condicionamento ambiental, o projeto pode responder para três diferentes cenários de condições ambientais internas. (DUARTE, 2004)

No primeiro cenário, tem-se um projeto totalmente passivo (free running building), em que o consumo de energia para a climatização é zero. Nesse caso, as características do projeto e os padrões de ocupação interagem com as condições ambientais externas, que vão determinar as condições ambientais internas.

No segundo cenário, o edifício é dependente por todo o seu tempo de ocupações de um sistema artificial para o controle das condições ambientais internas, o que pode ser uma imposição do clima ou mesmo das especificidades do uso. Sendo assim, deve ser projetado para minimizar os gastos de energia para o condicionamento artificial, seja para $o$ arrefecimento, seja parar o aquecimento.

No terceiro cenário, o uso do sistema artificial de climatização é parcial, ocorrendo apenas momentos do ano em que as condições ambientais internas estão fora dos padrões de desempenho estabelecidos, denominado condicionamento ambiental em modo misto (mixedmode).

Cada um desses cenários requer concepções de projeto diferentes, englobando forma, materiais, organização interna das funções e outros aspectos, mesmo tornando-se um mesmo sítio, ou diferentes sítios com condições ambientais similares.

\subsubsection{Materiais e resíduos}

Formas que facilitem a interação e conscientização por meio da criação de indicadores que possam medir a qualidade do ambiente local, podem ser fornecidas à população dessas 


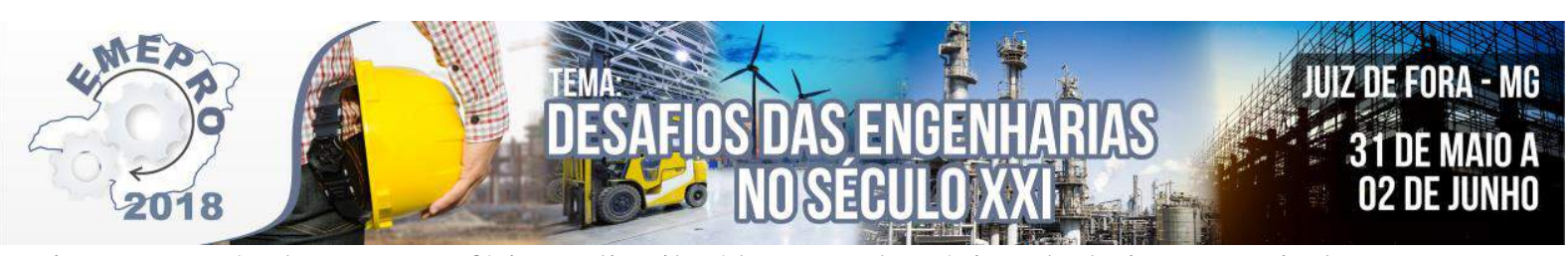

regiões, através de espaços físicos distribuídos nos domínios do bairro, servindo como ponto de disseminação da prática sustentável, ou canais de comunicação virtual, de maneira a alcançar um fluxo de informação continuo, fazendo com que haja o envolvimento do maior número de habitantes da região com a intenção de melhoria do espaço próprio (BRITO, 1999).

De acordo com Pinto (1999), outra maneira para que ocorra essa conscientização seria realizada através de sinalização e agentes educacionais. Em edifícios e nas ruas do bairro, por meio de trabalhos realizados pela administração, seria fornecido de forma direta, por meio de manuais, características do bairro como suas tecnologias, a tipologia da gestão de resíduos implantados no bairro, benefícios e responsabilidade dos usuários do sistema, biomas e fauna local e espécies arbóreas utilizadas no paisagismo.

\subsubsection{Gestão de água e afluentes}

Ao iniciar a concepção de um empreendimento, é importante verificar o regime de chuvas da região e a sua regularidade. Deve-se levar em consideração se a região apresenta falta de àgua ou enchente, problemas de erosão decorrentes das chuvas e carência de saneamento ou abastecimento na região. Esses dados ajudaram a alinhar as estratégias de projeto - para a implantação e operação - e definir a agenda do empreendimento, resultando na seleção de estratégias a serem utilizadas, contribuindo assim com sua sustentabilidade, alinhando à redução de custo em toda a vida útil do empreendimento (CORREA, 2009).

O uso racional consiste no desenvolvimento de sistemas hidráulicos com o consumo eficiente de água durante toda vida útil do empreendimento, isto é:

- $\quad$ Redução da quantidade de água extraída em fontes de suprimentos;

- $\quad$ Redução do consumo e do desperdício de água;

- $\quad$ Aumento da eficiência do uso de água;

- $\quad$ Aumento da reciclagem e do reuso de água.

De acordo com Correa (2009), a adoção deste princípio leva aos benefícios que vão desde a redução dos impactos sócio ambientais e redução de custo na fase de uso e operação até a divulgação da ação com os objetivos comerciais.

\subsubsection{Harmonização com o entorno}

A observação do entorno da região onde será executado o projeto, suas condições físicas ambientais e as reflexões críticas sobre os marcos adotados legalmente, pelo empreendedor, são consideradas ações que devem ser pesadas como uma atitude sustentável para um empreendimento.

Estes cuidados com o meio e com as ressalvas, e com uma atenção especial a uma postura sensível ao meio ambiente, as alterações acompanhadas devido a impactos gerados por meio de empreendimentos urbanos, ligados a decisões tomadas considerando efeitos de médio a longo prazo no entorno desta região, são partes de ações pregados pelo conceito de sustentabilidade (CORREA, 2009).

Adensamento, verticalização, impermeabilização, alteração da paisagem natural pelo desmatamento, desvio de cursos d'água, ocupação excessiva e intensiva nos grandes centros urbanos, alteração de lençóis, poluição e formação de barreiras arquitetônicas ao local, alterando o clima, o desempenho de ventos dominantes, a produção de espaço artificial em abundância, a alteração do comportamento das espécies vegetais etc. Todos estes são afetados 


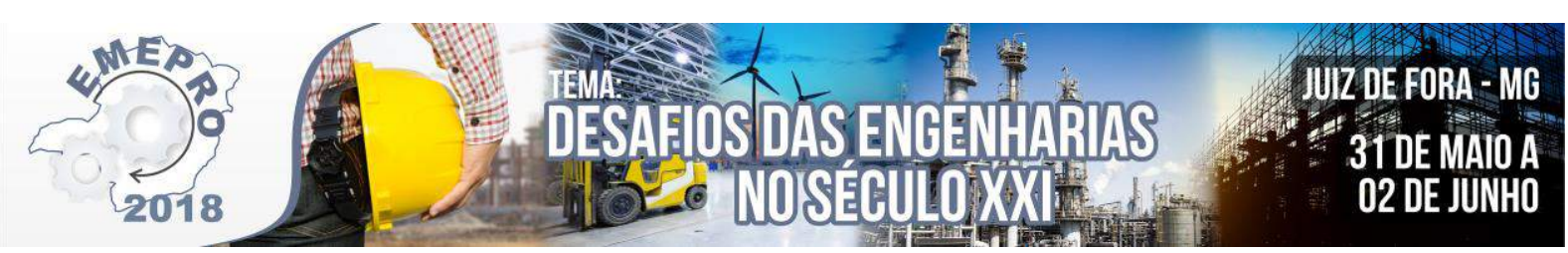

pela maneira como administramos o espaço construído.

Dessa forma, a maneira como olhamos para o entorno das regiões onde será executado um empreendimento deve ser a mais crítica possível para efeito de produção de cidades sustentáveis, se são também sustentáveis nossos condicionantes de uso e ocupação do solo e se estes, por si, respeitam a dimensão humana, do entorno, o meio natural, a projeção e o impacto da intervenção, bem como a possibilidade de construção harmoniosa de cidades (CORREA, 2009).

\subsubsection{Bairros sustentáveis e seus elementos}

Para Pimentel (2013), para que o conceito de sustentabilidade seja aplicado a um bairro, seis pilares são de extrema importância, pois buscam compreender um problema maior para que o empreendimento alcance o almejado título de bairro sustentável. Esses pilares são:

- Meio ambiente e sociedade: o desenvolvimento do projeto se reflete na busca pela acessibilidade universal e na análise de território e contexto local;

- $\quad$ Redução de gases de efeito estufa: Deve permear todas as iniciativas relativas à construção do empreendimento, principalmente em relação às técnicas construtivas, logísticas e escolha de materiais;

- Eficiência energética: Deve considerar como prioridade o uso de técnicas a nível de projeto. Pode ser analisada segundo a inserção urbana e o uso de tecnologias ativas, contudo, a ênfase é dada à segunda;

- $\quad$ Gestão da água: Se reflete em estratégias ativas de projeto;

- Materiais e resíduos: Aborda a conservação de recursos materiais e a gestão dos resíduos sólidos urbanos;

- Mobilidade: Abrange transporte e conectividade.

Como a questão relacionada à sustentabilidade é muito abrangente, dentro dos temas citados ainda há uma série de subtemas, objetivos e estratégias que permitem o desenvolvimento do bairro sustentável.

\subsubsection{Bairro sustentável e seus benefícios}

O bairro sustentável tem por finalidade uma estrutura desenvolvida aos recursos naturais e humanos. São vários os benefícios proporcionados por este, e podem ser divididos em três frentes: sociais, ambientais e econômicas.

Apesar de ser um investimento inicial com valores muito altos, na concepção e execução de espaços urbanos sustentáveis planejados, os empreendimentos que se encontram dentro dessas regiões têm um valor diferenciado. Fatores como a proximidade dos usuários aos seus serviços, facilidade relacionada aos meios de transporte públicos, ciclovias, lazer, entre outros exemplos, todos esses benefícios fazem com que o valor dessas residências localizadas nesses bairros seja elevado (FUNDAÇÃO VANZOLINI, 2011).

Segundo a USGBC (United States Green Building Council) uma ONG que visa fomentar a indústria sustentável no Brasil, os benefícios de um empreendimento sustentável podem ser resumidos pela Fig. 1. 

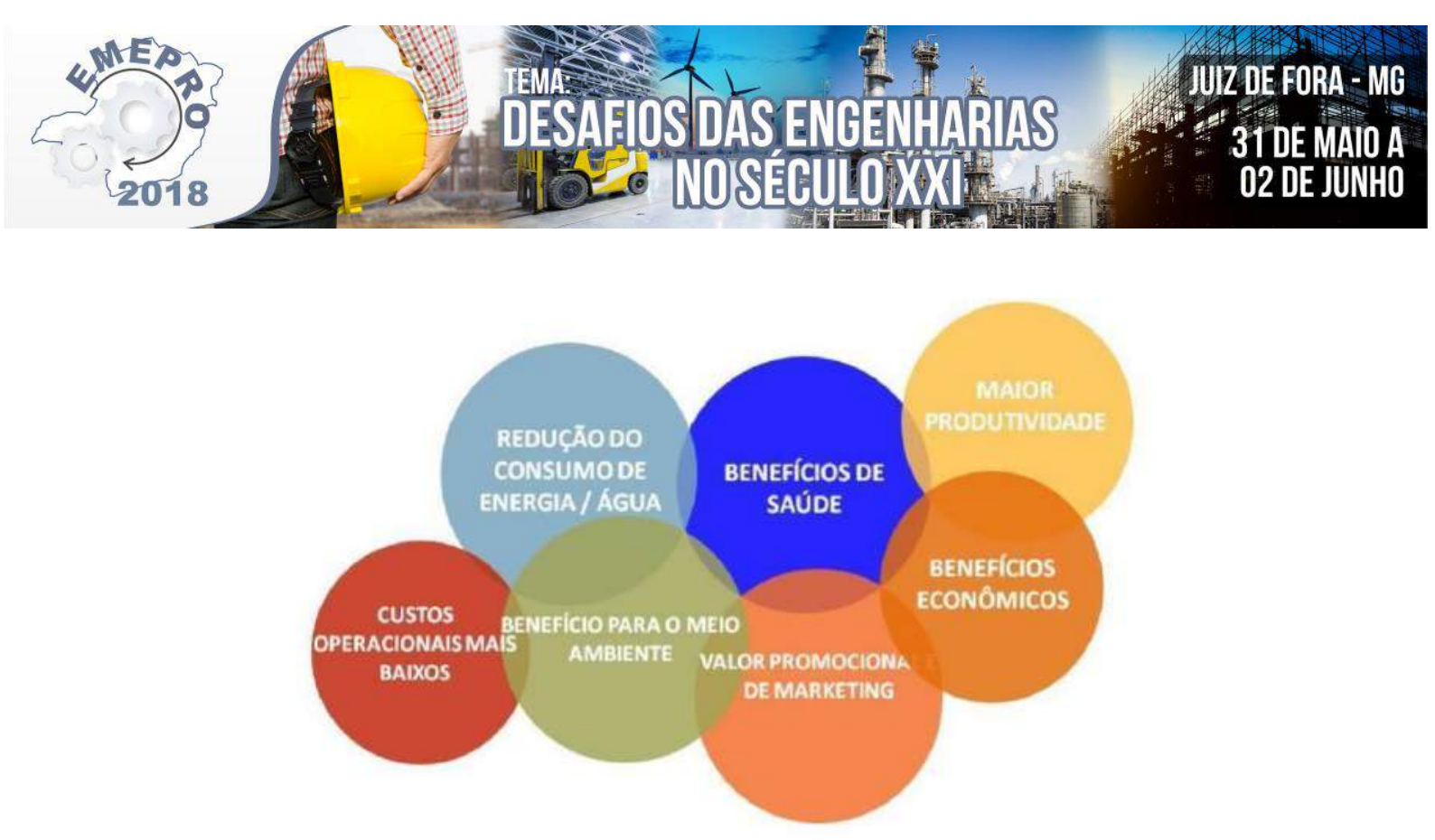

Figura 1 - Benefícios da construção sustentável. Fonte: USGBC, 2009.

\subsection{Especulação imobiliária, tendência do mercado e o desenho urbano}

A especulação causa um desmembramento de classes no espaço urbano, pois alguns ficam impossibilitados de manter suas vidas em determinadas regiões devido ao custo de vida e o crescimento indesejado e desordenado da cidade. De acordo com Gonçalves (2010), o ativo da especulação ocorre devido a decisões governamentais que são tomadas, pois o investimento, na maioria das vezes, não com o interesse de cumprir a função social da cidade, mas sim, com o interesse de empreendedores. Os vazios nas áreas urbanas, com o intuito de que esses terrenos num futuro tenham uma valorização, gera a necessidade da urbe se espalhar, o que agrava os problemas de infraestrutura técnica e social.

A combinação dos altos valores de residências localizadas em grandes centros com a necessidade por moradias impulsionou o surgimento de estabelecimentos em condições precárias e irregulares, ou em áreas de risco ou distantes de grandes centros, e a ampliação territorial da cidade para regiões sem infraestrutura básica.

Segundo Caldeira (1997), a partir dos anos 90, as diferentes classes sociais começaram a conviver mais próximas, no entanto condições foram criadas para que ocorresse demarcação do território de cada um. Nesse momento, os condomínios fechados ganharam destaque no Brasil, tornando-se assim o sonho de consumo das classes mais privilegiadas, sendo a nova tendência de moradia.

Conforme Caldeira, "esses espaços encontram no medo da violência [...] justificativas e vêm atraindo cada vez mais aqueles que preferem abandonar a tradicional esfera pública das ruas para os pobres, os 'marginais' e os sem-teto" e desta que espações reforçados geram cidades fragmentadas. Fragmentação essa espacial e social, pois há uma grande diferença dos que vivem cercados pelos muros e os que se encontram fora deles, visto que os condomínios tendem a ser ambientes mais homogêneos. Dessa maneira a heterogeneidade é vista como uma forma de vida insegura, assim a relação destes com a cidade passa a ser evitada e as vias públicas servem apenas para a circulação, geralmente dentro de seus veículos particulares, pois as calçadas e o transporte público passam a ser para as classes inferiores. As ruas deixam de ser espaços de sociabilidade (Caldeira, 1997). Apesar de ser mais um princípio da distinção social, há necessidade da utilização dos automóveis, pelo fato de que esses condomínios são 


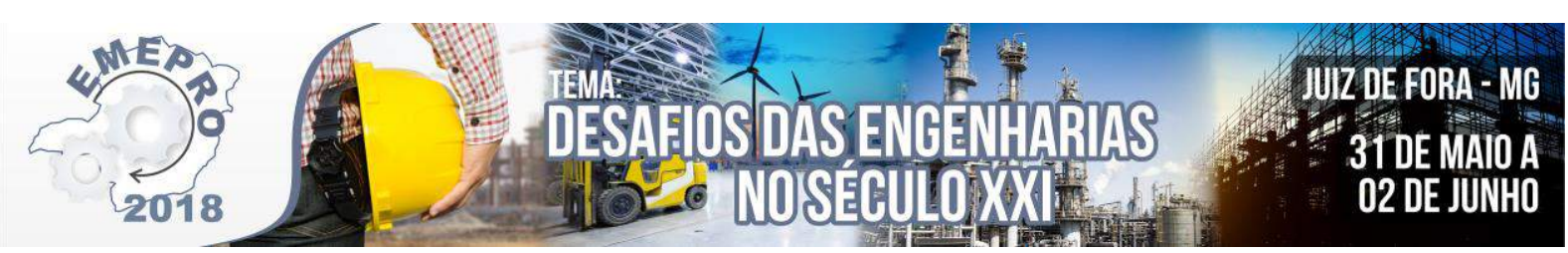

localizados distantes das áreas de ofertas de trabalhos e serviços públicos, e muitas vezes não são atendidos por transporte público. Esse distanciamento implica na ampliação dos limites das cidades, fazendo com que o atendimento de serviços de infraestrutura básica tenha que expandir o seu atendimento, proporcionando um aumento dos valores de ofertas, pois para alcançar esses locais, será necessário passar por vários vazios urbanos, chegando à conclusão de que as tendências do mercado imobiliário geram uma influência negativa quando se trata da questão social e urbanística, em função, da segregação, da negação aos espaços públicos e da necessidade de estender as redes de serviços básicos.

\subsection{Certificação}

Nos processos de certificação, é necessária a criação de esquemas que irão determinar parâmetros para a conferência da certificação do empreendimento em questão, colocando as precauções com o meio ambiente, com os meios naturais, usuários e com a sociedade (VALENTE, 2009).

O que se entende com o que pode ser considerado sustentável é a melhor maneira de avaliar essa sustentabilidade, podendo variar entre certificações. A realidade das diferentes nações onde são desenvolvidos, estão inseridas dentro de cada um dos processos econômico, social e ambiental, podendo gerar alguns problemas na implantação desses métodos em outras partes do mundo.

A certificação relacionada a edifícios exige uma maior harmonização do edifício com o entorno que o circunda, mas já o desenvolvimento de áreas urbanas demanda critérios de avaliação de certificação mais específicos, fazendo com que a certificação própria seja um documento indispensável para bairros (LEITE, 2011). Quando se trata de certificação de bairros há duas certificações que se destacam no cenário da construção civil no Brasil, que são, LEED ND (Leadership in Energy Environmental Design for Neighborhood Development), que é realizada pela Green Building Coucil Brasil, que acompanha os critérios de avaliação americano e o sistema de certificação AQUA (Alta Qualidade Ambiental) especificamente para bairros, desenvolvido pela Fundação Vanzolini, que vem tomando como base o sistema francês HQE (Haute Qualité Environnementale), que tem uma maior proximidade com a realidade do cenário brasileiro.

\subsubsection{Objetivos da certificação}

As certificações, por meio de um selo, atribuem qualidade ao empreendimento, somando a este uma maior credibilidade, o qualificando quanto a uma característica única ou a um grupo delas, facilitando quanto à busca por informação, e contribuindo para a decisão.

Os selos de certificação ambiental são uma forma de alerta a educar os atuais consumidores e os futuros sobre os impactos ambientais podem causar, uso e descarte de produtos, acarretando uma mudança ao padrão de consumo, fazendo com que ocorra a redução dos impactos negativos sobre o meio em que habitam (HAMZA, 2012).

Com a certificação realizada, a empresa certificadora assume o compromisso de acompanhar o desenvolvimento deste bairro desde a sua concepção. A realidade do projeto deve ser avaliada e as questões propostas relacionadas à sustentabilidade, definir e detectar a conduta sustentável do projeto, e o alvo a que a certificação tem o intuito de atingir. O órgão certificador deverá passar normas e instruções que deverão ser seguidas pela equipe responsável pelo empreendimento. O projeto irá sendo avaliado de acordo com o caminhar pelo processo de qualificação. A certificação ocorre em etapas que vão ocorrendo de acordo 


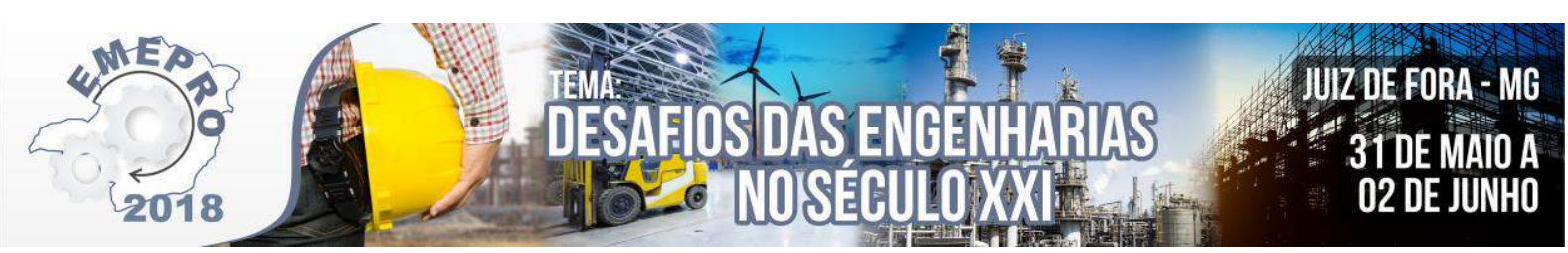

com a execução do projeto. Se a execução atender com todas as etapas propostas pela organização, ao fim da execução, este recebe um selo que o certifica como um produto sustentável, e de acordo com o seu grau de sustentabilidade.

\subsubsection{Vantagens na certificação}

Os empreendimentos certificados trazem vantagens para os clientes, as empresas e o próprio meio ambiente. A seguir são apresentados no QUADRO 1 algumas dessas vantagens.

Quadro 1 - Vantagens da certificação.

\begin{tabular}{|c|l|}
\hline BENEFICIADOS & \multicolumn{1}{|c|}{ VANTAGENS } \\
\hline Empresa & $\begin{array}{l}\text { Abertura de novos mercados; Aumento de credibilidade frente ao mercado; Redução de } \\
\text { acidentes ambientais; Redução com os custos devidos aos acidentes ambientais; Redução na } \\
\text { utilização dos recursos naturais; Redução nos custos com utilização de mão de obra } \\
\text { qualificada. }\end{array}$ \\
\hline Clientes & $\begin{array}{l}\text { Conservação de recursos naturais; Redução da poluição; Incentivo a reciclagem; Produtos e } \\
\text { processos mais limpos. }\end{array}$ \\
\hline Meio Ambiente & Conservação de recursos naturais; Redução da poluição; Incentivo a reciclagem. \\
\hline
\end{tabular}

Fonte: Melhado, 2009

As empresas adotam a estratégia ambiental por motivos como: sentido de responsabilidade ecológica, requisitos legais, salvaguarda da empresa, imagem, proteção de pessoal, pressão de mercado, qualidade de vida e lucro. (DONAIRE, 1999).

A exploração do tema sustentabilidade já é feito por muitas incorporações, por meio da vinculação dos benefícios que um projeto sustentável proporciona. Porém é preciso atenção para verificar a veracidade da propaganda anunciada pelas empresas, quanto a isso a credibilidade de um selo de certificação se faz indispensável ao cliente.

As vantagens de um bairro sustentável podem ser percebidas a longo prazo para as empresas de incorporação imobiliária, apesar de grandes investimentos iniciais, as vantagens em se planejar o ambiente onde serão lançados os empreendimentos imobiliários futuros agem a favor da viabilização do projeto.

A empresa passa a ser reconhecida no mercado por possuir princípios sustentáveis, o que agrega credibilidade à marca, propiciando o surgimento de novos negócios. Linhas de financiamento especiais já são fornecidas às empresas que investem em projetos sustentáveis e por vezes podem receber atenção diferenciada pelo poder público, como maior agilidade nos processos de licenciamento. $\mathrm{O}$ conceito de um marketing focado nas qualidades sócio ambientais, garantidas pela certificação do bairro, pode facilitar a venda dos empreendimentos desenvolvidos na região, e consequentemente a antecipação de receitas.

\subsubsection{Metodologia de avaliação da certificação}

Os métodos adotados para a certificação são baseados em três quesitos, relacionados à análise estatística, baseados em créditos e baseados no desempenho. Cada um desses quesitos gera suposições diferentes dados a metodologia diferenciada, conforme é demonstrado abaixo (PÓS-GRADUAÇÃO UFSC, 2008):

- Análise Estatística: os valores estatísticos de um edifício de uma população são usados como referência para a criação de uma nova marca com redução do uso energético. Necessita de muitos dados para a produção de uma amostra; 


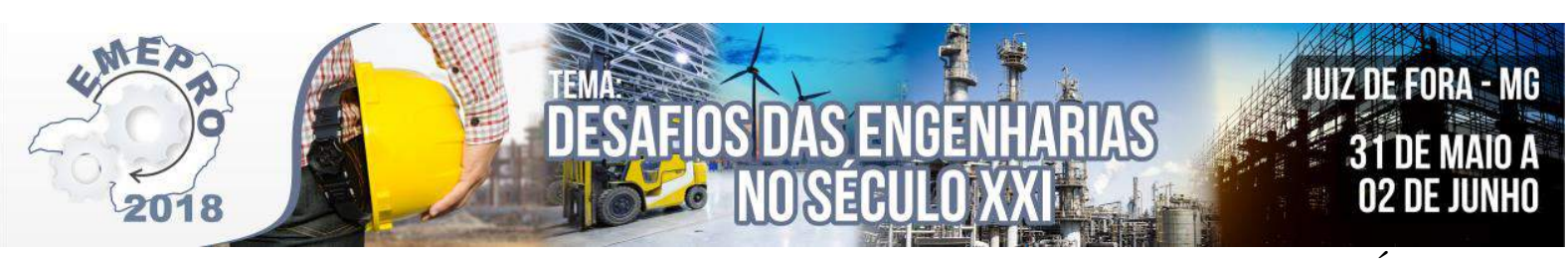

- Baseados em Pontos: é um sistema baseado em créditos que geram um índice. É feita uma ponderação por categorias. $\mathrm{O}$ empreendimento pode ser classificado em níveis ambientalmente corretos. Esse sistema fornece padrões e diretrizes de projetos para poder medir a eficiência e se está em sintonia com o ambiente;

- Baseado em Desempenho: é um sistema baseado mais na gestão e no processo. Todas as categorias devem apresentar desempenho pelo menos igual ao normalizado. $\mathrm{O}$ empreendimento é ou não é ambientalmente correto, não há escalas de atribuição do certificado.

\subsubsection{Certificação AQUA BAIRROS}

Devido ao crescimento da demanda por projetos a nível nacional, em janeiro de 2007, deu-se início a um experimento piloto com dez trabalhos, que tinham como objetivo, que em um tempo determinado de três anos iriam testar in loco o "Processo de Qualidade Ambiental em Assentamentos Urbanos” (FUNDAÇÂO VANZOLINI, 2011).

Em 2009, com os resultados obtidos das experiências realizadas, foi elaborada uma nova metodologia de certificação ambiental. A reformulação de um guia com a finalidade de sustentabilidade urbana levou à formulação de certificação AQUA dirigida para bairros e loteamentos.

O método de avaliação adotado pelo processo de certificação está embasado no desempenho; a aderência não é obrigatória, ela se dá de forma espontânea. O método está apoiado nas normas de qualidade ISSO 9001, ISSO 14001 e no registro de Abordagem Ambiental do Urbanismo criado pela agência francesa ADEME (Agência do Meio Ambiente e de Controle da Energia). Este foi adaptado de acordo com os parâmetros brasileiros pela Fundação Vanzolini, fundação esta sem fins lucrativos encarregados pela certificação AQUA BAIRROS.

O certificado AQUA BAIRROS, tem o intuito de integrar o empreendimento ao seu entorno, para que não ocorram impactos ambientais em grande escala, considerando as fases de execução do projeto. Sendo assim, busca por associar as questões econômicas, sociais e ambientais do empreendimento sustentável, buscando um ambiente mais econômico e social, com o objetivo de um melhor bem-estar.

Todos os empreendimentos considerados como loteamentos ou bairro podem realizar esses processos, não importando o contexto territorial no qual está inserido, sua dimensão e o destino empregado a esta região, por ter ampla qualidade, sua utilização se torna arqueável. Esta certificação pode ser atribuída a todos os agentes ligados ao empreendimento, tanto os setores particulares quanto os dos setores públicos.

As referências para o processo de certificação e o registro que expõe o sistema AQUA BAIRROS, é constituído por outros dois seguimentos de extrema importância, o SGB (Sistema de Gestão do Bairro) e a QAB (Qualidade Ambiental do Bairro).

O SGB é a base para o processo que administra a execução e eficácia de um projeto; sua finalidade é organizar e indicar as etapas do empreendimento, por meio das maneiras apropriadas à criação do bairro, com o intuito de alcançar uma melhor harmonia entre os stakeholders (público estratégico), atingindo os princípios de um bairro sustentável. O SGB é constituído por seis etapas importantes para o desenvolvimento do projeto e uma fase pósoperacional de acompanhamento, conforme demostrado no QUADRO 2. 


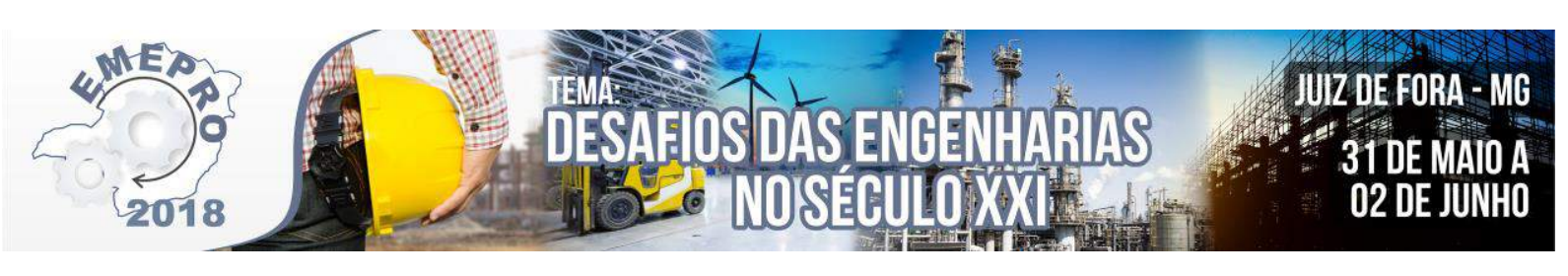

Quadro 2 - Etapas SGB (Sistema de Gestão do Bairro)

\begin{tabular}{|c|l|}
\hline \multicolumn{2}{|c|}{ SGB - Coordenação/Participação/Avaliação } \\
\hline 1 & Lançamento \\
\hline 2 & Análise inicial \\
\hline 3 & Negociação e escolha dos objetivos \\
\hline 4 & Concepção do projeto - Escolha das ações \\
\hline 5 & Realização \\
\hline 6 & Balanço - Capitalização \\
\hline 7 & Acompanhamento dos desempenhos \\
\hline & Fonte: FUNDAÇÂO VANZOLINI, 2011
\end{tabular}

Já o QAB tem o desafio de trazer o princípio da sustentabilidade para o cenário de desenvolvimento urbano, harmonizando as duas dimensões, para a elaboração de um projeto sustentável, coeso e coerente como um todo. O QAB deve servir como um apoio à equipe que irá realizar a elaboração do projeto fazendo ponderações globais de seu desenvolvimento, desde o dado momento do início dos trabalhos até a definição do programa de ações desenvolvidas para tornar o bairro sustentável. Com a finalidade de ajudar a concepção de um empreendimento, de maneira a adotar os conceitos globais de um bairro sustentável, são propostos dezessete temas ligados à sustentabilidade de áreas urbanas. Esses temas são separados em outros três grandes objetivos do desenvolvimento sustentável: assegurar a integração e a coerência com o tecido urbano e as outras características do território, preservar os recursos naturais e melhorar a qualidade ambiental e sanitária do bairro, promover a integração na vida social e fortalecer as dinâmicas econômicas (FUNDAÇÃO VANZOLINI, 2011).

\section{Considerações Finais}

Os conceitos para que um determinado bairro seja considerado como um empreendimento sustentável e a importância de um planejamento urbano foram expostos como uma maneira de impedir os problemas mais comuns à vida em comunidades nos centros urbanos.

Foram reconhecidas as dificuldades encontradas envolvendo o assunto. A busca em tornar o meio urbano em uma região onde se encontra uma melhor condição de vida humana, o desenvolvimento dos bairros sustentáveis, esbarram no obstáculo de uma demanda por diversos estudos e análises, considerando as especificidades do contexto urbano.

A implantação do conceito de bairro sustentável no cenário brasileiro é um grande avanço quanto à importância de centros urbanos com melhor qualidade de vida, que possuem uma grande dependência de frente importante, como, o poder público e privado, e seus próprios habitantes.

O processo de certificação AQUA BAIRROS, veio como uma ferramenta com o intuito de ajudar na qualificação dessas regiões. Foram expostas as qualidades dos métodos de avaliação e os passos para a certificação do empreendimento.

Mesmo estando evidente a necessidade de ir à procura de um meio urbano mais agradável aos que nele vivem, as atitudes e a busca por sustentabilidade partem nas maiorias 


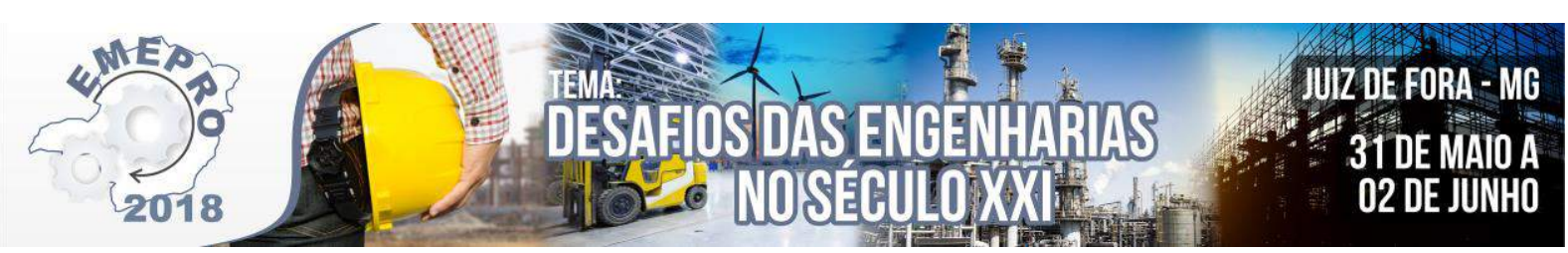

das vezes de iniciativas privadas. Com a apresentação de projetos relacionados a essa questão, a competitividade vem crescendo e com isso surgindo mais empreendimentos sustentáveis. A questão de edifícios sustentáveis e suas certificações são muito comentadas no cenário da construção civil, mas se é dada pouca ênfase ao que se trata da sustentabilidade do âmbito urbano, das vantagens oferecidas por sua utilização e de como esse meio de certificação própria disponíveis no mercado podem ser utilizadas como guia quanto a adição dessas áreas.

\section{Referências}

ARANHA, André. Estocolmo, Rio, Joanesburgo, o Brasil e as três conferencias ambientais das Nações Unidas. Brasilia: IRBr. 2006. 22 p.

BRITO, J.A. Cidade versus entulho. In: Seminário de Desenvolvimento Sustentável e a Reciclagem na Construção Civil, 2., São Paulo, 1999. Anais. São Paulo, Comitê Técnico CT206 Meio Ambiente (IBRACON), 1999. 67p.

CALDEIRA, T. P. R. Segregação urbana, enclaves fortificados e espaço publico. 3. ed. São Paulo: Editora 34. 1997. $343 \mathrm{p}$.

CORRÊA, Juliane. Educação a distância: orientações metodológicas. 5 ed. São Paulo: Artmed Editora, 2009. 195p.

DONAIRE, Denis. Gestão ambiental na empresa. 2. ed. São Paulo: Atlas. 1999. 176 p. Disponível em: https://www.skoob.com.br/livro/edicoes/160622/edicao:179251 > Acesso: 16 de outubro de 2017.

DUARTE, Denise. LABAUT: Laboratório de Controle Ambiental e Eficiência Energética. 3 ed. São Paulo, 2004. $142 \mathrm{p}$.

FRANZ, U. B. Por nossas cidades sustentáveis. 2011. Viçosa. 12 p. Conselho Federal de Engenharia, Arquitetura e Agronomia. Viçosa. 2011.

FOLADORI, Guillermo. Um olhar antropológico sobre a questão sobre a questão ambiental. 2 ed. Rio de Janeiro: Mana, 2004, 162 p. v. 10.

FUNDAÇÃO VANZOLINI. Processo de certificação. 2011 Disponível em: https://vanzolini.org.br/certificacao/ > Acesso: 17 de outubro de 2017.

GONÇALVES, L. M. Os vazios urbanos como elementos estruturador do projeto urbano. Algares. 2010. $147 \mathrm{f}$. Universidade do Minho, Algares - Portugal, 2010.

HAMZA, K. M.; DALMARCO, D. de A. S. As certificações sustentáveis e sua relevância para o consumo consciente e os negócios. Revista de Administração, Contabilidade e Sustentabilidade. Rio de Janeiro. v. 2, n. 2, p. 1-20, ago. 2012.

LEITE, V. F. Certificação ambiental na construção civil - Sistemas LEED AQUA. Belo Horizonte. 2011. 59 p. Monografia de Graduação em Engenharia Civil - Universidade Federal de Minas Gerais, Belo Horizonte, 2011.

PIMENTEL, T. M. Desenvolvimento de bairros sustentáveis. Rio de Janeiro. 2013. 53 p. Monografia de graduação em Engenharia Civil. Universidade Federal do Rio de Janeiro, Rio de Janeiro, 2013.

PINTO, T. P. Metodologia para a gestão diferenciada de resíduos sólidos da construção urbana. São Paulo. 1999. 189 f. Tese (Doutorado) - Escola Politécnica, Universidade de São Paulo, São Paulo, 1999.

VALENTE, J. P. Certificação na construção civil: comparativo entre LEED e HQE. 2009. 71 f. Projeto de Graduação de Engenharia Civil - Universidade Federal do Rio de Janeiro, Rio de Janeiro, 2009.

WORLD COMMISSION ON ENVIRONMENT AND DEVELOPMENT, 1987, Oxford, From One Earth to One World: An Overview, 1987, 36 p., v.14. Disponível em: <http://public.wsu.edu/ susdev/WCED87.html> Acesso em: 10 de outubro de 2017. 


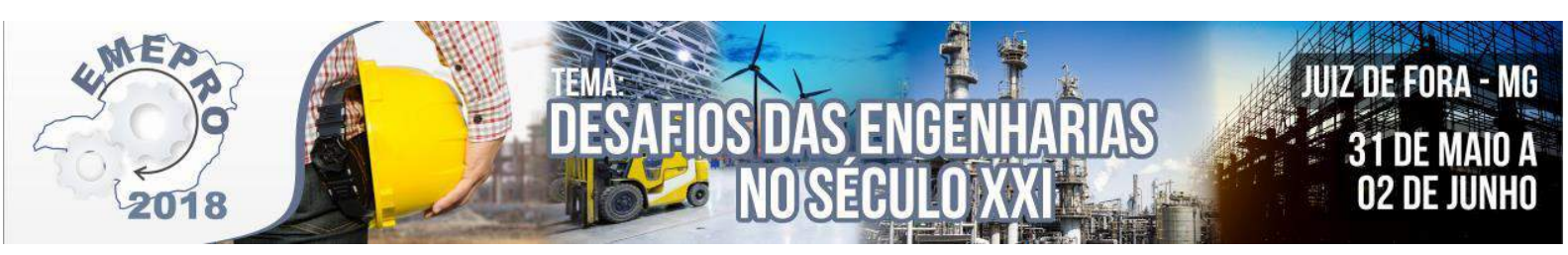

\title{
A análise da colaboração dos usuários com descarte responsável de móveis usados
}

\author{
Brigitte Lisset Rodríguez Castañeda (UAM) bri.0727@ hotmail.com \\ Víctor Alberto Zavaleta Rodríguez (UAM) vazaro@hotmail.com \\ Carlos Eduardo Gavilán Mezones (UAM) car_los9108@ hotmail.com \\ Paulo Sergio Pereira Salcedo (UAM) pereira.salcedo.p@gmail.com \\ Cristian Xavier Cruzado Alvarez (UAM) cristiancruzado15@gmail.com
}

Resumo: O presente trabalho tem como objetivo analisar a colaboração dos usuários com descarte responsável de móveis usados, de acordo com a Política Nacional de Resíduos Sólidos em 2010 no Brasil. Se tem como objetivo analisar o comportamento dos usuários no gerenciamento destes resíduos com a finalidade de identificar os principais barreiras no processo de descarte mediante os pontos de coleta, campanhas e empresas que realizam os serviços de reciclagem, retrabalho e coleta de móveis. Para atingir ao objetivo proposto, foi realizado uma survey exploratória aos usuários de diferentes bairros no município de São Paulo. Os resultados obtidos apontam para as diferentes práticas e comportamento dos usuários com seus resíduos móveis domésticos. Com os resultados deste trabalho espera-se contribuir com o bom gerenciamento de resíduos sólidos moveleiros no município de São Paulo.

Palavras-chave: Setor Moveleiro; Impacto Ambiental; Resíduos Sólidos.

\section{Introdução}

A inovação e tecnologia têm sido os dois grandes pilares do crescimento empresarial e social nos últimos anos, trazendo consequências positivas para o desenvolvimento econômico como o aumento na qualidade de vida das pessoas, satisfação do cliente baseada em produtos mais eficientes, entre outras. No entanto, assim como existem benefícios, esse crescimento tecnológico trouxe aspectos prejudiciais para a comunidade, pois o comportamento dos consumidores frente aos produtos disponíveis não tem sido o ideal na disposição final, causando um aumento na quantidade de resíduos expóstos ao meio ambiente, trazendo como sequela um avanço irreparável em termos de poluição ambiental.

Sobre o crescimento empresarial, segundo De Sá (2017) o setor moveleiro no Brasil "[...]reúne atualmente 17 mil companhias dedicadas à confecção de móveis, distribuídas nas cinco regiões brasileiras: Região Sul, Região Sudeste, Região Centro-Oeste, Região Norte e Região Nordeste". Além disso, é um setor que faz parte do dia a dia do consumidor, por isso é importante analisar o comportamento dos usuários, pois os mesmos contribuem ou prejudicam o meio ambiente, e tem grande responsabilidade no descarte responsável dos móveis.

A proposta de execução desta pesquisa será desenvolvida tendo como campo de estudo a indústria moveleira e a colaboração dos usuários no descarte responsável de móveis usados, pois "a indústria moveleiro emprega cerca de 300 mil trabalhadores diretos e gera 1,5 milhões de empregos indiretos" (PRADO, 2011, apud REIS et al., 2014, p.6); justificando sua relevância para a economia nacional. 


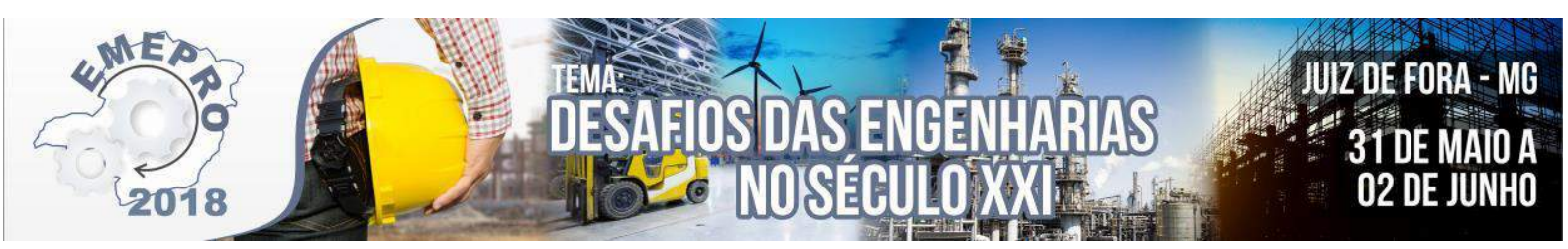

Porém, para a análise adequada dos usuários, é necessário conhecer mediante uma survey exploratória os principais aspectos e papeis de cada um deles, pois o presente trabalho busca analisar o comportamento dos usuários no descarte de móveis usados; para assim definir se o comportamento no processo de descarte é o adequado e qual é o relacionamento com a realidade do setor.

\section{Referencial teórico}

Atualmente no Brasil, a cadeia produtiva no setor de móveis, segundo o Instituto de Pesquisas Tecnológicas (2002) constitui-se dos seguintes blocos: origens, insumos, indústria de móveis, distribuição e consumidor. Em um estudo realizado no setor de móveis pelo Governo de Santa Catarina e o Sebrae (2011), o estado de São Paulo é o quarto maior fornecedor do setor. Os usuários de móveis utilizam diferentes canais no momento da compra, tais como: compra direta com o fornecedor, varejista, atacadista e compra online. Segundo Moraes e Nassar (2002 apud Silva; Neto, 2013), a indústria de móveis é desenvolvida nos polos Sul e Sudeste do Brasil: Rio Grande do Sul, Santa Catarina, Paraná, São Paulo, Minas Gerais e Rio de Janeiro.

Para a fabricação de móveis no Brasil, a maioria dos materiais utilizados apresentam uma grande heterogeneidade, dentre eles materiais como: madeira, metais, plásticos e vidro como materiais fundamentais, nos quais são usados de acordo a classificação, por exemplo: residenciais, escritório e institucionais, gerando grandes quantidades de resíduos sólidos, sendo o estado de São Paulo o maior gerador deles no Brasil, com uma população de mais de 44 milhões de habitantes e 645 municípios (Instituto Brasileiro d Geografia e Estatística, 2010). Para Associação Brasileira de Empresas de Limpeza Pública e Resíduos Especiais (2016) no Brasil, a geração dos resíduos sólidos tem aumentado ao longo do tempo, em 2008 foi de 53 milhões de toneladas, no ano 2009 houve uma expansão de 7,7\% gerando aproximadamente 57 milhões de resíduos sólidos; sete anos depois até 2016, o Brasil gerou aproximadamente 78,3 milhões de toneladas.

No entanto, existem um conjunto de ações, procedimentos e meios para viabilizar a restituição dos resíduos ou objetos que já não possuem uso ao setor empresarial e doméstico, regulados na Lei $\mathrm{n}^{\circ}$ 12.305, no capítulo Definições da Política Nacional de Resíduos Sólidos (BRASIL, 2010).

Além disso, existem alguns métodos estratégicos de recuperação de resíduos sólidos, com objetivo de resgatar objetos descartados ou em desuso. Segundo Berté e Mazzarotto (2013 apud Lomasso et. al. 2015), um desses métodos é a reciclagem, que visa o desvio de objetos destinados ao lixo para transformação de outra matéria prima. Outra estratégia é a recuperação e o reuso dos objetos velhos que segundo Machado (2014) no segmento citado é muito comum. Por fim, a redução é um dos métodos menos utilizados, pois consiste em reduzir o máximo de resíduos sólidos na fabricação dos móveis, fazendo com que as fabricas modifiquem o seu processo de produção.

Com a inclusão da Política Nacional de Resíduos Sólidos, a responsabilidade da gestão dos resíduos é compartilhada entre poder público, fabricas e consumidores. O usuário tem como responsabilidade colocar os produtos a disposição em locais previamente adequados marcados em toda cidade como pontos de coleta nas ruas. Estes têm a obrigação de, segundo a Política Nacional de Resíduos Sólidos, fazer a separação seletiva corretamente segmentando os resíduos: papel, plástico, metal e vidro em pontos de coleta de materiais recicláveis, conforme define a Lei $\mathrm{n}^{\circ} 12.305$ (BRASIL, 2010): 


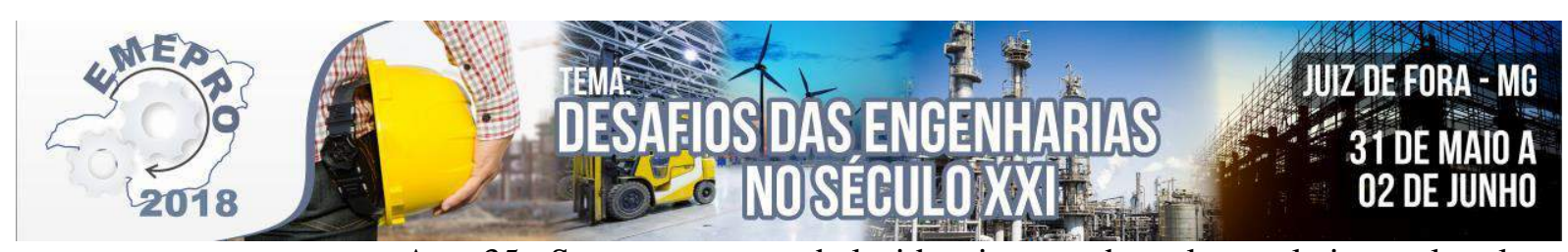

Art. 35. Sempre que estabelecido sistema de coleta seletiva pelo plano municipal de gestão integrada de resíduos sólidos e na aplicação do art. 33, os consumidores são obrigados a:

I - Acondicionar adequadamente e de forma diferenciada os resíduos sólidos gerados;

II - Disponibilizar adequadamente os resíduos sólidos reutilizáveis e recicláveis para coleta ou devolução (BRASIL, 2010).

Além disso, uma maneira de promover a participação dos consumidores no sistema de coleta seletiva é instituir incentivos econômicos pelo poder público municipal, conforme a Política Nacional de Resíduos Sólidos (BRASIL, 2010).

No entanto, ainda existem muitos consumidores que descartam seus resíduos sem consciência ambiental e preocupação com a poluição de acordo com Sousa et. al. (2016)

\section{Metodologia}

Na primeira etapa, foi realizado uma pesquisa bibliográfica com o objetivo de apurar as barreiras e conhecer o setor moveleiro na cidade de São Paulo.

A natureza deste artigo corresponde a uma pesquisa aplicada, pois de acordo com Silva e Menezes (2005), este tipo de pesquisa significa a busca de gerar conhecimento com o objetivo de solucionar problemas que envolvem interesses locais, assim como este trabalho busca analisar o comportamento do usuário no descarte responsável de móveis em São Paulo.

Além disso, o trabalho também tem a característica de uma pesquisa quantitativa, pois busca conhecer opiniões de um determinado tema traveis de uma survey. A Survey segundo Freitas, Oliveira, Saccol e Moscarola (2000) é um procedimento para a coleta de dados ou conhecimento de um grupo de pessoas sobre um determinado tema.

Por tanto, é importante determinar em primeiro lugar o tamanho da amostra, com uma margem de erro estimado de 0,05 e confiabilidade de $80 \%$, sendo necessário minimamente 164 respostas. Para a análise dos dados, foi utilizada métodos de estatística descritiva. Os aspectos considerados para a análise da colaboração do usuário no descarte responsável de móveis em São Paulo estão listados no Quadro 1.

\begin{tabular}{|l|l|}
\hline CATEGORIA & DESCRIÇÃO \\
\hline Caracterização & $\begin{array}{l}\text { Conhecer os dados dos usuários para fazer uma separação de mostra em } \\
\text { quanto a Idade, Escolaridade e Estado Civil. }\end{array}$ \\
\hline $\begin{array}{l}\text { Caracterização dos } \\
\text { Resíduos }\end{array}$ & $\begin{array}{l}\text { Definir a frequência de descarte e o tipo dos principais resíduos } \\
\text { moveleiros que os usuários descartam }\end{array}$ \\
\hline $\begin{array}{l}\text { Responsabilidade } \\
\text { Social }\end{array}$ & $\begin{array}{l}\text { Identificar a responsabilidade social dos usuários com respeito às Leis } \\
\text { conhecidas, as campanhas feitas e o reciclagem dos móveis }\end{array}$ \\
\hline $\begin{array}{l}\text { Caracterização do } \\
\text { processo atual de } \\
\text { descarte dos móveis }\end{array}$ & $\begin{array}{l}\text { Conhecer qual é o processo que seguem os usuários para descartar os } \\
\text { móveis que estão para descarte. }\end{array}$ \\
\hline
\end{tabular}

Quadro 1 - Categorias de Estudo. Fonte: Os autores (2018)

\section{Análise de resultados}

Depois de definir a metodologia de pesquisa, foi coletado dados de usuários que residem no estado de São Paulo através de um questionário. 


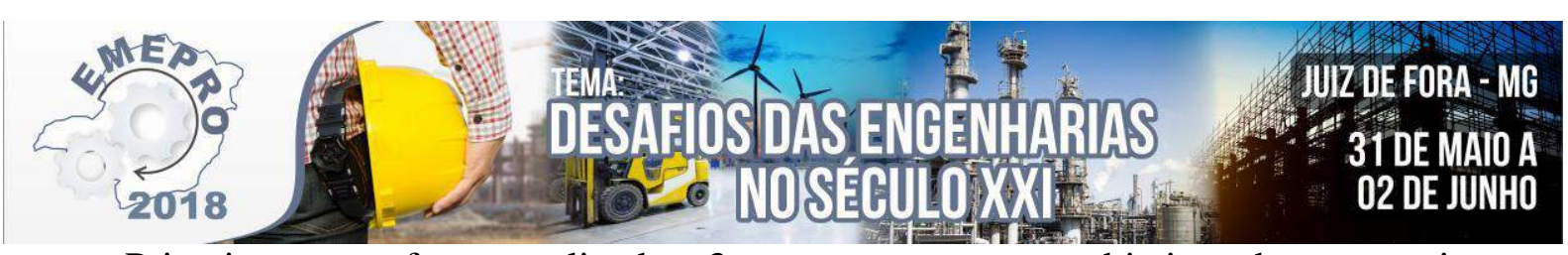

Primeiramente, foram aplicadas 3 perguntas com o objetivo de caracterizar os respondentes: gênero, idade, nível de escolaridade. Além disso foram aplicadas questões organizadas em quatro categorias: caracterização, caracterização do processo atual de descarte de móveis, caracterização dos resíduos e responsabilidade social. Algumas alternativas das questões seguem a escala Likert, sendo: (1) discordo totalmente, (2) discordo parcialmente, (3) indiferente, (4) concordo parcialmente e (5) concordo totalmente. Enquanto outras questões tiveram como alternativas, opções de materiais usados em móveis para identificar qual tipo de móvel é o mais descartado. Finalmente, obteve-se 164 respostas para a realização deste estudo.

Na primeira questão caracterizou-se aos usuários que responderam, sendo do gênero feminino 43,6\% e 56,4\% do gênero masculino conforme ilustrado na Figura 1.

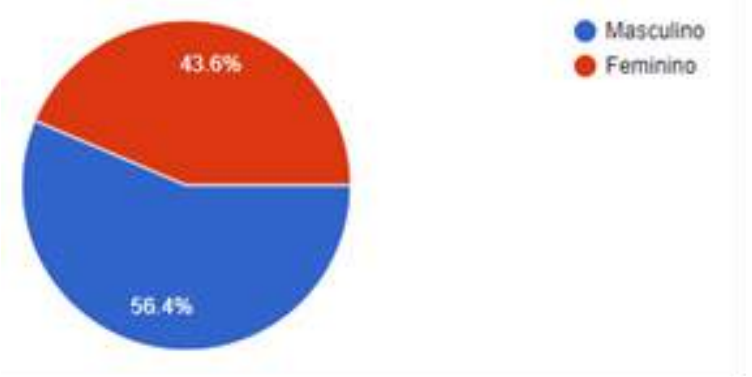

Figura 1 - Gênero. Fonte: Os autores (2018).

A Figura 2 apresenta a idade dos usuários entrevistados: $42 \%$ com idade entre 15 e 24 anos, $31 \%$ com idade entre 25 e 34 anos, e $17 \%$ com idade entre 35 e 44 anos.

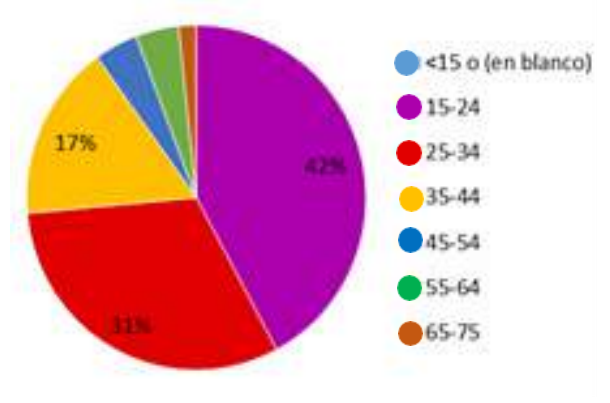

Figura 2 - Idade. Fonte: Os autores (2018)

Na Figura 3 ilustrada abaixo, foi identificado o nível de escolaridade dos usuários entrevistados. A maioria possui ensino superior completo, $71 \%$ e $12 \%$ possuem ensino pósgraduação. 

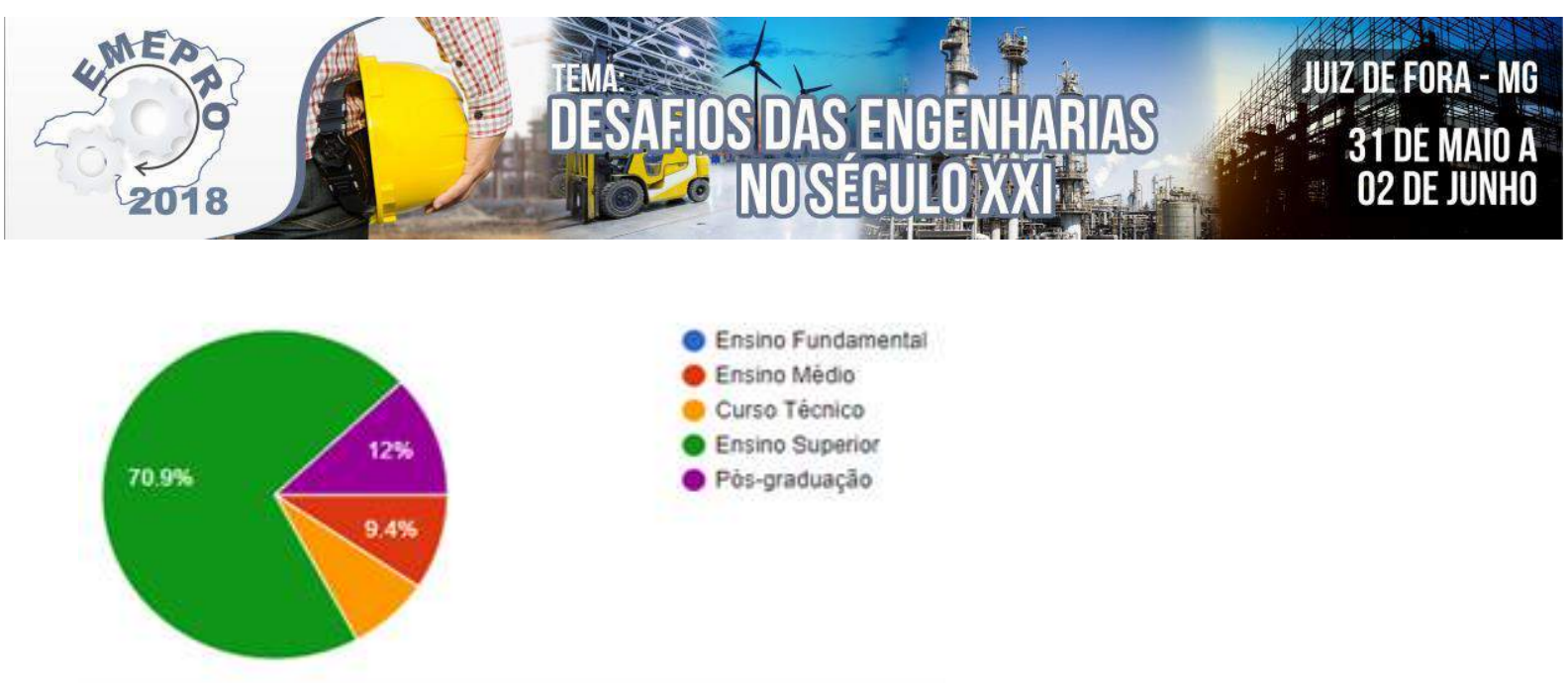

Figura 3 - Nivel de escolaridade. Fonte: Os autores (2018).

Depois de definir o segmento de investigação e identificar os aspectos básicos dos usuários como idade, nível de escolaridade e a ocupação dos mesmos, foi analisado o comportamento das pessoas no descarte de móveis usados, dentro da categoria: caracterização do processo atual de descarte de móveis.

A quarta questão ilustrada na Figura 4 foi útil para conhecer se as pessoas descartam os móveis usados de maneira adequada, obtendo respostas afirmativas correspondentes a $61 \%$ do total. Mostrando que ainda há um número significativo de pessoas que não descartam seus móveis adequadamente.

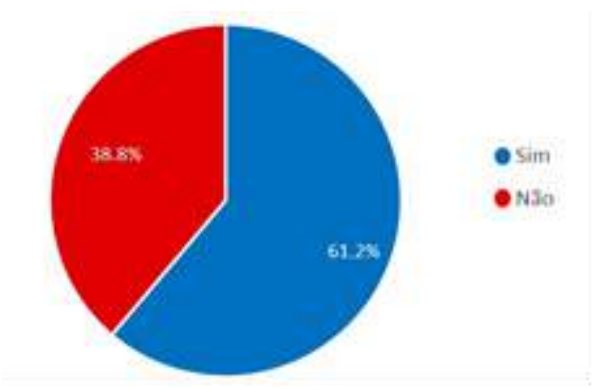

Figura 4 - Descarte de móveis adequadamente. Fonte: Os autores (2018).

No entanto, os usuários estão cientes de que seus móveis devem ser descartados corretamente para evitar desperdícios, conforme mostrado na figura a seguir. Aproximadamente 95\% dos usuários entrevistados concordam com a seguinte afirmação: "Os móveis descartados deveriam ser reutilizados em um novo processo e assim evitar desperdícios”.

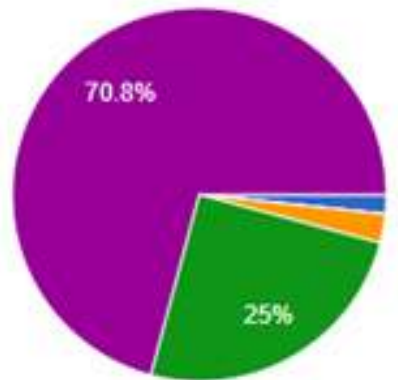

Discordo totaimente

Discordo parcialmente

Indiferente

Concordo parcialmente

Concordo totalmente

Figura 5 - Reutilização dos móveis descartados 


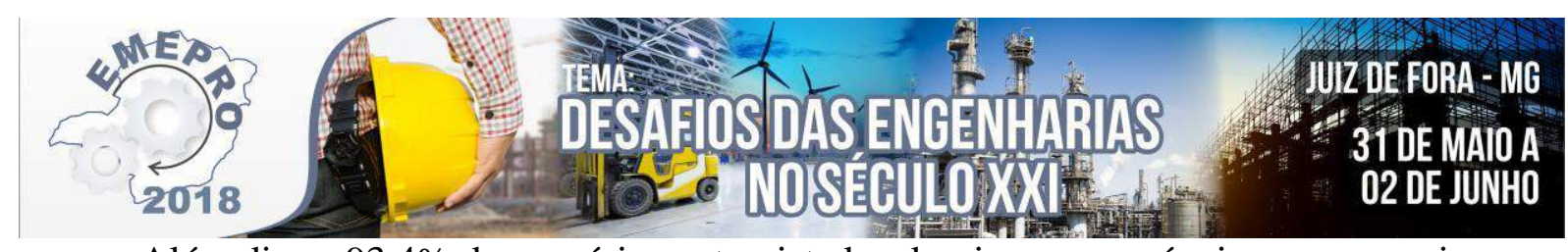

Além disso, 93,4\% dos usuários entrevistados doariam seus móveis para que sejam retrabalhados por empresas do setor.

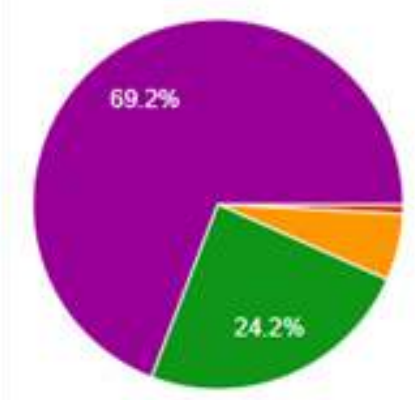

Discordo totalmente

Discordo parcialmente

Indiferente

Concordo parcialmente

Concordo totalmente

Figura 6 - Probabilidade de doação de móveis

No entanto, eles não descartam seus móveis adequadamente porque não possuem os meios necessários, como pontos de coleta e empresas dedicadas esse serviço, conforme ilustrado na Figura 7. A seguinte questão apresenta a falta de ação do Munícipio de São Paulo sobre a disponibilização de pontos de coleta adequados para móveis usados. Pois $78 \%$ dos usuários entrevistados não tem um ponto de coleta perto de casa.

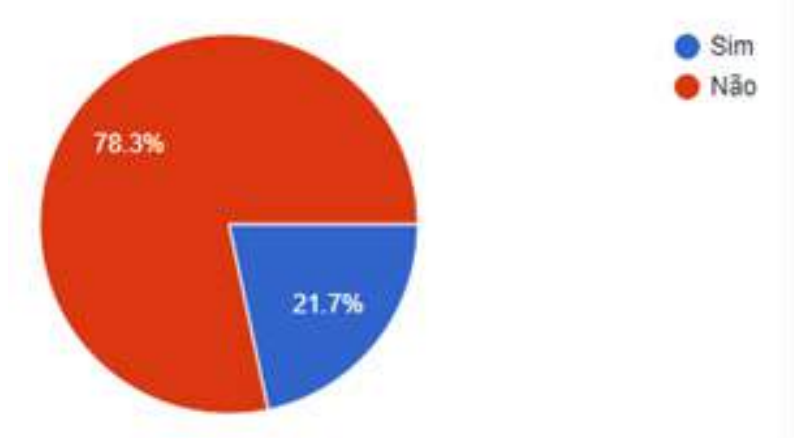

Figura 7 - Disponibilidade de pontos de coleta. Fonte: Os autores (2018).

Em relação ao conhecimento da existência de uma empresa que recolha os móveis usados, obteve-se as seguintes respostas na Figura 8: 77\% dos entrevistados não conhecem alguma empresa que recolha os móveis descartados, enquanto $23 \%$ conhecem.

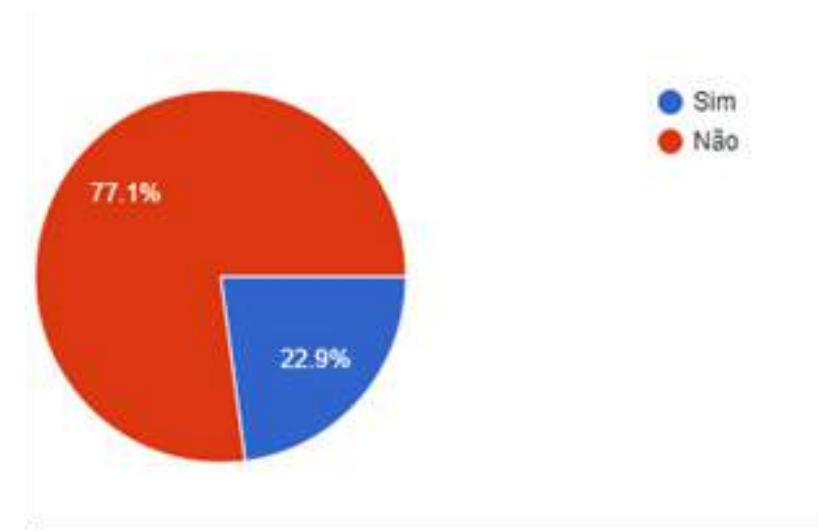

Figura 8 - Conhecimento de empresas que coletam móveis. Fonte: Os autores (2018).

Depois de analisar o comportamento dos usuários entrevistados, continuou-se com a categoria de caracterização dos resíduos. Perguntou-se qual é o tipo de móvel com maior 


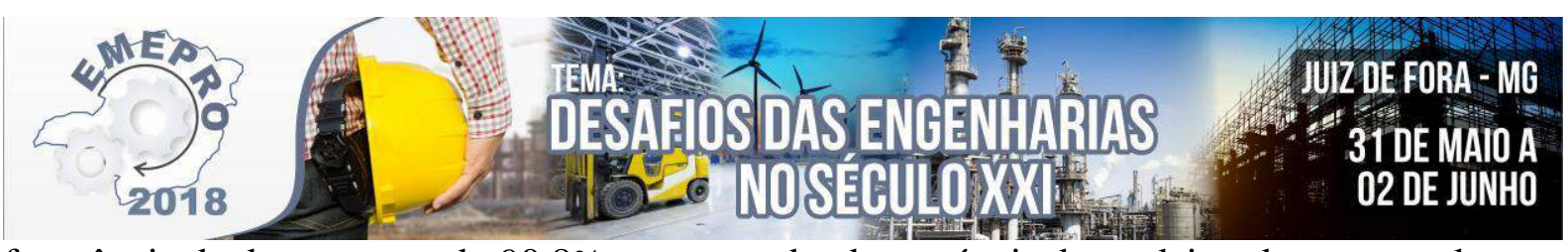

frequência de descarte, sendo 90,8\% correspondendo a móveis de madeira, demonstrando sua relevância para este artigo.

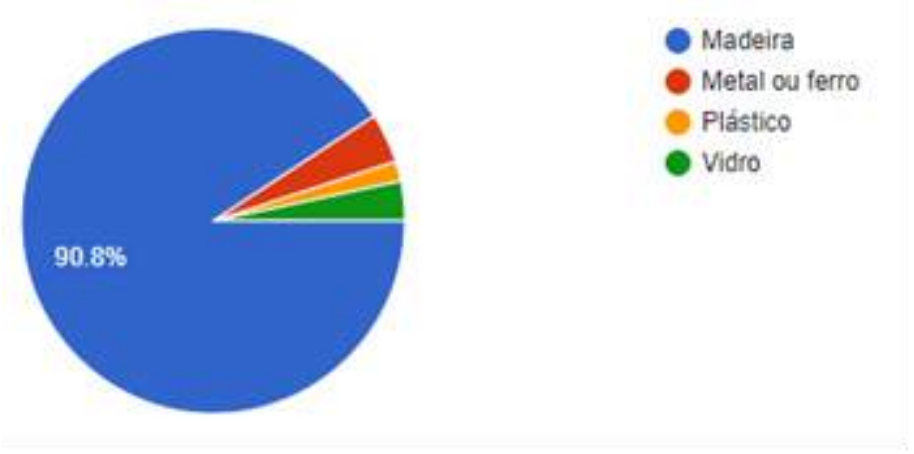

Figura 9 - Tipos de móveis descartados. Fonte: Os autores (2018).

$\mathrm{Na}$ categoria de responsabilidade social, a questão ilustrada na Figura 10 mostrou a influência das campanhas de descarte ou coleta de móveis. Os resultados estão ilustrados na figura abaixo: $45 \%$ dos usuários entrevistados concordam totalmente que as campanhas sociais influenciam o comportamento dos usuários no processo de descarte de móveis, $39 \%$ dos usuários concordam parcialmente e 9,2\% são indiferentes neste assunto. Assim, pode-se afirmar que as campanhas de descarte influenciam no comportamento dos consumidores.

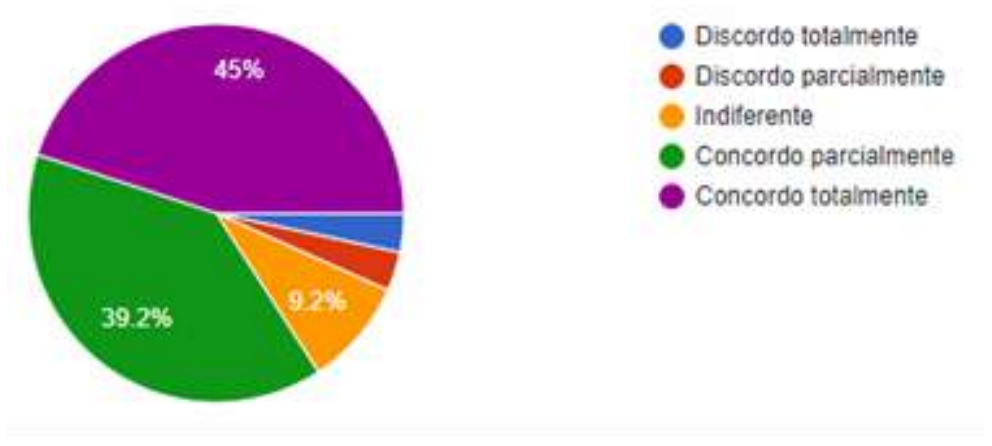

Figura 10 - Influência das campanhas de descarte ou coleta de móveis

Com a pergunta ilustrada na Figura 11 passou-se determinar a frequência dessas campanhas. Obteve-se como resultado: 45,8\% dos usuários entrevistados nunca viram uma campanha de descarte, $25 \%$ dos entrevistados quase nunca viram uma campanha e $23 \%$ deles viram um anúncio de campanha espontaneamente. Pode-se afirmar que é necessário aumentar a divulgação das campanhas.

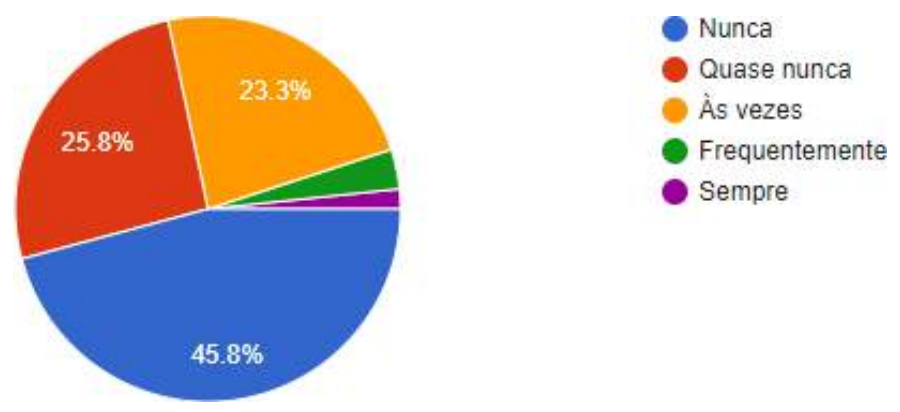

Figura 11 - Frequência de campanhas de descarte ou coleta de móveis. Fonte: Os autores (2018). 


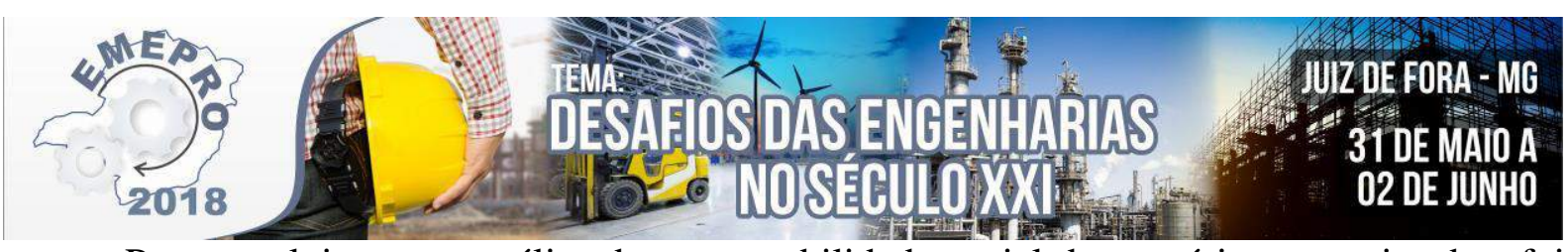

Para concluir com a análise da responsabilidade social dos usuários entrevistados, foi importante identificar se as pessoas conhecem alguma lei sobre descarte de móveis. Obteve-se os seguintes dados: $71,7 \%$ dos entrevistados desconhecem alguma Lei que regule o processo de descarte de móveis e $28 \%$ tem conhecimento de alguma norma.

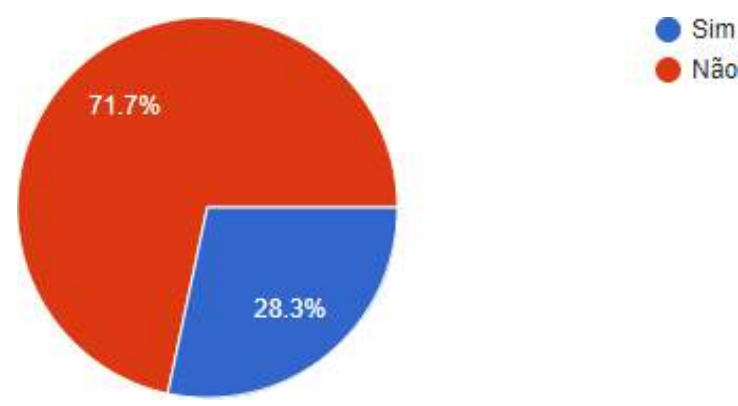

Figura 12 - Nivel de conhecimento da Lei. Fonte: Os autores (2018)

\section{Considerações finais}

O objetivo do presente artigo foi analisar o comportamento dos usuários no descarte dos móveis usados. A partir de uma estatística descritiva, foi possível verificar que a colaboração dos entrevistados com o descarte de móveis usados é irresponsável comparado ao processo adequado de descarte de móveis, isso é devido à falta de pontos de coleta de fácil acesso, pouco conhecimento de campanhas de coleta de móveis e da falta de empresas que oferecem esse serviço para a comunidade.

Pode-se afirmar que a maior limitação para conclusão desta pesquisa, foi o tempo. Entrevistou-se mais de 160 pessoas, porém, em vista a complexidade do análise do impacto ambiental no descarte de móveis, poderia ser realizada uma pesquisa para pessoas de outros municípios.

Sugere-se aprofundar o estudo ambiental no setor moveleiro relacionado ao processo de descarte de móveis, envolvendo em estudos futuros aos demais Stakeholders da indústria moveleira como fornecedores, fabricantes, cooperativas ou empresas de reciclagem.

\section{Referências}

ASSOCIAÇÃO BRASILEIRA DE EMPRESAS DE LIMPEZA PÚBLICA E RESÍDUOS ESPECIAIS. Panorama dos Resíduos Sólidos no Brasil 2015. São Paulo: Associação Brasileira de Empresas de Limpeza $\begin{array}{lllllll}\text { Pública e } & \text { Resíduos } & \text { Especiais, } & 2016 . & 64 & \text { p. } & \text { Disponível }\end{array}$ <http://www.abrelpe.org.br/Panorama/panorama2016.pdf>. Acesso em: 07 out. 2017.

BRASIL (Estado). Lei n ${ }^{\circ}$ 12.305, de 02 de agosto de 2010. Lei $\mathrm{N}^{\circ} 12.305$, de 2 de agosto de 2010. Disponível em: <http://www.planalto.gov.br/ccivil_03/_Ato2007-2010/2010/Lei/L12305.htm>. Acesso em: 05 out. 2017.

DE SÁ, Sueli. Setor moveleiro aumenta participação na produção industrial da Paraíba, diz presidente da FIEP. 2017. Publicado por Sistema Indústria. Disponível em: <http://www.fiepb.com.br/noticias/2017/04/24/setor_moveleiro_aumenta_participacao_na_producao_industrial_ da_paraiba_diz_presidente_da_fiep>. Acesso em: 28 mar. 2018.

FREITAS Henrique; OLIVEIRA Miriam; SACCOL Amarolinda e MASCAROLA Jean. O Metodo de Pesquisa Survey. Revista de Administração da USP, RAUSP, São Paulo/SP, v. 35, n. 3, p.105-112, Jul-Sep. 2000.

INSTITUTO BRASILEIRO DE GEOGRAFIA E ESTATÍSTICA. Brasil tem mais de 207 milhões de habitantes, segundo IBGE. 2017. Elaborada por Daniel Silveira. Disponível em: <https://g1.globo.com/economia/noticia/brasil-tem-mais-de-207-milhoes-de-habitantes-segundo-ibge.ghtml>. Acesso em: 07 out. 2017. 


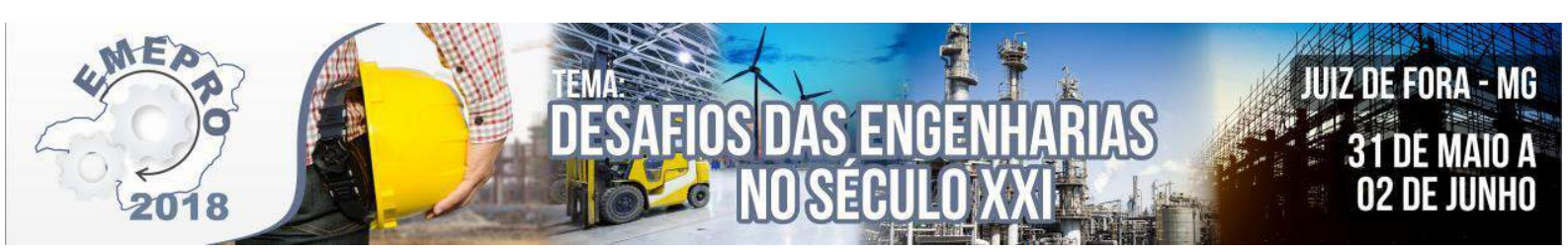

IPT - Divisão de Produtos Florestais São Paulo. Prospectiva tecnológica da cadeia produtiva madeira e móveis. Instituto de Pesquisas Tecnológicas, 2002. Disponível em: <http://docplayer.com.br/727382-Prospectivatecnologica-da-cadeia-produtiva-madeira-e-móveis-instituicoes-patrocinadoras.html>. Acesso em: 01 out. 2017.

LOMASSO, A. et al. Benefícios e desafios na implementação da reciclagem: um estudo de caso no centro mineiro de referência em resíduos (CMRR). Revista Pensar Gestão e Administração, v. 3, n. 2, jan. 2015. Disponivel em: http://revistapensar.com.br/administracao/pasta_upload/artigos/a104.pdf. Acceso em 28 mar. 2018.

MACHADO, About Gleysson B. Geração, Redução, Reutilização, Reciclagem e Tratamento de resíduos de madeira. 2014. Disponível em: <http://www.cursonegocios.com.br/nao-geracao-reducao-reutilizacao- reciclageme-tratamento-de-residuos-de-madeira/>. Acesso em: 01 out. 2017.

MUELLER, Carla Fernanda. Logística Reversa Meio Ambiente e Produtividade. Santa Catarina: UFSC, 2005. Disponível em: <http:www.tecspace.com.br/paginas/aula/faccamp/Rev/Artigo01.pdf. Acesso em: 30 set. 2017.

SANTA CATARINA. Governo de Santa Catarina. Secretaria O Desenvolvimento Econômico Sustentável. Estudo Setorial da Indústria Catarinense. 2011. 379 p. Disponível em:

<http://www.bibliotecas.sebrae.com.br/chronus/ARQUIVOS_CHRONUS/bds/bds.nsf/b9fcc1fff8d85dba9245d7 0d7732b19b/\$File/5746.pdf>. Acesso em: 27 mar. 2018.

SHIBAO, Fábio Ytoshi; MOORI, Roberto Giro; SANTOS, Mario Roberto dos. A logística reversa e a sustentabilidade empresarial. XIII SEMEAD - Seminários em Administração, set. 2010. Disponível em: <http: www.itpac.br/arquivos/Revista/64/9.pdf>. Acesso em: 30 set. 2017.

SILVA, Edna Lúcia da; MENEZES, Estera Muszkat. Metodologia da Pesquisa e Elaboração de Dissertação. 2005. 139 f. Monografia (Especialização) - Curso de Ciência da Informação, Universidade Federal de Santa Catarina, Florianópolis, $2005 . \quad$ Disponível em: <https://projetos.inf.ufsc.br/arquivos/Metodologia_de_pesquisa_e_elaboracao_de_teses_e_dissertacoes_4ed.pdf >. Acesso em: 23 out. 2017.

SILVA, Eliane; NETO, José. Logística reversa: um desafio ambiental para o setor moveleiro. EDUFPI, v.8, p. $131-152$ 2013

Disponível

em: <https://www.sigaa.ufpi.br/sigaa/verProducao?idProducao=537053\&key=fc2f34dd7d7c7e75303bc30b00ee44b1 $>$. Acesso em: 01 out. 2017.

SOUSA, Diego; DE OLIVEIRA, Gláucio; MENDONÇA, Paulo Cruz. Logística reversa e sustentabilidade. Revista Inovação, Projetos e Tecnologias - Journal of Innovation, Projects and Technologies - JIPT Revista Inovação, Projetos e Tecnologias - IPTEC Vol. 4, N. 1. Jan./Jun. 2016. 


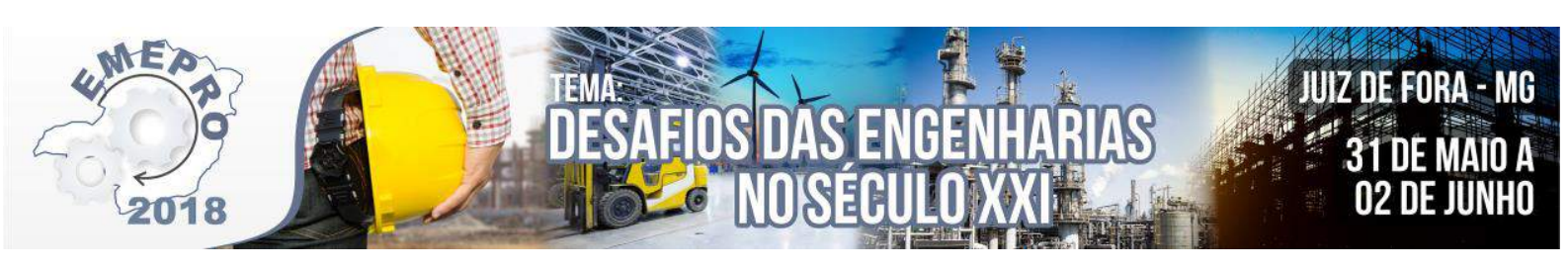

Pavimentos permeáveis

\author{
Rafael de Moura (FUPAC - Ubá) faelmoura123@ hotmail.com \\ Iorrana Vasconcelos Coimbra (FUPAC - Ubá) iorranavasconcelos@hotmail.com \\ Israel Iasbik (FUPAC - Ubá) israeliasbikcivil@ gmail.com \\ Iracema Mauro Batista (FUPAC - Ubá) imauro@bol.com.br \\ José Damato Neto (FUPAC - Ubá) josedamato@yahoo.com.br
}

Resumo: Este trabalho tem por objetivo estudar os pavimentos permeáveis de asfalto, concreto poroso e de blocos intertravados de concreto permeável sendo eles vazado ou não, suas vantagens e desvantagens, execução, qualidade e a viabilidade técnica dos mesmos. Os pavimentos tradicionais procuram atingir o máximo teor de impermeabilidade, viabilizando assim uma maior proteção ao solo, evitando a umidade que reduz a resistência do solo pavimentado. Com o rápido crescimento das cidades e áreas urbanas, ocorreu uma grande impermeabilização do solo, resultando na alteração do ciclo hidrológico e com isso ocorrendo um grande impacto ambiental, agravando a escassez de água, a degradação da qualidade das águas pluviais e um grande crescimento das enchentes, principalmente em grandes cidades. Para ajudar nos problemas provenientes da impermeabilização do solo, uma solução adequada pode ser a implantação do pavimento permeável que tem a função de reduzir o escoamento superficial através de sua infiltração, reduzindo o trabalho da drenagem pluvial, e consequentemente diminuindo assim o risco de inundação. Além de realizar um trabalho de infiltração, se executado com um sistema de captação, o pavimento permeável pode proporcionar a captação e reutilização das águas pluviais.

Palavras-chave: Infiltração; Drenagem urbana; enchentes; sustentabilidade

\title{
1. Introdução
}

Os pavimentos tradicionais procuram atingir o máximo teor de impermeabilidade, viabilizando assim uma maior proteção ao solo, evitando a umidade que reduz a resistência do solo pavimentado. $\mathrm{O}$ solo mais úmido tende a perder resistência e isso faz com que o pavimento venha a ceder, e por esse motivo há uma grande impermeabilização do solo, onde sua superfície é selada para que não ocorra a infiltração de água nas camadas de solo.

Com o rápido crescimento das cidades e áreas urbanas, ocorreu uma grande impermeabilização do solo, resultando na alteração do ciclo hidrológico e com isso ocorrendo um grande impacto ambiental, agravando a escassez de água, a degradação da qualidade das águas pluviais e um grande crescimento das enchentes, principalmente em grandes cidades. No que se refere a sistema de esgotamento urbano, ele tem a função de afastar as águas derivadas das precipitações o mais rápido possível, contribuindo para a geração de eventos de inundações que se repetem e agravam todo o ano. Para uma solução adequada deste transtorno é essencial a princípio uma intervenção da ação pública para devolver ao solo as condições originais de retenção do escoamento, e um dos recursos é o pavimento permeável. 


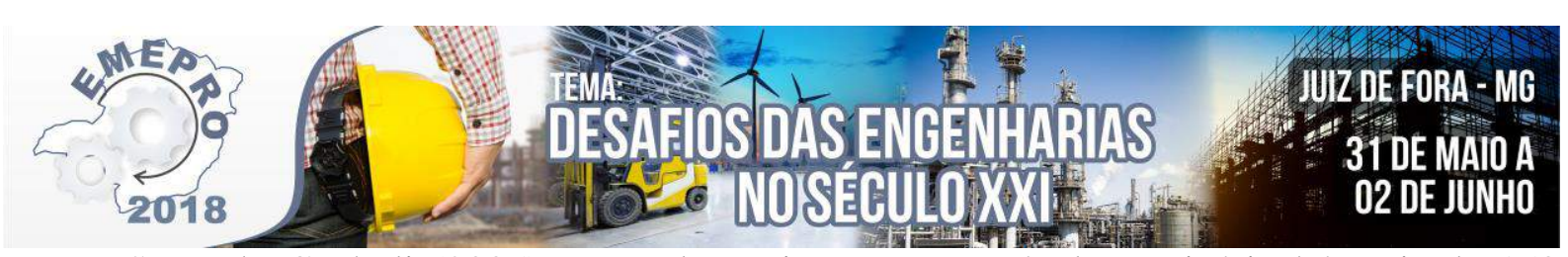

Segundo Canholi (2005) o uso de pavimento permeável teve início há mais de 150 anos, contudo a sua verdadeira aplicação para as mais inúmeras finalidades veio a apresentar somente um grande avanço há pouco mais de 20 anos, principalmente nos EUA. Hoje em dia pesquisas sobre o asfalto permeável tem se tornado cada vez mais interessante para o mercado, pois muitas empresas e condomínios preferem o asfalto permeável em seus estacionamentos e imediações.

Em alguns países têm sido feitas pesquisas, com o intuito de aprimorar e dominar a técnica do pavimento permeável, estudando seu comportamento, sua eficiência e durabilidade, abrangendo uma maior área de aplicação, trazendo benefício para o meio ambiente e para a população, sendo que no Brasil, esse dispositivo ainda é pouco conhecido e pouco aplicado.

Segundo Urbonas e Stahre (1993) pavimento permeável é um dispositivo de infiltração onde o escoamento superficial é desviado através de uma superfície permeável para dentro de um reservatório de pedra por onde infiltra através do solo, podendo sofrer evaporação, ou atingir o lençol freático. Essa água captada através da infiltração superficial se não tiver contato com resíduos tóxicos, pode também ser armazenada para que venha ser reaproveitada a fim de substituir a água potável em fins menos nobres como: limpeza de pisos e equipamentos em geral, irrigação, drenagem sanitária, resfriamento e processos industriais, entre outros usos. Os pavimentos permeáveis podem ser:

-Asfalto permeável: é um composto asfáltico semelhante aos convencionais, porém, em sua composição é retirado toda a parte dos agregados finos do pavimento asfáltico.

-Concreto permeável: Seu composto é parecido ao do concreto convencional, porém, em sua composição é retirado toda ou quase toda parte de agregados miúdos, aumentando seu índice de vazios.

-Blocos de concreto permeável vazados: são blocos feito de concreto permeável vazados, e após sua execução seus furos são preenchidos com vegetação rasteira.

-Blocos de concreto permeável: são blocos de concreto intertravados feitos de concreto permeável.

O presente trabalho, tem como objetivo estudar os pavimentos permeáveis de asfalto, concreto poroso e de blocos intertravados de concreto permeável, suas vantagens e desvantagens, execução e qualidade.

O pavimento permeável é um material sustentável que possibilita a penetração da água em sua superfície e consequentemente retarda o escoamento para a jusante, diminuindo assim os riscos de enchentes, alimentando o lençol freático ou reutilizando em processos simples como: substituir a água potável em fins menos nobres e proporcionar economia para o local aplicado.

\section{Desenvolvimento}

\subsection{Impermeabilização do solo}

Segundo Canholi (2005) durante muitos anos, tanto no Brasil como em outros países, a drenagem pluvial urbana tanto em grandes metrópoles como em cidades pequenas, foi deixada de lado dentro do contexto do parcelamento do solo para uso urbano. $\mathrm{O}$ avanço das áreas urbanizadas, e consequentemente impermeabilizadas, ocorreu a partir das zonas mais baixas, próximas as várzeas dos rios ou a beira mar, em direção a colinas e morros, em razão 


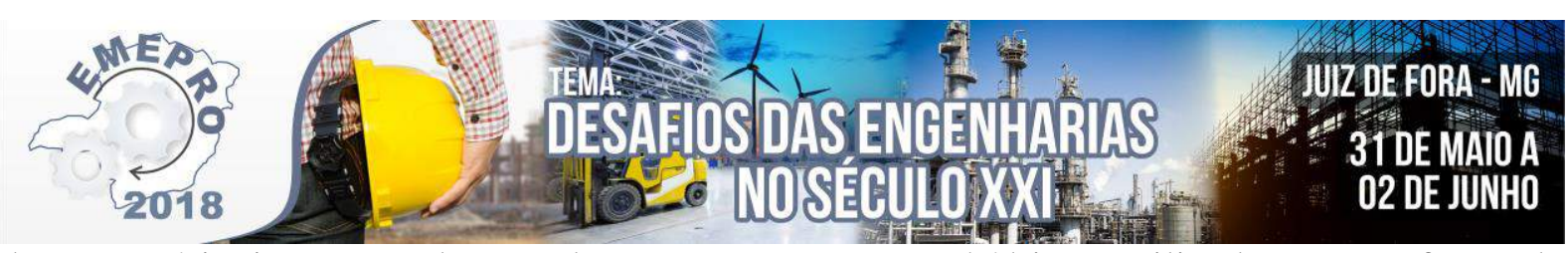

da necessária interação da população com os corpos hídricos utilizados como fonte de alimento e via de transporte.

Tucci (2009) define drenagem urbana como um conjunto de medidas capazes de diminuir os danos causados às populações por enchentes. Estas medidas vão desde o planejamento do uso da ocupação do solo, à construção de obras especificas para drenagem. Cita ainda que a urbanização é a que mais interfere na drenagem urbana, pois altera diretamente o escoamento superficial da água. Deste modo, é notório que o escoamento possui níveis maiores devido à impermeabilização do meio urbano, nos mostrando a importância de áreas de infiltração que contribui significativamente na dissipação da água da chuva.

As enchentes em áreas urbanas podem ser de dois tipos, uma delas é a enchente em áreas ribeirinhas, ou seja, são enchentes naturais e já previstas em eventos chuvosos extremos. Outro tipo de enchente, é a causada pela urbanização, que impermeabiliza o solo de maneira que uma parcela de água que iria infiltrar, agora escoa pelos condutos, aumentando o volume e demandando maior capacidade de escoamento na condução de água. Logo, um dos grandes efeitos da urbanização neste contexto, é o aumento da vazão máxima, a antecipação do pico e o aumento de volume do escoamento superficial. Para que não ocorram tais enchentes, além da canalização, existem dispositivos que auxiliam no controle, dentre eles, o uso de um pavimento que possibilite infiltração, o armazenamento da água da chuva em telhados e a existência de pequenos tanques residenciais (TUCCI,2003).

Portanto a aplicação do pavimento permeável em passeios públicos, em grandes ou pequenos estacionamentos de mercados, shopping e fábricas e em algumas áreas, contribui em parcela significativa na ajuda da penetração de água, podendo a mesma ser armazenada para uma reutilização, ou deixando que a água infiltre e alimente o lençol freático, diminuindo assim o escoamento superficial e o possível acúmulo de água que poderá resultar em inundação, contribuindo para a alimentação das nossas reservas de água. (MARTINS,2014)

O piso que impermeabiliza o solo, como o asfalto impermeável interfere diretamente no ciclo das chuvas e na penetração da água no solo, caracterizando uma ação predatória do ser humano contra a natureza.

De acordo com a UNESCO, escassez de água no mundo é um tema atual e muito debatido, estima-se que nos próximos cinquenta anos, problemas relacionados com a falta de água afetarão a todos. Uma dessas causas é a predação do homem, que continua intervendo no ciclo hidrológico, desmatando, impermeabilizando o solo, e poluindo o meio ambiente.

Com a escassez de água que enfrentamos uma boa solução pode ser a captação e a reutilização dessas águas que muitas vezes são perdidas ou contaminadas. A reutilização ou reuso de água não é um novo conceito e tem sido desenvolvido em todo o mundo há muitos anos. Há informações de sua aplicação na Grécia Antiga, com a disposição de esgotos e sua utilização na irrigação. Todavia, a procura crescente por água tem feito do reuso planejado da água um tema atual e de grande importância. Assim, deve-se considerar o reuso de água como parte de uma ação mais abrangente que é o uso racional ou eficiente da água, o qual compreende também o controle de perdas e desperdícios, e a minimização da produção de efluentes e do consumo de água. (MARTINS,2014) 


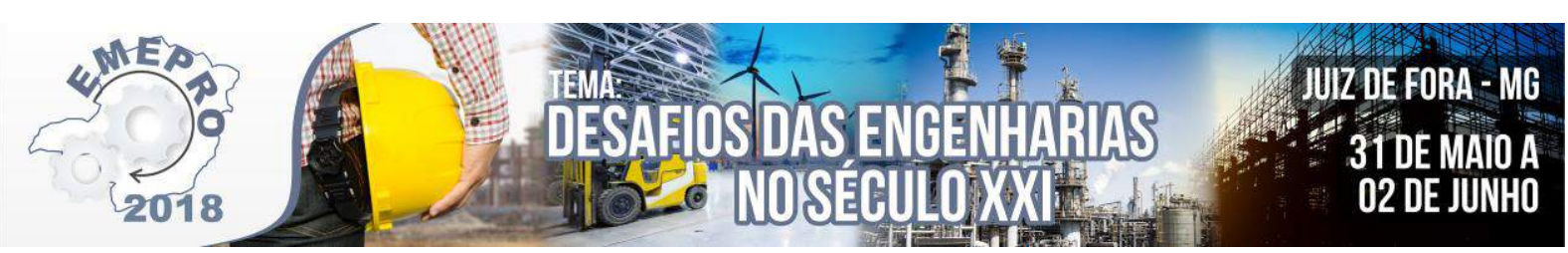

\subsection{Pavimentos permeáveis}

Araújo et. al. (2000) define pavimentos permeáveis sendo aqueles que possuem vazios por onde a água é capaz de escoar, fazendo com que a mesma se infiltre no solo ou seja captada por um sistema de drenagem. O pavimento permeável tem a função de reduzir o escoamento superficial através de sua infiltração, reduzindo o trabalho de drenagem, e consequentemente diminuindo a assim o risco de inundação. Além de realizar um trabalho de infiltração, se executado com um sistema de captação, o pavimento permeável pode proporcionar a captação e reutilização das águas pluviais.

Urbonas e Stahre (1993) mencionam que não há muitas restrições para o uso do pavimento permeável, exceto em locais onde há índice de trânsito pesado e em locais onde o solo não permite a infiltração da água devido à sua baixa permeabilidade, ou se o nível do lençol freático for alto. Neste caso o pavimento permeável poderá funcionar como um poço onde irá armazenar a água por um certo período, utilizando para isso uma membrana impermeável entre o reservatório e o solo existente, o sistema de esgotamento é feito com canos perfurados, prevendo a retirada de toda à água em um tempo de 6 a 12 horas. Outra solução pode ser a instalação de um sistema de captação onde toda a água é levada para uma cisterna e lá armazenada para ser usada para outros meios. Há igualmente, restrição quando a qualidade da água de infiltração levar a poluição de águas subterrâneas.

\subsubsection{Asfalto permeável}

De acordo com Bernucci et.al. (2008) a cobertura de asfalto permeável é constituída de forma semelhante às convencionais, no entanto é retirado a porção de agregados miúdos da sua composição e é feito o acréscimo de alguns aditivos permitindo que sejam mantidos os vazios. É conhecida como camada porosa de asfalto ou camada de atrito. O resultado dessa graduação é um composto asfáltico capaz de conter de $18 \%$ a $25 \%$ de vazios, proporcionando rápida passagem da água. Além da sua permeabilidade, o asfalto permeável possui também algumas vantagens como o acréscimo da aderência e a redução de ruído.

\subsubsection{Concreto permeável}

Segundo Bernucci et.al. (2008) o concreto permeável também possui sua composição semelhante ao convencional. A mistura é composta de materiais cimentícios, agregado graúdo e água com pequena proporção ou nenhuma de agregados finos. A inclusão de uma pequena quantidade de agregados finos irá normalmente reduzir o teor de vazios e aumentar a resistência, o que pode ser desejável em determinadas situações. Este material é sensível a alteração no teor de água, de modo que o ajuste de campo da mistura fresca é normalmente necessário. Um composto adequado trará uma aparência à mistura de um molhadometálico e deve apresentar $15 \%$ a $25 \%$ de vazios. Como consequência, o concreto permeável possui uma menor resistência comparado ao concreto convencional e é indicado para locais de tráfego leve e de pouca intensidade.

\subsubsection{Pavimento de blocos intertravados}

De acordo com a ABNT NBR 15953 (2011) pavimento intertravado e um pavimento flexível onde sua estrutura é composta por uma camada de base ou subbase, seguido pela camada de revestimento constituído de peças de concretos sobreposto, onde as juntas entre as peças são preenchidas por um material de rejuntamento. O intertravamento do sistema é proporcionado por contenções laterais. 


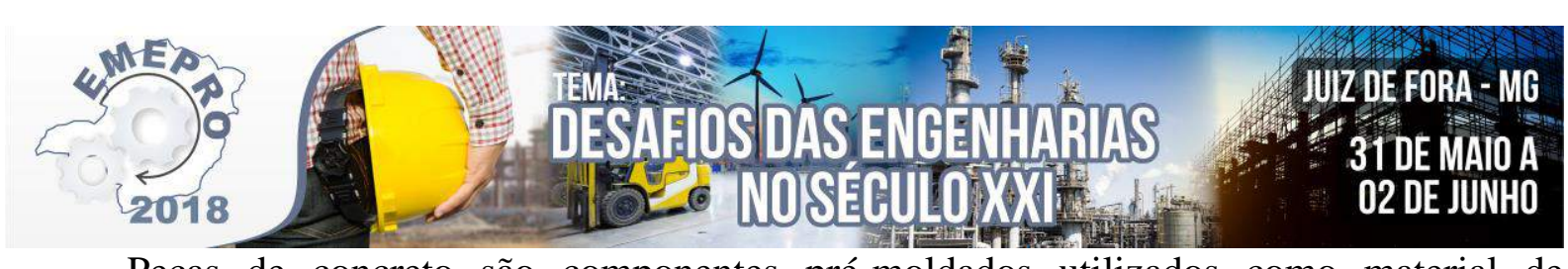

Peças de concreto são componentes pré-moldados utilizados como material de revestimento em pavimento intertravado, no caso do pavimento permeável essas peças são fabricadas a partir do concreto permeável. Segundo a ABNT NBR 15953 (2011) os blocos de concreto podem ser blocos de concreto permeável vazado ou blocos de concreto permeável.

\subsection{Comparação entre os pavimentos}

Marchione e Silva (2010) realizaram também algumas comparações englobando diferentes concepções dos pavimentos, incluindo o asfalto permeável. Na Tabela 1 tem-se uma síntese dos critérios mais relevantes, como o tipo de uso, a capacidade de absorção o custo de implantação, custo de manutenção, retenção de partículas solidas, entre outros. Podese observar que o pavimento permeável possui um custo de implantação e de manutenção de média a alta em relação aos pavimentos impermeáveis, porém sua capacidade de absorção é melhor em relação aos outros pavimentos, levando em conta que a de um pavimento impermeável é praticamente nula. É importante a comparação dos tipos de pavimentos ao se executar um projeto, levando em conta seu custo, sua manutenção, o local de aplicação e se não trará nenhum impacto para a região onde será executado.

TABELA 1: Comparação entre os pavimentos. Fonte: Marchione e Silva (2010)

\begin{tabular}{|c|c|c|c|c|c|}
\hline $\begin{array}{l}\text { Critérios } \backslash \\
\text { Material } \\
\end{array}$ & Solo Natural & $\begin{array}{l}\text { Blocos } \\
\text { Vazados } \\
\end{array}$ & $\begin{array}{l}\text { Asfalto } \\
\text { Poroso } \\
\end{array}$ & $\begin{array}{l}\text { Concreto } \\
\text { Poroso } \\
\end{array}$ & $\begin{array}{l}\text { Revestimento } \\
\text { Impermeável }\end{array}$ \\
\hline Tipo de uso & $\begin{array}{l}\text { Praças, } \\
\text { estacionamento } \\
\text { vias de pedestres, } \\
\text { quadras esportivas }\end{array}$ & $\begin{array}{l}\text { Praças, } \\
\text { estacionamentos } \\
\text { vias de pedestres, } \\
\text { calçadas }\end{array}$ & $\begin{array}{l}\text { Todos os } \\
\text { usos desde } \\
\text { Com } \\
\text { estrutura } \\
\text { reforçada }\end{array}$ & $\begin{array}{l}\text { Todos os } \\
\text { usos, desde } \\
\text { que com } \\
\text { estrutura } \\
\text { reforçada }\end{array}$ & Todos os usos \\
\hline $\begin{array}{l}\text { Capacidade de } \\
\text { absorção }\end{array}$ & $\begin{array}{l}\text { Varia de acordo } \\
\text { com o material }\end{array}$ & Média & Boa & Boa & Nula \\
\hline $\begin{array}{l}\text { Periodicidade } \\
\text { de manutenção }\end{array}$ & 6 meses & 6 meses a 1 ano & $\begin{array}{l}\text { Varia de } \\
\text { acordo } \\
\text { com o uso } \\
\text { (6 meses a } \\
2 \text { anos) }\end{array}$ & $\begin{array}{l}6 \text { meses a } \\
2 \text { anos }\end{array}$ & $\begin{array}{l}\text { Depende do } \\
\text { local }\end{array}$ \\
\hline $\begin{array}{l}\text { Custo de } \\
\text { implantação }\end{array}$ & Baixo & Alto & Médio & Médio & Médio \\
\hline $\begin{array}{l}\text { Custo de } \\
\text { manutenção }\end{array}$ & Médio & Alto & $\begin{array}{l}\text { Médio a } \\
\text { alto }\end{array}$ & $\begin{array}{l}\text { Médio a } \\
\text { alto }\end{array}$ & Boa \\
\hline $\begin{array}{l}\text { Resistêncial } \\
\text { arrancamento }\end{array}$ & Medíocre & Boa & Média & $\begin{array}{l}\text { Médio a } \\
\text { Boa }\end{array}$ & Boa \\
\hline
\end{tabular}

\subsection{Métodos de ensaio}

De acordo com a ABNT NBR 16416 (2015) antes da execução de um pavimento permeável é necessária uma avaliação prévia feita em laboratório para a aprovação dos materiais do revestimento com simulação das condições de permeabilidade do revestimento, porém para a aprovação final de qualquer tipo de pavimento permeável em relação ao seu coeficiente de permeabilidade é necessário a realização de um ensaio realizado em campo, após a execução final dos pavimentos. 


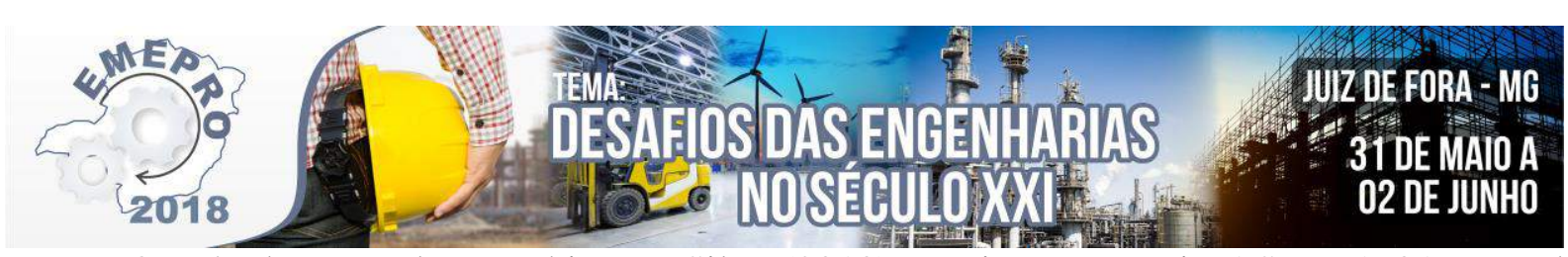

O método segundo Marchione e Silva (2010) consiste no ensaio ASTM 1701 - stard test method for infiltration rate of in place previous concret). No ensaio é utilizado um cilindro de 30 centímetro de diâmetro, com uma altura de no mínimo 20 centímetros.

O cilindro deve ser posicionado sobre a superfície do pavimento e para evitar perdas, a borda do cilindro deve ser vedada com massa de calafetar.

Para iniciar o ensaio é necessário despejar 3,6 litros de água no interior do cilindro e esperar a infiltração para que ocorra a saturação do solo. Se o tempo da pré-molhagem for inferior a 30 segundos, deve se utilizar 18 litros de água na execução do ensaio, porém se o tempo for superior a 30 segundos é utilizado 3,6 litros de água. Após determinada a quantidade de água e saturação do solo, o ensaio deve ser executado repetindo o procedimento anterior a fim de obter o tempo que a água levará para infiltrar.

Na pré-molhagem e durante o ensaio é necessário manter o fluxo de água constante a uma altura de 10 a 15 milímetros dentro do cilindro, sempre controlando o tempo de infiltração. O coeficiente de permeabilidade e obtido pelo cálculo matemático sobre a lei de Darcy:

$$
\mathrm{I}=(\mathrm{K} \times \mathrm{M}) \backslash\left(\mathrm{D}^{2} \times \mathrm{T}\right)
$$

Onde temos:

$\mathrm{I}=$ Coeficiente de Permeabilidade $(\mathrm{mm} / \mathrm{h})$

$\mathrm{M}=\mathrm{E}$ a quantidade da massa de água infiltrada no pavimento $(\mathrm{kg})$

$\mathrm{D}=$ É a dimensão do diâmetro interno do cilindro (mm)

$\mathrm{T}=$ É o Intervalo de tempo entre o despejamento da agua e a sua total infiltração no solo(s)

$\mathrm{K}=4.583 .666 .000$

\subsection{Medidas para melhorar o desempenho}

Inicialmente, é de extrema importância a verificação do local onde futuramente será feito a instalação da estrutura. Devido a qualidade da água, que se estiver contaminada pode vir a acarretar problemas de contaminação aos lençóis d'agua, vindo a causar grandes problemas ambientais. Além do que, é necessário a verificação do tipo de solo nativo, pois, se o mesmo apresentar problemas de permeabilidade, o desempenho final dos pavimentos pode vir a ser prejudicado. (MARCHIONI E SILVA,2010)

Com o passar do tempo, alguns elementos podem afetar os resultados de desempenho e prejudicar o pavimento permeável a chegar a sua máxima eficácia. Para que isso não venha a ocorrer é necessária uma manutenção feita periodicamente na superfície do pavimento, com a finalidade de retirar qualquer substância sólida dos poros superficiais. Substâncias sólidas soltas em torno do local devem ser evitadas, pois com a ação do vento essas substâncias podem ser carregadas e atrapalhar a passagem da água através dos poros, reduzindo a vida útil do pavimento. (MARCHIONI E SILVA,2010).

\subsection{Parâmetros dos projetos}

De acordo com Virgiliis (2009) para a aplicação do pavimento permeável, e necessário ter alguns parâmetros para o projeto. Além do mais é necessário antes de tudo um estudo mais aprofundado do local e do solo onde será a sua aplicação. Esses parâmetros são: 


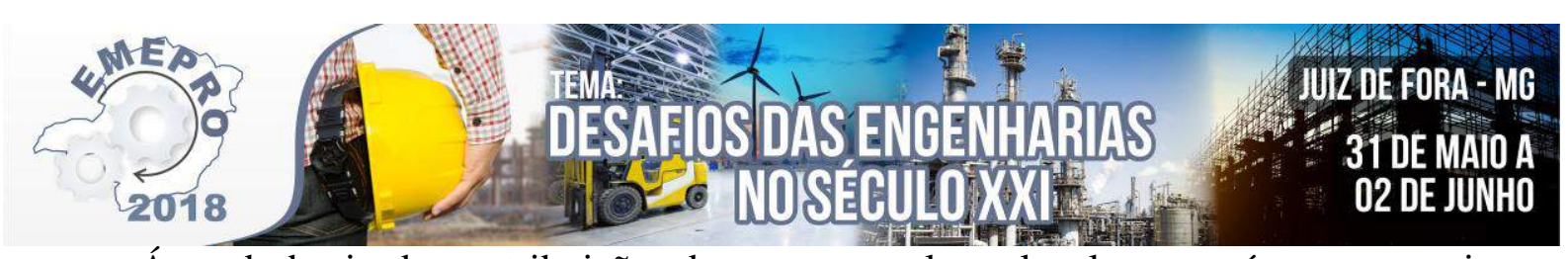

-Área da bacia de contribuição: deve-se controlar o local que as águas provenientes das chuvas serão direcionadas. Na situação dos pavimentos permeáveis, o recomendado e ter uma a área de controle menor do que $100.000 \mathrm{~m}^{2}$.

-Nível do lençol freático: é outro fator que influencia diretamente no desempenho dos pavimentos permeáveis, o nível máximo que o lençol freático pode estar das camadas do pavimento permeável é de $1 \mathrm{~m}$ abaixo do fundo do dispositivo.

-Risco de contaminação de aquífero: é de extrema importância o estudo do em torno, onde deve-se verificar se há algum tipo de risco de contaminação ou se o aquífero do local em questão é sensível à poluição, caso isso venha a ser constatado não é recomendado a utilização de pavimentos permeáveis.

-Declividade do terreno: em locais que possuem altas declividades não é recomendado a instalação de pavimento permeável.

-Fragilidade do solo à ação da água: alguns solos com a presença de água podem ter suas características modificadas e vir a sofrer algum tipo de deformação. Mesmo diante da medida de detenção ou retenção, o solo onde a estrutura ira ser instalada pode vir a se tornar muito barrento, trazendo risco da estrutura ceder.

-Grandes esforços e tráfego intenso: não é recomendada a implementação de pavimentos permeáveis em áreas de tráfego pesado e intenso.

-Flexibilidade do desenho: a implementação do pavimento permeável e de fácil modificação e está somente delimitada à geometria do local, podendo se adaptar ao seu local de execução.

\subsection{Execução das camadas do pavimento permeável}

\subsubsection{Pavimento permeável com infiltração total no solo}

De acordo com Virgiliis (2009), depois de ser feito todo o estudo do solo, o dimensionamento das camadas de base e sub-base deve ser feito para funcionar como um tipo de reservatório, para que a água possa infiltrar calmamente no solo, e também suportar a carga solicitada. A altura das camadas irá ter variações em função do tipo de tráfego, tipo de solo e o regime de chuvas da região. É sugerido que na base seja utilizado um agregado com volume de vazios maior que $40 \%$. As etapas de execução para um pavimento permeável com infiltração total no solo são:

-Limpeza do terreno e topografia: retira-se o material vegetal e os entulhos, levando os mesmos para uma área de descarte e de lá para aterros licenciados. A parte de topografia fica responsável pela locação da obra, os topógrafos fazem a locação posicionando estacas de 10 em 10 metros no sentido longitudinal e transversal.

-Abertura da caixa de pavimentação: logo após terminado a limpeza e locação da obra parte-se para a abertura da caixa de pavimentação, onde é determinado em projeto seu tamanho e altura para que a mesma possa vir a receber as várias camadas infiltrantes do material de base.

-Nivelamento e Compactação: no solo onde será executado o pavimento é necessário otimizar o terreno para que ele possa vir a ficar o mais plano possível, então é feito o espalhamento e a compactação do solo. Porém o solo não pode vir a ser compactado demais para que não prejudique a infiltração do mesmo. 


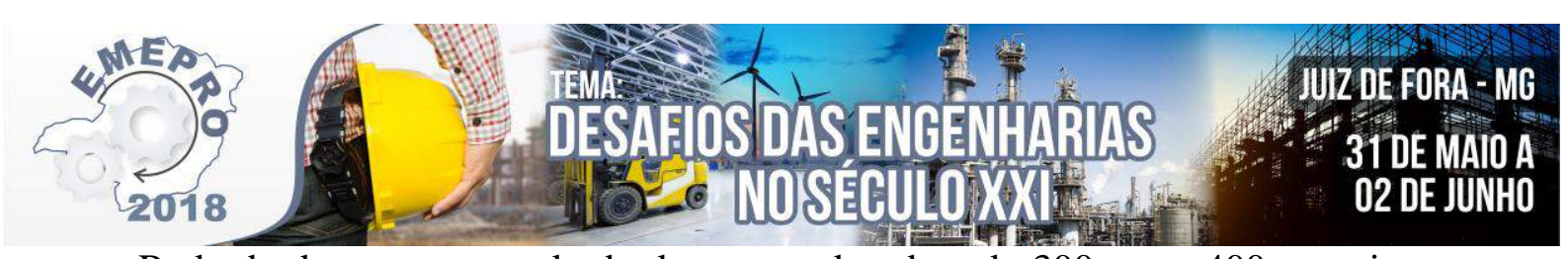

-Rede de drenagem: a rede de drenagem de tubos de $300 \mathrm{~mm}$ e $400 \mathrm{~mm}$ tipo ponta e bolsa de concreto é assentada sobre um berço de brita 3. A rede de drenagem deve obedecer rigorosamente aos parâmetros impostos em projeto.

-Assentamento da manta geotêxtil: manta geotêxtil é uma manta que possui uma alta permeabilidade e uma boa capacidade de retenção de sólidos, ela é utilizada como um filtro drenante para a eliminação de acúmulos superficiais, é assentada diretamente sobre o subleito, e é previamente salgada com uma fina camada de pó de pedra e depois e espalhado sobre ela outra camada de pó de pedra que serve como uma proteção para a mesma.

-Colocação e compactação do material de base: é feito o espalhamento de pedra de 19 $\mathrm{mm}$ de diâmetro, sendo aplicadas em camadas de $10 \mathrm{~cm}$ e compactadas com um rolo compactador liso e com vibração intermediária, até atingir sua altura máxima que é determinada em projeto.

-Execução das guias e sarjetas: após a compactação das camadas, são executadas guias e sarjetas, determinadas previamente em projetos, nos pavimentos intertravados as guias e sarjetas além da importância do escoamento de água, tem também importância no travamento dos blocos.

\subsection{Execução do pavimento permeável}

\subsubsection{Asfalto permeável.}

Segundo Virgiliis (2009), a execução do asfalto permeável é dada pelas seguintes etapas:

-Execução do Macadame Betuminoso: é feito uma preparação com uma camada de 5 $\mathrm{cm}$ de suporte ao revestimento com macadame betuminoso, esse material e travado com brita 1 e pedrisco que são compactados com rolo vibratório liso.

-Imprimadura com ligante asfáltico: depois da execução e compactação do macadame, o mesmo recebe um ligante de asfalto diluído de petróleo tipo CM-30, que é o resultado da diluição do cimento asfáltico por destilados leves de petróleo, fazendo o produto asfáltico menos viscoso e podendo ser aplicados a temperaturas mais baixas, na proporção de 0,8 litros $/ \mathrm{m}^{2}$. Esse ligante asfáltico é aplicado à quente e de forma rápida apenas para a aderências aos grãos, e sem reduzir significativamente seu teor de vazios.

-Camada de Asfalto permeável: para finalizar é executado o concreto asfáltico permeável, sendo que seu índice de permeabilidade é determinado através dos ensaios de permeabilidade e o volume de vazios da mistura deve ficar entre $15 \%$ a $25 \%$.

\subsubsection{Execução do concreto permeável}

De acordo com Virgiliis (2009) a execução do concreto permeável e feita pelas seguintes etapas:

-Aplicação do concreto permeável: é feito espalhamento do concreto permeável de forma rápida e contínua, sua aplicação é feita na base ou subleito úmido para evitar perda de água do concreto.

-Nivelamento: para o nivelamento utiliza-se uma régua vibratória ou é feita manualmente através de uma régua de alumínio. É de extrema importância que a vibração não seja feita por tempo excessivo para que assim não venha entupir os vazios do concreto. $\mathrm{O}$ Nível do concreto deve ser de 15 a $20 \mathrm{~mm}$ acima das guias para garantir posteriormente compactação. A consolidação do concreto é proporcionada por meio da compactação 


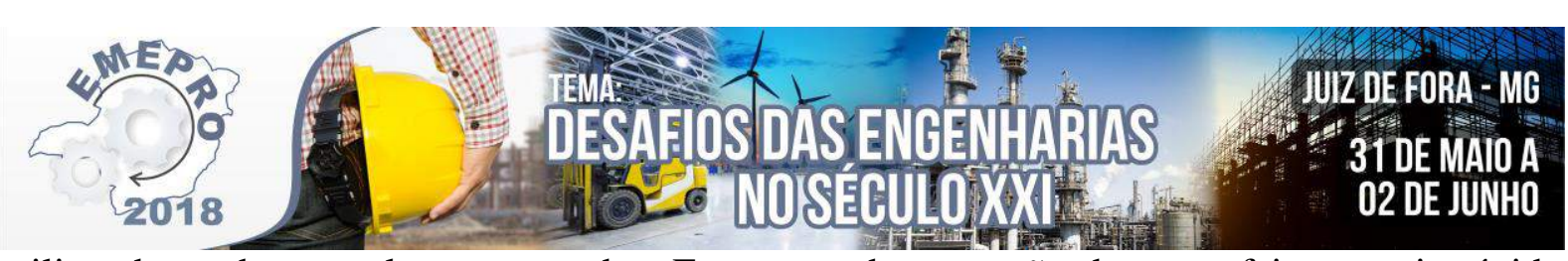

utilizando-se de um rolo compactador. Esta parte da execução deve ser feita o mais rápido possível.

-Cura e proteção do concreto fresco: é recomenda uma proteção utilizando uma manta plástica, e sua cura deve iniciar logo após a execução.

\subsubsection{Execução dos pavimentos de blocos intertravados}

Segundo Virgiliis (2006) a execução do pavimento de blocos intertravados permeáveis é feita da mesma forma que os pavimentos intertravados comuns, com a diferença no material dos blocos que são de concreto permeável. As etapas do da execução são:

-Camada de assentamento: na execução da camada de assentamento e juntas deve ser utilizado agregados graúdo com diâmetro de 6,5 a 9,5mm. Esses agregados são espalhados de forma uniforme com réguas de alumínio e não podem ser compactados. Não é recomendada a utilização de areia ou pó de pedra, pois eles podem prejudicar a infiltração da água.

-Assentamento dos blocos intertravados: os blocos intertravados são fixados normalmente sobre a camada de assentamento, e após a execução do assentamento das peças é retirado o excesso do material de rejuntamento depois com uma placa vibratória com proteção de borracha é realizado a compactação do revestimento de modo que não danifique as peças de concreto permeável.

-Verificação: após a compactação, de ser feito a verificação do material de rejuntamento e observando se ele está preenchendo todas as juntas e espaço de percolação da água.

-Limpeza: após ser feita toda execução é feito a limpeza da superfície, através deste processo é necessário fazer a inspeção no local e observar se o mesmo possui algum tipo de desnível ou se alguma peça está quebrada para que assim o pavimento esteja pronto para uso.

\subsection{Vantagem e desvantagem}

\subsubsection{Vantagens}

De acordo com CIRIA (2007) os pavimentos permeáveis, em geral, possuem algumas determinadas vantagens em relação a outros sistemas de drenagem. Algumas destas vantagens são:

-Com o sistema de infiltração dos pavimentos permeáveis ocorre uma redução significativa nas redes de drenagens, ajudando assim os riscos de enchentes.

-Pavimentos permeáveis são capazes de serem instalados em locais que não haja sistema de drenagem, podendo assim absorver o escoamento superficial.

-Com a eficiência da diminuição do escoamento superficial, o sistema de infiltração ajuda na redução dos impactos hidrológicos urbanos.

-A infiltração das águas pluviais pode ajudar na recarga e manutenção dos aquíferos sem comprometer a condição da água do subsolo.

-Possui construção normalmente rápida e simples.

-Os custos de toda sua vida útil podem ser menores em relação a sistema de drenagem.

-Tratamento das águas pluviais, através de remoção de alguns poluentes pelas camadas dos pavimentos. 


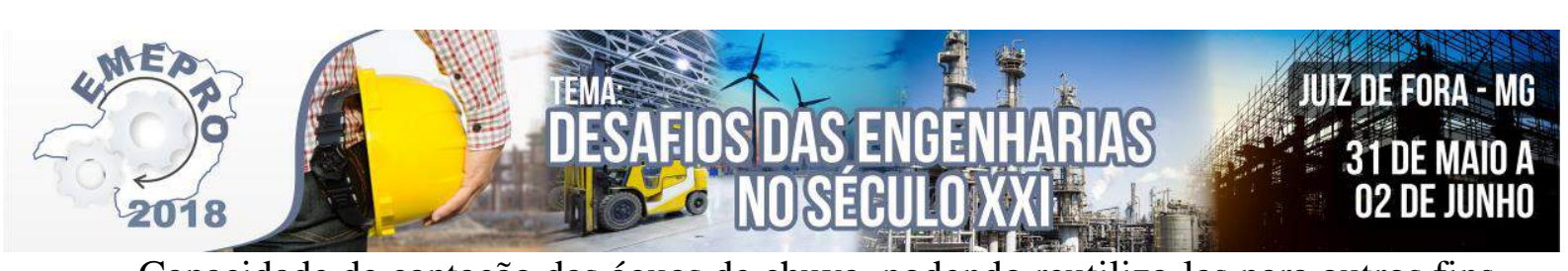

-Capacidade de captação das águas de chuva, podendo reutiliza-las para outros fins. exclusivo.

-Tem a capacidade de se integrar completamente à obra, não carecendo de espaço

\subsubsection{Desvantagens}

Araújo et. al. (2000), cita que os pavimentos permeáveis possuem algumas desvantagens. Algumas delas são:

-Possui restrição em algumas regiões com climas mais frio, pois podem ocorrer entupimentos pela neve e em regiões que possam possuir altas taxas de erosões.

-Poucas qualificações de engenheiros e mão de obra qualificadas para a execução.

-Se a água captada estiver contaminada, pode vir a ocorrer a contaminação de aquíferos e do lençol freático.

-O pavimento permeável tem um problema com durabilidade, pois o alto teor de vazios favorece o dano pela ação da água, como o desprendimento dos agregados se houver má adesividade entre o agregado e o ligante. Este problema pode ser combatido com o aumento da espessura da película de ligantes.

-Pela presença de asfalto modificado por polímero, é necessário um agregado de alta qualidade podendo fazer o custo do revestimento dobrar em relação a um pavimento convencional.

-O pavimento permeável não e recomendado para locais de trafego intenso e pesado, pois o alto teor de vazios o torna um pavimento menos resistente a altas cargas.

\section{Considerações Finais}

É importante lembrar que o pavimento permeável não é uma solução para resolver todos os problemas de enchente e escassez de água, mais sim um dispositivo que irá contribuir de maneira direta e eficaz. Tendo em vista que para poder resolver estes problemas é necessário um conjunto de fatores, que passa desde o incentivo público e privado procurando trazer meios de implantações de mão de obra especializadas até a conscientização da população nas questões ambientais e de desperdícios de água.

É possível identificar um maior necessidades de manutenção e com isso um custo elevado, porém esse custo vem a ser compensado pela redução de drenagem em sua área aplicada, é valido ressaltar também que o pavimento permeável apresenta uma melhoria para os risco de inundações, ou seja, a utilização dos pavimentos permeáveis pode sanar necessidades do uso de caixas de captação e dispositivos de drenagem em sua execução, pois o mesmo não gera praticamente nenhum escoamento superficial com isso ele pode ser extremamente viável se pensarmos em termos de urbanização, sociedade e sustentabilidade, no intuito de diminuir inundação, beneficiar o lençol freático através da sua infiltração ou na captação de água para a reutilização em simples processos, como na substituição da água potável para fins menos nobres, gerando uma economia para o local.

\section{Referências}

ASSOCIAÇÃO BRASILEIRA DE NORMAS TÉCNICAS. NBR 15953. Pavimento intertravado com peças de concreto: execução. Rio de Janeiro, 2011.

. NBR 16416. Pavimentos permeáveis de concreto: requisitos e procedimentos. Rio de Janeiro, 2015. 


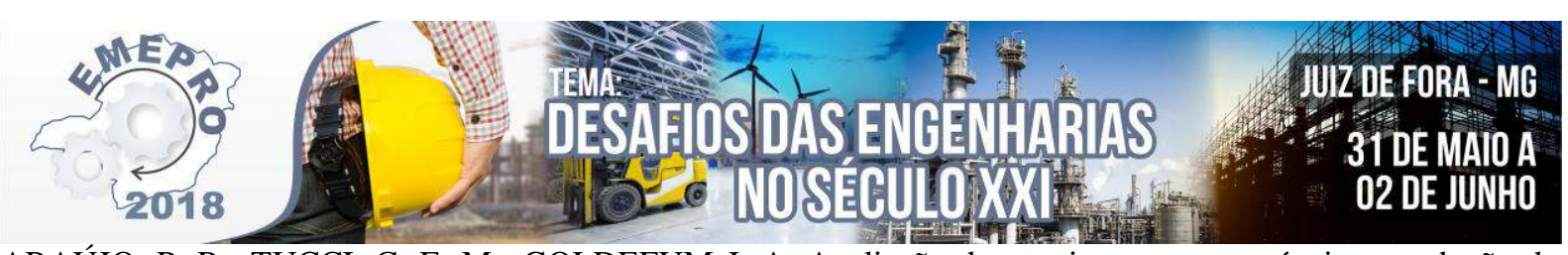

ARAÚJO, P. R.; TUCCI, C. E. M.; GOLDEFUM J. A. Avaliação dos pavimentos permeáveis na redução do escoamento superficial. Revista brasileira de recursos hídricos, Porte Alegre, v. 5, n. 3, p. 21-29, jul. / set. 2000.

BERNUCCI, Liedi B. Pavimentação asfáltica: formação básica para engenheiros. 3. ed. Rio de Janeiro: Imprinta, 2008. 114 p.

CANHOLI, Aluísio Pardo. Drenagem urbana e controle de enchentes. 2. ed. São Paulo: Oficina de textos, 2005. $384 \mathrm{p}$.

CIRIA-Construction Industry Research and Information Association. The SUDS manual. 1. ed. Londres: CIRIA, 2007. 599 p.

MARCHIONI, M.; SILVA, C. O. Pavimentos intertravado - Melhores práticas. Associação Brasileira de Cimento Portland, São Paulo, 2010, 24 p.

MARTINS, R. M. Análise da capacidade de infiltração do pavimento intertravado de concreto. 2014. $49 \mathrm{f}$. monografia (trabalho de conclusão de curso) - Universidade Tecnológica Federal do Paraná, Pato Branco, 2014.

TUCCI, Carlos E. M. Hidrologia: Ciência e Aplicação. 4. ed. Porto Alegre: Ed. da UFRGS, 2009. 943 p.

TUCCI, C. E. M.; BERTONI, J. C. Inundações urbanas na américa do sul. 1. ed. Porto Alegre: ABRH, 2003. $150 \mathrm{p}$.

URBONAS, B.; STAHRE, P. Stormwater best management pratices na detetion. 2. ed. New Jersey: Englewood Cliffs, 1993. $450 \mathrm{p}$.

VIRGILIIS, Luís Afonso Corrêa, Procedimentos de projeto e execução de pavimentos permeáveis visando a retenção e amortecimento de picos de cheias, 2009, 213 f. Dissertação (Mestrado em Engenharia de transporte) Escola Politécnica da Universidade de São Paulo, São Paulo, 2009. 


\title{
Din \\ Iluminação em pátios ferroviários: \\ Um estudo de caso sobre redução de consumo de energia elétrica
}

\author{
Jussara Fernandes Leite (FUPAC) leite.jussara@yahoo.com.br \\ Luciano José Vieira Franco (FUPAC) lucianov_franco@ hotmail.com \\ Alexandre Horta Tourinho (FUPAC) alexht27@hotmail.com \\ Bruno Dias Moreno (FUPAC) brunosdm103@gmail.com
}

Resumo: Os pátios são responsáveis por formar trens, receber máquinas de manutenção, garagear trens e controlar o fluxo. O pátio de manobra que foi abordado neste estudo opera $24 \mathrm{~h}$ por dia, sendo necessário o apoio de luz artificial no período noturno para que não tenha as operações paralisadas. Devido a constante alta na tarifa da energia elétrica, o que impacta diretamente no custo de empresa, é essencial que a utilização da energia elétrica seja de tal forma que venha agregar valor no produto final. Dessa forma, é necessário identificar pontos onde se tenha oportunidade de melhoria na gestão e no uso da iluminação e apresentar propostas de economia de energia elétrica. Este estudo de caso e caracterizado como exploratório e documental. O estudo foi desenvolvido em um Pátio de Manobras Ferroviário do estado de Minas Gerais. Os dados foram coletados por meio de observação, visita em campo e documentos da empresa. Portanto, a medida proposta foi a desligamento de uma parcela de torres de iluminação de locais onde não há fluxo de pessoas trabalhando e desenvolver um sistema de acendimento de torres de iluminação manual via software para ligar as torres somente quando for realmente necessário.

Palavras-chave: Pátio de manobra; Iluminação; Energia elétrica.

\section{Introdução}

A energia elétrica é um recurso energético fundamental para indústrias, residências e comércios. Ela se tornou o bem de consumo que rege toda a vida moderna, pois é por meio dela que o homem realiza as mais diversas atividades em máquinas e equipamentos.

Outra importante função da energia elétrica é a capacidade de iluminar ruas, praças, casas e empresas. Assim, ela promove o desenvolvimento de atividades no período noturno tanto nas organizações, como também nas residências.

No entanto, o consumo de energia elétrica vem se tornando um vilão para as empresas brasileiras, uma vez que, a cada dia o preço desse insumo aumenta. Sobre esse assunto, conforme apresentado na revista Exame, Ginesi (2015) informa que as tarifas de energia elétrica para empresas não param de subir no Brasil. Em 2014, o aumento médio foi de 5\% em relação a 2013. Em 2015, o preço do megawatt-hora deve subir pelo menos 12\%, segundo projeções da Associação Brasileira das Empresas de Serviços de Conservação de Energia (Abesco). Até 2020, o acréscimo deve ser de pelo menos 9\% ao ano.

Para as empresas ferroviárias, a energia elétrica é fundamental para suas operações. Toda empresa ferroviária possui grandes espaços ao ar livre ou cobertos que são denominados 


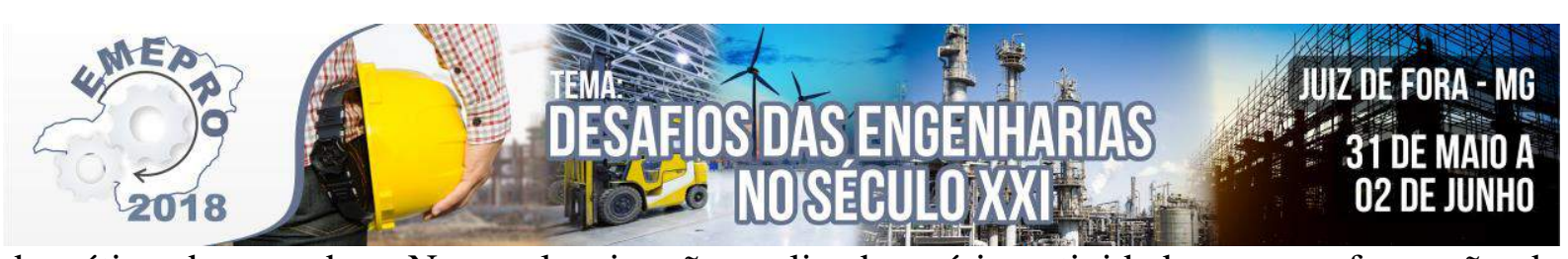

de pátios de manobra. Nesses locais, são realizadas várias atividades como: formação de trens, manutenção ou inspeção de via permanente, garagear trens, controle de fluxo dos trens, entre outras.

Os pátios de manobra normalmente operam 24 horas por dia e 365 dias por ano. Desta forma, a iluminação é fundamental para realizar as atividades. Assim, as empresas instalam torres de iluminação ao longo de todo pátio.

Nas torres, a iluminação, no período noturno, é acionada de forma automática, isto é, ao escurecer, as lâmpadas acendem. Entretanto, os tipos de lâmpadas utilizados podem impactar em alto consumo de energia, que consequentemente acarreta em grandes custos para as empresas ferroviárias. Acrescenta ainda, que os gastos podem ser maiores quando há necessidade de intervenção de manutenção em torres e troca de lâmpadas.

Nesse contexto, este trabalho tem o objetivo de apresentar melhorias para reduzir o consumo de energia elétrica com a iluminação de um pátio de manobra ferroviário do Estado de Minas Gerais.

\section{Economia de energia}

Voltimum (2016) salienta que para a sociedade a economia de energia de empresas e indústrias gera disponibilidade de energia para cidades, o que diminui a possibilidade de racionamento e, dessa forma, evitando desperdícios. Assim há mais recursos para outras áreas, nomeadamente as de desenvolvimento social.

Em relação ao meio ambiente, Voltimun (2016) esclarece que a economia de energia promove à preservação da água em muitas regiões do Brasil. A contenção no uso da energia elétrica pode ajudar no manejo do ciclo hidrológico brasileiro, considerando que quase toda energia gerada no país é feita através de hidrelétricas.

Para Vichi e Mansor (2009), no Brasil, a participação da energia hidráulica chega a $14,9 \%$ da matriz energética total, e corresponde a $85 \%$ da eletricidade gerada. A Tabela 1 mostra a evolução da participação desta fonte na oferta de energia elétrica em três momentos: 1970, 1994 a 2007.

TABELA 1 - Evolução da oferta de energia elétrica no Brasil

\begin{tabular}{cccc}
\hline Setor & $\mathbf{1 9 7 0}(\boldsymbol{\%})$ & $\mathbf{1 9 9 4}(\boldsymbol{\%})$ & $\mathbf{2 0 0 7}(\boldsymbol{\%})$ \\
\hline Hidráulica & 87 & 94 & 85 \\
Urânio & 0 & 0 & 3 \\
Gás Natural & 0 & 0 & 3 \\
Carvão Mineral & 3 & 2 & 1 \\
Derivados de Petróleo & 8 & 2 & 3 \\
Outras & 2 & 2 & 5 \\
\hline
\end{tabular}

Fonte: Balanço Energético Nacional (2007) apud. Vichi e Mansor (2009)

Conforme dados da Tabela 1, Vichi e Mansor (2009) apresentam que a redução entre 1994 e 2007 deve-se principalmente ao aumento da participação dos autoprodutores independentes, que vêm utilizando a biomassa, principalmente o bagaço de cana, na geração de eletricidade, além da entrada em operação de usinas termelétricas movidas a gás natural e nucleares. 


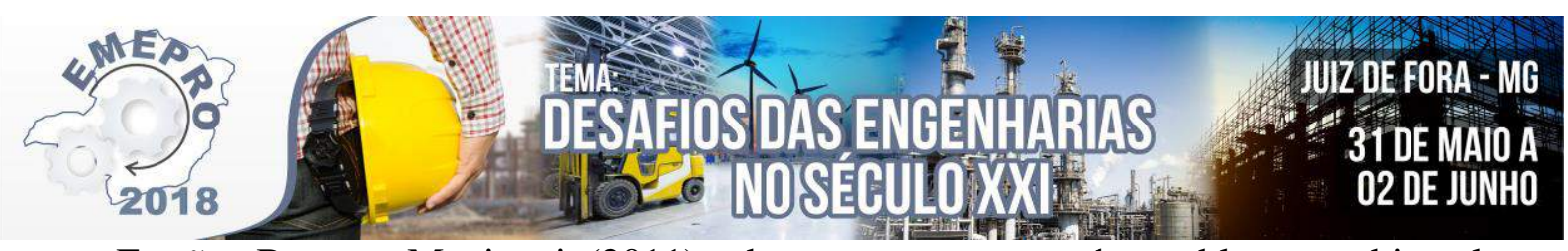

Frasão, Barra e Meniconi (2011) advogam que o grande problema ambiental - e também social - causado pelas hidroelétricas é a necessidade de represar os rios. Nessas situações, vastas regiões são alagadas, o que provoca não só a retirada das populações humanas do local, como alterações no ecossistema.

\section{Descrição do pátio de manobra}

Pátio ferroviário é um local onde a estrada de ferro se expande em uma vasta área composta de linhas paralelas conectadas por aparelhos de mudança de via (AMVs) e outros dispositivos ferroviários que permitem a passagem de uma linha para outra (GARD, s/d).

A Figura 1 apresenta um exemplo de pátio de manobra ferroviário.

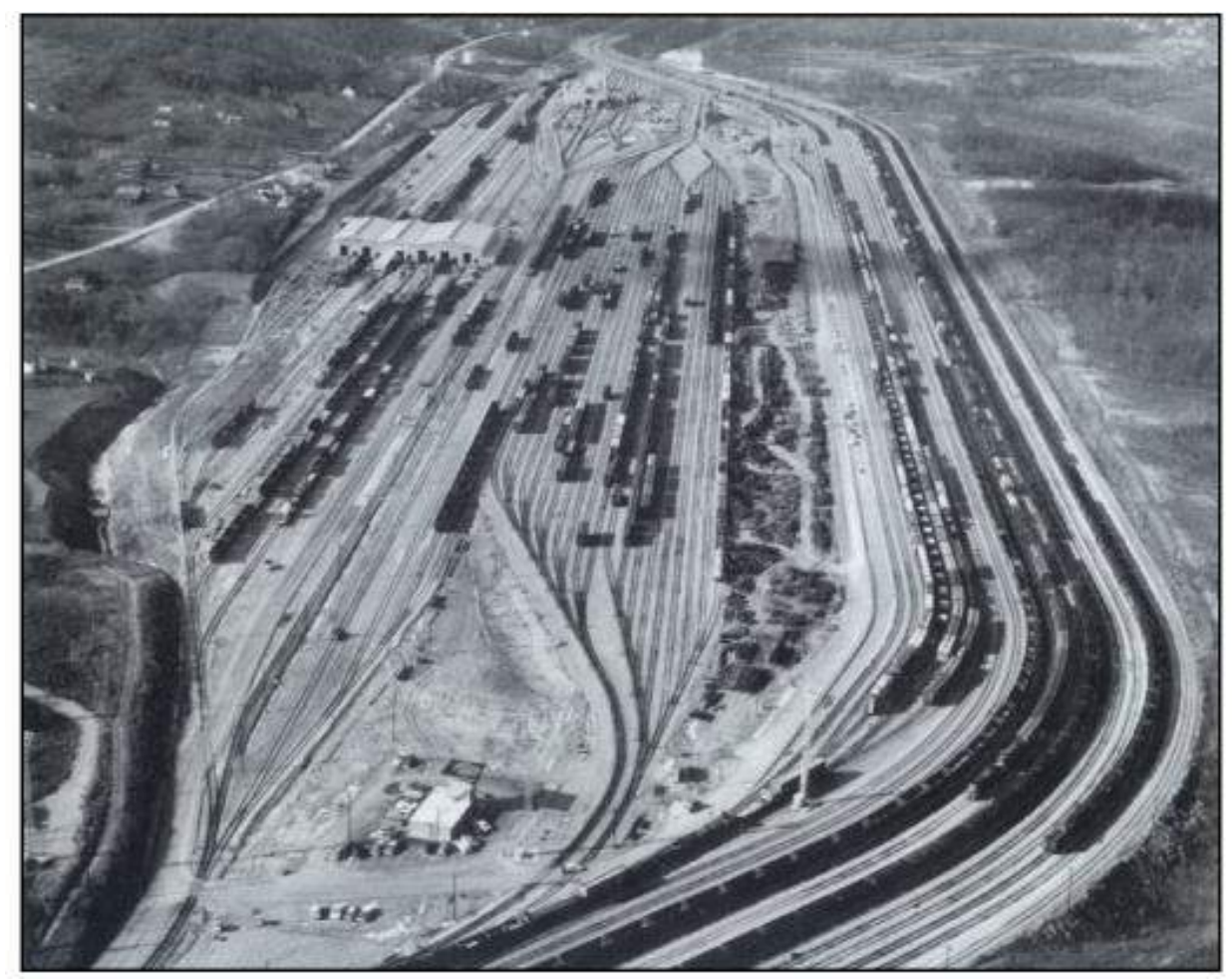

FIGURA1- Área de um pátio ferroviário em operação. Fonte: GARD (s/d)

De um modo geral, segundo Fernandes (2010), podem-se dividir os pátios ferroviários em três categorias: cruzamento, triagem e terminais.

Os pátios de cruzamento são destinados apenas ao cruzamento dos trens. São os pátios mais simples nos quais a única preocupação é ter desvio com comprimento suficiente para conter o trem de maior comprimento que circula no trecho (FERNANDES, 2010). Esse autor ainda afima que poderá, conforme a intensidade do tráfego, ter um ou dois desvios e, se necessário, mais um para estacionamento de vagões avariados.

Fernandes (2010) esclarece que os pátios de triagens são assim denominados os pátios caracterizados por duas situações principais: entroncamento de duas ou mais linhas ou ramais da ferrovia; e pontos de quebra de tração, em virtude de mudança de perfil da linha por exemplo, ponto final de serra e início de planalto.

Um pátio terminal se caracteriza pela circunstância de ter maior movimento de carregamento de mercadorias ou descarga ou, ainda, de ambas as operações. Sua posição não é necessariamente num ponto final de linha ou ramal. A expressão terminal tem sentido de predominância de chegada naquele pátio (FERNANDES, 2010). 


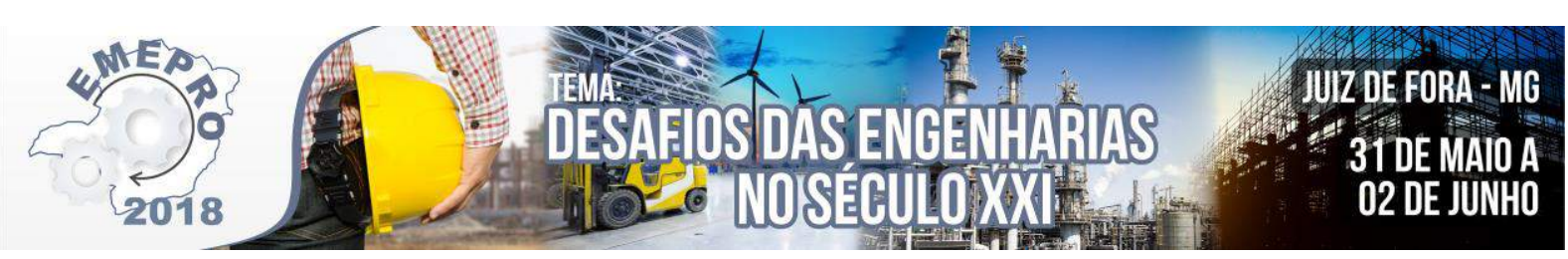

\section{Metodologia da pesquisa}

Essa pesquisa é um estudo de caso de natureza exploratória e documental. O estudo foi desenvolvido em um Pátio Ferroviário do Estado de Minas Gerais, onde foi levantado o consumo de energia elétrica do pátio, consumo individual e coletivo das torres de iluminação e foi verificado como poderia se fazer uma melhor utilização das torres.

O universo da pesquisa são as torres de iluminação do Pátio Ferroviário. Para melhor entendimento da situação, foi levantado o consumo de energia elétrica do pátio e o consumo de cada lâmpada, torre de iluminação e do coletivo das torres de iluminação.

A coleta de dados foi realizada por meio de observação em campo, visita às torres e acesso a documentos da empresa. Foi verificado consumo individual de cada lâmpada, de cada torre, do consumo total de todas as torres e em seguida, realizada uma análise em conjunto com os responsáveis pelos os usuários do pátio para verificar a necessidade de se ter torres acesas em toda a extensão do pátio.

O pátio em estudo possui 61 torres de iluminação, com 10 lâmpadas cada torre, totalizando 610 lâmpadas de 400 Watts e consumo total de energia mensal nas torres de iluminação do pátio na ordem de $84180 \mathrm{kWh}$.

A observação e os dados coletados em documentos possuem natureza qualitativa e quantitativo. Esses dados foram utilizados para descrição da característica do objeto de estudo. Os documentos forneceram dados quantitativos, que se referem aos valores de consumo de energia do pátio em estudo.

\section{Apresentação dos dados e resultados}

Neste capítulo, é contextualizado o pátio e a estrutura das torres de iluminação. Além disso, o estudo e a proposta de redução do consumo de energia elétrica.

\subsection{O pátio e a torres do estudo}

O pátio Ferroviário estudado possui 289 funcionários diretos, 11,5 km de extensão. Ele recebe máquinas de manutenção ferroviária, veículos de inspeção ferroviária, trens de carga em geral e trens de minério de ferro.

O pátio em estudo opera $24 \mathrm{~h}$ por dia e 365 dias por ano. Devido a sua importância, o pátio em estudo, para atender a uma demanda de produção cada vez mais crescente, necessita operar em período noturno. Para tal, necessita de apoio de iluminação artificial que são geradas por torres denominadas torres de iluminação.

O pátio em estudo possui 61 torres de iluminação. A Figura 2 apresenta a distribuição das torres ao longo do pátio. 

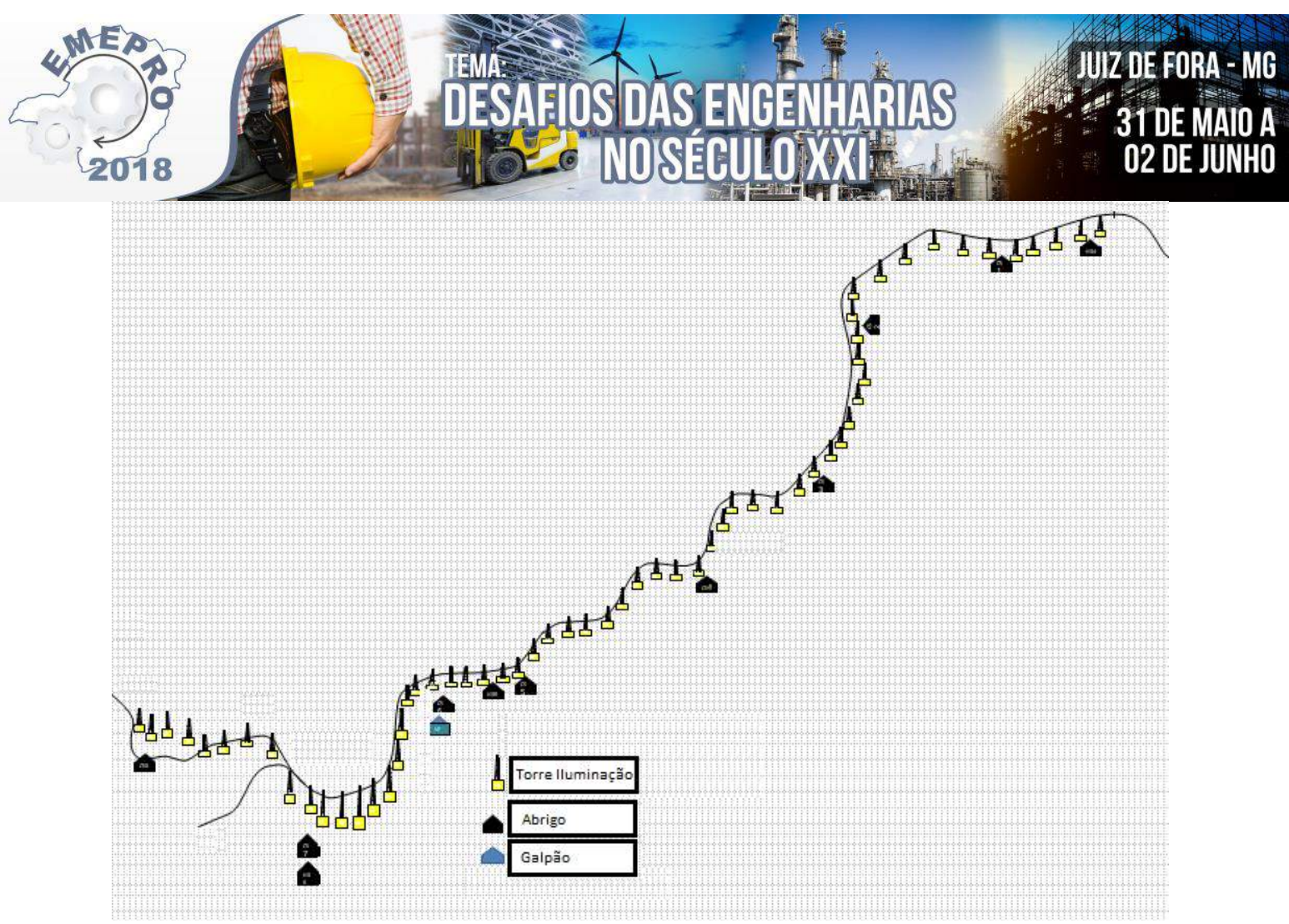

FIGURA 2 - Distribuição das torres ao longo do pátio. Fonte: Dados da pesquisa (2017)

Na Figura 2, pode-se verificar a distribuição das torres de iluminação e onde o local de abrigo e galpão, ou seja, edificações são onde está concentrado o maior fluxo de pessoas.

As torres de iluminação são equipamentos metálicos galvanizados, instalados em intervalos de 190 metros umas das outras cujo o comprimento é de 36 metros. Verifica-se na Figura 3 a seguir a ilustração de uma torre de iluminação do Pátio Ferroviário.

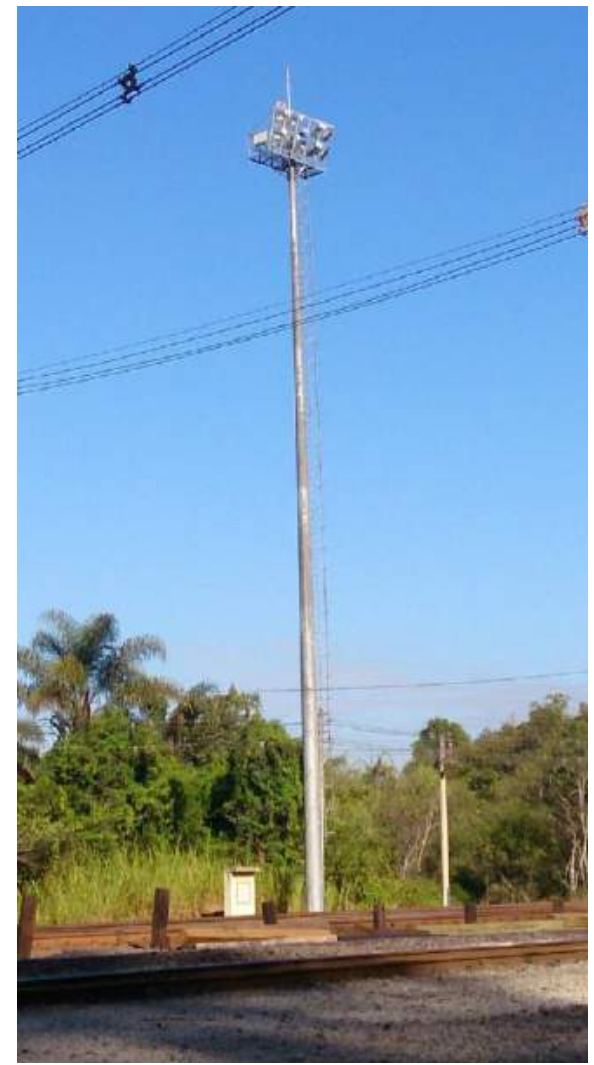

FIGURA 3 - Torre de Iluminação do Pátio em Estudo. Fonte: Dados da pesquisa (2017) 


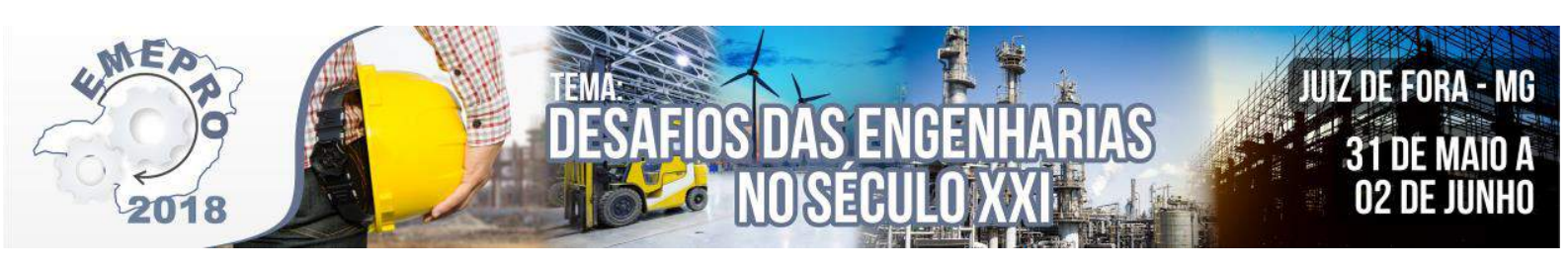

Apresentada na Figura 3, a torre de iluminação se divide em: corpo tubular em aço galvanizado, refletores, reatores, lâmpadas, painel de controle e para-raios. Cada torre de iluminação possui 10 refletores com lâmpadas vapor de sódio, com 10 reatores, com potência de 400 Watts cada lâmpada totalizando $4 \mathrm{~kW}$ de potência cada torre. Ao lado da torre fica o painel de controle no interior do painel de controle que fica o comando elétrico que, em conjunto com o relê fotoelétrico é responsável pelo funcionamento da torre. internos.

A Figura 4 apresenta a lâmpada utilizada nas torres de iluminação e seus componentes

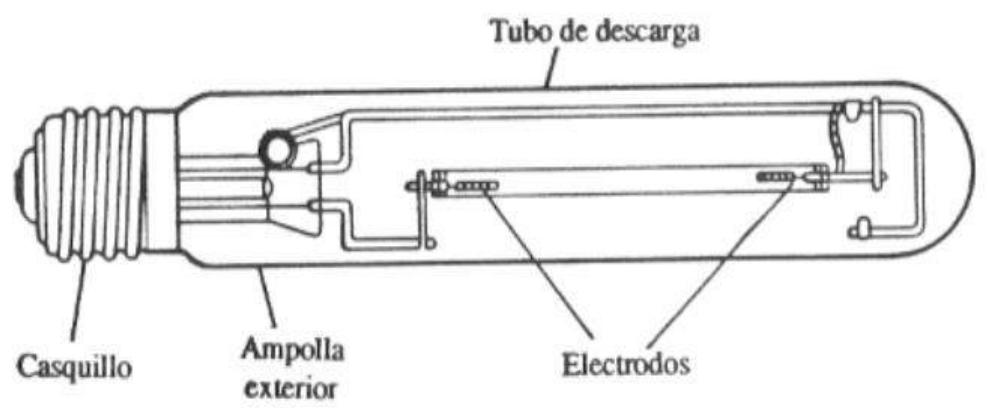

FIGURA 4 - Lâmpada vapor de sódio. Fonte: Usp (2005)

Apresentada na Figura 4 as lâmpadas da torre do pátio em estudo são do tipo vapor de sódio de alta pressão e possuem 400Watts de potência.

As torres de iluminação do pátio em estudo têm média de funcionamento de 11,5 horas por dia. Seu acionamento é feito de forma automática por meio de um dispositivo eletrônico chamado relê fotoelétrico, conforme pode ser verificado na Figura 5.

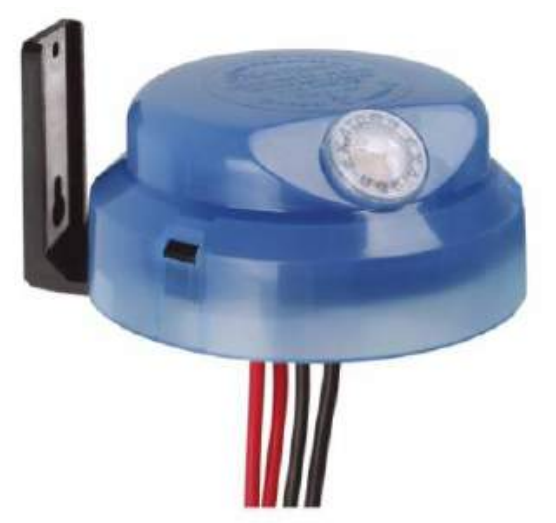

FIGURA 5 - Relé foto elétrico. Fonte: Fg (s/d)

O relê fotoelétrico é responsável por acionar a torre de iluminação e seu funcionamento é em função da incidência de luz sobre o mesmo. Cada torre possui um relê fotoelétrico. Na Figura 5 podemos observar a características construtivas do relê fotoelétrico. O funcionamento de relê foto elétrico é relativamente simples, quando a luminosidade incidente sobre o relê fotoelétrico diminui, ou seja, anoitece o mesmo aciona a torre de forma a energizar todas as lâmpadas da torre, quando a luminosidade incidente sobre o relê fotoelétrico diminui, ou seja, amanhece o relê fotoelétrico desenergiza as torres. 


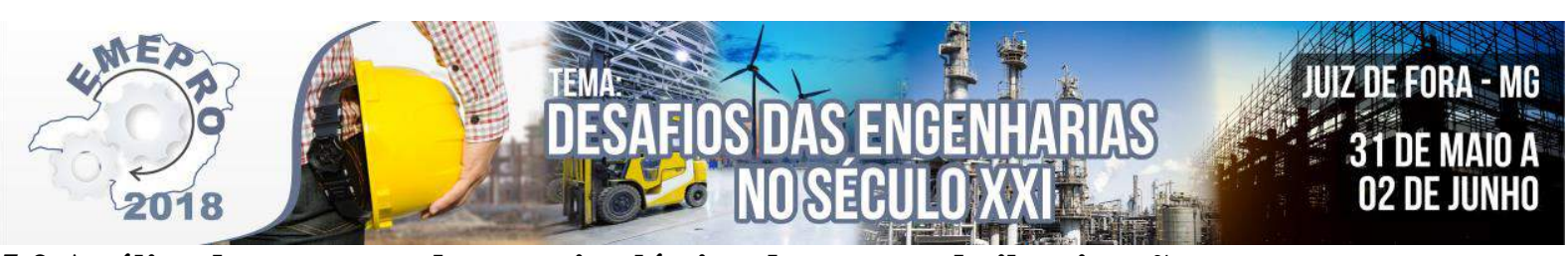

5.2 Análise do consumo de energia elétrica das torres de iluminação

O pátio em estudo dispõe de 61 (sessenta e uma torres de iluminação). Todos os dias em torno das 18:30 horas inicia-se o processo automático de acendimento das lâmpadas das torres do pátio e são desligadas em torno das 05:30 da manhã do próximo dia.

Para realizar o calculo do consumo de energia elétrica das torres de iluminação, neste estudo, foi identificado o consumo de energia elétrica por lâmpada, a quantidade de lâmpada por torre, o tempo diário que as lâmpadas permanecem acessas por dia e a quantidade de torre no pátio, conforme pode ser verificado na Tabela.

TABELA 2 - Dados da torre de iluminação

\begin{tabular}{cc}
\hline Consumo por lâmpada & 400 Watts \\
\hline Quantidade de lâmpada por torre & 10 unidades \\
Tempo diário de acendimento & 11,5 horas \\
Quantidade de torres & 61 \\
\hline
\end{tabular}

Fonte: Dados da pesquisa (2017)

Nesta pesquisa, foi identificado que o consumo de cada lâmpada é de 400 Watts, que cada torre de iluminação possui 10 unidades dessas lâmpadas, que o pátio dispõe de 61 torres de iluminação, que o tempo em que as torres de iluminação ficam ativas é em torno de 11,5 horas diárias e que ficam ativas em média 30 dias por mês.

\subsubsection{Consumo Atual das Torres de Iluminação}

A partir dos dados identificados na Tabela 2 pode-se calcular o consumo de energia elétrica da torre de iluminação. $\mathrm{O}$ cálculo do consumo de uma torre pode ser verificado no Quadro 1.

Consumo da torre: 400 Watts x 10 lâmpadas x 11,5 horas $=46 \mathrm{kWh}$

QUADRO 1 - Consumo de energia elétrica de uma torre de iluminação. Fonte: Dados da pesquisa (2017)

Verifica-se por meio do Quadro 1 que cada torre de iluminação consome diariamente $46 \mathrm{kWh}$ de energia elétrica. A partir desse resultado foi calculado o consumo diário de todas as torres iluminação do pátio ferroviário. O cálculo pode ser observado no Quadro 2.

\begin{tabular}{|c|}
\hline Consumo das torres diário: $46 \mathrm{kWh}$ x 61 torres $=2.806 \mathrm{kWh}$ \\
\hline QUADRO 2 - Consumo de energia elétrica de todas as torres de iluminação - diário. Fonte: Dados da pesquisa
\end{tabular} (2017)

Observa-se no Quadro 2, que as 61 torres de iluminação do pátio ferroviário consomem $2.806 \mathrm{kWh}$ diariamente. Por meio desse resultado, foi calculado o consumo mensal de energia elétrica das torres de iluminação do pátio ferroviário. Para isso, foram considerados 30 dias o mês. O Quadro 3 apresenta do cálculo do consumo de energia elétrica mensal.

Consumo das torres mensal: $2.806 \mathrm{kWh}$ x 30 dias $=84.180 \mathrm{kWh}$

QUADRO 3 - Consumo de energia elétrica de todas as torres de iluminação - mensal. Fonte: Dados da pesquisa (2017) 


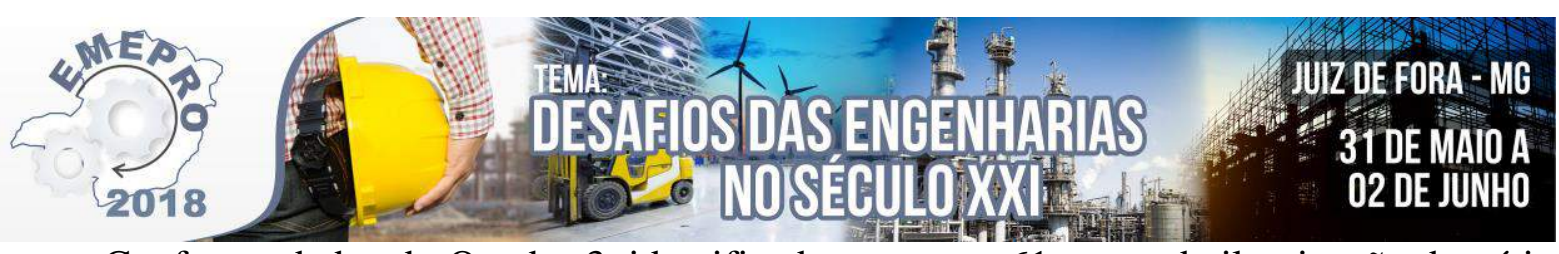

Conforme dados do Quadro 3, identificado-se que as 61 torres de iluminação do pátio ferroviário consomem $84.180 \mathrm{kWh}$ de energia elétrica em um mês.

\subsubsection{Proposta para redução do consumo de energia elétrica das torres de iluminação do pátio ferroviário}

A partir deste estudo, foi sugerido desativação de 39 torres de iluminação, ou seja, que nos períodos noturnos essas torres fiquem apagadas e deixadas em modo stand by, para que sejam somente utilizadas na situação de algum tipo de manutenção a ser executada, algum sinistro no pátio ou outra atividade que exija iluminação artificial.

Mediante visita em campo e levantamento feito via a supervisão e inspetoria do pátio, foi identificado que existem locais onde se faz necessário a iluminação em todo período noturno (devido à presença de edificações vulneráveis e locais com grande fluxo de pessoas) e locais onde não há necessidade de terem torres acessas no período noturno, salvo em raras situações especiais a exemplo: acidentes ferroviários, quebra de locomotivas, quebra de vagões e manutenção em equipamentos ferroviários.

A Figura 6 apresenta as torres que devem estar ativadas e as que não são necessárias estarem ativadas de acordo com a orientação da supervisão/inspetoria do pátio.

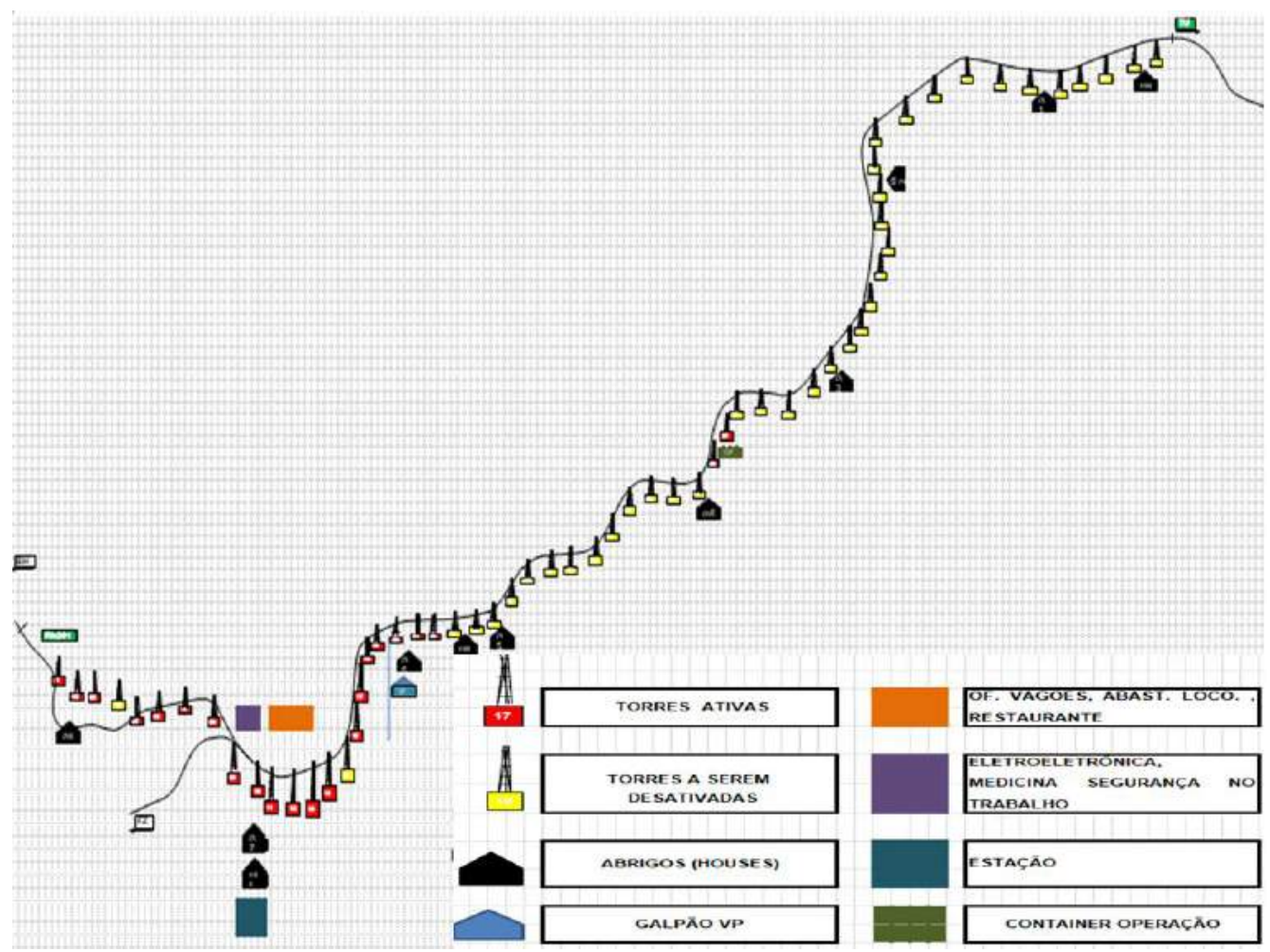

FIGURA 6 - Torres que podem ser desativadas. Fonte: Dados da pesquisa (2017)

A Figura 6 apresenta a legenda que detalha melhor a sugestão de quais as torres devem ficar ativadas/desativadas de acordo com o fluxo de pessoas que se concentram nas edificações do pátio em estudo e nas proximidades destas edificações em concordância com a orientação da supervisão/inspetoria do pátio.

Assim, nesta pesquisa, conforme Figura 6, foi sugerido que 22 torres deveriam permanecer ativadas e as demais desativadas sendo deixadas em modo stand by. O consumo de energia elétrica diário das 22 torres foi calculado e pode ser verificado no Quadro 4. 


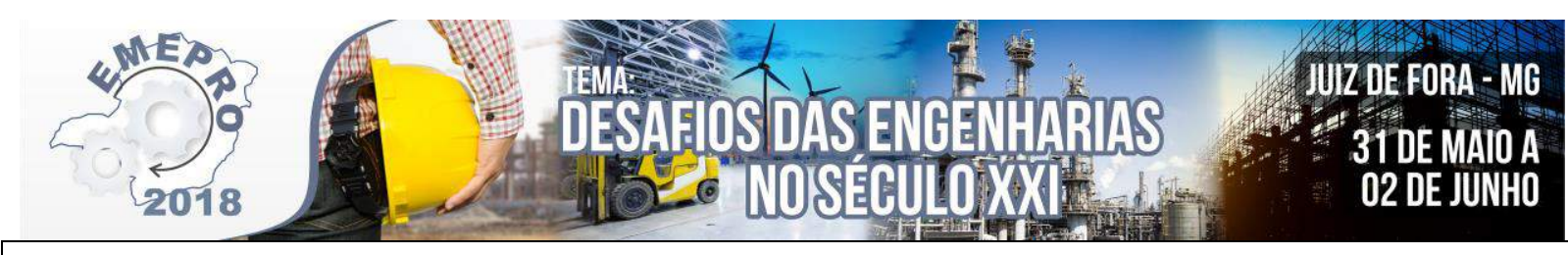

Consumo da torre diário:

400 Watts x 10 lâmpadas x 11,5 horas x 22 torres $=1.012 \mathrm{kWh}$

QUADRO 4 - Consumo de energia elétrica das 22 torres de iluminação - Diário. Fonte: Dados da pesquisa (2017)

Conforme se pode verificar no Quadro 4, o consumo diário de energia elétrica das 22 torres de iluminação seria de $1.012 \mathrm{kWh}$. Por meio desse resultado, foi calculado o consumo mensal das 22 torres. O Quadro 5 apresenta o cálculo.

Consumo das torres mensal: $1.012 \mathrm{kWh} \times 30$ dias $=30.360 \mathrm{kWh}$

QUADRO 5 - Consumo de energia elétrica das 22 torres de iluminação - Mensal. Fonte: Dados da pesquisa

(2017)

Nota-se no Quadro 5 que o consumo mensal de energia elétrica das 22 torres de iluminação seria de $30.360 \mathrm{kWh}$.

A título de comparação, o Gráfico 1 mostra qual é o consumo de energia elétrica em um mês com o funcionamento das 61 torres do pátio ligadas e qual seria o consumo de energia elétrica em um mês com as 22 torres do pátio ligada.

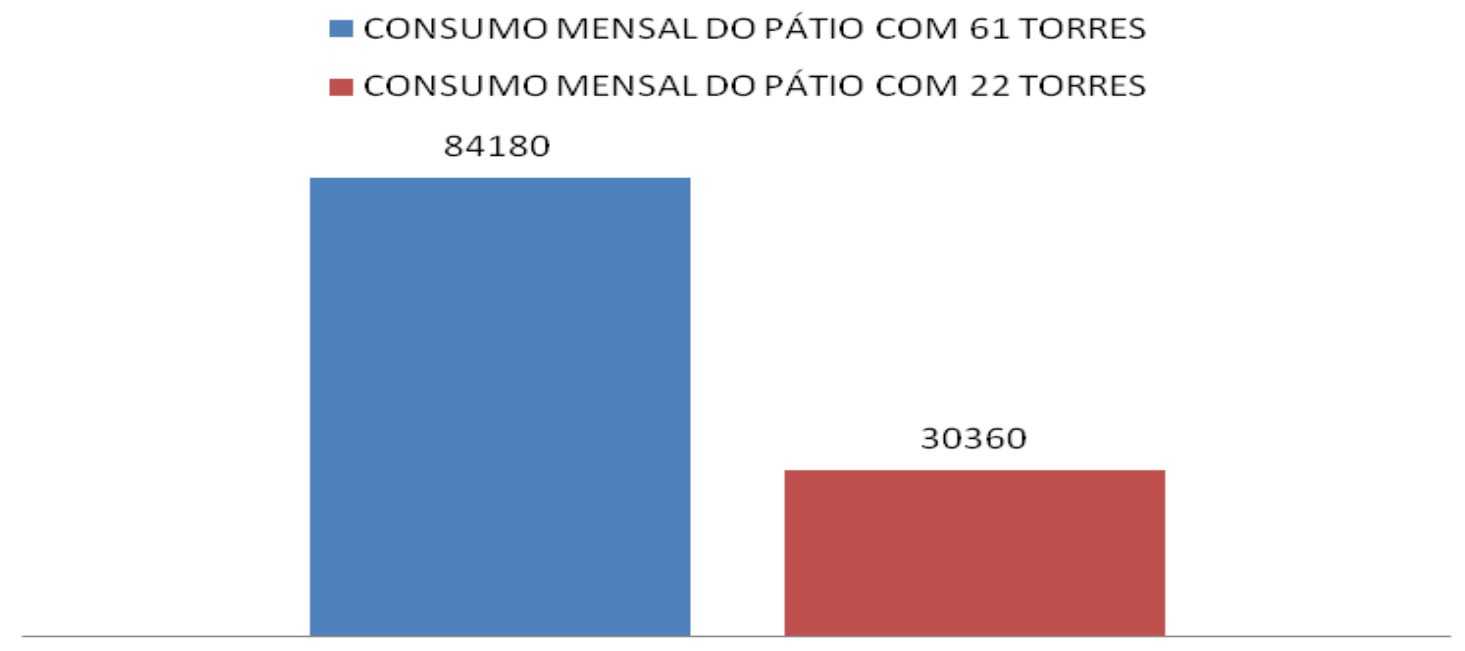

Valores em kWh

GRÁFICO 1 - Consumo Mensal das torres de iluminação. Fonte: Dados da pesquisa (2017)

O Gráfico 1 demonstra que caso a sugestão fosse implementada no pátio ferroviário em estudo a redução no consumo de energia elétrica seria da ordem de $53.820 \mathrm{kWh}$ mês, o que representa uma redução de $64 \%$ no consumo de energia elétrica das torres de iluminação em um mês.

\subsection{Outros estudos (troca de tipos de lâmpadas)}

Outra pesquisa realizada neste estudo foi à possibilidade de trocar as lâmpadas do pátio em estudo por outra lâmpada mais econômica e que conserve as mesmas características de fluxo luminoso das lâmpadas que são hoje utilizadas no pátio. Entretanto, por meio deste estudo não foi encontrada no mercado nacional uma lâmpada com tecnologia mais eficiente que possa substituir a atual lâmpada usada no pátio e que atenda aos requisitos: fluxo luminoso compatível; consumo menor; durabilidade maior ou igual; e menor geração de resíduos. 


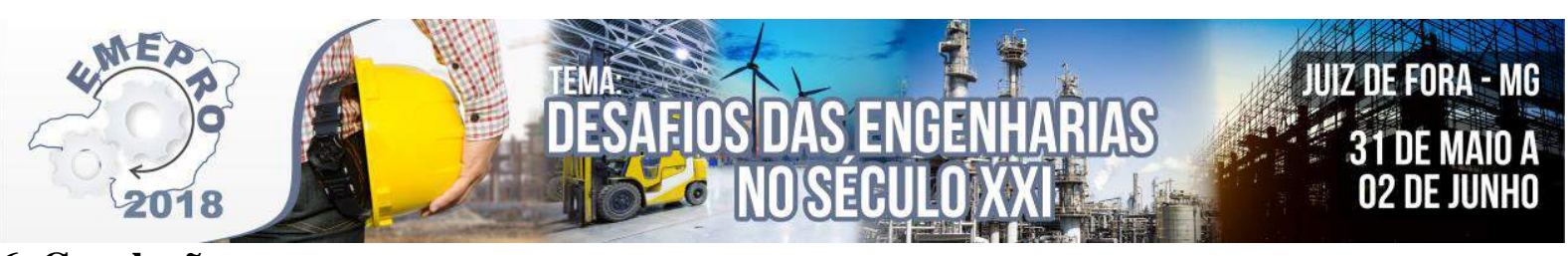

\section{Conclusões}

Diante de uma tarifa de energia elétrica cada dia mais impactante nos custos operacionais das empresas, de uma sociedade que cada dia mais ambientalmente consciente e de recursos naturais cada dia mais escassos, as organizações buscam reduzir o consumo de energia para reduzir seus custos e tornarem-se mais competitivas no mercado.

Nesse contexto, este trabalho foi desenvolvido com o objetivo de apresentar melhorias para reduzir o consumo de energia elétrica com a iluminação de um pátio de manobra ferroviário do estado de Minas Gerais. A partir do desenvolvimento da pesquisa foi sugerida a desativação de 39 torres, gerando redução de 64\% no consumo de energia das torres de iluminação. As 39 torres de iluminação desativadas ficariam em modo stand by para serem somente utilizadas em situações já mencionadas neste estudo.

Com a implementação da proposta sugerida a empresa poderá ter além de ganhos financeiros, ganhos ambientais e de segurança para o trabalhador. Os benefícios extrapolam os limites de economia de consumo energia se beneficiando a empresa com menos material em estoque, funcionários menos expostos a riscos em trabalho em altura, menos geração de resíduos, maior disponibilidade dos envolvidos na atividade de manutenção dessas torres em outras atividades e consequentemente uma empresa com um produto final com maior valor agregado, ou seja, um produto mais competitivo.

Acrescenta-se ainda que, se a proposta fosse implementada, os ganhos na economia de energia nas torres de iluminação podem ser potencializados caso as lâmpadas utilizadas no pátio forem substituídas por lâmpadas que utilizem tecnologia de iluminação via LED, mas para tal, a tecnologia de iluminação via LED deve ser desenvolvida ao ponto de que produza luminosidade equivalente ao tipo de lâmpada hoje utilizada no pátio, com o consumo de energia menor e podendo ser utilizada em grandes áreas abertas. Dessa forma, a empresa se beneficia ainda no que diz respeito a menos geração de resíduos e menos materiais em estoque.

\section{Referências}

FG. Relé fotoelétrico trifacil 220v - exatron. Disponível em: < http://www.fg.com.br/rele-fotoeletrico-trifacil220v---exatron/p >. Acesso em: 16/10/2017

FRASÃO, L.; BARRA, M.; MENICONI, T. Entenda como a geração de energia elétrica afeta o meio ambiente. Do G1, em São Paulo: 2011. Disponível em: <http://g1.globo.com/ciencia-e-saude/noticia/2011/03/entendacomo-geracao-de-energia-eletrica-afeta-o-meio-ambiente.html>. Acesso em: 16/05/2017.

FERNANDES. G. Pátios Ferroviários e Feixes de Desvios. Disponível em: <http://www.em.ufop.br/deciv/departamento/ gilbertofernandes/aula\%2010.pdf>. Acesso em: 15/10/2017

GARD. Otimização com colônia de formigas aplicada a programação de operações de locomotivas de manobras. Disponível em: <http://www2.dbd.puc-rio.br/pergamum/tesesabertas/0321287_08_cap_02.pdf> Acesso em: 06/10/2017

GINESI, Camila. 5 ideias para baixar os custos de energia na empresa. Revista Exame.com. 2015. Disponível em: <http://exame.abril.com.br/pme/em-busca-de-eficiencia/>. Acesso em: 22/03/2017.

VICHI, F. M.; MANSOR, M. T. C. Energia, meio ambiente e economia: o Brasil no contexto mundial. Revista eletrônica Scielo, Quim. Nova, Vol. 32, No. 3, São Paulo: 2009. Disponível em:< http://www.scielo.br/scielo.php?script=sci_arttext\&pid=S0100-40422009000300019>. Acesso em: 16/05/2017.

VOLTIMUM. Vantagens e benefícios da economia de energia elétrica. 2016. Disponível em: $<$ http://www.voltimum.com.br/artigos/noticias-do-setor/vantagens-e-beneficios-da-economia-de-energiaeletrica>. Acesso em: 16/05/2017. 


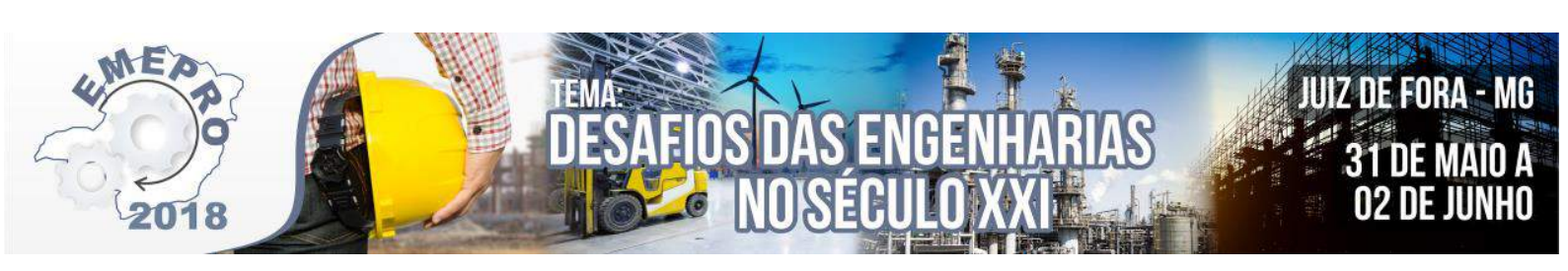

Comparativo entre processos de produção de carvão

\author{
GILVAN DOS SANTOS GAUDERETO.FUPAC - UBÁ.gilvan.gaudereto@hotmail.com \\ LUARA FERREIRA ALVES. FUPAC - UBÁ. luharaa@ hotmail.com \\ WILLIAM JOSÉ LOPES. FUPAC - UBÁ. williamjlopes@yahoo.com.br \\ LILIANE SOUZA OLIVEIRA MONI. FUPAC - UBÁ. lilianeso@gmail.com \\ ERIKA MARIA CARVALHO SILVA GRAVINA. FUPAC - UBÁ. ericamariacs@gmail.com
}

\begin{abstract}
Resumo: O Objetivo do trabalho foi comparar o sistema de produção de carvão vegetal de uma empresa que trabalha com queimador de gases. Foi analisado um período onde a empresa trabalhou com uma plataforma de fornos em sistema com queima de gases e a outra sem o sistema de queima. Onde foram usados dados que comprovaram a eficiência produtiva do sistema de queimador que auxiliam na retirada dos gases da carbonização. A matéria prima utilizada na produção foi analisada quanto à umidade e densidade para garantir uma igualdade nos tratamentos. No período avaliado, a qualidade do carvão foi monitorada e não foi detectada nenhuma alteração nos parâmetros exigidos pela indústria de Silício Metálico. Os trabalhos comprovaram a eficiência ecológica dos queimadores para a redução de poluentes emitidos pelo processo. Os resultados mostram ganhos significativos do sistema com queima de gases na produção e na forma sustentável de se produzir carvão para usos siderúrgicos no país. O sistema também foi considerado um novo conceito na produção de carvão com qualidade e por ser eficiente em produção limpa, sem poluir o meio ambiente e dar um aspecto mais humano à produção nacional de carvão.

Palavras-chave: Carvão vegetal ecológico; Queima de gases; Produção de carvão do futuro; Energia renovável
\end{abstract}

\title{
1. Introdução
}

O aproveitamento da madeira de eucaliptos como fonte de energia, vem se mostrando nos últimos anos como uma ótima solução para a demanda energética nacional, principalmente por atender a necessidade do setor por energia mais sustentável, potencializando-a como alternativa aos combustíveis fósseis, conduzindo seu uso à diminuição das emissões dos gases do efeito estufa.

As jazidas de carvão mineral nacionais apresentam em pequena quantidade, representando 0,5\% das reservas mundiais. Além disso, o carvão é de má qualidade, hulha (uma qualidade de carvão mineral com baixo poder calorífico e quantidade de cinza elevada (Brasil, 2014). A principal vantagem do carvão vegetal é ser renovável. O Brasil é responsável por $40 \%$ da produção mundial de carvão vegetal, tendo como destino principal a produção de ferro gusa, aço, ferro ligas e silício metálico, e, em 2008, o país consumiu cerca de 34 milhões de $\mathrm{m}^{3}$ de carvão vegetal (AMS, 2009).

Nos últimos anos a silvicultura vem ganhando espaço na agricultura da Zona da Mata mineira com os plantios de florestas de eucaliptos devido a incentivos privados e governamentais e a uma boa adaptação ao clima, relevo e economia da região. 


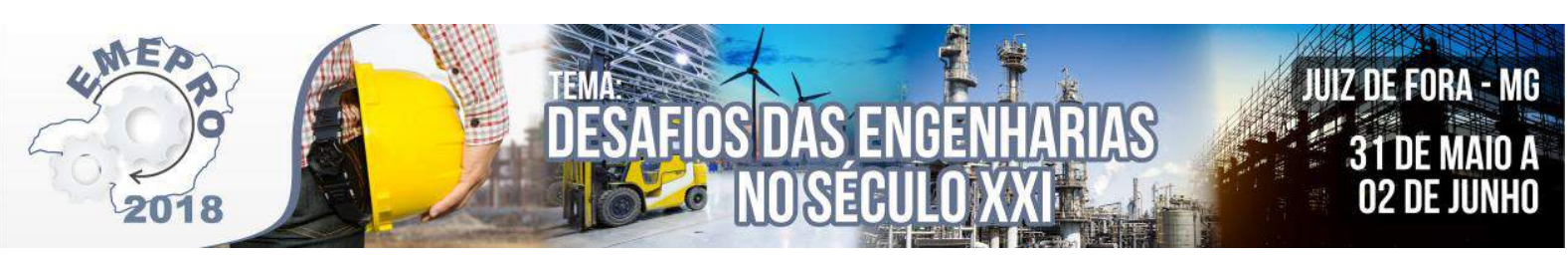

A produção de carvão vegetal no Estado de Minas Gerais mesmo em pleno século XXI, ainda é feita na sua maioria de uma forma muito primitiva e artesanal, proporcionando problemas ambientais e sociais. Essa realidade fez com que médias e grandes empresas dos setores florestais e siderúrgicos, desenvolvessem sistemas de produção voltados à mecanização das atividades, busca por processos ambientalmente corretos e relações mais responsáveis com empregados e com a sociedade.

Deste modo, o desenvolvimento de tecnologia na construção de fornos totalmente mecanizados e na evolução de sistemas que permitem a redução das emissões de gases do efeito estufa, provenientes do processo de carbonização da madeira, proporcionam vantagens aos colaboradores, ao meio ambiente, agregando valor ao produto por ser sustentável e ecologicamente correto.

Com inovador conceito integrado de produção em escala industrial de longo prazo e redução de emissões de gases de efeito estufa, o projeto conceitual da "Refinaria Guaxupé O aproveitamento da madeira de eucaliptos como fonte de energia, vem se mostrando nos últimos anos como uma ótima solução para a demanda energética nacional, principalmente por atender a necessidade do setor por energia mais sustentável, potencializando-a como alternativa aos combustíveis fósseis, conduzindo seu uso à diminuição das emissões dos gases do efeito estufa.

As jazidas de carvão mineral nacionais apresentam em pequena quantidade, representando 0,5\% das reservas mundiais. Além disso, o carvão é de má qualidade, hulha (uma qualidade de carvão mineral com baixo poder calorífico e quantidade de cinza elevada (Brasil, 2014). A principal vantagem do carvão vegetal é ser renovável. O Brasil é responsável por $40 \%$ da produção mundial de carvão vegetal, tendo como destino principal a produção de ferro gusa, aço, ferro ligas e silício metálico, e, em 2008, o país consumiu cerca de 34 milhões de $\mathrm{m}^{3}$ de carvão vegetal (AMS, 2009).

Nos últimos anos a silvicultura vem ganhando espaço na agricultura da Zona da Mata mineira com os plantios de florestas de eucaliptos devido a incentivos privados e governamentais e a uma boa adaptação ao clima, relevo e economia da região.

A produção de carvão vegetal no Estado de Minas Gerais mesmo em pleno século XXI, ainda é feita na sua maioria de uma forma muito primitiva e artesanal, proporcionando problemas ambientais e sociais. Essa realidade fez com que médias e grandes empresas dos setores florestais e siderúrgicos, desenvolvessem sistemas de produção voltados à mecanização das atividades, busca por processos ambientalmente corretos e relações mais responsáveis com empregados e com a sociedade.

Deste modo, o desenvolvimento de tecnologia na construção de fornos totalmente mecanizados e na evolução de sistemas que permitem a redução das emissões de gases do efeito estufa, provenientes do processo de carbonização da madeira, proporcionam vantagens aos colaboradores, ao meio ambiente, agregando valor ao produto por ser sustentável e ecologicamente correto.

Com inovador conceito integrado de produção em escala industrial de longo prazo e redução de emissões de gases de efeito estufa, o projeto conceitual da "Refinaria Guaxupé de Carvão Ecológico", (como é denominada a unidade), levou em consideração a utilização de fornos retangulares, construídos em alvenaria de tijolos comuns, estruturados em concreto armado, com operações de movimentação de madeira e carvão vegetal, totalmente mecanizada. A este conjunto de 30 fornos, foram agregados 2 sistemas para queima dos gases 


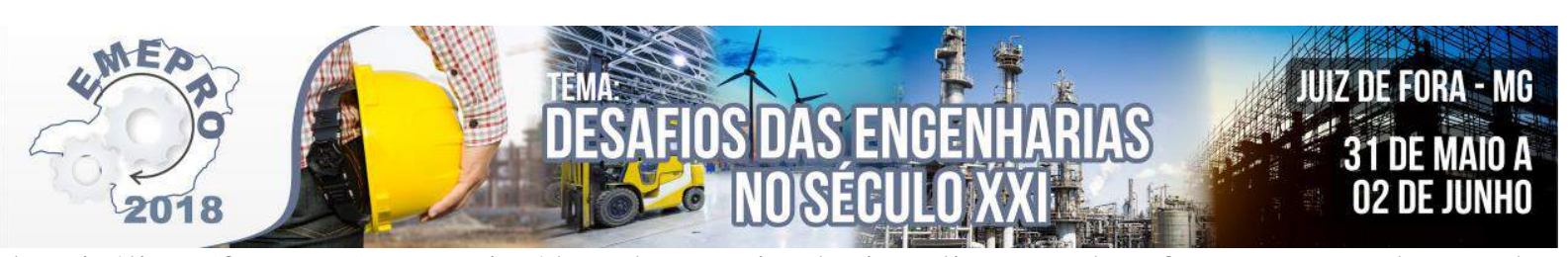

de pirólise (fumaças), constituídos de canais de interligação dos fornos e condução das fumaças, fornalhas para mistura e queima e chaminés de exaustão. $\mathrm{O}$ objetivo do sistema de queima é garantir a quase totalidade do abatimento das emissões, através de ações coordenadas da gestão dos ciclos de carbonização, associadas com a alimentação de combustível auxiliar (madeira e tiço) suficiente para manter o sistema em equilíbrio de queima. Essa estratégia de operação (produção + redução das emissões) contribui para a obtenção de um ambiente fabril mais salubre, além de um diferencial competitivo, do ponto de vista da comercialização do carvão vegetal, expresso pelo melhor preço de venda do produto final. Contratualmente, o produto é denominado como "carvão vegetal ecológico", o que também denota um diferencial importante.

A empresa Refinaria Guaxupé de Carvão Ecológico Ltda, hoje é a maior e a única fornecedora de carvão vegetal Ecológico, produção com redução dos gases poluentes do processo, para os altos fornos da Dow Química Silício do Brasil, uma multinacional Americana com unidade em Santos Dumont - MG. A empresa é líder mundial no setor de Silício. No processo da unidade da Dow Química o carvão vegetal é usado como um termo redutor junto com mineral quartzo na elaboração do Silício metálico.

Diante do exposto, este trabalho tem como objetivo principal fazer o levantamento do processo ecológico de produção de carvão vegetal de eucaliptos da empresa Refinaria Guaxupé de Carvão Ecológico Ltda / Fazenda Guaxupé.

Objetivo específico

- Comparar os processos de produção de carvão vegetal de uma empresa que trabalha com o sistema de queima dos gases da carbonização e analisar sua interferência no processo produtivo;

- Fazer um estudo bibliográfico de trabalhos relacionados a sistemas de produção com queima dos gases, analisando sua eficiência ecológica.

\section{Material e Métodos}

\section{1 - Caracterizações da Região Estudada}

O trabalho de estudo foi realizado em uma refinaria de carvão vegetal (Fazenda Guaxupé) da empresa Refinaria Guaxupé de Carvão Ecológico Ltda. A empresa está situada na Zona da Mata Mineira, mas especificamente no município de Ubá - MG.

Nos últimos anos a silvicultura vem ganhando espaço na agricultura dessa região mineira com os plantios de eucaliptos devido a incentivos privados e governamentais e a uma boa adaptação ao clima e relevo da região.

A produção de carvão vegetal como forma de agregar valor a madeira vem acompanhando esse crescimento e a empresa Refinaria Guaxupé de Carvão Ecológico Ltda (Fazenda Guaxupé) é pioneira na nossa região com um processo de produção industrial e ecologicamente correto.

A empresa dispõe de uma área de 1.400 hectares, sendo 1.000 hectares ocupados por florestas plantadas de eucaliptos. Florestas clonadas (Urograndis, espécie hibrida resultado do cruzamento das espécies Urophylla e Grandis). Material genético com alto rendimento 


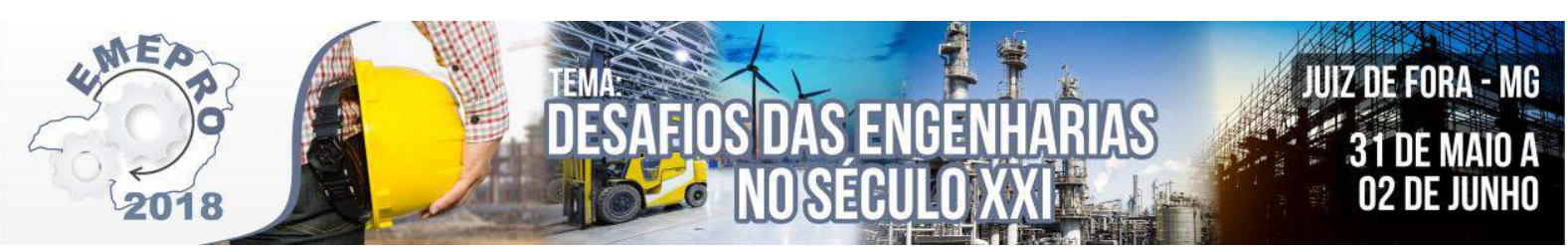

produtivo. A Refinaria de carvão ecológico, unidade de produção de carvão vegetal ocupa uma área de $40.000 \mathrm{~m}^{2}$, composta por trinta fornos e dois queimadores de gases, instalações de apoio, áreas para depósito de madeira e de carvão.

A capacidade instalada hoje da unidade de produção é de aproximadamente $3.000 \mathrm{~m}^{3}$ de carvão mês, que são todos vendidos a Dow Química Silício do Brasil, ressaltando que o carvão tem o seu valor negociado $\mathrm{em}^{3}$ e não em toneladas como é mais utilizado hoje pelas grandes siderúrgicas nacionais, portanto os números abordados no estudo vão ser em cima de conversão $\mathrm{m}^{3}$ de madeira para $\mathrm{m}^{3}$ de carvão e não peso de madeira para peso de carvão, que são os rendimentos gravimétricos.

O processo de carbonização é realizado em fornos construídos em alvenaria ou metal com ou sem sistema de queima de gases. No Brasil, utiliza-se com maior frequência os fornos de alvenaria, sendo estes mais simples e práticos (QUADROS, 2005).

A produção de carvão vegetal esteve sempre associada com pobreza, falta de tecnologia, até mesmo com crimes ambientais e sociais, porém, atualmente essa visão vem sendo modificada pela adoção de novas tecnologias, cada vez mais sustentáveis, do ponto de vista econômico, social e ambiental (CARDOSO, 2010)

Atualmente o alvo de grandes investimentos por parte de grandes empresas do ramo de energia florestal são os fornos retangulares, que chegam a uma capacidade de $450 \mathrm{~m}^{3} \mathrm{de}$ madeira, além de suas operações de carregamento e descarregamento serem mecanizados. Outra grande vantagem deste tipo de forno é permitir a recuperação ou queima dos gases gerados durante a carbonização (RAAD, 2000).

Além de um forno mais técnico para a produção, hoje se busca a otimização do processo de conversão da madeira em carvão vegetal.

A partir dos anos 70, pequenos grupos começaram a se organizar e debater sobre as questões ambientais, mas apenas a partir de meados da década de 90 os movimentos começam a chamar a atenção de população e, principalmente, de grupos políticos. As empresas percebendo que a boa gestão dos impactos ambientais derivados da sua atividade podem se converter não só em oportunidades de negócios, como também em diferencial competitivo na medida em que passam a cobrar e valorizar uma nova conduta de consumidor (NETO et al., 2016). A empresa vem apostando no conceito muito a atual de hoje que é o mercado verde, principalmente com o surgimento de consumidores conscientes que valorizam produtos sustentáveis e com as varias restrições legais sobre os recursos minerais não renováveis.

\section{2 - Características da Matéria-Prima}

A madeira utilizada para o produção de carvão é o eucalipto, clone (3335), desenvolvido pela empresa Plantar Siderúrgica S.A. Material com densidade variando entre $470 \mathrm{Kg} / \mathrm{m}^{3}$ a $510 \mathrm{Kg} / \mathrm{m}^{3}$, com umidade de $45 \%$ base seca $(\mathrm{U}(\%$ b.s.) = (massa de água / massa de matéria seca) x 100) e 180 dias de secagem no campo.

A área de florestas plantadas com a espécie Eucalyptus spp totalizou 5.473.176 ha, em 2013, representando crescimento de 3,2\% (169,012 há) frente ao indicador 2012. A cadeia produtiva do setor brasileiro de base florestal associado às florestas plantadas caracteriza-se pela grande diversidade de produtos finais nos segmentos industriais (IBÁ, 2014). Com a crescente demanda no Brasil por produtos florestais, as espécies de eucalipto passaram a ser 


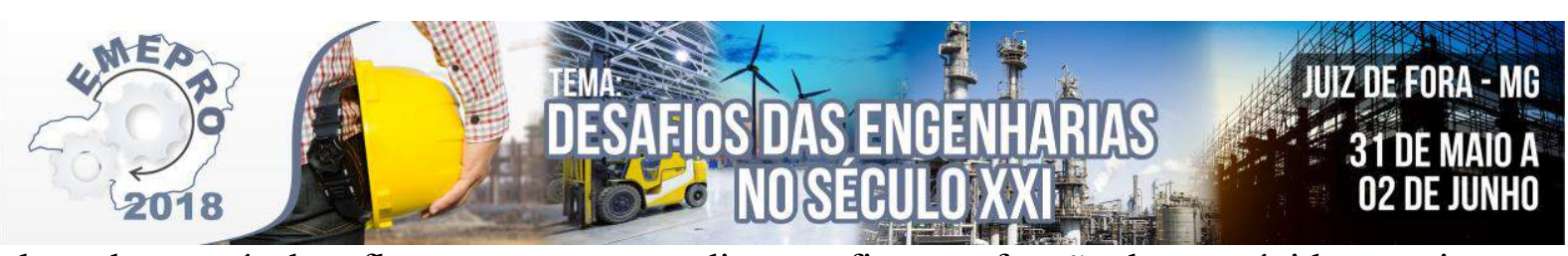

plantada através de reflorestamentos para diversos fins, em função do seu rápido crescimento, adaptabilidade, qualidade da madeira, aliados ao custo de produção (ANDRADE, 1991), os produtos florestais oriundos de florestas de eucalipto tornaram-se mais competitivos no mercado madeireiro (STAPE, 1995, apud FERNANDO, 2009).

\subsection{1 - Controle da Matéria-Prima}

Os caminhões e máquinas que chegam carregados de madeira são medidos em oito pontos na carga, fotografado, pesado em balança rodoviária, tudo registrado em planilhas que permitem a rastreabilidade da madeira. A madeira é colocada nos boxs dos fornos ou pátio de estocagem.

A empresa dispõe de um laboratório para análise de umidade e de densidade da madeira que entra para o processo produtivo.

\section{3 - Carbonização da madeira}

\subsection{1 - Carregamento do forno}

São utilizadas maquinas Pá carregadeira W20 com cabine, ar condicionado, adaptadas com sistema de braço garra para deslocar a madeira dos boxs até o interior dos fornos. São feitos quatro lances (pilhas) de madeira dentro dos fornos totalizando um volume carregado de $50 \mathrm{~m}^{3}$ de madeira.

\subsection{2 - Carbonização}

Após carregamento completo, as portas são fechadas e lacradas com uma mistura de argila e água, os controladores de ar (registros) dos fornos são abertos, e posteriormente é realizada a ignição do forno pela câmara de ignição.

Existe um procedimento escrito, PO (Procedimento Operacional) para a condução do processo, onde as entradas de oxigênio são controladas de acordo com a evolução das temperaturas.

O tratamento dado aos fornos no período dos testes segue a mesma PO. Durante o processo de carbonização as temperaturas são monitoradas por meio de um pirômetro infravermelho. São utilizadas planilhas físicas para coleta das informações que depois são lançadas em computador. Ao fim da carbonização os controladores de ar são fechados para que o forno entre na fase de resfriamento. A carbonização, portanto, é um processo de pirólise lenta, cujo objetivo principal é eliminar a maior parte do oxigênio e do hidrogênio pela ação do calor e, com isso, possibilitar a concentração do carbono na estrutura residual, que é carvão vegetal. A transformação da madeira em carvão é um processo de decomposição térmica físico-química irreversível, que se inicia com a secagem, com a perda de água livre ou capilar e água de adesão, assim inicia-se a fase de pirólise, com a produção de gases condensáveis e não condensáveis. (CARDOSO apud, VALE e GENTIL, 2008).

Segundo PIMENTA, 2000, O processo de carbonização pode ser dividido nas seguintes fases: 


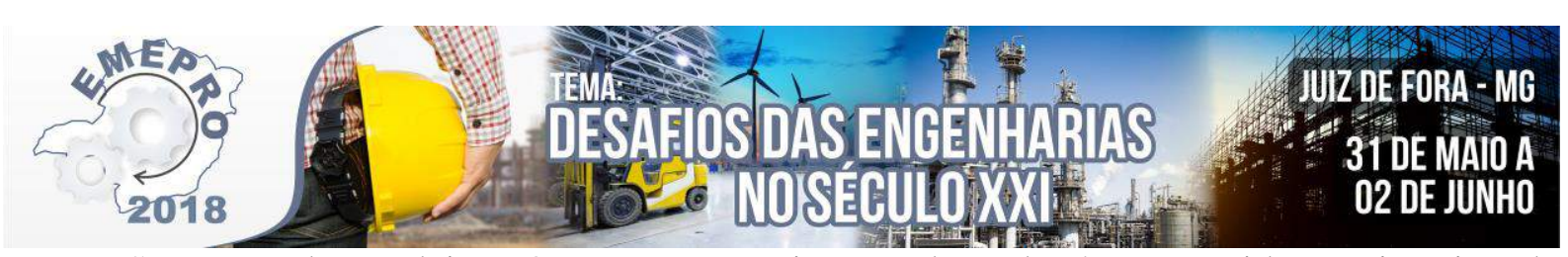

Secagem da madeira: Ocorre a vaporização de toda água contida no interior da madeira (água livre, água de adesão e água de constituição). As temperaturas registradas ficam abaixo de $180^{\circ} \mathrm{C}$. O calor necessário para manter a temperatura adequada deve ser fornecido ao processo mediante a queima de parte da madeira seja na própria câmara de combustão, como ocorre nos fornos mais rudimentares, ou em câmara de combustão própria nos fornos mais evoluídos.

Pré-carbonização: Ocorre entre $180^{\circ}$ a $290^{\circ} \mathrm{C}$. É um processo endotérmico onde se inicia a liberação dos voláteis. A madeira começa a se decompor, liberando monóxido de carbono $(\mathrm{CO})$, dióxido de carbono $(\mathrm{CO} 2)$, ácido acético e metanol.

Carbonização: Ocorre entre $300^{\circ}$ e $500^{\circ} \mathrm{C}$. A reação torna-se exotérmica e autossustentável. O processo de decomposição térmica acelera, liberando mais calor, de modo que a temperatura não diminua enquanto a carbonização continuar. Ocorre grande eliminação de gases como monóxido de carbono (CO), dióxido de carbono (CO2), hidrogênio ( $\mathrm{H} 2)$, metano (CH4) e vapores condensáveis. A liberação de alcatrão e acido pirolenhoso atinge o seu máximo, assim como a taxa de decomposição da madeira. $\mathrm{O}$ resíduo final dessa fase é o carvão vegetal, que quando aquecido próximo aos $500^{\circ} \mathrm{C}$ possui um baixo teor de carbono fixo.

Gaseificação: Acima de $500^{\circ} \mathrm{C}$ o carvão vegetal começa a se degradar termicamente iniciando a gaseificação.

Observa-se que a liberação de $\mathrm{CO} 2$ e $\mathrm{CO}$, notadamente os principais produtos gasosos da carbonização, se tornou significativa a partir dos $200^{\circ} \mathrm{C}$, atingindo picos próximos a $22 \%$ e $12 \%$ respectivamente aos $300^{\circ} \mathrm{C}$. A concentração de $\mathrm{CO}$ atingiu um novo pico aos $400^{\circ} \mathrm{C}$, de menor magnitude, ultrapassando, contudo, a concentração de $\mathrm{CO} 2$ nessa temperatura e estabilizou-se a partir de $500^{\circ} \mathrm{C}$ a patamares inferiores (OLIVEIRA, 2012).

\subsection{3 - Queima dos gases}

Os queimadores são construídos com alvenaria e possuem uma câmara de combustão retangular com entradas de oxigênio e chaminé cilíndrica com 12 metros de altura que são responsáveis pela exaustão dos gases.

Os gases provenientes do processo de carbonização são conduzidos por dutos que interligam os fornos até uma câmara de combustão, onde os mesmos entram em combustão com o auxílio de uma chama piloto, produzida com a queima de madeira e tiço.

São gastos diariamente $8 \mathrm{~m}^{3}$, entre madeira e tiço (madeira que não completou o processo de carbonização) para manter o sistema em equilíbrio térmico o que permite a queima completa dos gases e a não liberação de fumaça nas chaminés. Esse consumo varia de acordo com o sincronismo das faces da carbonização. Fase endotérmica maior e fase exotérmica menor. O desafio é encontrar o equilíbrio ideal para que não seja utilizado combustíveis auxiliares nesse processo, mais como a empresa tem compromissos assumidos em contrato em fazer a produção limpa, torna-se necessário esse gasto de combustível para fazer a queima.

A unidade conta com duas plataformas de 15 fornos, assim cada queimador é responsável pela queima dos gases desse total, lembrando que como os ciclos de carbonização e de resfriamento tem diferenças, normalmente são usados até no máximo 8 fornos por 


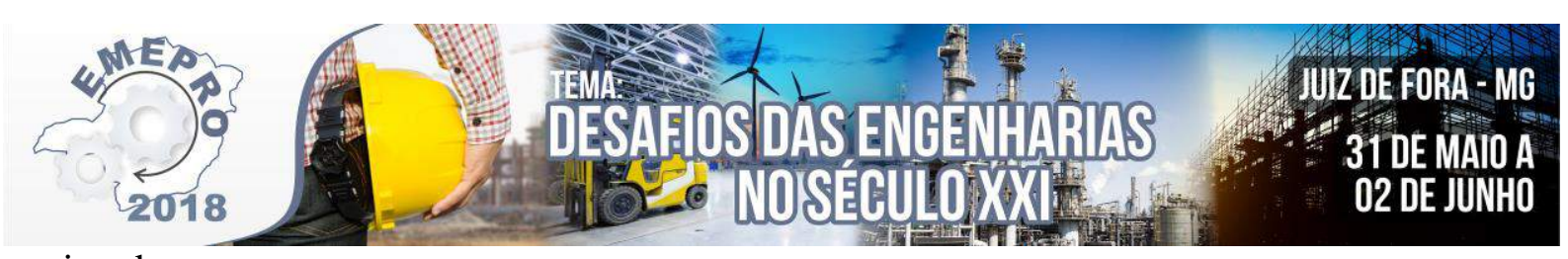

queimador.

Os gases gerados durante o processo de carbonização são substancias combustíveis ricos em carbono e hidrogênio, que sob condições adequadas de temperatura e pressão são capazes de sofrer reações químicas na presença de oxigênio, liberando energia sob a forma de luz e calor. $\mathrm{Na}$ carbonização da madeira são gerados gases não condensáveis, sendo os principais $\mathrm{CO}, \mathrm{CO} 2, \mathrm{H} 2$ e $\mathrm{CH} 4$ (TACCINI, 2011). No casso de queima completa desses gases, as emissões seriam constituídas apenas de $\mathrm{CO} 2$ e vapor de água. Segundo CARVALHO JUNIOR \& MCQUAY (2007), a combustão completa ocorre quando o carbono presente no combustível é oxidado para dióxido de carbono ( $\mathrm{CO} 2)$, o hidrogênio para água $(\mathrm{H} 2 \mathrm{O})$ e o enxofre para dióxido de enxofre (SO2). Quando os produtos gerados são monóxidos, considera-se a combustão como incompleta.

Segundo os testes feitos por Cardoso (2010), a concentração de metano foram reduzidas a valores próximos à zero com a combustão dos gases pelo queimador, tendo uma redução de 96,95\%. Isso mostra a eficiência e o poder oxidante que os queimadores, reduzindo na quase totalidade a emissão de um dos gases mais nocivos ao meio ambiente. Ainda dentro desse trabalho fica visível a importância para adicionalidade em projetos de créditos de carbono, pois apesar de a madeira utilizada no processo ser de reflorestamento, o que não contabiliza o $\mathrm{CO} 2$ liberado, a redução da emissão de metano no processo permite a criação de projetos visando a créditos de carbono.

Os trabalhos de Cardoso (2010) mostraram ainda uma redução de 93,76\% de monóxido de carbono enquanto os valores médios da concentração de dióxido de carbono sem combustão de gases foi de $4,11 \%$ e de $6,29 \%$ com combustão. Este aumento expressa as reações de oxidação ocorridas durante a combustão dos gases no queimador, ou seja, os gases $\mathrm{CO}, \mathrm{CH} 4$ e outros foram oxidados a $\mathrm{CO} 2$, água $(\mathrm{H} 2 \mathrm{O})$ e energia na forma de calor. Este aumento da concentração de dióxido de carbono demonstra indiretamente a eficiência do queimador para a redução de emissão dos poluentes mais nocivos, como principalmente a metano, uma vez que a CO2 é o produto da oxidação deste gás.

\subsection{4 - Resfriamento do forno}

Ao fim da carbonização todas as entradas de oxigênio e o registro de saída do forno são fechados, ficando assim o forno lacrado para evitar a entrada de oxigênio, o que permite seu resfriamento. O resfriamento é forçado com aplicação de barrelas (calda de Argila) lançada com o auxílio de um implemento agrupado a um trator para melhorar o resfriamento e vedação de trincas.

A água tem a função de fazer uma troca de calor com a superfície do forno acelerando seu resfriamento enquanto a argila faz a vedação de trinca que ocorre durante as fases do processo.

A temperatura de resfriamento é monitorada com o auxílio do pirômetro e quando chega ao ponto desejado o forno pode ser aberto para descarga do carvão.

\subsection{5 - Descarga de forno}

Identificado o resfriamento dos fornos através do monitoramento, são programados para descarga. As portas são destravadas, o forno é aberto para retirada do carvão. 


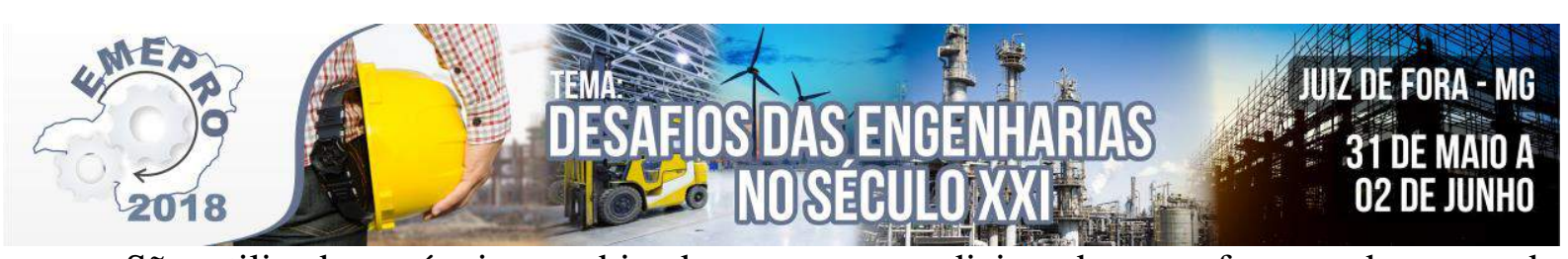

São utilizados máquinas cabinadas com ar condicionado para fazer a descarga do carvão do forno até as caçambas ou pátio de estocagem. Em torno de $70 \%$ do carvão descarregado do forno vai diretamente para as caçambas, o restante passa por um processo de pré-separação no pátio onde são retirados os tiços (madeira que não completou seu processo total de carbonização) antes de ser colocado nas caçambas. Na parte superior das caçambas é colocada uma peneira separadora, que tem a função de dar qualidade e melhorar a granulométrica do carvão. O carvão deve ficar por um período de 48 horas no pátio de estocagem antes de ser enviado a granel em carreta para a usina.

\section{4 - Coletas dos Dados do Processo de Carbonização}

O trabalho usou dados coletados na empresa em períodos onde se operou em sistema com queima de gases (sem emissão dos gases) e sem queima de gases (com emissão dos gases) para comparar o desempenho dos processos. No período de desenvolvimento do trabalho a empresa trabalhou com parte da unidade com emissão de gases nas chaminés, sistema convencional.

O controle dos ciclos dos fornos foi feito por planilhas físicas e planilhas em Excel e um questionário foi usado com os funcionários e com a gerência de produção para obtenção de dados para o comparativo.

Nessas planilhas são preenchidos dados como espécie da madeira, volumes e horas do carregamento e do descarregamento dos fornos, temperados dos fornos nos estágios de carbonização e de resfriamento, horas iniciais e finais de cada etapa. Depois são lançadas em computar pelo apontador de produção, onde são feitos relatórios e gráficos com os números da produção e produtividade mensal.

\section{Resultados e Discussões}

\section{1 - Comparativo entre os sistemas}

Para analisar todo o processo de carbonização da unidade de produção da Empresa Refinaria Guaxupé de carvão ecológico Ltda, utilizou-se os resultados obtidos através do questionário e os dados de produção do período. Também foi feito uma revisão bibliográfica dos trabalhos relacionados à eficiência ecológica do sistema.

O trabalho de comparação, entre o sistema do forno de superfície com chaminé e sistema de produção de forno cilíndrico vertical, que são sistemas parecidos com os comparados nesse trabalho, constatou que mesmo necessitando de um maior investimento inicial e também mão de obra qualificada, apresenta diversas vantagens por ser mais moderno e mais completo. Assim, é possível obter um maior controle do processo, melhorando a qualidade do carvão produzido; além de ser possível a utilização dos seus subprodutos em diversos fins, agregando valores a estes e com isso aumentando o rendimento da empresa. Consequentemente ocorre uma redução da poluição gerada pelo processo de carbonização, contribuindo assim para a prevenção do meio ambiente. Além disso, pode-se destacar o maior aproveitamento de lenha, uma vez que aumenta o rendimento do carvão produzido (COLOMBO, 2006 apud, AMODEI, 2008).

Segundo Oliveira (2012), o queimador, contribui para o processo de carbonização, 


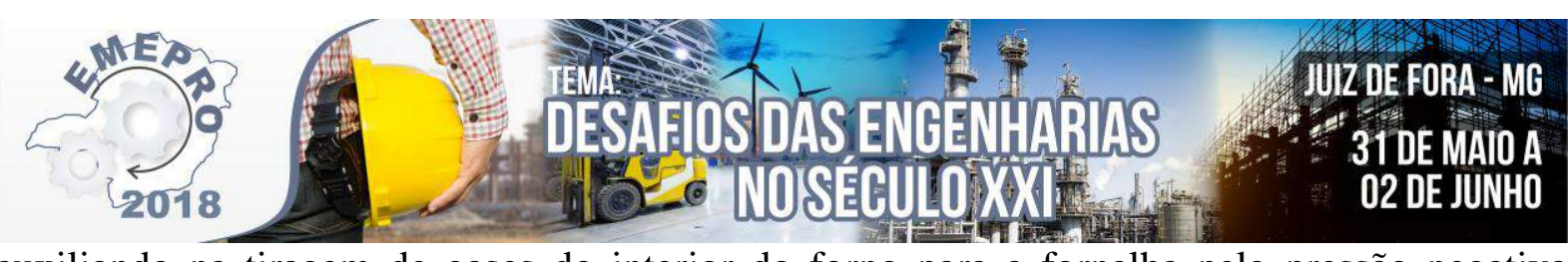

auxiliando na tiragem de gases do interior do forno para a fornalha pela pressão negativa gerada no sistema pela chaminé do queimador.

\section{2 - Comparativo Específico entre os Sistemas}

Foi usada uma planilha para coletas de dados mais específicos do período analisado, dessa forma pode-se fazer um comparativo com resultados e percentuais (Fig.1).

FIGURA 1 - Resultados obtidos no período

Legenda: >metros cúbicos $\left(\mathrm{m}^{3}\right)$ >massa de água/massa de matéria seca x 100 (Kg base seca) >percentual (\%)

\begin{tabular}{|c|c|c|c|c|c|}
\hline \multicolumn{6}{|c|}{ Resultados específicos do comparativo } \\
\hline \multicolumn{2}{|c|}{ Fornos sem 0 uso do queimador de gases } & \multicolumn{2}{|c|}{ Fornos com 0 uso do queimador de gases } & Resultados & $\%$ \\
\hline Numero de fornos & 15 formos & Numero de fornos & 15 fornos & Iguais & $0 \%$ \\
\hline $\mathrm{N}^{\circ}$ de tratamentos & 43,90 Fornadas & $\mathrm{N}^{\circ}$ de tratamentos & 47,82 fornadas & aumento de 3,92 fornadas & $8,92 \%$ \\
\hline $\begin{array}{l}\text { Tempo médio de } \\
\text { carbonização }\end{array}$ & 86,4 horas & $\begin{array}{l}\text { Tempo médio de } \\
\text { carbonização }\end{array}$ & 71,5 horas & $\begin{array}{c}\text { redução de } 14,9 \text { horas de } \\
\text { carbonização }\end{array}$ & $20,80 \%$ \\
\hline $\begin{array}{l}\text { Tempo médio de } \\
\text { resfriamento }\end{array}$ & 135,6 horas & $\begin{array}{l}\text { Tempo médio de } \\
\text { resfriamento } \\
\end{array}$ & 130,4 horas & $\begin{array}{c}\text { redução de } 5,2 \text { horas de } \\
\text { resfriamento } \\
\end{array}$ & $3,98 \%$ \\
\hline Tempo de Setup & 24 horas & Tempo de Setup & 24 horas & Iguais & $0 \%$ \\
\hline Tempo de ciclo & 246,0 horas & Tempo de ciclo & 225,9 horas & $\begin{array}{c}\text { redução } 20,1 \text { horas de } \\
\text { ciclo }\end{array}$ & $8,89 \%$ \\
\hline $\begin{array}{l}\text { Volume de madeira } \\
\text { utilizado }\end{array}$ & $2195 \mathrm{~m}^{3}$ & $\begin{array}{l}\text { Volume de madeira } \\
\text { utilizado }\end{array}$ & $2391,07 \mathrm{~m}^{3}$ & aumento de $196,07 \mathrm{~m}^{3}$ & $8,20 \%$ \\
\hline Carvão produzido & $1560,68 \mathrm{~m}^{3}$ & Carvão produzido & $1720,09 \mathrm{~m}^{3}$ & aumento de $159,41 \mathrm{~m}^{3}$ & $9,26 \%$ \\
\hline $\begin{array}{l}\text { Volume de tiço } \\
\text { produzido }\end{array}$ & $150,5 \mathrm{~m}^{3}$ & $\begin{array}{l}\text { Volume de tiço } \\
\text { produzido }\end{array}$ & $172,15 \mathrm{~m}^{3}$ & aumento de $21,65 \mathrm{~m}^{3}$ & $12,57 \%$ \\
\hline $\begin{array}{l}\text { Volume de carvão } \\
\text { médio forno }\end{array}$ & $35,55 \mathrm{~m}^{3}$ & $\begin{array}{l}\text { Volume de carvão } \\
\text { médio forno }\end{array}$ & $35,97 \mathrm{~m}^{3}$ & aumento de $0,42 \mathrm{~m}^{3}$ & $1,16 \%$ \\
\hline $\begin{array}{l}\text { Indice de conversão } \\
\text { madeira x carvão } \\
\text { (produtividade) }\end{array}$ & 1,31 & $\begin{array}{l}\text { Índice de conversão } \\
\text { madeira x carvão } \\
\text { (produtividade) }\end{array}$ & 1,29 & redução de 0,02 & $1,55 \%$ \\
\hline
\end{tabular}

Fonte: Os autores

Analisando os dados obtidos na figura 10, pode-se verificar várias vantagens em se utilizar o sistema com queima de gases.

Resumo dos resultados:

$1^{\mathrm{a}}$ - Diminuição no ciclo de produção das fornadas.

$2^{\mathrm{a}}$ - Melhora na conversão madeira x carvão (produtividade)

$3^{\mathrm{a}}$ - Aumento do tiço (madeira quase carvão)

$4^{\mathrm{a}}$ - Aumento da produção por forno.

Isso é possível graças ao fluxo de retirada dos gases que o sistema de queima produz 


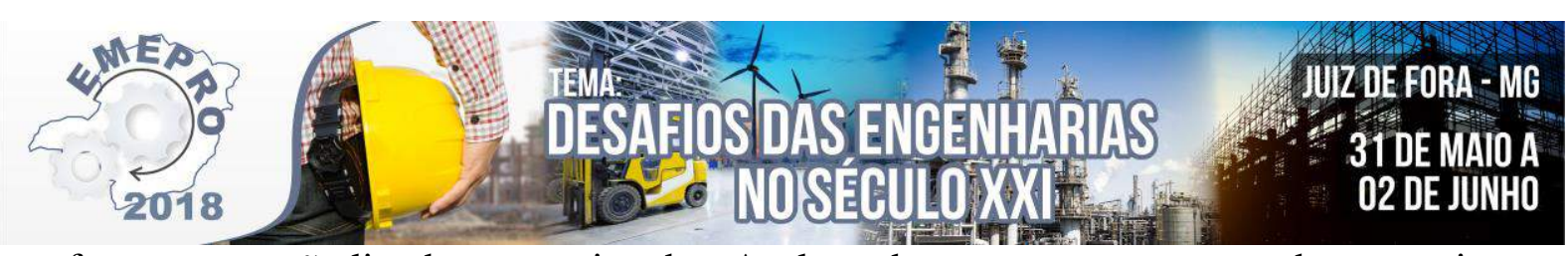

nos fornos que estão ligados ao queimador. Acelerando o processo e mostrando que o sistema além de sua eficiência ecológica, também gera uma eficiência produtiva.

Foi observada uma diminuição importante nas horas de carbonização, o que refletiu no tempo de resfriamento também, devido a um período menor de aquecimento do forno na fase de carbonização, contribuiu para um bom resfriamento na fase seguinte.

Segundo informações da gerencia de produção da empresa, a quantidade de tiço (madeira quase carvão) sem diminuir os rendimentos dos fornos, tem efeitos positivos na qualidade do carvão, além do tiço ser reaproveitado para o processo de produção das próximas fornadas ou combustão no queimador.

O ciclo de produção dos fornos tem efeito principal na produção geral de uma planta de carbonização, assim o sistema de queima de gases atua como uma ferramenta importante nessa função de dar velocidade ao processo. Como podemos ver o exemplo abaixo:

Exemplo do planejamento mensal de produção dos dois sistemas:

- Planejamento de produção mensal no sistema sem queimador

30 dias / 10,25 ciclo do forno $=2,92$ fornadas mês $x 30 \mathrm{~N}^{\circ}$ de fornos $=87,6$ fornadas $\mathrm{x}$ $35,55 \mathrm{~m}^{3}$ volume por forno $=3.114,18 \mathrm{~m}^{3}$.

- Planejamento de produção mensal no sistema com queimador

30 dias $/$ 9,41 ciclo do forno $=3,18$ fornadas mês $\mathrm{x} 30 \mathrm{~N}^{\circ}$ de fornos $=95,4$ fornadas $\mathrm{x}$ $35,97 \mathrm{~m}^{3}$ volume por forno $=3.431,53 \mathrm{~m}^{3}$.

Aumento de $317,35 \mathrm{~m}^{3}$ de carvão mês. Um percentual de $10,1 \%$ a mais de produção para o sistema com queima dos gases.

Os dados para o exemplo do planejamento foram extraídos da Figura 11. Com esse exemplo podemos observar a influência positiva do sistema de queima no ciclo de produção de uma planta.

A vazão da carbonização com combustão dos gases foi devido a um maior gradiente de temperatura entre a fornalha e o ambiente externo, observando que sua variação de temperatura não tem influência no processo, visto que a amplitude é baixa enquanto na fornalha (Queimador) a amplitude de variação de temperatura chega a $730^{\circ} \mathrm{C}$. Comparando-se os processos com e sem combustão dos gases apresenta uma temperatura máxima na fornalha de $120^{\circ} \mathrm{C}$ contra $25^{\circ} \mathrm{C}$ do ambiente externo. Já no processo com combustão dos gases a temperatura máxima da fornalha atinge $850^{\circ} \mathrm{C}$, contra os mesmos $25^{\circ} \mathrm{C}$ do ambiente, o que pode explicar esse aumento na vazão, pois durante a queima faz-se necessário a abertura nas laterais da fornalha para admissão do ar atmosférico para fornecer oxigênio para as reações de oxidação, e consequentemente o volume de gases é aumentado proporcional a quantidade de ar atmosférico admitido (CARDOSO, 2010).

\section{3 - Eficiência Ecológica}

Os queimadores ou fornalhas acopladas a fornos de carbonização têm o objetivo de incinerar os gases gerados durante o processo, transformando a poluição em energia na forma de calor. Estes equipamentos conferem as unidades de produção de carvão vegetal um aspecto limpo (OLIVEIRA, 2012). 


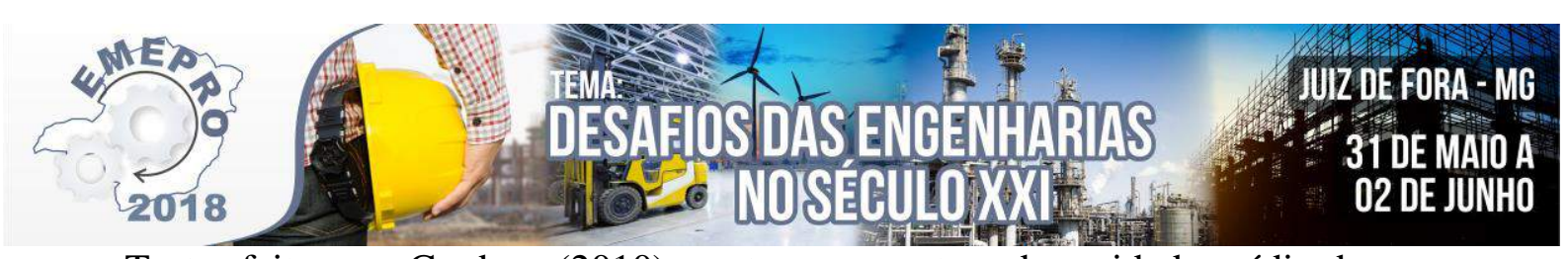

Testes feitos por Cardoso (2010) mostraram que teor de umidade médio dos gases sem e com combustão dos gases pela fornalha foram de $14 \%$ e $20 \%$ respectivamente, tendo essa diferença significativa entre si, mostrando com isso um aumento de vapor de água formado quando se procedeu à combustão, o que pode ser explicado pelo fato de quando ocorre a combustão completa de um material, espere-se que sejam liberados $\mathrm{CO} 2$, vapor de água e energia. Esse dado é, portanto, um indicativo da eficiência da fornalha para queima dos gases da carbonização.

Ainda segundo Cardoso (2010), as concentrações de metano foram reduzidas a valores próximos a zero com a combustão dos gases pela fornalha, passando de $0,293 \%$ para $0,015 \%$, tendo uma redução de $96,95 \%$. Esse fato demonstra a eficiência de poder oxidativo do sistema, reduzindo quase a totalidade da emissão de um dos gases mais nocivos ao meio ambiente.

Durante a queima dos gases no interior da fornalha foram obtidas temperaturas variando de 650 a $1150^{\circ} \mathrm{C}$, sendo essa faixa de temperatura suficiente para promover a combustão completa do alcatrão, do licor pirolenhoso, dos fenóis e dos gases $\mathrm{CO}$ e $\mathrm{CH} 4$ transformando-os em CO2 e H2O, conforme atestado por (CARDOSO, 2010).

Os estudos feitos por CARDOSO, 2010 mostraram que o poder calorífico dos gases da carbonização sem combustão pela fornalha atingiu valor máximo de $65 \mathrm{Kcal} / \mathrm{m}^{3}$, e quando a fornalha foi utilizada o poder calorífico foi reduzido a praticamente zero, mostrando que os gases foram queimados, liberando essa energia na forma de calor.

\section{Conclusões}

O sistema com queima dos gases se mostrou mais produtivo em relação ao sistema sem a queima. O efeito exaustão produzido pela chaminé do queimador, acelera o processo de carbonização, trazendo ganhos no ciclo total dos fornos. O que proporcionou um volume maior de carvão produzido em um mesmo intervala de tempo.

Os valores dos gases causadores do efeito estufa são reduzidos a números próximos a zero com o uso do sistema queimador/fornalha. Comprovando sua eficiência ecológica o que agrega valor ao produto.

A utilização do sistema de queima de gases não alterou as estruturas físico-químicas em relação ao sistema convencional de produção.

O carvão vegetal produzido na unidade Fazenda Guaxupé, tem qualidade e atende as especificações técnicas da usina siderúrgica para a produção do Silício Metálico.

Mesmo com um custo maior de implantação e de operação, as vantagens produtivas, financeiras e ecológicas viabilizam o sistema com queima de gases. O trabalho mostra que o sistema é eficiente e sustentável, pois atua nos três pilares da sustentabilidade. O Social, que promove o bem estar para o trabalhador e a comunidade ao seu redor, o ecológico, eliminando vários poluentes e por fim, o financeiro, agregando valor a um produto que antes era visto como o grande vilão da poluição e das condições análogas à escravidão no país. 


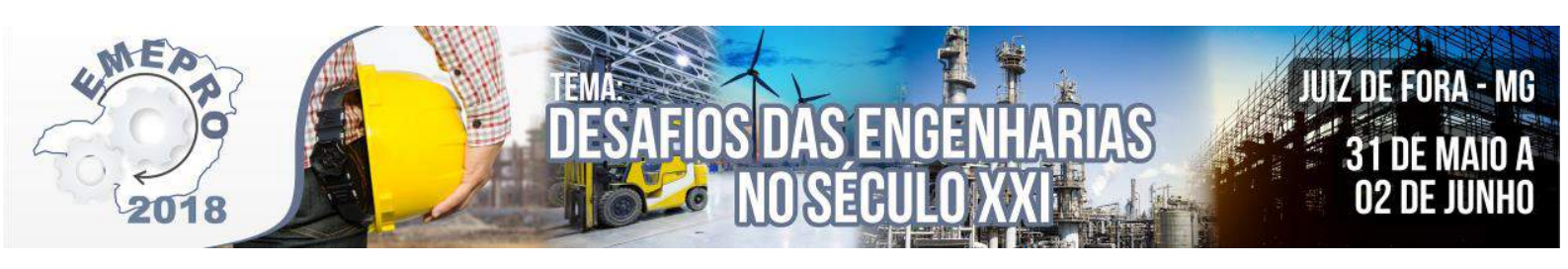

\section{Referências}

AMODEI, J. B. Avaliação do processo de carbonização da empresa Saint Gobain Ltda, UFRRJ, Seropédica - RJ, 2008. 13p.

ANDRADE, H. B. Avaliação de espécies e procedência de Eucalytus nas Regiões Norte e Nordeste do estado de Minas Gerais. 1991. Dissertação (Mestrado) - Escola Superior de Agricultura de Lavras, Lavras - MG.

CARDOSO, M.T. Desempenho de um sistema de forno-fornalha para combustão de gases na carbonização de madeira. 2010. 06, 48, 49, 50 e 51p. Dissertação (Mestrado em Ciência Florestal) Universidade Federal de Viçosa - MG. 2010.

CARVALHO JUNIOR, J. A.; MCQUAY, M. Q. Princípios de combustão aplicados. Florianópolis - SC, 2007, 176p.

NETO. J. D. Sustentabilidade empresarial e mercado verde. Viçosa - MG: Aprenda Fácil, 2016. 99p.

OLIVEIRA, A. C. M. Sistema forno-fornalha para produção de carvão vegetal, 2012. 73p. Dissertação (Mestrado em Ciência Florestal) Universidade Federal de Viçosa, Viçosa - MG. 2012.

PIMENTA, A. S. E BARCELLOS, D. C. 2000. Como produzir carvão churrasco. Viçosa, CPT. 76p.

QUADROS, L. Q. Sistema Brasileiro de Resposta Técnica, MINISTÉRIO DA CIENCIA E TECNOLOGIA. Disponível em: <HTTP//WWW.vitalflora.org.br/carvão.htm>, Acessado em 25 de julho de 2017.

RAAD, T.J. (2000). Instrumentação dos fornos industriais da V \& M Florestal In: Melhoria continua da carbonização da madeira. Seminário interno Vallourec \& Mannesmann Tubes. Paraopeba - MG. 32p.

SANTOS, M.A. S. Parâmetros da qualidade do carvão vegetal para uso em alto-forno. In.: FORUM NACIONAL SOBRE CARVÃO VEGETAL, 1 , 2008, Belo Horizonte, Anais... Belo Horizonte: UFMG, 2018.

STAPE, J.L.Utilização de delineamento sistemático tipo leque no estado de espaçamento florestal. 1995, 104p. Dissertação (Mestrado em Recursos Florestais) - Escola Superior de Agricultura. Universidade de São Paulo, Piracicaba, 1995.

TACCINI, M. M. Estudo das metodologias da Convenção-Quadro das Nações Unidas sobre Mudanças Climáticas, referentes à avaliação de emissões de gases do efeito estufa na produção de carvão vegetal. 2011. 86f. Dissertação (Mestrado em Ciência e Tecnologia de Produtos Florestais) - Universidade de São Paulo, Piracicaba - SP, 2011.

VALE, A.T.: GENTIL, L. V. Produção e uso energético de biomassa e resíduos agroflorestais . In: OLIVEIRA, J. T. S.; FIEDLER, N. C.; NOGUEIRA , M. (Ed). Tecnologias aplicadas ao setor madeireiro III. Jerônimo Monteiro - ES: 2008, p. 196-246. 


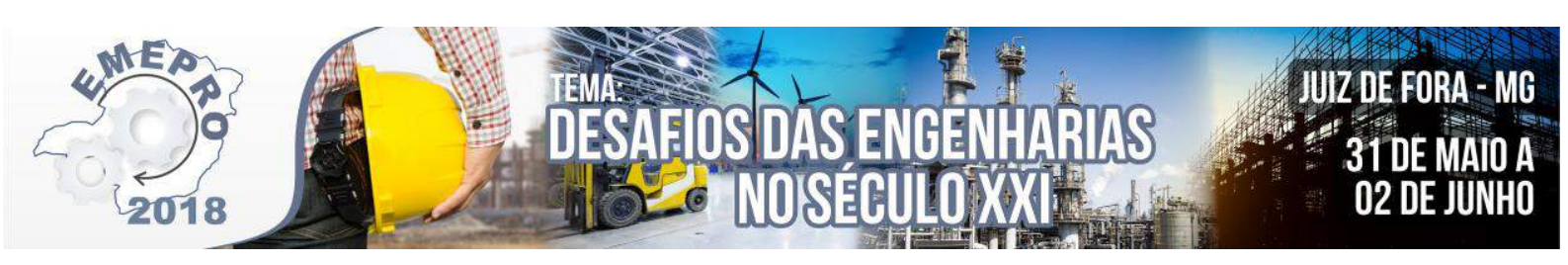

Construções sustentáveis

MATEUS OLIVEIRA COSTA, FUPAC-UBÁ, mateusocosta@hotmail.com

MIRELLA GOMES DE LIMA ANDRADE, FUPAC-UBÁ, mgjlimaa@gmail.com

ALEXANDRE SIQUEIRA DA SILVA, FUPAC-UBÁ, alexandresiqueira08@gmail.com

EUNICE SINGULANE, FUPAC-UBÁ, eunicesingulane@gmail.com

Resumo: A sustentabilidade atualmente é um tema bastante abordado em todas as áreas da engenharia devido à urgência na conservação dos recursos naturais, cada vez mais escassos em nossa biosfera. Surgem então, materiais capazes de contribuir para a durabilidade das edificações, preservando a manutenção do meio ambiente. Desde materiais ecologicamente corretos para elevação, como blocos de solo-cimento até concretos produzidos com agregados provenientes de resíduo de obras reciclados, tem-se atualmente uma gama de possibilidades que visam a sustentabilidade. Como resultado, a construção civil potencializa suas opções com várias opções de materiais sustentá- veis e sistemas construtivos ecologicamente corretos, capazes de edificar obras funcionais e tão atrativas quanto as construções concebidas pelos métodos tradicionais. Entendendo ser extremamente importante uma obra pensada de forma a garantir a manutenção do meio ambiente, tem-se como resultado engenheiros civis e arquitetos buscando qualificação profissional capaz de gerar bem-estar aos habitantes das edificações adotando uma exploração racional do meio ambiente. Portanto, o objetivo desse trabalho de conclusão de curso é apresentar algumas práticas da construção sustentável utilizadas atualmente, popularizando esse modelo de construção, difundindo o conceito de construção sustentável em contraponto à construção convencional, apresentando formas de minimizar desperdícios e buscando a conscientização dos construtores.

Palavras-chave: Materiais de construção; Materiais ecológicos; Sustentabilidade.

\section{Introdução}

A sustentabilidade atualmente é um tema bastante abordado em todas as áreas da engenharia devido à urgência na conservação dos recursos naturais, cada vez mais escassos em nossa biosfera. O termo sustentabilidade representa o incentivo ao progresso social e econômico sem, no entanto, degradar o meio ambiente e os elementos que dele decorrem. Sua aplicabilidade está relacionada em não degradar o meio ambiente, mantendo e construindo um ecossistema equilibrado ao mesmo tempo que a sociedade inserida nesse contexto evolui economicamente.

Pensando nisso, várias medidas cautelares são tomadas em diversas áreas de pesquisa no intuito de garantir um futuro de qualidade para as próximas gerações. Aplicando o tema à construção civil, pode-se obter o conceito de "construção sustentável", termo utilizado por pesquisadores que buscam minimizar os impactos ambientais causados pelos processos de construção.

Para isso, a construção civil conta atualmente com várias opções de materiais 


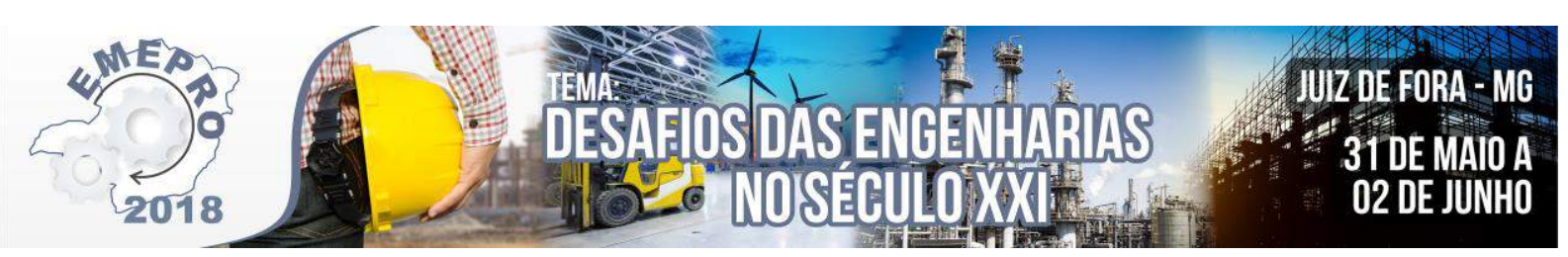

sustentáveis e sistemas construtivos ecologicamente corretos, capazes de edificar obras funcionais e tão atrativas quanto as construções concebidas pelos métodos tradicionais.

Nesses moldes, as construções sustentáveis visam essencialmente utilizar materiais ecologicamente corretos que também possam contribuir para a redução de entulho no canteiro de obras e promovam a redução de descarte de resíduos no meio ambiente, redução do consumo de energia elétrica e a promoção e conservação de áreas verdes, além do reaproveitamento das águas da chuva.

Desta forma, o objetivo desse trabalho de conclusão de curso é apresentar algumas práticas da construção sustentável utilizadas atualmente, popularizando esse modelo de construção, difundindo o conceito de construção sustentável, em contraponto à construção convencional, apresentando formas de minimizar desperdícios e buscando a conscientização dos construtores.

\section{Desenvolvimento}

\subsection{Construção civil e sustentabilidade}

\subsubsection{Sustentabilidade}

O termo "desenvolvimento sustentável” foi usado pela primeira vez em 1987, por Gro Harlem Brundtland, ex-primeira-ministra da Noruega que atuou como presidente de uma das comissões da Organização das Nações Unidas. Em sua publicação a ex-primeira-ministra descreve: "Desenvolvimento sustentável significa suprir as necessidades do presente sem afetar a habilidade das gerações futuras de suprirem as próprias necessidades" (BRASIL ESCOLA, 2017).

De acordo com Gore (2010), sustentabilidade é a capacidade de o ser humano suprir suas necessidades, sem afetar que gerações futuras supram as suas, ou seja, é a exploração do meio ambiente de forma correta, estruturada em três bases: econômica, ambiental e social.

Gore (2010) ainda afirma que é possível buscar convergências na influência positiva dos envolvidos na construção civil, visando à harmonização das necessidades reais com a preservação da natureza, dos serviços ecossistêmicos que ela nos presta através da biodiversidade.

Com base neste cenário, diversas políticas públicas têm sido aprovadas com a intensão de gerar uma economia mais sustentável, como a produção de energia elétrica a partir de outras fontes renováveis, a utilização de madeiras reflorestadas, a reciclagem de resíduos, entre outros. Contudo, a melhor política pública é a influência estatal no uso do poder de compra para a melhoria do meio ambiente: a rotulagem ambiental, a "consciência verde" e consequentemente o "consumidor verde".

Segundo Pereira e Guimarães (2009) o "consumidor verde" é o consumidor dotado de "consciência verde", atento às questões ambientais relacionadas à gestão empresarial, buscando consumir produtos fornecidos por empresas que possuam uma política ambiental transparente. Atualmente, o Estado caracteriza-se como um "consumidor verde", adotando uma série de exigências para a compra de insumos utilizados pelos órgãos estatais.

Segundo Pereira e Guimarães (2009), a preocupação já é tamanha que existem certificações para classificar um empreendimento sustentável, como o selo Leadership in Energy and Environmental Design (LEED) e o selo "AQUA". Estas certificações visam apoiar as práticas consideradas eficientes diminuindo os impactos ambientais delas 


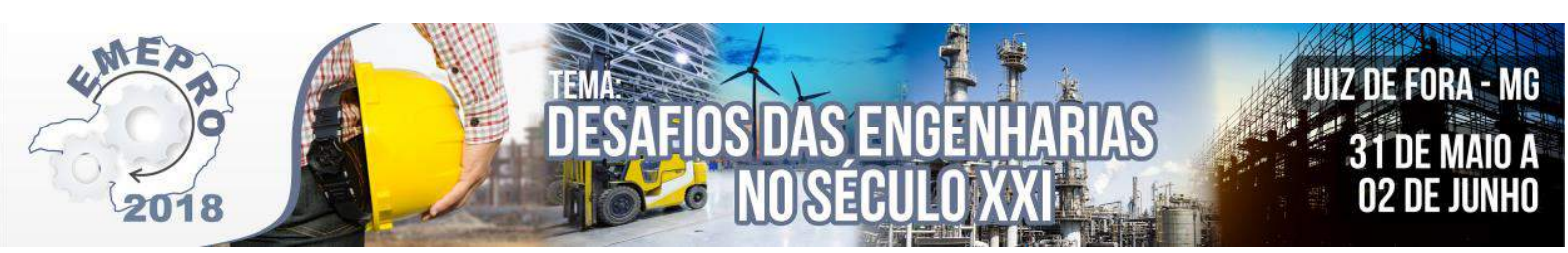

decorrentes. O foco é o consumo de energia e água sem deixar de lado o gerenciamento de resíduos.

Construções economicamente sustentáveis estão se popularizando cada vez mais, e no futuro certamente ditarão as regras do setor. Produtos corretos em termos ecológicos, melhores e sempre mais inovadores têm sido vistos com frequência no mercado, fazendo com que se consiga juntar a eficiência ambiental com ainda mais conforto a quem opta por este tipo de construção (GREENDOMUS, 2017)

\subsubsection{Impactos da construção civil no meio ambiente}

De acordo com o Ministério do Meio Ambiente (MMA), a melhoria nas diretrizes da construção civil está intimamente ligada ao contato direto com o desenvolvimento humano. Segundo o website, "o setor da construção civil tem papel fundamental para a realização dos objetivos globais do desenvolvimento sustentável". Com base nesse cenário, as melhorias experimentadas nas últimas décadas visam combater a degradação do meio ambiente provocada pelo setor, visto que a construção civil hoje está entre as principais causadoras de impactos ambientais no mundo, consumindo em média $75 \%$ dos recursos naturais, $20 \%$ da água potável das cidades, além de gerar 80 milhões de toneladas por ano em resíduos, de acordo com dados coletados no website do Conselho Brasileiro de Construção Sustentável (CBCS). O próprio termo, "construção sustentável", surge com o intuito de estudar as ações negativas nos canteiros de obra, sugerindo melhorias que possam contribuir para a conservação ambiental.

\subsubsection{Produção de resíduos}

Usando uma gama de recursos naturais, a área da construção é uma das maiores geradoras de resíduos, de acordo com Diana Scillag, diretora do CBCS. Extraídas para a utilização na construção civil, apenas entre $20 \%$ e $50 \%$ das matériasprimas naturais são realmente consumidas para a produção das obras, segundo aponta a revista digital AECweb . O economista e mestre em tecnologia ambiental Élcio Carelli, membro da Associação Brasileira de Reciclagem de Resíduos da Construção Civil e Demolição (ABRECON), menciona que mais da metade dos resíduos que vem das cidades são produzidos pela construção civil de acordo com a mesma matéria publicada pela AECweb.

Os materiais produzidos nas obras são os que mais geram poluição, em termos de poeira e dióxido de carbono ( $\mathrm{CO} 2)$. O cimento, quando produzido, libera gás carbônico, principal causador do efeito estufa. Ainda de acordo com o website,

"a reciclagem é prática ideal de transformação para reduzir o volume de extração de matérias-primas, através da substituição por resíduos reciclados, redução de áreas destinadas a aterros, redução de energia referente ao processo de extração, além de possibilitar o surgimento de novos negócios." (AECweb, 2017).

No Brasil, é possível a utilização de reciclagem de resíduos da construção civil de maneira padronizada. A NBR 15115 (ABNT, 2004) regulamenta os ensaios específicos para a utilização de agregados reciclados a partir de resíduos da construção civil para a execução de pavimentação, exigindo inclusive alguns controles tecnológicos para os agregados reciclados, como os ensaios de granulometria, normatizados pela NBR 7181 (ABNT, 2016) e Índice de Suporte Califórnia (CBR), regulamentado pela NBR 7185 (ABNT, 2016), além dos teores de umidade e massa específica, também regulamentados por normas brasileiras recomendadas próprias. Também é possível produzir concreto a partir de resíduos reciclados, obedecendo os critérios especificados pela NBR NM 248 (ABNT, 2003), que determina a composição 


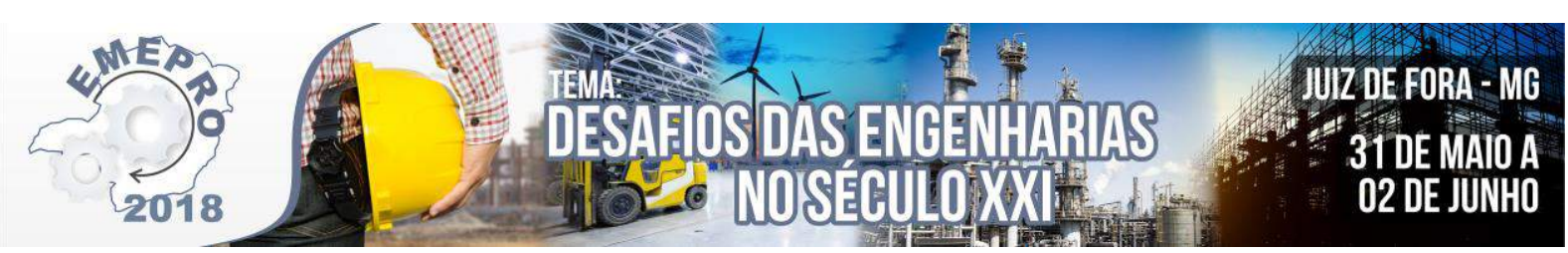

granulométrica dos agregados utilizados para sua produção e a NBR NM 53 (ABNT, 2003), que determina os limites aceitáveis de massa específica, massa específica aparente a absorção de água para agregados graúdos utilizados na produção de concreto estrutural.

\subsubsection{Energia e água}

De acordo com a AECweb, aproximadamente $40 \%$ da energia mundial são consumidas pelos edifícios, durante sua ocupação, manutenção e demolição. Embora o gasto de energia mude conforme o setor, estima-se que o setor residencial consome a mesma quantidade de energia elétrica que os setores público e comercial juntos.

Uma das maiores oportunidades para a construção civil mundial no combate às mudanças climáticas está no emprego de um consumo energético mais eficiente, por meio de investimentos em projetos de uso de energias renováveis, como a utilização da energia solar transformada em energia elétrica, por exemplo. Adotando um ponto de vista mais urgente, apenas a adoção de um consumo mais racional e consciente já seria suficiente para a diminuição do consumo de energia elétrica.

Grande parte do uso da água potável do planeta é responsabilidade da construção civil. Atualmente, o concreto é o material construtivo mais utilizado no mundo, segundo aponta o Instituto Brasileiro de Concreto (IBRACON) e uma grande parcela do produto é composto por água. A captação de águas pluviais ou até mesmo a reutilização de água para a produção de concreto segundo as diretrizes da NBR 15900-1 (ABNT, 2009) também auxiliaria na redução dos impactos causados pela construção civil no consumo global de água potável.

\subsubsection{Informalidade}

De acordo com os conceitos de sustentabilidade, a qualidade de vida, um dos principais fundamentos do termo, é amplamente desrespeitada pela construção, utilizando a informalidade dos contratos laborais em larga escala e a sonegação de impostos para a obtenção de lucros substanciais. Segundo a revista digital Piniweb,

"Um estudo elaborado pela FGV Projetos, a pedido da Abramat (Associação Brasileira da Indústria de Materiais de Construção) e Etco (Instituto Brasileiro de Ética Concorrencial), revelou que a informalidade é de 27,6\% no setor de material de construção e $60,8 \%$ na indústria da construção. De acordo com a pesquisa, utilizando dados de 2003, as despesas com esses materiais nas famílias brasileiras somaram R $\$ 26,5$ bilhões. Já a demanda das empresas formais de construção foi inferior: R\$ 19,5 bilhões." (PINIWEB, 2006).

Os resultados vão de perdas de arrecadação fiscal, até materiais desperdiçados. Segundo Vanderley John, professor-doutor em engenharia civil da Escola Politécnica da USP e conselheiro do CBCS, $72 \%$ dos trabalhadores são colocados na construção informal, sem nenhum direito social e com apenas $25 \%$ da produtividade dos trabalhadores da construção formal, e apenas $44 \%$ da produtividade média dos trabalhadores brasileiros (AECWEB, 2017).

Certamente a informalidade é um percalço para a introdução de práticas sustentáveis, uma vez que não é possível falar em sustentabilidade sem respeito ao contrato social. Ao assumir a informalidade, o setor da construção civil diminui seu potencial em fomentar o progresso social, limitando o alcance de políticas públicas. O CBCS incentiva a adoção do vínculo empregatício nas obras e aponta seis passos fundamentais na escolha de fornecedores que atuam formalmente:

1) Verificação da formalidade da empresa fornecedora; 


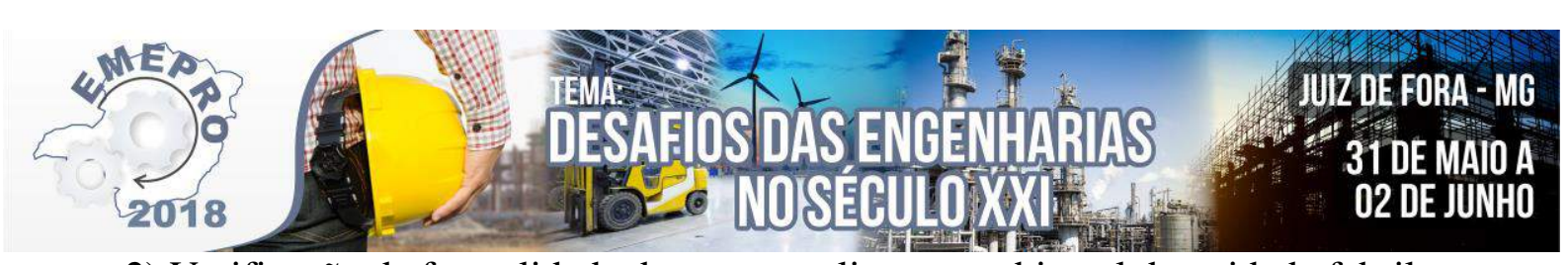

2) Verificação da formalidade da empresa: licença ambiental da unidade fabril;

3) Legalidade e regularidade da mão de obra;

4) Qualidade do produto - respeito às normas técnicas;

5) Analisar o perfil de responsabilidade socioambiental da empresa;

6) Cuidado com a propaganda enganosa.

Para Silvia Manfredi, segundo o MMA , um dos caminhos apontados para tornar a obra mais sustentável é a industrialização da construção, a fim de eliminar desperdícios nas obras, otimizando o uso dos materiais, aumentando a produtividade e reduzindo a informalidade da mão-de-obra.

\subsection{Construção Sustentável}

Cunha e Siqueira (2013) apontam que a construção sustentável é um sistema construtivo que promove intervenções no meio ambiente de forma a atender as necessidades de uso, produção e consumo humano, sem esgotar os recursos naturais, preservando-os para as gerações atuais e futuras.

De acordo com o Instituto para o Desenvolvimento da Habitação Ecológica (IDHEA), foram criados nove passos para a criação de uma construção sustentável, e com base nestes dados, em 2008 a Secretaria de Estado de Meio Ambiente e Desenvolvimento Sustentável do estado de Minas Gerais elaborou um Manual de Obras Públicas Sustentáveis, onde identificou os passos para a concepção e planejamento de construções sustentáveis, assim identificados:

1) Planejamento sustentável da obra;

2) Aproveitamento passivo dos recursos naturais;

3) Eficiência energética;

4) Gestão e economia de água;

5) Gestão dos resíduos na edificação;

6) Qualidade do ar e do ambiente interior;

7) Conforto termo acústico;

8) Uso racional de materiais;

9) Uso de produtos e tecnologias ambientalmente amigáveis.

Sendo assim, a construção sustentável tem por objetivo empregar materiais ecológicos e soluções tecnológicas para promover o bom uso e a economia de recursos finitos, a redução da poluição e o conforto dos moradores das edificações (CUNHA; SIQUEIRA, 2013).

Portanto, não só a construção deve ser sustentável, mas planejada de maneira que sua construção aproveite de forma racional e econômica os recursos naturais disponíveis, além de utilizar materiais que não poluam o meio ambiente nem o degradem. Todos estes termos se entrelaçam, formando um conceito mais amplo de sustentabilidade.

A Associação Brasileira dos Escritórios de Arquitetura (AsBEA), o Conselho Brasileiro de Construção Sustentável (CBCS) e o Instituto para o Desenvolvimento da Habitação Ecológica (IDHEA), apresentam diversos princípios básicos para a construção sustentável, conforme apontam Cunha e Siqueira (2013). São eles:

a) Redução do consumo de recursos;

b) Reutilização de recursos;

c) Utilização de recursos recicláveis;

d) Proteção da natureza;

e) Eliminação de produtos tóxicos;

f) Aplicação de análises de ciclo de vida em termos econômicos;

g) Assegurar a qualidade.

Os conceitos citados acima seguem a conceptualização do Conselho Internacional para a Pesquisa e Inovação em Construção (CIB), que trata a construção sustentável como o 


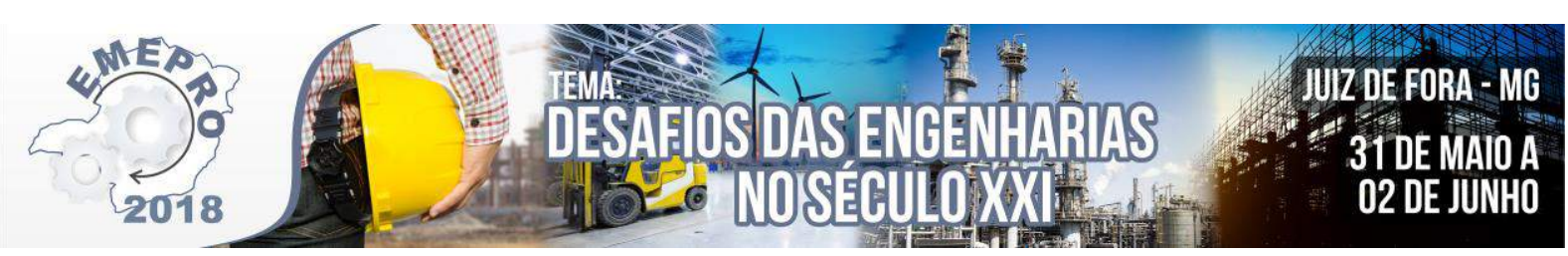

"processo holístico para restabelecer e manter a harmonia entre os ambientes construídos e criar estabelecimentos que confirmem a dignidade humana e estimulem a igualdade econômica" (CUNHA; SIQUEIRA, 2013, p. 3).

Baseado na definição do CIB, é possível perceber que a questão do restabelecimento da harmonia retoma uma preocupação que foi desaprendida com os aperfeiçoamentos tecnológicos, em que o aproveitamento passivo de fontes naturais, como luminosidade, calor, ventilação, entre outros, foram substituídos por sistemas elétricos, como, por exemplo, os aparelhos para aquecimentos e resfriamento artificiais (CUNHA, 2016).

O Comitê Técnico da International Standard Organization (ISO) definiu a edificação sustentável,

"como aquela que pode manter moderadamente ou melhorar a qualidade de vida e harmonizar-se com o clima, a tradição, a cultura e o ambiente na região, ao mesmo tempo em que conserva a energia e os recursos, recicla materiais e reduz as substâncias perigosas dentro da capacidade dos ecossistemas locais e globais, ao longo do ciclo de vida do edifício." (ARAÚJO, 2002, p. 2). Brasil.

O Quadro 1 apresenta os principais materiais sustentáveis disponíveis atualmente no

\begin{tabular}{|l|l|}
\hline \multicolumn{2}{|c|}{ QUADRO 1: Principais materiais sustentáveis disponíveis no Brasil } \\
\hline $\begin{array}{l}\text { Mabulações e reservatórios para captação de } \\
\text { águas pluviais }\end{array}$ & $\begin{array}{l}\text { Reduzem o valor da conta de água; reservam } \\
\text { água para períodos de estiagem; reduzem o } \\
\text { consumo de água para fins não-potáveis, } \\
\text { como regas de jardim, lavagem de } \\
\text { automóveis e descargas de vasos sanitários; } \\
\text { promovem educação ambiental. }\end{array}$ \\
\hline Cal & $\begin{array}{l}\text { Pode ser utilizada como tinta natural; isenta } \\
\text { de substâncias derivadas do petróleo; lavável } \\
\text { e hidrorrepelente; pode ser armazenada por } \\
\text { longos períodos; ideal para obras } \\
\text { sustentáveis. }\end{array}$ \\
\hline Ecotinta mineral & $\begin{array}{l}\text { Produzida com solo e solução aquosa, pode } \\
\text { ser utilizada como pintura sustentável, sem } \\
\text { compostos orgânicos voláteis (COV) ou } \\
\text { substâncias derivadas do petróleo. }\end{array}$ \\
\hline Miniestação de Tratamento de Água & $\begin{array}{l}\text { Indicada para qualquer tipo de imóvel, } \\
\text { visando o reuso da água tratada e correto } \\
\text { destino para os resíduos. }\end{array}$ \\
\hline Tijolos de solo-cimento & $\begin{array}{l}\text { Diferentemente dos tijolos tradicionais, não } \\
\text { são cozidos, evitando a derrubada de árvores } \\
\text { para a utilização de lenhas e exploração de } \\
\text { jazidas de argila. }\end{array}$ \\
\hline $\begin{array}{l}\text { Tão antimofo, antifúngicas, não trincam e } \\
\text { não quebram; possuem máxima resistência à } \\
\text { chuva de granizos e são 100\% impermeáveis; } \\
\text { protegem a temperatura solar em até 85\%; } \\
\text { não propagam chamas; suportam cargas de }\end{array}$ \\
\hline
\end{tabular}




\begin{tabular}{|l|l|}
\hline Concreto Verde & $\begin{array}{l}\text { Em fase de desenvolvimento pela } \\
\text { Universidade de São Paulo (USP), a mistura } \\
\text { emprega resíduos agrícolas para reduzir o } \\
\text { consumo de cimento, quando comparado aos } \\
\text { concretos convencionais. }\end{array}$ \\
\hline Piso Reciclado & $\begin{array}{l}\text { Desenvolvido pela Locaville, o piso } \\
\text { reciclado é composto por uma fibra de aço } \\
\text { reciclada incorporada ao concreto para a } \\
\text { produção de pisos industriais. }\end{array}$ \\
\hline Tubulação Verde & $\begin{array}{l}\text { Desenvolvido pela Braskem, as tubulações } \\
\text { são produzidas com plástico extraído do } \\
\text { etanol da cana-de-açúcar, uma fonte 100\% } \\
\text { renovável. }\end{array}$ \\
\hline Madeira Plástica & $\begin{array}{l}\text { Opção sustentável altamente resistente, é } \\
\text { produzida com plásticos reciclados e } \\
\text { resíduos vegetais de agroindústrias, são } \\
\text { altamente resistentes a insetos e roedores. }\end{array}$ \\
\hline
\end{tabular}

Fonte: Wieczynski, 2015, p. 9, adaptado pelo autor.

Como demonstra Wieczynski (2015), a possibilidade de utilização de matérias primas que estão atualmente no mercado e não agridam o meio ambiente é vasta.

Além disso, ainda podem proporcionar o bem-estar dos moradores das edificações com esses materiais construídas. Novas tecnologias surgem diariamente e hoje é visível a preocupação com a temática em vários setores da construção civil. As construtoras já começam a se voltar aos princípios sustentáveis, buscando alternativas para não degradar o meio ambiente. Cabe agora uma conscientização dos profissionais para o entendimento desta nova necessidade e consequente adaptação.

\subsubsection{Materiais sustentáveis para elevação de alvenaria de vedação}

Conforme orienta Sousa (2010), os materiais sustentáveis para elevação de alvenaria de vedação devem ser duráveis, o que aponta para uma vida útil longa e consequentemente, com menor impacto ambiental. Esses materiais poderão ser obtidos por meio da extração racional de recursos naturais, como é o caso dos blocos produzidos com solo e cimento ou por meio da incorporação da reciclagem de resíduos de outras indústrias ou materiais de construção como, por exemplo, os blocos de construção obtidos a partir da moagem de blocos quebrados no processo cotidiano de construção.

Os blocos de solo-cimento são uma excelente alternativa ao uso dos blocos cerâmicos, pois não há a necessidade de exploração de jazidas de argila. O solo-cimento é um "material de baixo custo, obtido pela mistura de solo, água e um pouco de cimento. A massa compactada endurece com o tempo, em poucos dias ganha consistência e durabilidade suficientes para diversas aplicações na construção civil”.

Sousa (2010) ainda aponta que esses materiais deverão exigir pouca manutenção e deverão ser livres de agentes tóxicos, não liberando substâncias nocivas à saúde dos moradores das edificações construídas com esses materiais.

\subsubsection{Sistemas de reaproveitamento de água}




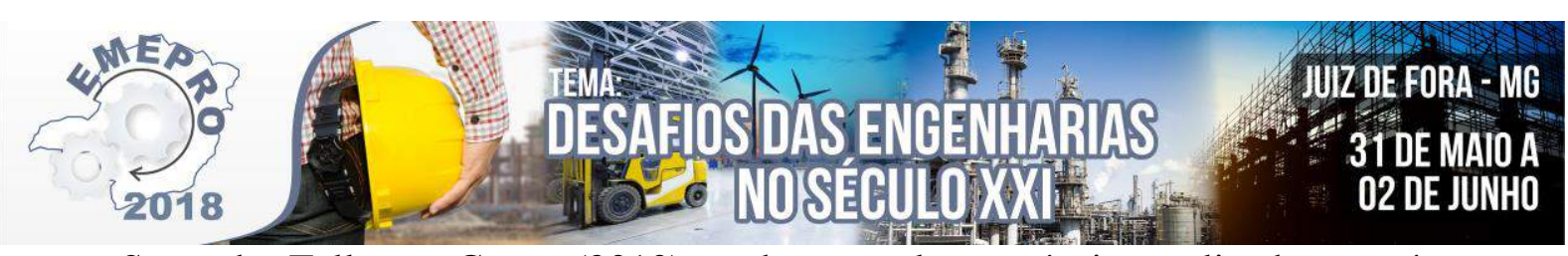

Segundo Telles e Costa (2010), toda e qualquer técnica aplicada estará sempre condicionada à relação custo-benefício. A tecnologia ambiental ultrapassa este conceito e ratifica a vivência sustentável como o único caminho de continuidade do desenvolvimento humano, ou seja, de uma forma ou de outra o próprio meio ambiente manifestará, e já está manifestando, uma renovada condição de subsistência de qualquer atividade.

A conscientização ocorre em escalas múltiplas e a realização ainda é limitada a contextos políticos, culturais, sociais, geográficos e econômicos. A técnica do reuso da água não foge à regra. Em suas várias formas de aplicação, revela-se uma técnica segura e confiável, atraindo investimentos que tendem a ser cada vez menores e que, por isso mesmo, incentivam uma prática cada vez mais acessível (TELLES; COSTA, 2010).

O Brasil caminha lentamente na direção da sustentabilidade já adotada mundialmente, principalmente no que se refere ao uso inteligente da água, ao controle ambiental e consequentes vantagens socioeconômicas. Neste contexto, é requisito básico a coerência das normas burocráticas, agilidade da política institucional e integração nas organizações públicas e privadas, em empenho conjunto ao setor educacional, numa ampla ação que vai se refletir na conduta de cada indivíduo e consequente adequação mercadológica (TELLES; COSTA, 2010).

O sistema de reaproveitamento de água de chuva vem de um conjunto de ações que visam aproveitá-la quando chegam às casas e antes que sigam para a rede de drenagem sem que consiga retirar partido de suas potencialidades.

Basicamente, o sistema de reaproveitamento de águas pluviais é composto pela captação das águas de chuva por calhas e direcionadas para um filtro que rejeita os resíduos maiores e direciona a água previamente filtrada para um reservatório que rejeita essa água, chamada de primeira água. Em seguida, um filtro mais fino retém as impurezas menores e direciona a água para um reservatório que receberá o devido tratamento.

O ideal seria poder utilizar esta água nas tarefas domésticas evitando, assim, o consumo de água potável fornecida pelo município, onde se investe tratamento e energia para que chegue ao consumidor (VERDADE, 2008). Entretanto, a água cinza, ou grey water, como também é denominada, não possui o tratamento adequado para se tornar potável, pois não se enquadra nas principais características de potabilidade: ser insípida, inodora e incolor.

Um sistema eficaz de captação de água de chuva deve garantir o máximo de eficiência, tal como uma qualidade de água aceitável. Neste sentido, a descrição do sistema abrange todas os componentes desde a superfície de recolha ao reservatório de armazenamento, passando também pelos órgãos de transporte, filtragem e rejeição de água de lavagem das superfícies de recolha, denominada de first-flush. (VERDADE, 2008).

\subsubsection{Sistema de aproveitamento de energia solar}

A energia solar fotovoltaica foi criada para atender a sistemas de pequeno porte, ou locais que ainda não contavam com energia elétrica, porém com o passar do tempo ela passou a ser um meio promissor de investimentos em termos de energia alternativa, pois seu fornecimento é feito de forma mais regular que os demais meios de produção, e pode ser utilizado em qualquer parte do país.

A Alemanha produz, hoje, 20 Gigawatts (GW), representando 50\% da eletricidade produzida no país, com uma taxa de insolação não superior a 3500 watt/ hora por metro quadrado $\left(\mathrm{Wh} / \mathrm{m}^{2}\right)$ por dia. Comparativamente, com uma taxa de insolação variável entre 4500 e $6000 \mathrm{Wh} / \mathrm{m}^{2}$, o Brasil poderia produzir até $200 \mathrm{GW}$ de eletricidade a partir da luz solar, segundo afirma Villalva (2015).

$\mathrm{O}$ interesse pela produção de energia solar fotovoltaica ganhou ainda maior notoriedade após os constantes aumentos nos preços da energia elétrica fornecida pelas 


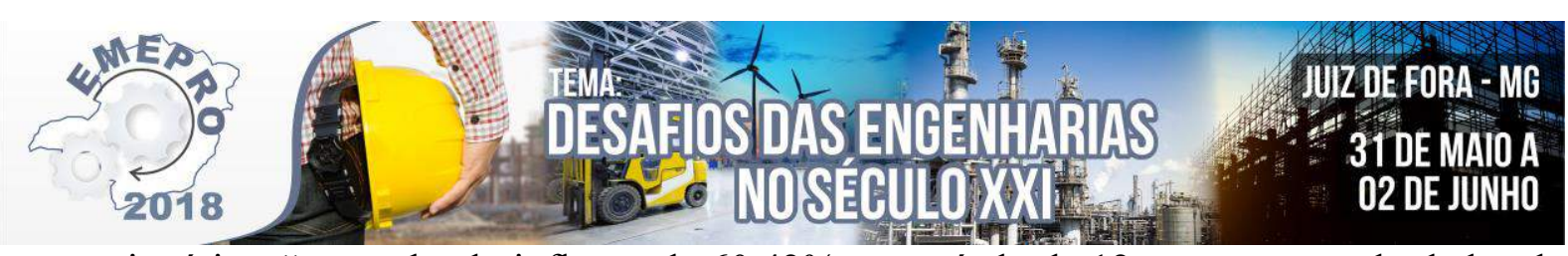

concessionárias, "acumulando inflação de $60,42 \%$ no período de 12 meses, segundo dados de março do Índice Nacional de Preços ao Consumidor Amplo (IPCA)” (ABDALA, 2015).

Segundo o website da Aneel (2017), a tarifação de energia elétrica visa assegurar aos prestadores dos serviços receita suficiente para cobrir custos operacionais eficientes e remunerar investimentos necessários para expandir a capacidade e garantir o atendimento com qualidade. No reajuste, os custos com a atividade de distribuição, esses sob completa gestão da distribuidora são corrigidos pelo índice de inflação constante no contrato de concessão que varia de acordo com o índice de inflação da economia brasileira.

Nos dias atuais a energia elétrica tem sofrido diversos aumentos de tarifação e de acordo com os avanços no setor de energia solar, tem-se visto o surgimento da produção desta energia limpa no país, e está cada vez mais comum sua utilização em obras, visto que é grande o interesse populacional nas questões que envolvem preservação do meio ambiente.

Diante do crescente encarecimento da energia elétrica e após constantes avanços na regulamentação do setor de energia fotovoltaico no Brasil, hoje se pode falar no surgimento de uma cultura de produção de eletricidade a partir da luz solar, de grande interesse para a sociedade brasileira e para as questões que envolvem a conservação do meio ambiente, de acordo com Villalva (2015).

Além disso, no lugar de grandes investimentos concentrados, a geração distribuída de eletricidade com sistemas fotovoltaicos tem a possibilidade de pulverizar investimentos e recursos, criando milhares de empregos diretos e indiretos em todas as regiões do país (VILLALVA, 2015, p. 35).

Conforme orienta Villalva (2015), a energia é um dos vetores indispensáveis que influenciam na questão ambiental e está no cerne dos debates globais que criaram o conceito de desenvolvimento sustentável, cuja efetivação tem sido possivelmente o maior desafio atual da humanidade.

O sistema de transformação da energia solar em fotovoltaica é constituída de cabos, painéis fotovoltaicos e inversores de tensão, dentre outros. Estes painéis são compostos de células fotovoltaicas, em sua maior parte de silício, que convertem imediatamente a energia proveniente do sol em elétrica (VILLALVA, 2015).

\subsubsection{Telhado verde}

De acordo com Tomaz (2008), o Telhado Verde é uma opção de construção em que uma cobertura de grama ou plantas é instalada em telhados ou lajes para ampliar o conforto em relação à temperatura, e para promover o conforto acústico dos ambientes no interior da obra.

Geralmente são aplicados em telhados praticamente planos com inclinação aproximadamente de $5^{\circ}$ para permitir o escoamento não muito rápido da água. Para telhados acima de $20^{\circ}$ deverão ser tomadas outras providências para deter o fluxo de água como barreiras ou outras estruturas (TOMAZ, 2008, p. 4).

$\mathrm{O}$ intuito deste tipo de telhado é aumentar a área verde da construção, contribuindo para uma melhoria no meio, diminuindo as ilhas de calor.

No Brasil, esse sistema construtivo ainda não é muito usado e começam a surgir leis de incentivo por parte do governo como forma de disseminação desse sistema. O primeiro projeto de telhado verde no Brasil foi em 1936, no prédio do Ministério da Educação (MEC) e foi construído por Roberto Burle Marx, depois em 1988 no Banco Safra em São Paulo e em 1992, a arquiteta Rosa Grená Kliass e Jamil Kfouri projetaram os jardins do Vale do Anhangabaú em São Paulo (TOMAZ, 2008).

\subsubsection{Gerenciamento de resíduos}

Hoje em dia o termo reciclagem vem ganhando força para resolver os problemas 


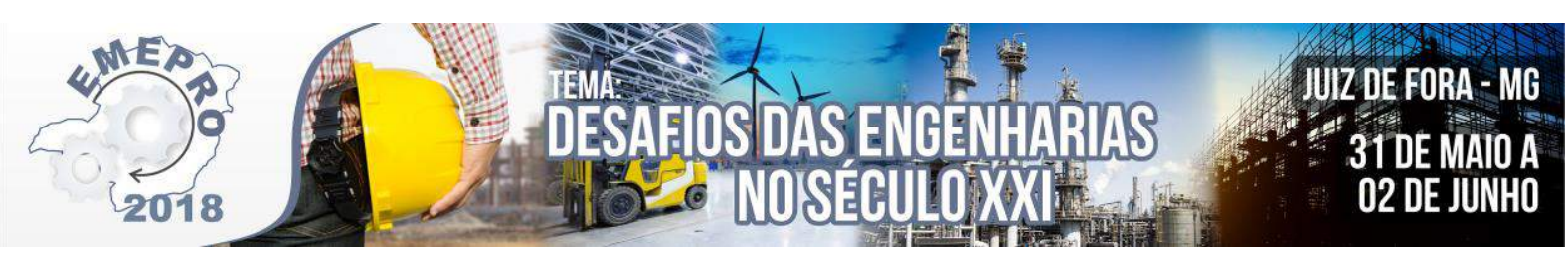

referentes ao não gerenciamento dos resíduos das obras de construção civil, além da busca incessante por materiais que substituam as matérias retiradas do meio ambiente devido à crise ambiental e a escassez de matéria prima.

Os Resíduos de Construção e Demolição (RCD), também denominados como entulho, tem se tornado um dos alvos do meio técnico-científico, utilizando o mesmo como agregado para inúmeros usos na construção civil e também na pavimentação rodoviária, entrando como substituto às matérias-primas hoje utilizadas nestes setores, de acordo com a Associação Brasileira para Reciclagem de Resíduos da Construção Civil e Demolição (ABRECON)30, (2017).

Nas obras da construção civil há um desperdício de material enorme, desde sua extração até sua chegada na obra.

Segundo Oliveira e Mendes (2008), aliada a tal reação desses setores tem-se a dificuldade por parte das empresas e governos municipais em criar mecanismos de gerenciamento eficazes, capazes de:

a) Nortear um uso mais inteligente dos materiais nas frentes de trabalho, visando com isso uma redução no volume de material a ser descartado mais tarde; posterior;

b) Contribuir com a segregação desses resíduos in loco, de modo a facilitar o seu reuso

c) Realizar e controlar a disposição do que não pode ser submetido a processos de reciclagem ou reuso direto em locais apropriados, diminuindo com isso o surgimento de áreas clandestinas de bota-fora, que ocorrem em muitas vezes em áreas de preservação.

Segundo a Resolução 307 do Conselho Nacional do Meio Ambiente (CONAMA) (2002), os resíduos de construção civil são:

Estes resíduos geralmente têm fins clandestinos, sem a destinação adequada. Segundo Oliveira e Mendes (2008), ocasiona proliferação de vetores de doenças, entupimento de galerias e bueiros, assoreamento de córregos e rios, contaminação de águas superficiais e poluição visual.

A ausência ou ineficiência de políticas específicas para este resíduo tem criado condições para que os mesmos apresentem atualmente efeitos ambientais significativos sobre a malha urbana, como o surgimento de aterros clandestinos e o esgotamento de aterros (inertes ou sanitários).

\subsubsection{Utilização de madeiras certificadas}

A madeira é um insumo extremamente importante para a construção civil. Desde os primórdios os seres humanos usam e moldam a construção de diversas obras desde as mais simples, como silos, até as mais complexas, como pontes, com esse material. As características únicas de beleza, charme, conforto térmico e acústico, fácil manuseio e usinagem, leveza, fonte renovável, grande resistência mecânica, estabilidade e durabilidade que só a madeira proporciona, fazem desde recurso uma opção indispensável em qualquer projeto.

\subsection{Estratégias para construção sustentável}

Por meio da simples orientação dos cômodos de uma casa na direção do sol é possível poupar até $30 \%$ na conta de energia elétrica necessária para o aquecimento de uma casa típica em um clima temperado (Roaf, Fuentes, Thomas, 2014, p. 21).

Para que as construções se tornem sustentáveis, é imprescindível diminuir os impactos ambientais e reduzir a interferência externa. Segundo Renato Júnior (2017), existem diretrizes para diminuir estes impactos, citadas a seguir:

a) Projetar a obra para usar a luz natural como fonte de iluminação principal durante o dia e proteger contra o excesso de calor; 


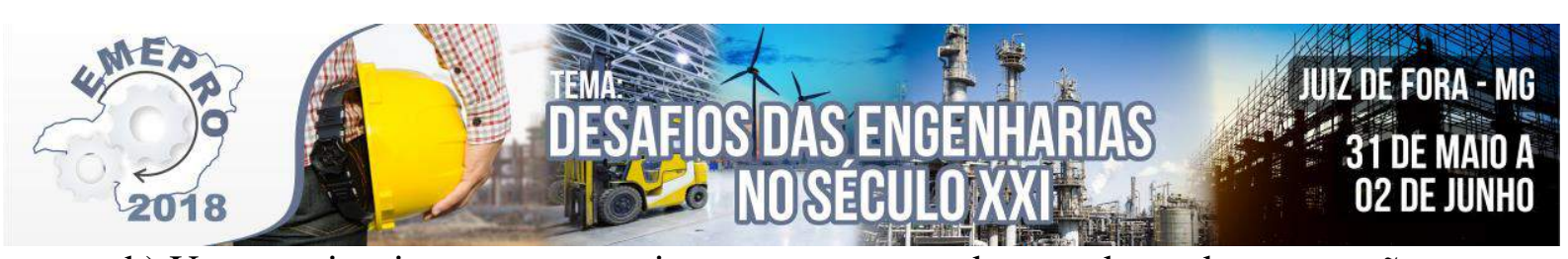

b) Usar o paisagismo para amenizar a temperatura dos arredores da construção;

c) Estudar a instalação de portas e janelas afim de favorecer a ventilação do interior da obra;

d) Usar materiais na obra que ajudem no conforto termoacústico da obra.

e) Usar um sistema que favoreça a temperatura ambiente, como o telhado verde e paredes ventiladas. Usar o plantio para produção de sombras no local;

f) Utilização de sistemas que diminuam o consumo da obra, em se tratando de consumo de energia, como exemplo, utilizar interruptores com luminosidade regulada e lâmpadas LED;

g) Uso de matéria prima correta em termos ecológicos com certificação e recicláveis;

h) Construção de pavimentação externa com materiais permeáveis;

i) Uso de torneiras e equipamentos com consumo de água reduzido, com controle de vazão e fechamento automático.

\section{Conclusão}

O presente trabalho procura apresentar a construção sustentável como premissa para construções civis ecologicamente corretas, contextualizando-se com a sustentabilidade, objetivando soluções limpas para o conforto local e a economia de recursos, a fim de minimizar diversas formas de agressão à natureza, procurando garantir que as gerações futuras possam ser autossuficientes em matéria prima, mantendo preservado o meio ambiente, além de aprimorar as técnicas de construção civil de maneira consciente por meio do conceito de construção sustentável apresentado.

Sendo assim, conclui-se ser extremamente importante uma obra pensada de forma à garantir a manutenção do meio ambiente, dotada de profissionais qualificados que não visem apenas o retorno financeiro, mas sim um ambiente capaz de gerar bem-estar aos habitantes com a exploração racional do meio ambiente, a fim de serem capazes de utilizar de meios para a preservação da natureza, proporcionando o bem para as pessoas que o utilizam, sem que deixem de lado a qualidade e o desenvolvimento das tecnologias da área da construção civil. Por meio deste trabalho, foi possível fornecer informações para popularizar as alternativas construtivas mais adequadas aos conceitos de sustentabilidade e difundir o modelo de construção sustentável como opção viável à construção convencional, apresentando formas de minimizar desperdícios e conscientizar os profissionais da construção civil.

\section{Referências}

BORGES, Fabricio Q. Layout Lato \& Sensu, Belém, v. 2, n. 4, dezembro, 2001.

GERLACH, Gustavo. Proposta de melhoria de layout visando a otimização do processo produtivo emu ma empresa de pequeno porte. Horizontina, 2013.

GONCHOROVSKI, Fernando Joel. Proposta de layout em uma nova Planta de um Tornearia de Pequeno Porte. Horizontina, 2014.

JANKOWSKY, P. Ivaldo. Fundamentos de secagem de madeiras. Piracicaba, 1990.

LIMA, Caldeira Rafael. Projeto de novo layout - Estudo de caso em uma indústria de confecção. Brasília, 2016.

MARTINS, P. G.; LAUGENI, F. P. Administração da produção. São Paulo: Saraiva, 2012.

NEUMANN, Clóvis; SCALICE, Régis Kovacs. Projeto de layout: Projeto de fábrica e layout. Rio de Janeiro: Elsevier, 2015.

SLACK, Nigel; CHAMBERS, Stuart; HARLAND, Christine, HARRISON, Alan; JOHNSTON, Robert. Administração da Produção. São Paulo: Atlas, 2009. 


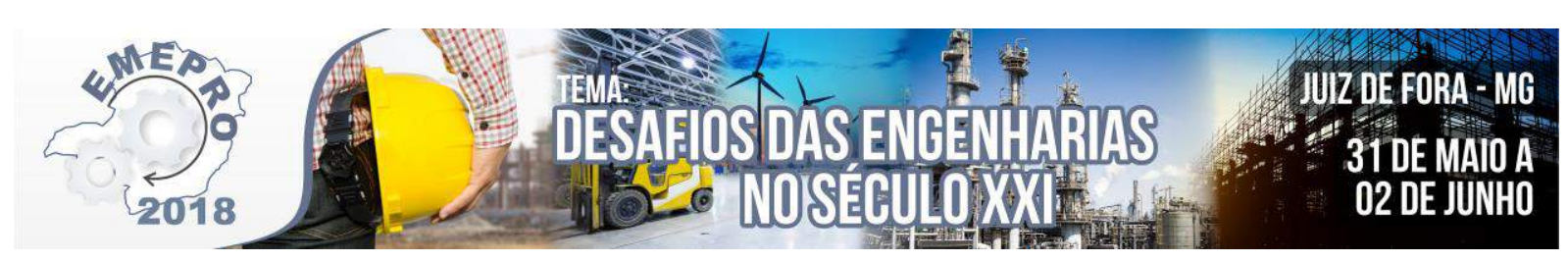

Resíduos da Construção Civil

LARISSA DOS SANTOS FERRARI. FUPAC - UBÁ. larissasantosferrari@ yahoo.com.br

LUARA FERREIRA ALVES. FUPAC - UBÁ. luharaa@hotmail.com

WILLIAM JOSÉ LOPES. FUPAC - UBÁ. williamjlopes@yahoo.com.br

LILIANE SOUZA OLIVEIRA MONI. FUPAC - UBÁ. lilianeso@gmail.com

ERIKA MARIA CARVALHO SILVA GRAVINA. FUPAC - UBÁ. ericamariacs@gmail.com

Resumo: O setor da construção civil é uma das atividades que contribuem para o desenvolvimento, porém a quantidade de resíduos gerados por essa atividade causa impactos ambientais, colocando em risco o meio ambiente e a saúde pública. Portanto, o objetivo é realizar uma análise através de referenciais teóricos sobre os $R C C$ (Resíduos da Construção Civil). Destaca-se que $61 \%$ dos resíduos sólidos urbanos são RCC e que $88 \%$ desses se enquadram na classe A, ou seja, material reutilizável ou reciclável na forma de agregado. As maiores incidências de descartes inadequados dos RCC's são em terrenos baldios, encostas, rios, entre outros, contribuindo para a poluição e aumentando a incidência de animais transmissores de doenças. É essencial realizar o gerenciamento dos RCC's visando a sustentabilidade desse setor, melhorando a limpeza urbana, preservando o ambiente, reduzindo a geração de resíduos e até reduzindo custos. Portanto, é destacado a importância da aplicação das etapas de redução, reutilização e reciclagem, que são capazes de diminuir a quantidade de RCC produzidos e minimizar os impactos causados. Portanto, todas a leis, os planos de gerenciamentos e de destinação final devem ser seguidos para alcançar a sustentabilidade no setor de construção civil.

Palavras-chave: Resíduo; Construção civil; Impactos; Gerenciamento; Sustentabilidade

\section{Introdução}

A construção civil é uma das mais antigas e importantes atividades que contribuem para o desenvolvimento humano e social, desde o início dos tempos. Porém, a quantidade de subprodutos de resíduo mineral gerado por essa atividade causa impactos ambientais, devido ao descarte incorreto, colocando em risco o meio ambiente e a saúde pública. Uma forma de minimizar esses problemas é reutilizando os resíduos produzidos. O primeiro registro dessa reutilização para construção de novas obras foi na época do Império Romano. Apenas em 1928 que construtores começaram a desenvolver pesquisas para avaliar a aplicação desse conceito na construção civil, onde a primeira grande aplicação se deu após a Segunda Guerra Mundial, pois os prédios foram demolidos e seus resíduos britados para utilização como agregados.

Os resíduos descartados que podem ser reaproveitados são materiais cerâmicos, aço, madeira, argamassa, pedras, areia, etc., sendo eles provenientes de várias atividades da construção civil, como reformas, demolições, construções novas, entre outras. Segundo dados da Associação Brasileira para Reciclagem de Resíduos de Construção Civil e Demolição (ABRECON), no Brasil é produzida, em média, meia tonelada de resíduos de construção civil por ano, representando mais $60 \%$ dos lixos sólidos das cidades e, desse total, $70 \%$ poderia ser 


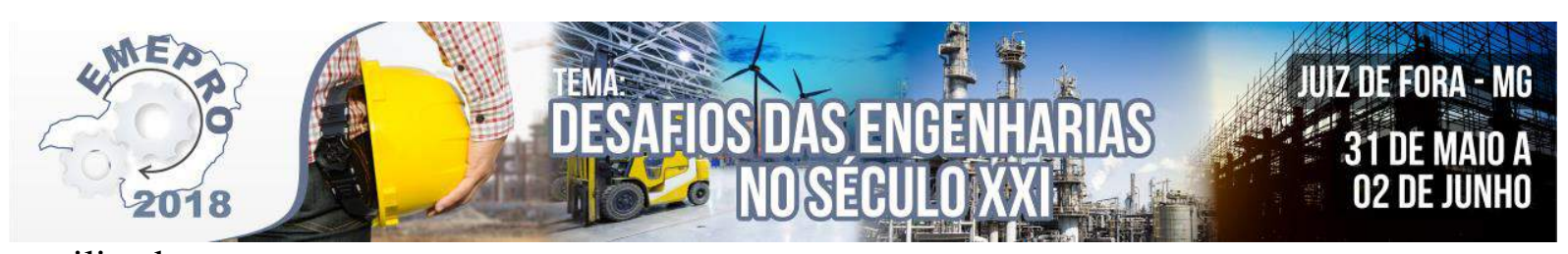

reutilizado.

A falta de informação, legislação e fiscalização municipal contribuem para o aumento desse índice. Para minimizar esse impacto, o Conselho Nacional do Meio Ambiente (CONAMA) criou a Resolução $\mathrm{n}^{\circ} 307 / 2002$, estabelecendo diretrizes e procedimentos para a gestão dos resíduos da construção civil nos municípios e para os geradores de Resíduos da Construção Civil (RCC), onde é feita a classificação dos materiais para reutilização ou descarte, mostrando a forma correta de ser descartados.

É importante sempre buscar a inovação e a sustentabilidade para diminuir os grandes impactos causados ao meio ambiente. A reutilização dos RCC é uma atividade que traz muitos benefícios, diminuindo os problemas causados pela construção civil e gerando uma economia ao dono do empreendimento, pois muitos materiais que eram considerados lixo foram reutilizados de alguma forma nas obras.

Sustentabilidade é a palavra chave no ambiente vivido hoje. Por isso, as empresas vêm investindo em tecnologias e projetos que possibilitam a obtenção da certificação de obras sustentáveis, assim alcançando o desenvolvimento sustentável. A reutilização e o descarte de forma correta dos resíduos são os principais fatores para a preservação do meio ambiente na construção civil. Sendo assim, é importante que seja elaborado um plano de gestão de resíduos. Através disso, a reutilização e reciclagem diminuem a quantidade de RCC e também a utilização de recursos naturais e energéticos.

Desta maneira, o trabalho tem como objetivo demonstrar a importância da redução, reutilização, reciclagem e descarte correto, que sejam capazes de diminuir a quantidade de resíduos produzidos hoje pela construção civil e minimizar os impactos causados ao ambiente.

\section{Referencial Teórico}

\subsection{Desenvolvimento sustentável na construção civil}

A principal atividade com grande representatividade no mercado para o desenvolvimento do país é a construção civil. Essa atividade traz grandes prejuízos ambientais por conta dos meios de construção e a grande quantidade de extração de recursos minerais, como areia, rochas, madeiras, entre outros materiais primários, causando impactos no meio ambiente. Esse tipo de exploração mostra que os recursos minerais são tidos como ilimitados, buscando apenas o desenvolvimento social e econômico, sem pensar nas possíveis consequências desse tipo de atividade (VASCONCELOS, 2011)

Segundo Vasconcelos (2011), a forma de desenvolvimento aplicada, apesar de trazer grande crescimento econômico, também traz grande degradação e poluição ao meio ambiente. Devido aos impactos causados, a busca por adequar o desenvolvimento e a sustentabilidade, hoje, é o ponto principal para conscientização global e assim analisar uma nova forma de produção que reduza a exploração dos recursos minerais e também a geração de resíduos provenientes da construção civil.

Para alcançar o desenvolvimento sustentável, as empresas seguem uma série de exigências a fim de obter a certificação de construções sustentáveis. O Ministério do Meio Ambiente (MMA) define como construção sustentável um conceito que denomina um conjunto de medidas, adotadas em todas as etapas da construção, que visam a sustentabilidade da obra. Com a adoção dessas medidas, é possível minimizar os impactos negativos ao meio 


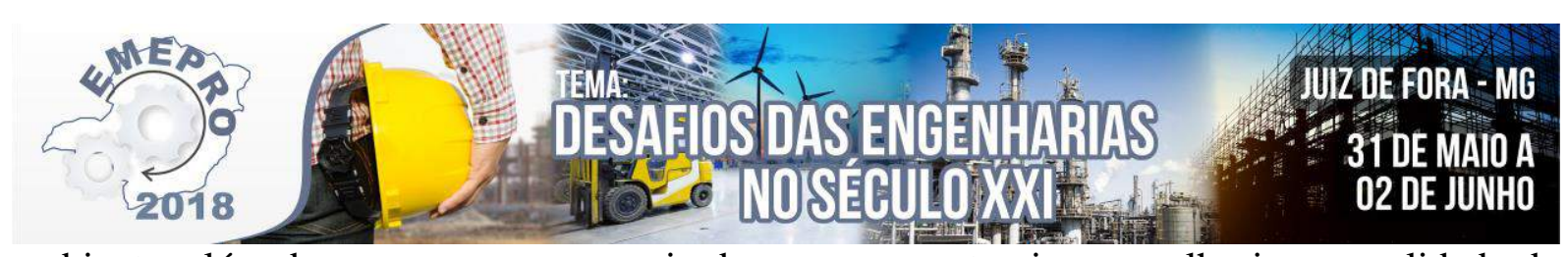

ambiente, além de promover a economia dos recursos naturais e a melhoria na qualidade de vida dos ocupantes. As certificações ambientais mais utilizadas no Brasil são:

- Lidership in Energy and Environmental Design (LEED) - é um sistema internacional de certificação e orientação ambiental, e tem como objetivo incentivar a transformação dos projetos, obras e operações das edificações, visando sempre a sustentabilidade. A certificação é emitida pelo Green Building Council Brasil (GBCB);

- Processo Alta Qualidade Ambiental (AQUA) - é um processo de gestão total do projeto para obter a Alta Qualidade Ambiental do empreendimento de construção. Essa certificação é baseada na certificação francesa Démarche HQE Vanzolini;

(Haute Qualité Environmentale) e aplicada no Brasil desde 2008 pela Fundação

- Selo Casa Azul - é um selo criado pela Caixa Econômica Federal, a fim de promover o uso racional de recursos naturais nas construções e melhoria na qualidade da habitação dos projetos que financia;

- Selo Procel Edifica - é o Programa Nacional de Eficiência Energética em Edificações. A criação do Programa incentiva a conservação e o uso eficiente dos recursos naturais (água, luz, ventilação etc.) nas edificações, reduzindo os desperdícios e os impactos sobre o meio ambiente. Foi instituído em 2003 pela Eletrobras/Procel, em conjunto com alguns ministérios e outras instituições.

\subsection{Geração de resíduos}

De acordo com Schwengber (2015), os resíduos gerados pela construção civil, definidos por Resíduos de Construção e Demolição (RCD), sendo eles provenientes do entulho produzido no canteiro de obras, representam uma parcela significativa em relação à quantidade total dos resíduos sólidos urbanos, sendo estimado em $61 \%$. Através do gráfico é notada a importância do estudo sobre a gestão de RCD, para diminuir esse número e contribuir para busca de meios urbanos mais sustentáveis.

De acordo com Karpinsk et al. (2009), o grande volume de resíduos gerados pelas cidades brasileiras mostra que o desperdício dos materiais é um caso importante a ser analisado pelas indústrias, órgãos públicos e pela sociedade. O entulho gerado representa $50 \%$ dos materiais que entram na obra, trazendo esse desperdício um custo para a sociedade, desde as pequenas taxas de encargos cobrados pela prefeitura ao aumento do custo final da edificação.

Zordan (1997), afirma que a grande utilização da matéria-prima está diretamente ligada ao grande desperdício de vários materiais nas obras, à vida útil das estruturas construídas e às obras de reparo e adaptação das edificações existentes. Os RCD são gerados principalmente durante três etapas da construção civil, sendo elas construção, manutenção e demolição. Os RCD gerados nas etapas de construção e manutenção são provenientes da produção de materiais de construção e utilização desses materiais. Porém, existem outras fontes geradoras de RCD, como os fenômenos naturais: por exemplo, furacões, enchentes, tsunamis, terremotos e outros.

Conforme dados do Sindicato da Industria de Construção Civil de São Paulo (SINDUSCON SP), os países desenvolvidos geram uma quantidade elevada de RCD devido as obras de demolição e reforma serem mais recorrentes que as obras de construção. Segundo a Associação Brasileira de Empresas de Limpeza Pública e Resíduos Especiais (ABRELPE, 


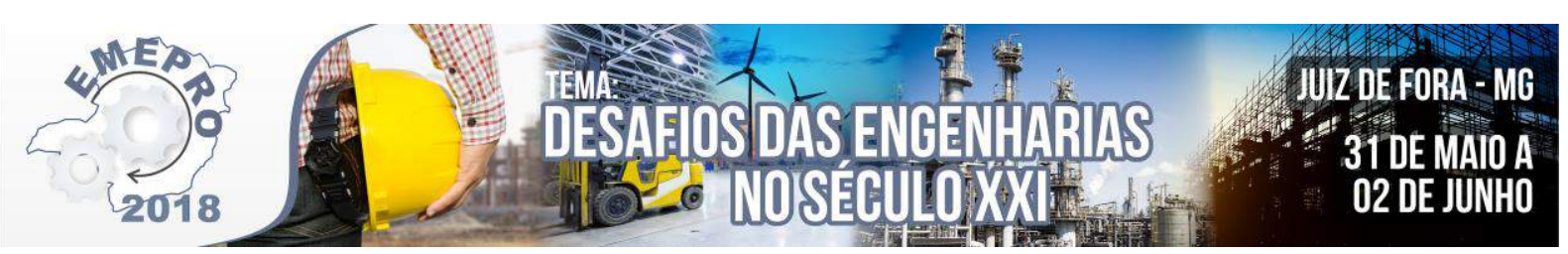

2010), um estudo feito em 350 cidades brasileiras mostrando a quantidade de RCC coletada no Brasil por região. É possível observar que o volume total encontrado no país, representa aproximadamente 31 milhões de toneladas por ano, cerca de $99.354 \mathrm{t} / \mathrm{dia}$.

Segundo Oliveira (2003), os resíduos da construção são mais limpos que os de demolição, pois estes ainda não passaram por processos de pintura ou misturados a outras substâncias de tratamento de superfície que podem contaminar o solo. No Brasil, assim como nos EUA, a maior incidência de resíduos são os provenientes da demolição, porém eles se diferem pelo tipo de material, devido aos diferentes processos construtivos dos países.

Na resolução do CONAMA n ${ }^{\circ} 307$, os resíduos classe A e classe B são considerados capazes de serem reciclados. No Brasil a composição do RCD é dada, em sua maioria, por essas duas classes, o que torna possível a reciclagem desse tipo de material.

O Poder Público toma algumas medidas, recolhendo resíduos, custeando o recolhimento e o transporte até sua destinação final. Porém, essas medidas não são suficientes para acabar com o problema: é preciso que todos envolvidos, produtores e consumidores, tenham consciência da dimensão dos danos causados e adotem medidas para diminuir os impactos ambientais causados e alcançar o desenvolvimento sustentável (SCHWENGBER, 2015).

O acúmulo e deposição irregular dos resíduos podem apresentar graves riscos sanitários e ambientais para o local devido à contaminação do solo e das águas, proveniente de resíduos que possuem em sua composição materiais indesejáveis, como cimento, gesso, alguns resíduos químicos, latas de tinta e solventes.

De acordo com Santos (2015), grande parte dos resíduos não trazem grandes riscos, porém a presença de alguns materiais químicos, além de contaminar os solos e águas, também contamina o ar devido à sua evaporação. O acumulo de RCC e Resíduos Sólidos Domésticos (RSD) contribui para poluição, devido ao mau cheiro, e aumenta a incidência de animais como ratos, escorpiões, baratas, mosquitos transmissores de doenças, entre outros, que trazem risco à saúde da população próxima a esses locais. Os resíduos também causam prejuízo à circulação das pessoas e veículos, pela ocupação de vias e locais públicos, quando descartados de forma incorreta.

\subsection{Impactos ambientais}

Segundo Vasconcelos (2011), a indústria da construção civil é apontada como a atividade que mais consome recursos naturais e utiliza energia de forma intensiva, gerando grandes impactos ambientais. Além disso, é também considerada a maior geradora de resíduos sólidos, líquidos e gasosos, que interferem diretamente no meio ambiente devido à forma de utilização e descarte dos materiais.

O crescimento populacional e a ocupação desordenada em áreas de encostas de rios, nascentes e áreas verdes provocam sérios problemas ambientais. A deposição de RCC e ocupação dos leitos dos rios causam assoreamento e degradação dos cursos d'água e poluição do lençol freático.

Os bota-foras clandestinos, localizados próximos às encostas e redes de drenagem, provocam assoreamento dessas áreas e obstrução das redes de drenagem, trazendo custos com limpeza pública e riscos de enchentes e deslizamentos de encostas.

Deste modo, pode-se observar que o principal problema são os RCD gerados pelas demolições e reformas. Logo, deve ser feito um plano de gerenciamento desses resíduos para 


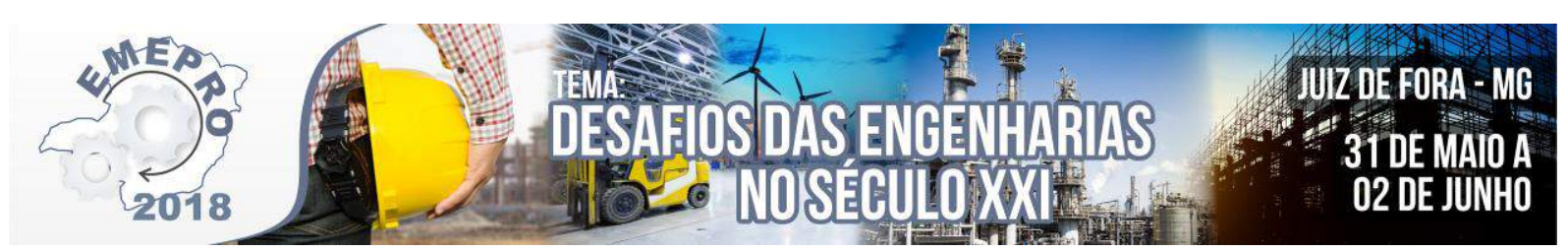

que eles sejam descartados e reaproveitados adequadamente, sem causar impactos ambientais.

\subsection{Legislação}

Devido ao desenvolvimento do país e ao crescimento populacional, as atividades da construção civil que contribuem para da geração de RCC tiveram um significante aumento. Com isso, nota-se a necessidade da criação de leis no âmbito nacional que orientem e direcionem todos os envolvidos com estas atividades a fim de minimizar os danos causados.

\subsubsection{Resolução CONAMA n⿳307/2002}

Em junho de 2002 o CONAMA criou a Resolução 307/2002, a fim de estabelecer diretrizes, critérios e procedimentos para a gestão de resíduos da construção civil. De acordo com essa resolução, o gerenciamento dos resíduos sólidos é o sistema de gestão que tem como objetivo reduzir, reutilizar ou reciclar os resíduos, por meio de planejamento, responsabilidades, práticas, procedimentos e recursos, a fim desenvolver e realizar os processos necessários para cumprir as etapas previstas no planejamento. Essa resolução entrou em vigor em janeiro de 2003 e destaca que é necessário priorizar a não-geração de resíduos, além de proibir a disposição final em locais que não sejam adequados, como aterros sanitários, bota-fora, lotes vagos, encostas, entre outros. São definidos como RCC aqueles derivados de atividades da construção, reforma, reparos e demolições de estruturas e estradas, como também resultantes de remoção de vegetação e movimentações de terra. Alguns exemplos de materiais provenientes das atividades da construção civil são: tijolos, blocos, cerâmicos, concreto em geral, solos, rochas, metais, resinas, colas, tintas, madeiras, forros, argamassa, gesso, telhas, pavimento asfáltico, vidros, plásticos, tubulações, fiação elétrica e etc.

A Resolução 307/2002 - CONAMA atualizada pela Resolução nº 348/04 (alterado o inciso IV do art. $3^{\circ}$, incluindo os resíduos provenientes do amianto com resíduos perigosos) estabeleceu uma classificação específica para esses RCC que estão organizados a seguir:

- Classe A - são resíduos reutilizados ou reciclados como agregados: solos, tijolos, blocos, telhas, revestimentos, argamassa, concreto, tubos, entre outros, provenientes de terraplanagem, obras de pavimentação e estruturais e processos de fabricação de materiais;

- Classe B - são resíduos reciclados para outras finalidades, como: plásticos, papéis, papelão, metais, vidros, madeiras e gesso;

- Classe C - são resíduos que não existem tecnologias ou aplicações economicamente viáveis para sua reciclagem e recuperação;

- Classe D - são resíduos considerados perigosos provenientes dos processos construtivos, como tintas, solventes, óleos, entre outros, ou materiais provenientes de demolições, reformas e reparos prejudiciais à saúde, como em clinicas radiológicas e instalações industriais, como telhas e outros materiais que contenham amianto ou outros produtos considerados prejudiciais à saúde.

Conforme SINDUSCON³ 2005, essa resolução leva em consideração as definições da Lei de Crimes Ambientais, de fevereiro de 1998, que determina penalidades para disposição final de resíduos que não cumprem com a legislação.

Segundo a Federação das Indústrias do Estado da Bahia (FIEB), a resolução determina que os geradores devem ter como principal objetivo a não-geração de resíduos e depois a redução, reutilização e destinação final. Outra exigência da Resolução 307 é a elaboração e 


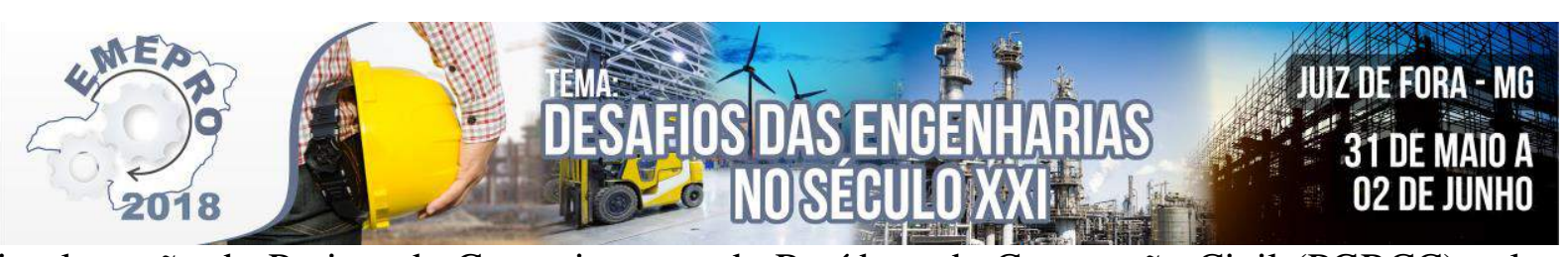

implantação do Projeto de Gerenciamento de Resíduos da Construção Civil (PGRCC) pelos geradores, sendo eles elaborados pelos maiores geradores para cada novo empreendimento e enviados para análise dó órgão municipal competente. Nos empreendimentos que precisam de licenciamento ambiental, o PGRCC deve ser examinado dentro do processo de licenciamento, junto ao órgão ambiental.

O PGRCC tem como objetivo determinar métodos necessários para a utilização e destinação final adequadas ao meio ambiente e atender as seguintes etapas:

- Caracterização - o gerador deve fazer a identificação e quantificação dos resíduos;

-Triagem - deverá ser feita, de preferência, na origem pelo gerador, ou nos locais de destinação licenciadas para essa finalidade, respeitando as classes dos resíduos;

- Acondicionamento - o gerador deve assegurar o armazenamento dos resíduos após a geração até a fase de transporte, garantindo, em todas as possibilidades, os requisitos de reutilização e de reciclagem;

- Transporte - deve ser feito conforme as fases anteriores e as normas técnicas vigentes para o transporte de resíduos;

- Destinação - deve ser prevista conforme a classificação de cada resíduo.

\subsubsection{Normas ABNT aplicáveis a gestão de RCC}

NBR 10004 (ABNT, 2004): esta norma determina critérios para classificação dos resíduos sólidos quanto à periculosidade, identificando seu processo de origem, seus constituintes e características. Desta forma, os resíduos sólidos são classificados em:

- Resíduos classe I - Perigosos: são aqueles que suas propriedades físicas, químicas ou biológicas apresentam riscos à saúde e ao meio ambiente. Possuindo as seguintes propriedades: inflamabilidade, corrosividade, reatividade, toxicidade, patogenicidade;

- Resíduos classe II - Não perigosos: o Resíduos classe IIA - não inertes: são os resíduos que apresentam características de biodegradabilidade, combustibilidade ou solubilidade em água;

- Resíduos classe IIB - inertes: são os resíduos que não apresentam nenhum componente solubilizado a concentrações superiores aos critérios de potabilidade da água, com exceção aos aspectos, cor, turbidez dureza e sabor.

NBR 13221 (ABNT, 2010): caracteriza as exigências para o transporte terrestre de resíduos, de forma que evite danos ao ambiente e à saúde pública, determinando que esse processo deve ser feito com equipamento adequado, seguindo as regulamentações e impedindo vazamento ou derramamento do resíduo em vias públicas, sendo necessário obedecer às legislações ambientais especificas (federal, estadual ou municipal), quando existir.

NBR 15112 (ABNT, 2004): destaca as obrigações exigidas para projeto, implantação e operação de áreas de transbordo e triagem de resíduos da construção civil e resíduos volumosos.

NBR 15113 (ABNT, 2004): determina os requisitos para projeto, implantação e operação de aterros de RCC classe A e de resíduos inertes.

NBR 15114 (ABNT, 2004): estabelece as obrigações mínimas para projeto, implantação e operação de áreas de reciclagem de resíduos sólidos da construção civil classe A. 


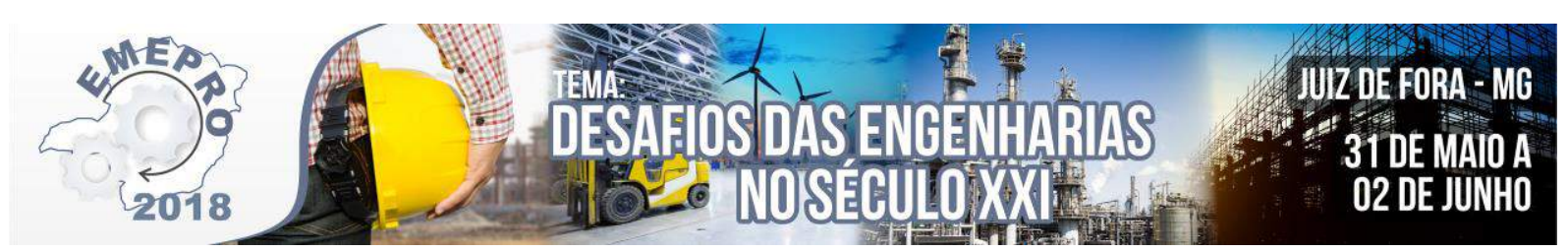

NBR 15115 (ABNT, 2004): estabelece as orientações para execução de camadas de reforço do subleito, sub-base e base de pavimentos, bem como camada de revestimento primário, com agregado reciclado de RCC, denominado agregado reciclado.

NBR 15116 (ABNT, 2004): estabelece as orientações para a utilização dos agregados reciclados de resíduos sólidos da construção civil. Especificam as condições de preparo dos agregados reciclados para uso em pavimentação e em concreto sem função estrutural e o controle de qualidade do agregado reciclado.

\subsection{Gerenciamento de resíduos}

A falta de gerenciamento adequado de RCC é um dos agravantes do impacto ambiental causado pela construção civil, devido ao descompromisso com a coleta dos resíduos, à carência de políticas públicas que regularizem a destinação dos resíduos, à ineficiência dos agentes de físcalização e gerenciamento ambiental no setor de gestão dos RCC. Com isso, todos esses problemas causam principalmente um grande número de áreas degradadas, como os bota-fora clandestinos ou deposições irregulares.

A gestão de RCD visa melhorar a limpeza urbana, reduzir custos, preservação ambiental, redução da geração de resíduos nas atividades construtivas e preservação do sistema de aterros para a sustentação do desenvolvimento (SANTOS, 2008).

Segundo Morand (2016), para ter uma gestão consciente dos resíduos gerados nos canteiros de obras é necessário compreender a complexidade do método de construção e a dificuldade de adequar as formas de disposição dos resíduos. Esta complexidade necessita de um planejamento adequado das formas de disposição. A primeira consideração é a nãogeração dos resíduos, ou seja, diminuir essa geração na obra. A segunda é considerar a reutilização do resíduo uma vez que ele foi gerado. Terceira alternativa, considerar uma possível reciclagem. A quarta forma de disposição é a recuperação de energia, ou seja, incineração. A quinta alternativa possível de disposição é o aterro sanitário. Considerando que a legislação atual proibiu, em julho de 2004, o despejo dos resíduos sólidos da construção em aterros sanitários e domiciliares, o principal interesse da gestão de RCC é na redução, reutilização e reciclagem dos resíduos gerados nos canteiros de obras.

Em Karpinsk et al (2009), estão destacadas as principais formas de gestão e gerenciamento dos resíduos de construção civil e demolição, classificadas de forma hierárquica em função do nível de impacto ambiental. Sendo eles:

- Redução da geração de resíduos: é a principal alternativa para a diminuição do impacto ambiental e no ponto de vista econômico;

- Reutilização dos resíduos: é a utilização de materiais para outra aplicação, sendo uma ação com o mínimo de processamento e energia;

- Reciclagem dos resíduos: é a modificação dos materiais em outros produtos;

- Compostagem dos resíduos: é a transformação da parte orgânica em húmus para o tratamento do solo;

- Incineração dos resíduos: é uma forma de extrair energia sem geração de substâncias tóxicas, se operacionalizada de forma correta;

- Aterramento dos resíduos: é a última alternativa quando não há mais o que reaproveitas dos resíduos.

A Resolução 307/2002 do CONAMA classifica a reutilização de resíduos como o 


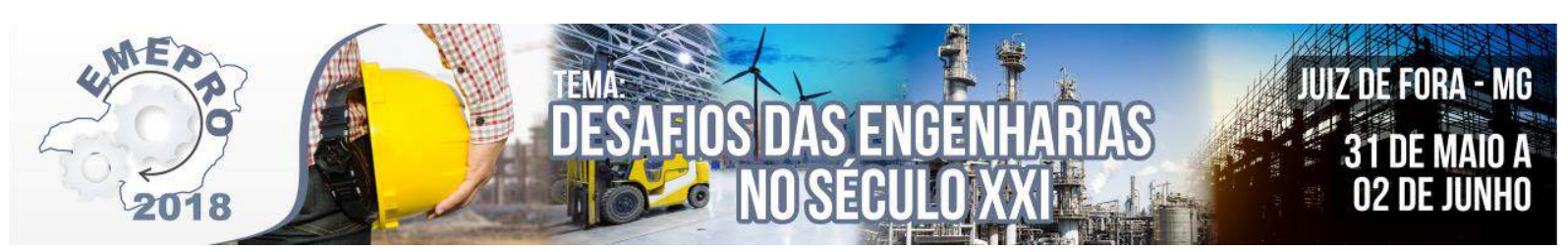

processo de reaproveitamento do material, sem que esse sofra modificações em suas características.

De acordo com Carneiro et al. (2001), devido à carência de matéria-prima cada vez maior, a reutilização é de grande importância para a minimização e controle dos danos ambientais causados pela geração de subprodutos de atividades urbanas e rurais.

A reutilização possui relevância econômica, ambiental e social, já que impede investimentos periódicos de compra, reduz o descarte inadequado de resíduos e permite a comercialização de um material que ainda possui valor agregado. Sua aplicabilidade em larga escala depende de vários fatores, dentre os quais a existência de um projeto municipal bem elaborado e a sensibilização social através dos trabalhos contínuos de educação ambiental.

A Resolução n³07 do CONAMA define como reciclagem a reutilização do material após ser submetido a processos que modifiquem suas características. Segundo FIEB, a reciclagem dos RCD no Brasil é considerada recente. Foram feitos alguns estudos sobre esse segmento, no início da década de 80 , que introduziu a utilização de reutilização.

John (2000), destaca que a reciclagem de RCD no Brasil em comparação aos países desenvolvidos é bastante pequena, porém com grande capacidade para ampliação. Essa diferença em relação a esses países tem por motivo diversos fatores. Um deles é a forma que o estado lida com a questão do impacto ambiental no Brasil, que ainda é tido como problema de preservação da natureza, com foco principal nas florestas e animais, deposição de materiais em aterros controlados e controle de poluição do ar. A Lei Federal de Crimes Ambientais de 1998 é a confirmação disso, pois mostra o estado muito mais preocupado com punições e transgressões, em vez de elaborar fatores que promovam a redução dos impactos ao meio ambiente como, por exemplo, as atividades de reciclagem.

Alguns outros fatores que atrasam as atividades de reciclagem de RCD no Brasil são:

- Dificuldade na inclusão de novas tecnologias na construção civil;

- Conceito errado sobre o produto desenvolvido a partir de os resíduos possuírem qualidade inferior aos outros desenvolvidos com materiais primários;

- Impressão de risco de baixo desempenho em relação ao uso de novas tecnologias;

- Menor custo dos agregados naturais;

- Falta de cultura para segregação de resíduos.

Conforme citado por Figueira (2016), em geral, a reciclagem de RCC/RCD ocorre numa série de etapas consecutivas, que incluem, após a coleta, a separação dos materiais nos grupos destacados, seguida de trituração dos mesmos, obtendo-se os agregados reciclados que, por sua vez, são destinados à fabricação de peças pré-moldadas não estruturadas, agregados para uso em pavimentação, guias e sarjetas e em blocos de concreto de vedação.

As principais vantagens da reciclagem de acordo com a FIEB, são:

- Preservação de recursos naturais com a substituição destes por resíduos, aumentando a vida útil das reservas naturais e diminuindo o impacto ambiental;

- Redução da ocupação de áreas para aterro por conta da diminuição do volume de resíduos a serem depositados;

- Redução no consumo de energia, seja ele para produção de um novo produto, seja com transporte e gestão do aterro;

- Geração de empregos com o surgimento das empresas para reciclagem; 


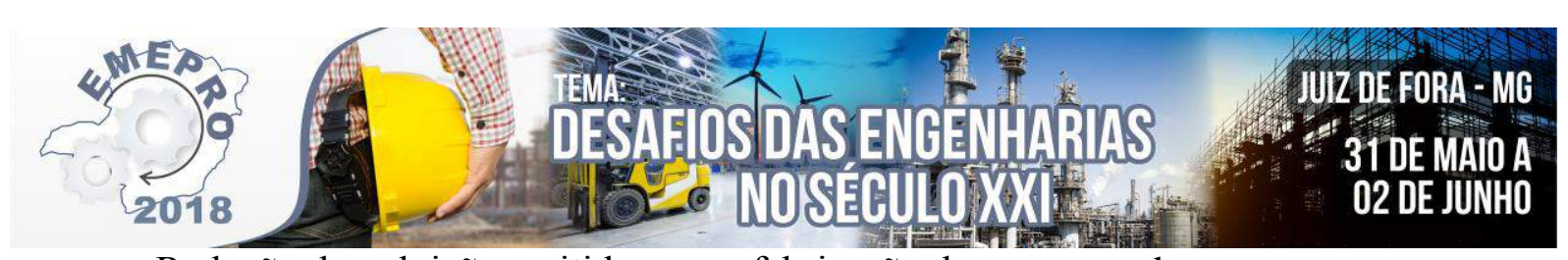

- Redução da poluição emitida com a fabricação de novos produtos;

- Aumento da durabilidade da construção em determinadas situações como, por exemplo, na adição de escória de alto forno e pozolanas ao cimento.

De acordo com Ângulo et al. (2001), assim como as outras atividades, a reciclagem de resíduos também pode causar impactos ambientais se não for escolhida de forma correta, de confome as características do material, como, por exemplo, o tipo de resíduos, a tecnologia a ser utilizada e a utilização prevista para o material reciclado. Com isso, se não houve planejamento e estudo desse processo ele pode se tornar mais impactante do que o resíduo antes de ser reciclado, por isso esse processo necessita ser gerenciado adequadamente. A quantidade de energia e a necessidade de utilização de matéria prima no processo de reciclagem podem torná-lo inviável economicamente e ambientalmente, pois esse processo pode gerar impactos ao meio ambiente. Por isso, é necessário que a escolha do processo de reciclagem seja criteriosa e considere todas as alternativas em relação ao consumo de energia e matéria prima.

\subsection{Destinação final}

Abramovay et al (2013), destaca que em 2012, as cidades coletaram 35 milhões de toneladas de resíduos de construção e demolição (mais da metade de tudo o que foi coletado dos domicílios). Isso representa 5,3\% a mais que o recolhido no ano anterior. E, como aponta o trabalho da Abrelpe (2013), esse volume deve estar subestimado, já que inclui apenas o que é "lançado nos logradouros públicos". O despejo irregular de resíduos da construção civil em São Paulo, por exemplo, atinge proporções gigantescas. Segundo Silvano Silvério da Costa, presidente da Autoridade Municipal de Limpeza Urbana (AMLURB/SP), foram encontrados em oito subprefeituras de São Paulo, em 2013, nada menos que 1.183 pontos de descarte irregular de resíduos de construção e demolição.

De acordo com o CONAMA, a Resolução no 307/2002 foi essencial para redução dos impactos ambientais gerados pela construção civil, pois ela contém diretrizes e procedimentos a serem realizados com os materiais descartados. Sabendo que a disposição dos resíduos em locais inadequados contribui para a degradação ambiental, foi discriminada a destinação correta de cada tipo de resíduo, conforme sua classificação. Esses resíduos não podem ser descartados em aterros de resíduos sólidos urbanos, em áreas de bota fora, encostas, terrenos baldios e em áreas protegidas legalmente. Eles dever ser destinados, após triagem da seguinte forma:

- Classe A - devem ser reutilizados ou reciclados como agregados ou encaminhados a aterro desse tipo de resíduos para seu armazenamento e possível uso futuro;

- Classe B - devem ser reutilizados reciclados ou levados para área de acondicionamento temporário, de modo que permita sua utilização futura;

- Classe $\mathrm{C}$ - devem ser acondicionados, transportados conforme as normas técnicas especificas;

- Classe D - devem ser acondicionados, transportados conforme as normas técnicas especificas.

Segundo dados da Pesquisa Nacional de Saneamento Básico (PNSB)4 de 2008, mostra que $71 \%$ dos munícipios brasileiros fornecem serviço de coleta de RCD, porem isso não garante que sejam descartados em locais adequados, classificados pelo CONAMA. 


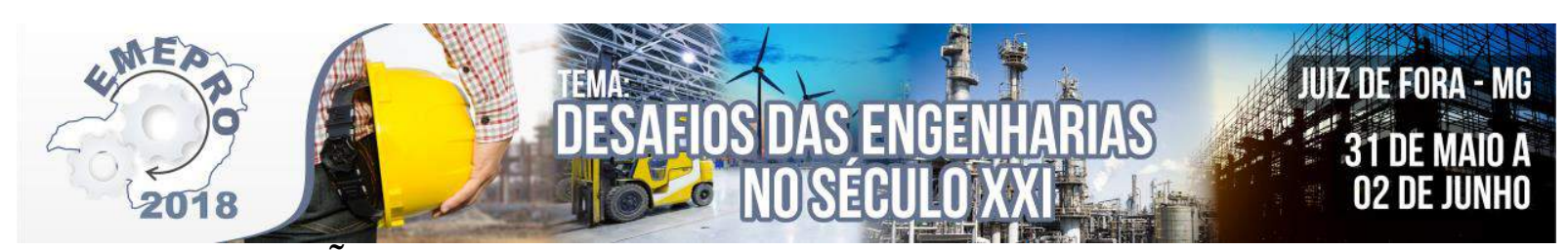

\section{CONSIDERAÇÕES FINAIS}

Devido ao desenvolvimento e crescimento populacional, a quantidade de resíduos sólidos gerados é cada vez maior e o setor da construção civil é um grande responsável pela geração de resíduos e, consequentemente, pela degradação do meio ambiente, pela falta da cultura de gerenciamento de RCC.

Para destinação correta dos RCC é muito importante minimizar a degradação ambiental, pois, devido ao crescimento demográfico, o volume de RCC produzidos é expressivo. Apesar de existirem normas e leis que abordam esse tema, como por exemplo a Resolução 307/2002 do CONAMA e a Política Nacional dos Resíduos Sólidos, é necessário maior comprometimento por parte das empresas em relação à gestão de resíduos. São poucas as iniciativas realizadas a fim de reduzir a geração desses materiais, o que contribui para o aumento do volume de resíduos produzidos devido à atual condição do país.

O mundo necessita de atividades que ressaltem a sustentabilidade, com isso, economias que tendem a se desenvolver, como o Brasil, precisam investir em políticas mais sustentáveis. É importante destacar que a reutilização e a reciclagem são processos distintos, com isso, é uma sugestão novos trabalhos que busquem por informações mais especificas, como também o investimento em tecnologias de reutilização e mecanismos capazes de reduzir a quantidade de resíduos e diminuir os impactos.

O gerenciamento que mais se aplica, no contexto sustentável, aos resíduos produzidos pelas empresas abrange a redução, reutilização e reciclagem. Essas medidas minimizam os impactos ambientais negativos, pois reduzem a extração de matéria-prima e impedem a destinação final inadequada. Existem muitas aplicações e áreas possíveis para o crescimento da utilização dos materiais reciclados. No Brasil, a quantidade de resíduos gerados é grande, porém não existe uma cultura de reutilização e reciclagem, onde obras realizadas por grandes empresas têm como principal disposição final o aterro de resíduos. A reciclagem de outros resíduos, como papel, plástico e metal, já pode ser notada com mais frequência, porém a reciclagem de entulho da construção ainda é muito pequena.

A utilização de materiais de construção reciclados possibilita às construções se tornarem mais ambientalmente corretas. Ainda devem ser realizados muitos estudos e pesquisas para melhorar as propriedades e aplicação de materiais recicláveis e assim vencer algumas barreiras, mas, com o crescimento do setor da construção no Brasil, as inciativas em favor ao meio ambiente vêm se tornando mais presentes.

A utilização dos resíduos da construção civil como materiais de construção, mesmo que ainda sejam realizadas em pequena escala, é uma pratica que só traz benefícios, sejam eles ambientais, econômicos ou sociais. É de extrema importância também a aplicação do Plano de Gerenciamento de Resíduos, para que mesmo se não forem destinados à reciclagem, tenham uma disposição final correta, assim garantindo a minimização dos impactos ambientais causados pela construção. 


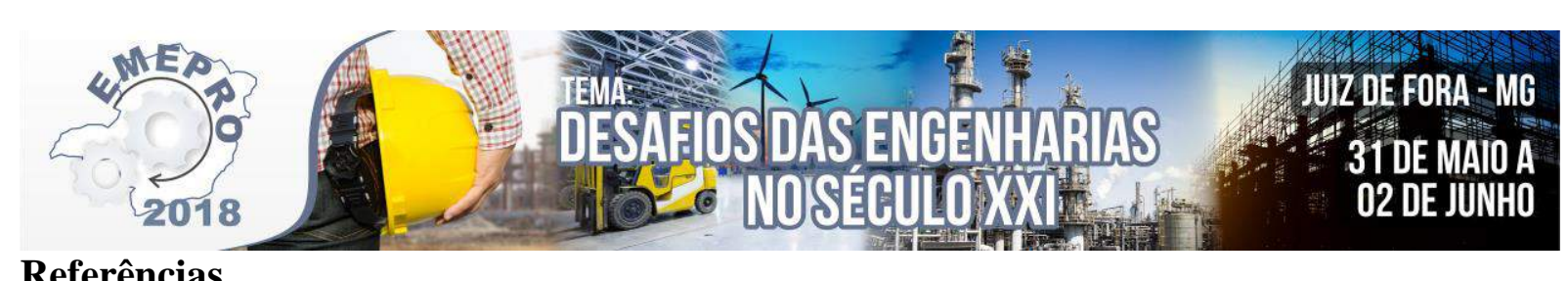

Referências

ABRAMOVAY, R.; SPERANZA J. S.; PETITGAND C. Lixo zero: Gestão de resíduos sólidos para uma sociedade mais próspera, São Paulo: Planeta sustentável: Instituto Ethos, 2013. 77p.

ÂNGULO, S. C. et al. Desenvolvimento sustentável e a reciclagem de resíduos na construção civil. IV Seminário Desenvolvimento Sustentável e a Reciclagem na construção civil - materiais reciclados e suas aplicações. CT206 - IBRACON. São Paulo - SP. 2001.

ASSOCIAÇÃO BRASILEIRA DE EMPRESAS DE LIMPEZA PÚBLICA E RESÍDUOS ESPECIAIS ABRELPE. Panorama dos resíduos sólidos no Brasil. São Paulo, 2010.

Panorama dos resíduos sólidos no Brasil. São Paulo, 2013.

ASSOCIAÇÃO BRASILEIRA DE NORMAS TÉCNICAS. NBR 10004. Classificação de resíduos sólidos. Rio de Janeiro, 2004.

NBR 13221. Transporte terrestre de resíduos sólidos. Rio de Janeiro, 2010.

NBR 15112. Resíduos da construção civil e resíduos volumosos - Áreas de transbordo e triagem Diretrizes para projeto, implantação e operação. Rio de Janeiro, 2004.

NBR 15113. Resíduos sólidos da construção civil e resíduos inertes - Aterros - Diretrizes para projeto, implantação e operação. Rio de Janeiro, 2004.

NBR 15114. Resíduos sólidos da construção civil - Áreas de reciclagem - Diretrizes para projeto, implantação e operação. Rio de Janeiro, 2004.

NBR 15115. Agregados reciclados de resíduos sólidos da construção civil - Execução de camadas de pavimentação - Procedimentos. Rio de Janeiro, 2004.

NBR 15116. Agregados reciclados de resíduos sólidos da construção civil - Utilização em pavimentação e preparo de concreto sem função estrutural - Requisitos. Rio de Janeiro, 2004.

ASSOCIAÇÃO BRASILEIRA PARA RECICLAGEM DE RESÍDUOS DA CONSTRUÇÃO CIVIL E DEMOLIÇÃO - ABRECON. Disponível em: <http://www.abrecon.org.br/>. Acesso em 17 set. 2017

CARNEIRO, A. P. et al. Uso do agregado reciclado em camadas de base e sub-base de pavimentos. In: CASSA, J. C. S. et al. Reciclagem de entulho para a produção de materiais de construção. Salvador: Editora da UFBA, 2001. Capítulo 6, 188-227 p.

FEDERAÇÃO DAS INDÚSTRIAS DO ESTADO DA BAHIA - FIEB. Gestão de resíduos na construção civil: Redução, reutilização e reciclagem. Projeto Competir. 2013.

FIGUEIRA, A. C. B. Gerenciamento de resíduos sólidos. Rio de Janeiro: Seses, 2016. 160 p. Disponível em: < https://www.passeidireto.com/arquivo/22205352/livro-residuos-solidos>. Acesso em 21 out. 2017.

JOHN, V. M. Reciclagem de resíduos na construção civil - contribuição à metodologia de pesquisa e desenvolvimento. Tese (Livre Docência) - Escola Politécnica, Universidade de São Paulo, São Paulo, 2000.

KARPINSK, L. A. et al. Uma gestão diferenciada de resíduos da construção civil: uma abordagem ambiental. Porto Alegre: Edipucrs, 2009. 163 p.

MORAND, F. G. Estudo das principais aplicações de resíduos de obras como materiais de construção. TCC (Graduação em Engenharia Civil), Universidade Federal do Rio de Janeiro, Rio de Janeiro, 2016.

SANTOS, A. N. Diagnóstico da situação dos resíduos de construção e demolição (RCD) no município de Petrolina (PE). Dissertação (Mestrado em Engenharia Civil), Universidade Católica de Pernambuco, Recife, 2008.

SANTOS, G. O. Resíduos sólidos e aterros sanitários: Em busca de um novo olhar, Fortaleza, [s.n.], 2015.80 p. Disponível em: < https://www.passeidireto.com/arquivo/28328924/livro-gemmelle-oliveira-dos-santos>. Acesso em: 20 out. 2017.

SANTOS, I. R. Medidas para a redução dos impactos ambientais gerados pela construção civil. TCC (Graduação em Engenharia Civil), Universidade Federal do Rio de Janeiro, Rio de Janeiro, 2015.

SCHWENGBER, E. R. Resíduos da construção civil. TCC (Graduação em Especialização em Direito Ambiental 


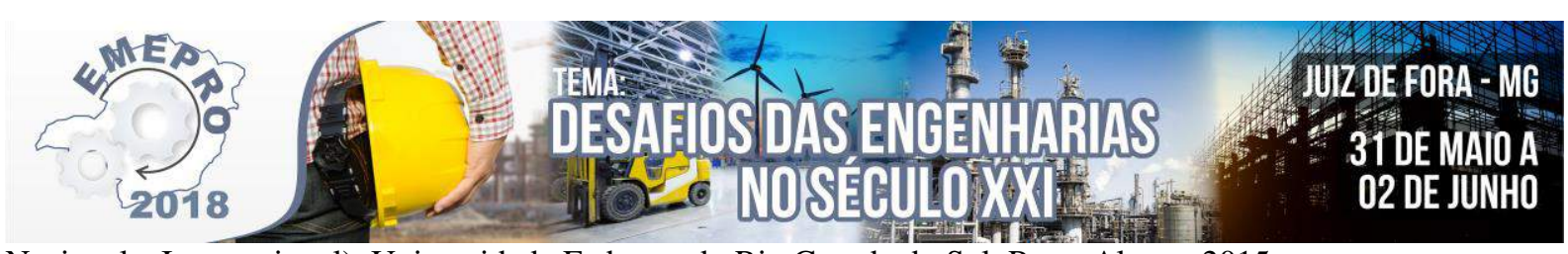

Nacional e Internacional), Universidade Federam do Rio Grande do Sul, Porto Alegre, 2015.

SECRETERIA DE ASSUNTOS ESTRATÉGICOS. Instituto de Pesquisa Econômica e Aplicada. Diagnósticos dos resíduos sólidos da construção civil. Relatório de Pesquisa, Brasília, 2012.

SILVA, M. B. L. Novos materiais à base de resíduos de construção e demolição (RCD) e resíduos de produção de cal (RPC) para uso na construção civil. Dissertação (Mestrado em Engenharia e Ciência dos Materiais), Universidade Federal do Paraná, Curitiba, 2014.

SINDICATO DA INDUSTRIA DA CONSTRUÇÃO CIVIL DO ESTADO DE SÃO PAULO - SINDUSCON SP, 2005. Disponível em < https://www.sindusconsp.com.br/>. Acesso em: 11 out. 2017.

VASCONCELOS, C. R. F. Análise do gerenciamento de resíduos da construção civil na cidade de Mossoró RN, TCC (Graduação em Ciências Ambientais e Tecnológicas), Universidade Federal Rural do Semi-Árido, Mossoró, 2011.

ZORDAN, S. E. A utilização do entulho como agregado na confecção do concreto. 1997. Dissertação (Mestrado em Saneamento e Meio Ambiente) - Faculdade de Engenharia Civil, Universidade Estadual de Campinas, Campinas, 1997. 


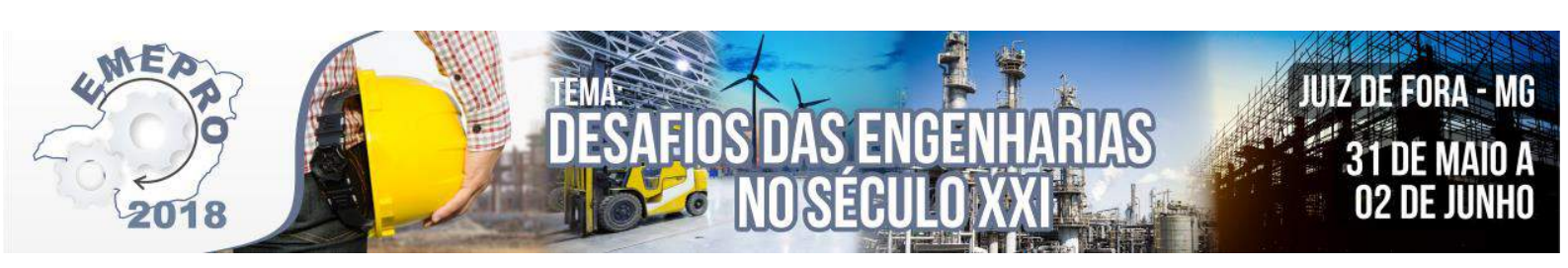

A importância do reuso de águas cinzas para fins residenciais

\author{
DIOGO ROMAN, FUPAC-UBÁ, diogoroman@hotmail.com \\ MIRELLA GOMES DE LIMA ANDRADE, FUPAC-UBÁ, mgjlimaa@gmail.com \\ ALEXANDRE SIQUEIRA DA SILVA, FUPAC-UBÁ, alexandresiqueira08@gmail.com \\ EUNICE SINGULANE, FUPAC-UBÁ, eunicesingulane@gmail.com
}

Resumo: Com a eminente escassez de água para o abastecimento da população, devido a grande degradaçao ambiental, aquecimento global e crescimento desordenado da populaçao, faz- -se necessário a busca por novas fontes de fornecimento deste insumo. Uma das formas de economizar água potável, que vem chamando a atenção de vários pesquisadores pelo mundo, é o reúso planejado delas, dentre elas as águas cinzas, que são as provinientes do banho, lavatórios e máquinas de lavar, por possuirem menos contaminantes que as águas negras geradas pelas descargas sanitárias e pias de cosinha. O reúso indicado, refere-se a fins menos nobres que não necessite da potabilidade. Para que o reúso não ofereça risco à saúde e proporcione o bem-estar do usuário é necessário a utilização de um processo de tratamento, sistema de coleta e distribuição independente da água potável.

Palavras-chave: Água; Escassez; Reuso; Águas cinzas; Sustentabilidade

\title{
1. Introdução
}

A água é, sem dúvida, o recurso natural mais importante para a sobrevivência de toda a vida existente no mundo, ocupando $3 / 4$ do planeta e está presente em toda a atividade humana, como na agricultura, nas indústrias, na geração de energia elétrica, no abastecimento domiciliar dentre outras. Embora a quantidade de água existente no planeta continue sendo sempre a mesma, por se tratar de um recurso renovável devido ao ciclo hídrico, a quantidade de água potável, com qualidade para atender a demanda da população, vem se tornando cada vez mais escassa, devido ao crescimento desordenado da população urbana, a degradação, poluição do meio ambiente e as alterações climáticas. Hoje, a falta de água potável para o abastecimento domiciliar já é um problema enfrentado em diversas localidades.

Segundo Bazzarella (2005), o crescimento populacional e o desenvolvimento industrial, combinado com o uso irracional da água, têm aumentado, consideravelmente, a demanda e a produção de águas residuárias no mundo. Esses influentes, tanto de origem industrial quanto urbana, quando lançados no ambiente, degradam ainda mais os mananciais onde essas são captadas. Pensando nesse contexto, é fundamentalmente importante que se tome medidas de conservação, proteção e economia deste bem tão valioso e indispensável para a manutenção da vida humana das atuais e futuras gerações. Uma das formas de economia de água potável, proposto nesta pesquisa, é a reutilização das águas cinza, que são as provenientes dos banhos, dos lavatórios e da máquina de lavar para fins menos nobres como, descarga sanitária, lavagem de pisos e de carros, aguagem de jardins e reutilização na lavagem de roupas, economizando desta forma a água fornecida pela concessionária local e diminuindo a quantidade de dejetos lançados na rede de esgoto. 


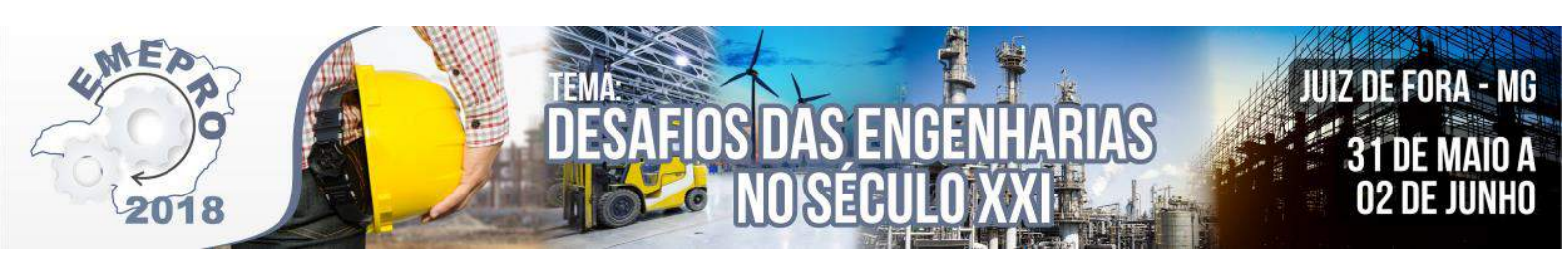

Monteiro (2009) diz que o reúso direto planejado considera que a água deve passar por algum tratamento, de tal forma que ela reaproveitada apresente características físicoquímicas e microbiológicas, que não proporcione risco ao usuário. Embora o país possua pouca legislação referente ao incentivo da reciclagem de águas cinza, os padrões relacionados estão mais envolvidos ao "adorno arquitetônico, exigindo grau de transparência, ausência de cor, escuma ou qualquer outra substância ou componentes flutuantes" (FEDERAÇÃO DAS INDÚSTRIAS DO ESTADO DE SÃO PAULO, FIESP 2005). Desta forma, o emprego de filtro para a desinfecção das águas cinza é imprescindível para o funcionamento do sistema, a fim de fornecer uma água não potável, mas que não ofereça riscos à saúde e proporcione o bem-estar do usuário.

A pesquisa tem como objetivo descrever a importância do reúso de águas cinzas, tratando das formas de instalações; processos de filtragem; características da água de reúso, verificando se é ou não economicamente viável, visando o conceito de sustentabilidade e conservação dos recursos hídricos.

\section{Desenvolvimento}

\section{1 Água}

A água é um recurso natural, considerado renovável e de volume constante no planeta. Segundo Telles e Costa (2010) é através de seus estados físicos (sólido, líquido e gasoso) que a água se recicla na natureza. Pelas condições climáticas, geográficas e meteorológicas, a água apresenta-se em forma de vapor, neblina, chuva ou neve. Atingindo a superfície dos oceanos, mares, continentes ou ilhas, caracterizando dessa forma como um recurso renovável e migratório, de caráter aleatório, de forma a manter constante seu volume.

Embora ocupe $3 / 4$ de nosso planeta, a água doce disponível não soma mais que $3 \%$. Destes, cerca de $75 \%$ estão congelados nas calotas polares e $10 \%$ reservadas em aquíferos. Então, apenas $15 \%$ de água doce do mundo estão disponíveis para o consumo, e, sua reserva, tem-se reduzido com o aumento da população, pelos diversos tipos de uso e pela degradação do meio ambiente (TUNDISI, 2003).

Até pouco tempo atrás a água era um exemplo de "bem não econômico", ou seja, aquele que é tão abundante e inesgotável que não tem, portanto, valor econômico. Entretanto, nos últimos anos, este quadro está mudando. A escassez de água nos grandes centros urbanos é iminente, devido ao crescimento acelerado das populações, ao lançamento de efluentes sem tratamento que poluem os mananciais e a necessidade cada vez maior de uso deste insumo nas indústrias e na agricultura, impulsionada pelo crescimento econômico (SANTOS, 2008).

Deve-se também considerar que as mudanças em curso no planeta poderão afetar, drasticamente, os recursos hídricos do mundo. Essas mudanças globais, em parte resultantes da aceleração dos ciclos produtivos e contribuição de gases de efeito estufa para a atmosfera, também poderão interferir nas características do ciclo hidrológico, afetar a temperatura das águas superficiais de lagos, rios e represas, alterar a evapotranspiração e produzir impactos diversos na biodiversidade. Elas poderão ter efeitos na agricultura, na distribuição da vegetação e, consequentemente, poderão alterar a quantidade e qualidade dos recursos hídricos (TUNDISI, 2003).

Desta forma, enfrentaremos, em um futuro próximo, uma crise de abastecimento deste recurso indispensável para a manutenção da economia, da biodiversidade, da vida e da existência do planeta. Segundo Telles e Costa (2010), os mananciais do planeta estão secando 


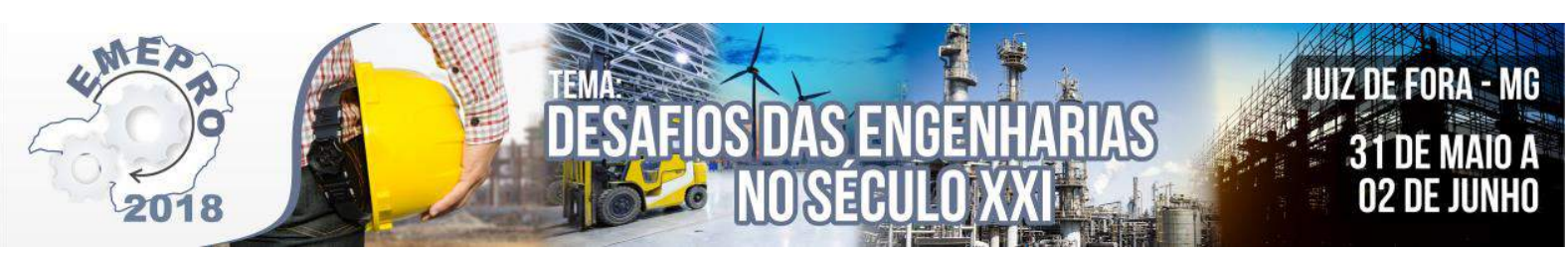

gradativamente, fato esse que somando ao crescimento desordenado da população, à poluição, a degradação do meio ambiente e ao aquecimento global, tem tendência a reduzir em um terço nos próximos 20 anos a quantidade de água disponível para cada pessoa no mundo. Os autores seguem dizendo que a situação crítica deverá atingir cerca de 30 países no ano de 2025, o que sugere a "guerra eminente da água".

\subsection{Tipos clássicos de Layout/Arranjo físico}

Uma unidade produtiva com seus devidos recursos (máquinas, equipamentos, pessoas etc.) deve possuir um layout ou arranjo físico adequado para atender as necessidades e capacidades de produção. Segundo Neumann e Scalice (2015, p. 221) "os tipos de layout definem o sistema de organização da produção, dependendo da natureza dos produtos e do tipo de operações executadas, e são usualmente classificados em quatro tipos principais, descritos a seguir".

\subsection{Escassez de água no Brasil}

O Brasil é um país privilegiado no quesito hídrico, não possui $3 \%$ da população mundial, mas $12 \%$ da água doce do planeta está localizada em seu território. Essa participação sobe para $18 \%$ quando se considera apenas a água de superfície, excluindo-se as reservas em aquíferos subterrâneos, e os lençóis freáticos. As reservas superficiais brasileiras somam escoamento médio de quase 180 milhões de litros por segundo. Onze dos 50 rios mais caudalosos do mundo estão aqui. O país também aparece bem no subsolo, metade do território nacional acomoda 20 bacias que garantiriam uma vazão de 42,3 milhões de litros por segundo. (EM DISCURSSÃO..., 2014. P.7).

Dito isso, fica difícil de acreditar que um país com tanta diversidade hídrica, vem sofrendo problemas referente a escassez de água, principalmente, no que se refere ao abastecimento residencial urbano. Um dos motivos apontados por Rapoport (2004), é a má distribuição demográfica existente no Brasil, onde 68,5\% da água doce encontra-se na região norte e 31,5\% nas demais regiões, as quais concentram $95 \%$ da população do país.

No Brasil, o problema da escassez não está relacionado somente a má distribuição geográfica, mas também a grande poluição dos mananciais, onde está água é disponibilizada para captação, o grande consumo industrial e agrícola, a impermeabilização do solo pelo crescimento da população urbana, e para agravar, a prolongada estiagem, que algumas regiões do país vêm enfrentando.

Segundo (EM DISCURSSÃO...,2014. P.8), o país padece, em diversas regiões, de uma preocupante falta de chuva, que colocou boa parte dele em risco real e imediato de racionamento. Faltar água nas áreas semiáridas do Nordeste já é fenômeno secular, a região viveu sua pior seca em 50 anos, entre 2012 e 2013, afetando quase 10 milhões de pessoas e mais de 1.200 municípios. Com a mais baixa precipitação pluviométrica em décadas na Região Sudeste como um todo, não só o desabastecimento de água virou ameaça na maior cidade do país, São Paulo, como também o temor de crise elétrica.

Tundisi (2003) faz um apanhado geral da atual situação da escassez de água que cada região brasileira vem atravessando.

- Região Norte: é a mais abundante em disponibilidade hídrica, principalmente levando em conta a baixa densidade demográfica, entretanto, as condições sanitárias (drenagem de esgoto e tratamento de água) são precárias agravando o problema da saúde humana; 


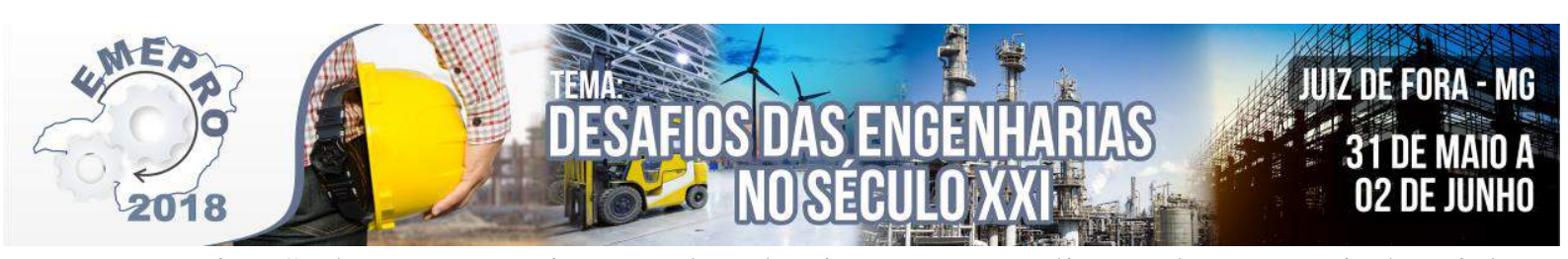

- Região Sudeste: o crescimento da urbanização, a ampliação do parque industrial e a intensificação das atividades agrícolas, além do crescimento populacional e da diversificação dos múltiplos usos, sem contar longos períodos de estiagem, tornaram a água um bem cada vez mais escasso;

- Região Sul: o problema também está relacionado com a diminuição de água por habitante, o aumento das atividades agrícolas e industriais, o aumento do custo de tratamento e a diversidade dos usos múltiplos;

- Região Nordeste: a escassez, a contaminação por doenças tropicais de veiculação hídrica e a falta de saneamento. Deve ser acrescido de que as águas disponíveis na superfície e no aquífero podem ser salobras, o que causa diminuição no potencial de uso;

- Região Centro Oeste: tem uma área de alta biodiversidade, única no mundo, o pantanal mato-grossense, altamente ameaçado no ponto de vista ecológico, quantitativo e qualitativo pela diversificação dos impactos (desmatamento, criação de gado, hidrovias e excesso de atividades turística).

"O que falta no Brasil não é água, mas determinado padrão cultural que agregue ética e um melhor empenho dos governantes, da sociedade como um estado, das ações públicas e privadas, promotoras do desenvolvimento econômico em geral e da água doce em particular" (TELLES e COSTA, 2010, P.79). Os autores seguem dizendo que é necessário:

- Que os poderes públicos, em geral, realizem os investimentos necessários para um eficiente gerenciamento, controle e fiscalização das condições de uso, e proteção dos recursos hídricos;

- Que as empresas de saneamento básico, forneçam com eficiência, a água de qualidade garantida, coletando e tratando o esgoto;

- Que a sociedade por sua vez, reveja sua atitude de descaso em relação ao abuso e desperdício, como se a água fosse um recurso ilimitado, de propriedade particular e individual.

Enquanto isso, mais de 40 milhões de brasileiros não recebem água de forma regular, não podem confiar na qualidade da mesma que chega nas suas torneiras e vivem num penoso regime de rodízio ou de fornecimento muito irregular da água" (REBOLÇAS, 2003, p.342).

\subsection{Economizar para não faltar}

Um dos grandes problemas enfrentados referente ao uso domiciliar da água está relacionado ao desperdício, é preciso que todos tomem consciência do grande caos que as gerações futuras, até mesmo as atuais, enfrentarão diante à escassez de água.

Os autores, Fernandes e Fiori e Pizzo (2004), mencionam que impera no Brasil uma cultura de desperdício em relação à água que precisa ser alterada. Eles seguem dizendo, que desperdício, é deixar a água potável escoar pelo "ralo", sem que seja utilizada. Como exemplo, citam que um vazamento que enche uma xícara de $125 \mathrm{ml}$ em 10 minutos, desperdiçará 6.750 litros de água por ano. Isso equivale a beber 90 copos de água de $200 \mathrm{ml}$, por dia, durante um ano. Seguem dizendo que $20 \%$ dos vasos sanitários das casas norteamericanas têm vazamento atualmente, e no Brasil, esse número se eleva para 70\%. Em geral, os usuários nem sabem disso. Em um ano, um vazamento sanitário é capaz de desperdiçar mais de 83 mil litros de água, o que é suficiente para se tomar quatro banhos por dia, durante 


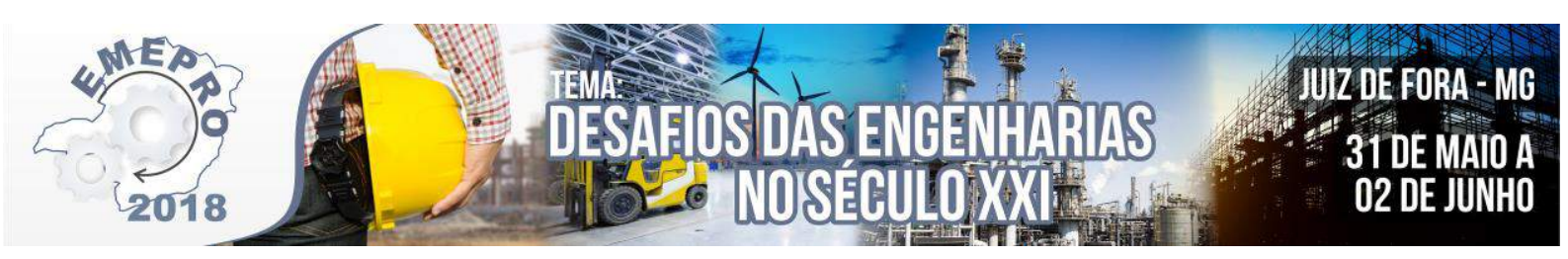

um ano.

Para restabelecer o equilíbrio entre oferta e demanda de água, garantir a sustentabilidade do desenvolvimento econômico e social é necessário que métodos e sistemas alternativos modernos sejam desenvolvidos e aplicados em função de características de sistemas e centros de produção específicos. Nesse sentido, reuso, reciclagem, gestão da demanda, redução de perdas e minimização da geração de efluentes se constituem, em associação às práticas conservacionistas, as palavras-chaves mais importantes em termos de gestão de recursos hídricos e de redução da poluição (FIESP, 2005).

Bazarella (2005), refere-se à "Conservação de água" como sendo um conjunto de ações que propiciam a economia da mesma, seja nos mananciais, no sistema público de abastecimento ou nas habitações. Restringindo-se ao cenário das habitações, de acordo com o Manual de Conservação e Reuso de Água em Edificações, elaborado pela FIESP (2005), a conservação dela pode ser definida como qualquer ação que reduza a quantidade extraída em fontes de suprimento, diminua o consumo, elimina o desperdício de água, aumente a eficiência do uso da mesma ou aumente a reciclagem e o seu reuso.

“Juntamente com a preservação do meio ambiente sob todos os seus aspectos, a necessidade de economizar água vem sendo apontada como alternativa para se contornar o problema da escassez" (RAPOPORT, 2004, P.12).

\subsection{Reuso de água}

Com o aumento da escassez de água potável, se faz necessário a busca por fontes alternativas para a manutenção da vida, da economia e do ecossistema do planeta. Um dos meios que vem se difundindo e chamando a atenção de vários pesquisadores, é o reuso da água. Segundo Silveira (2008), a água reaproveitada pode ser utilizada na recarga do lençol freático, na geração de energia elétrica na reabilitação de corpos d'água nas indústrias, na refrigeração de equipamentos, lavagem de ruas e feiras livres, em limpeza de monumentos, sistemas de controle de incêndio, limpeza de banheiros e pátios, descargas sanitárias, fontes luminosas, etc. Em vários países do mundo o reuso planejado da água já é uma solução adotada com sucesso em diversos processos.

Segundo Santos (2008), a escolha de fontes alternativas de abastecimento de água e o seu reuso é um caminho inteligente para combater a escassez do produto. A reutilização ou reuso da água, bem como o uso de águas residuais, não é um conceito novo e tem sido praticado de várias formas, há muitos anos. Existe, por exemplo, relatos de sua prática na Grécia Antiga, China, e América Andina. A demanda crescente, atualmente, por água e a escassez de recursos hídricos têm feito do reuso planejado da água um tema atual e de grande importância.

A grande vantagem da utilização da água de reuso é a preservação da água potável, reservando-a, exclusivamente, para o atendimento das necessidades que exijam a sua potabilidade para o abastecimento humano. Além disso, há diminuição da demanda sob os mananciais de água pura devido à substituição da fonte, ou seja, substituição de uma água de boa qualidade por outra inferior, porém, que contenha qualidade requerida para o destino traçado para ela (FIORI, FERNANDES e PIZZO, .2004).

"Em um futuro próximo, serão imprescindíveis novos projetos, elaborados e administrados na perspectiva da sustentabilidade econômica, social e ambiental, para atender a demanda de água, buscando novas fontes que propiciem seu uso mais eficiente" (TELLES e 


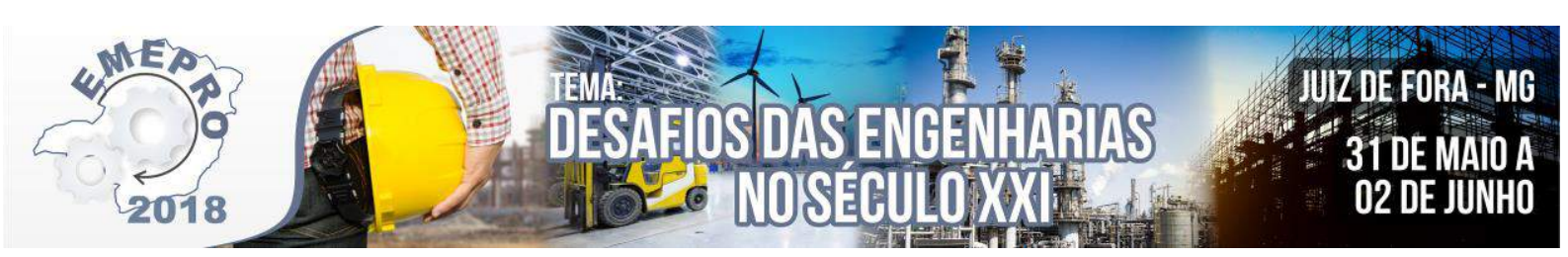

COSTA 2010, P. 155).

Santos (2008), define o reuso de água pela utilização da mesma, por duas ou mais vezes, após tratada ou não. É usada com diferentes propósitos, como por exemplo, minimizar os impactos causados pelo lançamento de esgotos sem tratamento nos mananciais, a fim de se preservar os recursos hídricos existentes e garantir a sustentabilidade, a exemplo do que é feito pela natureza através do ciclo hidrológico. Em vários países do mundo, o reuso planejado da água já é uma solução adotada com sucesso em diversos processos. Neste sentido, deve-se considerar o reuso como parte de uma atividade mais abrangente, o qual compreende também o controle de perdas e desperdícios, a minimização da produção de efluentes e do consumo de água. O autor segue dizendo, que a racionalização do uso aliada ao reuso geram um instrumento de gestão ambiental dos recursos hídricos. Com a sua utilização o Brasil estará apto ao enfrentamento sustentável da escassez iminente.

Entretanto, qualquer técnica aplicada, estará sujeita à relação custo-benefício. Embora, as necessidades de preservação ambiental ultrapassem este conceito, ratifica a vivência sustentável como o único caminho de sobrevivência e desenvolvimento humano, ou seja, de uma forma ou de outra o próprio meio ambiente se manifestará. A conscientização ocorre em escalas múltiplas, mas ainda é tímida e limitada a contextos culturais e econômicos. O reuso, embora reconhecido como uma das opções mais inteligentes para a racionalização dos recursos hídricos, não foge à regra, depende da aceitação popular, aprovação mercadológica e vontade política para se firmar como tecnologia eficiente (TELLES e COSTA, 2010).

\subsubsection{Tipos de reuso}

Segundo Telles e Costa (2010), para que se entenda as diversas formas de reuso devese lembrar que a capitação de uma estação de tratamento de esgoto, na maioria das vezes, é feita em mananciais. Quando esta água é reutilizada, consideram-se algumas de suas aplicações como reuso, mesmo de forma direta ou indireta, decorrentes de ações planejadas ou não:

- Reuso indireto não planejado da água: é quando o esgoto é lançado em um corpo hídrico (após ser tratado ou não), onde ocorre sua diluição, podendo ser reaproveitado em sua jusante de maneira não intencional e não planejada;

- Reuso indireto planejado da água: ocorre quando o esgoto tratado é lançado de forma planejada nos corpos de água superficiais ou subterrâneos para serem utilizados, de maneira controlada, no atendimento de algum benefício;

- Reuso direto planejado da água: ocorre quando o esgoto, depois de tratado, é encaminhado, diretamente, até o local de reuso, não sendo descarregados no meio ambiente;

- Reciclagem da água: é o reuso interno da água antes de sofrer algum tipo de tratamento ou ser descartada, funciona como fonte suplementar de abastecimento e é um caso particular do reuso direto planejado.

Já Bazarella (2005), classifica-o como reuso potável e não potável, como forma de simplificar a classificação, Bazarella ainda diz, que o reuso potável divide-se em direto e indireto. O reuso potável direto ocorre quando o esgoto é recuperado por meio de tratamento avançado e reutilizado, diretamente, no sistema como água potável, já o indireto ocorre quando o esgoto, após o tratamento, é disposto nas coleções de águas superficiais ou subterrâneas para diluição, purificação natural e subsequente captação, tratamento e 


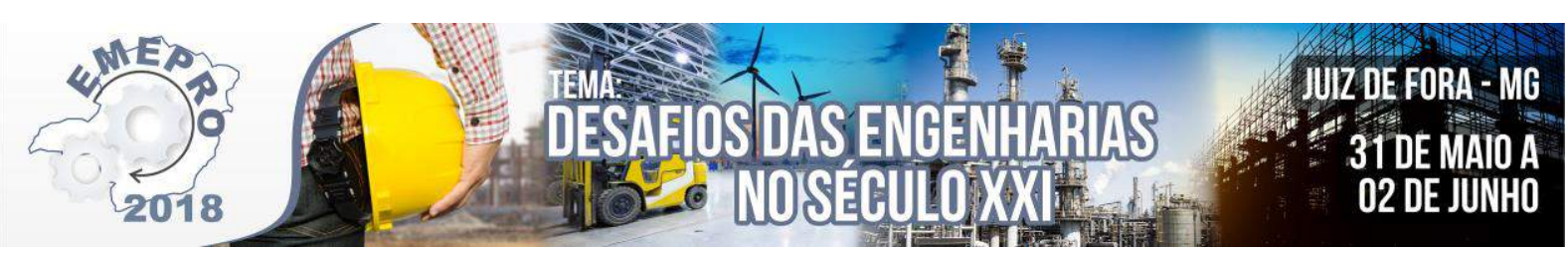

finalmente utilizado como água potável. O reuso não potável é quando a água, após sua utilização, passa por algum tipo de tratamento e assume características de água de reuso para fins não potáveis, sendo utilizada para uso múltiplos, como por exemplo: fins agrícolas, industriais, domésticos, recreativos, manutenção de vazões, agricultura e recarga de aquíferos subterrâneos.

Para o reuso não potável o manual da FIESP (2005), sobre conservação e reuso de água em edificações, separa a água de reuso em classes de acordo com a qualidade exigida para cada fim, que são:

- Água de reuso classe 1: os principais usos para as águas tratadas desta classe, nos edifícios, são, descarga de bacias sanitárias, lavagem de pisos e fins ornamentais (chafarizes, espelhos de água etc.), lavagem de roupas e de veículos. Apesar desta aplicação incorporar diversas atividades, todas convergem para a mesma condição de restrição que é a preocupação com a saúde do usuário. Outro fator de grande importância, relativo aos usos benéficos em consideração, diz respeito aos aspectos estéticos da água de reuso. Neste caso, ele está vinculado ao "adorno arquitetônico", exigindo grau de transparência, ausência de odor, cor, escuma ou quaisquer formas de substâncias ou componentes flutuantes;

- Água de reuso classe 2: os usos preponderantes nessa classe são associados às fases da construção civil como, lavagem de agregados, preparação de concreto, compactação do solo e controle de poeira;

- Água de reuso classe 3: o uso preponderante das águas dessa classe é na irrigação de áreas verdes e rega de jardins. Neste caso, a maior preocupação do emprego da água de reuso fica condicionada às concentrações de contaminantes biológicos e químicos, incidindo sobre o meio ambiente e o homem, particularmente, o operário que exerce suas atividades nesse ambiente. Alguns dos principais problemas relacionados com o gerenciamento da qualidade da água são: salinidade, toxicidade;

- Reuso de água classe 4: o uso preponderante para esta classe é no resfriamento de equipamentos nas indústrias.

Um exemplo do tipo de reuso e sua aplicação é citada por Santos (2008), quando diz que, em uma casa, se direcionar a água servida de lavatórios, chuveiros, tanque, máquinas de lavar roupa, para um tratamento e uma redistribuição para descargas, irrigação de jardins, lavagem de pisos, ou seja, atividades que não demandam água potável, estamos fazendo reuso direto planejado de água. Dentro dessa perspectiva, os esgotos tratados têm um papel fundamental no planejamento e na gestão sustentável dos recursos hídricos, como um substituto para o uso de águas destinadas a fins que podem prescindir desse recurso dentro dos padrões de potabilidade.

\section{Reuso de águas cinzas}

“Água cinza para reuso é o efluente doméstico que não possui contribuição da bacia sanitária e pia de cozinha, ou seja, os efluentes gerados pelo uso de banheiras, chuveiros, lavatórios, máquinas de lavar roupas em residências, escritórios comerciais, escolas, etc" (FIESP, 2005, P. 22).

Segundo Bazarella (2005), o reuso de água cinza enquadra-se no não potável. Ela pode ser utilizada, principalmente, para o reaproveitamento doméstico (rega de jardins residenciais, lavagem de veículos e de áreas impermeáveis, descarga de vasos sanitários) e agrícola. A 


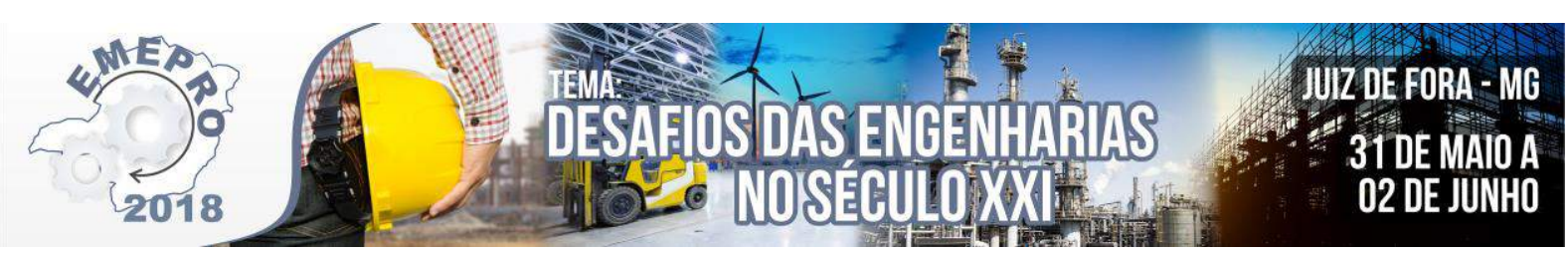

autora segue dizendo, que diferentes tipos de água cinza podem ser adequados para diferentes tipos de reuso e irá requerer diferentes tipos de tratamento, dependendo do reuso que se pretende dar a ela.

Segundo o Programa de Pesquisa em Saneamento Básico PROSAB (2006), que dedica um capítulo sobre o referido assunto, diz que o reuso de águas cinzas pode resultar em economia de água potável, de energia elétrica e menor produção de esgoto sanitário na escala das edificações. Em uma escala maior, resulta em preservação dos corpos d'água, por diminuir a quantidade dela captada e por reduzir o lançamento de esgoto sanitário pelas áreas urbanas, além de minimizar o consumo de energia elétrica. O programa ainda menciona que a água cinza pode ser condicionada até atingir características compatíveis com qualquer tipo de reuso, inclusive potável direto, como no caso da estação espacial internacional.

Não se trata de pensar em curto prazo, mas sim em médio prazo, quando provavelmente, a exemplo do que está acontecendo em outros estados brasileiros, poderá faltar água de qualidade para consumo. Neste sentido, o reuso das águas cinzas, que são as águas provenientes de todas as atividades domésticas com exceção de fontes de águas negras tais como sanitários bidês, urinol e pias de cozinha, vem sendo estudadas com forma de reuso tanto em irrigação como em unidades familiares (RAPOPORT, 2004).

Outro ponto positivo no que diz respeito ao reuso de águas cinza, é referente a economia financeira. Segundo Rapoport (2004), o incentivo a alternativa de reuso das águas cinzas, está no fato de que o sistema típico de tarifação do consumo dela, nas grandes cidades brasileiras, foi multiplicado, na maioria das vezes, por dois, uma vez que o esgoto é tarifado na mesma conta. Desta forma, ao se reaproveitar um litro de água, além de estarmos reduzindo o consumo, estaremos economizando tarifa equivalente a dois litros na conta e preservando a água de qualidade para fins nobres.

\subsection{Qualidade e restrições}

A água cinza contém componentes decorrentes do uso de sabão ou de outros produtos para lavagem do corpo, de roupas ou de limpeza em geral. Suas características em termos de quantidade e de composição, variam de acordo com os seguintes fatores: localização, nível de ocupação da residência, faixa etária, estilo de vida, classe social, costumes dos moradores e com o tipo de fonte de água cinza que está sendo utilizado (lavatório, chuveiro, máquina de lavar etc.) (SANTOS 2008).

Segundo o manual da (FIESP, 2005, P 50), "utilizar água não proveniente da concessionária traz o ônus de alguém se tornar "produtor de água" e, portanto, responsável pela gestão qualitativa e quantitativa deste insumo". No entanto, cuidados específicos devem ser considerados para que não haja risco de contaminação à pessoas, produtos ou danos a equipamentos. $\mathrm{O}$ mesmo manual dita exigências mínimas para o reuso não potável da água, para diferentes tipos de uso, que são:

- Água para irrigação, rega de jardim, lavagem de pisos: não deve apresentar mau cheiro, conter componentes que agridam as plantas ou que estimulem o crescimento de pragas, não ser abrasiva, manchar superfícies, propiciar infecções, contaminação por vírus ou bactérias prejudiciais à saúde humana;

- Água para descarga em bacias sanitárias: não deve apresentar mau cheiro, ou ser abrasiva, não manchar superfícies, não deteriorar os metais sanitários, não propiciar infecções ou a contaminação por vírus ou bactérias prejudiciais à saúde humana; 


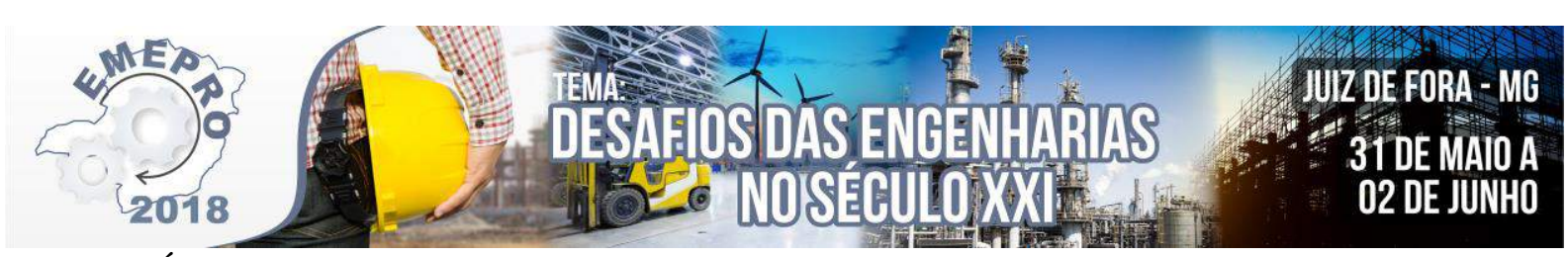

- Água para lavagem de veículos: não deve apresentar mau cheiro ou ser abrasiva, manchar superfícies, conter sais ou substâncias remanescentes após secagem, propiciar infecções ou a contaminação por vírus ou bactérias prejudiciais à saúde humana;

- Água para lavagem de roupa: deve ser incolor, não deve ser turva, não apresentar mau cheiro, deve ser livre de algas e de partículas sólidas, ser livre de metais, não deteriorar os metais sanitários e equipamentos, não propiciar infecções ou a contaminação por vírus ou bactérias prejudiciais à saúde humana;

- Água para uso ornamental: deve ser incolor, não deve ser turva, ou apresentar mau cheiro, não deteriorar os metais sanitários e equipamentos, não propiciar infecções ou a contaminação por vírus ou bactérias prejudiciais à saúde humana.

Segundo o Manual de Conservação e Reutilização de Água da FISP (2005), o reuso de águas cinza para fins domésticos, como lavagem de carros e pisos, rega de jardins, lavagem de roupas e descargas sanitárias, se enquadra no reuso de água classe 1.

\subsection{Tratamento}

Segundo a PROSAB (2006), estudos realizados no Brasil e no exterior indicam que as águas cinzas contêm elevados teores de matéria orgânica, de sulfatos, além de turbidez e de moderada contaminação fecal, também presença de compostos orgânicos rapidamente biodegradáveis na sua constituição. Por tais motivos, seu reuso direto nas edificações (em estado bruto) não é recomendável, tendo em vista, sobretudo, o aspecto desagradável e à possibilidade de produção de mau cheiro nas instalações sanitárias. Para a obtenção de água de reuso com baixa turbidez, inodora e isenta de microrganismos patogênicos, um tratamento a nível secundário que promova a bio-degradação das matérias orgânicas, seguido de desinfecção.

Segundo o manual da FIESP (2005), o reaproveitamento de águas cinzas, classe 1, deve garantir ao usuário, além de nenhum risco à saúde, "adornos arquitetônico", como ausência de cor, espuma, mau cheiro, ou materiais suspensos. Para isso, recomenda que uma associação de etapas de tratamento de água cinza seja utilizada:

- Sistema aeróbio de tratamento biológico lodos ativados;

- Sistema físico: sedimentação e filtração simples através de decantado e filtro de areia;

- Desinfecção;

- Correção de PH, se necessário.

Basicamente, o sistema de tratamento consiste no direcionamento das águas cinzas para o tratamento biológico, para que ocorra a degradação do material orgânico, gerados pela utilização do chuveiro, pias e máquinas de lavar, em seguida, passa para o reservatório de decantação secundário onde a sedimentação ocorre em forma de lodo, decorrente do material orgânico já degradado, após isso, passa pelo sistema de filtragem para retirada de materiais sólidos ainda dispersos, em seguida, segue para desinfecção por adição de cloro (SELLA, 2011).

Rapoport (2004) sugere um tipo de tratamento menos rigoroso seguido de uma filtragem grosseira e desinfecção. Segundo a autora, é o sistema mais empregado para reuso doméstico. O processo consiste basicamente em um curto tempo de retenção das águas cinzas, 


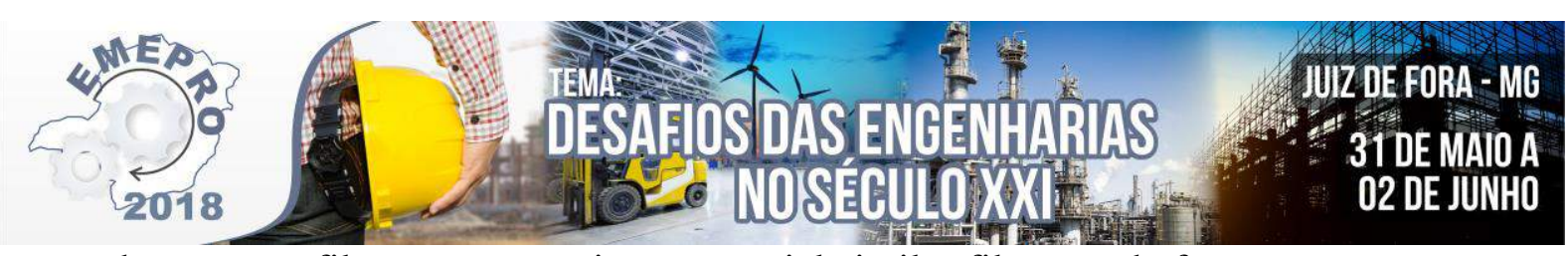

passando por uma filtragem em areia ou material similar filtrante, de forma que sua natureza química permaneça inalterada e um mínimo tratamento seja necessário. Embora haja pouca remoção de contaminantes químicos e biológicos, a água tratada segue livre de organismos nocivos, tornando-a, potencialmente, segura para reuso, porém, podem ocorrer problemas com o processo de desinfecção. A água permanece com carga orgânica alta e turbidez, podendo limitar o poder desinfetante do produto utilizado.

A PROSAB (2006), propõe um tratamento simples para uso residencial, composto basicamente, por uma filtragem realiza com brita em uma caixa de polietileno, onde a água cinza é depositada de forma regular sobre a superfície e, posteriormente, retirada através de uma tubulação situada no fundo da caixa filtrante, seguindo para desinfecção por adição de cloro, depois é bombeada para o reservatório superior, para então ser distribuída nos sistemas de reuso.

\subsection{Instalações}

Segundo Santos (2008), a infraestrutura necessária para a implantação de um sistema de reuso inclui uma rede dupla de abastecimento, necessária para transportar a água, potável e a de reuso, e uma coleta separada da água cinza, incluindo as unidades complementares de bombeamento e reserva da água de reuso. Edificações que comportam sistemas de reuso de água cinza, devem ser projetadas e executadas com sistemas hidráulicos prediais independentes, sendo um para água de reuso e outro para água potável, de preferência com cores distintas. $\mathrm{O}$ autor segue dizendo, que a configuração básica de um sistema de reuso de águas cinzas seria o de coleta da mesma servida, do subsistema de condução da água (ramais, tubos de queda e condutores), para a unidade de tratamento da água (por exemplo, gradeamento, decantação, filttro e desinfecção) e do reservatório de acumulação. É necessário ainda um sistema de recalque, um reservatório superior e a rede de distribuição da água reutilizada, totalmente isolada da distribuição de água potável. É recomendável que as válvulas e os registros de cada rede possuam abertura e fechamento diferenciados. No caso de falta de água de reuso, os sistemas devem ser abastecidos com água potável.

Segundo Rapoport (2004), o armazenamento de água cinza também deve ser considerado para que haja um balanceamento entre oferta e demanda, uma vez que estas não são utilizadas ao mesmo tempo em que são geradas. Este tempo de retenção afeta a qualidade do produto. Sendo assim, os tanques de armazenamento devem ser projetados de forma ideal, uma vez que, as águas cinzas não devem ficar armazenadas por tempo superior a $48 \mathrm{~h}$, porque fatalmente vão gerar odores desagradáveis.

"A implantação de rede dupla de distribuição nas residências e condomínios deve ser proposta para novos empreendimentos, pois, a implantação em empreendimentos já existentes, pode ser de difícil solução e tornar a obra bastante onerosa" (RAPOPORT, 2004, P.67).

\subsection{Avaliação financeira}

Segundo Rapoport (2004), à economia a ser realizada com o reuso das águas cinzas, provenientes de pias de banheiros e chuveiros e máquinas de lavar, em descargas sanitárias e levando-se em consideração que estudos preliminares indicam que, aproximadamente, 29\% das águas utilizadas em uma residência são direcionadas a descargas sanitárias e que as águas geradas em chuveiros e pias correspondem a 34\%, foi feito o cálculo em reais dos valores cobrados por $\mathrm{m}^{3}$ utilizado somado ao esgoto sanitário. Foi então calculado o consumo de água na residência, menos $29 \%$ que seriam reusados nas descargas sanitárias e, consequentemente, 


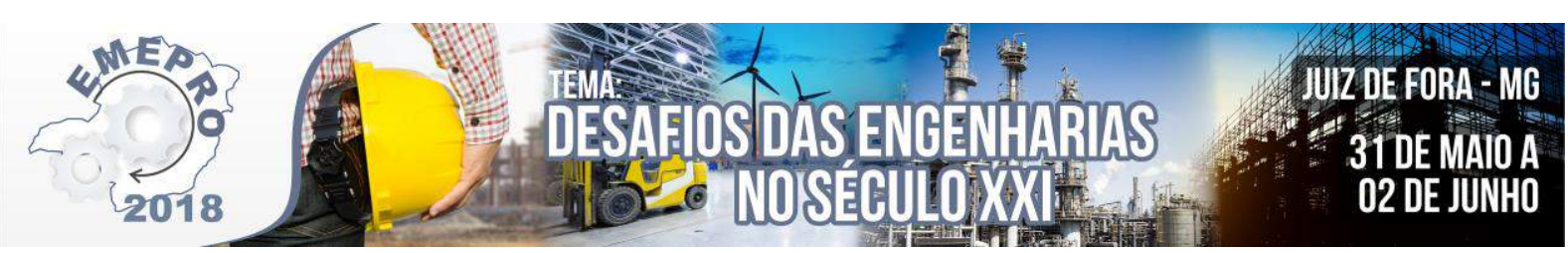

seriam excluídos da captação seguinte. Posteriormente, avaliou-se a economia gerada em reais com a redução dos volumes de água utilizados e o quanto estes valores representam em percentual na economia gerada. A autora conclui que para consumos mínimos de água até 15 $\mathrm{m}^{3}$ não há redução dos valores a serem pagos. A partir de $20 \mathrm{~m}^{3}$, observa-se que a economia mensal realizada começa a ser representativa até alcançar o máximo em $63 \mathrm{~m}^{3}$. Neste ponto, o reuso das águas cinzas significará que apenas $44,73 \mathrm{~m}^{3}$ serão provenientes da concessionária. O valor correspondente a este consumo será duplicado por dois devido ao esgotamento sanitário. A economia mensal corresponderá a $61 \%$. A partir desta informação, a análise de custo benefício poderá direcionar a escolha do método de tratamento mais adequado

Pelo exposto fica evidente, que quanto mais água potável se consome, maior será a economia, com a utilização do reuso de águas cinzas, entretanto, os gastos referentes a implantação do sistema de reuso são relativamente altos e demandam um tempo de retorno entre 9 a 12 anos para o investimento empregado, conforme a literatura utilizada nesta pesquisa. No entanto, a ideia principal da pesquisa não seja exclusivamente a economia financeira, mas também para a gestão dos recursos hídricos, que se encontram em eminência de escassez, tornando desta forma, o reuso de águas cinzas viáveis, tanto do ponto de vista econômico e sustentável, garantindo para gerações futuras a preservação deste recurso indispensável para o ser humano e de toda vida existente no planeta.

\section{Conclusão}

Diante do exposto, fica claro que a grave crise hídrica que enfrentamos é gerada pela poluição ambiental, crescimento desordenado e cada vez maior da população urbana, aumento do uso na agricultura e indústrias, e ao aquecimento global. De uma forma ou de outra, a natureza se manifestará, visto que o problema da falta de água já não é mais exclusivo da região nordeste do país. Cabe a população se concientizar que a água aparentemente abundate, é um recurso finito, que necessita ser economizado e gerido de forma consciente e responsável.

O reúso da água cinza, como qualquer outro tipo planejado, é uma das formas sustentáveis sugeridas mais inteligente no que diz respeito a preservação dos recursos hídricos, pois além de economizar as águas retiradas dos mananciais, devolve-se menos poluição a jusante e, consequentemente, menos degradação ao meio ambiente. As várias formas de tratamento para as águas cinzas, são eficazes no que diz respeito a remoção de organismos nocivos a saúde e ao bem-estar do usuário, tornando esta água não potável mais bem aceita para os fins a que se destina.

Ainda existe uma certa dificuldade na aceitação mercadológica do sistema de reúso de águas cinzas no Brasil, por se tratar de uma técnica pouco difundida na sociedade e pouco incentivada pelo governo. Cabe a população pensar, não só em uma solução para fins econômicos, mas também, uma forma de controlar a escassez do produto e garantir que as futuras gerações possam consumir água de forma satisfatória.

\section{Referências}

ASSOCIAÇÃO BRASILEIRA DE NORMAS TÉCNICAS. NBR 13969. Tanques sépticos - unidades de tratamento complementar e disposição final dos efluentes líquidos - Projeto, construção e operação. Rio de Janeiro, 1997.

Bazzarella, B. B. Caracterização e aproveitamento de água cinza para uso não-potável em edificações. 2005.165 f. Dissertação (Mestre em Engenharia Ambiental) - Universidade Federal do Espirito Santo, Vitória, 2005.

Bernado, Luiz Di. Tratamento de água: métodos e técnicas. 2 ed. São Carlos: Rima, 2005. 792 p.v. 2. 


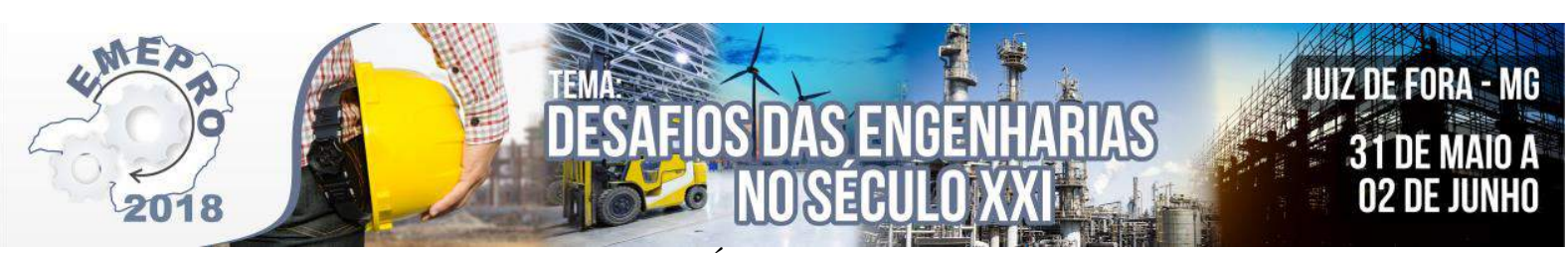

Bicudo, C.E.de M.; Tundisi, J.G.; Sche uenstuhl, Águas do Brasil: Analise estrategica. São Paulo: Instituto de Botânica, 2010. 224p.

Carvalho, Nathalia Leal et al. Reutilização de águas residuárias. Monografias Ambientais - REMOA, Santa Maria, V. 14, N. 2, p. 3164 - 3171, março, 2014. Disponível em: < https://periodicos.ufsm.br/remoa/article/download/12585/pdf>. Acesso em: 20 Out. 2017.

Ciciliato, R. C. Tratamento de águas cinzas sintética para fins de reúso através de método eletroquímico. 2013. 61 f. Dissertação (Engenheiro Ambiental) - Universidade Tecnológica Federal do Paraná, Londrina, 2013.

Em discursão. A escassez da água: Cada gota é preciosa. Brasilia. Segraf. N.23, Dez. 2014.

FIESP. Conservação e reúso de água em edificações. São Paulo, Prol editora e gráfica, 2005. 151 p. Fiori, S. Fernandes, V. M. C. Pizzo, H. Avaliação qualitativa e quantitativa do reúso de águas cinzas em edificações. Ambiente Construido. Porto Alegre, v. 6, n. 1, p 19-30, jan./mar. 2006.

Fiori, Simone et al. Avaliação qualitativa e quantitativa do reúso de águas cinzas em edificações. Revista Ambiente Construido, v. 6, n. 1, p. 19-30, jan./mar. 2006. Disponível em: <http://www.seer.ufrgs.br/ambienteconstruido/article/viewFile/3676/2042..>. Acesso em: 28 out. 2017.

May, S. Caracterização, tratamento e reúso de águas cinzas e aproveitamento de águas pluviais em edificações. 2009. 200f. Tese (Doutorado em Engenharia) - Escola Politécnica, Universidade de São Paulo, São Paulo, 2009.

Monteiro, R. C. M. iabilidade técnica do emprego de sistemas tipo "etlandas" para tratamento de águas cinzas visando o reúso não potável. 2009. 84 f. Tese (Mestre em Engenharia Civil) - Escola Politécnica, Universidade de São Paulo, São Paulo, 2009.

Philippi Jr, Arlindo. Saneamento, saúde e ambiente: fundamentos para um desenvolvimento sustentável. São paulo: Manoele, 2005. 842 p.

Programa de Pesquisa em Saneamento Básico (PROSAB). Tecnologias de Segregação eTratamento de Esgotos Domésticos na Origem Visando a Redução do Consumo de Água e da Infra-Estrutura de Coleta, Especialmente nas Periferias Urbanas. Urbanas. Rio de Janeiro : ABES, 2006, 352 p.

Rapoport, B. Águas cinzas: caracterização, avaliação finaceira e tratamento para reúso domiciliar e condominial. 2004. 72 f. Dissertação (Mestrado) - Escola Nacional de Saúde Publica, Fundação Osvaldo Cruz, Rio de Janeiro, 2004.

Rebolças, Aldo da C. Água no Brasil, abundância, desperdício e escassez. Bahia análise e dados. Salvador, v13, n. espescial, p. 341-345, maio, 2003. Disponível em: <http://files.geografia24horas.webnode.com.br/2000000680276f03713/Agua\%20I.pdf>. Acesso em: 02 nov. 2017.

Santos, W. P. Avaliação da viabilidade econômica do reúso de águas cinzas em edificações domiciliares. 2008. 63 f. Dissertação (Engenheiro Civil) - Universidade Estadual de Feira de Santana, Feira de Santana, 2008)

Schroeder, A. K. Eestudo comparativo de viabilidade econômica do aproveitamento de água pluvial e reúso de água cinzaa em uma residência. 2016, 107 f . Disseratação ( Engenheiro Sanitário e Ambiental) - Univercidade Federal de Santa Catarina, Florianópolis, 2016.

Secretaria Executiva da Rede Nossa Sao Paulo. Programa Cidades Sustentáveis. São paulo: Interfill, 212,32 p.

Sella, M. B. Reúso de águas cinzas avaliação da viabilidadeda implantação do sistema em residéncias. 2011. 85 f. Dissertação (Engenharia Civil) - Universidade Federal do Rio Grande de Sul, Porto Alegre, 2011.

Silveira, B. Q. Reúso da água pluvial em edificações residenciais. 2008. 44 f. Dissertação (Engenharia Civil) Escola de Engenharia, Universidade Federal de Minas Gerais, Belo Horizonte, 2008.

Telles, D. D”Alkmin; Costa, R. P. Reúso da água: conceitos, teorias e préticas.12 ed. São Paulo: Blucher, 2010. $407 \mathrm{p}$.

Tundisi, José galizia. Água no século XXI. Enfrentando a escassez. 1 ed. Rio de Janeiro: Rima, 2003. 248 p. 


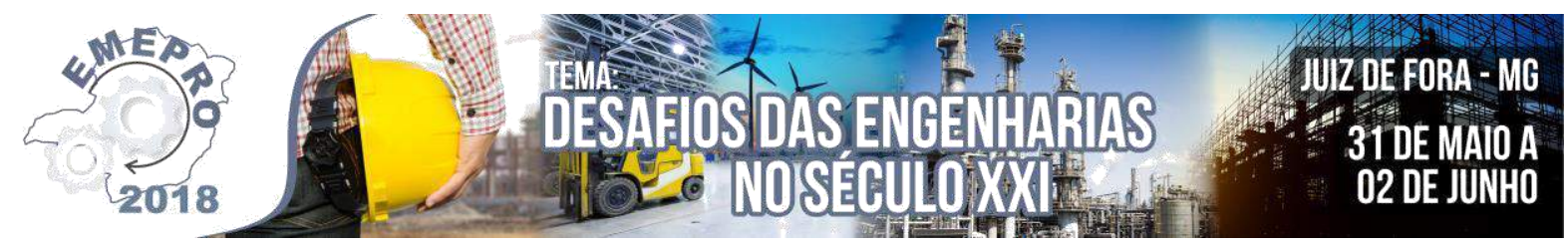

Tecnologia de Bioprocessamento aplicada à Gestão de Resíduos em Agroindústrias: Um Estudo Teórico

\author{
Vitor Hugo dos Santos Filho - Universidade Tecnológica Federal do Paraná - \\ vitorhugosantosfilho@ hotmail.com \\ Vander Luiz da Silva - Universidade Tecnológica Federal do Paraná - vander-luiz@ hotmail.com \\ Maria Helene Canteri - Universidade Tecnológica Federal do Paraná - canteri.mhg@ gmail.com
}

Resumo: Nas indústrias de maneira geral, de modo a minimizar impactos ambientais torna-se fundamental a gestão dos resíduos. Tal prática, além de proporcionar benefícios ao meio ambiente, também pode refletir em ganhos econômicos e sociais. Este estudo teve por objetivo construir um portfólio sistêmico sobre o que tem sido pesquisado e publicado referente ao tema de gestão de resíduos sólidos agroindustriais, a partir de tecnologia bioprocessos. Foram pesquisados em três bases de dados. A busca se fez por meio das bases: Scopus, Science Direct e Web of Science, localizadas no portal de periódicos CAPES. Foram encontrados 57 artigos semelhantes ao tema, contudo, após todas as filtragens, apenas 19 foram considerados aptos para leitura na íntegra. Concluiu-se que a partir dos bioprocessos, uma infinidade de materiais que poderiam ser descartados tornam-se matérias primas para novos produtos.

Palavras-chave: Resíduos Agroindustriais; Bioprocessos; Inovação Agroindustrial.

\title{
1. Introdução
}

Nos primórdios, os seres humanos já produziam resíduos sólidos em atividades básicas para a sobrevivência. Com o decorrer dos anos, infinitas outras atividades surgiram e, consequentemente, a disposição de resíduos no ambiente se intensificou (MATTOS DEUS; BATTISTELLE; SILVA, 2015).

Entre os principais fatores que têm favorecido a crescente geração de resíduos no ambiente estão o crescimento populacional, a urbanização e o desenvolvimento industrial acelerado (MAZZER; CAVALCANTI, 2004; GOUVEIA, 2014). Embora, o modo como esses resíduos são gerenciados também reflete em impactos ambientais e/ou sociais e/ou econômicos.

Segundo o levantamento da Associação Brasileira de Empresas de Limpeza Pública e Resíduos Especiais (ABRELPE, 2016), a produção de resíduos sólidos urbanos (RSU) no Brasil foi de 78,3 milhões de toneladas de lixo em 2016, representando uma redução de $2 \%$ em relação ao ano anterior. No entanto, a disposição final dos RSU e o montante de recursos aplicados aos serviços de limpeza nos municípios apresentaram queda quando comparados ao ano de 2015.

De acordo com Gouveia (2012), a gestão adequada de resíduos é uma importante prática de preservação e conservação do meio ambiente. Neste contexto, para alcance de objetivos sustentáveis, melhora na qualidade de vida das pessoas, e outras vantagens é necessário que indústrias, sociedade e governo cumpram com seus respectivos papéis.

Tratando-se das indústrias de maneira geral, de modo a minimizar impactos ambientais, as mesmas devem incorporar conceitos e práticas sustentáveis nos seus processos, 


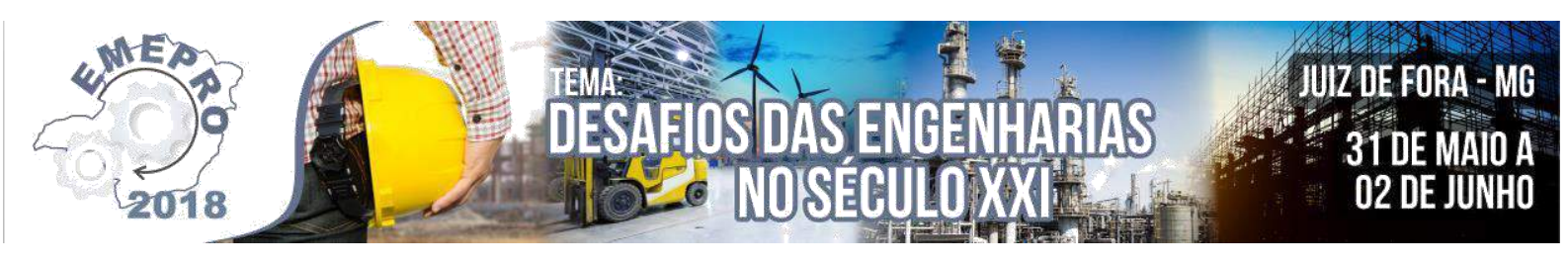

bem como, aplicar princípios e dispor de tecnologias para gestão de resíduos (TOCCHETTO, 2005). Além disso, a gestão adequada de determinados resíduos pode-se representar economicamente viável.

Laufenberg et al. (2003) afirmam que, diariamente são produzidas grandes quantidades de resíduos provenientes dos setores agroindustrial, podendo ser apresentado na forma liquida ou sólida. Atualmente, esses resíduos são transformados em subprodutos por meio da bioconversão de resíduos, diferentemente do que ocorria no passado, cujos resíduos eram descartados em aterros sanitários.

Diante do exposto, este estudo tem por objetivo realizar um levantamento sistêmico bibliográfico referente a gestão de resíduos sólidos agroindustriais a partir de tecnologias de bioprocessos. O estudo justifica na necessidade de se conhecer mais sobre o tema em estudo, suas práticas, a fim de realizar futuras pesquisas práticas sobre bioprocessos de resíduos agroindustriais.

\section{Revisão Teórica}

\subsection{Gestão de Resíduos}

\subsubsection{Política Nacional de Resíduos Sólidos}

A instituição da Política Nacional de Resíduos Sólidos (PNRS), ocorrida pela promulgação da Lei ${ }^{\circ} 12.305$ de 02 de agosto de 2010, impulsionou e deu novos rumos à discussão sobre a temática no Brasil. A lei é bastante atual e contém instrumentos importantes para permitir o avanço necessário ao país no enfrentamento dos principais problemas decorrentes do gerenciamento inadequado dos resíduos sólidos.

Demajorovic e Migliano (2013) afirmam que a PNRS estabeleceu um novo marco regulatório no Brasil, definindo um regime de responsabilidade compartilhada sobre o ciclo de vida dos produtos. A Lei determina planos, programas, prazos e objetivos que obrigam os principais agentes do mercado, governo e indústrias a promoverem uma destinação adequada aos resíduos sólidos gerados pelas indústrias.

A PNRS abrange todos os tipos de resíduos sólidos e define diretrizes, princípios e instrumentos fundamentais ao tema. $\mathrm{Na}$ mesma foi estabelecida a responsabilidade compartilhada na destinação dos resíduos, onde cada integrante da cadeia produtiva e os órgãos governamentais possuem funções específicas no manejo e controle adequado dos resíduos sólidos. Outro importante avanço alcançado com a PNRS é a distinção dos conceitos de gerenciamento e de gestão de resíduos sólidos.

\subsubsection{Classificação dos Resíduos Sólidos}

De acordo com Woiciechowski et al. (2013) o Brasil produz aproximadamente 1 giga toneladas (Gt) de alimentos por ano, sendo representando principalmente pelo setor agrícola. Os alimentos produzidos podem ser divididos em dois tipos sendo: os que são processados como é o caso das frutas e verduras, e aqueles que sofrem separações de frações.

Resíduo sólido pode ser definido como todo material, substância, objeto ou bem descartado resultante de atividades humanas em sociedade, cuja destinação final se procede nos estados sólido ou semissólido, bem como gases contidos em recipientes e líquidos.

A NBR 10.004/04 da ABNT dispõe sobre a classificação dos resíduos sólidos quanto aos seus riscos potenciais ao meio ambiente e à saúde pública para que possam ser gerenciados adequadamente. Assim, os resíduos são classificados em: 


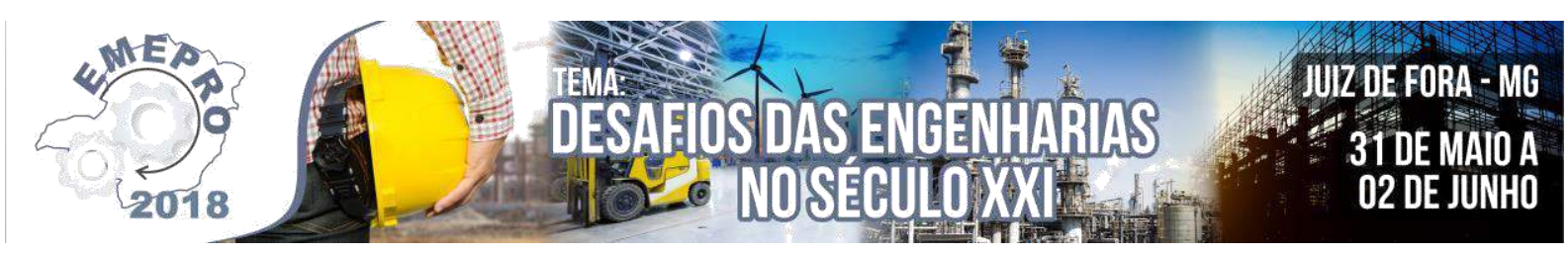

1) Resíduos Classe I - Perigosos: São aqueles que apresentam periculosidade e características como inflamabilidade, corrosividade, reatividade, toxicidade e patogenicidade.

2) Resíduos Classe II: Não Perigosos

A) Resíduos Classe II A - Não Inertes: São aqueles que não se enquadram nas classificações de resíduos classe I - Perigosos ou de resíduos classe II B Inertes. Estes podem apresentar propriedades como biodegradabilidade, combustibilidade ou solubilidade em água;

B) Resíduos Classe II B - Inertes: São quaisquer resíduos que, quando amostrados de uma forma representativa e submetidos a um contato dinâmico e estático com água destilada ou deionizada, não tiverem nenhum de seus constituintes solubilizados a concentrações superiores aos padrões de potabilidade de água, excetuando-se aspecto, cor, turbidez, dureza e sabor.

Os resíduos agroindustriais estão inseridos na classe II B - Inertes. De acordo com Sistema Nacional de Informações sobre a Gestão dos Resíduos Sólidos (SINIR, 2017), os resíduos sólidos também podem ser classificados quanto á sua origem, sendo:

(i) resíduos domiciliares, originados das atividades domésticas em residências urbanas;

(ii) resíduos de limpeza urbana, originados da limpeza de ruas e vias públicas na área urbana;

(iii) resíduos sólidos urbanos incluem as alíneas "i e ii"; (iv) resíduos de estabelecimentos comerciais e prestadores de serviços incluem as alíneas "ii, v, vii, viii, e x"; (v) resíduos dos serviços públicos de saneamento básico incluí a alínea "iii"; (vi) resíduos industriais originados nos processos produtivos e instalações industriais; (vii) resíduos de serviços de saúde gerados nos serviços de saúde conforme definido em regulamentos ou em normas estabelecidas pelos órgãos do Sisnama e do SNVS; (viii) resíduos da construção civil são aqueles gerados nas construções, reformas, reparos e demolições de obras de construção civil;

(ix) resíduos agrossilvopastoris gerados nas atividades agropecuárias e silviculturais; (x) resíduos de serviços de transportes são aqueles gerados em portos, aeroportos, terminais alfandegários, rodoviários e ferroviários e (xi) resíduos de mineração são aqueles gerados na atividade de extração ou beneficiamento de minérios.

\subsection{Resíduos Agroindustriais}

De acordo com Silva (2016), o resíduo agroindustrial ou industrial é um dos principais responsáveis pelas agressões ao meio ambiente. A agroindústria é responsável pela emissão de produtos químicos, solventes químicos e metais que ameaçam constantemente os ciclos naturais onde são depositados.

Olivier (2011) menciona que os resíduos agroindustriais possuem forma sólida e líquida e que são gerados no processamento de alimentos, fibras, couro, madeira, fabricação de açúcar, entre outros infinitos produtos, sendo que sua produção ocorre de forma sazonal, o que se torna ainda mais agravante a disposição incorreta desses no ambiente.

Gerber (1999) define resíduo industrial como aquele produzido por meio de atividades dos mais diversos setores industriais (metalúrgica, química, petroquímica, papeleira, alimentícia, entre outros), sendo bastante variado, e pode ser representando nas mais diversas formas como cinzas, lodos, óleos, resíduos alcalinos ou ácidos, plásticos, papel, madeira, fibras, borracha, metal escórias, vidros e cerâmicas. É importante ressaltar que na grande maioria, estes resíduos são considerados tóxicos ao meio ambiente.

Os resíduos agroindustriais são compostos principalmente de polissacarídeos complexos que fortalecem o crescimento microbiano para a produção de enzimas de 
importância industrial (AHMED et al., 2016). Recentemente, estes resíduos atraíram uma grande atenção como novas potenciais fontes de alternativas verdes, como exemplo a biotransformação para combustíveis e outros produtos (GONZALES et al., 2011). El-Naggar et al. (2014) afirmam que o uso de resíduos agroindustriais de baixo custo para a produção de enzimas industriais é uma das maneiras de reduzir significativamente os custos de produção e impactos ambientais.

\subsection{Bioprocessos}

Os sistemas biotecnológicos são complexos e necessitam ser coordenados e monitorados, uma vez que envolvem elementos de caráter biológico, como células e enzimas, que são influenciados por fatores físicos e químicos (SCHEPER et al., 1996; RAMKRISHN; SONG, 2016).

Com a evolução da biotecnologia e o avanço de pesquisas nesta área, múltiplas abordagens e aplicações de processos são desenvolvidos nas agroindústrias (WANG et al., 2009). Uma das aplicações é o emprego de tecnologia de bioprocessos na gestão de resíduos agroindustriais, originando moléculas de alto valor agregado como proteínas, ácidos orgânicos, etanol, enzimas, entre outros (ALEXANDRINO et al., 2007).

Nas agroindústrias, a biotecnologia apresenta ampla aplicação seja no campo de biocombustíveis, ou de produtos químicos e alimentícios, rações para animais, entre outros (FARINAS et al., 2008). De acordo com Alexandrino et al. (2007), o uso de resíduos agroindustriais como substratos em bioprocessos resultam em benefícios ao meio ambiente, como consequência da redução de acúmulo de resíduos, bem como, vantagens econômicas obtidas nas indústrias, a partir da produção e comercialização novos produtos e subprodutos.

Os resíduos agroindustriais podem ser gerados durante o processamento de produtos agrícolas ou de origem animal, sob forma de palha, caule, casca, pele, popa, e assim por diante (PANESAR et al., 2016). No Brasil, alguns tipos de resíduos agroindustriais são abundantes, como bagaço de cana de açúcar, bagaço de laranja, casca de arroz, farelo de soja, e muitos outros, o que viabiliza os usos desses para outros fins a partir de bioprocessos (FARINAS et al., 2008).

\section{Metodologia de Pesquisa}

Para realização do estudo, foi elaborada uma revisão sistemática de literatura. Foram adaptadas as etapas do Methodi Ordinatio, proposto por Pagani, Kovaleski e Resende (2015), que consiste em: i) Selecionar bases de dados bibliográficos; ii) Estabelecer palavras-chave e combinações de palavras-chave; iii) Definir critérios de buscas nas bases de dados; iv) Executar as buscas nas bases de dados; v) Definir e aplicar critérios de filtragem; vi) Qualificar artigos a partir do cálculo e análise de valores de InOrdinatio conforme o Método, e; vii) Analisar os artigos selecionados. Primeiramente, foram selecionadas bases de dados, realizadas combinações de palavras-chave e estabelecidos procedimentos de buscas, conforme apresentados no Quadro 1.

\begin{tabular}{c|c|c|c|}
\hline Palavras-chave & $\begin{array}{c}\text { Science } \\
\text { Direct }\end{array}$ & Scopus & Web of Science \\
\hline $\begin{array}{c}\text { Agro-industrial waste AND } \\
\text { "Bioprocessing" }\end{array}$ & \multirow{2}{*}{ i) Keywords in: All Fields (Agro-industrial waste/residue) } \\
\cline { 1 - 2 } $\begin{array}{c}\text { Agro-industrial residue AND } \\
\text { "Bioprocessing" }\end{array}$ & \multicolumn{3}{|c|}{ AND Title ("bioprocessing"), e; ii) AllYears. } \\
\hline
\end{tabular}

Quadro 1 - Requisitos básicos para elaboração de revisão bibliográfica. Fonte: Autores (2018) 


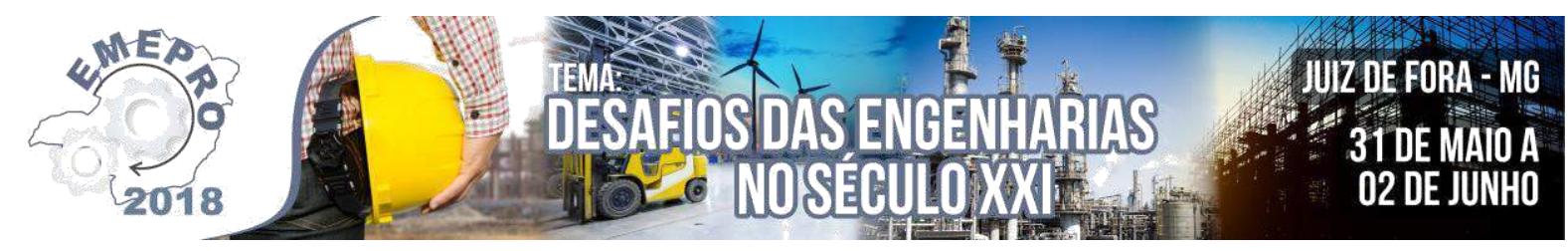

Sucedendo a execução de buscas, os artigos obtidos foram agrupados no Zotero® versão 4.0, onde foram aplicados critérios de filtragem (eliminar duplicidades, capítulos de livros e artigos de conferências), bem como, aplicado o Methodi Ordinatio de Pagani, Kovaleski e Resende (2015). Conforme esses autores, tal método é útil para qualificar os artigos mais relevantes, pois, relaciona o ano de publicação, o fator de impacto e o número de citações na literatura em uma única equação (InOrdinatio). Posteriormente, os melhores artigos foram selecionados para análises e, destes, foram extraídas informações relevantes. $\mathrm{O}$ estudo é de natureza descritiva e explicativa, e quanto aos meios, classifica-se como do tipo pesquisa bibliográfica exploratória.

\section{Resultados e Discussões}

No Quadro 2 são apresentados os totais de artigos encontrados nas bases de dados Science Direct, Scopus e Web of Science.

\begin{tabular}{|c|c|c|c|}
\hline \multirow{2}{*}{ KEYWORDS } & \multicolumn{3}{|c|}{ QUANTIDADE DE ARTIGOS } \\
\cline { 2 - 4 } & $\begin{array}{c}\text { SCIENCE } \\
\text { DIRECT }\end{array}$ & SCOPUS & WEB OF SCIENCE \\
\hline Agro-industrial wastes AND "Bioprocessing” & 12 & 15 & 6 \\
\hline Agro-industrial residue AND "Bioprocessing” & 8 & 13 & 3 \\
\hline TOTAL DE ARTIGOS POR BASE & $\mathbf{2 0}$ & $\mathbf{2 8}$ & $\mathbf{9}$ \\
\hline TOTAL FINAL DAS BASES & \multicolumn{3}{|c|}{$\mathbf{5 7}$ ARTIGOS } \\
\hline
\end{tabular}

Quadro 2 - Resultados obtidos na base de dados Science Direct, Scopus e Web of Science. Fonte: Autores (2018)

Os respectivos resultados de artigos encontrados nas três bases de dados estão restritos às palavras-chave definidas no Quadro 1. Foi possível filtrar somente artigos com foco de gestão de resíduos em agroindústrias, e não demais setores da indústria. Os 57 artigos foram submetidos a critérios básicos de filtragem, como pode ser visualizado por meio do Quadro 3.

\begin{tabular}{|c|c|}
\hline \multicolumn{2}{|c|}{ FILTRAGEM DOS ARTIGOS } \\
\hline Total de Artigos Brutos (=) & 57 \\
\hline Artigos Duplicados (-) & 31 \\
\hline Eliminação por Corte Temporal (-) & 0 \\
\hline Eliminação por Título (incompatível ao tema proposto) (-) & 4 \\
\hline Eliminação pelo Resumo (incompatível ao tema proposto) (-) & 3 \\
\hline TOTAL FINAL DO PORTFÓLIO (=) & $\mathbf{1 9}$ \\
\hline
\end{tabular}

Quadro 3 - Etapas da Filtragem dos Artigos Fonte: Autores (2018)

Por meio do Quadro 3, observa-se que do total de 57 artigos encontrados nas três bases de dados escolhidas, 31 estavam duplicados entre as bases, 4 foram eliminados por meio de leituras de títulos e 3 foram eliminados por meio dos resumos dos artigos. Sendo assim, obteve-se um resultado final de 19 artigos para análises na íntegra. Um fator importante a ser discutido é o ano de publicação dos 19 artigos, conforme apresentado no Gráfico 1. 

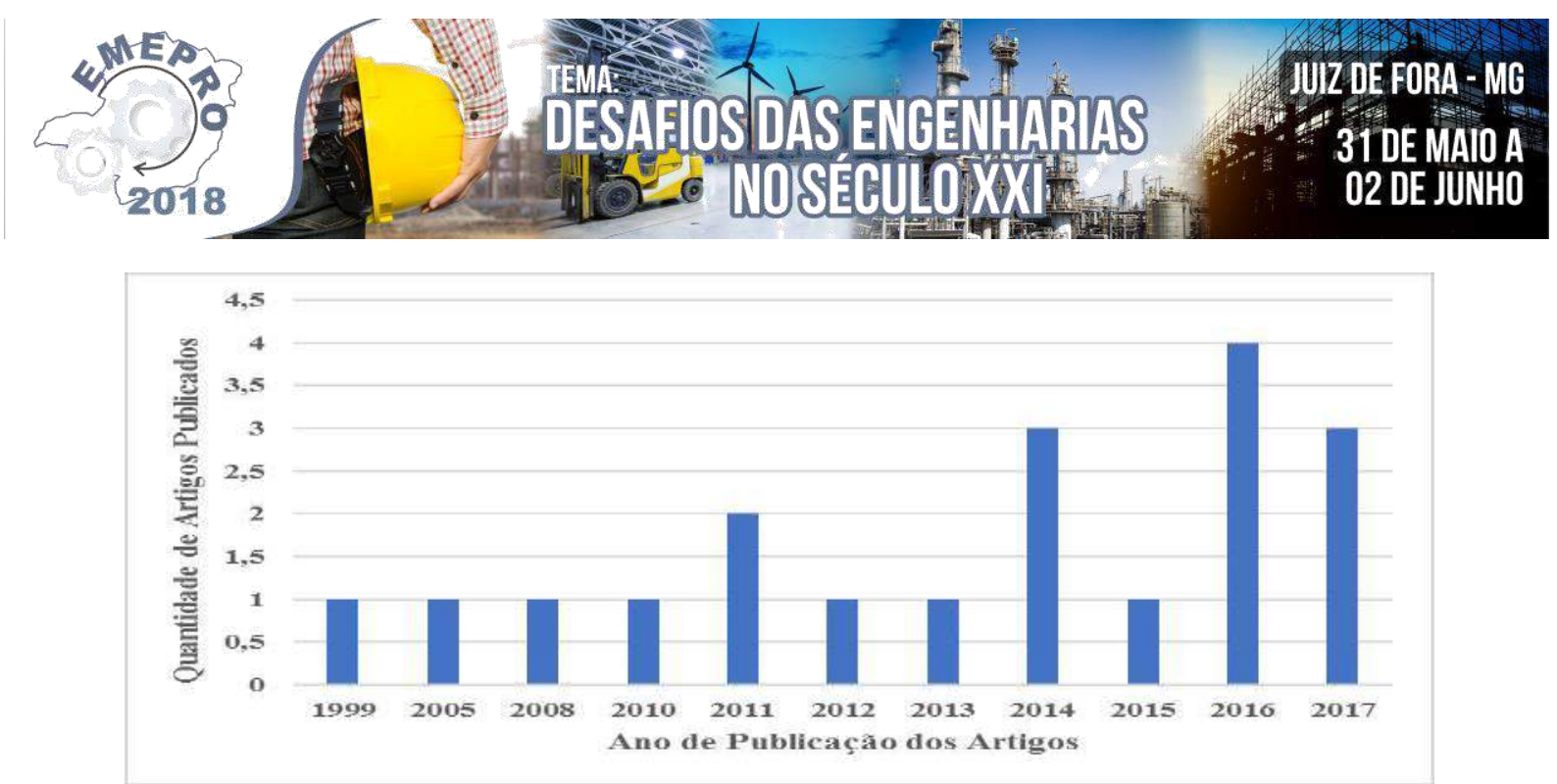

Gráfico 1 - Quantidade de Artigos Publicados (Artigos do Portfólio Final). Fonte: Autores (2018)

Observou-se que dos 19 artigos, o ano de 2013 foi o que mais apresentou publicações alinhadas ao tema deste estudo (gestão de resíduos agroindustriais a partir de bioprocessos), apresentando um total de 4 artigos, seguido pelo ano de 2014 e 2017 ambos com 3 artigos, e os demais anos (1999, 2005, 2008, 2010, 2012, 2013 e 2015) apresentaram somente 1 artigo.

O portfólio de artigos obtido foi submetido ao Methodi Ordinatio para qualificar os estudos mais relevantes. As informações básicas dos artigos estão apresentadas no Quadro 4.

\begin{tabular}{|c|c|c|c|c|c|c|c|}
\hline Ranking & Autores & Título & Journal & Ano & $\begin{array}{l}\text { Fator de } \\
\text { impacto }\end{array}$ & $\begin{array}{c}\text { N. de } \\
\text { citações }\end{array}$ & InOrdinatio \\
\hline 1 & Brandelli, A. & $\begin{array}{l}\text { Bacterial Keratinases: } \\
\text { Useful Enzymes for } \\
\text { Bioprocessing } \\
\text { Agroindustrial Wastes and } \\
\text { Beyond }\end{array}$ & $\begin{array}{l}\text { Food and } \\
\text { Bioprocess } \\
\text { Technology }\end{array}$ & 2008 & 2,576 & 221 & 321,00 \\
\hline 2 & Krishna, C. & $\begin{array}{l}\text { Production of bacterial } \\
\text { cellulases by solid state } \\
\text { bioprocessing of banana } \\
\text { wastes }\end{array}$ & $\begin{array}{l}\text { Bioresource } \\
\text { Technology }\end{array}$ & 1999 & 5,36 & 203 & 123,01 \\
\hline 3 & $\begin{array}{l}\text { Ahmed, I., Zia, } \\
\text { M.A., Hussain, } \\
\text { M.A., Akram, Z., } \\
\text { Naveed, M.T. and } \\
\text { Nowrouzi, A. }\end{array}$ & $\begin{array}{l}\text { Bioprocessing of citrus } \\
\text { waste peel for induced } \\
\text { pectinase production by } \\
\text { Aspergillus niger; its } \\
\text { purification and } \\
\text { characterization }\end{array}$ & $\begin{array}{c}\text { Journal of } \\
\text { Radiation } \\
\text { Research and } \\
\text { Applied Sciences }\end{array}$ & 2016 & 0 & 11 & 101,00 \\
\hline 4 & $\begin{array}{c}\text { Amore, A. and } \\
\text { Faraco, V. }\end{array}$ & $\begin{array}{c}\text { Potential of fungi as } \\
\text { category I Consolidated } \\
\text { BioProcessing organisms } \\
\text { for cellulosic ethanol } \\
\text { production }\end{array}$ & $\begin{array}{l}\text { Renewable and } \\
\text { Sustainable } \\
\text { Energy Reviews }\end{array}$ & 2012 & 8,05 & 50 & 100,01 \\
\hline 5 & $\begin{array}{c}\text { Sobucki, L., Ramos, } \\
\text { R. and Daroit, D. }\end{array}$ & $\begin{array}{l}\text { Protease production by the } \\
\text { keratinolytic Bacillus sp. } \\
\text { CL18 through feather } \\
\text { bioprocessing }\end{array}$ & $\begin{array}{c}\text { Environmental } \\
\text { Science and } \\
\text { Pollution Research }\end{array}$ & 2017 & 2,97 & 0 & 100,00 \\
\hline 6 & $\begin{array}{c}\text { Valdez-González, F. } \\
\text { et al. }\end{array}$ & $\begin{array}{l}\text { Bioprocessing of common } \\
\text { beans in diets for tilapia: } \\
\text { in vivo digestibility and } \\
\text { antinutritional factors }\end{array}$ & $\begin{array}{l}\text { Journal of the } \\
\text { Science of Food } \\
\text { and Agriculture }\end{array}$ & 2017 & 2,29 & 0 & 100,00 \\
\hline
\end{tabular}




\begin{tabular}{|c|c|c|c|c|c|c|c|}
\hline 7 & $\begin{array}{l}\text { Akpinar, M. and } \\
\text { Ozturk Urek, R. }\end{array}$ & $\begin{array}{c}\text { Induction of fungal laccase } \\
\text { production under solid } \\
\text { state bioprocessing of new } \\
\text { agroindustrial waste and } \\
\text { its application on dye } \\
\text { decolorization } \\
\end{array}$ & 3 Biotech & 2017 & 1,361 & 0 & 100,00 \\
\hline 8 & $\begin{array}{l}\text { Vijayaraghavan, P., } \\
\text { Vincent, S.G.P. and } \\
\text { Dhillon, G.S. }\end{array}$ & $\begin{array}{c}\text { Solid-substrate } \\
\text { bioprocessing of cow dung } \\
\text { for the production of } \\
\text { carboxymethyl cellulase } \\
\text { by Bacillus halodurans } \\
\{\text { IND } 18\end{array}$ & $\begin{array}{c}\text { Waste } \\
\text { Management }\end{array}$ & 2016 & 1,9 & 10 & 100,00 \\
\hline 9 & $\begin{array}{c}\text { Khuong, L., Kondo, } \\
\text { R., De Leon, R., } \\
\text { Kim Anh, T., } \\
\text { Shimizu, K. and } \\
\text { Kamei, I. }\end{array}$ & $\begin{array}{c}\text { Bioethanol production } \\
\text { from alkaline-pretreated } \\
\text { sugarcane bagasse by } \\
\text { consolidated bioprocessing } \\
\text { using Phlebia sp. MG-60 }\end{array}$ & $\begin{array}{c}\text { International } \\
\text { Biodeterioration } \\
\text { and } \\
\text { Biodegradation }\end{array}$ & 2014 & 2,9 & 30 & 100,00 \\
\hline 10 & $\begin{array}{l}\text { Sharma, M., Patel, } \\
\text { S.N., Lata, K., } \\
\text { Singh, U., } \\
\text { Krishania, M., } \\
\text { Sangwan, R.S. and } \\
\text { Singh, S.P. } \\
\end{array}$ & $\begin{array}{c}\text { A novel approach of } \\
\text { integrated bioprocessing of } \\
\text { cane molasses for } \\
\text { production of prebiotic } \\
\text { and functional bioproducts }\end{array}$ & $\begin{array}{l}\text { Bioresource } \\
\text { Technology }\end{array}$ & 2016 & 5,36 & 8 & 98,01 \\
\hline 11 & $\begin{array}{l}\text { Zerva, A., Savvides, } \\
\text { A.L., Katsifas, E.A., } \\
\text { Karagouni, A.D. } \\
\text { and Hatzinikolaou, } \\
\text { D.G. }\end{array}$ & \begin{tabular}{|c|} 
Evaluation of \\
Paecilomyces variotii \\
potential in bioethanol \\
production from \\
lignocellulose through \\
consolidated bioprocessing
\end{tabular} & $\begin{array}{l}\text { Bioresource } \\
\text { Technology }\end{array}$ & 2014 & 5,36 & 27 & 97,01 \\
\hline 12 & $\begin{array}{c}\text { López-Gómez, J.P., } \\
\text { Blanco-Rosete, S. } \\
\text { and Webb, C. }\end{array}$ & $\begin{array}{l}\text { Extending shelf life of } \\
\text { wheat based animal feed } \\
\text { using solid state } \\
\text { bioprocessing }\end{array}$ & $\begin{array}{l}\text { Chemical } \\
\text { Engineering } \\
\text { Research and } \\
\text { Design }\end{array}$ & 2016 & 2,81 & 1 & 91,00 \\
\hline 13 & $\begin{array}{l}\text { Zhang, H., Wang, } \\
\text { Y.-J., Lü, F., Chai, } \\
\text { L.-N., Shao, L.-M. } \\
\text { and He, P.-J. }\end{array}$ & $\begin{array}{l}\text { Effects of Dilute Acid } \\
\text { Pretreatment on } \\
\text { Physicochemical } \\
\text { Characteristics and } \\
\text { Consolidated } \\
\text { Bioprocessing of Rice } \\
\text { Straw }\end{array}$ & $\begin{array}{l}\text { Waste and } \\
\text { Biomass } \\
\text { Valorization }\end{array}$ & 2015 & 1,37 & 2 & 82,00 \\
\hline 14 & \begin{tabular}{|} 
Anasontzis, G.E., \\
Zerva, A., \\
Stathopoulou, P.M., \\
Haralampidis, K., \\
Diallinas, G., \\
Karagouni, A.D. \\
and Hatzinikolaou, \\
D.G. \\
\end{tabular} & \begin{tabular}{|c|} 
Homologous \\
overexpression of xylanase \\
in Fusarium oxysporum \\
increases ethanol \\
productivity during \\
consolidated bioprocessing \\
(CBP) of lignocellulosics
\end{tabular} & $\begin{array}{c}\text { Journal of } \\
\text { Biotechnology }\end{array}$ & 2011 & 2,599 & 40 & 80,00 \\
\hline 15 & \begin{tabular}{|l} 
El-Naggar, N.E.-A., \\
Abdelwahed, \\
N.A.M., Saber, \\
W.I.A. and \\
Mohamed, A.A. \\
\end{tabular} & $\begin{array}{c}\text { Bioprocessing of some } \\
\text { agro-industrial residues for } \\
\text { endoglucanase production }\end{array}$ & $\begin{array}{l}\text { Brazilian Journal } \\
\text { of Microbiology }\end{array}$ & 2014 & 0,96 & 6 & 76,00 \\
\hline 16 & $\begin{array}{l}\text { Cassales, A., Souza- } \\
\text { Cruz, P.B.d., Rech, } \\
\text { R. and Ayub, } \\
\text { M.A.Z. }\end{array}$ & $\begin{array}{c}\text { Optimization of soybean } \\
\text { hull acid hydrolysis and its } \\
\text { characterization as a } \\
\text { potential substrate for } \\
\text { bioprocessing }\end{array}$ & $\begin{array}{l}\text { Biomass and } \\
\text { Bioenergy }\end{array}$ & 2011 & 3,219 & 33 & 73,00 \\
\hline
\end{tabular}




\begin{tabular}{|c|c|c|c|c|c|c|c|}
\hline Ranking & Autores & Título & Journal & Ano & $\begin{array}{l}\text { Fator de } \\
\text { impacto }\end{array}$ & $\begin{array}{c}\text { N. de } \\
\text { citações }\end{array}$ & InOrdinatio \\
\hline 17 & $\begin{array}{c}\text { Aravinth Vijay } \\
\text { Jesuraj, S., Marylin } \\
\text { Jeya Praya, S., Bino } \\
\text { Kingsley, R., } \\
\text { Dinesh Kumar, L. } \\
\text { and Ravikumar, M. }\end{array}$ & \begin{tabular}{|c|} 
Bioprocessing of Ar \\
isolates for economical \\
production Of L - \\
Glutaminase by solid state \\
fermentation
\end{tabular} & $\begin{array}{l}\text { International } \\
\text { Journal of } \\
\text { ChemTech } \\
\text { Research }\end{array}$ & 2013 & 0,271 & 2 & 62,00 \\
\hline 18 & $\begin{array}{c}\text { Espindola- } \\
\text { Gonzalez, A., } \\
\text { Martinez- } \\
\text { Hernandez, A.L., } \\
\text { Angeles-Chavez, C., } \\
\text { Castano, V.M. and } \\
\text { Velasco-Santos, C. }\end{array}$ & \begin{tabular}{|c} 
Novel Crystalline SiO2 \\
Nanoparticles via Annelids \\
Bioprocessing of Agro- \\
Industrial Wastes
\end{tabular} & $\begin{array}{c}\text { Nanoscale } \\
\text { Research Letters }\end{array}$ & 2010 & 1,99 & 32 & 62,00 \\
\hline 19 & $\begin{array}{l}\text { Shah, M.P., Reddy, } \\
\text { G.V., Banerjee, R., } \\
\text { Babu, P.R. and } \\
\text { Kothari, I.L. }\end{array}$ & $\begin{array}{c}\text { Microbial degradation of } \\
\text { banana waste under solid } \\
\text { state bioprocessing using } \\
\text { two lignocellulolytic fungi } \\
\text { (Phylosticta spp. MPS-001 } \\
\text { and Aspergillus spp. MPS- } \\
002 \text { ) }\end{array}$ & $\begin{array}{c}\text { Process } \\
\text { Biochemistry }\end{array}$ & 2005 & 2,7 & 76 & 56,00 \\
\hline
\end{tabular}

Quadro 4 - Informações básicas de artigos e resultados de InOrdinatio. Fonte: Autores (2018)

Entre o total de 19 artigos analisados, 17 deles tratam de estudos empíricos e 2 correspondem a estudos teóricos. O Quadro 5 apresenta uma breve síntese de informações extraídas dos estudos analisados.

\begin{tabular}{|c|c|c|c|}
\hline Ranking & Foco de estudo & $\begin{array}{l}\text { Microrganismo } \\
\text { empregado no } \\
\text { bioprocesso }\end{array}$ & Principais Conclusões \\
\hline 1 & $\begin{array}{c}\text { Apresentar avanços recentes } \\
\text { sobre proteases } \\
\text { queratinolíticas de origem } \\
\text { bacteriana com ênfase em } \\
\text { suas propriedades } \\
\text { bioquímicas e discutir sobre } \\
\text { suas aplicações atuais e } \\
\text { potenciais em indústrias. }\end{array}$ & $\begin{array}{c}\text { Keratinolytic Bacteria } \\
\text { (genera Streptomyces } \\
\text { and Bacillus) }\end{array} \mid$ & $\begin{array}{c}\text { As bactérias queratinases são enzimas valiosas para o } \\
\text { bioprocessamento de resíduos queratinosos. Sua } \\
\text { capacidade de degradar a queratina da proteína } \\
\text { recalcitrante constitui-se uma propriedade notável. }\end{array}$ \\
\hline 2 & $\begin{array}{l}\text { Aplicar bioprocessos } \\
\text { utilizando talos de banana e } \\
\text { testar diferentes métodos de } \\
\text { bioprocessamento. }\end{array}$ & Bacillus subtilis & $\begin{array}{l}\text { O talo de banana foi encontrado como o substrato } \\
\text { mais adequado entre alguns lignocelulósicos } \\
\text { facilmente disponíveis }\end{array}$ \\
\hline 3 & $\begin{array}{c}\text { Apresentar as aplicações } \\
\text { potenciais das pectinases em } \\
\text { diferentes setores industriais, } \\
\text { utilizando como principal } \\
\text { insumo a casca de laranja }\end{array}$ & Aspergillus niger & $\begin{array}{c}\text { A produção máxima de pectinase na presença de } \\
\text { substrato mais barato em baixa concentração torna a } \\
\text { enzima útil em setores industriais, especialmente para } \\
\text { indústria de sumo e têxtil. Constatou-se que A. niger } \\
\text { apresentou um potencial incrível para a síntese de } \\
\text { pectinase, aliada ao tipo de insumo utilizado. }\end{array}$ \\
\hline 4 & \begin{tabular}{|c|} 
Analisar o potencial de fungos \\
para produção de enzimas \\
degradantes de biomassa \\
celulósica destinada à \\
composição de etanol. \\
\end{tabular} & $\begin{array}{l}\text { T. reesei ; Aspergillus } \\
\text { spp.; Fusarium spp.; } \\
\text { F. oxysporum; } \\
\text { Rhizopus spp. }\end{array}$ & $\begin{array}{c}\text { A capacidade limitada das bactérias de produzir } \\
\text { enzimas em quantidade e qualidade suficientes para a } \\
\text { degradação da lignocelulose torna os fungos } \\
\text { alternativos e melhores candidatos para bioprocessos. }\end{array}$ \\
\hline 5 & $\begin{array}{c}\text { Investigar a aplicabilidade de } \\
\text { uso do Bacillus sp. para } \\
\text { bioprocesso de pena de frango } \\
\text { como substrato orgânico. }\end{array}$ & Bacillus sp. CL18 & \begin{tabular}{|c|} 
Nem todos os microrganismos proteolíticos são \\
capazes de degradar as penas. A concentração de \\
penas apareceu como um fator importante a ser \\
considerado para a produção de protease por Bacillus \\
sp. CL18. Notou-se que Bacillus sp. CL18 \\
conseguiram desintegrar eficientemente a estrutura \\
de penas quando estes estavam presentes em até $30 \mathrm{~g}$ \\
1-1 em mídia cultural.
\end{tabular} \\
\hline
\end{tabular}




\begin{tabular}{|c|c|c|c|}
\hline 6 & \begin{tabular}{|c|} 
Testar refeições de feijão \\
comum (Phaseolus vulgaris) \\
como substitutos de farinha de \\
peixe em dietas para tilapia \\
(Oreochromis niloticus).
\end{tabular} & Rhizopus oligosporus & $\begin{array}{c}\text { A fermentação significativamente }(\mathrm{P}<0,05) \\
\text { aumentou o teor de proteína e digestibilidade de } \\
\text { matéria seca e proteína em comparação com grãos de } \\
\text { feijão inteiro e diminuiu os teores de lipídios, cinzas } \\
\text { e ácido fítico. }\end{array}$ \\
\hline 7 & $\begin{array}{c}\text { O objetivo deste estudo é } \\
\text { otimizar o bioprocesso de } \\
\text { resíduos de pêssego para obter } \\
\text { uma maior produção de lacase } \\
\text { mais econômica. }\end{array}$ & Pleurotus eryngii & $\begin{array}{c}\text { A biotransformação do produto com importância } \\
\text { biotecnológica ocorreu economicamente através da } \\
\text { utilização de resíduos de pêssego. De longe, uma das } \\
\text { abordagens mais eficazes para aumentar o } \\
\text { rendimento da enzima lacase é a suplementação do } \\
\text { nutriente. }\end{array}$ \\
\hline 8 & $\begin{array}{l}\text { Utilizar o esterco de vaca } \\
\text { como um produto potencial } \\
\text { para a produção de } \\
\text { carboximetilcelulose }\end{array}$ & Bacillus halodurans & $\begin{array}{l}\text { O estudo provou o potencial do esterco de vaca como } \\
\text { um substrato ideal para a produção de CMCase. Ele } \\
\text { contém nutrientes essenciais e alta capacidade de } \\
\text { retenção de umidade, e tem vantagens para o } \\
\text { crescimento de espécies bacterianas. O esterco de } \\
\text { vaca está presente em abundância a baixo custo. }\end{array}$ \\
\hline 9 & $\begin{array}{c}\text { A otimização do pré- } \\
\text { tratamento alcalino para a } \\
\text { biodegradação do bagaço de } \\
\text { cana de açúcar pelo fungo } \\
\text { Phlebia sp. MG-60 foi } \\
\text { estudado. }\end{array}$ & Phlebia sp. MG-60 & $\begin{array}{l}\text { Phlebia sp. MG-60 é um candidato potencial para a } \\
\text { produção de etanol a partir de bagaço pré-tratado } \\
\text { com álcali em um único biorreator, sem hidrólise } \\
\text { enzimática ou química. }\end{array}$ \\
\hline 10 & $\begin{array}{c}\text { Investigar a aplicabilidade do } \\
\text { uso de melaço de cana de } \\
\text { açúcar como subproduto de } \\
\text { bioprocessos para fins } \\
\text { específicos. }\end{array}$ & L. mesenteroides & $\begin{array}{l}\text { O bioprocesso enzimático do melaço de resíduos de } \\
\text { cana de açúcar resultou na produção de prebiótico } \\
\text { oligosacarídeos. Sendo assim, o melaço foi } \\
\text { demonstrado como um substituto alternativo para } \\
\text { produção de dextransucrase, destinado à fabricação } \\
\text { de aditivos alimentares. }\end{array}$ \\
\hline 11 & $\begin{array}{c}\text { Avaliar uma espécie de fungo } \\
\text { para produção de bioetanol, } \\
\text { por meio de abordagens } \\
\text { consolidadas de bioprocessos. }\end{array}$ & $\begin{array}{c}\text { Ascomicê } \\
\text { Paecillomyces }\end{array}$ & $\begin{array}{c}\text { O fungo foi capaz de fermentar eficientemente a } \\
\text { glicose e a xilose para produção de bioetanol. Além } \\
\text { disso, o fungo possui a fábrica de enzimas necessária } \\
\text { para a degradação da biomassa lignocelulósica, pois, } \\
\text { foi capaz de cultivar e produzir etanol em derivados } \\
\text { agroindustriais comuns. } \\
\end{array}$ \\
\hline 12 & $\begin{array}{c}\text { Investigar a utilização de } \\
\text { tecnologias de bioprocessos } \\
\text { para fins de prolongar a vida } \\
\text { útil de alimentos para } \\
\text { animais. }\end{array}$ & Rhizopus oryzae & $\begin{array}{l}\text { R. oryzae é capaz de evitar o crescimento de } \\
\text { microrganismos não desejados durante pelo menos } \\
20 \text { dias. As amostras que não foram inoculadas com } \\
\text { R. oryzae mostraram crescimento após apenas } 2 \text { dias } \\
\text { e as amostras que foram administradas com um } \\
\text { conservante comercial apresentaram crescimento de } \\
\text { patógenos após } 7 \text { dias. }\end{array}$ \\
\hline 13 & \begin{tabular}{|c|} 
Pré-tratar resíduo \\
agroindustrial (palha de arroz) \\
por ácido sulfúrico diluído, \\
bem como submete-lo ao \\
bioprocesso.
\end{tabular} & $\begin{array}{l}\text { Clostridium } \\
\text { thermocellum }\end{array}$ & $\begin{array}{l}\text { De maneira mais ampla, a produção de etanol por C. } \\
\text { thermocellum foi acelerada e melhorada após o pré- } \\
\text { tratamento no estágio inicial de fermentação, devido } \\
\text { à maior acessibilidade enzimática. }\end{array}$ \\
\hline 14 & $\begin{array}{c}\text { Visando aumentar a } \\
\text { produtividade do etanol } \\
\text { durante o bioprocessamento } \\
\text { consolidado de } \\
\text { lignocelulósicos, buscou-se } \\
\text { agregar melhorias ao genoma } \\
\text { de F. oxysporum. }\end{array}$ & F. oxysporum & $\begin{array}{l}\text { Foram desenvolvidos transformantes de F. } \\
\text { oxysporum, isto é, o gene endo- } \beta \text {-1,4-xilanase } 2 \text { foi } \\
\text { incorporado no F. oxysporum, de modo a aumentar a } \\
\text { produtividade do etanol, durante o bioprocessamento } \\
\text { de subprodutos agrícolas complexos. Ambos tiveram } \\
\text { melhor desempenho do que o tipo selvagem em } \\
\text { relação à produtividade do etanol com espiga de } \\
\text { milho, enquanto que para o farelo de trigo a } \\
\text { transformação se mostrou benéfica para apenas uma } \\
\text { das cepas analisadas. }\end{array}$ \\
\hline
\end{tabular}




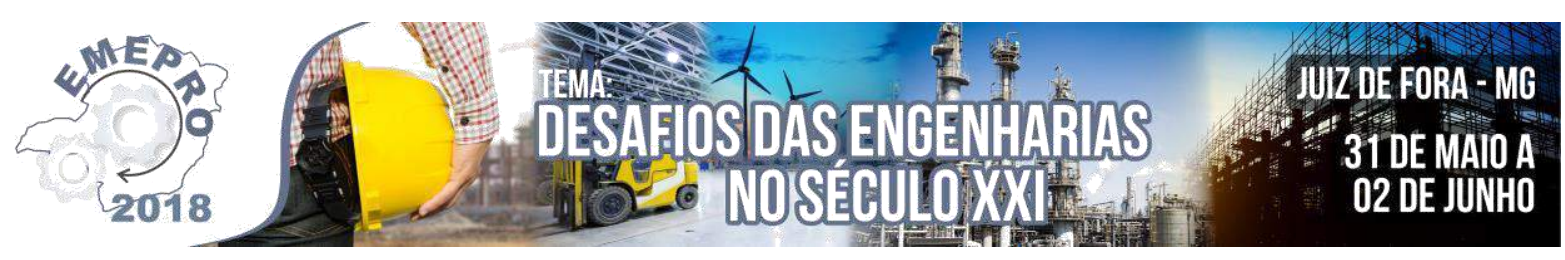

\begin{tabular}{|c|c|c|c|}
\hline Ranking & Foco de estudo & $\begin{array}{c}\text { Microrganismo } \\
\text { empregado no } \\
\text { bioprocesso }\end{array}$ & Principais Conclusões \\
\hline 15 & $\begin{array}{l}\text { Realizar o isolamento de } \\
\text { cepas de actinomicetos, que } \\
\text { possuem atividades } \\
\text { celulolíticas, e maximizar a } \\
\text { produção de enzima } \\
\text { endoglucanase. }\end{array}$ & $\begin{array}{l}\text { Streptomyces } \\
\text { albogriseolus }\end{array}$ & $\begin{array}{c}\text { Entre os diferentes resíduos agroindustriais utilizados } \\
\text { para a produção de endoglucanasa de Streptomyces } \\
\text { albogriseolus subsp. cellulolyticus, o rendimento da } \\
\text { enzima obtido a partir do bagaço de cana-de-açúcar é } \\
\text { comparativamente maior que o obtido a partir de } \\
\text { carboximetilcelulose }\end{array}$ \\
\hline 16 & $\begin{array}{l}\text { Investigar a composição } \\
\text { química e a cinética da } \\
\text { hidrólise diluída do ácido } \\
\text { obtido de cascas de soja. }\end{array}$ & $\begin{array}{l}\text { Nenhum em } \\
\text { específico, e sim, } \\
\text { emprego de ácidos }\end{array}$ & $\begin{array}{l}\text { O potencial uso de cascas de soja como substrato } \\
\text { para vários bioprocessos após sua hidrólise ácida foi } \\
\text { testada. Sua composição de açúcar corresponde à de } \\
\text { outros materiais hemicelossóicos, enquanto seu } \\
\text { conteúdo de compostos tóxicos se compara } \\
\text { favoravelmente, com conteúdo muito baixo de } \\
\text { lignina. Deste modo, surge uma perspectiva quanto } \\
\text { ao uso de cascas soja como um substrato potencial } \\
\text { para a produção de biocombustíveis. }\end{array}$ \\
\hline 17 & $\begin{array}{l}\text { Gerar L-Glutaminase } \\
\text { economicamente viável } \\
\text { utilizando resíduos } \\
\text { agroindustriais (fibra de } \\
\text { coco), a partir de } \\
\text { bioprocessos. }\end{array}$ & $\begin{array}{c}\text { Não especificado no } \\
\text { estudo. }\end{array}$ & $\begin{array}{c}\text { Constatou-se que os resíduos de fibra de coco são } \\
\text { uteis e economicamente viáveis para produção da } \\
\text { enzima L-glutaminase. Fatores críticos como } \mathrm{pH} \text {, } \\
\text { temperatura de incubação, volume de inoculações e } \\
\text { nutrientes adicionais desempenham um papel vital na } \\
\text { produção desta enzima. }\end{array}$ \\
\hline 18 & \begin{tabular}{|c|} 
Desenvolver um novo \\
processo para a síntese de \\
diversos materiais \\
nanométricos com matrizes de \\
cristal específicas como \\
precursores de resíduos \\
agroindustriais. \\
\end{tabular} & Eisenia foetida & $\begin{array}{c}\text { Enquanto que as partículas sintéticas possuem } \\
\text { estrutura amorfa, as partículas sintetizadas usando } \\
\text { Eisenia foetida apresentam diferentes características, } \\
\text { como cristalino e dimensão nanométrica. }\end{array}$ \\
\hline 19 & $\begin{array}{c}\text { Phylosticta spp. MPS-001 e } \\
\text { Aspergillus spp. MPS-002 } \\
\text { foram investigados pela sua } \\
\text { capacidade de produzir várias } \\
\text { enzimas lignolíticas e } \\
\text { celulolíticas. }\end{array}$ & $\begin{array}{l}\text { Phylosticta spp. MPS- } \\
\text { 001 e Aspergillus spp. }\end{array}$ & $\begin{array}{c}\text { O presente estudo proporciona uma visão da } \\
\text { dinâmica da produção de enzimas extracelulares } \\
\text { pelos dois isolados potenciais de Phylosticta spp. } \\
\text { MPS-001 e Aspergillus spp. MPS-002 sobre resíduos } \\
\text { de banana. }\end{array}$ \\
\hline
\end{tabular}

Quadro 5 - Principais abordagens de estudos analisados. Fonte: Autores (2018)

Conforme exposto no Quadro 5, o foco macro de estudos no geral foi fornecer subsídios, por meio de pesquisas empíricas, que auxiliem na maximização da produção e na eficiência de bioprocessos aplicados nas agroindústrias. Enquanto um grupo de estudos se propôs a avaliar potenciais microrganismos para determinados tipos de bioprocessamentos, outros estudos avaliaram usos de insumos para melhores resultados produtivos de enzimas. $\mathrm{O}$ bioetanol foi o produto foco da maior parcela dos estudos. Foram constatados nos estudos resultados favoráveis da aplicação de bioprocessos nas indústrias, o que reflete no alcance de vantagens ambientais e econômicas.

\section{Considerações finais}

Este estudo buscou discutir sobre o gerenciamento de resíduos agroindustrial por meio da tecnologia de bioprocessos. A partir de bioprocessos, uma variedade de resíduos que poderiam ser descartados no ambiente passa a ser gerenciados, como casca de laranja, palha de arroz, farelo de trigo residual, entre outros. Além de proporcionar benefícios ao meio ambiente, tais práticas podem refletir em ganhos econômicos às indústrias, e à sociedade no geral que são contempladas com os produtos e substâncias produzidas.

Se gerenciados adequadamente, os resíduos sólidos adquirem valor comercial e podem ser utilizados em forma de novas matérias-primas ou novos insumos. A implantação de um plano de gestão trará reflexos positivos no âmbito social, ambiental e econômico, pois não só tende a diminuir o consumo dos recursos naturais, como proporciona a abertura de novos 
mercados, gera trabalho, emprego e renda, conduz à inclusão social e diminui os impactos ambientais provocados pela disposição inadequada dos resíduos.

\section{Referências}

ABNT - ASSOCIAÇÃO BRASILEIRA DE NORMAS TÉCNICAS. NBR 10004:2004. Resíduos sólidos Classificação. Rio de Janeiro: ABNT, 2004.

ABRELPE - ASSOCIAÇÃO BRASILEIRA DE EMPRESAS DE LIMPEZA PÚBLICA E RESÍDUOS ESPECIAIS 2016. Disponível em: http://www.abrelpe.org.br._Acesso em 06 de dezembro de 2017.

AHMED, I.; ZIA, M. A.; HUSSAIN, M. A.; AKRAM, Z.; NAVEED, M. T.; NOWROUZI, A. Bioprocessing of citrus waste peel for induced pectinase production by Aspergillus niger; its purification and characterization. Journal of Radiation Research and Applied Sciences, v. 9, n. 2, p. 148-154, 2016.

AKPINAR, M.; UREK, R. O. Induction of fungal laccase production under solid state bioprocessing of new agroindustrial waste and its application on dye decolorization. 3 Biotech, v. 7, n. 2, p. 98, 2017.

ALEXANDRINO, A. M.; FARIA, H. G.; SOUZA, C. G. M.; PERALTA, R. M. Aproveitamento do resíduo de laranja para a produção de enzimas lignocelulolíticas por Pleurotus ostreatus. Ciênc. Tecnol. Aliment. v. 27, n. 2, p. 364-368, 2007.

AMORE, A.; FARACO, V. Potential of fungi as category I Consolidated BioProcessing organisms for cellulosic ethanol production. Renewable and Sustainable Energy Reviews, v. 16, n. 5, p. 3286-3301, 2012.

ANASONTZIS, G. E.; ZERVA, A.; STATHOPOULOU, P. M.; HARALAMPIDIS, K.; DIALLINAS, G.; KARAGOUNI, A. D.; HATZINIKOLAOU, D. G. Homologous overexpression of xylanase in Fusarium oxysporum increases ethanol productivity during consolidated bioprocessing (CBP) of lignocellulosics. Journal of biotechnology, v. 152, n. 1, p. 16-23, 2011.

BRASIL. Lei Federal no 12.305 - Institui a Política Nacional de Resíduos Sólidos; altera a Lei no 9.605, de 12 de fevereiro de 1998; e dá outras providências. Diário Oficial da União, 03 de agosto de 2010.

BRANDELLI, A. Bacterial keratinases: useful enzymes for bioprocessing agroindustrial wastes and beyond. Food and Bioprocess Technology, v. 1, n. 2, p. 105-116, 2008.

CASSALES, A.; SOUZA-CRUZ, P. B.; RECH, R.; AYUB, M. A. Z. Optimization of soybean hull acid hydrolysis and its characterization as a potential substrate for bioprocessing. Biomass and bioenergy, v. 35, n. 11, p. 4675-4683, 2011.

DEMAJOROVIC, J.; MIGLIANO, J. E. B. Política Nacional de Resíduos Sólidos e suas implicações na Cadeia da Logística reversa de Microcomputadores no Brasil. Gestão \& Regionalidade, v. 29, n. 87, p. 64-80, 2013.

EL-NAGGAR, N. E. A.; ABDELWAHED, N. A. M.; SABER, W. I. A.; MOHAMED, A. A. Bioprocessing of some agroindustrial residues for endoglucanase production by the new subsp.; Streptomyces albogriseolus subsp. cellulolyticus strain NEAE-J. Brazilian Journal of Microbiology, v. 45, n. 2, p. 743-751, 2014.

ESPÍNDOLA-GONZALEZ, A.; MARTINEZ-HERNANDEZ, A. L.; ANGELES-CHAVES, C.; CASTANO, V. M.; VELASCO-SANTOS, C. Novel crystalline $\mathrm{SiO} 2$ nanoparticles via annelids bioprocessing of agroindustrial wastes. Nanoscale research letters, v. 5, n. 9, p. 1408, 2010.

FARINAS, C. S.; URSULA, V. L.; ZÚÑIGA, F. R.; BERTUCCI NETO, V.; COURI, S. Avaliação de Diferentes Resíduos Agroindustriais como Substratos para a Produção de Celulases por Fermentação Semisólida. São Paulo: Embrapa Instrumentação Agropecuária, 2008.

GERBER, W. Impacto ambiental: resíduos sólidos e reciclagem. Pelotas: UCPEL, 1999.

GOUVEIA, N. Resíduos sólidos urbanos: impactos socioambientais e perspectiva de manejo sustentável com inclusão social. Ciência \& Saúde Coletiva, v. 17, n. 6, p. 1503-1510, 2012.

JESURAJ, S. A. V.; MARYLIN, J. P.; BINO, R. K.; KUMAR, L. D.; RAVIKUMAR, M. Bio-processing of Ar isolates for economical production of 1-glutaminase by solid-state fermentation. Int. J. ChemTech Res, v. 5, p. 1428-1436, 2013.

KRISHNA, C. Production of bacterial cellulases by solid state bioprocessing of banana wastes. Bioresource technology, v. 69, n. 3, p. 231-239, 1999.

KHUONG, L.; KONDO, R.; DE LEON, R.; KIM, A. T.; SHIMIZU, K.; KAMEI, I. Bioethanol production from alkaline-pretreated sugarcane bagasse by consolidated bioprocessing using Phlebia sp. MG-60. International Biodeterioration \& Biodegradation, v. 88, p. 62-68, 2014.

LAUFENBERG, G.; KUNZ, B.; NYSTROEM, M. Transformation of vegetable waste into value added products: (A) the upgrading concept; (B) practical implementations. Bioresource Technology, v. 87, n. 2, p. 167$198,2003$. 
LÓPEZ-GÓMEZ, J. P.; BLANCO-ROSETE, S.; WEBB, C. Extending shelf life of wheat based animal feed using solid state bioprocessing. Chemical Engineering Research and Design, v. 107, p. 147-152, 2016.

MATTOS DEUS, R.; BATTISTELLE, R. A. G.; SILVA, G. H. R. Resíduos sólidos no Brasil: contexto, lacunas e tendências. Eng Sanit Ambient, v.20, n.4, p. 685-698, 2015.

MAZZER, A.; CAVALCANTI, O. A. Introdução à gestão ambiental de resíduos. Infarma, v. 16, n. 11, p. 67-77, 2004.

OLIVIER, S. Aplicação de resíduos agroindustriais e urbanos em áreas de reflorestamento com Eucalyptus spp. Piracicaba, SP. USP, 2011. 107p. (Tese de Doutorado Ciências, centro de Energia Nuclear na Agricultura). Universidade de São Paulo.

PAGANI, R. N.; KOVALESKI, J. L.; RESENDE, L. M. M. Methodi Ordinatio: a proposed methodology to select and rank relevant scientific papers encompassing the impact factor, number of citation, and year of publication. Scientometrics, v. 105, n. 3, p. 2109-2135, 2015.

PANESAR, P. S.; KAUR, R.; SINGLA, G.; SANGWAN, R. S. Bio-processing of Agro-industrial Wastes for Production of Food-grade Enzymes: Progress and Prospects. Appl Food Biotechnol, v. 3, n. 4, p. 208-227, 2016.

RAMKRISHN, D.; SONG, H. S. Analysis of Bioprocesses - Dynamic Modeling is a Must. Materials Today: Proceedings, v. 3, p. 3587-3599, 2016.

SCHEPER, T. H.; HILMER, J. M.; LAMMERS, F.; MIILLER, C.; REINECKE, M. Biosensors in bioprocess monitoring. Journal of Chromatography A, v. 725, p. 3-12, 1996.

SHAH, M. P.; REDDY, G. V.; BANERJEE, R.; BABU, P. R.; KOTHARI, I. L. Microbial degradation of banana waste under solid state bioprocessing using two lignocellulolytic fungi (Phylosticta spp. MPS-001 and Aspergillus spp. MPS-002). Process biochemistry, v. 40, n. 1, p. 445-451, 2005.

SHARMA, M.; PATEL, S. N.; LATA, K.; SINGH, U.; KRISHANIA, M.; SANGWAN, R. S.; SINGH, S. P. A novel approach of integrated bioprocessing of cane molasses for production of prebiotic and functional bioproducts. Bioresource technology, v. 219, p. 311-318, 2016.

SILVA, W. L. Resíduos Industriais e Agroindustriais: Uma abordagem ecotecnológica na produção de fotocatalisadores suportados. Porto Alegre, RS. UFRS, 2016. 82p. (Tese de Doutorado em Engenharia Química). Universidade do Rio Grande do Sul.

SINIR - SISTEMA NACIONAL DE INFORMAÇÕES SOBRE A GESTÃO DOS RESÍDUOS SÓLIDOS. Tipos de Resíduos. Disponível em: http://sinir.gov.br/web/guest/tipos-de-residuos. Acesso em: 02 de dezembro de 2017.

SOBUCKI, L.; RAMOS, R. F.; DAROIT, D. J. Protease production by the keratinolytic Bacillus sp. CL18 through feather bioprocessing. Environmental Science Pollution Research, v. 24, n. 29, p. 23125-23132, 2017.

TOCCHETTO, M. R. L. Notas de aula: Gerenciamento de resíduos sólidos industriais. Departamento de Química, Universidade Federal de Santa Maria, 2012.

VALDEZ-GONZÁLEZ, F.; GUTIÉRREZ-DORADO, R.; HERNÁNDEZ-LLAMAS, A.; GARCÍA-ULLOA, M.; SÁNCHEZ-MAGAÑA, L.; CUEVAS-RODRÍGUEZ, B.; RODRÍGUES-GONZÁLES, H. Bioprocessing of common beans in diets for tilapia: in vivo digestibility and antinutritional factors. Journal of the Science of Food and Agriculture, 2017.

VIJAYARAGHAVAN, P.; VINCENT, S. G. P.; DHILLON, G. S. Solid-substrate bioprocessing of cow dung for the production of carboxymethyl cellulase by Bacillus halodurans IND18. Waste Management, v. 48, p. 513-520, 2016.

WANG, Y.; CHU, J.; ZHUANG, Y.; WANG, Y.; XIA, J.; ZHANG, S. Industrial bioprocess control and optimization in the context of systems biotechnology. Biotechnology Advances, v. 27, p. 989-995, 2009.

WOICIECHOWSKI, A. L.; CARVALHO, J. C.; SPIER, M. R.; HABU, S.; YAMAGUISHI, C. T.; GHIGGI, V.; SOCCOL, C. R. Empregos de Resíduos Agroindustriais em Bioprocessos Alimentares. 2013. DOI: 10.13140/RG.2.1.1508.7529.

ZERVA, A.; SAVVIDES, A. L.; KATSIFAS, E. A.; KARAGOUNI, A. D.; HATZINIKOlAOU, D. G. Evaluation of Paecilomyces variotii potential in bioethanol production from lignocellulose through consolidated bioprocessing. Bioresource technology, v. 162, p. 294-299, 2014.

ZHANG, H.; WANG, Y. J.; LÜ, F.; CHAI, L. N.; SHAO, L. M.; HE, P. J. Effects of dilute acid pretreatment on physicochemical characteristics and consolidated bioprocessing of rice straw. Waste and Biomass Valorization, v. 6, n. 2, p. 217-223, 2015. 


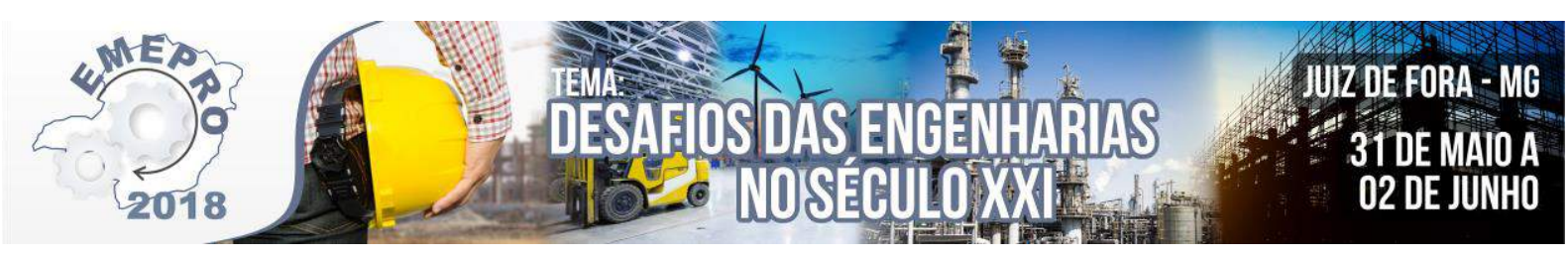

\title{
Análise comparativa de viabialidade ambiental e econômica de três métodos de contenção em encostas em uma área situada no munícipio de Pará de Minas/MG
}

\author{
Leonardo Gonçalves Almeida (FEAMIG) leonardo.almeida@ copasa.com.br \\ Ulisses Domingos Pereira Júnior (FEAMIG) ulissesvendedor@ hotmail.com \\ Deny Figueredo Alves (FEAMIG) denyfalves@ hotmail.com \\ Lázaro César Rita (FEAMIG) lazaro.cezar@yahoo.com.br \\ Jocilene Ferreira da Costa (FEAMIG) jocilene_fc@yahoo.com.br
}

Resumo: $O$ surgimento de metodologias de contenções que sejam ambientalmente sustentáveis justifica-se pela rápida expansão urbana e a elevada valorização imobiliária. Este trabalho tem como objetivos analisar os processos de construção de três métodos de contenção: Gabião, Terramesh ${ }^{\circledR}$ e Muro de Arrimo, com o intuito de verificar a melhor viabilidade ambiental e econômica, para implantação em uma área de um empreendimento habitacional multifamiliar. Trata-se de uma pesquisa qualitativa exploratória, e estudo de caso, cuja amostra da pesquisa foi a encosta localizada no conjunto habitacional Vila Atlântica. Realizou-se uma revisão bibliográfica, posteriormente coletaram-se os dados junto à empresa Via Sul Engenharia e à Prefeitura Municipal de Pará de Minas/MG. Os dados foram tabulados no programa Excel, sendo criadas planilhas de comparação de preços para que se equalizassem os valores econômicos de cada método, apresentando os valores por $m^{2}$. Os resultados mostram que entre os métodos de estruturas de contenção, estudados na presente pesquisa, o que melhor atendeu o objetivo de promover a estabilidade dos maciços de terra presentes na área de objeto do estudo, foi a contenção do tipo Gabião além de apresentar maiores vantagens ambientais e econômicas.

Palavras-chave: Processos erosivos; Métodos de contenção Muro de Gabião; Terramesh ${ }^{\circledR}$; Muro de Arrimo.

\section{Introdução}

Atualmente é crescente a preocupação com o meio ambiente, revelando-se uma crise ambiental, resultado dos efeitos globais, tais como: mudanças climáticas, diminuição dos recursos naturais, poluição das águas e dos solos.

Entre os principais fatores relacionados ao aumento da degradação ambiental, encontram-se as frequentes alterações no uso não planejado do solo. Tais alterações são responsáveis pelo aumento dos processos erosivos tanto em áreas agrícolas como urbanas.

A necessidade do surgimento de diferentes metodologias de contenções e suas aplicabilidades justifica-se pela rápida expansão urbana e a elevada valorização imobiliária. Tem-se buscado métodos e inovações tecnológicas para a contenção, por exemplo, de encostas que sejam ambientalmente sustentáveis, visando a proteção do meio ambiente. 


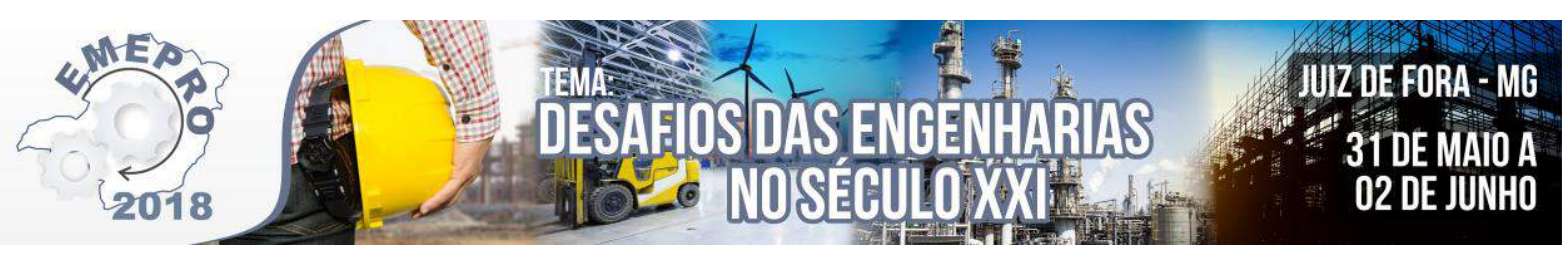

O presente trabalho tem como objetivos analisar os processos de construção de três métodos de contenção: Gabião, Terramesh ${ }^{\circledR}$ e Muro de Arrimo, com o intuito de verificar a melhor viabilidade ambiental e econômica, para implantação em uma área do empreendimento Villa Atlântica, situado no município de Pará de Minas/MG.

\section{Fundamentação teórica}

\subsection{Históricos das estruturas de contenção de encostas}

Desde o início dos tempos, o homem vem alterando as condições topográficas originais de terrenos para construção de edificações como moradias, comércios, construção de vias de acesso. Desta forma sempre existiu a necessidade de implantação de contenções de encostas. Obras de contenção não são contemporâneas, os registros mais antigos estão entre 3.200 e 2.800 a.C., onde os sumerianos construíam muros de alvenaria de argila para estabilizar encostas na região do Iraque. Entretanto as construções seguindo preceitos de engenharia começaram surgir no início do século XVIII, através de projetos de engenheiros franceses (MENDONÇA, 2015).

\subsection{Encostas Naturais}

São definidos como superfícies de ângulos inclinados, cuja base é de natureza terrosa, rochosa ou mista, originados por diferentes processos geológicos e geomorfológicos (PINOTTI, 2011). Uma encosta natural pode ser observada na Figura 1.

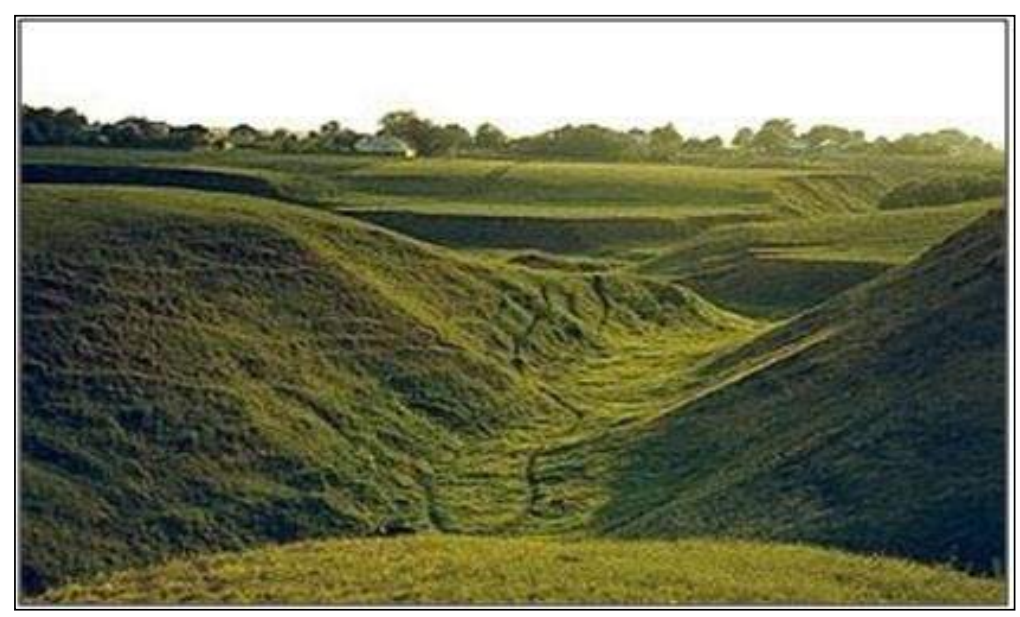

FIGURA 1 - Encosta Natural. Fonte: CEMADEN ( 2016).

\subsection{Solos: Conceituação}

O solo é um sistema aberto que está constantemente sob ação de fluxos de matéria e energia, o tornando um sistema dinâmico (EMBRAPA, 2017). Segundo Branco (2014), quando as modificações são causadas pelo intemperismo, reorganização e conforme a estrutura, também por erosão, transporte e sedimentação, pode-se chamar de solo. São classificados em minerais e orgânicos, e têm características físicas, químicas e físico-químicas diferenciadas. Estes, poderão ser argilosos, arenosos, ricos ou pobres de matéria orgânica, vermelhos, amarelos ou cinza-esbranquiçados, espessos ou rasos, homogêneos ou estruturados (BRANCO, 2014).

\subsubsection{Processos Erosivos do Solo}

Erosão é um fenômeno da superfície, onde as condições físicas da parte superior do solo desempenham papel primordial. Processos erosivos, apresentados na Figura 2, além de 


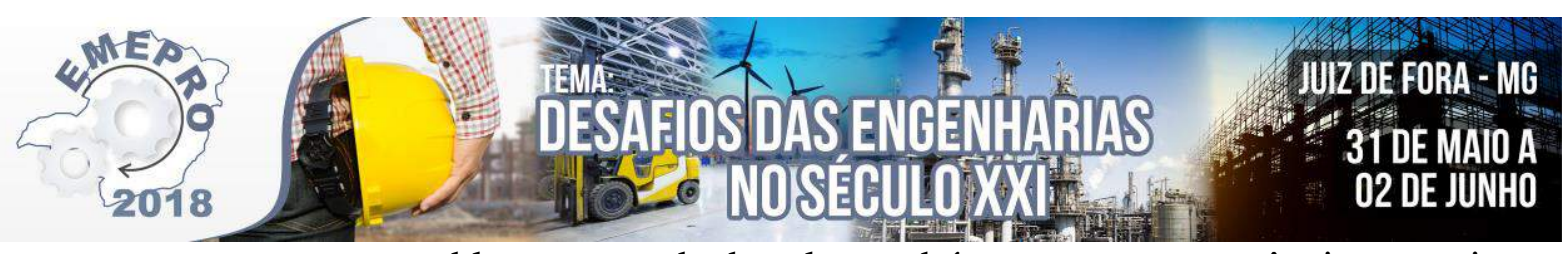

representarem um grave problema na perda de solo, também trazem consequiências negativas relacionadas à deslizamento de terra, assoreamento e contaminação dos cursos d'água (BARROS, 2014). A erosão é classificada de acordo com o agente atuante, podendo ser a água, o vento ou geleiras (MAGALHÃES, 2001).

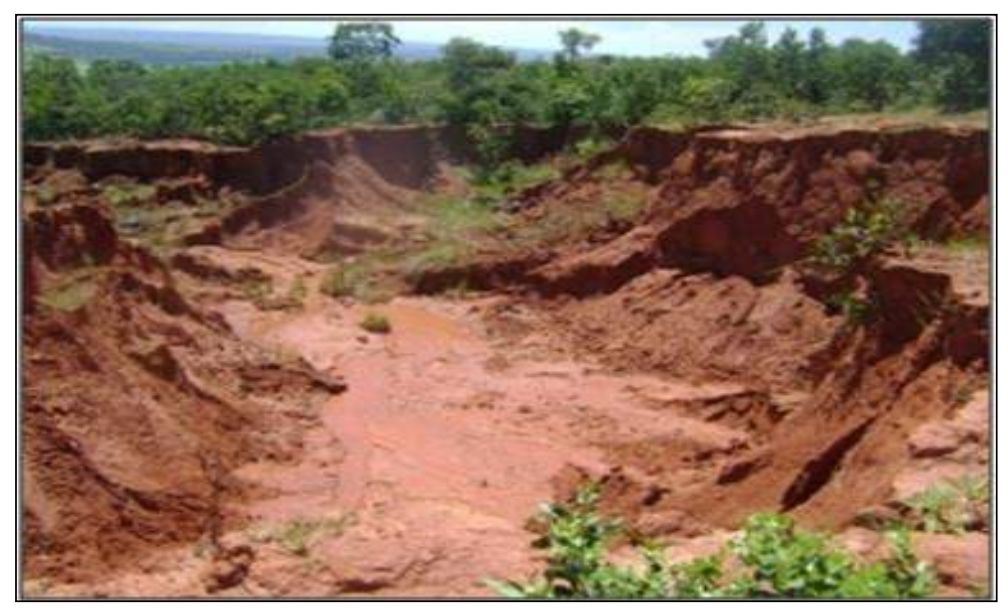

FIGURA 2 - Processo Erosivo. Fonte: Caapuãetê (2016).

\subsection{Movimentos de Massa}

São classificados de acordo com uma série de características, e para Pinto et al. (2012), estão relacionadas ao tipo de material envolvido e a velocidade do deslocamento. Os movimentos são: deslizamentos, escorregamento, ruptura de taludes, quedas de barreiras, dentre outros (Centro Nacional de Monitoramento e Alertas de Desastres Naturais - CEMADEN, 2016).

\subsection{Estruturas de contenção}

Em virtude das alterações que os solos estão expostos e aos processos erosivos, métodos de contenção de encostas vem sendo desenvolvidos e têm como função prover a estabilidade de maciços de terra ou de rocha, prevenindo sua ruptura e consequentes perdas materiais e humanas (BARROS, 2014).De acordo com a Geofoco (2015), as estruturas de contenção são paredes verticais ou quase vertical, apoiadas em uma fundação rasa ou profunda. Existem diversos tipos de métodos de contenção, com diferentes formas e metodologias, dentre eles estão o Gabião, Terramesh ${ }^{\circledR}$ e Muro de Arrimo, objetos do presente estudo.

\subsubsection{Tipos de Estruturas de contenção}

Muros de gabiões são constituídos por gaiolas de telas metálicas de malha hexagonal de dupla torção, preenchidas por pedras arrumadas manualmente, de acordo Figura 3. A rede metálica que compõe as telas dos gabiões apresenta resistência mecânica elevada, pois em casos de ruptura de um dos arames, a dupla torção assegura a forma e a flexibilidade da gaiola (GERSCOVICH, 2015). Este tipo de muro de contenção possui ainda a vantagem na simplicidade de construção e a dispensa de dispositivos de drenagem, por já possuir material drenante. Além disso, destaca-se a redução do custo, principalmente quando já existem blocos de rochas disponíveis no local e que a estabilidade interna do muro requer blocos de dimensões regulares, para que exista menor atrito entre as pedras (GERSCOVICH, 2015). 


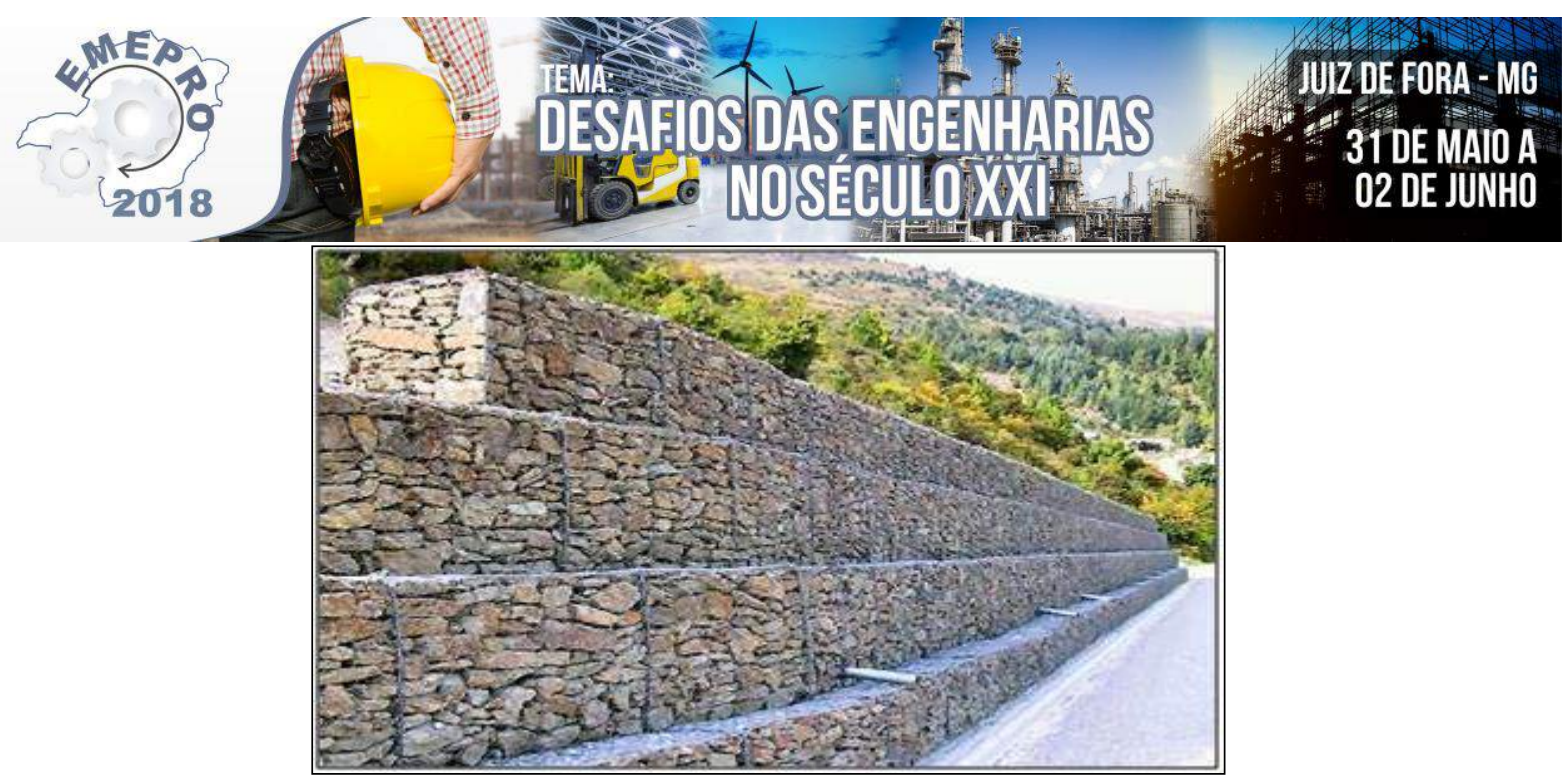

FIGURA 3 - Muro de Gabião. Fonte: CYPE Ingenieros S.A. (2016).

Outro tipo de contenção em encostas é a Terramesh ${ }^{\circledR}$, trata-se da execução de uma estrutura de contenção em solo reforçado com fitas metálicas e placas frontais de concreto. A estrutura Terramesh $^{\circledR}$ possibilita o uso de materiais do local, como também tem facilidade de aplicação em áreas onde os taludes estão mais íngremes, em locais de difícil acesso, apoio sobre o solo natural e a não necessidade de execuções de fundações específicas (ANANIAS et al. 2009).

Ainda segundo Ananias et al., (2009), a estrutura Terramesh ${ }^{\circledR}$, possui vantagens quanto à permeabilidade, possibilitando eficiência na drenagem do local, versatilidade quanto à construção, pois permite que as estruturas estejam em parâmetro frontal vertical, inclinado ou com degraus. Além disso, o mesmo autor afirma que os impactos ambientais sejam reduzidos, pois assim como o gabião, a Terramesh ${ }^{\circledR}$, possibilita a inserção de vegetação na estrutura, o que de fato ajuda a harmonizar e reduzir os efeitos agressivos das intervenções. Na Figura 4 observa-se um exemplo de estrutura Terramesh ${ }^{\circledR}$.

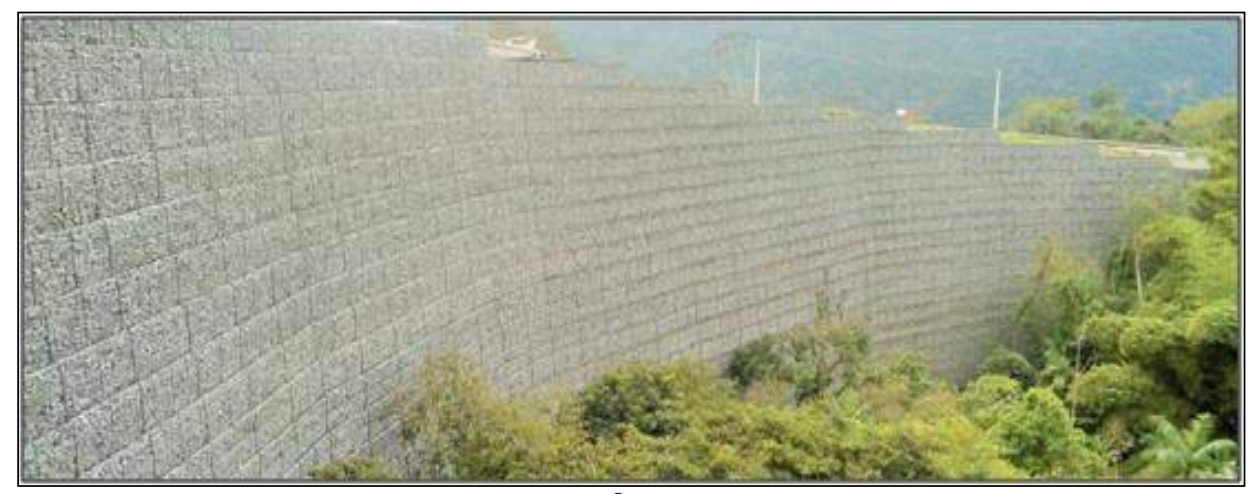

FIGURA 4 - Estrutura Terramesh ${ }^{\circledR}$. Fonte: Maccaferri (2016).

Já o Muro de Arrimo, demostrado na Figura 5, são estruturas de contenção criadas com o intuito de resistir aos empuxos laterais de terra ou água, são utilizados quando existe uma mudança íngreme de elevação do terreno, podendo gerar risco de escorregamentos (BONISSONI, 2017). Estes muros são estruturas construídas em terrenos para sustentação do solo, onde o próprio peso é o responsável pela sua estabilidade, além disso, também isolam um determinado local (DOMINGUES, 1997).

Muros de arrimo são elementos localizados em obras de estabilização de taludes e encostas, em regiões íngremes, junto às edificações, estradas ou ruas (DUARTE, 2013). De acordo com Lobo et al. (2003), os muros de arrimo são muito utilizados em áreas urbanas, quando se 


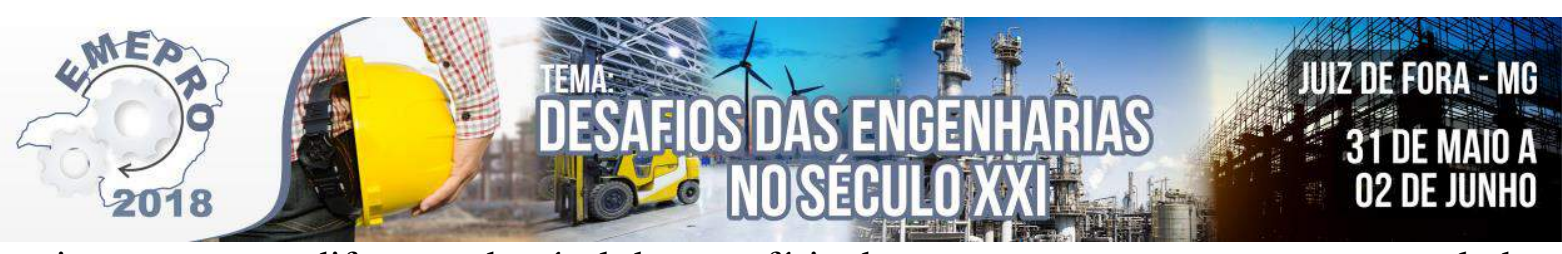

deseja manter uma diferença de nível da superfície do terreno, sem ter que recorrer a taludes, pois se perde uma grande área ao recorrer a este recurso.

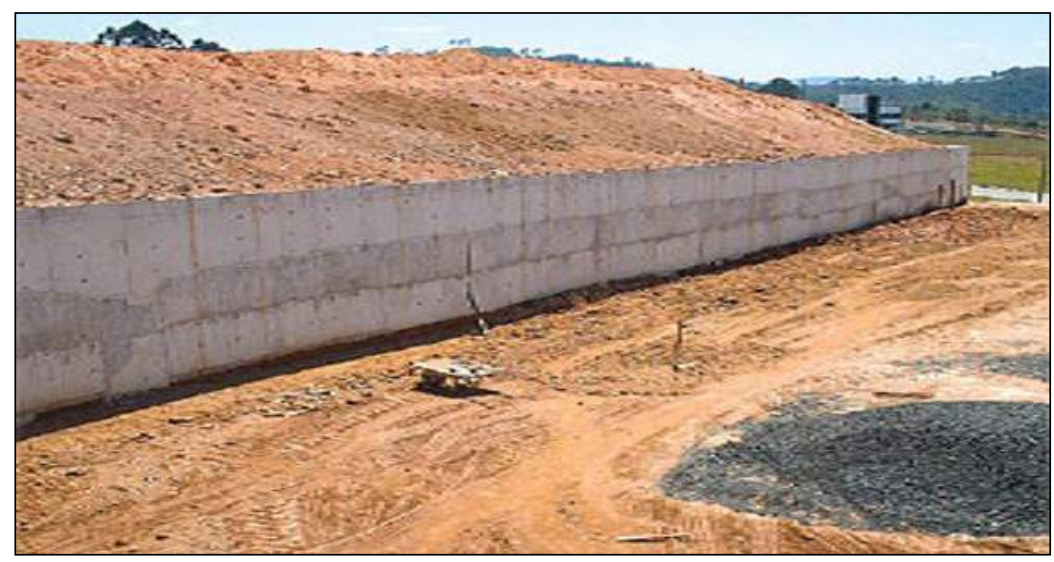

FIGURA 5 - Muro de Arrimo. Fonte: Schramm (2016).

\section{Metodologia}

Utilizou-se como metodologia uma pesquisa quali-quantitativa exploratória, com levantamento de dados na literatura em livros e artigos publicados em periódicos. É um estudo de caso com pesquisa aplicada. Para Cesar (2006) este tipo de pesquisa enquadra-se como uma abordagem qualitativa, na qual é frequentemente utilizado para coleta de dados nas áreas de estudos organizacionais. E realizam-se através de dados baseados em livros, jornais, revistas, sites da internet e visitas ao local estudado (VERGARA, 2007).

\subsection{Caracterização da área de Estudo}

Trata-se de uma área pertencente a empresa Via Sul Engenharia Ltda, que atua no mercado imobiliário há cerca de 10 anos, em diversos estados brasileiros. Seu foco principal é a construção de conjuntos habitacionais do programa Minha Casa Minha Vida 3 e sua sede está situada no município de Belo Horizonte/MG. O terreno do empreendimento imobiliário, do tipo multifamiliar, denominado Villa Atlântica, onde foi implantada a estrutura de contenção está localizado no município de Pará de Minas/MG, na Rua Antônio Rocha, s/n, Bairro José do Bem-Vindo. Possui área útil de $13.714,94 \mathrm{~m}^{2}$ e é drenado em sua porção Leste pelo Córrego Ribeirão da Paciência, integrante da Bacia Hidrográfica do Rio São Francisco. Do ponto de vista da cobertura vegetal, a área insere-se no bioma Mata Atlântica.

\subsection{Universo e Amostra da pesquisa}

O Universo estudado foi metodos de contenção para encostas ambientalmente sustentaveis. A amostra da pesquisa foi a encosta do conjunto habitacional denominado Residencial Villa Atlântica, da cidade Pára de Minas/MG, onde foi construída a estrutura de contenção.

\subsection{Coletas de dados}

O objetivo principal da presente pesquisa é a análise comparativa do melhor método de contenção em enconstas a ser aplicado em um empreendimento situado no município de Pára de Minas/MG, no qual foram coletados dados com a empresa responsável pelo empreendimento, para que fossem esclarecidos os objetivos propostos. 


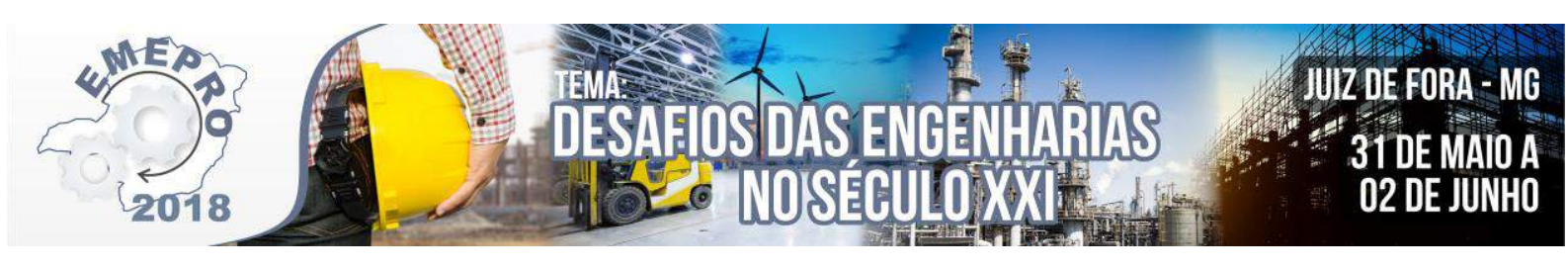

O processo de coleta de dados no estudo de caso é mais complexo que o de outras modalidades de pesquisa. Isso porque na maioria das pesquisas utiliza-se uma técnica básica para a obtenção de dados, embora outras técnicas possam ser utilizadas de forma complementar (GIL, 2002, p. 140).

De acordo com o objetivo acima citado, foram efetuadas as seguintes ações para obtenção dos dados necessários:

a) Duas visitas à área do empreendimento, sendo uma em setembro de 2017, para conhecimento da área e outra em janeiro de 2018, para análise da área, solo, vegetação e características gerais.

b) Em janeiro de 2018 foi realizada uma visita à Prefeitura Municipal de Pára de Minas/MG, para pesquisar características gerais do empreendimento.

c) Análise de documentos internos da empresa responsável pelo empreendimento, relatórios de caracterização da área, projetos, ordens, gráficos e planilhas de serviços, documentos referentes à licenciamento junto aos órgãos competentes.

d) Para o levantamento dos custos da implantação de cada método, foram feitos orçamentos em 3 empresas distintas para cada tipo de contenção, onde no intuito de manter a confidencialidade e segurança da informação quanto aos seus dados, foram usados nomes fictícios no capítulo de Análise e Discussão dos Resultados. As empresas foram denominadas como: Empresas Gabião GA, GB e GC; Empresas Terramesh ${ }^{\circledR}$ TA, TB e TC; Empresas Muro de Arrimo MA, MB e MC. Não serão divulgados neste trabalho dados comerciais, nem tampouco informações industriais beneficiando qualquer tipo de empresa.

\subsection{Análise de dados}

Os dados foram tabulados no programa do Excel, sendo criadas planilhas de comparação de preços para que se equalizassem os valores econômicos de cada método, apresentando o preço por $\mathrm{m}^{2}$. Considerou como fator limitante para a pesquisa, a dificuldade na coleta de dados e informações junto à empresa responsável pela obra, por alegação de sigilo empresarial.

\section{Resultados e Discussão}

Observou-se que a porção onde será realizada a contenção, localiza-se na divisa Leste do empreendimento "Vila Atlântica", junto à área de preservação permanente (APP) do Córrego Ribeirão da Paciência, conforme Figura 6, o que reiterou a necessidade de promover a obra no local, de modo a evitar a instalação de processos erosivos e o consequente carreamento de material inconsolidado até a calha do mencionado recurso hídrico, além do melhor aproveitamento da área util. Para avaliar o tipo de solo foram realizados pelo empreendedor furos de sondagem no terreno, que tiveram como resultados a existência de uma camada pedológica superficial formada por aterro argilo-arenoso, que possui maior quantidade de argila e menos de areia, com incorporação de materiais alóctones (matacões e outros). 


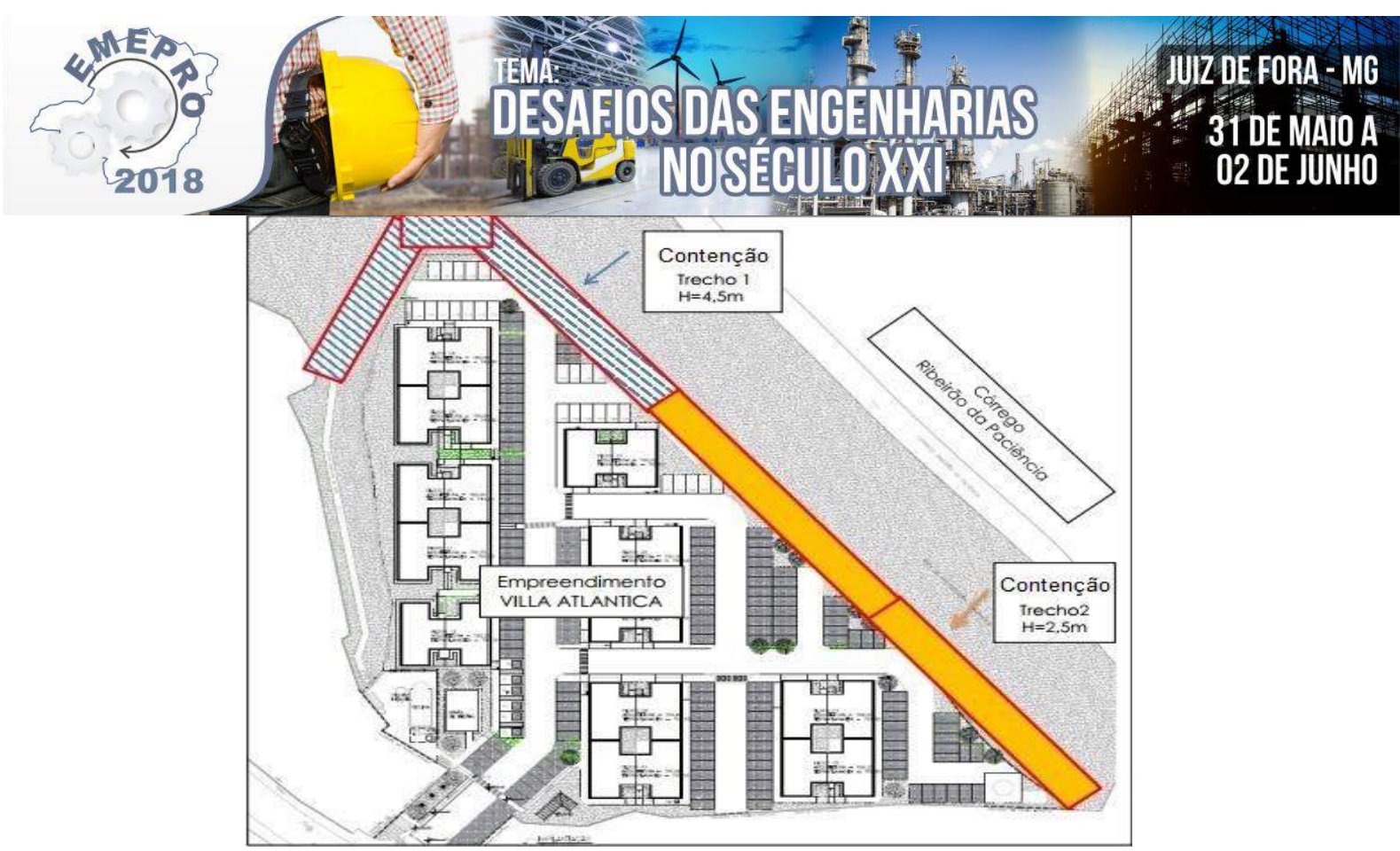

FIGURA 6 - Localização da área de implantação da contenção. Fonte: Via Sul Engenharia Ltda (2018).

Encontraram-se na literatura os seguintes critérios de avaliação ambiental e econômica na construção dos três métodos de contenção: Gabião, Terramesh ${ }^{\circledR}$ e Muro de Arrimo.

\subsection{Método tipo Gabião}

\subsubsection{Aspectos Ambientais}

- Benefícios ambientais devido ao uso de um recurso natural não renovável (pedra) (GERSCOVICH, 2015);

- Baixo impacto ambiental devido a sua composição, principalmente em obras de proteção hidráulica, o gabião não interpõe obstáculo impermeável para as água de infiltração e percolação, e interfere o mínimo possível na fauna e flora local (DALDEGAN, 2017);

- Esse tipo de estrutura integra-se rapidamente ao meio circundante, ou seja, possibilita que o ecossistema, anterior à obra, se recupere quase que totalmente (DALDEGAN, 2017);

- Retardamento de processos erosivos (GERSCOVICH, 2015);

- Este tipo de estrutura permite a sua integração com o meio ambiente ao permitir o crescimento de plantas ou gramíneas na sua superfície (DALDEGAN, 2017).

\subsubsection{Aspectos Econômicos}

- Não exige mão-de-obra especializada para sua construção (FINOTTI et al. 2013);

- Quando se opta por enchimento mecânico dos elementos, pode ser utilizado qualquer tipo de equipamento destinado à terraplanagem e escavações (GERSCOVICH, 2015);

- Quando comparadas com outros tipos de contenção, com mesma resistência estrutural, apresentam custos diretos e indiretos mais baixos (FINOTTI et al. 2013);

- Pode ser construída em etapas, de acordo com o balanço financeiro da obra (GERSCOVICH, 2015);

- Baixo custo, pelo fato de poder utilizar o recurso natural disponível no próprio local da obra (GERSCOVICH, 2015).

A Tabela 1 apresenta os valores aplicados no mercado para o tipo de contenção por Gabião, nesses valores estão inclusos gastos com material, equipamento e mão de obra na unidade de $\mathrm{m}^{2}$. 


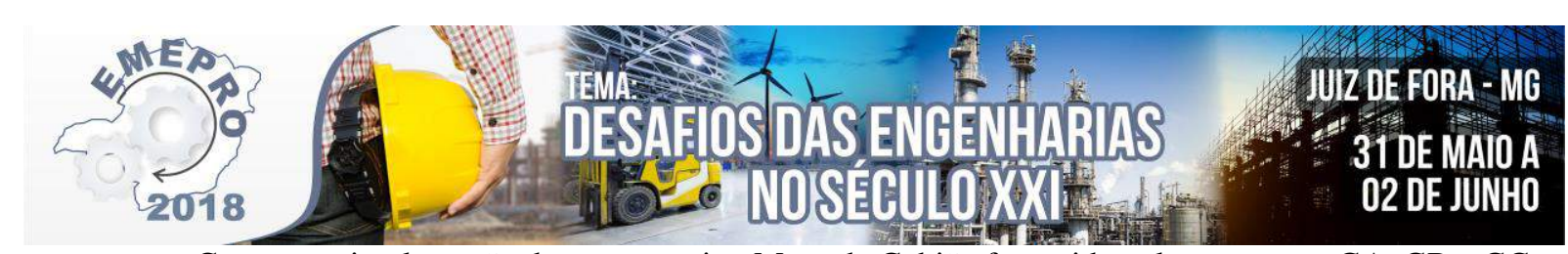

TABELA 1 - Custo para implantação da estrutura tipo Muro de Gabião fornecido pelas empresas GA, GB e GC.

\begin{tabular}{|c|c|c|}
\hline EMPRESA GA & EMPRESA GB & EMPRESA GC \\
\hline Custo Total R\$ 1.982,69/m² & Custo Total R $\$ \mathbf{2 . 0 6 2 , 6 7 / \mathbf { m } ^ { 2 }}$ & Custo Total R\$ $\mathbf{2 . 1 2 0 , 5 0 / \mathbf { m } ^ { 2 }}$ \\
\hline
\end{tabular}

Fonte: (Empresas GA, GB e GC, 2018).

\subsection{Método tipo Terramesh ${ }^{\circledR}$}

\subsubsection{Aspectos Ambientais}

- Possui vantagens quanto à permeabilidade, possibilitando eficiência na drenagem do local (ANANIAS et al. 2009);

-Este tipo de método, possibilita a inserção de vegetação na estrutura, o que de fato ajuda a harmonizar e reduzir os efeitos agressivos das intervenções (BRITO, 2003);

- Retardamento de processos erosivos (BRITO, 2003);

- Flexibilidade que garante à estrutura capacidade de absorver assentamentos diferentes do terreno mantendo sua integridade (ANANIAS et al. 2009);

- Segurança estrutural em caso de incêndios (ANANIAS et al. 2009).

\subsubsection{Aspectos Econômicos}

- Simplicidade construtiva, consequente, menos gastos, pois o parâmetro externo e a armadura de reforço constituem uma única estrutura que é fabricada à medida (BRITO,2003).

Na Tabela 2 encontra-se demonstrado o custo de implantação do método de contenção tipo Terramesh, onde o valor apresentado por metro quadrado engloba valores de material, equipamento e mão de obra.

TABELA 2 - Custo para implantação da estrutura tipo Terramesh ${ }^{\circledR}$ fornecido pelas empresas GA, GB e GC.

\begin{tabular}{c|c|c}
\hline EMPRESA TA & EMPRESA TB & EMPRESA TC \\
\hline Custo Total R $\$ \mathbf{2 . 2 8 2 , 5 2} / \mathrm{m}^{\mathbf{2}}$ & Custo Total R $\$ \mathbf{2 . 3 6 7 , 5 7} / \mathrm{m}^{\mathbf{2}}$ & Custo Total $\mathrm{R} \$ \mathbf{2 . 6 7 3 , 5 0} / \mathrm{m}^{\mathbf{2}}$ \\
\hline
\end{tabular}

Fonte: (Empresas TA, TB e TC, 2018).

\subsection{Método tipo Muro de Arrimo:}

\subsubsection{Aspectos Ambientais}

- Para a construção deste tipo de muro é necessário evitar escavação no terreno natural, para não ocorrer instabilidade. Diferente do muro de gabião e Terramesh ${ }^{\circledR}$, o muro de arrimo necessita que seja construído também um sistema de drenagem adequado (DUARTE, 2013);

- Os muros de arrimo não podem ser construídos em locais com solo mole ou ainda a localização próxima a pontos com grande acúmulo ou surgência de água (BONISSONI, 2017).

- Retardamento de processos erosivos (DOMINGUES, 1997).

\subsubsection{Aspectos Econômicos}

- Elevado ônus no orçamento total de uma obra, devido aos altos gastos com concreto e aço (GERSCOVICH, 2015);

- No muro de arrimo é utilizado concreto, esse tipo de material tem suas vantagens e desvantagens, pois é um material com boa resistência mecânica de compressão, mas é péssimo de resistência à tração, ou seja, quando recebe uma sobrecarga além daquela para qual foi projetado, pode sofrer ruptura imediata (FERRETI, 2016). 


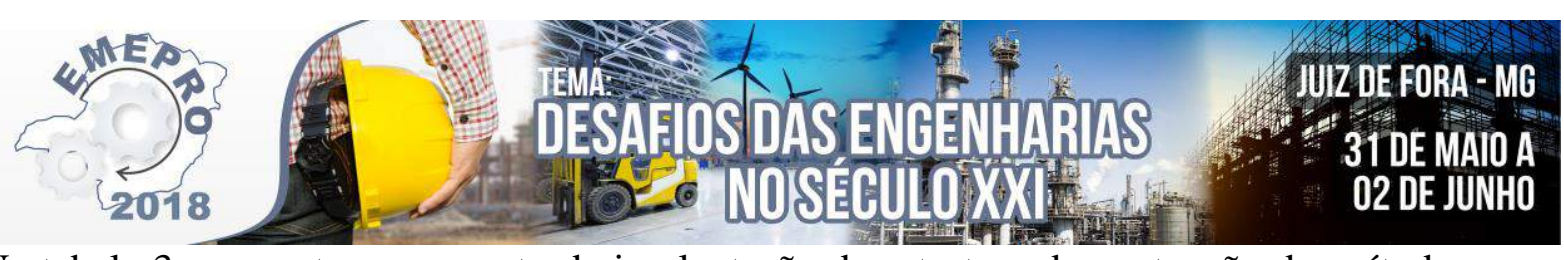

Na tabela 3 apresentamos o custo de implantação da estrutura de contenção do método muro de Arrimo, onde as empresas MA, MB e MC demostram seus valores aplicados no mercado por $\mathrm{m}^{2}$ englobando materiais, equipamentos e mão de obra.

TABELA 3 - Custo de implantação da estrutura tipo Muro de Arrimo fornecido pelas empresas MA, MB e MC.

\begin{tabular}{c|c|c}
\hline EMPRESA MA & EMPRESA MB & EMPRESA MC \\
\hline Custo Total R\$ 7.301,46/m² & Custo Total R $\$ \mathbf{7 . 5 9 6 , 7 8} / \mathrm{m}^{\mathbf{2}}$ & Custo Total $\mathrm{R} \$ \mathbf{7 . 3 7 5 , 5 0} / \mathrm{m}^{\mathbf{2}}$ \\
\hline
\end{tabular}

Fonte: Empresas MA, MB e MC, (2018).

Para observar o melhor método a ser aplicada, a Tabela 4, apresenta um comparativo demonstrando o grau de interferência entre os métodos de contenção estudados, sendo baixo e alto o grau de interferência em relação aos outros métodos, levando em consideração parâmetros ambientais, econômicos e a necessidade da empresa.

TABELA 4 - Comparativa Econômica e Ambiental

\begin{tabular}{|c|c|c|c|c|c|c|}
\hline \multicolumn{7}{|c|}{ COMPARATIVO ECONÔMICO E AMBIENTAL } \\
\hline \multirow{3}{*}{ COMPARATIVO AMBIENTAL } & \multicolumn{2}{|c|}{ GABIÃO } & \multicolumn{2}{|c|}{ TERRAMESH ${ }^{\circledR}$} & \multicolumn{2}{|c|}{ ARRIMO } \\
\hline & \multicolumn{6}{|c|}{ GRAU DE INTERFERÊNCIA } \\
\hline & Baixo & Alto & Baixo & Alto & Baixo & Alto \\
\hline Impacto Ambiental & $\mathrm{x}$ & & $\mathrm{x}$ & & & $x$ \\
\hline Interferência no lençol freático & $x$ & & $x$ & & & $\mathrm{x}$ \\
\hline Fauna e flora & $\mathrm{x}$ & & $x$ & & & $\mathrm{x}$ \\
\hline Utilização de equipamentos grande porte & $\mathrm{x}$ & & $\mathrm{x}$ & & & $\mathrm{x}$ \\
\hline Parâmetros Geotécnicos & $\mathrm{x}$ & & $x$ & & & $x$ \\
\hline Preparação da Fundação & $\mathrm{x}$ & & $x$ & & & $x$ \\
\hline Verificação dos esforços atuantes & & $\mathrm{x}$ & & $\mathrm{x}$ & & $\mathrm{x}$ \\
\hline Área implantação (Praça de trabalho) & $\mathrm{x}$ & & & $x$ & $\mathrm{x}$ & \\
\hline Estrutura Permeável e Drenante & & $\mathrm{x}$ & & $\mathrm{x}$ & $x$ & \\
\hline Flexibilidade Estrutural & & $x$ & & $x$ & $x$ & \\
\hline Execução (Tempo de Cura) & $\mathrm{x}$ & & $\mathrm{x}$ & & & $\mathrm{x}$ \\
\hline Redução na velocidade do curso d'água & & $x$ & & $x$ & $x$ & \\
\hline Integração Paisagística & & $x$ & & $\mathrm{x}$ & $x$ & \\
\hline Durabilidade (No caso da obra) & & $x$ & & $x$ & $x$ & \\
\hline Obra Sustentável & & $x$ & & $\mathrm{x}$ & $x$ & \\
\hline Movimentação de solo & $\mathrm{x}$ & & $\mathrm{x}$ & & & $\mathrm{x}$ \\
\hline Projeto de Drenagem & $x$ & & $x$ & & & $x$ \\
\hline \multicolumn{7}{|l|}{ COMPARATIVO ECONÔMICO } \\
\hline Equipamentos & $\mathrm{x}$ & & & $\mathrm{x}$ & & $x$ \\
\hline Mão de obra & $\mathrm{x}$ & & & $x$ & & $\mathrm{x}$ \\
\hline Material & $\mathrm{x}$ & & $\mathrm{x}$ & & & $x$ \\
\hline
\end{tabular}

Fonte: Lázaro César,(2018).

\section{Considerações Finais}

O processo de urbanização e uma das formas mais agressivas de relacionamento entre o homem e meio ambiente. Este processo se dá devido ao crescimento desordenado das metrópoles, acarretando assim cada vez mais o desenvolvimento de métodos para atender o 


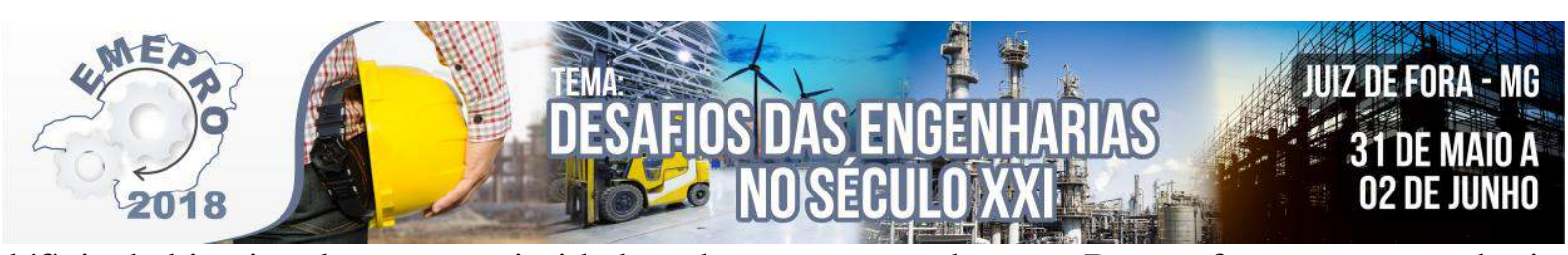

déficit habitacional nas proximidades dos centros urbanos. Dessa forma a engenharia apresenta métodos para contenção de encostas, para que seja mais bem aproveitado as áreas antes inabitáveis, métodos estes que buscam a integração entre o meio e as obras civis.

No presente trabalho apresentamos três métodos que atendem a necessidade da empresa Via Sul na obra em questão. Para a escolha do método de contenção, levamos em consideração não apenas o valor econômico, mas também o método que menos impactaria na região e na Área de Preservação que delimita o terreno.

Através dessa avaliação podemos observar que os métodos apresentam influencia no parâmetro ambiental e econômico entre si. $\mathrm{O}$ método do muro de arrimo apresenta menor prazo para implantação, mas também apresenta maior interferência no meio ambiente. $\mathrm{O}$ método por Terramesh ${ }^{\circledR}$ se torna inviável devido ao valor econômico e também a interferência causada no meio ambiente. Com estas circunstancias chegamos ao método que menos interfere ao meio ambiente e possui menor valor econômico em relação aos outros métodos, o método de contenção por gabião que nada mais e que uma armação de aço retangular onde se adiciona a rocha (pedra de mão), para que não ocorra a movimentação do maciço.

O método de contenção por gabião em um método ambientalmente correto visto que além de exercer a função de estabilidade do maciço, promove uma maior e mais rápida integração entre o meio ambiente e a intervenção civil que ocorreu no local.

Por se tratar de uma Área de Preservação Permanente, a execução da obra esta acondicionada a apresentação da documentação necessária junto aos órgãos ambientais para que a mesma seja implantada.

\section{Referências}

ANANIAS, E.J.; CAMPOS, G.O.; SILVEIRA, J.E.S. Muro de contenção em terramesh e geogrelhas para a contenção de britagem primária em mineração - Alto Horizonte/GO. Disponível em: < http://igsbrasil.org.br/wp-content/uploads/2017/12/CCO-2014-Muro-de-conten\%C3\%A7\%C3\%A3o-emterramesh-e-geogrelhas-para-a-conten $\% \mathrm{C} 3 \% \mathrm{~A} 7 \% \mathrm{C} 3 \% \mathrm{~A} 30-$ de-britagem-prim\%C3\%A1ria-emminera\%C3\%A7\%C3\%A3o.pdf> Acesso em: 27/03/2018.

BARROS, P. L. A. Obras de contenção. Disponível em <https://www.aecweb.com.br/cls/catalogos/maccaferri/obras_de_contencao_opt.pdf> Acesso em: 15/10/2017.

BONISSONI, L. Dimensionamento e execução de muros de arrimo em alvenaria estrutural. 2017. Disponível em:<http://coral.ufsm.br/engcivil/images/PDF/2_2016/TCC_LUCAS\%20BONISSONI.pdf> Acesso em 02/02/2018.

BRANCO, P. M.; Os Solos. Disponível em: <http://www.cprm.gov.br/publique/Redes-Institucionais/Rede-deBibliotecas---Rede-Ametista/Canal-Escola/Os-Solos-2620.html> Acesso em: 28/10/2017.

CAAPUÃETÊ. Engenharia Ambiental. Disponível em: <http://caapuaete.com.br/> Acesso em: 27/11/2017.

CEMADEN. Movimento de Massa. Disponível em: <http://www.cemaden.gov.br/deslizamentos/> Acesso em: $30 / 10 / 2017$.

CESAR, A. M. R. V. C. Método do Estudo de Caso (Case Studies) ou Método do Caso (Teaching Cases)? Uma análise dos dois métodos no Ensino e Pesquisa em Administração. São Paulo, Mackenzie, 2006. 


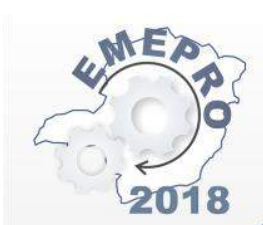

CYPE,

Ingenieros.

Gabião.

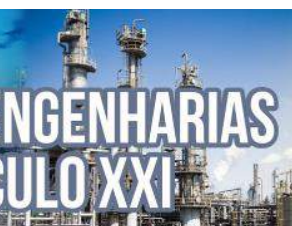

Disponível

gabioes.html> Acesso em: 29/11/2017.

DOMINGUES, P.C. Indicações para projeto de muros de arrimo em concreto armado. 1997. Disponível em: <http://web.set.eesc.usp.br/static/data/producao/1997ME_PauloCesarDomingues.pdf> Acesso em: $27 / 11 / 2017$

DUARTE, M.P. Estabilidade de talude e muro de arrimo. 2013. Disponível em: <http://www.bibliotecadigital.ufmg.br/dspace/bitstream/handle/1843/BUBD-

9GFJNM/monografia_estabilidade_de_talude_2013.pdf?sequence=1> Acesso em: 20/01/2018.

EMBRAPA - Classificação dos Solos. Disponível em: <https://www.embrapa.br/solos/sibcs/classificacao-desolos>. Acesso em 01/11/2017.

FABBRIS, E.; MANFIO, D.A.L.; VALDAMERI, G.; BRUM, J.P.; Porosidade do solo. Disponível em: <http://www.cafw.ufsm.br/mostraciencias/2011/resumos/209.pdf> Acesso em: 30/03/2018.

FERRETI, P.C.B. Muro de arrimo. Disponível em: < https://www.aecweb.com.br/cont/m/rev/muro-de-arrimoprojeto-exige-estudo-do-solo_9687_10_0> Acesso em: 25/03/2018.

GEOFOCO. Conheça os diferentes tipos de muro de contenção. Disponível em: <http://geofoco.com.br/conheca-os-diferentes-tipos-de-muro-de-contencao/> Acesso em: 14/11/2017.

GERSCOVICH, D.M.S.; Estruturas de Contenção - Muros de arrimo. Disponível em: <http://www.eng.uerj.br/ denise/pdf/muros.pdf> 2015. Acesso em: 18/10/2017

JUNIOR, G.B.S.; Estudo numérico do comportamento de muros de arrimo em alvenaria estrutural de blocos vazados. Disponível em: <https://repositorio.ufrn.br/jspui/bitstream/123456789/14854/1/GilvanBSJ_DISSERT.pdf> Acesso em: $27 / 03 / 2018$

LOBO, A.S., FERREIRA, C.V., RENOFIO, A. Muros de arrimo em solos colapsíveis provenientes do arenito Bauru: problemas executivos e influência em edificações vizinhas em áreas urbanas. 2003. Disponível em:<http://eduem.uem.br/ojs/index.php/ActaSciTechnol/article/view/2191/1335> Acesso em: $18 / 01 / 2018$.

LORENZO, M. Propriedades e Atributos Físicos do solo. Disponível em: <https://marianaplorenzo.com/2010/10/16/pedologia-\%E2\%80\%93-morfologia-estrutura-do-solo/> Acesso em: 23/03/2018.

MC ENGENHARIA. Terramesh System. Disponível em: <http://mcengenhariabrasil.com.br/servicosterramesh.php> Acesso em: 27/11/2017;

MAGALHÃES, R.A. Erosão: Definições, tipos e formas de controle. Disponível em: <http://www.cbdb.org.br/documentos/L3363.PDF> Acesso em: 12/01/2018.

MENDONÇA, A.K. Estudo comparativo de duas estruturas de contenção em uma obra em Goiânia/Go. Goiânia, 2015.2 Disponível em: <https://www.eec.ufg.br/up/140/o/ESTUDO_COMPARATIVO_DE_DUAS_ESTRUTURAS_DE_CONTEN\% C3\%87\%C3\%83O_EM_UMA_OBRA_EM_GOI\%C3\%82NIAGO.pdf> Acesso em: 10/09/2017.

PINOTTI, A. M.; Técnicas de Geologia Estrutural para previsão e contenção de queda de blocos em encostas: Aplicação na área do granito Santos. Santos, SP, 2011. Disponível em

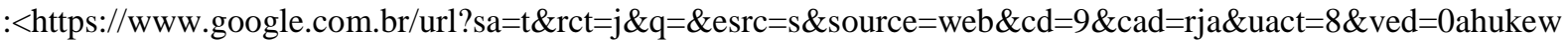
ivweq7lqhxahvklzakha1gad0qfgg8mag\&url=http $\% 3 \mathrm{a} \% 2 \mathrm{f} \% 2 \mathrm{fwww} \cdot$ bibliotecadigital.unicamp.br $\% 2 \mathrm{fdocument} \%$ 2f\%3fdown\%3d000797588\&usg=aovvaw1bssv66saiqewlkygyf2xs> Acesso em: 29/10/2017. 


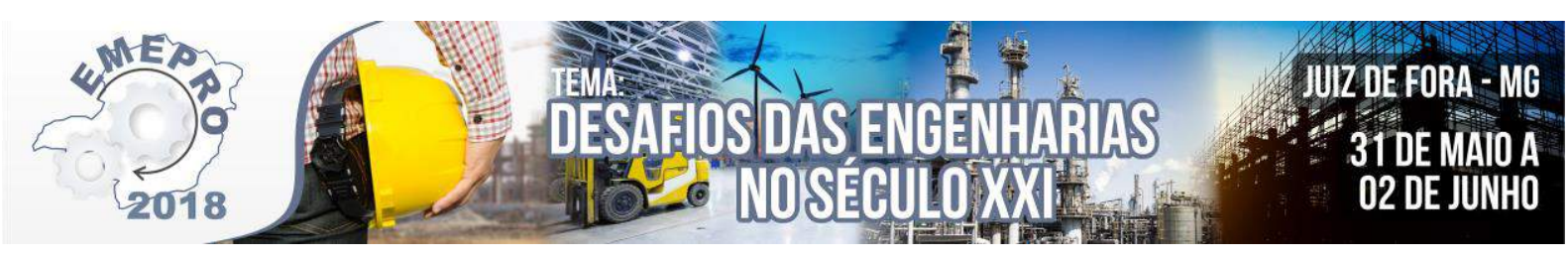

PINTO, R.C., PASSOS, E., CANEPARO, S.C. Classificação dos movimentos de massa ocorridos em Março de 2011 na Serra da Prata, Estado do Paraná. Disponível em: $<$ https://www.google.com.br/url?sa=t\&rct=j\&q=\&esrc=s\&source=web\&cd=12\&cad=rja\&uact=8\&ved=0ahUK EwjWy6fajeTXAhWCHZAKHcgZCTU4ChAWCCwwAQ\&url=http\%3A\%2F\%2Feduem.uem.br\%2Fojs\%2Fin dex.php\%2FGeoinga\%2Farticle\%2Fdownload\%2F18951\%2F10252\&usg=AOvVaw21Aj5CZueMBzUMI8uBD K_s> Acesso em: 26/11/2017.

RIBEIRO, K.D., MENEZES, S.M.; MESQUITA, M.G.B.F.; SAMPAIO, F.M.T.; Propriedades físicas do solo, influenciadas pela distribuição de poros, de seis classes de solos da região de Lavras/MG. Disponível em: <http://www.scielo.br/pdf/cagro/v31n4/33.pdf> Acesso em: 29/03/2018.

SCHARAMM. Enrocamento de Pedras e Drenagens Pluviais. 2016. Disponível em: <http://www.terraplanagemschramm.com.br/produto/view/0005-enrocamento-de-pedras-e-drenagenspluviais\#.WiCMJFVKu00> Acesso em: 29/11/2017.

VERGARA, S.C. Projetos e relatórios de pesquisa em administração. 9 ed. São Paulo: Atlas, 2007.

VIA SUL ENGENHARIA. Disponível em: < http://viasul.com/> Acesso em: 10/01/2018.

ZEE - Zoneamento Ecológico Econômico de Minas Gerais. Disponível em: <http://geosisemanet.meioambiente.mg.gov.br/zee/> Acesso em: 15/03/2018. 


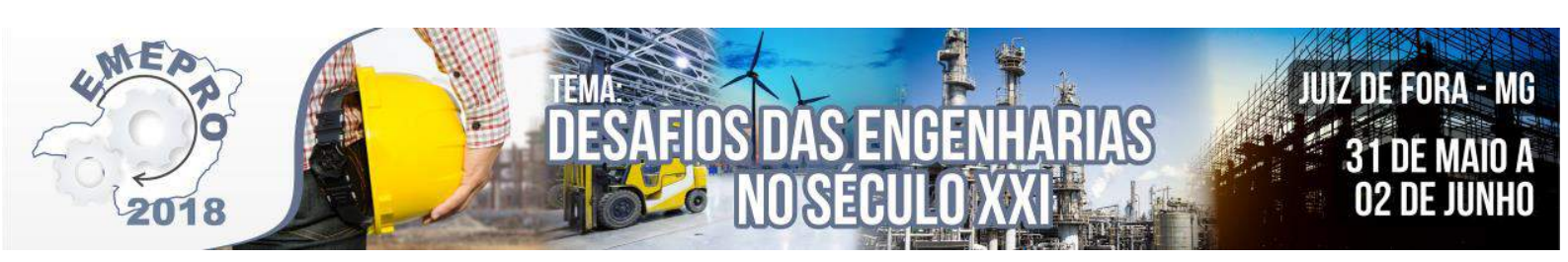

\title{
Logística Reversa e Reciclagem de pilhas e baterias no Brasil: geração de vantagem competitiva baseada no estudo de caso de uma indústria metalúrgica
}

\author{
Caroline Brasileiro Pena (UFJF) caroline.brasileiro@engenharia.ufjf.br \\ Aleson Lameck Pinheiro (UFJF) aleson.lameck@engenharia.ufjf.br \\ Júlia Moreira Santos Teixeira (UFJF) julia.moreira@engenharia.ufjf.br \\ Taynara Polyanna Rocha Costa (UFJF) polyanna.costa@engenharia.ufjf.br
}

Resumo: A logística reversa trata do retorno dos bens ao ciclo produtivo com a finalidade de recapturar valor ou destiná-los adequadamente. O presente artigo é um breve estudo de como a logística reversa de pilhas e baterias no Brasil pode ser uma oportunidade de gerar vantagem competitiva e como a gestão ambiental influencia tal desempenho através de uma análise em uma organização multinacional brasileira do setor metalúrgico. Desta forma, pode-se perceber que o controle desses produtos ainda é irrisório. Foi utilizada uma pesquisa com caráter exploratório e qualitativo, face ao aprofundamento do referencial bibliográfico disponível e por meio de entrevistas, gerando um estudo de caso.

Palavras-chave: Logística reversa; Vantagem competitiva; Gestão ambiental; Resíduos eletroeletrônicos.

\section{Introdução}

Com a crescente globalização, as empresas enfrentam um mercado cada vez mais competitivo, sendo obrigadas a criar estratégias de diferenciação para satisfazer os interesses dos stakeholders e se manter no mercado. Diante disso, as empresas viram na gestão ambiental uma oportunidade de estratégia competitiva, indo além do simples cumprimento das exigências legais (SHIBAO; MOORI; SANTOS, 2010).

De acordo com Silva e Colmenero (2010), a logística reversa não se restringe a questões ambientais e ecológicas. No seu sentido mais amplo, o processo busca a geração de valor nos produtos retornados, gerando vantagem competitiva à empresa que a realiza e prolongando o ciclo de vida do produto. Em adição, segundo Leite (2003, apud SILVA, ADILSON; LEITE, 2012), a logística reversa tem o propósito de recapturar valor ou dar o destino adequado aos bens de pós-venda (bens sem uso ou com pouco uso) e de pós-consumo (bens no final da vida útil), satisfazendo os múltiplos interesses, sejam eles das manifestações ecológicas do mercado consumidor, passando uma imagem corporativa ambientalmente responsável ou apenas por exigências legais.

O presente artigo tem como objetivo estudar a logística reversa de pilhas e baterias no Brasil como forma de gerar vantagem competitiva e como a gestão ambiental pode influenciar no desempenho da empresa através de um estudo de caso em uma unidade de uma indústria metalúrgica na cidade de Juiz de Fora.

O procedimento utilizado para sua elaboração foi uma pesquisa com caráter qualitativo, pois foca no caráter subjetivo do estudo analisando as suas particularidades, e 


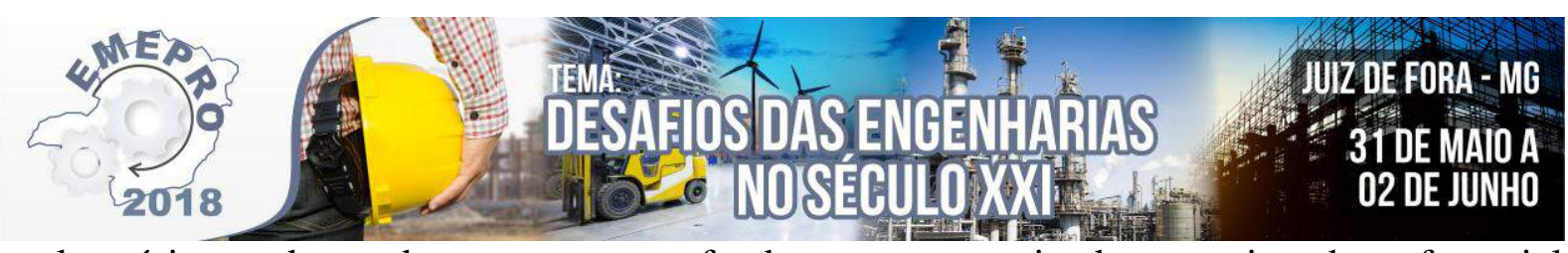

exploratório, onde se buscou um aprofundamento a partir da pesquisa do referencial bibliográfico e por meio de entrevista para embasamento do estudo de caso e familiarização com o assunto abordado.

Este artigo abordará, inicialmente, além desta introdução ao assunto pesquisado, a conceituação teórica de logística reversa. Na sequência, apresenta-se o cenário brasileiro da logística reversa, seguindo-se dos impactos ambientais gerados pelas pilhas e de considerações acerca da logística reversa de pilhas e baterias no Brasil. Por fim, apresenta-se o estudo de caso da Votorantim Metais e se ealizam considerações finais.

\section{Revisão bibliográfica}

\subsection{Logística Reversa: conceito}

Atualmente, a sustentabilidade tem sido um tema bastante discutido e buscado pelas empresas em geral, seja pela consciência sobre a utilização dos recursos e minimização do impacto ambiental ou pelos benefícios acarretados não apenas ao meio ambiente, mas sim para a própria empresa, que procura se tornar cada vez mais competitiva e apresentar produtos de qualidade com os custos cada vez mais reduzidos (SHIBAO; MOORI; SANTOS, 2010). Dessa forma, as empresas se utilizam da "Logística Reversa" para tratar do caminho contrário dos bens produzidos, atentando-se ao melhor aproveitamento de seus resíduos.

A Logística Reversa pode ser definida como:

"Processo do planejamento, implementação e controle da eficiência e custo do fluxo de matérias-primas, estoques em processo, produtos acabados e as informações correlacionadas do ponto do consumo ao ponto de origem com o propósito de recapturar valor ou para uma disposição apropriada."

Reverse Logistics Executive Council (2004, apud SOUZA; FONSECA, 2009)

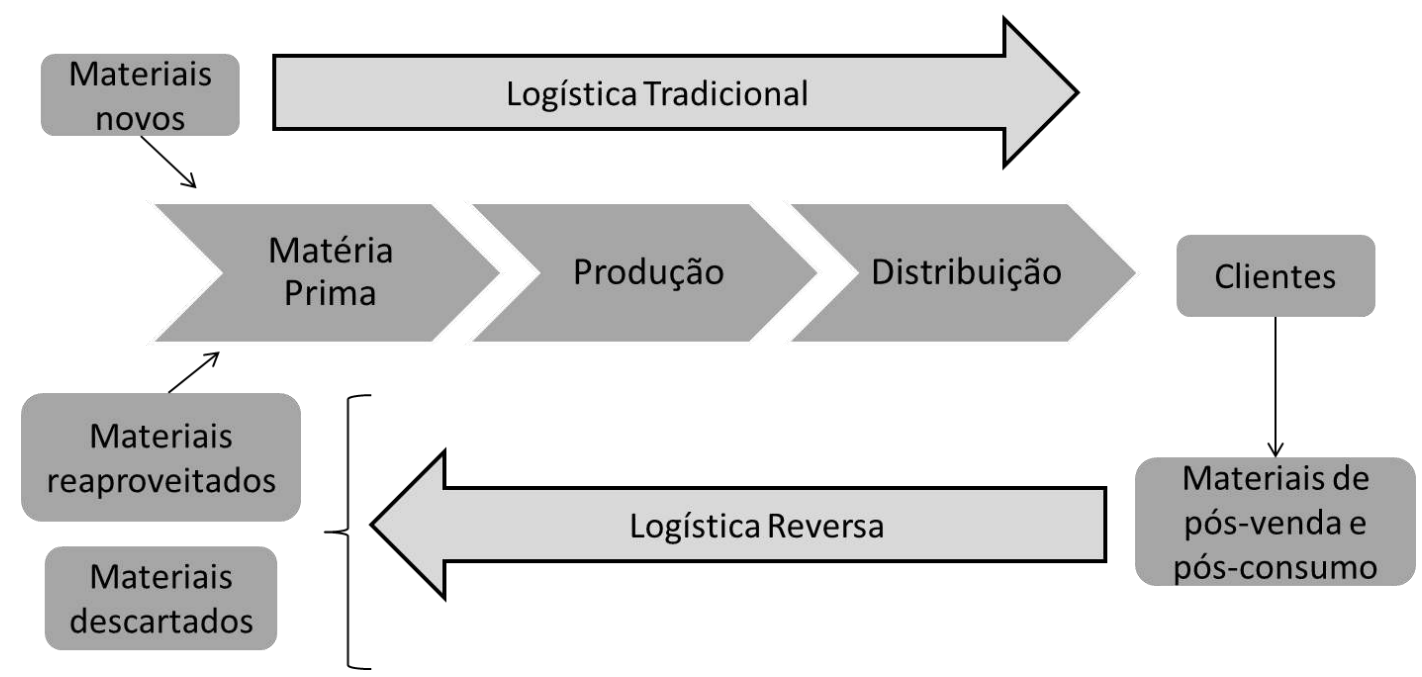

IMAGEM 1 - Processo logístico tradicional vs. Processo logístico reverso. Fonte: os autores, adaptado de Shibao, 2010 


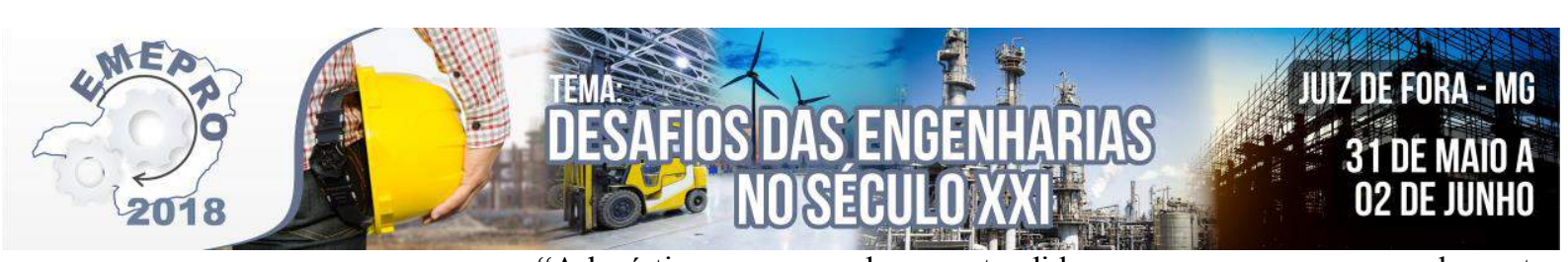

"A logística reversa pode ser entendida como um processo complementar à logística tradicional, pois enquanto a última tem o papel de levar produtos dos fornecedores até os clientes intermediários ou finais, a logística reversa deve completar o ciclo, trazendo de volta os produtos já utilizados dos diferentes pontos de consumo à sua origem."

Lacerda (2002, apud GARCIA, 2006)

A utilização crescente da logística reversa nas empresas é justificada pelo aumento da responsabilidade sobre o produto fabricado e devido às leis ambientais, que estão cada vez mais rígidas com o objetivo de minimizar cada vez mais os impactos causados pela produção de produtos de diversos setores, sem contar que a empresa ganha maior visualização e valor no mercado, por estar atenta aos recursos e ao meio ambiente e, consequentemente, leva à redução de custos pelo melhor aproveitamento dos insumos e pela redução de desperdício (SHIBAO; MOORI; SANTOS, 2010; SILVA, ADILSON; LEITE, 2012; SOUZA, SUELI; FONSECA, 2009).

\subsection{Logística Reversa: cenário brasileiro}

A Política Nacional de Resíduos Sólidos estabelece alguns produtos ou partes de produtos, como embalagens, que devem, obrigatoriamente, possuir um sistema de logística reversa, devido ao seu caráter nocivo para o meio ambiente. Segundo dados do Relatório de Pesquisa sobre resíduos sólidos de logística reversa obrigatória, disponibilizado pelo Instituto de Pesquisa Econômica Aplicada (IPEA) (2012), apenas 2.937 municípios brasileiros, cerca de 53\%, realizam controle sobre a destinação destes resíduos. O estudo contemplou informações sobre o controle de três tipos de resíduos: pneumáticos, pilhas e baterias e lâmpadas fluorescentes.

Pela análise dos dados de 2010, pode-se perceber que o controle da logística reversa desses produtos no Brasil ainda é mínimo. Os resíduos pneumáticos são os que apresentam maior controle entre os três estudados devido, principalmente, às atividades econômicas relacionadas a reutilização destes materiais. Em relação às regiões, as Regiões Sudeste e Sul aparecem com maior quantidade de municípios com sistema de controle deste tipo de logística. A região Norte aparece com menor número de municípios (IPEA, 2012).

Os resíduos eletrônicos também merecem atenção neste cenário. O avanço tecnológico crescente acelerou o processo de obsolescência destes produtos o que gera uma quantidade enorme de resíduos muitas vezes tóxicos ao meio ambiente. Segundo estimativas da Fundação Estadual do Meio Ambiente (FEAM), no estado de Minas Gerais em 2010 foram geradas cerca de 68.630 toneladas de resíduos eletrônicos (IPEA, 2012). Os principais tipos de Resíduos Eletroeletrônicos (REE's) são monitores, televisores, computadores, celulares, geladeiras, máquinas de lavar, entre outros. As projeções para os próximos anos são de aumento da participação destes na geração de resíduos sólidos no Brasil e no mundo, justificando assim a maior atenção que deve ser prestada a este setor (IPEA, 2012).

Referente ao objeto de estudo deste trabalho, as pilhas e baterias, no Brasil são produzidas cerca de 800 milhões de pilhas e 17 milhões de baterias por ano. Desta produção, a quantidade coletada é muito pequena, significando toneladas de pilhas e baterias descartadas de forma incorreta em lixões, aterros e demais localidades inapropriadas (IPEA, 2012).

O órgão responsável por parte da coleta de pilhas e baterias atualmente no Brasil é a Associação Brasileira da Indústria Elétrica e Eletrônica (ABINEE). Trata-se de uma sociedade sem fins lucrativos que visa a representatividade das empresas dos setores elétrico e 


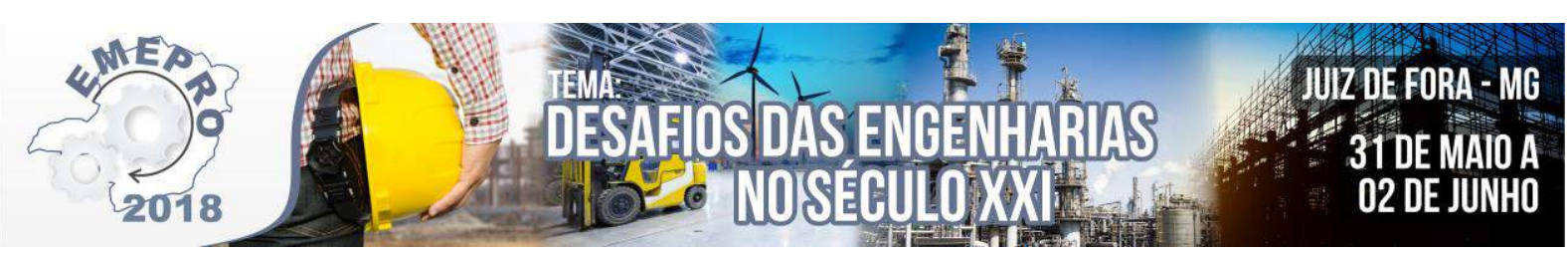

eletrônico do país. A Abinee foi fundada em 1963 e sua sede está localizada em São Paulo. Como parte de suas atividades está o atendimento à demanda pelo correto descarte de artigos elétricos e eletrônicos, incluindo pilhas e baterias, das empresas associadas, sendo estas de diversas partes do país e com portes diversos (ABINEE, 2016).

O programa específico da Abinee para descarte correto de pilhas e baterias é o ABINEE Recebe Pilhas. O projeto foi iniciado em 2010 com o objetivo de estabelecer um sistema adequado para a logística reversa de pilhas e baterias de uso doméstico, incluindo o recolhimento destes artigos e a destinação final adequada. Para isso, são disponibilizados centenas de postos de coleta por todo o Brasil, concentrados principalmente na Região Sudeste, onde os consumidores das empresas associadas podem descartar as pilhas e baterias usadas. Algumas das empresas que fazem parte do programa são a Alfacell, BIC, Energizer, Kodak, Panasonic, Philips e Rayovac (ABINEE, 2016). Somente no estado de São Paulo, segundo o Fecomércio SP (2018), foram coletadas 220 toneladas de pilhas e baterias por meio do programa, em 2017.

\subsection{Pilhas e seus componentes: Impactos no Meio Ambiente}

Historicamente, chumbo e cádmio foram adicionados às pilhas tradicionais de Leclanché, desenvolvida em 1866 por George Leclanché, no ânodo de zinco, para melhorar sua propriedades mecânicas. Já o mercúrio foi adicionado ao ânodo de zinco com o objetivo de reduzir sua corrosão (SILVA, BRUNO et al., 2011).

A pilha de Leclanché começou a ser insuficiente em termos de eficiência energética por volta da década de 1950, com o crescimento da indústria eletroeletrônica e seus aparelhos que consumiam cada vez mais energia para funcionar. Para solucionar o problema, Lewis Urry desenvolveu a pilha alcalina, mais eficiente energeticamente, em comparação com as pilhas tradicionais de Zn-C de Leclanché (SILVA, BRUNO et al., 2011). Ainda de acordo com Silva et al. (2011), as pilhas alcalinas são mais resistentes a altas temperaturas, oferecem maior segurança contra vazamentos e, dependendo do uso, duram de quatro a dez vezes mais que as pilhas $\mathrm{Zn}-\mathrm{C}^{1}$. Entretanto, as primeiras formulações das pilhas alcalinas exigiam maior concentração de mercúrio que as pilhas $\mathrm{Zn}-\mathrm{C}$, podendo chegar a $1 \% \mathrm{~m} / \mathrm{m}$ de mercúrio. Chumbo, cádmio, níquel, cobre e cromo estão presentes como impurezas no cátodo ou como aditivos para melhorar a eficiência da pilha (SILVA, BRUNO et al., 2011). Segundo Reidler et al. (2002), o tipo mais comum de pilhas e baterias não recarregáveis, de Zinco-Carbono (Zn-C) representa, atualmente, cerca de $70 \%$ do mercado, enquanto as pilhas e baterias alcalinas não recarregáveis representam o restante do mercado. Sob o ponto de vista ambiental, tal constatação é positiva, especialmente por esses produtos apresentarem maior durabilidade, o que pode acarretar numa menor taxa de descarte.

Em 2009, segundo Silva et al. (2011), o consumo de pilhas no Brasil era de 6 pilhas/pessoa $\mathrm{x}$ ano, e nos países desenvolvidos esse consumo podia ser três vezes maior, levando a um consumo mundial de 12 bilhões de pilhas por ano. Isto gera preocupações acerca dos potenciais impactos ambientais e à saúde humana que o descarte de pilhas pode causar.

De acordo com Reidler e Günther (REIDLER; GÜNTHER, 2000), o atual perfil de consumo indica que $80 \%$ das baterias são do tipo Níquel-Cádmio (Ni-Cd), consideradas as de maior impacto ambiental. Estima-se que as de Níquel Metal Hidreto (NiMH) representem

\footnotetext{
${ }^{1}$ Zn-C é uma pilha de Zinco e Carbono
} 


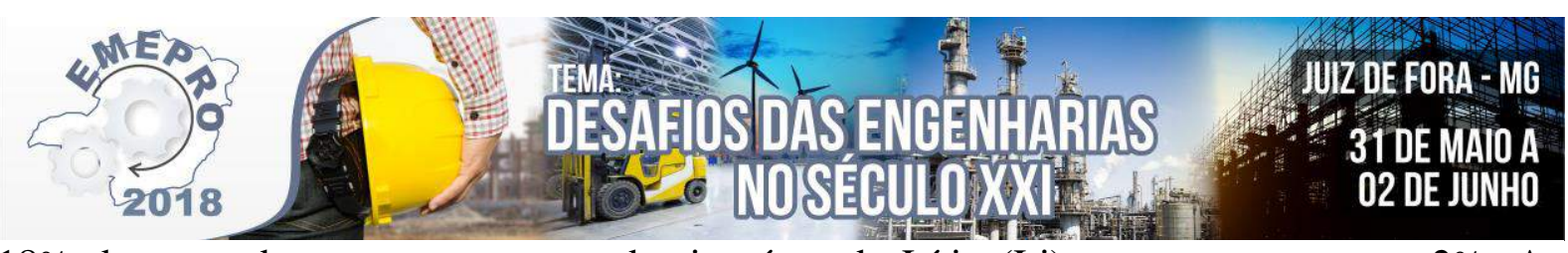

$18 \%$ do mercado, enquanto que as do tipo íons de Lítio (Li) representam apenas $2 \%$. As diferenças entre os três tipos de baterias estão, principalmente, na capacidade de armazenamento de energia, peso, durabilidade e preço. As do tipo $\mathrm{Ni}-\mathrm{Cd}$ são as mais pesadas, menos duráveis e mais baratas.

Quando descartadas sem controle e misturadas com o resíduo sólido comum, as pilhas de Ni-Cd podem vir a ser extremamente perigosas, pela possibilidade de interação com outras substâncias. Dessa forma, o uso de pilhas Ni-Cd tem sido significativamente reduzido e estas pilhas têm sido substituídas pelas pilhas de $\mathrm{Ni}-\mathrm{MH}^{2}$. A Resolução $\mathrm{n}^{\circ} 401 / 08$ do Conselho Nacional do Meio Ambiente CONAMA (2008) não dispõe sobre baterias do tipo Ni-MH, apesar de o níquel ser considerado um elemento potencialmente carcinogênico (Simões, 2007 apud FORTUNATO, 2009).

Silva et al. (SILVA, BRUNO et al., 2011) fizeram uma pesquisa prática exaustiva da evolução na composição de pilhas entre os anos 1991 e 2009 e os gráficos abaixo foram obtidos:

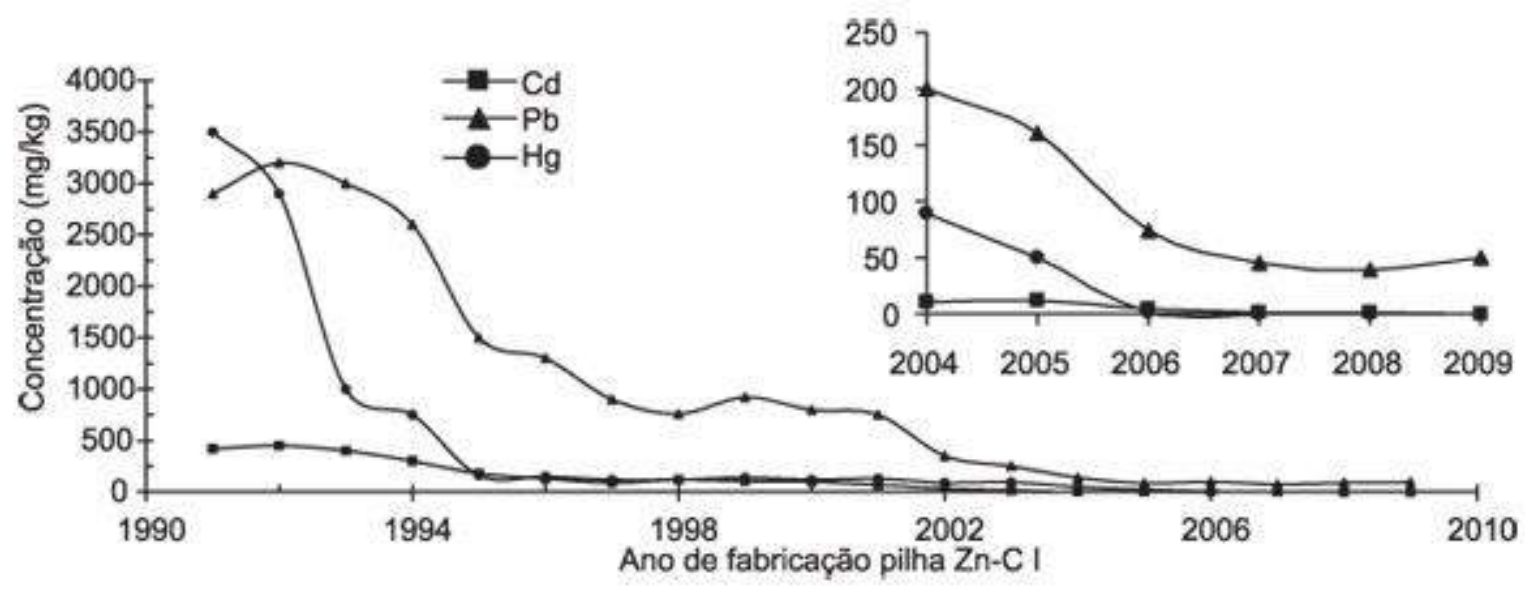

IMAGEM 2 - Teores de chumbo, cádmio e mercúrio na série histórica de pilhas ZN-C I. Fonte: Silva et al., 2011

\footnotetext{
${ }^{2} \mathrm{Ni}-\mathrm{MH}$ é uma pilha ou bateria em que o ânodo é composto por níquel e o cátodo por um metal-hidreto
} 


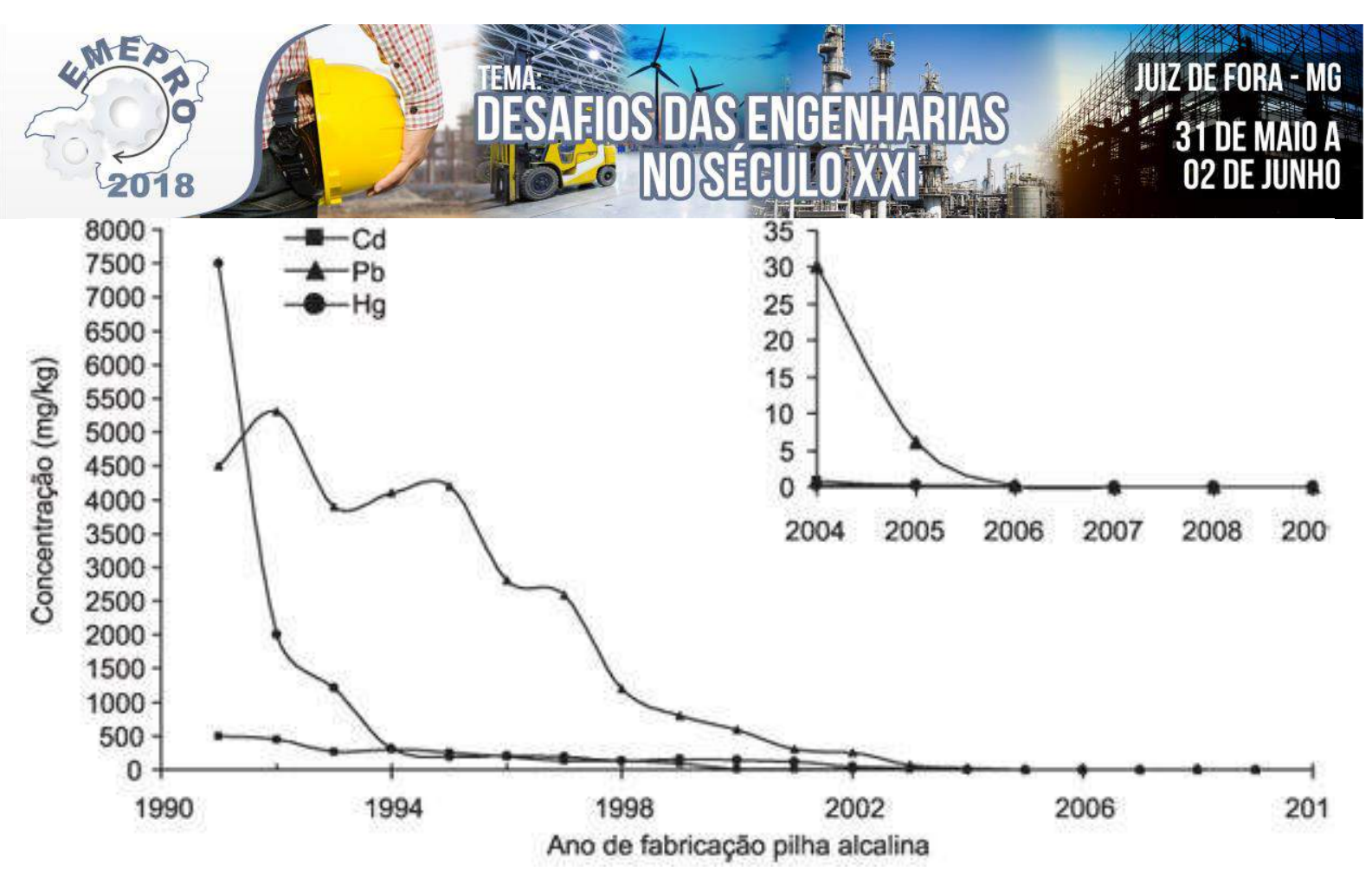

IMAGEM 3 - Teores de chumbo, cádmio e mercúrio na série histórica de pilhas alcalinas. Fonte: Silva et al., 2011

Fica evidente, portanto, que as concentrações dos principais metais pesados que causam danos à saúde e ao meio ambiente e que compõem pilhas e baterias estão sendo sumariamente reduzidas com o tempo, principalmente após regulamentações. Entretanto, isto não configura motivo de poder despreocupar-se com o descarte inadequado dos resíduos de tais produtos, uma vez que suas concentrações no solo e em ambientes aquáticos, bem como em organismos vivos, é do tipo cumulativo, de acordo com Trevizani (2014).

Quanto aos seus efeitos dos referidos metais pesados no corpo humano, segundo Rocha (2009), o cádmio afeta o córtex renal podendo levar à falência renal; o chumbo afeta o sistema nervoso, a medula óssea e os rins; por fim, o mercúrio afeta o sistema nervoso central, os sistemas renal e pulmonar, conduzindo, assim, ao aparecimento de inúmeras patologias.

Portanto, pilhas e baterias são classificadas como resíduos perigosos pela norma NBR 10.004 (ABNT, 2004) devido às suas características de corrosividade, reatividade e toxicidade, e desde 1999 têm índices de chumbo, mercúrio e cádmio limitados de acordo com a Resolução $n^{\circ}$ 257/1999, que foi posteriormente revogada pela Resolução CONAMA $n^{\circ}$ 401/2008 (CONAMA, 2008; CONSELHO NACIONAL DO MEIO AMBIENTE CONAMA, 1999).

A legislação brasileira determina que todas as pilhas e baterias, que contenham em sua composição certas concentrações de cádmio, mercúrio e chumbo sejam coletadas, tratadas e dispostas adequadamente. Entretanto, não dispõe sobre outros tipos, que contenham em sua composição outros metais ou substâncias tão prejudiciais à saúde e ao ambiente. De acordo com a resolução $n^{\circ} 401 / 08$ do CONAMA (2008), o artigo $7^{\circ}$ faz referência às pilhas e baterias de zinco- manganês e alcalino-manganês do tipo portátil, botão e miniatura deverão atender aos seguintes teores máximos dos seguintes metais: portátil;

-conter até $0,0005 \%$ em peso de mercúrio quando for do tipo pilha ou acumulador portátil;

-conter até $0,002 \%$ em peso de cádmio quando for do tipo pilha ou acumulador 


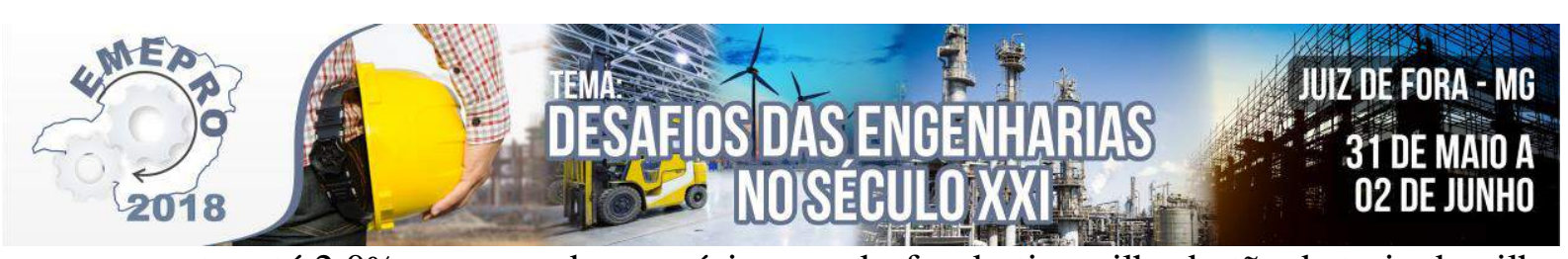

-conter até $2,0 \%$ em peso de mercúrio quando for do tipo pilha-botão, bateria de pilha botão e pilha miniatura;

-conter traços de até $0,1 \%$ em peso de chumbo.

De acordo com o artigo $8^{\circ}$, as baterias de chumbo-ácido não podem ser descartadas em qualquer tipo de aterro sanitário e nem incineradas, e não poderão conter teores acima de:

- mercúrio - 0,005\% em peso;

- cádmio - 0,010\% em peso.

A resolução traz ainda, que pilhas e baterias que possuem teores acima dos citados anteriormente deverão ser devidamente descartados e as que atenderem aos limites previstos no artigos $7^{\circ}$ e $8^{\circ}$ poderão ser dispostas, juntamente com os resíduos domiciliares, em aterros sanitários licenciados.

A coleta, a segregação, o tratamento e a disposição final adequada de todos os tipos de pilhas são recomendáveis, independente de modelo ou classificação, devido principalmente ao número crescente de consumo das pilhas, podendo ultrapassar o limite de concentração desses metais tóxicos permitido.

A seguir são apresentados os principais métodos de reciclagem de pilhas atualmente utilizados:

TABELA 1 - Métodos de reciclagem por tipo de pilha

\begin{tabular}{|c|c|}
\hline Recarregados de níquel-cádmio & $\begin{array}{l}\text { - relativamente fáceis de reciclar, tanto por processos } \\
\text { térmicos como hidrometalúrgicos; } \\
\text { - recuperação do cádmio é de cerca de } 100 \% \text { para } \\
\text { reutilização na indústria de pilhas ou fabrico de outros } \\
\text { produtos; } \\
\text { - o níquel é, geralmente, recuperado como ferro-níquel com } \\
\text { aplicação na indústria do aço; }\end{array}$ \\
\hline Pilhas primárias de "botão" & 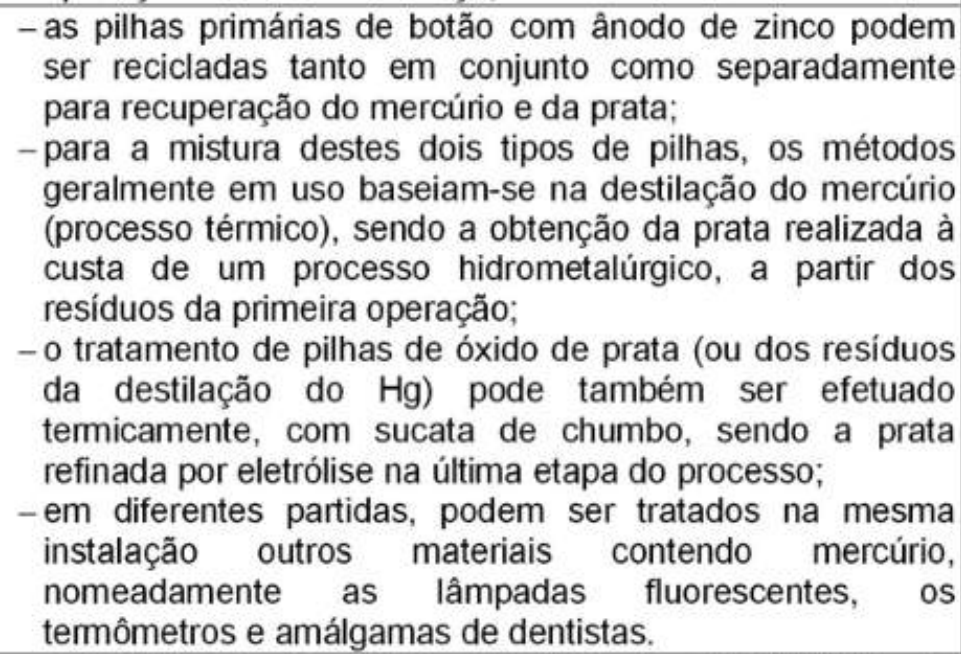 \\
\hline Pilhas primárias cilíndrias & $\begin{array}{l}\text { - a reciclagem de pilhas primárias de zinco/dióxido de } \\
\text { manganésio tem sido difícil de implementar pelos elevados } \\
\text { custos associados aos processos e pelos problemas de } \\
\text { comercialização de alguns dos produtos obtidos na } \\
\text { operação. }\end{array}$ \\
\hline
\end{tabular}

Fonte: Cavalcante et al. (CAVALCANTE et al., 2009) 


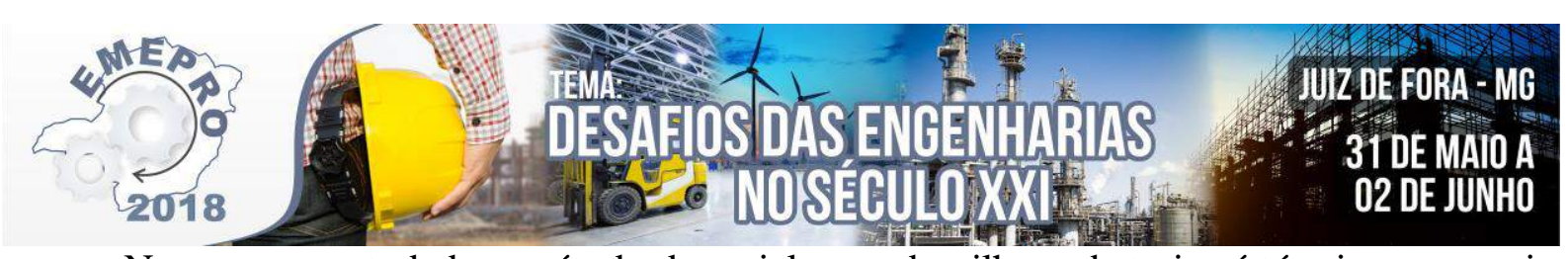

Na empresa estudada o método de reciclagem de pilhas e baterias é térmico, por meio de coprocessamento em forno a temperaturas elevadas.

\subsection{Logística Reversa de pilhas e baterias}

Em sua maioria, o material sobre logística reversa encontrado na literatura discorre sobre o processo de recolhimento dos resíduos. É muito comum deparar-se com a insinuação de que os resíduos recolhidos pela logística reversa devem ter uma destinação final adequada, de acordo com o que determina a Política Nacional de Resíduos Sólidos, instituída pela Lei $\mathrm{n}^{\circ}$ 12.305/10. Porém há raras referências ao pós-logística reversa, ou seja, como os resíduos sólidos são efetivamente tratados após a logística reversa.

O material sobre logística reversa de pilhas e baterias no Brasil é escasso. Pesquisando-se nas duas maiores bases de artigos científicos da área da Engenharia localizaram-se apenas cinco artigos científicos que discorriam sobre tal tema. Dentre eles, Demajorovic et al. (DEMAJOROVIC et al., 2012) analisa os websites das maiores empresas de aparelhos celulares do Brasil e verifica que em apenas um se encontravam informações sobre a destinação dos componentes após a desmontagem dos aparelhos, e ainda assim eram informações generalizadas e sem muito aprofundamento. Silva et al.(SILVA, ANTÔNIO CARLOS; SOUSA; BRAGA, 2015) e Araújo et al.(ARAUJO et al., 2013) ficam no âmbito da coleta de resíduos, não explorando mais a fundo o destino destes. Apenas Cavalcante et al.(2009) e Santos et al. (SANTOS et al., 2016) exploram o tema mais a fundo, abordando a destinação dos resíduos.

Neste sentido, o presente trabalho tem caráter inovador por abordar não somente a coleta de resíduos como também a destinação destes, no caso a reciclagem.

\section{Estudo de caso: Votorantim Metais}

A Votorantim Metais é uma holding que faz parte da Votorantim S.A., uma organização multinacional brasileira que atua em diversos setores estratégicos da economia e está presente em vinte e três países. A Votorantim Metais está entre as cinco maiores produtoras mundiais de zinco (VOTORANTIM METAIS, 2017a). Dentre seus produtos estão zinco metálico, cobre, chumbo, prata e produtos químicos provenientes de minérios.

A Votorantim Metais de Juiz de Fora, MG, é uma planta de metalurgia de zinco e polimetálicos. Este é um ramo importante para a holding, dado que há uma perspectiva de preços estáveis e até mesmo de aumento para os próximos anos, uma vez que a oferta mundial de zinco tende a cair com o esgotamento de minas importantes e com o aumento do consumo, de acordo com o relatório do ano de 2014 da empresa (VOTORANTIM METAIS, 2015).

É importante ressaltar que a Votorantim Metais de Juiz de Fora tem foco em aumentar sua produtividade e reduzir custos e resíduos por meio de projetos voltados ao desenvolvimento sustentável. Em 2007, de acordo com notícia publicada pela Votorantim (MONTENEGRO, 2007), a unidade recebeu o prêmio "Preservação do Meio Ambiente" concedido pelo Clube de Engenharia de Juiz de Fora pelos projetos de cunho ambiental realizados pela empresa. Dentre eles foram destacados projetos de redução do consumo de água, redução do consumo de energia e o de maior importância, o Projeto de Polimetálicos, que permitiria a adoção do conceito de Resíduo Zero nas novas plantas.

Nesse sentido, e em busca de uma redução de custos com matéria prima para seu processo, a unidade da Votorantim Metais de Juiz de Fora adota, desde 2011, a produção de zinco e outros metais - entre eles índio, chumbo metálico e liga de prata e ouro - por meio da 


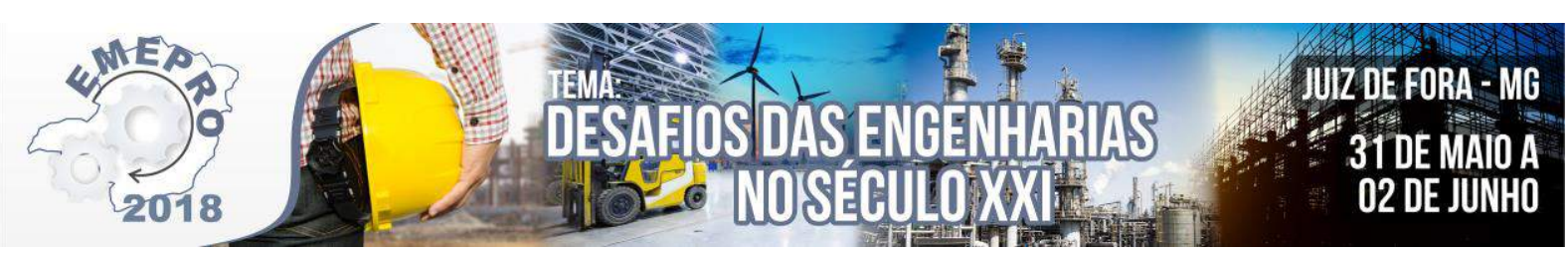

reciclagem de resíduos da indústria siderúrgica e da reciclagem de pilhas e baterias. De acordo com Votorantim Metais (2015), a produção do zinco na unidade de Juiz de Fora por meio do coprocessamento de pó de aciaria elétrica elimina problemas ambientais de outras indústrias - diretamente as indústrias siderúrgicas - e aumenta a competitividade da unidade. O principal fornecedor de zinco, proveniente de jazidas, da Votorantim se localiza no Peru e, por isso, os custos de importação dessa matéria prima são altíssimos, estimados em US\$145 milhões em 2014, de acordo com o Departamento Nacional de Produção Mineral (DNPM, 2013). O Projeto Polimetálicos da unidade Juiz de Fora, com o desenvolvimento de um sistema de reciclagem de materiais ricos em zinco, representa, portanto, uma alternativa para a produção da linha Polimetálicos e aumenta a vantagem competitiva da corporação (SOUZA, SÉRGIO, 2017).

Foram investidos $\mathrm{R} \$ 521$ milhões no projeto Polimetálicos em Juiz de Fora. O processo de produção tem como principal equipamento o forno Waelz, que permite o tratamento de materiais com baixos teores de zinco que antes eram colocados em aterros industriais controlados (VOTORANTIM METAIS, 2015). O material mais utilizado para reciclagem no forno Waelz é o pó de aciaria elétrica (SOUZA, 2017), classificado como resíduo classe I, ou seja, perigoso, da indústria siderúrgica. Além deste podem ser utilizados componentes eletroeletrônicos, como pilhas e baterias, placas de circuitos, dentre outros.

No caso das pilhas, elas são compradas pela Votorantim da Associação Brasileira da Indústria de Elétrica e Eletrônica (ABINEE) (SOUZA, 2017), que recolhe pilhas e baterias por meio do programa "ABINEE Recebe Pilhas". O programa visa fazer a logística reversa de pilhas e baterias no Brasil a fim de cumprir a Resolução CONAMA 401/2008 e a Política Nacional de Resíduos Sólidos, de 2010. Os consumidores levam pilhas e baterias usadas em postos de coleta espalhados em lojas e distribuidores e quando se atinge um volume mínimo estipulado o transporte desses resíduos é realizado e este é encaminhado para reciclagem (ABINEE, 2016).

Em números, segundo a Votorantim Metais (2015), o forno Waelz tem capacidade para tratar $85 \%$ do pó de aciaria elétrica gerado no Brasil, o que corresponde a todo resíduo desse tipo gerado em Minas Gerais. Além disso, a produção de zinco secundário, ou seja, o zinco produzido a partir de reciclagem, permitiu já em 2012 substituir $13 \%$ do zinco primário que seria utilizado. Essa porcentagem de substituição vem crescendo desde então, alcançando 16\% em 2013, 19,5\% em 2014, 23\% em 2015 e 32\% em 2016 (VOTORANTIM METAIS, 2015, 2017b). Em relação às pilhas recicladas no processo, de acordo com Conexão Mineral (CONEXÃO MINERAL, 2017), apenas no período entre setembro de 2016 e maio de 2017 foram tratadas 84 toneladas de pilhas, o que representam 13 toneladas de zinco contido.

Pode-se destacar ainda que, a partir da adoção das técnicas de reciclagem pela Votorantim Metais unidade Juiz de Fora, houve redução na produção de Jarosita, um resíduo mineral sulfetado que é colocado em barragens controladas. Isto aumentará a vida útil da Barragem da Pedra, localizada nas imediações da unidade industrial, em cerca de 25 anos, conforme previsto no Relatório Anual de 2016 da Votorantim (2017b).

\section{Considerações finais}

A logística reversa e sua devida finalização, com a destinação final adequada dos resíduos, geram vantagem competitiva às empresas que as adotam, tanto no que tange o cumprimento da Lei 12.305/12, quanto ao valor agregado para o cliente através de marketing e principalmente ao se reduzir custos com matéria-prima proveniente de fontes primárias. $\mathrm{Na}$ 


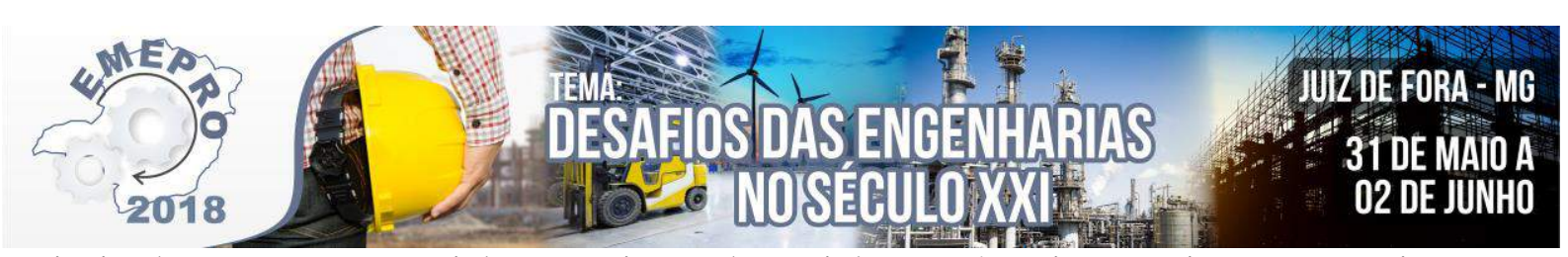

maioria dos casos o material proveniente de reciclagem é mais vantajoso economicamente, mesmo que este ainda tenha um custo de compra para a empresa, como no caso da Votorantim, o preço do resíduo é muito reduzido em comparação ao preço da matéria-prima primária.

Diante disto devem-se avaliar os investimentos que serão necessários com tecnologia e infraestrutura para processar resíduos e analisar se é economicamente viável esta alternativa no processo produtivo.

No caso da Votorantim Metais unidade Juiz de Fora, mesmo havendo necessidade de compra dos resíduos utilizados para abastecer o forno Waelz, a implantação do projeto se mostrou vantajosa ao se reduzir a importação de Zinco primário proveniente de jazidas do Peru. Além disso, os resíduos de outros processos de produção da própria fábrica são tratados no forno Waelz, o que aumenta a vida útil das barragens de rejeitos da unidade e diminui o desperdício de metais valiosos para a empresa.

Um ponto a ser considerado acerca da dinâmica de funcionamento do processo de logística reversa e reciclagem das pilhas no caso estudado é o custo que o resíduo de pilhas e baterias gera para a empresa de reciclagem. Se a coleta e a destinação adequada de resíduos sólidos devem ser realizadas pelas empresas que produziram os produtos que geraram tais resíduos, de acordo com a Política Nacional de Resíduos Sólidos, seria justo que estas empresas pagassem pela reciclagem dos resíduos de seus produtos, e não o contrário, como acontece atualmente. Em adição, há poucas empresas no Brasil que realizam a reciclagem de pilhas e baterias, o que teoricamente deveria aumentar o poder de barganha da Votorantim Metais.

\section{Bibliografia}

ABINEE. Cartilha do Programa Abinee Recebe Pilhas. Disponível em: <http://gmcons.com.br/gmclog/downloads/61-Cartilha_Abinee.pdf>. Acesso em: 4 maio 2017. , 2016

ABNT. 10004. . Norma NBR 10.004., 2004.

ARAUJO, Ana Carolina et al. Reverse logistics in the e-commerce: a case study. Gestão \& Produção v. 20, n. 2, p. 303-320, jun. 2013.

CAVALCANTE, Rejane et al. Logística reversa como ferramenta para redução dos impactos ambientais: um exemplo a ser seguido no tocante a reciclagem química e o descarte de pilhas no estado do Amazonas. ENEGEP v. 13, p. 8 , out. 2009.

CONAMA. 401. . RESOLUÇÃO CONAMA n ${ }^{\circ} 401$, de 4 de novembro de 2008 Publicada no DOU n ${ }^{\circ} 215$, de 5 de novembro de 2008, Seção 1, página 108-109. , 4 nov. 2008, Seção 1, p. 108-109 . Disponível em: <http://www.mma.gov.br/port/conama/legislacao/CONAMA_RES_CONS_2008_401.pdf>. Acesso em: 6 jun. 2017.

CONEXÃO MINERAL. Planta de reciclagem e subprodutos gera bons ganhos financeiros $e$ de sustentabilidade. Disponível em: <http://www.conexaomineral.com.br/noticia/531/>. Acesso em: 8 jun. 2017. 


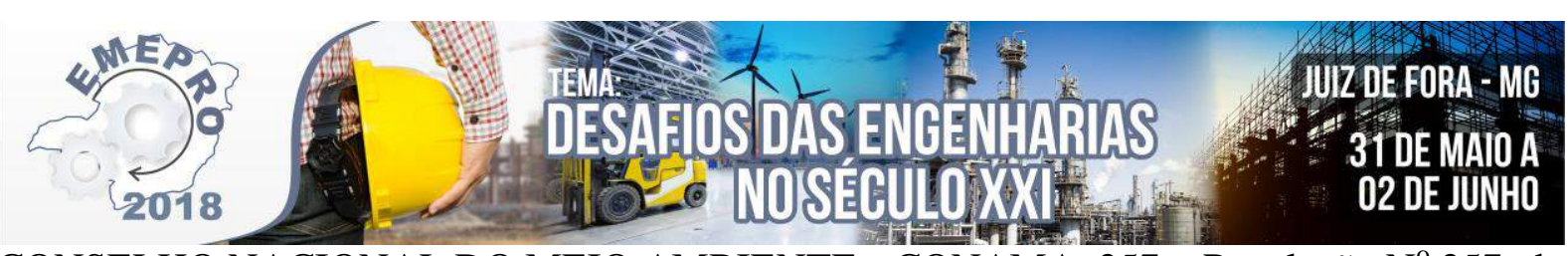

CONSELHO NACIONAL DO MEIO AMBIENTE - CONAMA. 257. . Resolução ${ }^{0}{ }^{257}$, de 30 de junho de 1999., 1999 .

DEMAJOROVIC, Jacques et al. Reverse logistics: how do companies report the disposal of batteries and cell phones? Revista de Administração de Empresas v. 52, n. 2 , abr. 2012. Disponível em: <http://www.scielo.br/scielo.php?script=sci_arttext\&pid=S0034$75902012000200004 \&$ lang=pt $>$. Acesso em: 12 jul. 2017.

DNPM. Departamento Nacional de Produção Mineral. Disponível em: <http://www.dnpm.gov.br/>. Acesso em: 8 jun. 2013.

FECOMÉRCIO SP. Termo de compromisso para Logística Reversa de pilhas e baterias portáteis completa um ano com a marca de 220 toneladas de material recolhido . [S.1.]: Fecomércio SP. Disponível em: $<$ http://www.noticia.abinee.org.br/publique/cgi/cgilua.exe/sys/start.htm?from_day=06\&from_ info_index $=101 \&$ from_month=02\&from_year=2009\&infoid $=250275 \&$ query=advsearch\&sea rch_by_authorname=all\&search_by_field=tax\&search_by_keywords=any\&search_by_priorit $\mathrm{y}=$ all\&search_by_section $=111 \&$ search_by_state=all\&search_text_options=all\&sid=111\&text =>. Acesso em: 12 maio 2018. , 13 abr. 2018

FORTUNATO, Janaína. Comportamento dos íons chumbo, cobre, níquel e zinco em área de manguezal associado a antigo lixão no município de Santos - SP. Mestrado Universidade de São Paulo, São Paulo, 2009. 75 p. . Acesso em: 1 abr. 2018.

GARCIA, Manuel. Logística Reversa : uma alternativa para reduzir custos e criar valor. XIII SIMPEP v. 1, n. 1, p. 12, 2006.

IPEA. Diagnóstico dos Resíduos Sólidos de Logística Reversa Obrigatória. Brasília: IPEA, 2012. Disponível em: <http://www.ipea.gov.br/portal/images/stories/PDFs/relatoriopesquisa/120807_relatorio_resid uos_solidos_reversa.pdf $>$. Acesso em: 12 jul. 2017.

MONTENEGRO, Marcelo. Votorantim Metais é premiada por atuação responsável em Juiz de Fora (MG). Disponível em: <http://www.votorantim.com.br/ptbr/Noticias/listaNoticias/Paginas/071207VotorantimMetaispr.aspx>. Acesso em: 7 jun. 2017.

REIDLER, Nivea; GÜNTHER, Wanda. Gerenciamento de resíduos constituídos por pilhas e baterias usadas. XXVII Congresso Interamericano de Engenharia Sanitária e Ambiental v. 27 , p. $12,2000$.

ROCHA, Adriano. Cádmio, Chumbo, Mercúrio - A problemática destes metais pesados na Saúde Pública? Trabalho de Conclusão do curso de Ciências da Nutrição - Universidade do Porto, Porto - Portugal, 2009. 63 p. Disponível em: <https://repositorioaberto.up.pt/bitstream/10216/54676/4/127311_0925TCD25.pdf>. Acesso em: 1 abr. 2018.

SANTOS, Ana Carla et al. Logística reversa: uma análise da gestão de pilhas e baterias no município de Campos dos Goytacazes. ENEGEP v. 17, p. 14 , out. 2016.

SHIBAO, Fábio; MOORI, Roberto; SANTOS, Mário Roberto. A logística reversa e a 


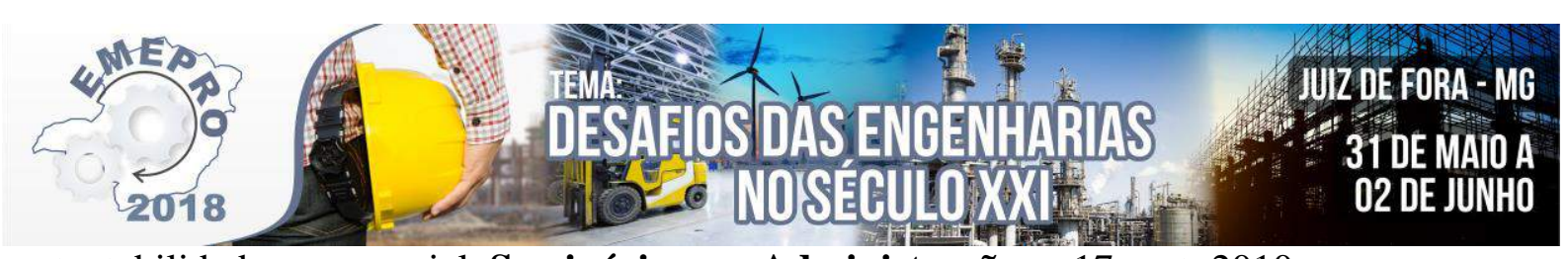

sustentabilidade empresarial. Seminários em Administração p. 17, set. 2010.

SILVA, Adilson; LEITE, Paulo Roberto. Empresas brasileiras adotam políticas de logística reversa relacionadas com o motivo de retorno e os direcionadores estratégicos? Revista de Gestão Social e Ambiental v. 6, n. 2, p. 79-92, ago. 2012.

SILVA, Antônio Carlos; SOUSA, Jorgiane; BRAGA, Guilherme. Avaliação da logística reversa de produtos eletroeletrônicos em uma instituição de ensino. ENEGEP v. 16, p. 20 , out. 2015.

SILVA, Bruno et al. Historical series of chemical composition of alkaline and zinc-carbon batteries manufactured between 1991 and 2009. Química Nova v. 34, n. 5 , 2011. Disponível em: <http://www.scielo.br/scielo.php?script=sci_arttext\&pid=S0100-40422011000500016>. Acesso em: 1 abr. 2018.

SILVA, Mayara Cristina Ghedini Da; COLMENERO, João Carlos. Legislações brasileiras que incentivam o desenvolvimento da logística reversa. $5^{\mathbf{0}}$ Encontro de Engenharia e Tecnologia dos Campos Gerais p. 11, out. 2010.

SOUZA, Sérgio. Entrevista com o gestor de Meio Ambiente da Votorantim Metais unidade Juiz de Fora, maio 2017

SOUZA, Sueli; FONSECA, Sérgio Ulisses. Logística reversa: oportunidades para redução de custos em decorrência da evolução do fator ecológico. Revista Terceiro Setor v. 3, n. 1, p. 29-39, 2009.

TREVIZANI, Tailisi. Bioacumulação de metais pesados e avaliação da biomagnificação na biota da Baía do Almirantado, Ilha Rei George, Antártica. Mestrado - Universidade de São Paulo, São Paulo, 2014. 117 p. . Acesso em: 1 abr. 2018.

VOTORANTIM METAIS. Quem Somos. Disponível em: <http://www.vmetais.com.br/ptBR/Institucional/Paginas/QuemSomos.aspx>. Acesso em: 7 jun. 2017a.

VOTORANTIM METAIS. Relatório Votorantim Metais 2014. São Paulo, 2015. Disponível em: <http://www.vmetais.com.br/pt-BR/Sustentabilidade/Documents/RS_VM_PT-BR.pdf>. Acesso em: 7 jun. 2017.

VOTORANTIM METAIS. Relatório Votorantim Metais 2016. São Paulo, 2017b. Disponível em: <http://www.vmetais.com.br/ptBR/Sustentabilidade/Documents/VM_ra_2016_pt.pdf>. Acesso em: 7 jun. 2017. 


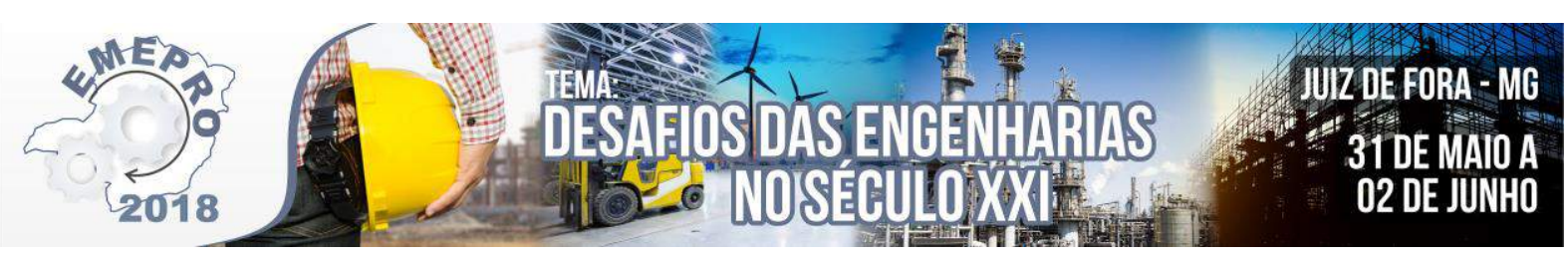

\title{
Produção Mais Limpa como vantagem competitiva: Estudo de Caso em uma indústria de meias
}

\author{
Caroline Brasileiro Pena (UFJF) caroline.brasileiro@engenharia.ufjf.br \\ Aleson Lameck Pinheiro (UFJF) aleson.lameck@engenharia.ufjf.br \\ Taynara Polyanna Rocha Costa (UFJF) polyanna.costa@engenharia.ufjf.br \\ Júlia Moreira Santos Teixeira (UFJF) julia.moreira@engenharia.ufjf.br
}

Resumo: Em um mercado no qual a concorrência é cada vez mais acirrada, principalmente em épocas de crise financeira, é necessário que as empresas invistam em ações que aumentem sua vantagem competitiva perante suas concorrentes. $O$ presente artigo estuda como a adoção de Produção Mais Limpa pode gerar vantagem competitiva para indústrias. São avaliados aspectos e tomadas de decisões através da análise de situações práticas em uma indústria de confecção de meias localizada no polo de meias de Juiz de Fora, na Zona da Mata do estado de Minas Gerais. Aspectos ambientais, econômicos e sociais foram avaliados e, por fim, foram sugeridas novas ações sustentáveis com o objetivo de aumentar ainda mais a vantagem competitiva da empresa em estudo.

Palavras- chave: Produção Mais Limpa; Sustentabilidade; Indústria têxtil; Meias.

\section{Introdução}

O atual cenário de globalização traz competições acirradas entre empresas de um mesmo ramo. Países conhecidos por ter mão de obra e/ou matéria prima a preços muito inferiores aos dos seus concorrentes, e ainda com alta capacidade produtiva, como a China, vêm ganhando batalhas de competitividade em todo o mundo. No setor têxtil, sobre o qual o presente estudo discorrerá, a chegada de produtos chineses e coreanos têm trazido dificuldades para as indústrias brasileiras do ramo. São cada vez mais fáceis e mais comuns as compras de roupas e acessórios pela internet, e grandes sites de e-commerce chineses já têm traduções para o português.

Dessa forma, alternativas que visem redução de custos e agregação de valor ao cliente têm papel fundamental na sobrevivência de empresas brasileiras e na competitividade destas frente suas concorrentes internacionais, e também na competição umas em relação às outras nos mercados nacional e internacional.

Estratégias tipo ganho-ganho têm sido amplamente utilizadas, e esforços de cunho ambiental vêm conquistando espaço, seja por conta da intensificação da política ambiental, com o efetivo controle de atividades, por parte de órgãos ambientais governamentais, a partir do final da década de 1990 (FERREIRA; SALLES, 2016), seja pelo apelo junto ao consumidor, ou ainda visando reduções de gastos provenientes de desperdícios. Uma dessas estratégias é a Produção Mais Limpa, em que o desperdício é considerado como um "produto" de valor econômico negativo e prevenir ou reduzir a geração de desperdícios pode elevar a produtividade e trazer benefícios financeiros às empresas (UNITED NATIONS ENVIRONMENT PROGRAME - UNEP, 1990).

A Produção Mais Limpa, de acordo com Milanez (2017b) visa melhorar o processo produtivo em busca de condutas sustentáveis ambiental e economicamente, através da 


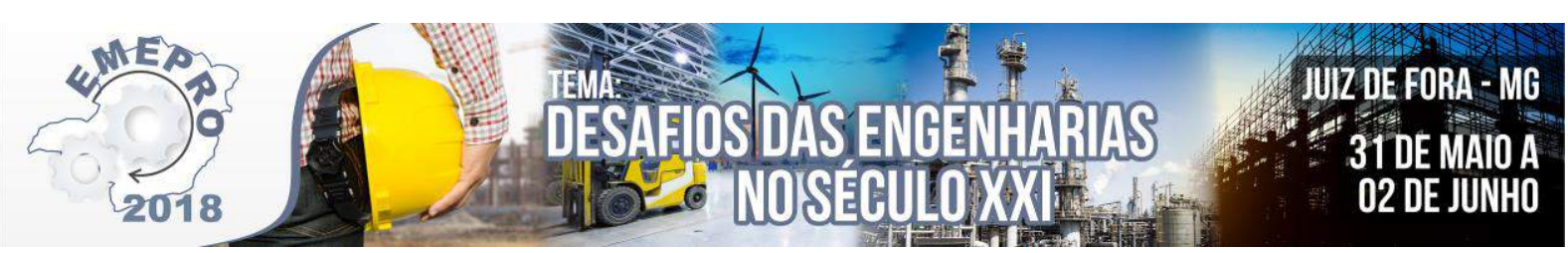

redução de desperdícios de recursos, de estocagem, de tempo, de movimentação, além de desperdícios com retrabalho e com geração de refugo, minimizando perdas e reduzindo riscos para a organização ao se aumentar a eficiência do processo.

O objetivo do presente estudo de caso é mostrar como práticas sustentáveis aumentam a vantagem competitiva de indústrias. Para tanto, foi realizada uma análise das atividades e das soluções de cunho ambiental, social e econômico adotadas por uma indústria do ramo de confecções de meias à luz dos conceitos e preceitos da Produção Mais Limpa.

Esse estudo é dividido em cinco sessões, sendo a primeira a presente introdução. Na segunda sessão é apresentada uma revisão teórica acerca do tema em estudo, a Produção Mais Limpa. Na sessão 3 é abordado o estudo de caso, com análise de conjuntura de mercado; análise SWOT do mercado de meias; análise da relação entre desempenho ambiental, competitividade e ganhos do mercado; breve apresentação da empresa em estudo; explicação simplificada do seu processo produtivo através de um fluxograma de macroprocessos; e, finalmente, a análise da política ambiental da empresa. Já na sessão 4 são feitas propostas de melhoria do processo de produção à luz dos preceitos da $\mathrm{P}+\mathrm{L}$. Por fim, na sessão 5 , é feita uma conclusão após a análise do estudo de caso.

Para realização desse estudo, além de revisão da bibliografia, foram feitas visitas à fábrica em estudo e as informações numéricas e financeiras foram obtidas a partir de entrevistas com um dos diretores da empresa.

\section{Revisão teórica}

A indústria tal qual conhecemos hoje, com alta capacidade produtiva e alto poder de impactar nocivamente o ambiente, teve seu início em fins do século XVIII, com a primeira Revolução Industrial, ocorrida na Grã Bretanha. Desde então, a indústria com sua alta capacidade produtiva, juntamente com o capitalismo, com sua corrida pelo acúmulo de riquezas, têm gerado cenários de injúrias sociais e ambientais (PENA et al., 2016).

De acordo com Pena et al. (2016), a partir do final da década de 1960, com a crescente conscientização acerca da necessidade de se preservarem os recursos naturais, o processo produtivo começou a ser regulamentado, com a finalidade de se tornar menos nocivo ambientalmente. Com isso, as empresas começaram a criar meios de controle internos para se adequar às novas leis ambientais.

Segundo Takata et al. (2004, apud MORENGHI; ANDRADE; ROSANO, 2006), "se antes eram minérios, o carvão, o petróleo, hoje se tratam também, de água, da atmosfera, que, considerados recursos renováveis, parecem atingir um limite para a sua recomposição, pois o tempo geológico contrasta cada vez mais com a velocidade de utilização". Portanto, alternativas para processos de produção cada vez mais eficientes e que impactam cada vez menos o meio ambiente precisam ser exploradas.

Nessa perspectiva, foi criado em 1988, pela UNEP (United Nations Environmental Program - Programa das Nações Unidas para o Meio Ambiente) o conceito de Produção Mais Limpa (MORENGHI; ANDRADE; ROSANO, 2006).

A Produção Mais Limpa (P+L) é um conjunto de estratégias que têm o objetivo de evitar ou reduzir a emissão de poluentes no meio ambiente através da modificação de processos de produção e do próprio produto visando à redução da quantidade de resíduos gerados que, por sua vez, representam custos para a empresa, tanto em relação à matéria prima adquirida que foi transformada em resíduos, quanto em relação a custos com descarte e armazenamento 


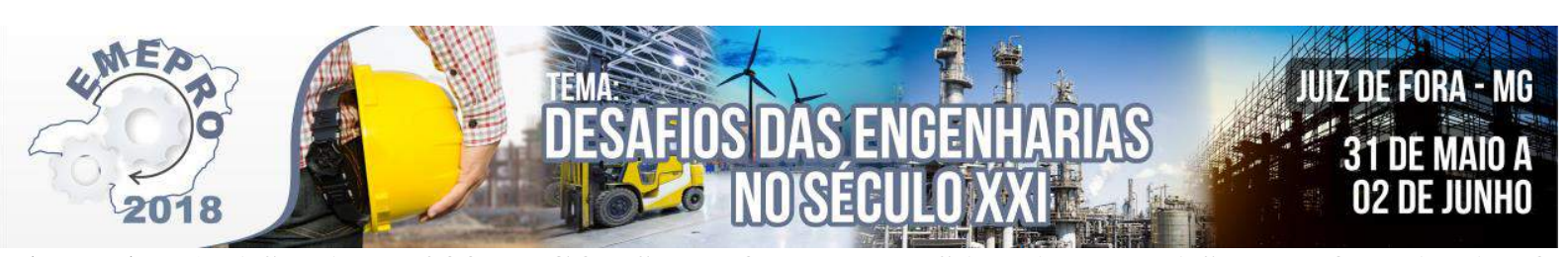

adequado (BASTIAN, 2009; CONSELHO EMPRESARIAL BRASILEIRO PARA O DESENVOLVIMENTO SUSTENTÁVEL (CEBDS)).

No Brasil, em 1995 foi criado o Centro Nacional de Tecnologias Limpas - CNTL, no Rio Grande do Sul, e em 1999 foi implementada a Rede Brasileira de Produção Mais Limpa, tendo como objetivo promover o desenvolvimento sustentável nas micro e pequenas empresas brasileiras (PIMENTA; GOUVINHAS, 2012) e atualmente é ferramenta amplamente utilizada para aumento de competitividade em empresas brasileiras de ramos diversos.

\section{Estudo de caso}

\subsection{O mercado}

Algumas das maiores empresas do ramo de meias no Brasil são a Lupo, que obteve faturamento de R\$686 milhões em 2015 (ÉPOCA NEGÓCIOS, 2016) e produção mensal de 6 milhões de pares de meias em 2007 (SINTEX: SINDICATO DAS INDÚSTRIAS DE FIAÇÃO, TECELAGEM E DO VESTUÁRIO DE BLUMENAU, 2007), e a Puket, que, em 2015, produzia 12 milhões de pares de meias anualmente, de acordo com Destino Negócio (DESTINO NEGÓCIO, 2015).

De acordo com o Sistema IBGE de Recuperação Automática - SIDRA (2017), em 2015 havia mais de 300 mil indústrias de transformação no Brasil, que empregavam mais de 7 milhões de pessoas e que possuíam uma receita líquida anual de mais de $\mathrm{R} \$ 2$ bilhões.

Para o setor de meias, especificamente, de acordo com Alice Web (2017), em 2016 as exportações brasileiras somaram US $\$ 2.142 .342,00 \mathrm{em} 381.931$ pares de meias considerando exportações para qualquer país e todos os tipos de meias, excluindo-se as meias-calças. Já as importações somaram US\$2.907.970,00 em 9.893.201 pares de meias, sendo 52 mil pares (US\$354.918,00) provenientes dos Estados Unidos, 71 mil pares (US\$351.625,00) da União Europeia, 96 mil pares (US\$101.896,00) da Índia e mais de 2 milhões de pares (US\$621.971,00) provenientes da China (ALICE WEB, 2017b). Isso mostra que as importações de meias são mais significativas do que as exportações e que o preço das meias brasileiras é alto no mercado, em comparação com o preço das meias que o Brasil importa.

Segundo SIDRA (SISTEMA IBGE DE RECUPERAÇÃO AUTOMÁTICA - SIDRA, 2017b), a produção de meias no Brasil em 2015 alcançou o valor de $\mathrm{R} \$ 943.770 .000,00$, enquanto o valor de vendas do setor no mesmo ano foi de $\mathrm{R} \$ 918.492 .000,00$, gerando um prejuízo de aproximadamente $\mathrm{R} \$ 25$ milhões, reflexo da crise econômica e política que prejudicou a maioria dos setores da indústria no referido ano.

Em termos de números de produção e de vendas, segue série histórica para análise:

TABELA 1 - Série Histórica da quantidade de meias produzidas no Brasil (em pares)

\begin{tabular}{|c|c|c|c|c|c|}
\cline { 2 - 6 } \multicolumn{1}{c|}{} & $\mathbf{2 0 1 1}$ & $\mathbf{2 0 1 2}$ & $\mathbf{2 0 1 3}$ & $\mathbf{2 0 1 4}$ & $\mathbf{2 0 1 5}$ \\
\hline TOTAL & 230.659 .889 & 211.465 .143 & 226.382 .647 & 243.738 .276 & 210.674 .885 \\
\hline
\end{tabular}

Fonte: Adaptado de SIDRA (SISTEMA IBGE DE RECUPERAÇÃO AUTOMÁTICA - SIDRA, 2017b) 


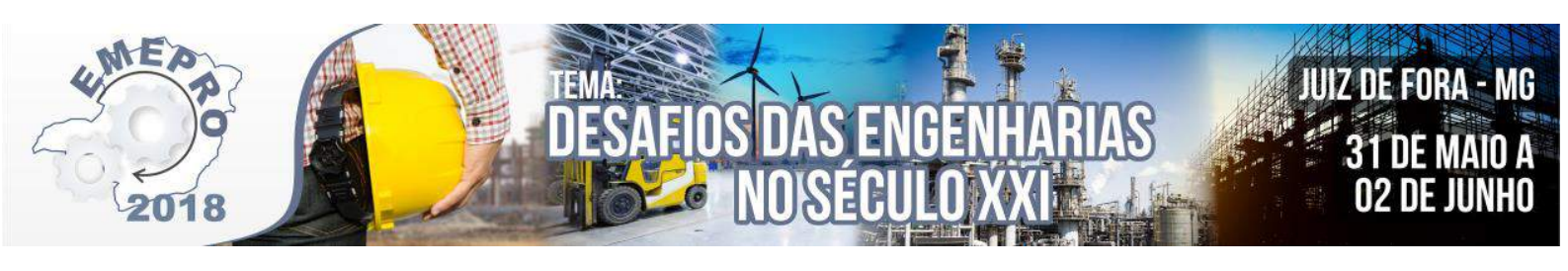

TABELA 2 - Série Histórica da quantidade de meias vendidas no Brasil (em pares)

\begin{tabular}{|c|c|c|c|c|c|}
\cline { 2 - 6 } \multicolumn{1}{c|}{} & $\mathbf{2 0 1 1}$ & $\mathbf{2 0 1 2}$ & $\mathbf{2 0 1 3}$ & $\mathbf{2 0 1 4}$ & $\mathbf{2 0 1 5}$ \\
\hline TOTAL & 226.074 .661 & 235.820 .820 & 255.432 .620 & 253.447 .317 & 226.844 .336 \\
& & & & & \\
\hline
\end{tabular}

Fonte: Adaptado de SIDRA (SISTEMA IBGE DE RECUPERAÇÃO AUTOMÁTICA - SIDRA, 2017b)

Nessa perspectiva, observa-se que o setor de meias experimenta uma leve expansão no Brasil e de forma geral o setor vende mais do que produz, o que sugere que há venda de produtos importados de outros países produtores de meias e que a venda das meias produzidas no Brasil é majoritariamente para o mercado interno.

Juiz de Fora, de acordo com o Sindicato das Indústrias de Meias de Juiz de Fora (SINDICATO DAS INDÚSTRIAS DE MEIAS DE JUIZ DE FORA, 2017), possui 88 fábricas de meias e uma capacidade produtiva de 36 milhões de pares por ano, sendo uma referência no setor, que é altamente concentrado, sendo atualmente o segundo maior polo de meias do Brasil, ficando atrás apenas de São Paulo.

\subsection{Matriz SWOT para o mercado de meias}

A análise SWOT é muito utilizada por organizações visando orientações estratégicas. Sua sigla vem de Strengths (forças), Weaknesses (fraquezas), Opportunities (oportunidades) e Threats (ameaças). Sua sigla em português é, então, FOFA. Nela, os pontos fortes e os pontos fracos da organização são determinados por elementos internos; os elementos externos, por sua vez, são traduzidos em oportunidades e ameaças. Dessa forma, a matriz SWOT permite que a equipe de gestão da empresa tome uma decisão balanceada, após uma cuidadosa análise do cenário no qual a empresa se insere (GONÇALVES et al., 2010).

Para análise em termos de sustentabilidade foi utilizada uma matriz SWOT contendo os três pilares da sustentabilidade: aspectos econômicos, aspectos ambientais e aspectos sociais. Dessa forma, pode-se verificar os principais pontos de atenção e as principais vantagens competitivas que podem ser obtidas a partir de medidas estratégicas. 


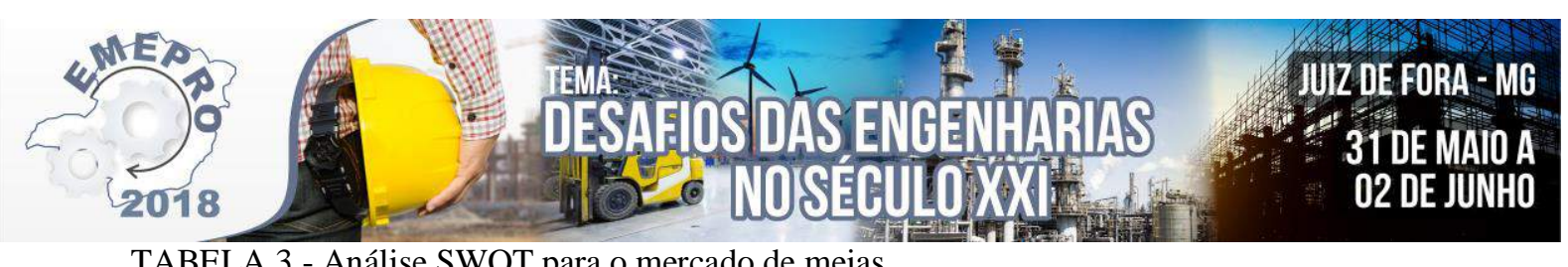

TABELA 3 - Análise SWOT para o mercado de meias

\begin{tabular}{|c|c|c|c|c|}
\hline & Pontos Fortes & Pontos Fracos & Oportunidades & Ameaças \\
\hline Econômicos & $\begin{array}{l}\text { - Baixo custo de } \\
\text { Produção }\end{array}$ & $\begin{array}{l}\text { - Baixo valor } \\
\text { agregado no produto } \\
\text { - Baixo custo de } \\
\text { substituição para o } \\
\text { cliente } \\
\text { - Alto consumo } \\
\text { energético }\end{array}$ & $\begin{array}{l}\text { - Aumento do } \\
\text { consumo de meias } \\
\text { diferenciadas }\end{array}$ & $\begin{array}{l}\text { - Crise } \\
\text { financeira }\end{array}$ \\
\hline Ambientais & $\begin{array}{l}\text { - Não utilização } \\
\text { de recursos } \\
\text { hídricos no } \\
\text { processo } \\
\text { produtivo }\end{array}$ & $\begin{array}{l}\text { - Uso de material } \\
\text { sintético na } \\
\text { composição } \\
\text { - Geração de resíduos } \\
\text { sólidos }\end{array}$ & $\begin{array}{l}\text { - Desenvolvimento de } \\
\text { novas tecnologias em } \\
\text { têxteis }\end{array}$ & \\
\hline Sociais & $\begin{array}{l}\text { - Produto de uso } \\
\text { popular } \\
\text { - Baixo preço de } \\
\text { venda }\end{array}$ & $\begin{array}{l}\text { - Sazonalidade da } \\
\text { demanda } \\
\text { - Alta rotatividade de } \\
\text { funcionários, devido } \\
\text { ao salário } \\
\text { desvalorizado da } \\
\text { classe }\end{array}$ & $\begin{array}{l}\text { - Campanhas sociais } \\
\text { (agasalho) }\end{array}$ & \\
\hline
\end{tabular}

Fonte: os autores

Realizando uma análise cruzada dos pontos observados na matriz SWOT podem ser levantados alguns pontos de atenção. $\mathrm{O}$ baixo custo de produção associado a um baixo preço de venda se mostram como atenuadores da ameaça de crise financeira, já que possibilitam um acesso mais fácil ao produto pelas famílias de baixa renda. O desenvolvimento de novas tecnologias têxteis também pode ser utilizado para reduzir os efeitos ambientais causadas pela utilização de materiais sintéticos na composição do produto. $\mathrm{O}$ baixo custo de produção também auxilia no aproveitamento de campanhas sociais para promoção da marca, já que as doações realizadas não apresentam grandes prejuízos para a organização, com ênfase para a possibilidade de utilização do refugo para realização desta ação. Novamente, o baixo custo de produção associado ao aumento de consumo de meias diferenciadas pode gerar lucros maiores para a empresa, com a venda de produtos de maior valor agregado. Além disso, é importante se pensar em políticas e práticas para reduzir o consumo energético e para valorizar o trabalhador do setor de meias.

\subsection{Relação entre desempenho ambiental, competitividade e ganhos do mercado}




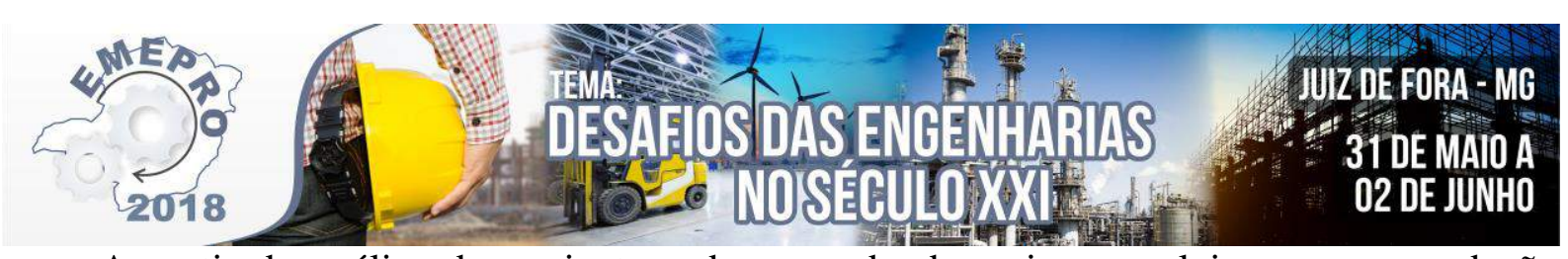

A partir da análise da conjuntura do mercado de meias, conclui-se que a produção brasileira é voltada para o mercado interno.

Meia é considerada um produto de conveniência e apenas recentemente tem mostrado potencial na moda com o surgimento de meias estampadas e meias diferenciadas para atividades como pilates e crossfit. Os fabricantes segmentam os produtos por sexo, por faixa etária, por poder aquisitivo dos consumidores e estações do ano, principalmente (BASIL, 1999). Se observa no mercado, de forma geral, que o preço é um fator forte na decisão de compra dos consumidores, uma vez que meia é majoritariamente um produto de conveniência. No que tange o preço, o que se tem de mais caro na produção de meias são a energia elétrica consumida pelos teares automáticos e a mão de obra, que é intensiva no setor. Dessa forma, busca-se uma maior eficiência energética e um melhor aproveitamento da mão de obra em indústrias de meias.

A indústria têxtil usualmente gera resíduos provenientes de restos de fios e de retalhos e uma correta destinação desses resíduos contribui na conquista a novos mercados, principalmente em relação a exportações e à venda para grandes empresas, uma vez que estas fazem inspeções de qualidade e de cumprimento de normas e leis ambientais em seus fornecedores, a fim de verificar se o fornecedor atende aos seus requisitos de avaliação (QUALIDADE ONLINE, 2010).

Além disso, o marketing social é relativamente forte no setor, a exemplo do projeto Meias do Bem, da Puket (CICLOVIVO, 2016; PUKET, 2017), pois a meia é um artigo que ajuda a proteger do frio e, dessa forma, o refugo gerado pode ser doado ou pode ser transformado em outros produtos, como cobertores, que podem ser doados a pessoas carentes ou a instituições de caridade.

\subsection{A empresa}

A empresa em estudo é localizada na Zona da Mata mineira, com 28 anos de existência e proveniente de uma tradição familiar no ramo têxtil.

Atualmente conta com cerca de 90 colaboradores diretos, que envolvem tecelões, costureiras, passadores, embaladeiras, estoquistas, expedidores, mecânicos, supervisores, equipe de escritório e diretores; produz cerca de 360 mil dúzias de meias por ano e possui três turnos de trabalho, funcionando em tempo integral.

Busca se diferenciar de seus concorrentes pela melhoria contínua do serviço oferecido aos seus clientes e parceiros e pela sua vocação inovadora, buscando sempre estar à frente em relação à variedade e à qualidade de seus produtos (AMARAL, 2017).

\subsection{Fluxograma de macroprocessos}




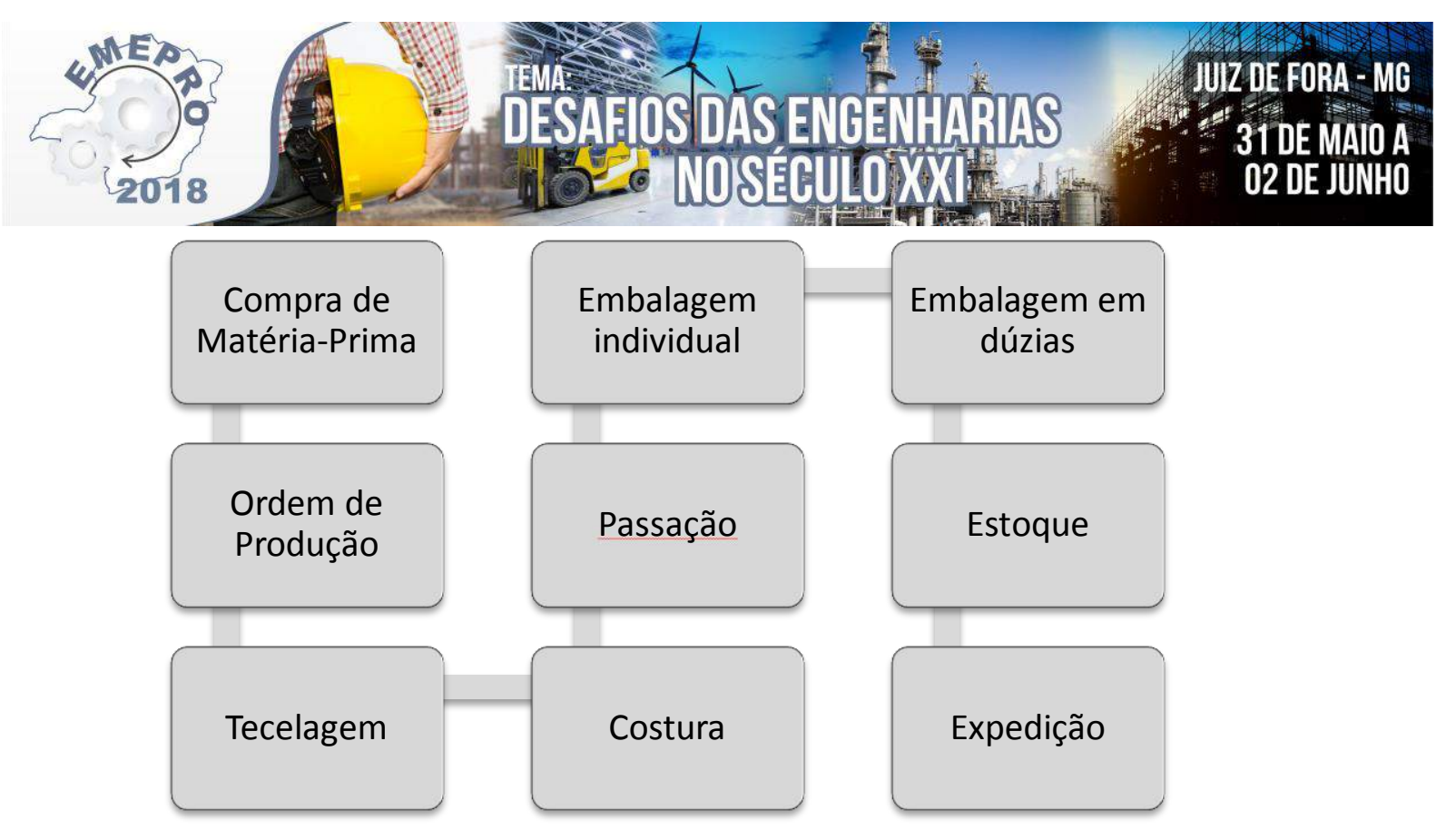

IMAGEM 1- Fluxograma de macroprocessos de fabricação de meias na empresa em estudo. Fonte: os autores

O processo das meias tem início nos teares automáticos, pois os fios já chegam tingidos, sendo eles de algodão e sintéticos. Esta etapa é denominada tecelagem. Durante esse processo os fios podem vir a arrebentar e dado isso há uma máquina de sucção conectada a todos os teares, denominada colepó, que suga esses fios arrebentados. O emaranhado de fios arrebentados é chamado de estopa e é um tipo de resíduo gerado pela etapa. Outro tipo de resíduo gerado no tear é o refugo, que são meias defeituosas ou pedaços de meias que apresentaram alguns defeitos. Após passar pelo tear automático, ocorre uma etapa manual, onde os tecelões viram e contam as meias, e em seguida as amarram em dúzias, com aparas que são geradas no processo seguinte.

O próximo processo é a costura. As meias passam por uma máquina de costura denominada remalhadeira, cuja função é costurar a meia que chega com a ponteira aberta e simultaneamente cortar a pontinha que foi deixada na etapa do tear. Essa pontinha é utilizada como apara para separar dúzias na tecelagem. Esse é o único resíduo da etapa.

Em seguida as meias são passadas em robôs apropriados, e primeiramente embaladas em pares ou em kits e depois embaladas em dúzias para facilitar o transporte e a contagem do produto.

Para finalizar, as meias vão para o estoque e depois são encaminhadas para expedição. A embalagem gera alguns resíduos sólidos, como uma fita de proteção ao adesivo da embalagem plástica. Esta é recolhida adequadamente e posteriormente vendida a uma empresa de reciclagem.

\subsection{Política ambiental da empresa}

A organização adota ações para reduzir o consumo de energia elétrica, de água e de copos plásticos, reutilizar embalagens, reduzir resíduos, reciclar o lixo gerado pelo processo produtivo (quando possível) e transformar refugo que não pode ser vendido em produtos de cunho social.

A fábrica consome, em média, 51 mil $\mathrm{KW}$ de energia mensalmente. O principal consumidor de energia, além das máquinas necessárias no processo, é o motor utilizado para distribuir ar de sucção para as máquinas de tear e para dutos de limpeza. Ele é responsável por aproximadamente $20 \%$ do consumo energético. 


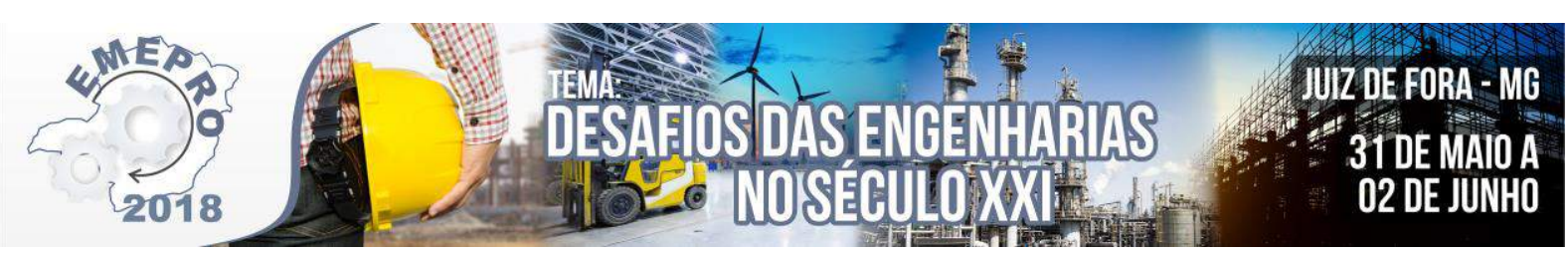

A troca de três motores que desempenhavam a função de distribuir ar para o maquinário por apenas um, mais moderno e mais eficiente, já foi uma forma de se reduzir o consumo energético e para se reduzir o consumo de energia por tal motor foi instalado um regulador eletrônico de pressão que diminui ou aumenta a quantidade de energia fornecida ao motor dependendo da demanda por ar. $\mathrm{O}$ regulador de pressão e o novo motor levaram à diminuição de $25 \%$ do consumo de energia, em média, sendo $44 \%$ mais eficiente energeticamente em relação ao conjunto de três motores instalado anteriormente. Ainda nessa perspectiva, é feita uma conscientização contínua dos tecelões para que os dutos de limpeza sejam usados corretamente visando não sobrecarregar o motor e, consequentemente, não aumentar o consumo de energia elétrica. Em adição, válvulas foram adicionadas a cada máquina de tear para que a sucção cesse nas máquinas que estiverem desligadas, e foi implantada uma política de limpeza dos dutos do colepó, equipamento de sucção de estopa, de hora em hora. A ação consiste em desligar e ligar novamente o colepó rapidamente, o que faz com que a estopa que obstruía dutos caia por gravidade dentro do equipamento, desobstruindo dutos de saída e diminuindo a carga no motor de ar comprimido.

Para reduzir ainda mais o consumo de energia elétrica, a organização investiu na troca das lâmpadas fluorescentes pelas de LED, o que reduziu o consumo mensal em aproximadamente $3.000 \mathrm{kWh}$. As lâmpadas fluorescentes que foram retiradas da fábrica foram em parte vendidas para outras fábricas e outra parte foi doada para instituições de caridade e conjuntos habitacionais. Além disso, foi feita uma conscientização junto aos funcionários para que eles apagassem as lâmpadas e os monitores dos computadores quando estes não estão sendo utilizados e foram colados lembretes em pontos estratégicos, como abaixo dos interruptores.

Em adição, durante 3 horas de funcionamento, no horário de pico de consumo de energia elétrica, a empresa usa gerador a diesel na alimentação de toda a fábrica, o que alivia a rede elétrica pública e contribui para reduzir os riscos de falta de energia e sobrecarga da rede, além de baratear a energia elétrica fornecida para a empresa, através dos descontos que a companhia de energia oferece pela não utilização de energia em horário de pico. O gerador a diesel foi o maior investimento já feito pela empresa, depois da construção do prédio próprio. Tal investimento está sendo pago em 7 anos, mas possui payback de 2 anos e meio e a vida útil do equipamento é estimada em 25 anos, ou mais, realizando-se todas as manutenções corretamente. A média de economia que o gerador proporciona à empresa é de $\mathrm{R} \$ 7$ mil por mês, sendo um importante aliado econômico.

Os resíduos gerados durante a produção são, quando possível, reutilizados na produção ou reaproveitados, como as aparas que são utilizadas para amarrar as meias em dúzias durante a produção na tecelagem, o refugo que é aproveitado na produção de cobertores, e o refugo que não possui graves defeitos que é vendido a um preço inferior ao preço das meias boas. Os resíduos do processo que não são passíveis de reaproveitamento ou de venda, atualmente representando cerca de $4 \%$ das meias produzidas, em $\mathrm{kg}$, são descartados em lixo comum, e há análises de possibilidades para aproveitá-los ou vendê-los para outros tipos de indústrias, como as aparas que sobram, que poderiam ser destinadas ao coprocessamento ou à confecção de cobertores a partir de moagem, o que ainda não se conseguiu realizar por motivos econômicos (há custos de transporte, de armazenamento e, em alguns casos, de serviço pela utilização do material por outra indústria). A estopa, formada por pedaços de fios que são cortados nas máquinas de tear, é vendida para oficinas mecânicas. Os cones plásticos e de papelão provenientes dos fios, entre outros descartes recicláveis oriundos do processo 


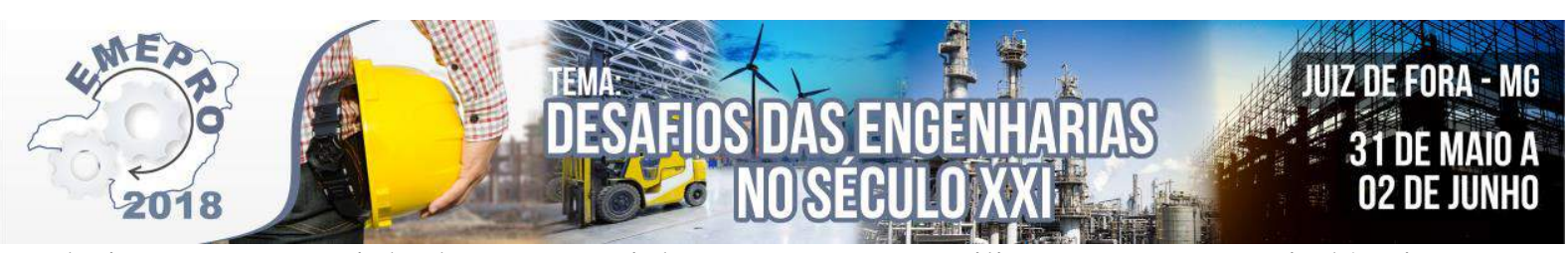

produtivo, são encaminhados para reciclagem ou para reutilização em outras indústrias, como os cones plásticos e alguns de papelão em perfeito estado que são encaminhados para reaproveitamento em indústrias de fiação.

Como medida de aumento de qualidade das meias a empresa está investindo em teares que costuram também a ponta das meias, que já saem das máquinas fechadas e prontas, não necessitando da etapa de costura e não produzindo aparas. Desde 2013 a fábrica em estudo aposta nessa tecnologia e o maquinário novo é composto somente por teares desse tipo, o que vem reduzindo, ano a ano, substancialmente, a porcentagem, e também a quantidade, de aparas geradas no processo. Desde o início do investimento já foram produzidas mais de 200 mil dúzias de meias sem aparas, deixando de gerar mais de 4 mil quilos de aparas e economizando mais de 100 mil reais em fios e em mão de obra. Atualmente, a porcentagem de meias "sem costura" gira em torno de $20 \%$ da produção mensal da empresa.

Outra decisão tomada pela organização visando diminuição de custos tem impacto ambiental positivo: gradualmente a empresa foi substituindo elástico por elastano na composição dos produtos. Apesar de o quilo do elastano ser mais caro que o quilo do elástico e de ser necessário investimento em adaptação para os teares automáticos, se gasta menos da metade de elastano em comparação com o elástico em cada meia produzida, compensando economicamente o investimento e a matéria-prima mais cara. Isto representa ainda uma redução de utilização de materiais provenientes de petróleo pela fábrica.

Em relação à embalagem, originalmente as dúzias eram todas embaladas em sacos plásticos de 0,12 $\mathrm{mm}$ de espessura, de tamanho padrão, que muitas vezes ficavam grandes dependendo do modelo da meia, chegando a ser dobrados ao meio em alguns casos, além de necessitar de fita adesiva para colar os sacos. Atualmente as embalagens em dúzias são feitas em máquina de embalagem, que utiliza bobinas plásticas de $0,05 \mathrm{~mm}$ de espessura e ajusta $\mathrm{o}$ tamanho do saco plástico ao volume ocupado pela dúzia em diferentes modelos de meias. Porém a máquina tem limitações e nem todos os modelos podem ser embalados por ela. Apesar disso, a diminuição do tamanho das embalagens em dúzias e da espessura do plástico, na maioria dos modelos produzidos pela fábrica, já representa uma redução da quantidade de plástico que será descartado posteriormente pelos lojistas.

A matéria-prima chega na fábrica em caixas de papelão. Com o intuito de reduzir a quantidade de lixo gerado pela empresa e de diminuir custos com compra de caixas, começouse a reutilizar as caixas de papelão vindas dos fornecedores para embalar pedidos de clientes.

Há aproximadamente 8 anos a empresa inovou ao desenvolver cartelas para embalagem que dispensam o uso dos tradicionais cabidinhos de plástico. Dessa forma, economizam-se cerca de 174 mil reais por ano com a compra dos cabides e com mão de obra. A embalagem de papel desenvolvida não representa nenhum aumento de custo, uma vez que é utilizada a área de papel original para o cabide de papel. Adicionalmente, deixam-se de descartar aproximadamente 4 milhões de cabides plásticos por ano somente com os produtos da empresa em estudo. Considerando-se que outras indústrias de meias também começaram a utilizar esse tipo de cartela, a economia de cabides plásticos é ainda muito maior.

Por fim, projetos sociais ajudam na destinação de refugos que não têm possibilidade de serem vendidos como produtos com Leves Defeitos (LD). Um desses projetos é a confecção e doação de cobertores feitos de pedaços de meias. Outro projeto é o de confecção de bonecos feitos de meias sem par e de refugos por artesãs do entorno da fábrica.

\section{Propostas de melhorias}




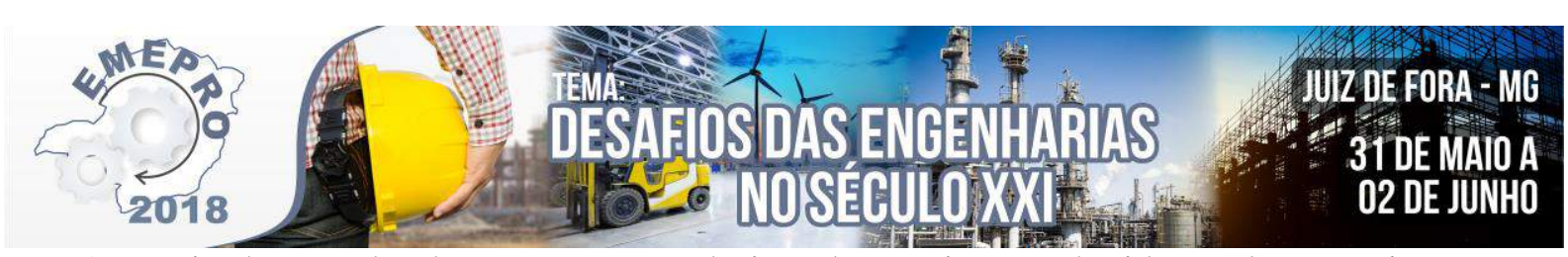

A partir do estudo do processo produtivo das meias produzidas pela organização em estudo e de conceitos de Produção Mais Limpa, propõem-se as seguintes medidas para minimizar impactos ambientais e aumentar ainda mais a competitividade da organização adotando-se práticas sustentáveis:

\subsection{Redução da espessura do plástico de embalagem em pares}

Atualmente se utiliza um plástico de espessura $0,12 \mathrm{~mm}$ para embalagem em pares. Discutiu-se a possibilidade de abolir o uso de sacos plásticos nas embalagens em pares, como se vê no mercado em meias de outras marcas, porém os clientes lojistas da empresa em estudo muitas vezes têm estrutura de portas abertas, sem proteção de vidro, e se situam em locais onde há muita poeira e pó de asfalto, o que sujaria as meias desprotegidas. Portanto, essa opção se torna inviável.

Por outro lado, embalagens com espessura menor podem ser bem aceitas pelo mercado e ainda cumprirem sua missão de proteção. Nesse sentido, testes deverão ser realizados reduzindo-se a espessura da embalagem plástica para pares.

\subsection{Utilização de fios provenientes de algodão colorido naturalmente}

Existem tipos de algodão coloridos naturalmente que são cultivados de forma orgânica no sertão paraibano (SANTOS, 2015). Essa matéria prima não gera impactos ambientais decorrentes de tratamento do solo, agrotóxicos e tingimento das fibras de algodão na fase de beneficiamento.

Estudos de custo $\mathrm{x}$ benefício necessitam ser realizados a fim de avaliar se é vantajoso adotar fios provenientes desse tipo de algodão na empresa estudada.

\subsection{Planejamento e Controle da Produção}

Atualmente a organização estudada possui uma política informatizada de Planejamento e Controle da Produção deficitária, ficando esta área à mercê de decisões tomadas empiricamente pelo setor de planejamento da produção da fábrica. Isto gera inconvenientes, como desperdício de matéria-prima com itens que não terão demanda, estocagem excessiva e alongada de itens que serão vendidos apenas muito tempo após sua produção e, ainda, descarte de embalagens que muitas vezes precisam ser trocadas após a chegada de pedidos.

Tais desperdícios custam recursos monetários, custo de oportunidade e também geram resíduos que não deveriam ser gerados pela empresa. Portanto, chega-se à conclusão que a estruturação do planejamento e do controle da produção na fábrica é de suma importância para o aumento da sustentabilidade e da competitividade desta.

\subsection{Adoção de filosofia de qualidade}

A fim de se reduzir a quantidade de refugo gerado na fábrica de meias em questão, vê-se a importância de se implantar uma cultura e uma filosofia da qualidade em todos os processos, incluindo políticas como Zero Defeito e Controle Total da Qualidade.

\section{Conclusão}

A empresa estudada tem uma política ambiental bem ampla e está sempre inovando em produtos e no processo produtivo a fim de diminuir custos, aumentar a qualidade do produto e do serviço prestado, diminuir impactos ambientais, aumentar a produtividade, melhorar condições de trabalho, e, dessa forma, aumentar sua competitividade no mercado. Muitas das 


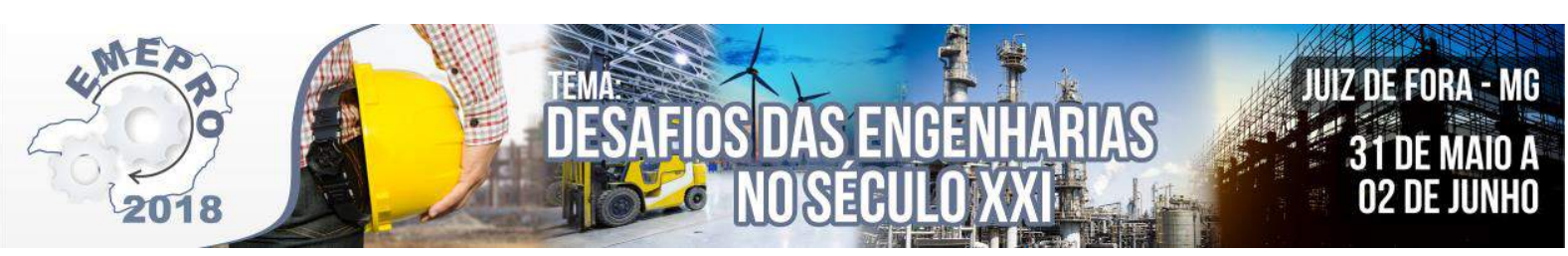

ideias de melhoria implementadas consistem em modificações que muitas vezes não demandam grandes esforços, mas geram resultados que surpreendem positivamente.

Por fim, apenas com as medidas sustentáveis apresentadas nesse estudo de caso, a empresa economiza mais de $\mathrm{R} \$ 500$ mil por ano, o que aumenta diretamente sua vantagem competitiva no mercado, pois essa economia é convertida em investimentos com melhoria de qualidade, expansão da fábrica, pesquisa e desenvolvimento, entre outros. Além disso, é possível diminuírem-se os preços dos produtos que a organização oferece, pois se gasta menos para se fabricar o mesmo.

Portanto, fica evidente que a implementação de práticas visando a Produção Mais Limpa aumenta a competitividade de empresas do ramo industrial.

\section{Bibliografia}

ALICE WEB. Exportações de Meias no Brasil em 2016. Disponível em: <http://aliceweb.mdic.gov.br/>. Acesso em: 18 out. 2017a.

ALICE WEB. Importações de Meias no Brasil em 2016. Disponível em: <http://aliceweb.mdic.gov.br/>. Acesso em: 18 out. $2017 \mathrm{~b}$.

AMARAL, João. Conversa com um dos diretores da empresa em estudo, 21 set. 2017

BASIL, Carla Marina. O atacado como canal de distribuição: subsídios para a análise do mercado de meias e lingerie. , 1999. Disponível em: <http://bibliotecadigital.fgv.br/dspace/handle/10438/11592>. Acesso em: 18 out. 2017.

BASTIAN, Elza. Guia Técnico Ambiental da Indústria Têxtil - Série P+L. 21. ed. São Paulo: CETESB : SINDITÊXTIL, 2009. 85 p. Disponível em: <http://www.sinditextilsp.org.br/guia_p\%2Bl.pdf.pdf>. Acesso em: 6 dez. 2017. .

CICLOVIVO. Projeto transforma meias velhas em cobertores para pessoas carentes. Disponível em: <http://ciclovivo.com.br/noticia/projeto-transforma-meias-velhas-em-cobertores-para-pessoas-carentes/>. Acesso em: 18 out. 2017.

CONSELHO EMPRESARIAL BRASILEIRO PARA O DESENVOLVIMENTO SUSTENTÁVEL (CEBDS). Guia da Produção Mais Limpa - Faça Você Mesmo . CEBDS.

DESTINO NEGÓCIO. Puket é referência em moda infantil .Destino Negócio. Disponível em: $<$ http://destinonegocio.com/br/casos-de-sucesso/franquias-de-sucesso-conheca-a-puket-especializada-emmoda-infantil/>. Acesso em: 22 set. 2017. , 5 abr. 2015

ÉPOCA NEGÓCIOS. Lupo: da quase falência ao topo do mercado. Disponível em: <http://epocanegocios.globo.com/Empreendedorismo/noticia/2016/01/lupo-da-quase-falencia-ao-topo-domercado.html>. Acesso em: 22 set. 2017.

FERREIRA, Marcus Bruno; SALLES, Alexandre. Política ambiental brasileira: análise histórico-institucionalista das principais abordagens estratégicas. Revista de Economia v. 43, n. 2, p. 17, ago. 2016.

GONÇALVES, L. R. G. et al. Aplicação da ferramenta SWOT para avaliação das técnicas de dano ao choque térmico em materiais refratários. Cerâmica v. 56, n. 340, p. 320-324 , dez. 2010.

MILANEZ, Bruno. Produção Mais Limpa . Universidade Federal de Juiz de Fora . Acesso em: 5 dez. 2017. , 2017

MORENGHI, Luiz Carlos; ANDRADE, Rogério; ROSANO, Robson. Produção Mais Limpa e Produção Enxuta: Haverá simbiose na busca de conformação ambiental com a flexibilização dos fatores de produção? . Bauru, SP, 


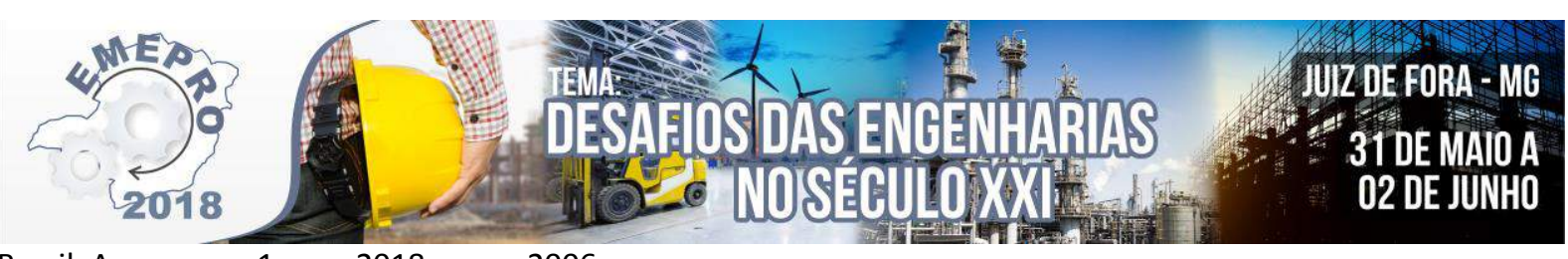

Brasil. Acesso em: 1 mar. 2018. , nov. 2006

PENA, Caroline et al. As fragilidades do sistema de licenciamento ambiental no Brasil com base no estudo de caso da Companhia Siderúrgica do Atlântico. LinkSciencePlace interdisciplinar v. 3, n. 4 , dez. 2016. Disponível em: <http://revista.srvroot.com/linkscienceplace/index.php/linkscienceplace/article/view/260/163>. Acesso em: 21 set. 2017.

PIMENTA, Handson Claudio Dias; GOUVINHAS, Reidson Pereira. A produção mais limpa como ferramenta da sustentabilidade empresarial: um estudo no estado do Rio Grande do Norte. Production v. 22, n. 3, p. $462-476$ , 21 jun. 2012.

PUKET. Puket - Meias do Bem: Sobre a Campanha. Disponível em: <http://meiasdobem.com.br/campanha>. Acesso em: 18 out. 2017.

QUALIDADE ONLINE. Os conceitos da qualidade assegurada de fornecedores qualidadeonline's Blog. Disponível em: <https://qualidadeonline.wordpress.com/2010/01/28/os-conceitos-da-qualidade-asseguradade-fornecedores/>. Acesso em: 18 out. 2017. , 28 jan. 2010

SANTOS, Edna. Algodão colorido conquista mercado internacional de moda. Disponível em: <https://www.embrapa.br/busca-de-noticias/-/noticia/2565547/algodao-colorido-conquista-mercadointernacional-de-moda>. Acesso em: 7 dez. 2017.

SINDICATO DAS INDÚSTRIAS DE MEIAS DE JUIZ DE FORA. Mercado de Meias - Juiz de Fora: agosto de 2017, 8 set. 2017

SINTEX: SINDICATO DAS INDÚSTRIAS DE FIAÇÃO, TECELAGEM E DO VESTUÁRIO DE BLUMENAU. Lupo construirá fábrica de meias na PB. Disponível em: <http://www.sintex.org.br/noticia/2007/08/06/56367-lupo-construirfbrica-de-meias-na-pb>. Acesso em: 22 set. 2017.

SISTEMA IBGE DE RECUPERAÇÃO AUTOMÁTICA - SIDRA. Pesquisa Industrial Anual - Produto. Disponível em: <https://sidra.ibge.gov.br/pesquisa/pia-produto/quadros/brasil/2015>. Acesso em: 22 set. 2017 a.

SISTEMA IBGE DE RECUPERAÇÃO AUTOMÁTICA - SIDRA. Série Histórica de Produção e Vendas de meias no Brasil - 2011 a 2015. Disponível em: <https://sidra.ibge.gov.br/geratabela?format=ods\&name=Histórico Meias 2011-

2015.ods\&compress=false\&query=t\%2F5807\%2Fn1\%2Fall\%2Fv\%2F214\%2C215\%2C1982\%2C1983\%2C1001983 \%2Fp\%2Flast\%205\%2Fc718\%2F34724\%2C34725\%2C34726\%2C34729\%2Fd\%2Fv1001983\%202\%2Fl\%2Fv\%2Cp \%2Bc718\%2Ct>. Acesso em: 18 out. 2017b.

UNITED NATIONS ENVIRONMENT PROGRAME - UNEP. UNEP DTIE SCP Branch: Resource Efficient and Cleaner Production. Disponível em: <http://www.unep.fr/scp/cp/understanding/>. Acesso em: 10 maio 2018. 


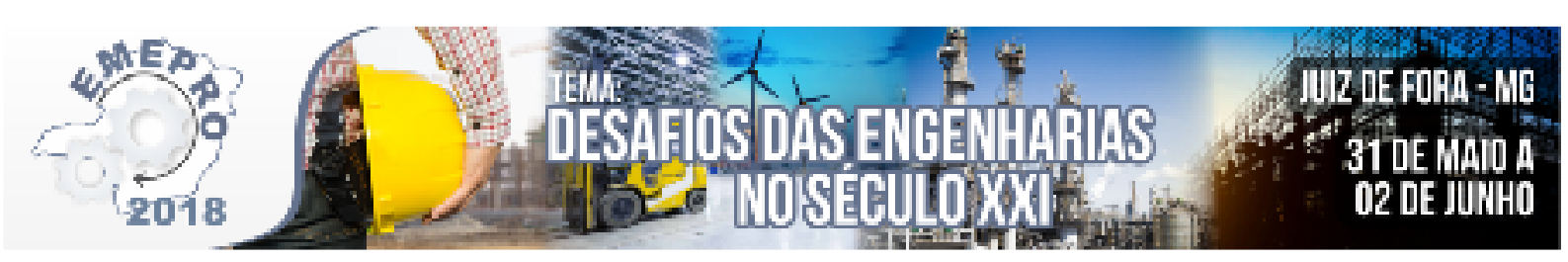

\title{
Aquecedores Solares: alte rnativa para redução do consumo de ene rgia elétrica
}

\begin{abstract}
Eliziane Medeiros Santos (Faculdades Doctum) - elizianemsantos@gmail.com Jéssica de Almeida Rocha (Faculdades Doctum) - jssicaalmeida@yahoo.com.br
\end{abstract}

Resumo: O sistema de aquecimento de água por coletores solares vem sendo cada vez mais utilizado em centros urbanos como alternativa energética, e principlamete, adotado com o objetivo de reduzir o consumo de energia elétrica. Não somente em residências e comércios, mas também em centros de saúde e hospitais, este tipo de sistema tornou-se uma alternativa viável para sua utilização em grande escala. $O$ sistema de aquecedores solares foi a alternativa de redução de gastos de energia solar do Hospital Santa Casa de Misericórida em Juiz de Fora - MG, que passou a atuar na redução da conta de energia elétrica desde 2013.

Palavras-chave: Aquecedores solares; Energia solar; Energia elétrica

\section{Introdução}

Os raios solares, além de trazerem a luz e o calor, essenciais para a vida na Terra, podem ser aproveitados para a geração de energia, tanto na forma de calor como na forma de eletricidade. Para se ter uma ideia, uma hora de sol na superfície da Terra contém mais energia do que o planeta utiliza em um ano.

No seu movimento de translação ao redor do Sol, a Terra recebe $1.410 \mathrm{~W} / \mathrm{m}^{2}$ de energia, medição feita numa superfície normal (em ângulo reto) com o Sol. Disso, aproximadamente $19 \%$ é absorvido pela atmosfera e $35 \%$ é refletido pelas nuvens. Ao passar pela atmosfera terrestre, a maior parte da energia solar está na forma de luz visível e luz ultravioleta.

Em termos mais técnicos a Energia solar é a designação dada a qualquer tipo de captação de energia luminosa, energia térmica (e suas combinações) proveniente do sol, e posterior transformação dessa energia captada em alguma forma utilizável pelo homem, seja diretamente para aquecimento de água ou ainda como energia elétrica ou energia térmica.

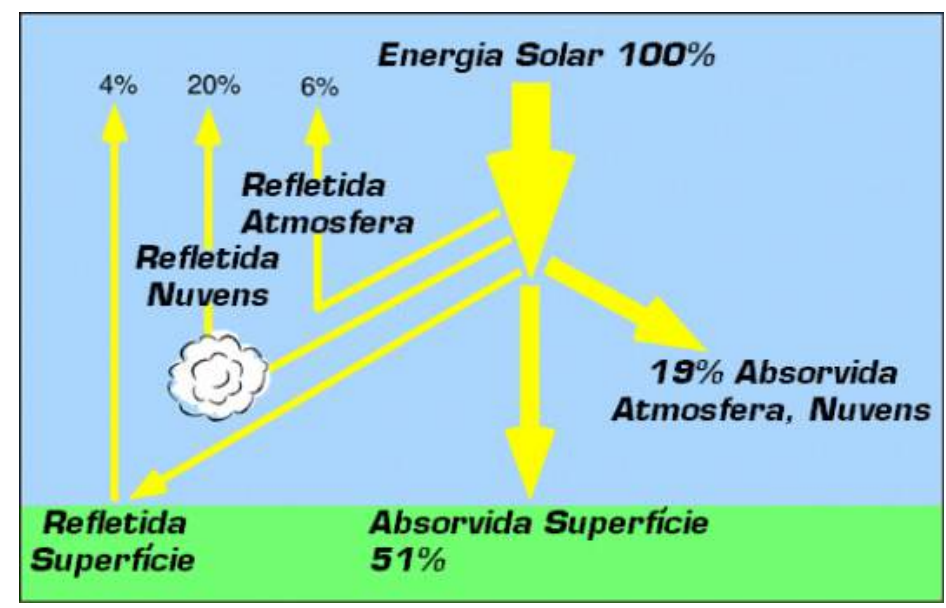

FIGURA 1 - Incidência de raios solares e sua distribuição. Fonte: Tudo Sobre Energia Solar (2010). 


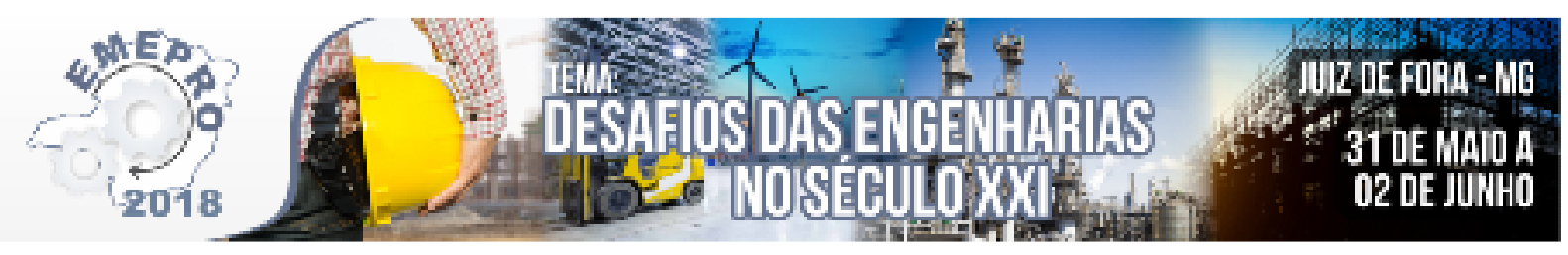

\section{Tipos de sistemas de captação de Energia Solar}

2.1 Energia fototérmica: Este tipo de energia possui relação com o aquecimento de líquidos ou gases através da absorção dos raios solares que causam o seu aquecimento. Geralmente são empregadas no aquecimento de água para uso em chuveiros, ou mesmo gases para secagem de grãos ou uso em turbinas.

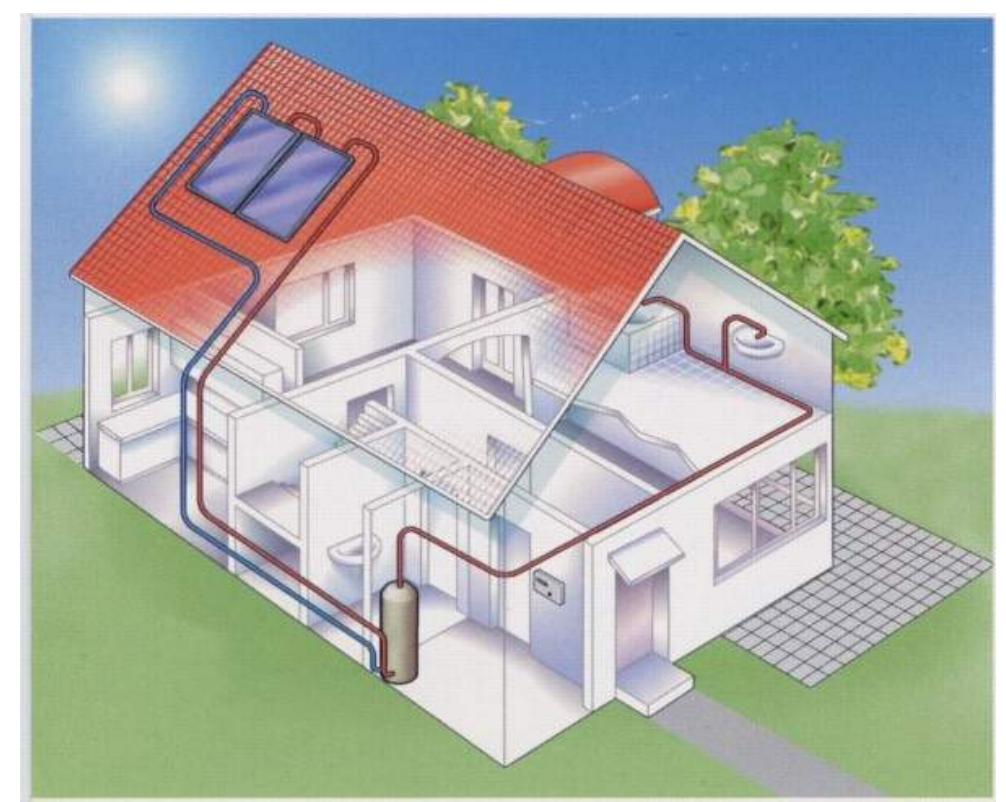

FIGURA 2 - Sistema Fototérmico. Fonte: Arquitetura Sustentável: Residencial (2013).

2.2 Energia fotovoltaica: Este tipo de energia visa a conversão da energia solar em energia elétrica através de células fotovoltaicas. As células fotovoltaicas mais conhecidas e utilizadas são feitas de silício por possuir características intermediárias entre um condutor e um isolante. Apesar de mais tradicional, a célula de silício é mais cara. No entanto, existem alternativas mais baratas que são capazes de gerar cerca de 4 volts, as chamadas DSC ("Dye-sensitized Solar Cell", ou célu la solar sensibilizada por corante).

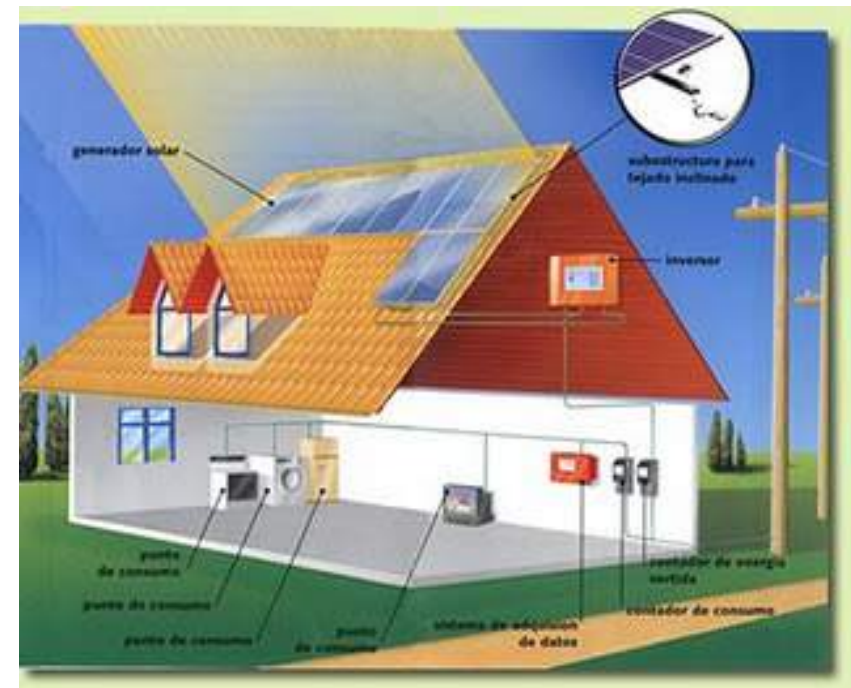

FIGURA 3 - Sistema Fotovoltaico. Fonte: Green Peace Porto Alegre (2011). 


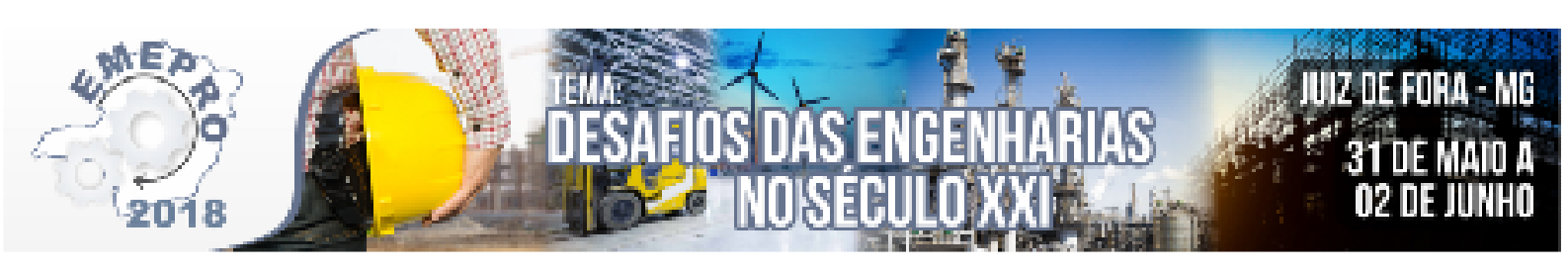

\section{Tipos de captura da Energia Solar}

3.1 Método Direto: No método direto a energia solar é transformada em outro tipo de energia que pode ser usada pelo homem no seu dia-a-dia. Exemplo: A energia solar atinge um painel solar, sendo após transformada em eletricidade.

3.2 Método Indireto: No método indireto significa que mesmo recebendo e transformando toda a energia do Sol, ela não pode ser usada de forma útil sem ter um processo de transformação maior. Um exemplo disso é os sistemas que controlam automaticamente cortinas conforme a disponibilidade e presença da luz do sol.

\section{O Sistema de Aquecimento Solar}

O sistema de aquecimento solar é divido em três subsistemas básicos. São eles:

- Captação: composto pelos coletores solares por onde circula o fluido a ser aquecido e pelas tubulações de ligação entre os coletores e entre a bateria de coletores e o reservatório térmico. Em instalações maiores há ainda a bomba hidráulica. No Brasil, o fluido de trabalho mais usado é a água;

- Armazenamento: composto pelo reservatório térmico e pelo sistema complementar de energia;

- Consumo: composto por toda a distribuição hidráulica entre o reservatório térmico e os pontos de consumo.

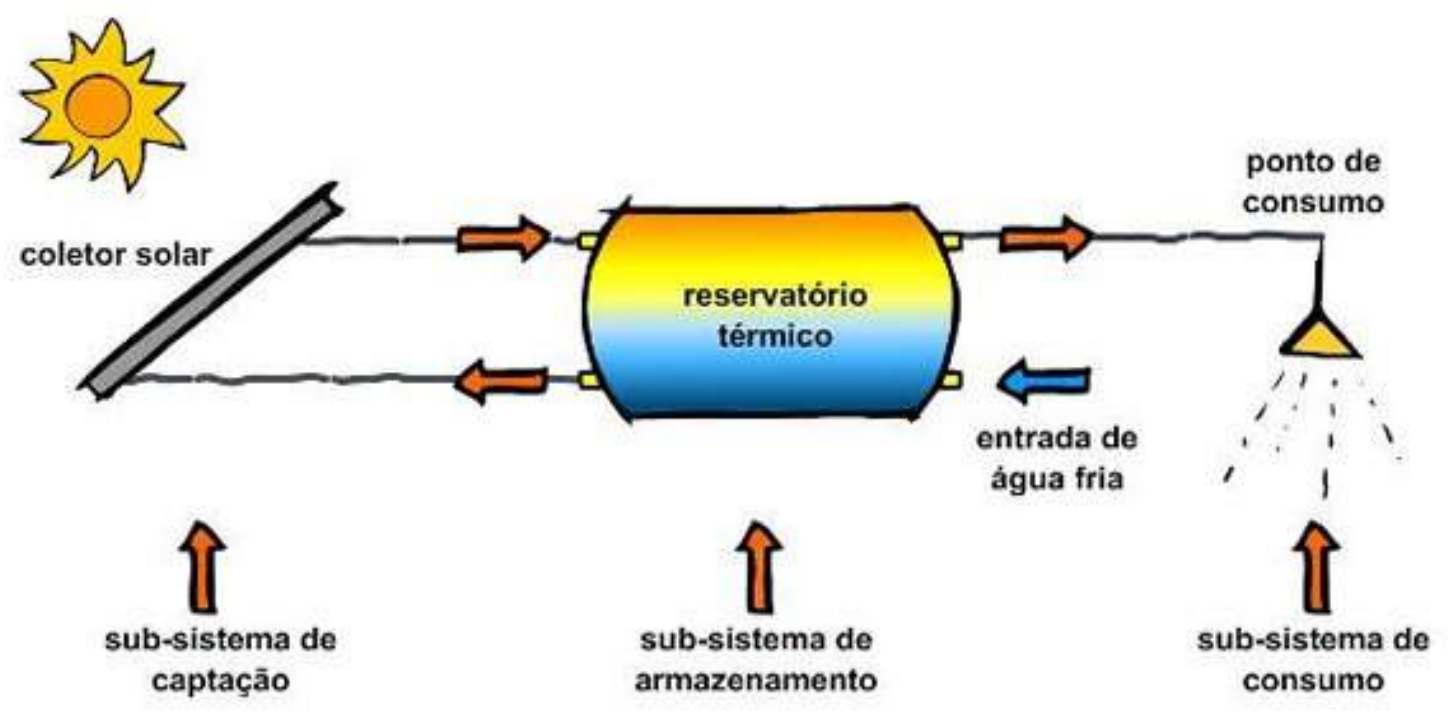

FIGURA 4 - Subsistemas do Aquecimento Solar. Fonte: Portal Metálica (2012). 

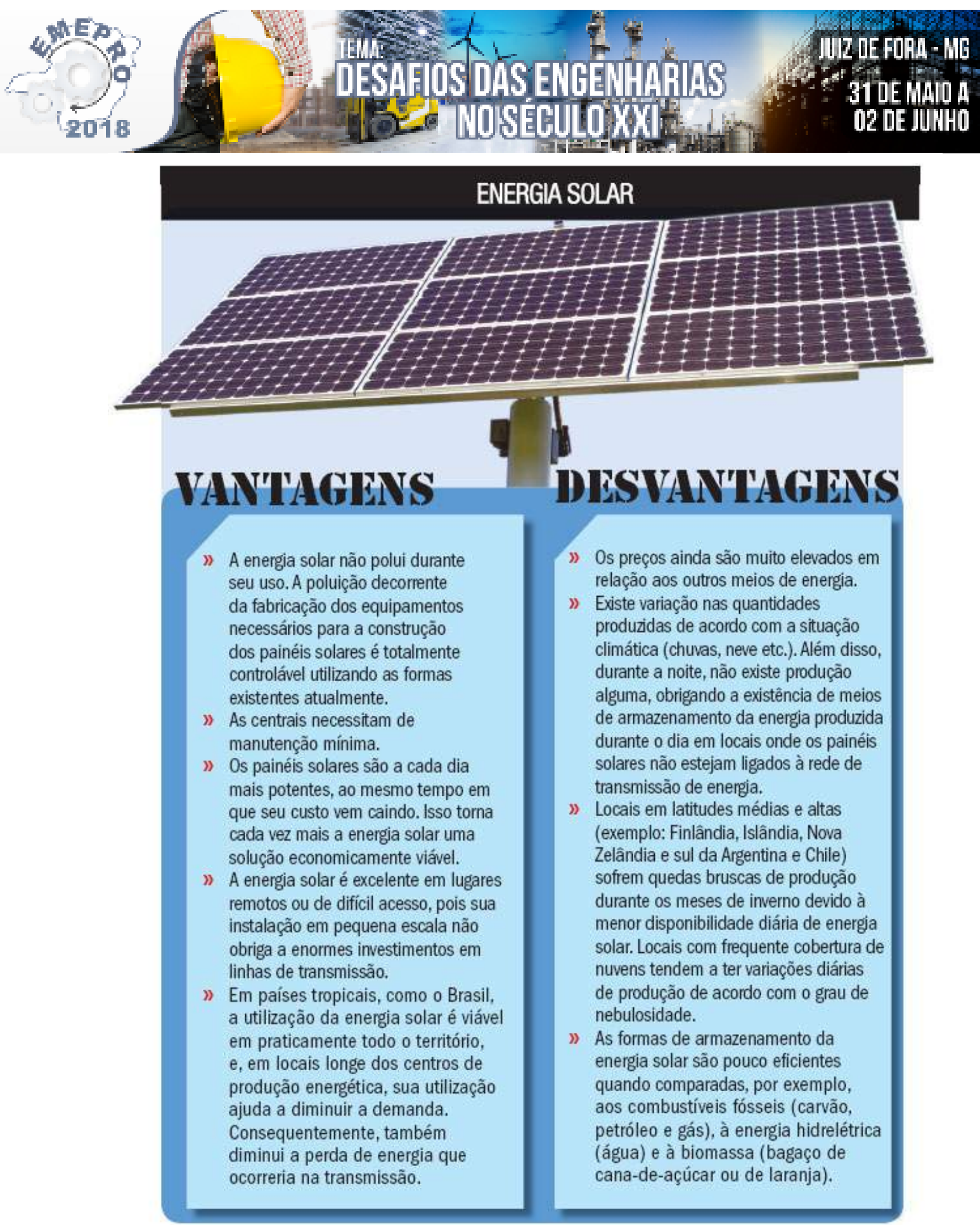

FIGURA 5 - Vantagens e Desvantagens do Sistema de Aquecimento Solar. Fonte: Energia Sustentável (2010).

\section{Como funciona o sistema de aquecimento solar?}

Os coletores são formados por uma placa de vidro que isola do ambiente externo aletas de cobre ou alumínio pintadas com tintas especiais na cor escura para que absorvam o máximo da radiação. Ao absorver a radiação, estas aletas deixam o calor passar para tubos em forma de serpentina geralmente feitos de cobre. Dentro desses tubos existe água, que é aquecida antes de ser levada para o reservatório de água quente. Estas placas coletoras podem ser dispostas sobre telhados e lajes e a quantidade de placas instaladas varia conforme o tamanho do reservatório, o nível de insolação da região e as condições de instalação. No 


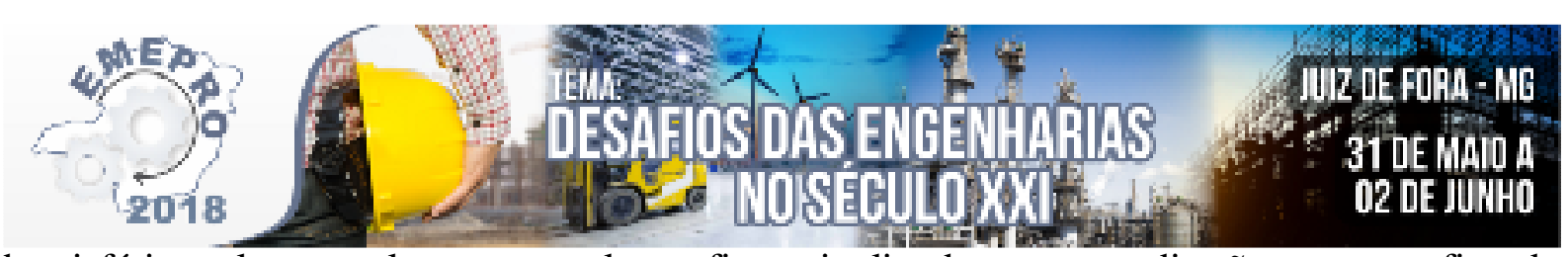

hemisfério sul, normalmente as placas ficam inclinadas para a direção norte a fim de receberem a maior quantidade possível de radiação.

Os reservatórios são cilindros de alumínio, inox ou polipropileno com isolantes térmicos para que mantenham pelo maior tempo possível a água aquecida. Uma caixa de água fria abastece o sistema para que o boiler fique sempre cheio.

Os reservatórios devem ser instalados o mais próximo possível das placas coletoras (para evitar perda de eficiência do sistema), de preferência devem estar sob o telhado (para evitar a perda de calor para a atmosfera) e em nível um pouco elevado. Dessa forma, consegue-se o efeito chamado de termossifão, ou seja, conforme a água dos coletores vai esquentando, ela torna-se menos densa e vai sendo empurrada pela águ a fria. Assim ela sobe e chega naturalmente ao boiler, sem a necessidade de bombeamento. Em casos específicos, em que o reservatório não possa ser instalado acima das placas coletoras, podem-se utilizar bombas para promover a circulação da água.

Apesar de poderem ser instalados de forma independente, os aquecedores solares normalmente trabalham com um sistema auxiliar de aquecimento da água. Este sistema pode ser elétrico ou a gás. Quando houver uma sequência de dias nublados ou chuvosos em que a energia gerad a pelo aquecedor solar não seja suficiente para esquentar toda a água necessária para o consumo diário, um aquecedor elétrico ou a gás é acionado, gerando água quente para as pias e chuveiros.

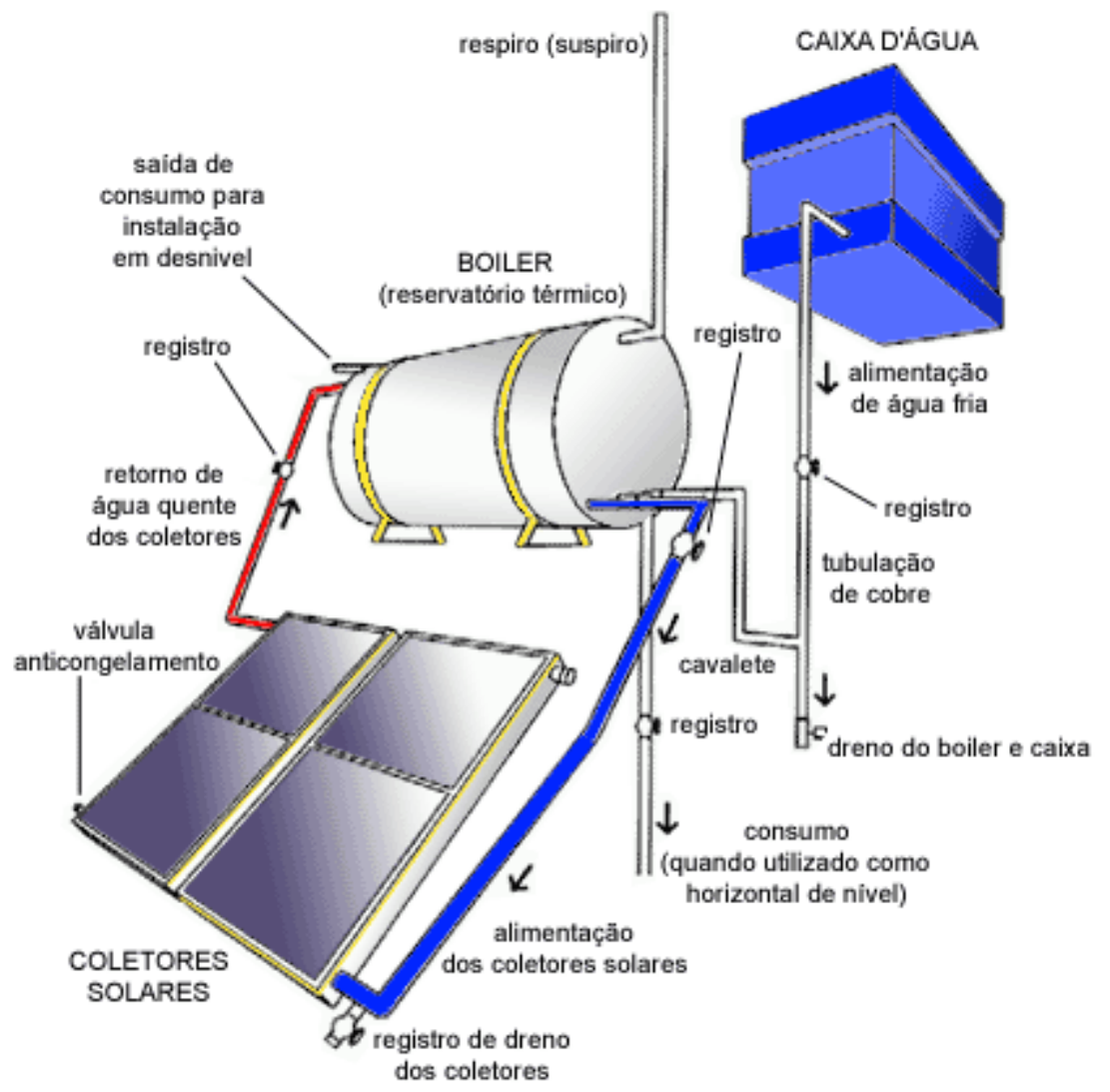

FIGURA 6 - Componentes do Sistema de Aquecimento Solar. Fonte: Vettor Solar (2012). 

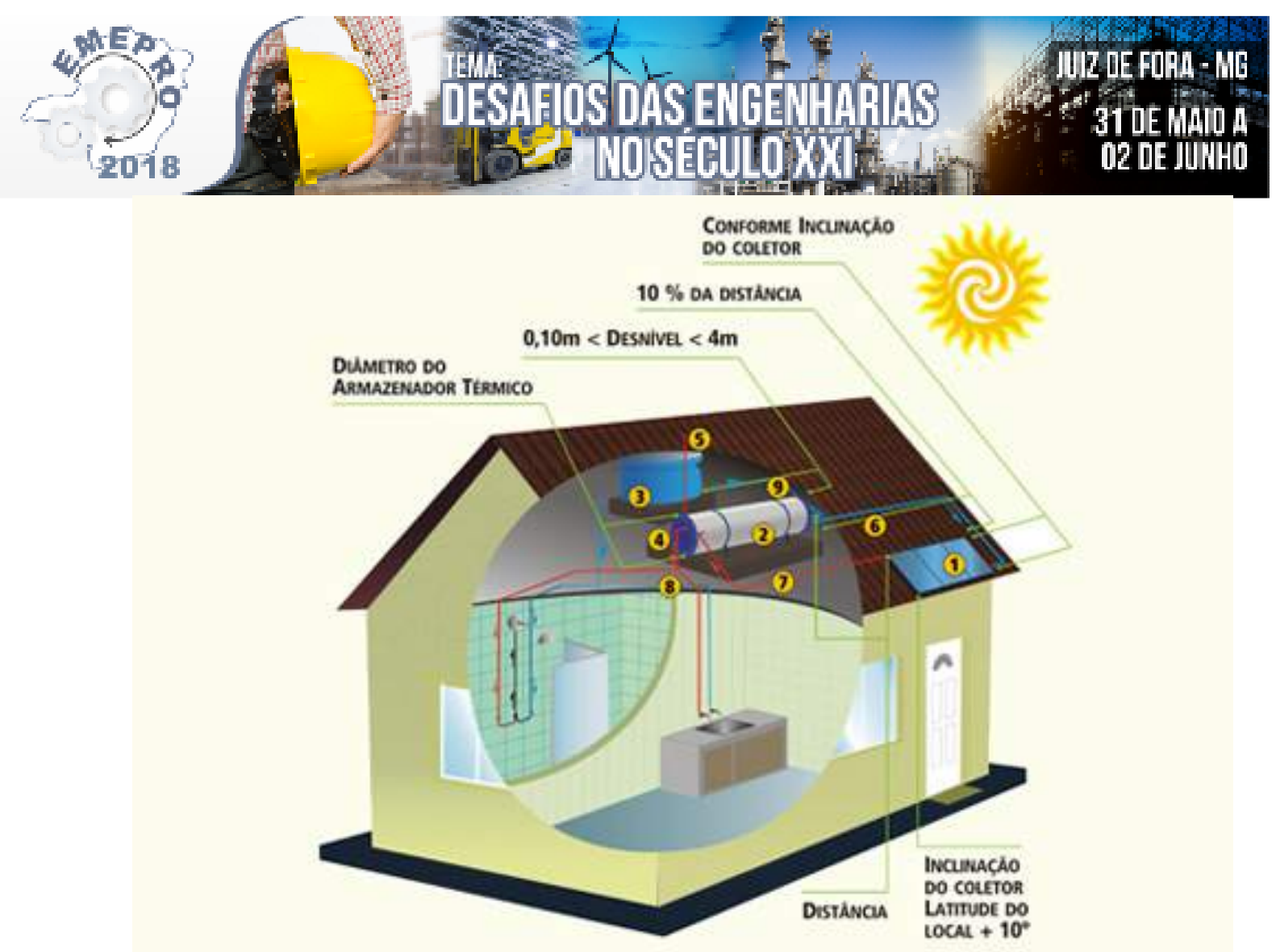

FIGURA 7 - Locação dos componentes do Sistema de Aquecimento Solar em uma residência.

Fonte: Hidro Shop (2012).

\section{Curiosidades}

- Somente cerca de $1 \%$ da energia produzida e consumida no mundo atual é de energia solar. Mas a boa notícia é que a produção de energia solar está aumentando a cada ano.

- Os países que mais produzem energia solar são: Japão, Estados Unidos e Alemanha.

\section{A utilização do sistema de aquecimento solar em hospitais na cidade de Juiz de Fora -} MG

- O maior sistema de aquecimento solar da América Latina foi inaugurado na Santa Casa de Misericórdia de Juiz de Fora

No dia $1^{\circ}$ de março de 2013, o maior sistema de aquecimento solar da América Latina foi inaugurado na Santa Casa de Misericórdia de Juiz de Fora. Cerca de 400 pessoas entre autoridades, como o deputado estadual Marcus Pestana e vice-prefeito Sérgio Rodrigues, colaboradores da Santa Casa e membros do corpo clínico da Instituição prestigiaram o evento, que aconteceu no Salão Nobre do Hospital.

O presidente da Santa Casa, Dr. Renato Villela Loures, ressaltou a importância da utilização correta de en er gia. "A Santa Casa, que possui 1.800 colaboradores, 750 médicos, 508 leitos, sendo 315 leitos destinados ao Sistema Único de Saúde (SUS) e mantém sua preocupação com a sustentabilidade de uma en ergia limpa". 


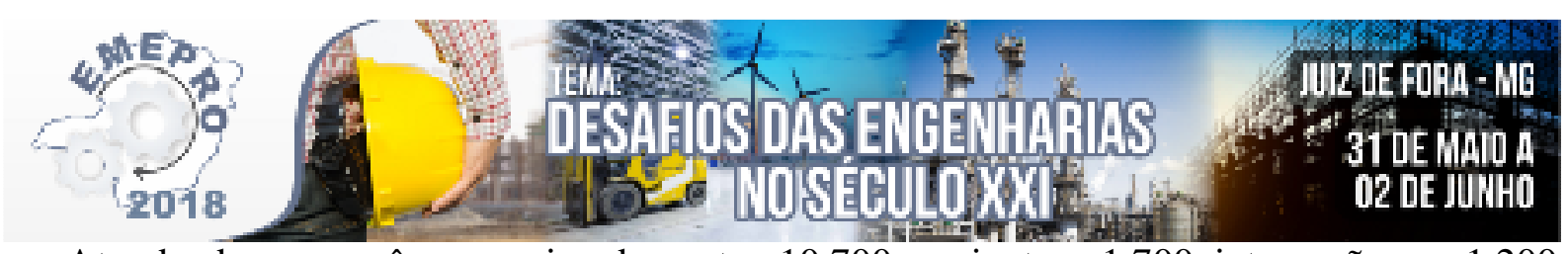

Atendendo, por mês, aproximadamente, 10.700 pacientes, 1.700 internações e 1.200 cirurgias, a Santa Casa reduzirá os gastos anuais em mais de $\mathrm{R} \$ 600$ mil reais, pois além de diminuir $30 \%$ o consumo de energia elétrica, o volume de óleo utilizado na caldeira cairá em torno de $40 \%$.

De acordo com o presidente da Cemig, Dr. Djalma Bastos de Morais, “(...) o investimento no sistema de aquecimento solar que estamos inaugurando hoje na Santa Casa, é algo inédito em todo o Estado, no que se diz respeito à eficiência energética. São R \$ 2 milhões de reais, o que mais do que duplica os recursos já aplicados pelo Energia Inteligente em Juiz de Fora, no prazo de dois anos (...)".

Satisfeito com a concretização do projeto, o presidente da Santa Casa cita os planos futuros da Instituição. "O sistema implantado, vem ao encontro da nova visão, que é de sermos reconhecidos pela excelência em gestão de saúde até o final deste ano".

- Santa Casa de Juiz de Fora recebe maior sistema de Aquecimento Solar da América do Sul

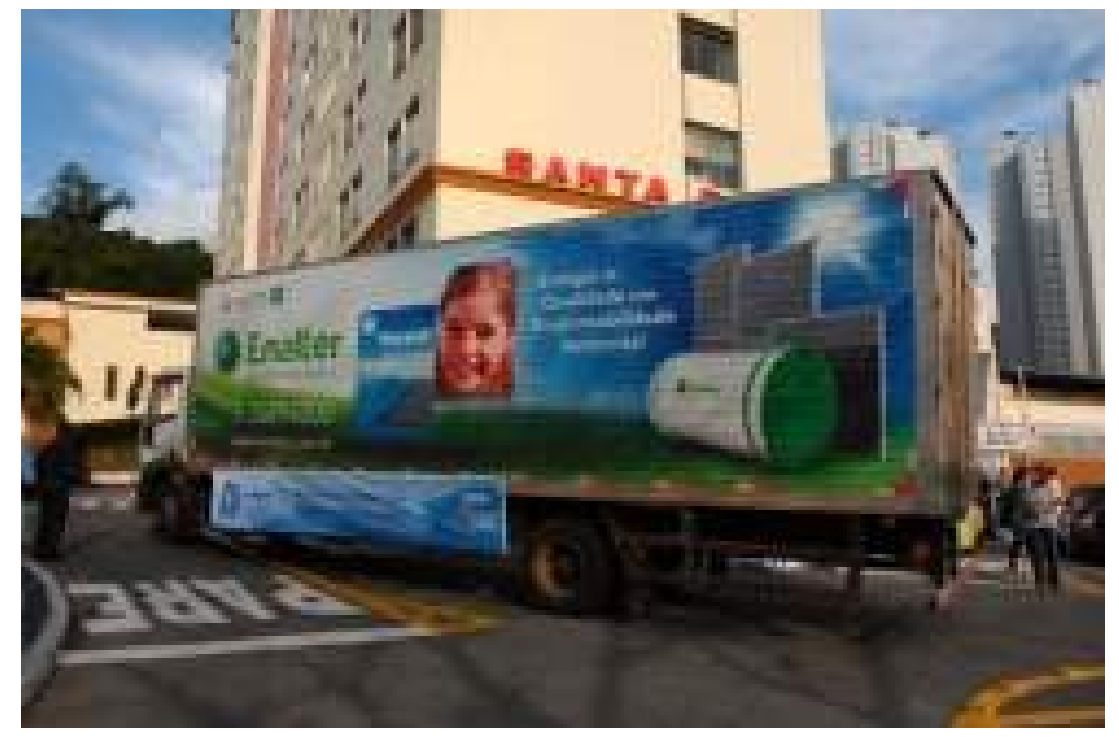

FIGURA 8 - Sistema de Aquecimento Solar - Santa Casa de Misericórdia em Juiz de Fora - MG.

Fonte: Santa Casa (2013).

A Santa Casa de Misericórdia de Juiz de Fora, na Zona da Mata mineira, passou a contar, em substituição aos chuveiros elétricos, com o maior sistema de aquecimento solar já instalado em uma única unidade consumidora da América do Sul.

A instalação dos equipamentos será feita por meio do Projeto Solar ILPI, que faz parte do Programa Energia Inteligente (EI), da Cemig. Fruto de uma parceria entre o Governo de Minas, a Cemig e o Serviço Voluntário de Assistência Social (Servas), o projeto tem o objetivo de gerar mais conforto nos banhos dos internos e garantir aos funcionários qualidade nos serviços prestados.

O sistema de aquecimento solar instalado possui 1.270 metros quadrados de placas coletoras e 10 reservatórios com capacidade para armazenar 66 mil litros de água quente. É o maior investimento destinado a um projeto que atende a uma única instituição, totalizando $R$ \$ 2 milhões. 


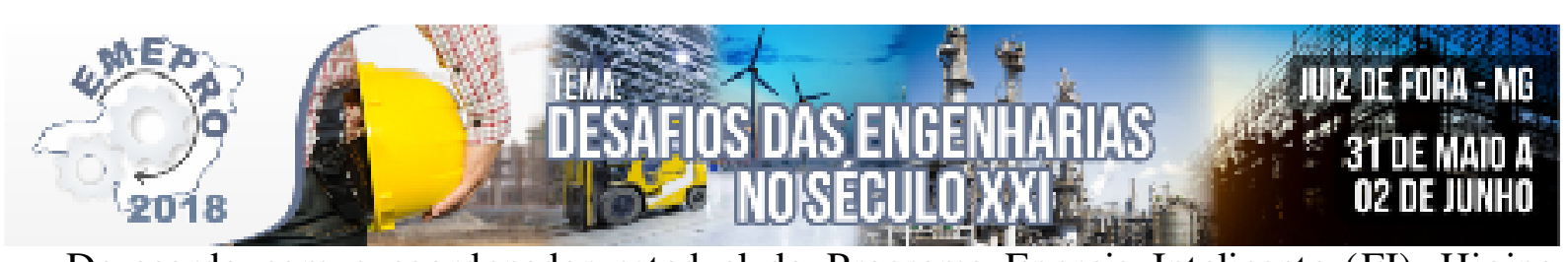

De acordo com o coordenador estadual do Programa Energia Inteligente (EI), Higino Zacarias de Souza, o sistema de aquecimento solar vai gerar $70 \%$ de economia na energia utilizada para aquecer a água, além de proporcionar mais conforto nos banhos, deslocando a demanda para fora do horário de ponta.

\section{- Projeto Autoclaves}

A Cemig também realizou a substituição de duas autoclaves ineficientes por outras de alto rendimento no Hospital e Maternidade Therezinha de Jesus, com um investimento de R\$ 230 mil. Atualmente, a instituição atende 869 pacientes por mês, possui 160 leitos e realiza 869 internações e 600 cirurgias por mês. Com o novo sistema, haverá uma redução de R \$ 30 mil nos custos de energia por ano.

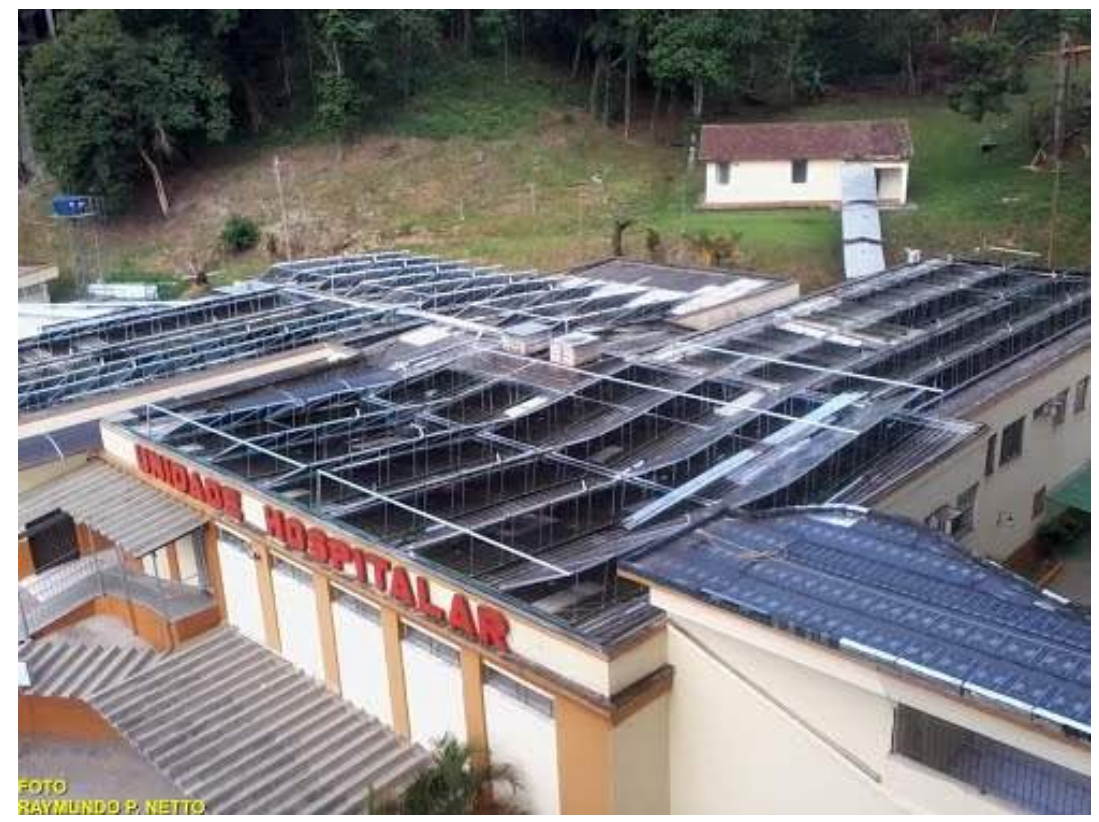

FIGURA 9 - Sistema de Aquecimento Solar instalado no Hospital e Maternidade Therezinha de Jesus em Juiz de Fora - MG. Fonte: Hospital e Maternidade Therezinha de Jesus (2013).

\section{Referências}

ASSOCIAÇÃO BRASILEIRA DE NORMAS TÉCNICAS. NBR 14724: Informação e Documentação Trabalhos acadêmicos - Apres entação. Rio de Janeiro: ABNT, 2001.

ASSOCIAÇÃO BRASILEIRA DE NORMAS TÉCNICAS. NBR 10520: Informação e Documentação Citações em Documentos - Apresentação. Rio de Janeiro: ABNT, 2002a.

ASSOCIAÇÃO BRASILEIRA DE NORMAS TÉCNICAS. NBR 6023: Informação e Documentação Referências - Elaboração. Rio de Janeiro: ABNT, 2002b.

Cemig, Alternativas Energéticas. Disponível em: <http://www.cemig.com.br>. Acesso em 09 de março de 2018.

Green PUC Minas, Energia Solar Fotovoltaica. Disponível em: <http://ipuc.pucminas.br>. Acesso em $10 \mathrm{de}$ março de 2018.

Hospital e Maternidade Therezinha de Jesus. Disponível em: < http://www.hmtj.org.br >. Acesso em 17 de março de 2018.

Mundo Educação, Fontes de Energia. Disponível em: <http://mundoeducacao.bol.uol.com.br $>$. Acesso em 17 de março de 2018. 


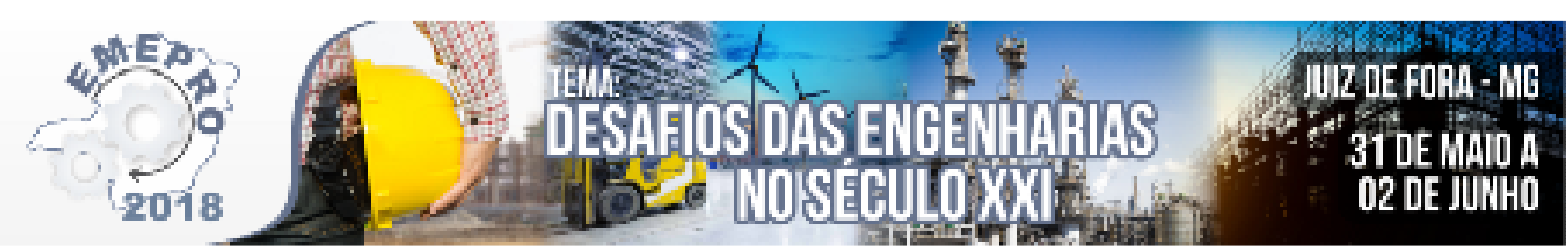

Santa Casa de Misericórdia de Juiz de Fora, Santa Casa ganha maior sistema de aquecimento solar. Disponível em: <http://www.santacasaj f.org.br>. Acesso em 09 de março de 2018.

Solarem, Aquecimento Solar. Disponível em: <http://www.aquecedorsolaragua.com.br>. Acesso em $15 \mathrm{de}$ março de 2018.

Sua Pesquisa, Portal de pesquisas temáticas e educacionais. Disponível em: <https://www.suapesquisa.com>. Acesso em 17 de março de 2018. 


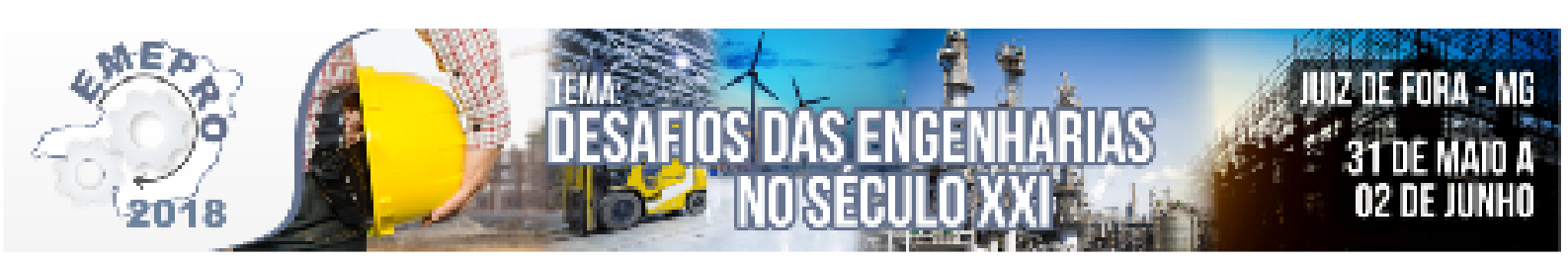

A tecnologia LED e sua economia ene rgética

Eliziane Medeiros Santos (Faculdades Doctum) - elizianemsantos@gmail.com Jéssica de Almeida Rocha (Faculdades Doctum) - jssicaalmeida@yahoo.com.br

Resumo: Os chamados LED's (diodos emissores de luz) são componentes eletrônicos semicondutores que transformam energia elétrica em luz. Além do baixo consumo de energia, vida útil mais longa e menor impacto ambiental, as lâmpadas LED possuem diversas vantagens em sua utilização. Atualmente, grande número de residências veem trocando as lâmpadas incandescentes por lâmpadas LED.

Palavras-chave: Lâmpadas; LED; Eficiência Energética

\section{Introdução}

Estudos recentes apontam que aproximadamente $19 \%$ do consumo de energia elétrica no mundo está relacion ado à iluminação. No caso do Brasil, este número sobe para $20 \%$. Para minimizar os impactos causados por esse consumo, empresas do ramo de iluminação e pesquisa estão investindo cada vez mais em novas tecnologias, objetivando também a melhora na qualidade da luz e iluminação. Dentro desse contexto, surgiram as lâmpadas LED que prometem reduzir o consumo de energia em até $80 \%$, apresentando excelente eficiência energética e durabilidade.

O uso da tecnologia LED está cada vez mais presente no nosso dia a dia, sejam em aparelhos eletro eletrônicos como televisões e celulares ou em escritórios e iluminação de ruas. Apesar de o LED ter sido criado nos anos 60, ainda é uma tecnologia muito recente no mercado, mas já está sendo considerada a ilu minação do futuro.

O LED é um componente eletrônico semicondutor, ou seja, um diodo emissor de luz (L.E.D=Light emitter diode), mesma tecnologia utilizada nos chips dos computadores, que tem a propriedade de transformar energia elétrica em luz. Tal transformação é diferente da encontrada nas lâmpadas convencionais que utilizam filamentos metálicos, radiação ultravioleta e descarga de gases, dentre outras. Nos LEDs, a transformação de energia elétrica em luz é feita na matéria, sendo, por isso, chamada de estado sólido.

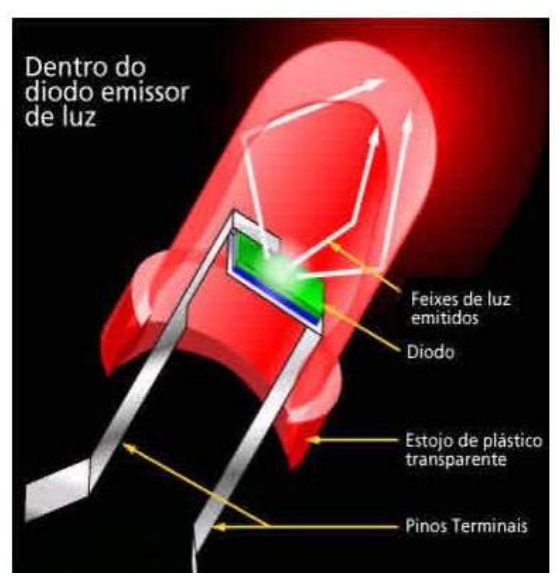

FIGURA 1 - Diodo da lâmpada LED. Fonte: Eletrônica Analógica (2013). 


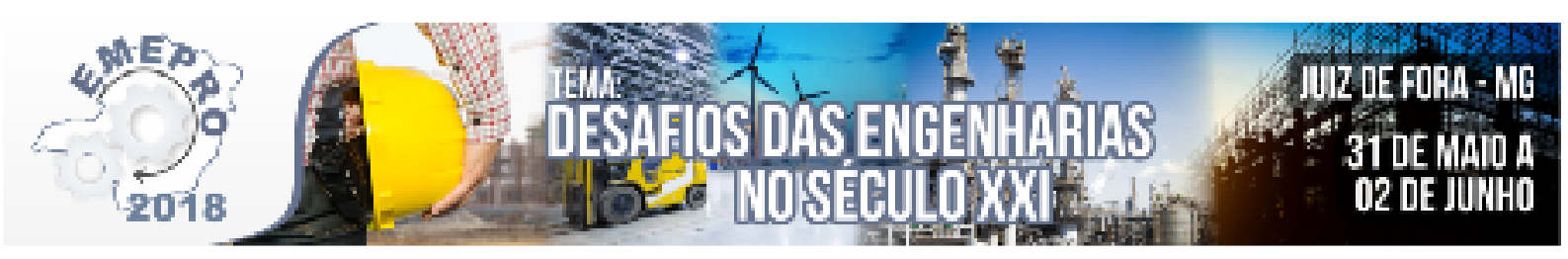

Não ter filamentos significa que os LEDs não produzem muito calor e nem vibram. LEDs funcionam passando corrente elétrica por um chip semicondutor. O chip tem dois lados: o lado tipo-P e o lado tipo-N. O lado tipo-P é positivo e o tipo-N é negativo. O elétron se locomove do lado $\mathrm{P}$ para o $\mathrm{N}$, e isso produz luz. Isso é o que faz com que o chip emita fótons ou feixes de luz. O chip é normalmente feito de arsênico, fósforo ou gálio. Alguns LEDs possuem um ou mais semicondutores que produzem cores diferentes. Os LEDs de verdade possuem vários diodos numa só unidade, o que torna difícil a identificação de onde a luz está sendo emitida.

Os LEDs são fabricados especialmente para liberar um grande número de fótons para fora. Além disso, eles são montados em bulbos de plásticos que concentram a luz em uma direção específica, conforme a necessidade, dispensando o uso de luminárias e evitando as perdas que esta representaria.

\section{LED CONVENCIONAL DE Ø $5 \mathrm{~mm}$}

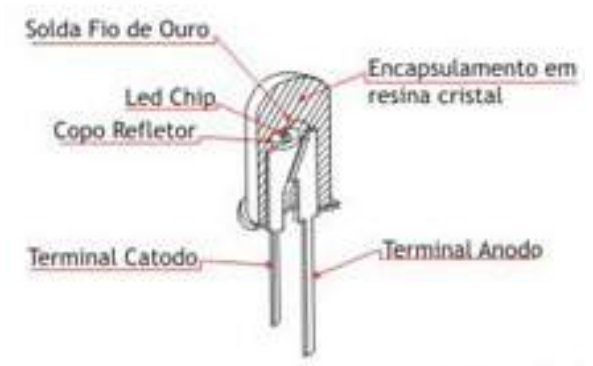

FIGURA 2 - Componentes do LED. Fonte: Akari Lâmpadas (2012).

\section{Tipos de lâmpada LED}

Nos LEDs redondos, duas codificações são comuns: identifica-se o terminal K como sendo aquele junto a um pequeno chanfro na lateral da base circular do seu invólucro ("corpo"), ou por ser o terminal mais curto dos dois. Existem fabricantes que adotam simultaneamente as duas formas de identificação.

Nos LEDs retangulares, alguns fabricantes marcam o terminal $\mathrm{K}$ com um pequeno "alargamento" do terminal junto à base do componente, ou então deixam esse terminal mais curto.

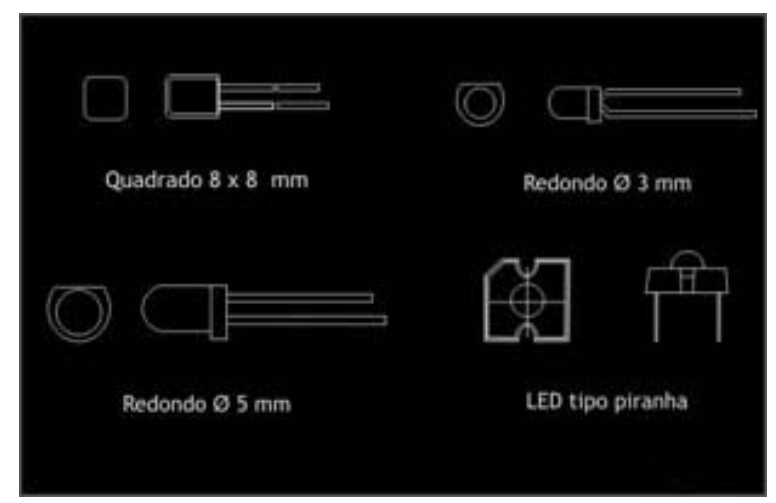

FIGURA 3 - Tipos de lâmpada LED. Fonte: Unicamp IAR (2013). 


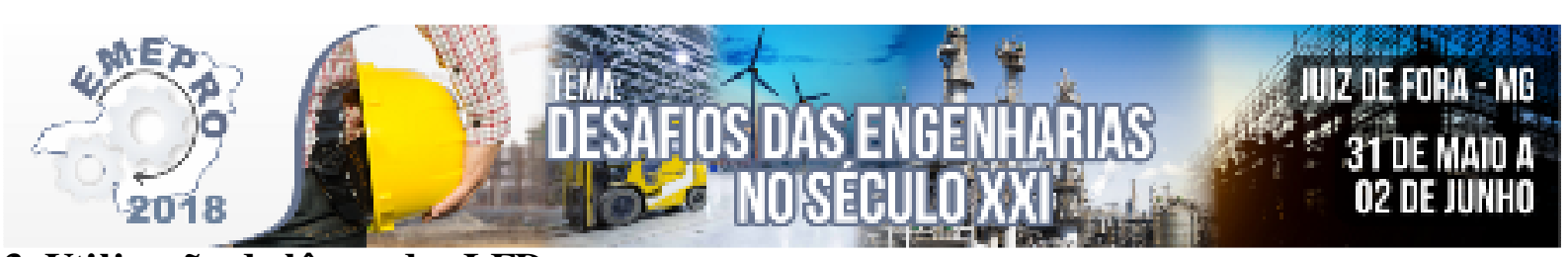

\section{Utilização de lâmpadas LED}

Especialmente utilizado em produtos de microeletrônica como sinalizador de avisos, também pode ser encontrado em tamanho maior, como em alguns modelos de semáforos. Também é muito utilizado em painéis de LED, cortinas de LED, pistas de LED e postes de iluminação pública, permitindo uma redução significativa no consumo de eletricidade.

Iluminação de destaque em ambientes residenciais e comerciais. Podem ser utilizadas em spots (sobre bancadas, objetos decorativos), arandelas (criar efeitos na parede), balizadores (ilu minação de corredores e escadas) e na ilu minação de fachadas.

Uma das formas com que essa tecnologia tem sido mais facilmente absorvida é a utilização dos LEDs na substituição das lâmpadas que usamos atualmente, como dicróica, PAR20, PAR30, incandescente comum, lâmpada balão e até tubos similares a fluorescentes. O uso dos LEDs no formato de lâmpadas pré-existentes já é muito interessante, pois embora tenha um custo inicial elevado, o LED tem vida útil muito mais longa do que as incandescentes e fluorescentes, além de ter um consumo de energia muito baixo, o que compensa o custo inicial.

A utilização das "lâmpadas" compostas por LEDs é especialmente boa no uso externo, porque sua reprodução de cor ainda não é excelente. Embora já seja satisfatória, tende a melhorar ainda mais. Mas o fato de ter vida útil muito longa e consumo baixo torna seu uso excelente para um jardim, por exemplo, em que a reprodução de cor não é tão importante quanto em uma escrivaninha.

Outro exemplo de utilização caseira de LEDs que vale muito a pena é o uso dessas lâmpadas em balizadores. Seja para uma escada, um corredor ou mesmo indicar o caminho externo, os LEDs permitem que a luminária seja realmente mínima, podendo ser embutida em um contra piso convencional. E a luz não precisa ser forte, basta apenas ser um pontinho que indica o degrau ou o caminho de forma elegante e discreta.

As fitas LEDs já são um exemplo inicial de como a tecnologia poderá gerar novos e interessantíssimos produtos. A fita LED é uma fonte de luz vendida por metro linear e é muito útil para iluminar detalhes, sancas, rodapés e diversas outras formas de utilização de forma prática e com resultados excepcionais.

O "chuveirinho" - aquele conjunto de LEDs que formam uma lâmpada mimetizada e que não agrad a muito - também está com os dias contados. A novidade das fontes de luz de LEDs é o uso de um difusor de tamanho variável e que torna os LEDs invisíveis. O que se vê no uso desse difusor é algo como u ma "folha" que se acende e, em breve, essa nova forma de se utilizar LEDs, de aspecto formal incrível, é o que veremos no mercado.

\section{Vantagens e Desvantagens de lâmpadas LED}

\subsection{Vantagens}

- Maior vida útil: Dependendo da aplicação, a vida útil do equipamento é longa, sem necessidade de troca. Considera-se como vida útil uma manutenção mínima de luz igual a 70\%, após 50.000 horas de uso.

- Custos de manutenção reduzidos: Em função de sua longa vida útil, a manutenção é bem menor, representando menores custos. 


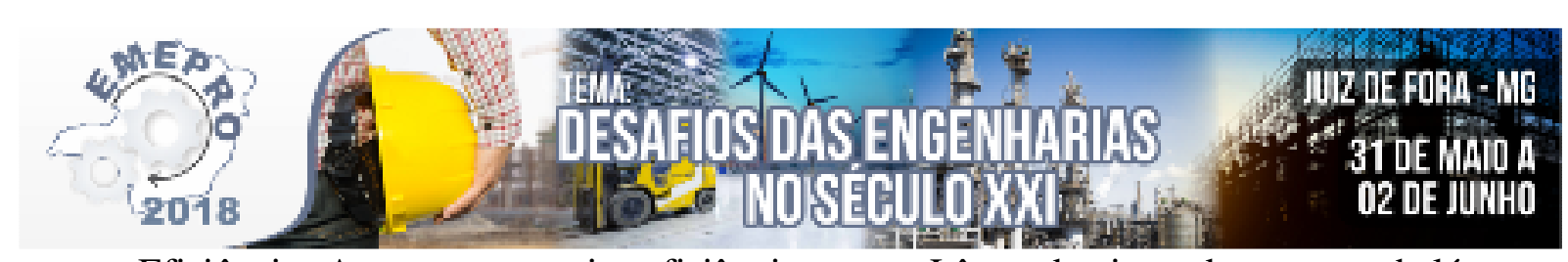

- Eficiência: Apresentam maior eficiência que as Lâmpadas incandescentes e halógenas e, hoje, muito próximo da eficiência das fluorescentes (em torno de 50 lumens / Watt) mas este número tende a aumentar no futuro.

- Baixa voltagem de operação: Não representa perigo para o instalador.

- Resistência a impactos e vibrações: Utiliza tecnologia de estado sólido, portanto, sem filamentos, vidros, etc, aumentando a sua robustez.

- Controle dinâmico da cor: Com a utilização adequada, pode-se obter um espectro variado de cores, incluindo várias tonalidades de branco, permitindo um ajuste perfeito da temperatura de cor desejada.

- Acionamento instantâneo: Tem acionamento instantâneo, mesmo quando está operando em temperaturas baixas.

- Controle de Intensidade variável: Seu flu xo lu minoso é variável em função da variação da corrente elétrica aplicada a ele, possibilitando, com isto, um ajuste preciso da intensidade de luz da luminária.

- Cores vivas e saturadas sem filtros: Emite comprimento de onda monocromático, que significa emissão de luz na cor certa, (veja espectro de cores) tornando-a mais viva e saturada. Os LEDs coloridos dispensam a utilização de filtros que causam perda de intensidade e provocam uma alteração na cor, principalmente em luminárias externas, em função da ação da radiação ultravioleta do sol.

- Luz direta, aumento da eficiência do sistema: Apesar de ainda não ser a fonte luminosa mais eficiente, pode-se obter luminárias com alta eficiência, em função da possibilidade de direcionamento da luz emitida pelo LED.

- Ecologicamente correto: Não utiliza mercúrio ou qualquer outro elemento que cause dano à natureza.

- Ausência de ultravioleta: Não emitem radiação ultravioleta sendo ideais para ap licações onde este tipo de radiação é indesejada. Ex.: Quadros - obras de arte etc.

- Ausência de infravermelho: Também não emitem radiação infravermelha, fazendo com que o feixe luminoso seja frio.

- Ao contrário das lâmpadas fluorescentes que tem um maior desgaste da sua vida útil no momento em que são ligadas, nos LEDs é possível o acendimento e apagamento rapidamente possibilitando o efeito "flash", sem detrimento da vida útil.

\subsection{Desvantagens}

- Custo: o custo de uma lâmpada de LED ainda é muito superior ao custo de outras lâmpadas. Uma lâmpada fluorescente compacta de $15 \mathrm{w}$ custa em média $\mathrm{R} \$ 9,00$ enquanto uma lâmpada de LED com $7 \mathrm{w}$ custa por volta de $\mathrm{R} \$ 35,00$.

- Dependência de componentes importados: parte da matéria-prima utilizada na fabricação das lâmpadas ainda é importada. 


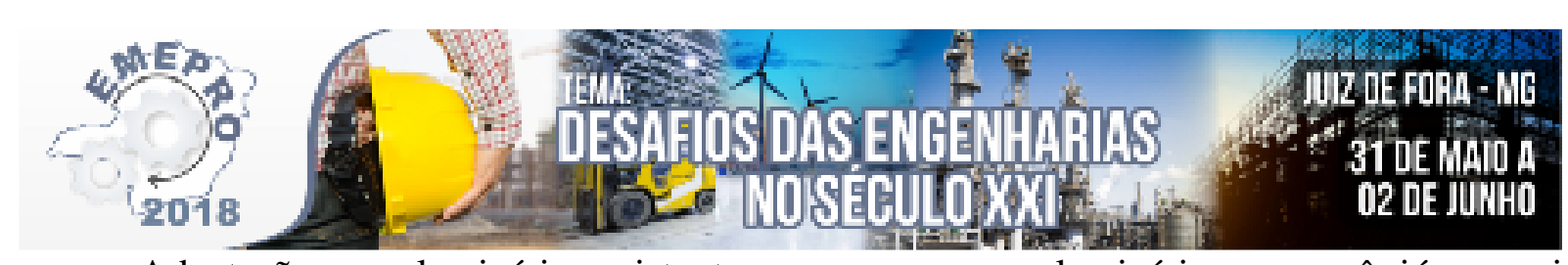

- Adaptação para luminárias existentes: nem sempre a luminária que você já possui consegue se adaptar a uma lâmpada de LED, assim, antes de fazer a troca é preciso verificar esse item para que a substituição se justifique.

- Sobre tensão: A rede elétrica está vulnerável a alterações no sistema, como picos de alta/baixa tensão. Para proteger sua lâmpada LED é indispensável investir em aparelhos de segur ança para impedir prejuízos na iluminação.

- Custo inicial: Como se trata de uma nova tecnologia o custo se comparado com outras fontes de iluminação é notavelmente mais alto.

- Mão de obra especializada: A implantação de iluminação em LED requer cuidados especiais para que seus benefícios sejam alcançados. Dessa forma, para que um projeto tenha um resultado de sucesso, a procura por mão de obra especializada é imprescindível, porém a oferta desse trabalho específico não é tão grande quanto a procura, fazendo com que os valores destes prestadores sejam elevados.

- Baixo IRC - as lâmpadas de LED ainda deixam a desejar no que diz respeito ao Índice de Reprodução de Cor que gira em torno de 80 IRC, diferente da fluorescente que consegue atingir IRC de 85 a 95.

\section{Custo benefício das lâmpadas LED}

As lâmpadas de LED são muito mais eficientes do que as comuns pois produzem a mesma quantidade de luz (ou lúmem, para ser mais correto) utilizando bem menos energia. Além disso, a geração de calor durante esse processo é praticamente nula, o que ajuda na economia energética.

Enquanto uma lâmpada incandescente gasta certa de $60 \mathrm{~W}$ para produzir uma determinada quantia de lúmem, um conjunto de LED precisa de apenas $20 \mathrm{~W}$. Outra grande vantagem das lâmpadas de LED é que elas são muito mais resistentes do que as incandescentes e fluorescentes.

Mas, como nem tudo é perfeito, as lâmpadas de LED possuem um defeito razoavelmente grande: o preço. Uma pesquisa rápida no Google pelo preço dos produtos do gênero revela um valor médio de $\mathrm{R} \$ 50$ por lâmpada. Mesmo com o investimento inicial bastante alto, os benefícios no uso das lâmpadas de LED podem fazer a troca valer a pena. 


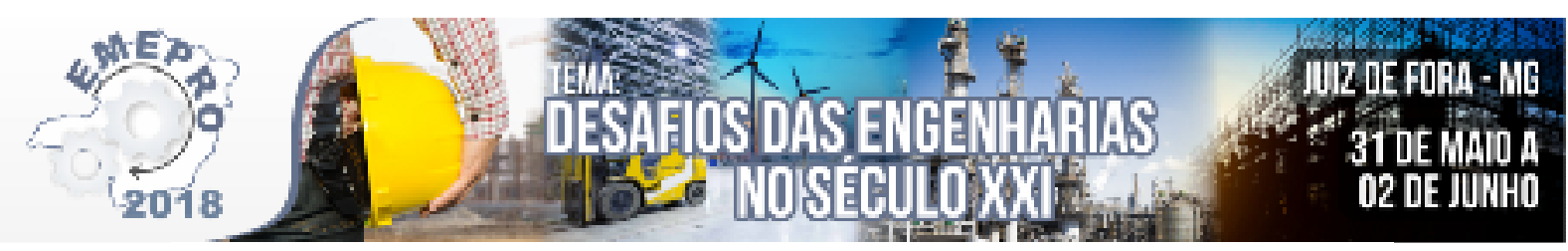

\begin{tabular}{|l|c|c|c|}
\hline & LED & Fluorescente & Incandescente \\
\hline Vida útil da lâmpada & 50,000 hours & 10,000 hours & 1,200 hours \\
\hline $\begin{array}{l}\text { Watts por lâmpada (equiv. 60 } \\
\text { watts) }\end{array}$ & 6 & 14 & 60 \\
\hline Preço por lâmpada & $\$ 35.95$ & $\$ 3.95$ & $\$ 1.25$ \\
\hline $\begin{array}{l}\text { KWh de eletricidade usados por } \\
50,000 \text { horas }\end{array}$ & 300 & 700 & 3000 \\
\hline $\begin{array}{l}\text { Custo da eletricidade @ 0.20per } \\
\text { KWh) }\end{array}$ & $\$ 60$ & $\$ 140$ & $\$ 600$ \\
\hline $\begin{array}{l}\text { Lâmpadas necessárias para 50k } \\
\text { horas de uso }\end{array}$ & 1 & 5 & 42 \\
\hline Equivalente a 50k horas de uso & $\$ 35.95$ & $\$ 19.75$ & $\$ 52.50$ \\
\hline Custo total de 50k horas & $\$ 95.95$ & $\$ 159.75$ & $\$ 652.50$ \\
\hline
\end{tabular}

FIGURA 4 - Comparação de custos entre os tipos de lâmpadas disponíveis no mercado. Fonte: Lâmpadas Ecológicas (2012).

\section{CONTAS NO CLARO}

Eis os gastos estimados, ao longo de cinco anos, para uma casa com vinte pontos de luz e utilização média de dez lâmpadas acesas durante seis horas

\begin{tabular}{|l|l|l|}
\cline { 2 - 3 } \multicolumn{1}{c|}{} & Incandescente \\
\hline $\begin{array}{l}\text { Investimento inicial } \\
\text { com lâmpadas }\end{array}$ & $\mathrm{R} \$ 36$ & $\mathrm{RED}$ \\
\hline $\begin{array}{l}\text { Potência média de } \\
\text { consumo das lâmpadas }\end{array}$ & $60 \mathrm{~W}$ & $8 \mathrm{~W}$ \\
\hline Consumo de energia & $6480 \mathrm{kWh}$ & $1080 \mathrm{kWh}$ \\
\hline Lâmpadas trocadas & 110 & zero \\
\hline Gasto com energia & $\mathrm{R} \$ 2628$ & $\mathrm{R} \$ 345$ \\
\hline Gasto com lâmpadas & $\mathrm{R} \$ 195$ & zero \\
\hline Total & $\mathrm{R} \$ 2859$ & $\mathrm{R} \$ 1845$ \\
\hline
\end{tabular}

FIGURA 5 - Gasto comparativo estimado de uma casa utilizando lâmpadas comuns e lâmpadas LED.

Fonte: IBDA (2013).

\section{O que considerar ao escolher uma lâmpada LED}

Existem dois tipos de lâmpadas LED, as de baixa potência que são utilizadas para sinalização, árvores de Natal, decorações luminosas e situações que requerem baixa luminosidade, e as lâmpadas de alta potência, que emitem mais luz, e podem ser utilizadas para iluminação de ambientes que necessitam de grande luminosidade.

As lâmpadas de alta potência podem variar em relação ao seu tipo de distribuição luminosa, podendo ser não-direcional, que são as lâmpadas de iluminação geral, possuem o foco aberto fazendo com que a distribuição da intensidade luminosa seja uniforme em todo o 


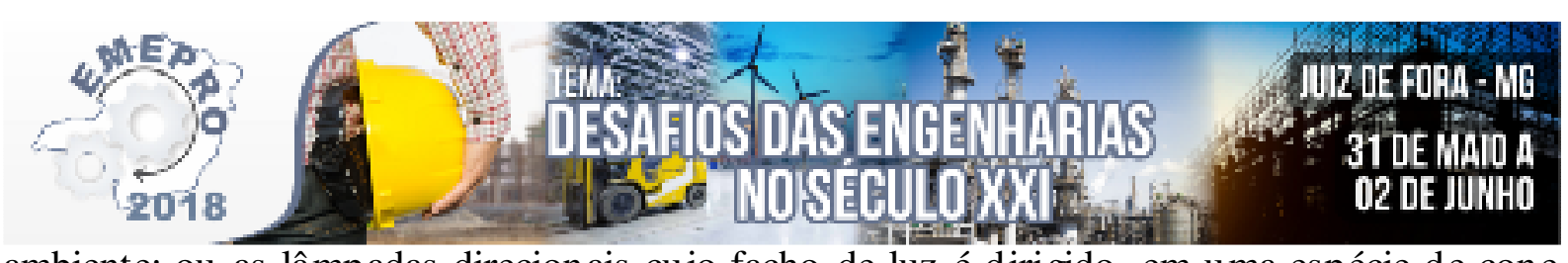

ambiente; ou as lâmpadas direcionais cujo facho de luz é dirigido, em uma espécie de cone direcion ando a luz.

Existem também as lâmpadas de LED tubulares cujo foco luminoso equivale ao da fluorescente tubular. As lâmpadas LED normalmente possuem tonalidades de cores diferentes que vêm indicadas nas embalagens como "temperaturas de cor", expressas em Kelvin (K) (unidade de temperatura). Esses valores de temperatura não estão associados à quantidade de calor gerado pela lâmpada, essa luz emitida passa por uma gama seqüencial de cores, que vai do vermelho ao laranja, amarelo, branco e azul. Atualmente estão disponíveis no mercado as seguintes tonalidades de cores para as lâmpadas LED:

- Um tom amarelo-alaranjado, considerado "quente ou morno", mais próximo da cor emitida pela lâmpada incandescente, sendo mais apropriado para ambientes de descanso como quartos e salas de TV $(2.700 \mathrm{~K})$.

- Um tom branco, "intermediário ou neutro", mais comum em ambientes de trabalho (entre 3.800 e $4.200 \mathrm{~K}$ ).

- Um tom branco-azulado, classificado como "frio". Essas são mais utilizadas em cozinhas, áreas de serviço e outros lugares que precisem de plena iluminação (acima de $6.000 \mathrm{~K})$.

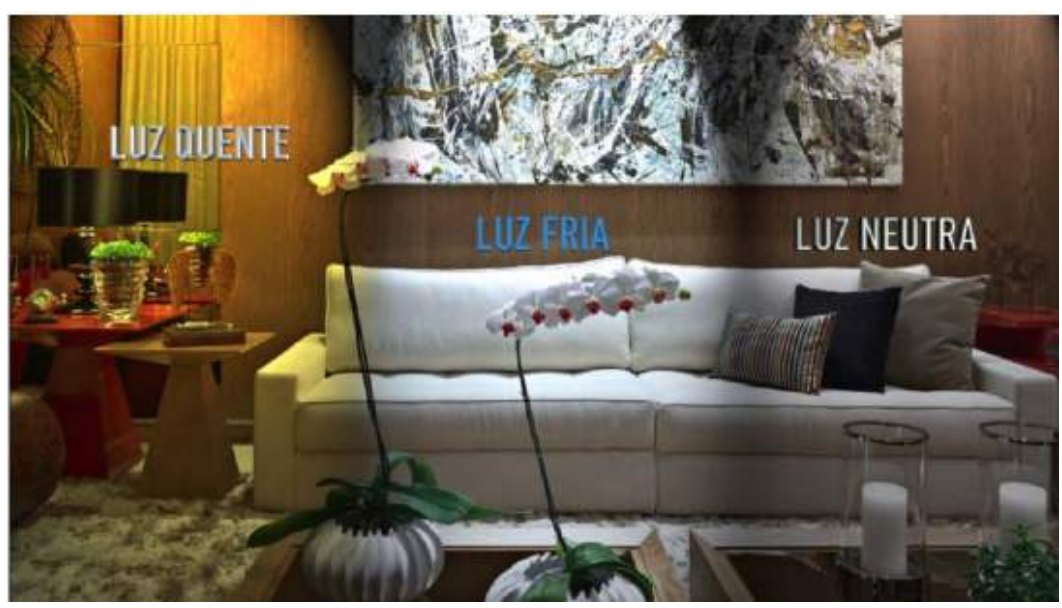

FIGURA 6 - Tonalidade de cores das lâmpadas LED. Fonte: INMETRO (2012).

Considerando a tensão ou voltagem das lâmpadas, podem ser encontradas no mercado quatro opções: 12 volts (para luminárias), 127 volts, 220 volts ou bivolt.

\section{Singularidade das lâmpadas LED}

- LED dificilmente queima: As lâmpadas de LED vão perdendo a intensidade luminosa com o passar o tempo. Além disso, essas 50 mil horas podem significar até 10 anos, dependendo do quanto a pessoa usa o LED. Com um driver interno que a faz funcionar, esse tipo de lâmpada só vai queimar se houver algum problema com esse dispositivo eletrônico.

- Se um milhão de pessoas trocasse uma lâmpada normal por uma LED, iria corresponder, em termos de emissões de $\mathrm{CO} 2$, a retirar cerca de 3.900 carros da estrada por ano. Corresponderia igualmente à diminuição do consumo de eletricidade anual de cerca de 4.400 casas. 


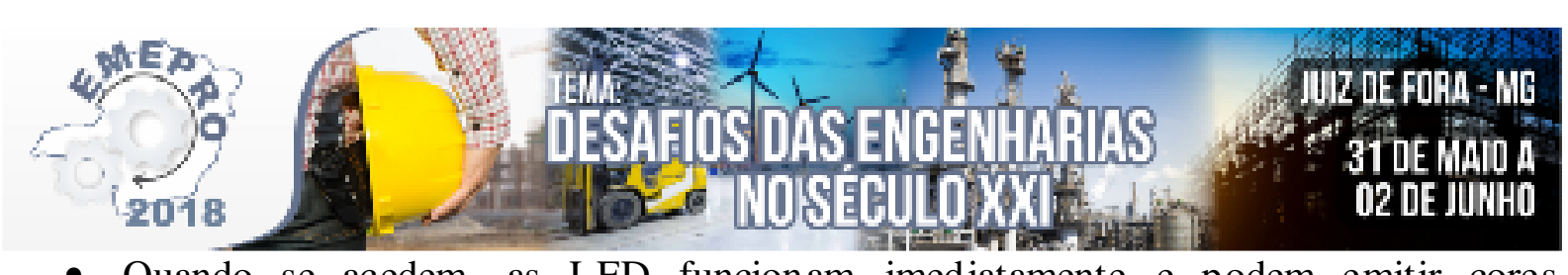

- Quando se acedem, as LED funcionam imediatamente e podem emitir cores diferentes, desde mais frias até as mais quentes.

- Não contêm mercúrio.

- Permitem novas soluções de design.

- Podem ser reciclad as.

\section{Normas em desenvolvimento}

Testes realizados em 2011 pelo Cepel (Centro de Pesquisas de Energia Elétrica) constataram que as lâmpadas de LED disponíveis no mercado brasileiro não atendem aos prérequisitos do programa americano de qualidade Energy Star. Cerca de $80 \%$ das amostras de lâmpadas tubulares de $600 \mathrm{~mm}$ apresentaram mais de $10 \%$ de depreciação do fluxo luminoso com 6 mil horas de ensaio.

Juliana Kawasaki, coordenadora da Comissão de Normas Técnicas de Aplicações Luminotécnicas e Medições Fotométricas do Cobei (Comitê Brasileiro de Eletricidade, Eletrônica, Iluminação e Telcomunicações), disse que as Normas estão sendo trabalhadas e que as Portarias específicas e compulsórias do INMETRO para produtos de iluminação com LED devem ser aprovadas ainda esse ano. "Será um grande passo para tirar do mercado os produtos de baixa qualid ade", garante Juliana.

Antes de comprar, Juliana aconselha exigir uma série de testes - mesmo que terciários - para eliminar produtos que não atendam desempenhos mínimos. Ela diz que é necessário considerar o histórico da empresa e não confiar somente na especificação técnica. "É o único método de averiguar a qualidade do produto", afirma.

\section{Referências}

ASSOCIAÇÃO BRASILEIRA DE NORMAS TÉCNICAS. NBR 14724: Informação e Documentação Trabalhos acadêmicos - Apres entação. Rio de Janeiro: ABNT, 2001.

ASSOCIAÇÃO BRASILEIRA DE NORMAS TÉCNICAS. NBR 10520: Informação e Documentação Citações em Documentos - Apresentação. Rio de Janeiro: ABNT, 2002a.

ASSOCIAÇÃO BRASILEIRA DE NORMAS TÉCNICAS. NBR 6023: Informação e Documentação Referências - Elaboração. Rio de Janeiro: ABNT, 2002b.

AEC Web. Disponível em: <https://www.aecweb.com.br>. Acesso em 15 de março de 2018.

INMETRO. Disponível em: <http://www.inmetro.gov.br>. Acesso em 18 de março de 2018.

IPOG. Disponível em: < http://www.businesstur.com.br>. Acesso em 10 de março de 2018.

Jornal Econômico. Disponível em: < http://www.jornaleconomico.sapo.pt>. Acesso em 16 de março de 2018.

UNICAMP. Disponível em: < http://www.iar.unicamp.br>. Acesso em 10 de março de 2018. 


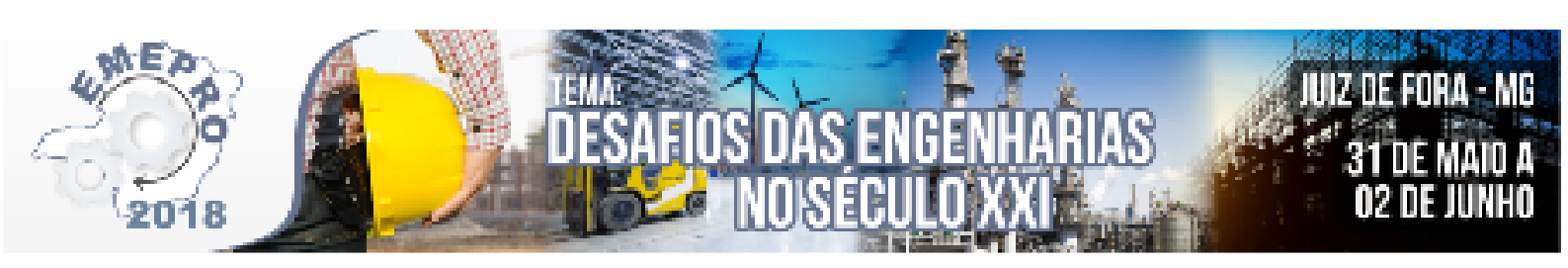

Biomassa: alternativa eficaz de produção e distribuição de ene rgia

Eliziane Medeiros Santos (Faculdades Doctum) - elizianemsantos@gmail.com Jéssica de Almeida Rocha (Faculdades Doctum) - jssicaalmeida@yahoo.com.br

Resumo: A biomassa é uma das fontes para produção de energia com maior potencial de crescimento nos próximos anos. Tanto no mercado internacional quanto no mercado interno, ela é considerada uma das principais alternativas para a diversificação da matriz energética e a consequente redução da dependência dos combustiveis fósseis. Dela é possível obter energia elétrica e biocombustíveis, como o biodiesel e o etanol, cujo consumo é crescente em substituição a derivados de petróleo como o óleo diesel e a gasolina. Porém, o seu uso sem o devido planejamento pode ocasionar a formação de grandes áreas desmatadas pelo corte incontrolado de árvores, perda dos nutrientes do solo, erosões e emissão excessiva de gases.

Palavras-chave: Biomassa; Fonte de energia; Biodiesel

\section{Introdução}

A busca por alternativas eficazes de produção e distribuição de energia é um elemento essencial para o ser humano, principalmente na atual sociedade, onde os modos de consumo se intensificam a cada dia. Diante dessa dependência de recursos energéticos, surge a necessidade de diversificar a utilização dessas fontes. Atualmente, o petróleo é a principal substância empregada na geração de energia, porém, a biomassa é uma fonte utilizada bem antes da descoberta do "ouro negro".

O homem utiliza a lenha como fonte ener gética desde o início da civilização. Portanto, a biomassa faz parte da história da humanidade como fonte de energia. Segundo o B alanço Ener gético Nacional - BEN, as biomassas (Madeira e cana), responderiam por 27\% da energia primária do Brasil, a maior parte destinada a usos industriais. No entanto, a estatística oficial não contempla alguns usos e processos de modo que subestima a participação das biomassas. $\mathrm{Na}$ avaliação do INEE, ultrapassa um terço a ener gia primária do país.

Apenas o etanol e o biodiesel têm políticas específicas. Não obstante, apesar da política do álcool ter sido a única grande revolução energética em resposta às crises do petróleo, sucessivos governos têm tido dificuldade em conviver com este biocombustível. A Lei n 9.478 que criou a Política de Energia, em 1997, no lugar de instituir uma agência para regular e controlar os combustíveis de um modo geral, criou a "ANP - Agência Nacional do Petróleo". Em 2005, para acomodar o biodiesel a ANP foi rebatizada para "Agência Nacional do Petróleo, Biocombustível e Gás Natural". Em 2011, o conceito de biocombustível que, em todo o mundo, tem uma definição simples e direta foi assim definido pela ANP:

"Substância derivada de biomassa renovável, tal como biodiesel, etanol e outras substâncias estabelecidas em regulamento da ANP, que pode ser empregada diret amente ou mediante alterações em motores a combustão interna ou para outro tipo de geração de energia, podendo substituir parcial ou totalmente combustíveis de origem fóssil;", 


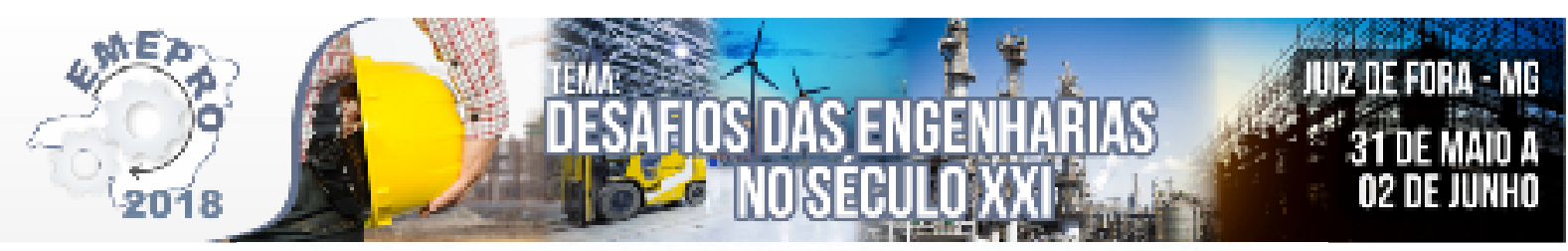

PERFIL DAS PRINCIPAIS FONTES ALTERNATIVAS DE BIOMASSA NO BRASIL.

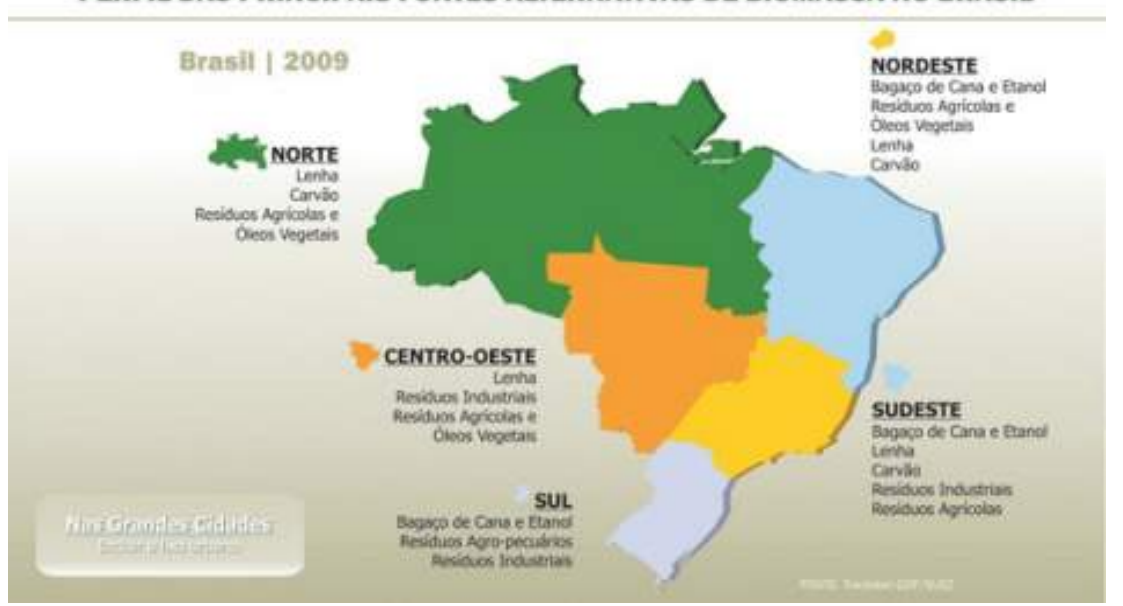

FIGURA 1 - Principais fontes alternativas de biomassa no Brasil. Fonte: BEN e INEE (2011).

\begin{tabular}{|l|l|l|}
\hline & Mtep & $(\%)$ \\
\hline Petróleo & 94 & 33 \\
\hline GN & 28 & 10 \\
\hline Carvắo & 14 & 5 \\
\hline Urânio & 4 & 1 \\
\hline Hidro & 37 & 13 \\
\hline Madeira & $35^{\mathrm{i}}$ & 13 \\
\hline Cana & $65^{\mathrm{ii}}$ & 23 \\
\hline Outros & $5^{\mathrm{i}}$ & 2 \\
\hline
\end{tabular}

FIGURA 2 - Fontes de energia primária no Brasil. Fonte: BEN e INEE (2011).

\section{A Biomassa}

Biomassa é qualquer matéria orgânica, ou seja, de animais e vegetais, que possa ser transformada em en ergia mecânica, térmica ou elétrica. De acordo com a sua origem, pode ser: florestal (madeira, principalmente), agrícola (soja, arroz e cana-de-açúcar, entre outras) e rejeitos urbanos e industriais (sólidos ou líquidos, como o lixo). Os derivados obtidos dependem tanto da matéria-prima utilizada (cujo potencial energético varia de tipo para tipo) quanto da tecnologia de processamento para obtenção dos energéticos.

$\mathrm{Na}$ definição de biomassa para a geração de energia não se contabiliza os tradicionais combustíveis fósseis, apesar destes também serem deriv ados da vida vegetal (carvão mineral) ou animal (petróleo e gás natural), mas são resultado de várias transformações que requerem milhões de anos para acontecerem. A biomassa conta com recursos naturais renováveis, contrariamente aos combustíveis fósseis.

Nas regiões menos desenvolvidas, a biomassa mais utilizada é a de origem florestal. Além disso, os processos para a obtenção de energia se caracterizam pela baixa 


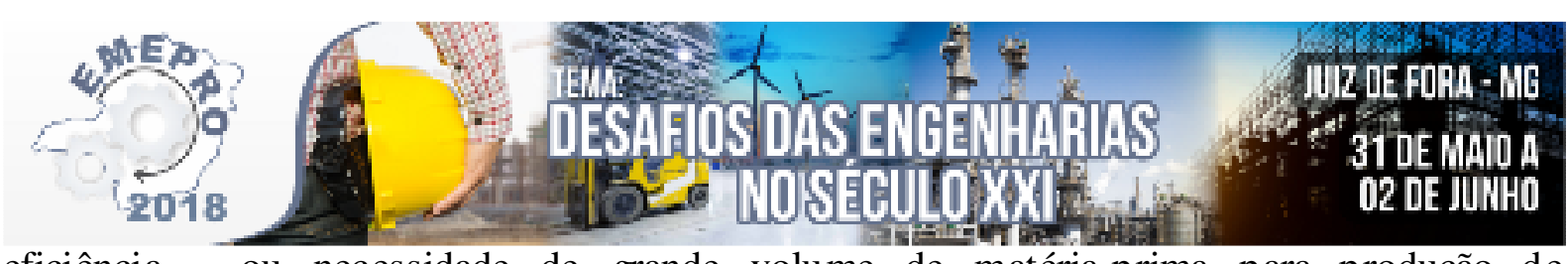

eficiência - ou necessidade de grande volume de matéria-prima para produção de pequenas quantidades.

\section{Tipos de Biomassa}

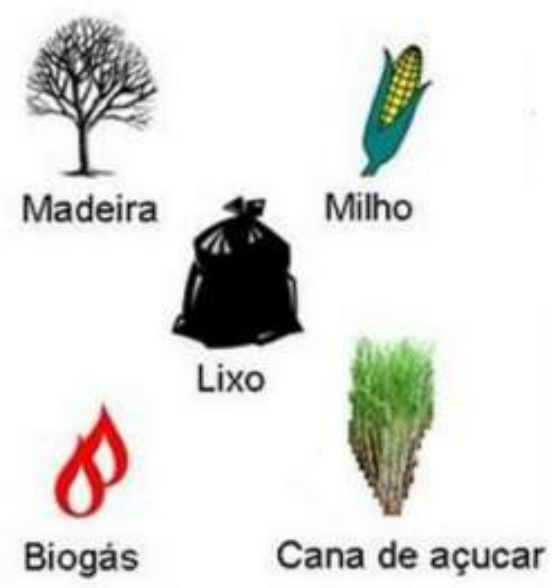

FIGURA 3 - Tipos de biomassa. Fonte: Centro de Referência Virtual do Professor (2010).

Para fazê-la são utilizados materiais como biomassa arborícola, sobra de serragem, vegetal e frutas, bagaço de cana e alguns tipos de esgotos. Ela é transformada em energia por meio dos processos de combustão, gaseificação, fermentação ou na produção de substâncias líquidas.

\subsection{Materiais que são usados para gerar energia}

- A lenha é muito utilizada para produção de energia por biomassa - no Brasil, já representou $40 \%$ da produção energética primária. A grande desvantagem é o desmatamento das florestas, porém, vale destacar que existe a possibilidade de utilizarmos a floresta plantada evitando assim a utilização de florestas nativas;

- Cana-de-açúcar - no Brasil, diversas usinas de açúcar e destilarias estão produzindo metano a partir da vinhaça. O gás resultante está sendo utilizado co mo combustível para o funcionamento de motores estacionários das usinas e de seus caminhões. O equipamento onde se processa a queima ou a digestão da biomassa é chamado de biodigestor. Numa destilaria com produção diária de 100.000 litros de álcool e $1.500 \mathrm{~m}^{3}$ de vinhaça, possibilita a obtenção de $24.000 \mathrm{~m}^{3}$ de biogás, equivalente a 247,5 bilhões de calorias. $\mathrm{O}$ biogás obtido poderia ser utilizado diretamente nas caldeiras, liberando maior quantidade de bagaço para geração de energia elétrica através de termoelétricas, ou gerar $2.916 \mathrm{~kW}$ de potência, suficiente para suprir o consumo doméstico de 25.000 famílias;

- Serragem (ou serrim, ou aind a serradura);

- Papel já utilizado;

- Galhos e folhas decorrentes da poda de árvores em cidades ou casas;

- Embalagens de papelão descartadas após a aquisição de diversos eletrodomésticos ou outros produtos;

- Casca de arroz;

- Capim-elefante; 


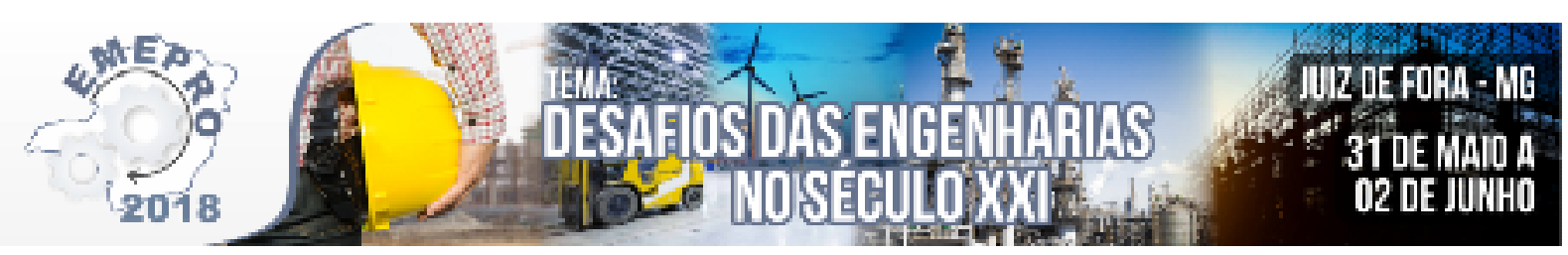

- Lodo de ETE: Especialmente os provenientes do processo de lodos ativados amplamente utilizados na indústria têxtil.

A energia de biomassa é renovável, garante o fornecimento de energia e também auxilia na diminuição do $\mathrm{CO} 2$ na atmosfera. Além disso, há uma utilização do lixo na produção, diminuindo a quantidade de dejetos nos aterros. A bioenergia pode ser convertida em três produtos: eletricidade, calor e combustíveis. Nesse sentido, a utilização da biomassa, desde que controlada, não agride o meio ambiente, visto que a composição da atmosfera não é alterada de forma significativa.

As técnicas utilizadas são:

- Combustão: Libera o calor para a produção de eletricidade por meio da biomassa, que pode ser utilizada em usinas de carvão. Na indústria de madeira, é utilizada a combustão de restos de madeira para a produção de calor e eletricidade.

- Gaseificação: Converte biomassa em combustível na forma gasosa tendo como principais produtos o hidrogênio e o monóxido de carbono, utilizados na geração de energia e indústria química.

- Fermentação: Desintegra a biomassa com uma bactéria anaeróbica para que se forme uma mistura contendo metano e dióxido de carbono. É utilizado para a formação de eletricidade e nas indústrias para purificação de lixo e es goto.

- Produção de substâncias líquidas: Produzida a partir de um material que seja vegetal. Pode ser feita de duas formas: conversão biológica, onde os açúcares da cana são transformados de bactérias em etanol. Já a conversão térmica ocorre quando o material vegetal se decompõe sem o oxigênio e sob um forte calor. Nesse processo, pode ocorrer a produção de combustíveis líquidos e gasosos.

- Sistemas de Cogeração da Biomassa: Permitem produzir simultaneamente energia elétrica e calor útil. Estes sistemas configuram a tecnologia mais racional para a utilização de combustíveis. Este é o caso das industrias sucroalcooleira e de papel e celulose, que além de demandar potência elétrica e térmica, dispõem de combustíveis residuais que se integram de modo favorável ao processo de cogeração.

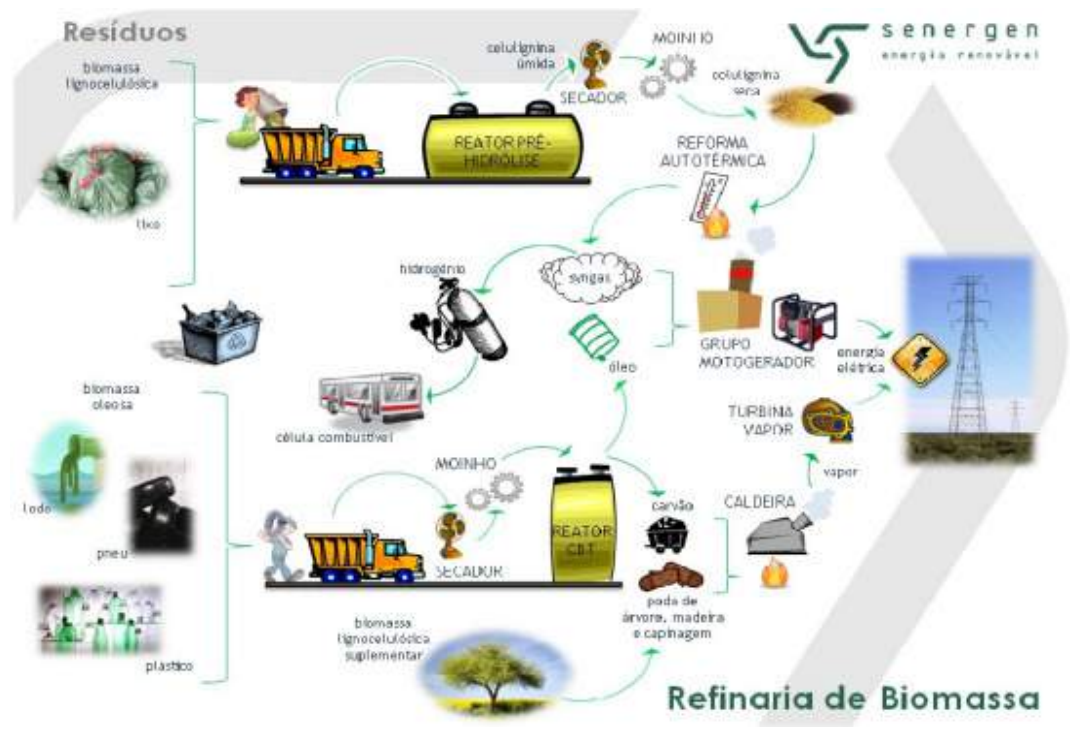

FIGURA 4 - Técnicas de transformação da biomassa. Fonte: Senergen (2011). 


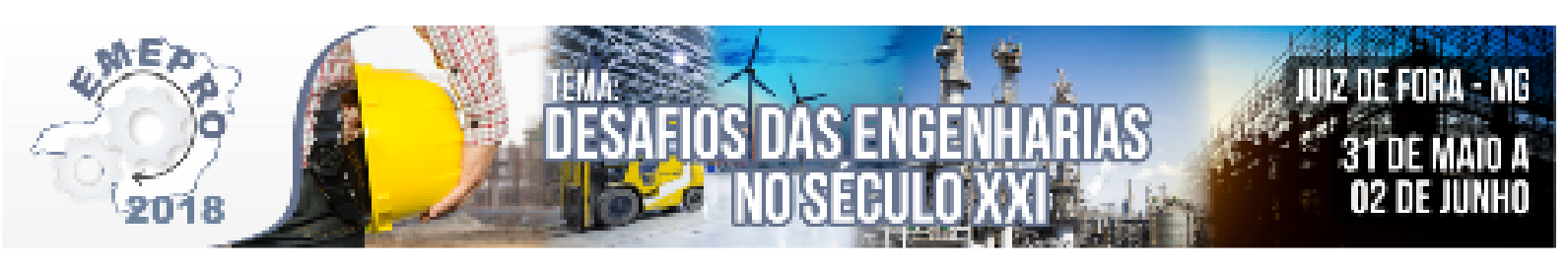

Quanto às técnicas utilizadas para transformar matéria-prima em energético, existem várias. Cada uma dá origem a determinado derivado e está em um nível diferente do ponto de vista tecnológico. Há, por exemplo, a combustão direta para obtenção do calor. Ela ocorre em fogões (cocção de alimentos), fornos (metalurgia) e cald eiras, para a geração de vapor. Outra opção é a pirólise ou carbonização - o mais antigo e simples dos processos de conversão de um combustível sólido (normalmente lenha) em outro de melhor qualidade e conteúdo energético (carvão). Este processo consiste no aqu ecimento do material original entre $300 \mathrm{oC}$ e 500 o C, na "quase ausência" de ar, até a extração do material volátil. O principal produto final é o carvão vegetal, mas a pirólise também dá origem ao alcatrão e ao ácido pirolenhoso.

O carvão vegetal tem densidade energética duas vezes superior à do material de origem e queima em temperaturas muito mais elevadas. $\mathrm{Na}$ gaseificação, por meio de reações termoquímicas que envolvem vapor quente e oxigênio, é possível transformar o combustível sólido em gás (mistura de monóxido de carbono, hidrogênio, metano, dióxido de carbono e nitrogênio). Este gás pode ser utilizado em motores de combustão interna e em turbinas para geração de eletricidade. Além disso, é possível dele remover os componentes químicos que prejudicam o meio ambiente e a saúde humana - o que transforma a gaseificação em de Câncer e o Trópico de Capricórnio.

Ainda assim, Estados Unidos e União Européia, ambos no hemisfério norte, são produtores de etanol. O primeiro a partir do milho e do trigo, da madeira e do switchgrass (variedade de grama). A segunda, com base principalmente na beterraba. De qualquer maneira, a faixa tropical e subtropical do planeta abrange alguns países das Américas Central e do Sul, como o Brasil, o continente africano e Austrália. Estes últimos são caracterizados pela existência de áreas desérticas e, portanto, pouco propensas à produção agrícola. O Brasil, porém, além da grande quantidade de terra agriculturável, apresenta solo e condições climáticas adequadas.

Ao contrário do que ocorre com outras fontes, não existe um ranking mundial dos maiores produtores de biomassa, apenas estatísticas sobre os principais derivados. Assim, se os Estados Unidos lideravam a produção de energia elétrica a partir da biomassa, em 2005 Alemanha era a maior produtora de biodiesel e o Brasil, o segundo maior produtor de etanol. Nesse ano, a produção brasileira já era superada pelos Estados Unidos. Um processo bastante utilizado no tratamento de dejetos orgânicos é a digestão anaeróbica que consiste na decomposição do material pela ação de bactérias e ocorre na ausência do ar. O produto final é o biogás, composto basicamente de metano ( $\mathrm{CH} 4)$ e dióxido de carbono (CO2). Já na agroindústria, o mais comum é a fermentação, pela qual os açúcares de plantas como batata, milho, beterraba e cana-de-açúcar são convertidos em álcool pela ação de microorganismos (geralmente leveduras). O produto final é o etanol na forma de álcool hidratado e, em menor escala o álcool anidro (isto é, com menos de $1 \%$ de água). Se o primeiro é usado como combustível puro em motores de combustão interna, o segundo é misturado a gasolina (no Brasil, na proporção de $20 \%$ a $22 \%$ ). O resíduo sólido do processo de fermentação pode ser utilizado em usinas termelétricas para a produção de eletricidade.

Finalmente, a transesterificação é a reação de óleos vegetais com um produto intermediário ativo obtido pela reação entre metanol ou etanol e uma base (hidróxido de sódio ou de potássio). Os derivados são a glicerina e o biodiesel. Atualmente, o biodiesel é produzido no Brasil a partir da palma e babaçu (região Norte), soja, girassol e amendoim 


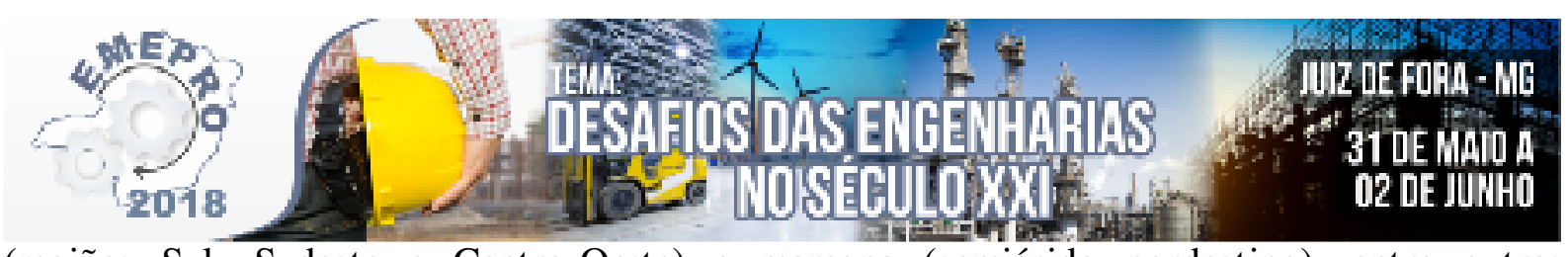

(regiões Sul, Sudeste e Centro-Oeste) e mamona (semiárido nordestino), entre outras matérias-primas de origem vegetal.

Os resíduos da biomassa podem ser classificados em: resíduos sólidos urbanos, resíduos animais, resíduos vegetais, resíduos industriais e resíduos florestais.

- Resíduos sólidos urbanos: Usados por meio da queima direta que já é adotada nos países desenvolvidos. O lixo pode conter até 705 materiais com potencial energético.

- Resíduos animais: O método indicado para esse tipo de resíduo é a digestão anaeróbica.

- Resíduos vegetais: Podem ser transformados facilmente em energia graças à baixa umidade e à facilidade de processamento. A sua disponibilidade é sazonal, necessitam de armazenamento e isso pode alterar os processos de fermentação.

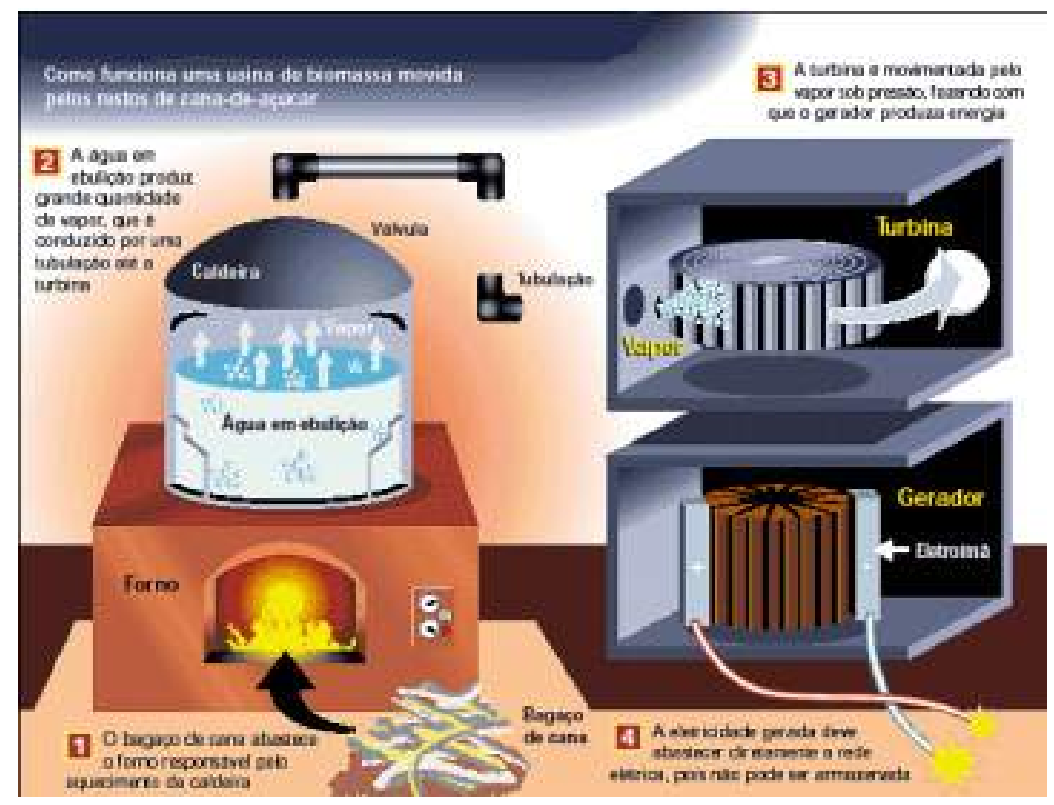

FIGURA 5 - Usina de biomassa. Fonte: Energias Alternativas (2010).

\section{O Biogás}

O biogás é outra forma de aproveitamento da biomassa, é uma fonte barata e abundante de energia. Pode ser obtido de resíduos agrícolas, ou mesmo de excrementos de animais e dos homens.

A formação do biogás acontece, basicamente, durante a decomposição da matéria viva por bactérias microscópicas. Durante este processo, as bactérias retiram da biomassa parte das substâncias de que necessitam para continuarem vivas, e lançam na atmosfera gases e calor. Este é o bio gás.

O biogás pode ser utilizado no funcionamento de motores, geradores, moto picadeiras, resfriadores de leite, aquecedor de água, geladeira, fogão, lampião, lançachamas. Pode ainda substituir o gás liquefeito de petróleo na cozinha, porém o biogás não compete com a produção de alimentos. 


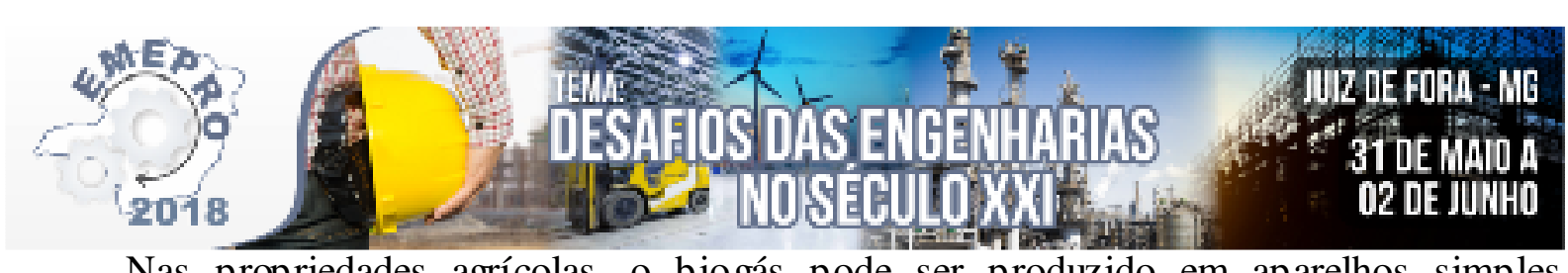

Nas propriedades agrícolas, o biogás pode ser produzido em aparelhos simples chamados biodigestores. Os resíduos que sobram, uma substância com aspecto de lodo, quando diluída em água, podem ser utilizados como fertilizantes.

\section{Vantagens e Desvantagens}

1. Vantagens:

- Baixo custo de aquisição;

- Não emite dióxido de en xofre;

- As cinzas são menos agressivas ao meio ambiente que as provenientes de combustíveis fósseis;

- Menor corrosão dos equipamentos (caldeiras, fornos);

- Menor risco ambiental;

- Recurso renovável;

- Emissões não contribuem para o ef eito estufa.

2. Desvantagens:

- Menor poder calorífico;

- Maior possibilidade de geração de material particulado para a atmosfera. Isto significa maior custo de investimento para a caldeira e os equipamentos para remoção de material particulado;

- Dificuldades no estoque e armazenamento.

Além das citadas acima, existem algumas vantagens indiretas, como é o caso de madeireiras que utilizam os resíduos do processo de fabricação (serragem, cavacos e pedaços de madeira) para a própria produção de energia, reduzindo, desta maneira, o volume de resíduo do processo industrial.

Algumas das desvantagens podem ser compensadas através de monitoramento de parâmetros do processo. Para o controle do processo de combustão devem ser monitorados o excesso de ar, $\mathrm{CO}$ e, para instalações de grande porte, também, deve existir o monitoramento da densidade calorimétrica da fumaça por um sistema on-line instalado na chaminé. Esses controles do processo de combustão são medidas para impedir a geração de poluentes e, assim chamadas indiretas. As Medidas Indiretas visam reduzir a geração e o impacto de poluentes sem ap licação de equipamentos de remoção.

$\mathrm{O}$ uso de equipamentos de remoção é uma medida direta que visa remover aquela parte de poluentes impossíveis de remover com as medidas indiretas. Portanto, deve-se, sempre que possível, tentar implantar as medidas indiretas antes de aplicar as diretas. 


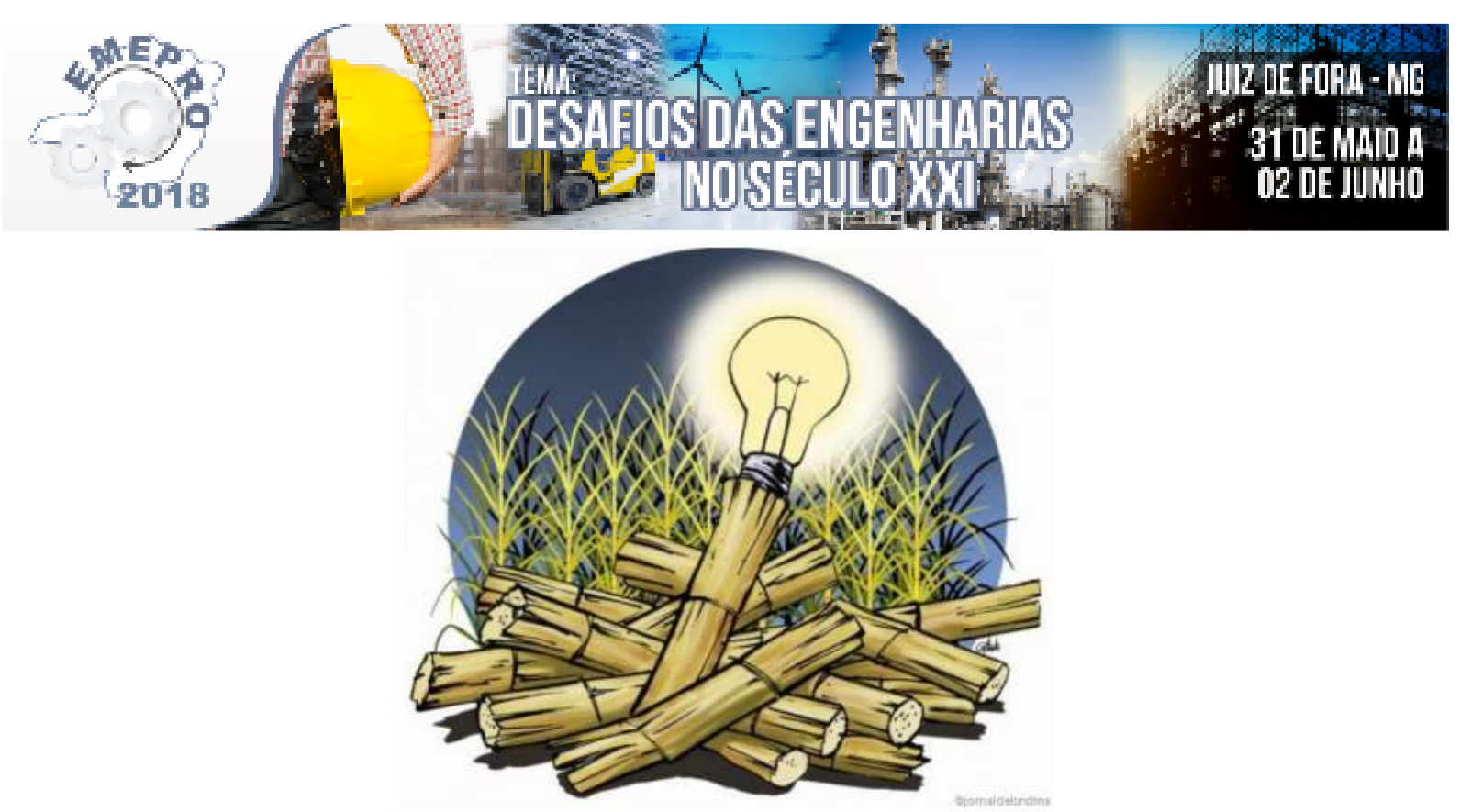

FIGURA 6 - Energia elétrica atrav és da biomassa. Fonte: Jornal de Londrina (2012).

\section{Curiosidades}

- De acordo com o Banco Mundial, $50 \%$ a $60 \%$ da energia nos países em desenvolvimento vêm da biomassa, e metade da população mundial cozinha com madeira. A geração de energia por queima da madeira cresceu de 200 megawatts em 1980 para 7.800 megawatts atualmente. No Brasil, o principal uso é a fermentação e a destilação da cana-de-açúcar para a produção de etanol - um biocombustível;

- Energia a partir da casca de cupuaçu: Um projeto pioneiro na produção de energia a partir de biomassa está sendo desenvolvido no município amazonense de Manacapuru. O Centro Nacional de Referência em Biomassa, em parceira com o Instituto Nacional de Colonização e Reforma A grária (INCRA) e com o Instituto de Pesquisas Tecnológicas (IPT), está testando a casca de cupuaçu como combustível para produção de eletricidade. Para o projeto, foram escolhidas 187 famílias de agricultores do assentamento de Aquidaban. Após a definição de como será feita a distribuição da eletricid ade gerada;

- Plantas brasileiras produzem valiosas fontes de en ergia: a carnaúba por exemplo, pode ser utilizada para a produção da biomassa. Várias plantas que crescem no Brasil produzem óleo de valor comercial, bom combustível para indústrias e transporte. É a energia da biomassa, extraída da massa biológica das plantas, renovável e não poluente;

- O Governo Federal possui um Programa de Incentivo às Fontes Alternativas de Energia Elétrica (PROINFA) que prevê a geração de energia com a utilização de dejetos da cana, lixo e esgoto. Essa demanda traz vantagens ambientais e, principalmente, incide nos grandes centros, reduzindo a emissão de poluentes e o efeito estufa. As usinas que utilizam a biomassa com fins energéticos são principalmente as usinas de cana-de-açúcar e destilarias, cerâmicas e olarias, fábricas de papel e celulose, siderúrgicas, padarias, restaurantes, dentre outros;

- Em Vila Real (Portugal), o aquecimento das escolas é feito através da energia da biomassa; 


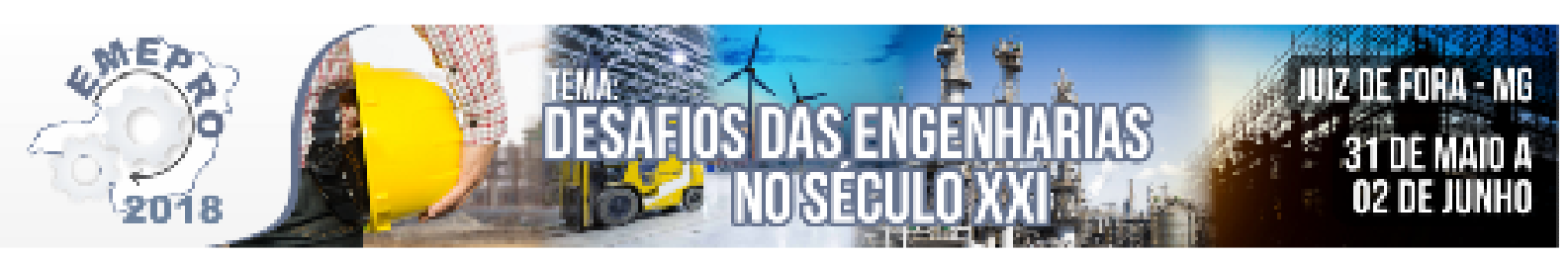

- A central termelétrica de Mortágua (Portugal) utiliza a energia do biogás para produzir energia elétrica;

- Na Califórnia (EUA), a biomassa é responsável pela produção de 2,77\% de toda a energia elétrica.

\section{Referências}

ASSOCIAÇÃO BRASILEIRA DE NORMAS TÉCNICAS. NBR 14724: Informação e Documentação Trabalhos acadêmicos - Apres entação. Rio de Janeiro: ABNT, 2001.

ASSOCIAÇÃO BRASILEIRA DE NORMAS TÉCNICAS. NBR 10520: Informação e Documentação Citações em Documentos - Apresentação. Rio de Janeiro: ABNT, 2002a.

ASSOCIAÇÃO BRASILEIRA DE NORMAS TÉCNICAS. NBR 6023: Informação e Documentação Referências - Elaboração. Rio de Janeiro: ABNT, 2002b.

ANEEL. Disponível em: < http://www.aneel.gov.br>. Acesso em 10 de março de 2018.

Ambiente Brasil. Disponível em: < http://www.ambientebrasil.com.br>. Acesso em 09 de março de 2018.

Energias Renováveis. Disponível em: < http://ifbaer.blogspot.com.br>. Acesso em 09 de março de 2018.

Fontes de Energia. Disponível em: < http://fontes-de-en ergia.in fo/>. Acesso em 15 de março de 2018.

Instituto Nacional de Eficiên cia Energética. Disponível em: < http://www.inee.org.brl>. Acesso em 10 de março de 2018.

Copel, Pura Energia. Disponível em: < http://www.copel.com/hpcopel/root/index.jsp>. Acesso em 09 de março de 2018. 


\title{
D n \\ Impactos econômicos e ambientais da substituição de lâmpadas fluorescentes por lâmpadas de LED em uma instituição de ensino
}

\author{
Rafael Rodrigues Benelli (FIEL) rr.benelli@yahoo.com.br \\ Renata Rodrigues Teixeira (FIEL) renatarodrigues333@ hotmail.com \\ Lucas Scavariello Fransciscato (FIEL) professorlucasfranciscato@gmail.com \\ Vanessa Moraes Rocha de Munno (FIEL) vanessa.moraes8@ hotmail.com
}

Resumo: A necessidade de se utilizar os recursos naturais sem comprometer as futuras gerações tornou-se, com o passar dos anos, uma tarefa de toda sociedade. O futuro depende de atitudes viáveis economicamente, socialmente e ambientalmente corretas, por isso devemos utilizar de forma eficiente os recursos naturais e propor soluções para se alcançar a sustentabilidade.

Visando atingir esses objetivos, foi elaborado um estudo de caso que apresenta os impactos econômicos e ambientais da substituição das lâmpadas fluorescente tubular por lâmpadas LED tubular (diodo emissor de luz, do inglês lighting emission diode) em uma instituição de ensino, mostrando qual o investimento necessário para se implementar o projeto, o payback, o saving e as vantagens ambientais deste projeto.

Palavras-chave: Sustentabilidade; Lâmpada LED; Investimento; Payback, Saving.

\section{Introdução}

Diante do cenário econômico atual e de preocupação com o uso dos recursos, os empreendedores deveriam priorizar a busca por maneiras de reduzir o consumo de energia elétrica (HOLLANDA, 2015), por isso a utilização desta fonte energética gasta com iluminação deve ser reduzida ao ponto de ser o mais eficiente possível.

Uma parcela considerável de toda energia gerada é gasta com a iluminação artificial, assim, desenvolver sistemas que façam uso de recursos de uma maneira mais racional é extremamente vantajoso e necessário (PINTO, 2008). Ainda para este autor, o uso de lâmpadas LED contribui para uma maior eficiência e longevidade nos sistemas e isso tem feito com que essas lâmpadas ganhem sua parcela do mercado por mostrarem sua economia através de sua melhor eficiência energética.

Porém antes de um projeto ser implementado é necessário verificar sua viabilidade econômica, desta forma pode-se identificar quais são os fatores envolvidos e os benefícios de se seguir com o projeto proposto (VERAS, 2001) e para isso as alternativas para validação de um investimento ou projeto podem ser dadas pela análise do tipo TIR, VPL ou payback.

Com a viabilidade econômica feita antes da implantação do projeto pode-se identificar quais são os fatores envolvidos e os benefícios de se seguir com o projeto proposto (VERAS, 2001), e complementando Laponni (2000) apresenta como um fator primordial antes de realizar o investimento conhecer e analisar o tempo previsto para recuperar o recurso aplicado (payback). 


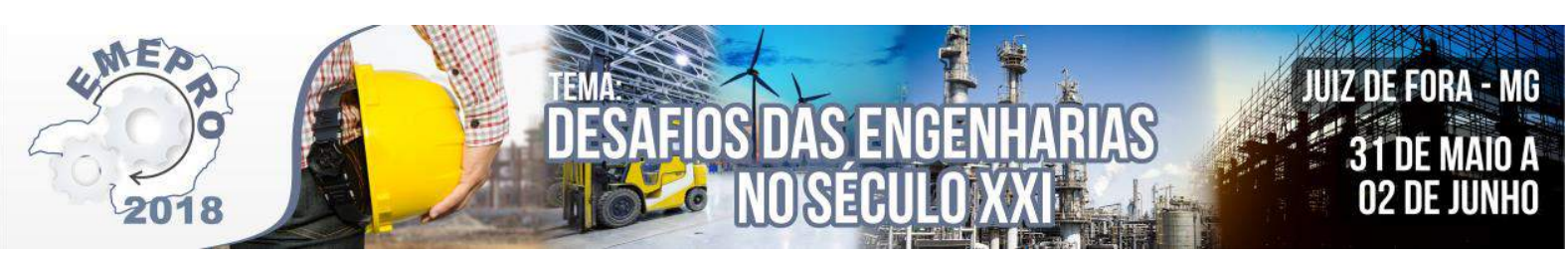

\section{Referencial Teórico}

\subsection{Lâmpada Fluorescente}

Lâmpadas fluorescentes são constituídas por longos cilindros de vidro, cujo interior é revestido por camadas de fósforos, produto esse, que possui a capacidade de emitir luz visível quando injetado luz ultravioleta (SOUZA, 2012). As lâmpadas fluorescentes tubulares não podem controlar o fluxo de corrente sozinhas, assim, é preciso instalar em conjunto com a lâmpada um reator, o que pode aumentar o consumo da instalação.

O inconveniente das lâmpadas fluorescentes é quanto a sua reciclagem. Segundo Inovação Tecnológica, (2006) "No Brasil são consumidas cerca de 100 milhões de lâmpadas fluorescentes por ano. Desse total, $94 \%$ são descartadas em aterros sanitários, sem nenhum tipo de tratamento, contaminando o solo e a água com metais pesados".

O uso de Mercúrio em lâmpadas fluorescentes é essencial para que elas funcionem corretamente, mas sua concentração não deve exceder os $5 \mathrm{mg}$ por lâmpada (REY-RAAP \& GALLARDO, 2012). Geralmente, o conteúdo de mercúrio varia entre 4 a $5 \mathrm{mg}$, quantidade que não causa danos diretos à saúde humana. Porém, o fato do mercúrio ser cumulativo na cadeia trófica faz com que estes resíduos sejam problemáticos, em especial em situações em que ocorre a acumulação das lâmpadas fluorescentes quebradas. Nestes casos, o elemento liberado pode destruir a camada protetora de ozônio na atmosfera, contaminar corpos hídricos superficiais ou águas subterrâneas e acumular-se nos biomas, na biota, etc. (ENERGY STAR, 2010).

O mercúrio pode afetar todos os grupos de organismos e Ecossistemas, incluindo microrganismos da água e solo e a fauna de uma maneira geral (WANG et al., 2012). A presença desta substância no ambiente é um risco eminente à saúde humana, há relatos na literatura sobre casos de Alzheimer, Parkinson e mortalidade infantil relacionados à exposição à contaminação ambiental por mercúrio (WANG et al., 2012; BOSE-O`REILLY et al., 2010). Atualmente, apenas $20 \%$ das lâmpadas fluorescentes podem ser recicladas, processo que é considerado muito oneroso (AMAN et al., 2013).

\subsection{Tecnologia LED}

O diodo emissor de luz, do inglês "Lighting Emitting Diode", é popularmente conhecido como LED, um componente eletrônico semicondutor, que tem a propriedade de transformar energia elétrica em luz. Ele não utiliza filamentos metálicos, como as lâmpadas incandescentes, e nem radiação ultravioleta, como as fluorescentes. O LED é um componente bipolar, tem um terminal chamado cátodo e outro chamado ânodo, que, quando polarizado, permitem a passagem de corrente elétrica, gerando luz (LABORATÓRIO DE ILUMINAÇÃO, 2012).

A lâmpada LED é fabricada utilizando o material semicondutor, que, quando é percorrido por corrente elétrica emite luz. Os principais materiais semicondutores empregados atualmente são o germânio e o silício, sendo este último o mais utilizado (STRYHALSKI, 2012). Destaca-se, ainda, que os materiais semicondutores não são prejudiciais ao meio ambiente.

No mercado são oferecidos Lâmpadas LED dos mais diversos tipos como: no formato da incandescente, LED spot no lugar das halógenas, LED tubular no lugar das fluorescentes tubulares, fitas LED, entre outros modelos e com uma grande variedade das cores disponíveis. A utilização desta tecnologia é uma forma de diminuir gastos com energia elétrica e preservar 


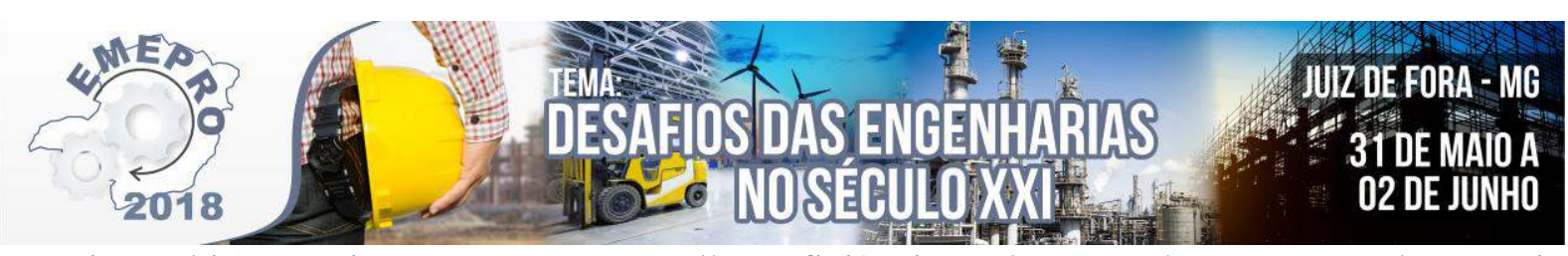

o meio ambiente pois possuem uma melhor eficiência e desempenho no gasto de energia elétrica, com uma transformação relativamente baixa em calor, (SILVEIRA et al., 2010).

Ainda analisando os aspectos ambientais, $98 \%$ dos materiais da composição da lâmpada LED são recicláveis e não contêm metais pesados, como o mercúrio, sendo menos agressivas ao homem e ao meio ambiente do que as fluorescentes, além disso, possuem uma longa expectativa de vida, com cerca de 50.000 mil horas enquanto lâmpadas fluorescentes têm em média 16.000 mil horas.

\subsection{Investimento}

De acordo com Camargo (2007) investimento é o comprometimento de dinheiro ou outros recursos feitos na expectativa de colher benefícios maiores no futuro.

Gitman (2010) define investimento como um desembolso de caixa realizado pela organização com perspectiva de produzir benefícios, e que o capital investido agregue valor e lucratividade para a organização.

O investimento deve ser projetado de acordo com os fatos iniciais, que em conjunto possibilitam classificar as vantagens e desvantagens econômicas ao implantar investimentos na produção de bens ou serviços (REBELLATO,2004).

Assaf (2009) afirma que para uma decisão de investimento estruturada, é necessário a preparação, avaliação, e escolha das propostas de aplicar recursos, com objetivo de ter retorno em médio e longo prazo.

Newman e Lavelle (2000) indicam que inicialmente para que o processo de decisão seja viável é necessário avaliar e explorar o investimento para conhecer sua efetividade econômica.

Assaf (2009) complementa que o investimento apropriado é aquele capaz de cobrir e pagar o capital nele aplicado.

\subsection{Payback}

Gitman (2010) afirma que payback é um instrumento usado para determinar quanto tempo a empresa leva para recuperar o capital inicial investido em projeto, através de uma análise a partir do fluxo de caixa de entrada o lucro obtido em cada período. O tempo de retorno é gerenciado com base em investimentos anteriores, rentabilidade pretendida entre outros fatores definidos pela organização.

Segundo Sebrae (2004) a ferramenta payback é o tempo em que o investidor necessita para a recuperação do capital investido. Calculado pela fórmula:

- $\quad$ Payback = Investimento Total /Lucro Líquido (por ano)

Onde o resultado é o tempo (em anos) de recuperação do capital.

Braga (1994) indica que quanto mais extenso o período de tempo considerado, maiores são as incertezas de previsão para atingir o retorno do capital investido. Portanto investimentos que propõe retorno em menor tempo possuem menor risco.

Ross (2013) identificou através de uma pesquisa que empreendedores preferem optar em investir em projetos que possuem retorno financeiro de máximo um ano. 


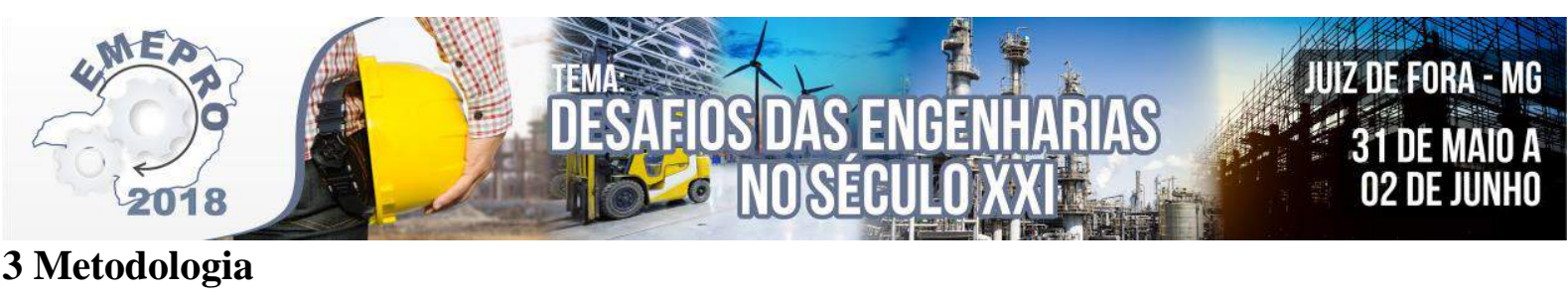

Essa pesquisa foi realizada através do Programa de Apoio à Pesquisa e Iniciação Científica para graduação que a instituição oferece aos alunos e esta se apoiando nas teorias apresentadas no referencial teórico, que conforme Yin (2015) é por onde se deve começar o estudo de caso, e posteriormente colocando-as em prática através de estudos e experimentos com os dados coletados na própria instituição de ensino.

O estudo de caso segundo Cauchick (2007) possui carácter empírico que estuda situações, geralmente, atuais dentro de um contexto real, com a proposta de aprofundar e ampliar o conhecimento em relação a um problema, estimular a compreensão, sugerir hipóteses e desenvolver teorias com o objetivo de justificar a decisão ou decisões que forem tomadas, a maneira como devem ser implementadas e quais serão os resultados obtidos. Cauchick também define que o estudo de caso deve ser conduzido através de métodos e técnicas para que atinja os objetivos da pesquisa, primeiramente deve-se definir uma estrutura conceitualteórica, planejar o caso, conduzir teste piloto, coletar e analisar os dados e gerar um relatório.

Este estudo de caso foi realizado em uma instituição de ensino que possui mais de 3500 estudantes matriculados em seus cursos, atuando desde a Pré-Escola até o ensino universitário, inclusive a pós-graduação, instalada em uma área de $21.000 \mathrm{~m}^{2}$ e situada na cidade de Limeira, interior do estado de São Paulo, com o objetivo de analisar a viabilidade econômica e ambiental da substituição de lâmpadas tubular fluorescentes por lâmpadas tubular de LED.

\section{Estudo de caso}

Com a proposta de se substituir o atual sistema de iluminação artificial de uma instituição de ensino baseado na tecnologia de lâmpada fluorescente tubular, por um sistema de iluminação que pudesse oferecer vantagem financeira, social e ambiental, foi encontrado os modelos de lâmpada LED tubular. A seguir a tabela 01 mostra as características de uma lâmpada fluorescente tubular de 40 Watts comparada a sua compatível de LED tubular para observar as vantagens que o novo sistema pode oferecer.

Tabela 01 - Comparação de Características de Lâmpada Fluorescente Tubular X Lâmpada LED Tubular

\begin{tabular}{lccc}
\hline Características & Unidade & Fluorescente Tubular & LED Tubular \\
\hline Potência & Watt & 40 & 18 \\
Fluxo Luminoso & Lúmen & 2.700 & 1.650 \\
Eficiência Luminosa & Lúmen/watt & 67,5 & 91,67 \\
Tempo Médio de Vida & Horas & 20.000 & 40.000 \\
Custo Unitário & Reais & 7,10 & 19,80 \\
\hline
\end{tabular}

Fonte: AUTORES, 2018

Com a comparação entre os dois tipos de tecnologia é possível identificar as vantagens técnicas da lâmpada LED tubular em relação a fluorescente tubular. Com a utilização de uma menor potência a lâmpada LED tubular de tem uma maior eficiência luminosa, seu tempo de vida é maior e não necessita de reator para funcionar, o que pode causar dúvidas sobre a sua utilização é quanto a sua viabilidade econômica, pois seu preço é maior que o de uma lâmpada fluorescente tubular.

Porém para a substituição das lâmpadas ser eficaz o novo sistema de iluminação deve respeitar os valores de iluminância média estabelecido pela NBR 5413. Segundo esta norma o ambiente de sala de aula deve ter uma iluminância média de 300 a 500 lux, então para garantir 


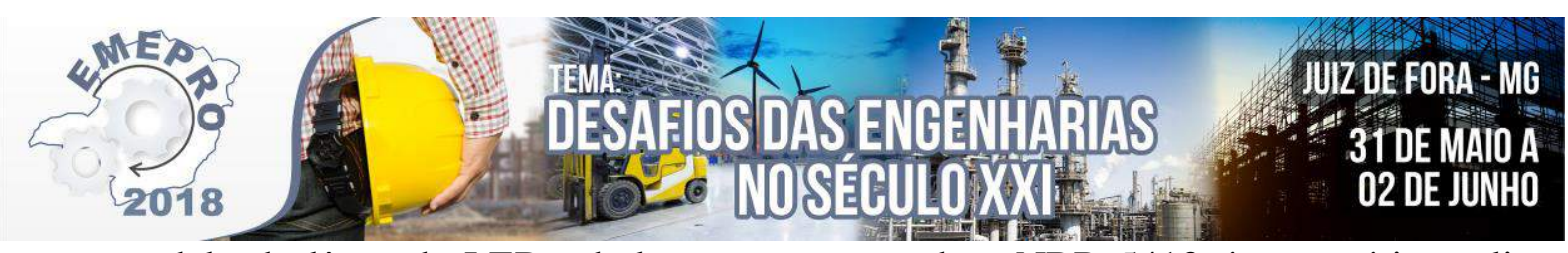

que o modelo de lâmpada LED tubular proposto atende a NBR 5413 é necessário realizar medições com o luxímetro a fim de garantir que a iluminância do ambiente não seja afetada.

As medições foram realizadas com o auxílio de um luxímetro em 10 pontos da sala de aula e posteriormente feito a média aritmética para comparar se a substituição das lâmpadas fluorescentes modelo T10 40W pelas lâmpadas LED modelo T8 $18 \mathrm{~W}$ garantiriam que a luminosidade das salas estaria de acordo com a NBR 5413.

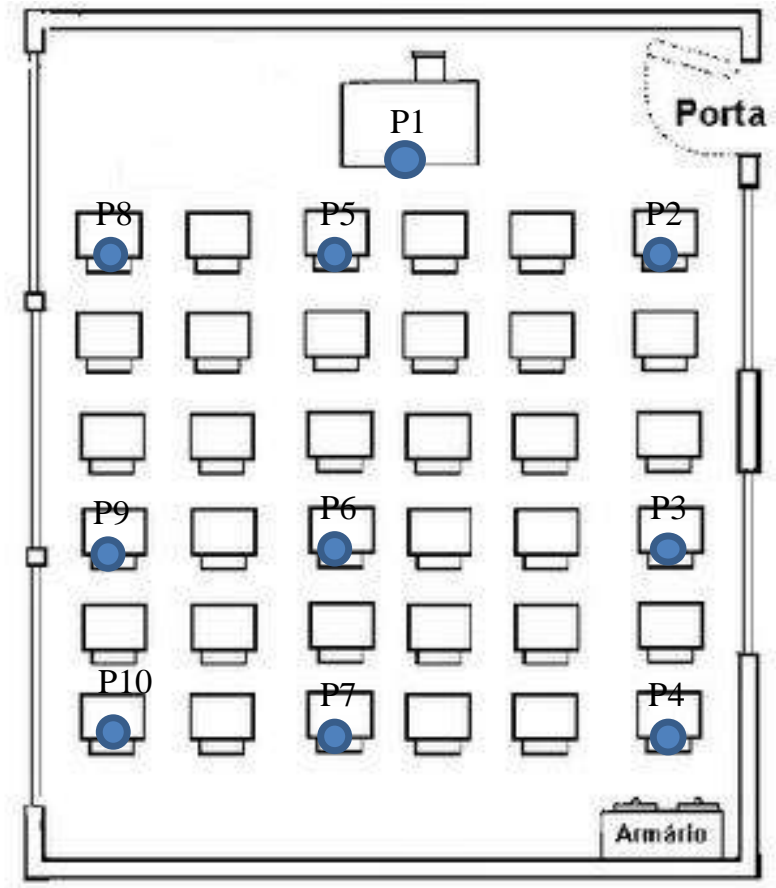

FIGURA 1- Medições da iluminância na sala de aula. Fonte: Autores, 2017

Os dados apresentados na tabela 02 foram resultados das medições realizadas em uma sala de aula. A tabela traz uma comparação entre o modelo atual e o proposto, apresentando um ganho na luminosidade da sala com o uso de lâmpadas LED, além disso, as lâmpadas LED não perdem seu fluxo luminoso com o tempo, ao contrário das fluorescentes que quanto mais perto do fim de sua vida útil têm seu fluxo luminoso reduzido.

TABELA 02 - Medição de Iluminância

\begin{tabular}{lccc}
\hline \multicolumn{1}{c}{ Características } & Unidade & Fluorescente tubular & LED Tubular \\
\hline Iluminância P1 & Lux & 348 & 457 \\
Iluminância P2 & Lux & 315 & 352 \\
Iluminância P3 & Lux & 408 & 355 \\
Iluminância P4 & Lux & 304 & 326 \\
Iluminância P5 & Lux & 389 & 470 \\
Iluminância P6 & Lux & 354 & 469 \\
Iluminância P7 & Lux & 309 & 419 \\
Iluminância P8 & Lux & 324 & 332 \\
Iluminância P9 & Lux & 295 & 346 \\
Iluminância P10 & Lux & 249 & 310 \\
\hline Iluminância Média & Lux & 329,5 & 383,6 \\
& Fonte: Autores, 2017. &
\end{tabular}




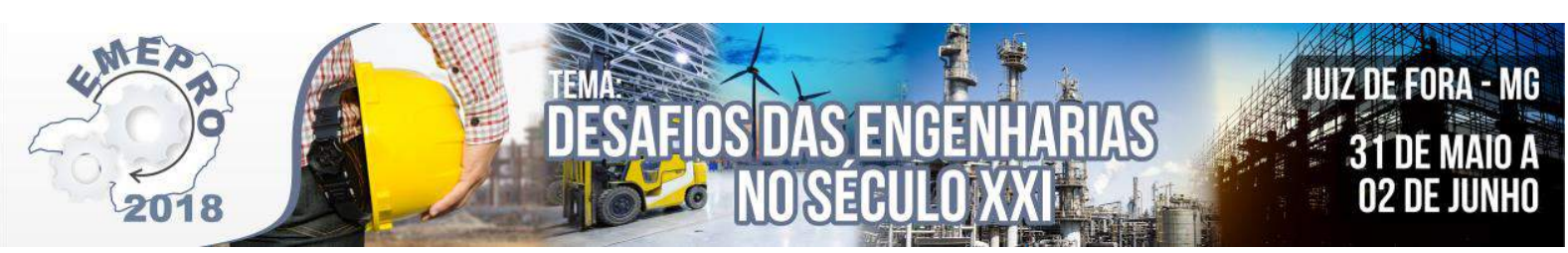

Com a definição do modelo de lâmpada LED tubular a ser utilizado para substituir a lâmpada fluorescente tubular é necessário se obter respostas que ajudem a analisar viabilidade econômica, para isso é preciso realizar uma comparação financeira entre os dois tipos de tecnologia baseado em: potência de cada lâmpada, quantidade de lâmpadas necessárias, custo individual do produto, potência do reator, quantidade de reatores, custo unitário do reator, custo inicial do sistema, custo de energia por hora, consumo de energia horário, consumo de energia mensal, custo de energia mensal, custo de energia ao ano. Consumo mensal baseado no uso de 8 horas/dia, 22 dias/mês.

TABELA 03 - Análise de Viabilidade Econômica

\begin{tabular}{lccc}
\hline Características & Unidade & Fluorescente Tubular & LED Tubular \\
\hline Potência da Lâmpada & Watt & 40 & 18 \\
Quantidade de Lâmpadas & Unidade & 3.330 & 3.330 \\
Custo Unitário da Lâmpada & Reais & 7,10 & 19,80 \\
Potência do Reator & Watt & 8 & - \\
Quantidade de Reatores & Unidade & 1.665 & - \\
Custo Unitário do Reator & Reais & 21,86 & - \\
Custo inicial do Sistema & Reais & $60.039,90$ & $65.934,00$ \\
Custo de Energia & Reais/KW & 0,420 & 0,420 \\
Consumo de Energia & kW/Horas & 146,5 & 60 \\
Consumo mensal de energia & kW/Mês & 25.788 & 10.549 \\
Custo de Energia Mensal & Reais & $10.830,76$ & $4.430,76$ \\
Custo de Energia Anual & Reais & $129.969,10$ & $53.169,18$ \\
Custo Total Anual & Reais & $129.969,10$ & $119.103,18$ \\
\hline
\end{tabular}

Em toda análise financeira os custos fixos e variáveis assumem elevada importância para se efetivar o estudo. Nos custos fixos, a mão-de-obra e depreciação das lâmpadas não está sendo considerados nos cálculos, pois a mão-de-obra é feita por um funcionário da própria instituição e a lâmpada não será vendida após completar sua vida útil, será trocada por uma nova. Nesse estudo de viabilidade econômica, identificou-se como responsável pela maioria dos custos o gasto com energia elétrica e o custo inicial dos sistemas, contudo o custo inicial do sistema de lâmpada fluorescente tubular não é contabilizado pois o mesmo já se encontra instalado, então, consideramos somente o custo inicial da implantação do sistema baseado na tecnologia LED. Para custos variáveis temos o insumo com energia elétrica até o final da vida útil da lâmpada. Apesar de o investimento inicial com o sistema de iluminação baseada na tecnologia LED ser alto ele se paga, pois, a energia gasta pelas lâmpadas LED tubular é menor do que pelas lâmpadas fluorescentes tubulares, assim o sistema de iluminação de LED será pago em menos de um ano como mostra a progressão dos gastos com ambas as tecnologias no gráfico 01 . 

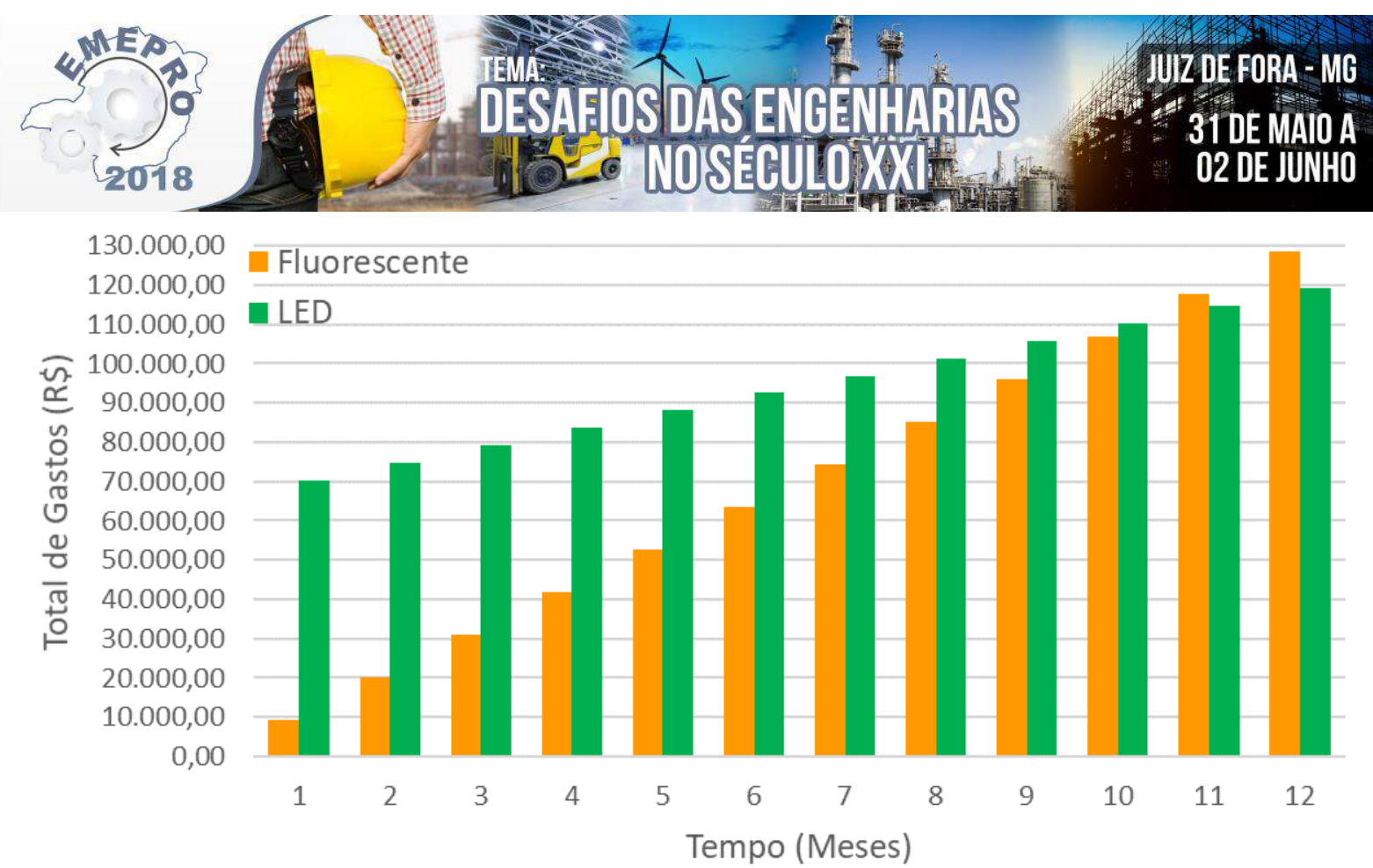

GRÁFICO 01: Projeção de gastos no primeiro ano com a tecnologia fluorescente tubular e LED tubular.

Fonte: Autores, 2018.

O payback deste investimento é de 11 meses e ainda é possível obter um saving, o quanto será feito de economia ou o quanto de custo foi evitado, de mais de $\mathrm{R} \$ 610.000,00$ dentro de 8 anos, conforme apresentado no gráfico 02, prazo aproximado que o sistema de lâmpada tubular fluorescente chegaria ao fim de sua vida útil.

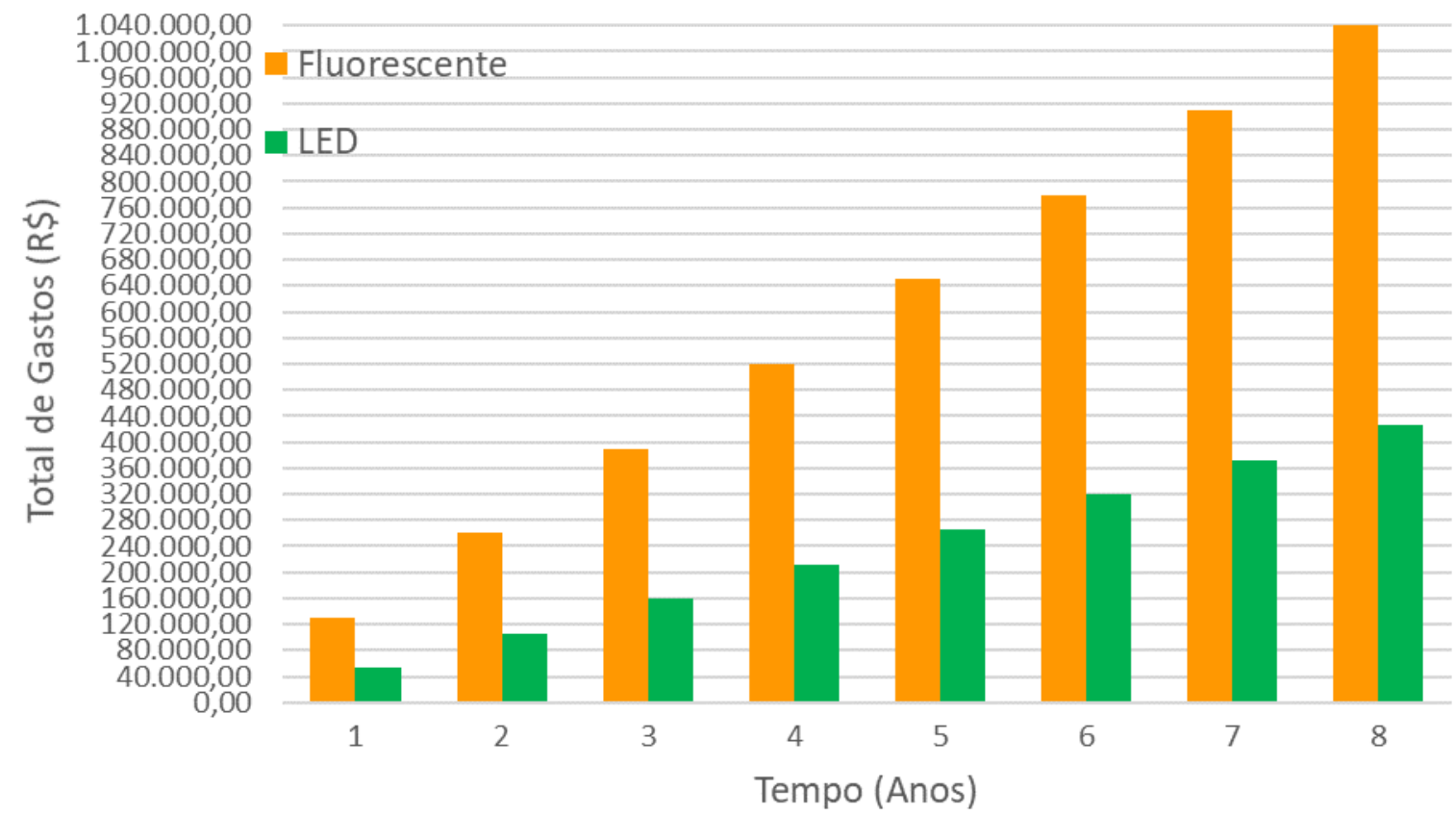

GRÁFICO 02: Projeção de gastos em 8 anos com energia elétrica de lâmpadas fluorescentes tubular e LED tubular.

Fonte: Autores, 2018.

O fato de as lâmpadas LED tubular quando comparada com as lâmpadas fluorescentes tubular economizarem energia já é de grande importância para o meio ambiente, mas, além disso, as 


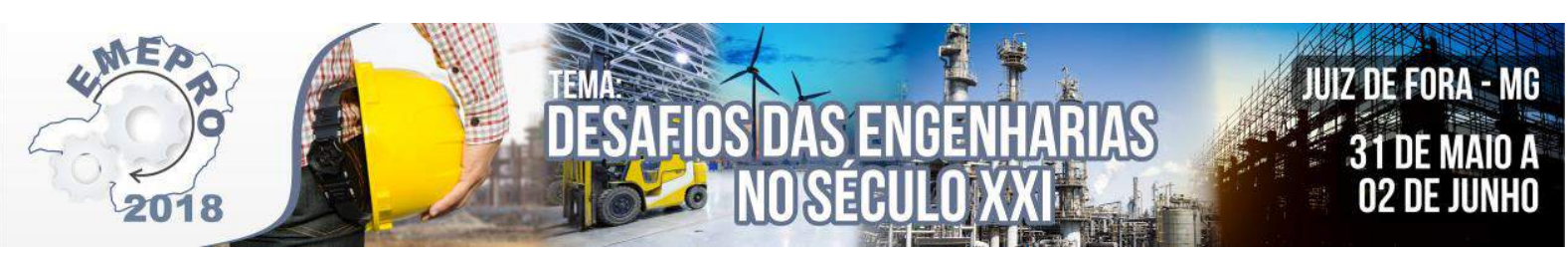

lâmpadas LED têm outras vantagens, como não possuírem metais pesados em sua composição, não correndo o risco de contaminar o solo e a água, e possuem uma vida útil maior, reduzindo a necessidade de substituições frequentes.

\section{Resultados}

O presente trabalho pode constatar que a lâmpada LED tubular é mais econômica e eficiente, quando comparada com a tubular fluorescente. Utilizando uma potência menor do que a metade de uma lâmpada fluorescente tubular, a lâmpada LED é melhor para iluminância das salas, requer menor consumo, e consequentemente menor gasto, de energia elétrica.

Podemos observar desvantagens na utilização de lâmpadas fluorescente tubular quando comparada com a lâmpada LED tubular em aspectos como, um menor tempo de sua vida útil; utilização de metais pesados em sua constituição; necessidade de reator (o que aumenta o consumo de energia e gasto com manutenção).

Com o estudo de viabilidade econômica, é possível prever os resultados que se será obtido com a execução da proposta de utilizar um sistema baseado na tecnologia de iluminação de lâmpadas LED tubular em relação a fluorescente tubular. Com um payback de 11 meses e um saving de mais de $\mathrm{R} \$ 600.000,00$ em 8 anos as lâmpadas LED tubular se mostram viáveis economicamente.

Os fatores ambientais demonstram que a lâmpada LED tubular afeta menos o meio ambiente. Por não utilizar metais pesados em sua constituição; não emitir radiação ultravioleta; possuir uma maior vida útil; não necessita de reator para ser utilizada e apresentar uma melhor eficiência energética; fazem a lâmpada LED tubular ser viável ambientalmente.

\section{Conclusão}

Conforme os resultados apresentados e visando utilizar os recursos naturais da maneira mais eficiente possível para se atingir a sustentabilidade, a lâmpada LED tubular se mostra como uma alternativa viável, socialmente, economicamente e ambientalmente, para o uso eficiente da energia elétrica gasta iluminação.

\section{Referências}

NBR 5413: Iluminância de interiores ASSOCIAÇÃO BRASILEIRA DE NORMAS TÉCNICAS. - Rio de Janeiro: ABNT, 1992.

AMAN, M.M.; JASMON, G.B.; MOKHLIS, H.; BAKAR, A.H.A. Analysis of the performance of domestic lighting lamps. Energy Policy, v.52 (2013).

ASSAF, A. N. Finanças Corporativas e Valor. 4. ed. São Paulo: Atlas, 2009.

BRAGA, R. Fundamentos e técnicas de administração financeira. São Paulo: Atlas, 1994.

BOSE-O`REILLY, S.; McCARTY, K.M.; STECKLINH, N.; LETTMEIER, B. Mercury exposure and children's health. Current Problems in Pediatric and Adolescent Health Care, v.40, 2010

CAMARGO, C. Análise de investimentos e demonstrativos financeiros. Curitiba: Ibpex , 2007.

CAUCHIK, P.A.M. Estudo de caso na engenharia de produção: estruturação e recomendações para sua condução. POLI - USP, v 17, n.1, Jan./Abr, 2007.

ENERGY STAR. Information on Compact Fluorescent Light Bulbs (CFLs) and Mercury. Energy Star Program: U.S. Department of Energy, 2010.

INOVAÇÃO TECNOLÓGICA. Reciclagem de lâmpadas fluorescentes tem solução brilhante. Disponível em: $\langle$ http://www.inovacaotecnologica.com.br/noticias/noticia.php?artigo=010125060623\#.VgL-7cuwG0c>. Acesso em 16 de abril de 2017. 


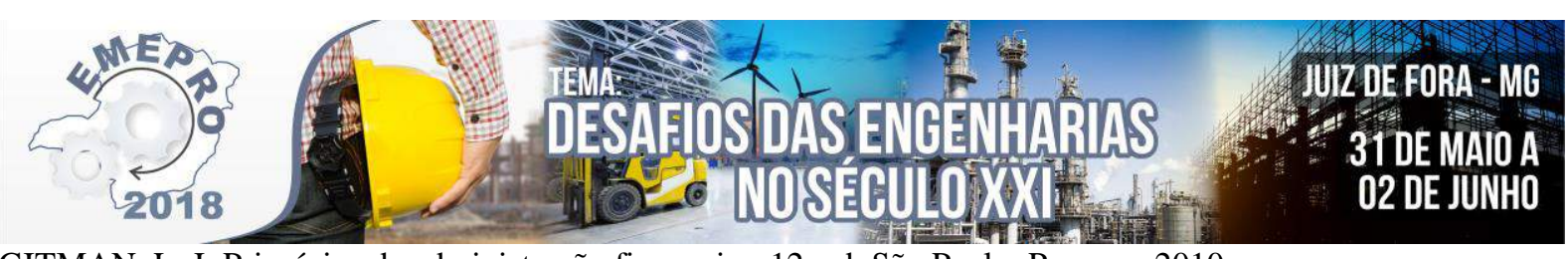

GITMAN, L. J. Princípios de administração financeira. 12. ed. São Paulo: Pearson, 2010.

HOLLANDA, J.B., Cinco idéias para baixar os custos de energia na empresa. Revista Exame, 2015.

LABORATÓRIO DE ILUMINAÇÃO. LED - o que é, e como funciona, 2012. Disponível em: http://www.iar.unicamp.br/lab/luz/dicasemail/ led/dica36.htm. Acesso em: 25 de julho 2017.

LAPPONI, J. C. Projetos de investimento: construções e avaliação do fluxo de caixa. São Paulo: Lapponi treinamentos, 2000.

PINTO, R.A. Projeto e implementação de lâmpadas para iluminação de interiores empregando diodos emissores de luz (LED). Dissertação de Mestrado - Universidade Federal de Santa Maria, Santa Maria, 2008.

REBELlATO, D. Projeto de investimento. Barueri: Manole ltda, 2004.

REY-RAAP, N. \& GALLARDO, A. Determination of mercury distribution inside spent compact fluorescent lamps by atomic absortion spectrometry. Waste Management, v.32, 2012.

NEWMAN, D.; LAVELLE, J. Fundamentos de Engenharia Econômica. 1. ed. Rio de Janeiro: LTC, 2000.

ROSS, W. J. Fundamentos da Administração Financeira. 9.ed. Porto Alegre: AMGH, 2013

SEBRAE. Como elaborar um plano de negócios. Minas Gerais, 2004.

SILVEIRA, M C. F.; MALDONADO, O. A. A.; CARVALHO, S. G. P.; SILVEIRA, J.

L. Benefícios ambientais e energéticos da utilização da tecnologia LED em Sistema de iluminação pública. XVIII Congresso Brasileiro de Automática, Mato Grosso do Sul, 2010.

STRYHALSKI, J. Semicondutores, um pouco de Física do Estado Sólido. Joinville: Udesc,2012.

SOUZA; T.C., FERRARI; L.C.D.B. Análise econômica da substituição de lâmpadas fluorescentes por tecnologia LED em uma empresa de manutenção de máquinas. XXXII Encontro Nacional de Engenharia de Produção. Rio Grande do Sul, 2012.

VERAS, L. L. Matemática financeira: uso de calculadoras financeiras, aplicações ao mercado financeiro, introdução à engenharia econômica, 300 exercícios resolvidos e propostos com respostas. 4. ed. São Paulo: Atlas, 2001

YIN, K. R. Estudo de caso: planejamento e métodos. 5. Ed. Porto Alegre: Bookman,2015

WANG, J.; FENG, X.; ANDERSON, C.W.N.; XING, Y.; SHANG, L. Remediation of mercury contaminated sites - A rewiew. Journal of Hazardous Materials, v. 221-222, 2012. 


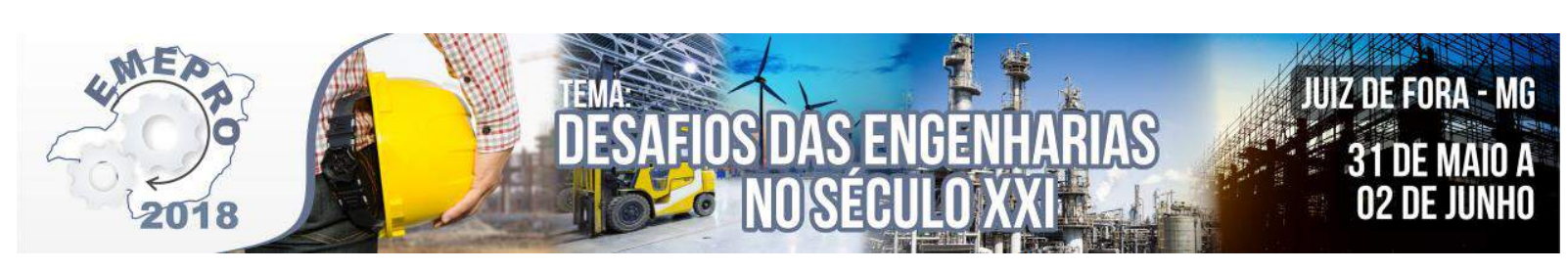

Materiais de construção e seus impactos ambientais

Eliziane Medeiros Santos (IME-Instituto Militar de Engenharia) - elizianemsantos@gmail.com Jéssica de Almeida Rocha (Faculdades Doctum) - jssicaalmeida@yahoo.com.br

Resumo: O setor da construção civil é um setor que requer grande consumo de matéria prima o que gera grandes impactos ao meio ambiente. Não apenas a extração de matérias primas, mas existem também vários fatores que contribuem para a degradação do meio ambiente. $\mathrm{Na}$ construção civil podemos ver este problema em várias áreas, porém neste artigo serão mostrados os impactos ambientais que os materiais de construção geram. A extração da matéria prima, o consumo energético, a poluição do ar, a geração de resíduos e grandes quantidades de entulho, são problemas que podem ser estudados e amenizados com até mesmo pequenas ações sustentáveis. Com o pensamento sustentável desde a concepção do projeto e um bom planejamento, a construção civil pode deixar de gerar tantos impactos ambientais. Não é apenas buscar construções totalmente sustentáveis, mas sim mostrar que através das pequenas ações teremos um mundo melhor.

Palavras-chave: Construção civil. Meio ambiente. Materiais.

\section{Introdução}

A construção civil é a atividade econômica que mais consome matéria-prima além de consumir grande quantidade de energia. Reduzir o consumo de energia resolve o problema tanto econômico quanto ambiental decorrente das emissões de carbono das termoelétricas. Os materiais de construção podem representar quase $15 \%$ da energia na construção de um edifício. Assim, a escolha do material a ser utilizado tem importância significativa no consumo de energia. O transporte de materiais também implica em grande consumo de energia, fazendo com que se priorizem os materiais locais (TORGAL E JALALI, 2007).

Os materiais de construção têm um impacto ambiental considerável tanto no emprego de recurso (matéria-prima e fontes de energia), quanto de fontes poluidoras. Para a redução dos impactos na construção civil é indispensável desenvolver materiais com menor consumo energético e matérias-primas naturais. Buscando a redução de resíduos e entulhos, é preciso promover o desenvolvimento de tecnologias de reciclagem, onde a matéria-prima poderá ser substituída pelo material reciclado (BERTOLINE, 2010).

O Setor da construção civil é responsável pelo consumo de aproximadamente $40 \%$ de pedra britada, cascalho e areia utilizados globalmente a cada ano. Não apenas a construção de edifícios, mas também a manutenção e operação das edificações consomem grandes quantidades de recursos tanto renováveis como não renováveis. Os resíduos sólidos produzidos em construções e demolições, normalmente são destinados para depósitos de lixo urbano que exigem uma área considerável, o que gera vários problemas.

$\mathrm{Na}$ construção civil existem alguns pontos que podem gerar impactos ambientais como:

- Materiais de construção;

- Resíduos;

- Eficiência energética; 


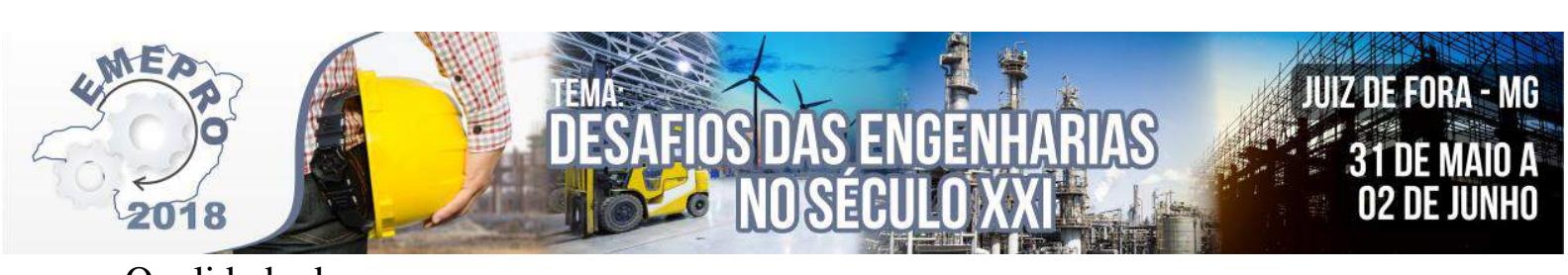

- Qualidade do ar;

- Operação e manutenção de edifícios;

- Meios de transporte;

- Eficiência na utilização do terreno;

- Eficiência na utilização da água;

Os casos citados acima devem ser analisados e estudados para que se alcance ao menos uma minimização dos impactos ao meio ambiente (JOHN, 2010).

\section{Objetivo}

O objetivo deste artigo é analisar e discutir os impactos ambientais gerados pelos materiais de construção. Busca-se mostrar algumas ações que podem ser aderidas e incentivar estudos que ao menos minimizem tais impactos sobre o ambiente. Alertar os danos causados, que por muitas vezes são irreversíveis, na extração de matéria prima, na geração de resíduos, no consumo energético, e mostrar a grande importância de um pensamento sustentável quando se fala em construção.

\section{Metodologia}

A metodologia adotada foi através de coleta de dados sobre os impactos ambientais gerados pelos materiais de construção. Foi elaborado um estudo onde se reuniu informações e ideias sobre o assunto em questão, para que fosse possível discutir e analisar as informações, atingindo assim o objetivo desejado. Com a coleta dos dados e sua análise, foi possível chegar a algumas soluções para que os impactos ambientais gerados pelos materiais de construção sejam minimizados.

Após o estudo, espera-se ter uma maior conscientização das pessoas envolvidas na área da construção sobre os impactos ambientais que este setor pode proporcionar, e também das atitudes que podem ser tomadas para que este problema não se agrave.

\section{Análise}

Os materiais de construção devem ser escolhidos com prioridade nos materiais locais, com baixo índice de emissão de compostos orgânicos voláteis, com conteúdo reciclado e materiais reutilizados. Os danos que os materiais de construção causam à natureza, na maioria das vezes são irreversíveis. Eles necessitam também de gastos energéticos para sua produção, o que pode gerar poluição do ar, da água e da terra.

Com os avanços ambientais que se relacionam ao setor da construção civil, pode-se observar que existem alguns métodos de análises de impactos ambientais, sendo que a maioria se baseia no conceito de análise de ciclo de vida. Esses tipos de análises passam desde a concepção, passando pelo projeto, construção, utilização, manutenção, recuperação, chegando até sua disposição final, pois todos os estágios do ciclo de vida do material podem gerar impactos ambientais. Dentre as principais preocupações ambientais, temos:

- Explorar o mínimo possível dos recursos naturais durante a fase de projeto, construção e utilização;

- Facilitar a reforma ou renovação de uma edificação onde adapte as novas exigências dos usuários e minimize o consumo de recursos e geração de resíduos;

- Facilitar a desmontagem tanto parcial como total de uma edificação para posteriormente reutilizar componentes e reciclar materiais. 


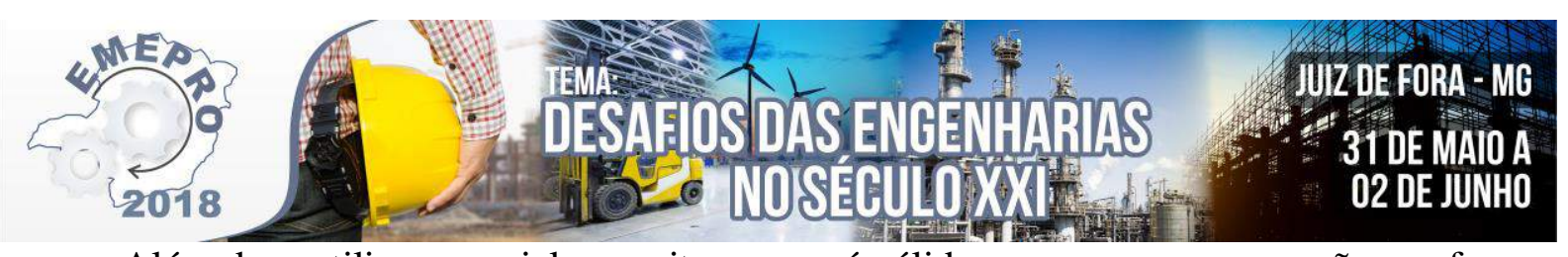

Além de reutilizar e reciclar, muitas vezes é válido pensar em recuperação e reforma. Estas podem trazer grandes vantagens ao serem executadas ao invés de demolir uma edificação (JOHN, 2010).

Os materiais de construção são de grande importância na realização de estruturas e dos elementos construtivos. Vale salientar o comportamento dos materiais quando em uso na construção e também sua interação com o meio ambiente.

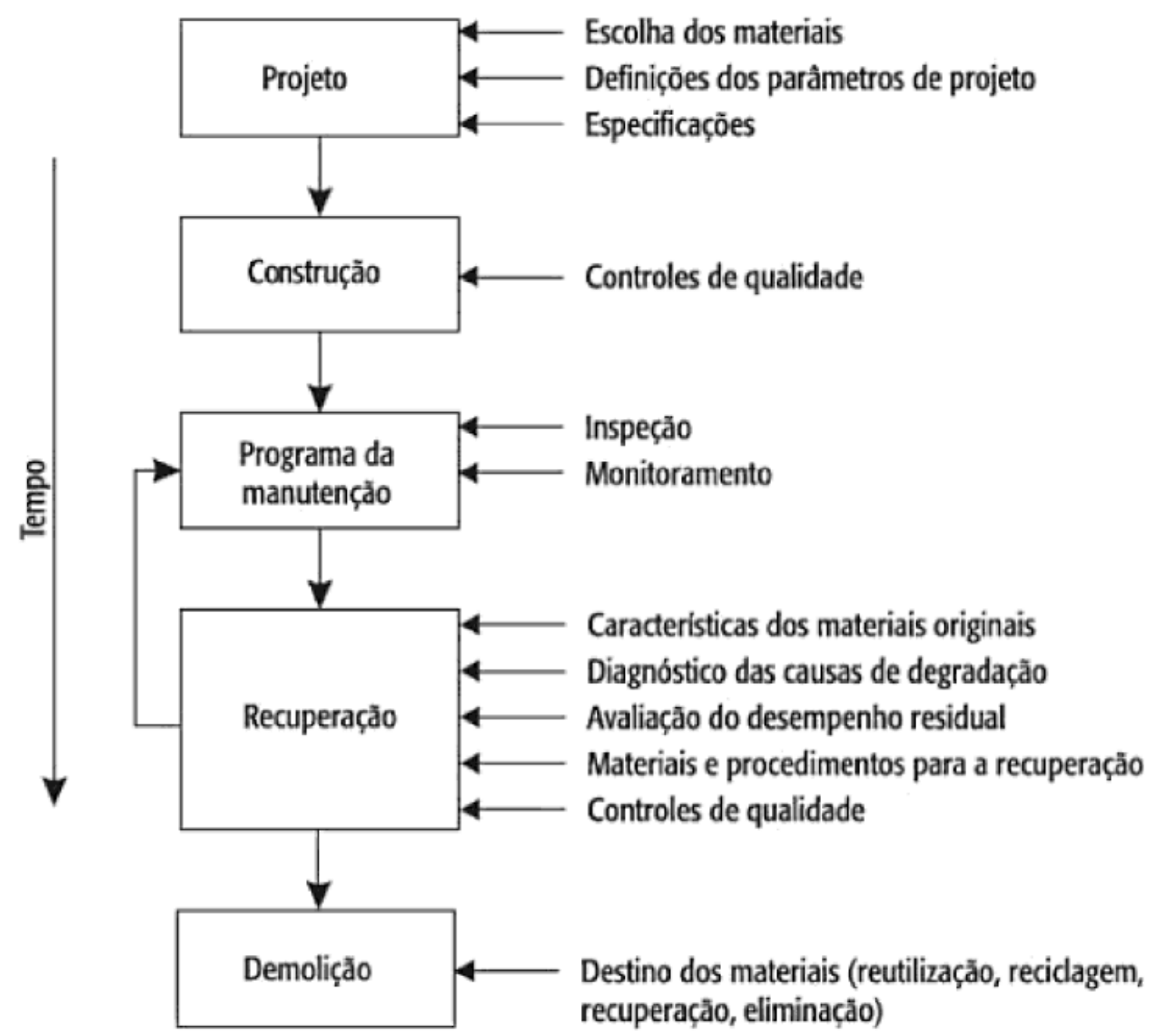

Figura 1: Fases da vida de uma construção e papel do material. Fonte: Bertoline (2010)

Na figura 1, temos fases da vida de uma construção em que se pode pensar no estudo de seus materiais, se causam impactos ambientais e se podem ser substituídos por materiais sustentáveis. Estuda-se também a possibilidade de reciclagem para produção de novos materiais, o que traz vantagens ambientais, seja para redução de resíduos e entulhos como para economia de novos recursos. Outro caso a se pensar é nos fenômenos de degradação dos materiais onde é preciso buscar métodos de prevenção. Abordar também o ciclo de vida dos materiais é de suma importância no pensamento sustentável de uma construção, pois uma maior durabilidade diminui a produção e utilização dos materiais (BERTOLINE, 2010). 

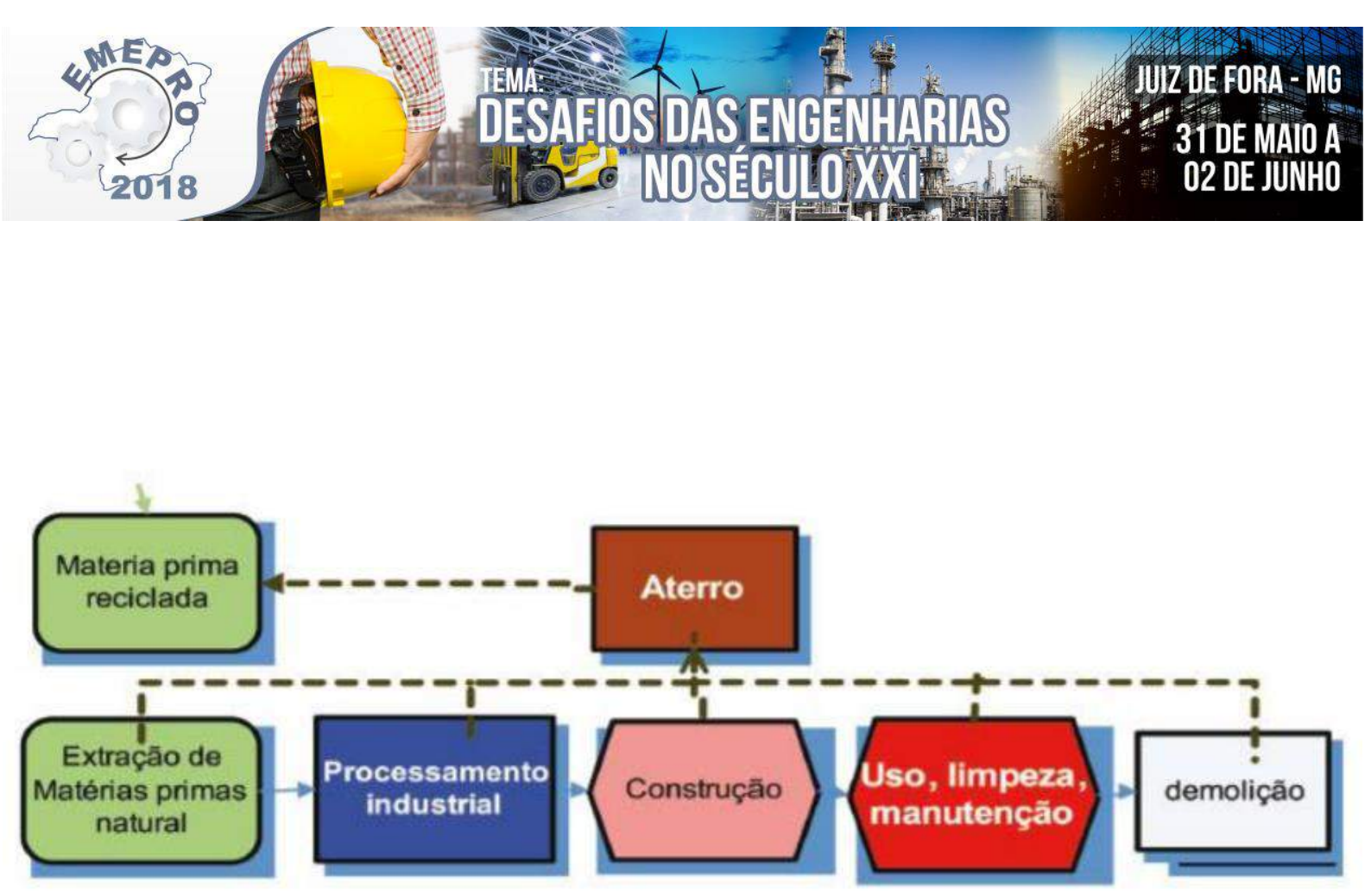

Figura 2: Ciclo de vida simplificado de materiais de construção. Os fluxos de resíduos estão em linha pontilhada. Fonte: John (2010).

Na figura 2, temos uma simplificação do ciclo de vida dos materiais, onde se encontra etapas como extração de matérias-primas naturais, processamento industrial, construção, uso, limpeza, manutenção e demolição que se direcionam ao aterro e chega até a matéria prima reciclada. Nesta simplificação, tem-se também o fluxo de resíduos que está representado pelas linhas pontilhadas (JOHN, 2010).

\subsection{Vida útil e durabilidade}

Os materiais de construção, ao longo do tempo, podem sofrer alterações em seu desempenho devido a efeitos do ambiente. Desta forma, é preciso levar em conta a evolução da degradação dos materiais. A vida útil de um material é o período durante o qual garanta suas funções a qual foi projetado. Já a durabilidade está associada à expectativa de projeto.

Para que a durabilidade seja garantida deve-se:

- Definir a vida útil de projeto;

- Definir as condições ambientais;

- Avaliar os efeitos do ambiente prevendo a evolução da degradação;

- Escolher os materiais visando sua vida útil (BERTOLINE, 2010).

Buscando a sustentabilidade, é válido pensar que quanto mais durável o material, maior será sua vida útil e consequentemente menos será seu impacto ambiental. Os materiais provenientes de fontes renováveis também é uma alternativa para contribuir com o meio ambiente, visto que o ritmo de renovação seja superior ao ritmo de consumo. Um bom exemplo disso é o bambu e a madeira que são e podem ser bem utilizados nas construções (TORGAL E JALALI, 2007).

\subsection{Prevenção da degradação}

Sem uma previsão de degradação ao longo do tempo, não é possível fazer uma avaliação com relação à vida útil de um material. Para cada tipo de material existem várias estratégias de prevenção o que pode se relacionar com a escolha do material. A escolha da 


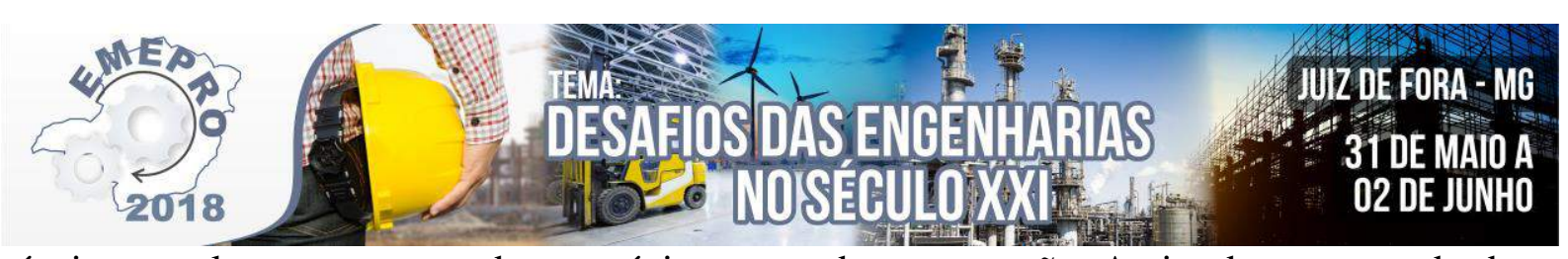

técnica envolve custos tanto da estratégia quanto da manutenção. Assim deve-se estudar bem a escolha do material antes de adquiri-lo, pensando na prevenção de sua degradação para que este tenha uma vida útil maior possível (BERTOLINE, 2010).

\subsection{Redução}

Quando um material não pode ser recusado, busca-se a redução da utilização desse material. Para solucionar problemas como resíduos, deve-se evitar seu apareimento. Quando reduzimos a quantidade utilizada, o lixo gerado é reduzido, contribuindo assim com o meio ambiente (CORRÊA, 2009).

\subsection{Reutilização}

Reutilizar um material é aproveita-lo sem que ele sofra alteração. A criatividade e a inovação fazem com que o material possa ser utilizado novamente de várias maneiras. $\mathrm{Na}$ construção civil é preciso que os materiais não sejam misturados a ponto de nao conseguir separa-los, para que assim possam ser reutilizados. Materiais como elementos estruturais, portas, pisos, painéis, entre outros, podem ser reutilizados apenas retirando do lugar de origem e recolocando-os no lugar desejado (CORRÊA, 2009).

\subsection{Reciclagem}

Os materiais recicláveis possuem grandes vantagens ambientais. Quando sua vida útil acaba, eles podem gerar outros materiais. Neste caso, quase todos os materiais metálicos se enquadram. Na indústria da construção, grande parte dos materiais possui potencial de reciclagem baixo. Porém, alguns materiais podem ser reciclados várias vezes (TORGAL E JALALI, 2007).

A reciclagem consiste na reintrodução, no processo produtivo dos resíduos sólidos, líquidos e gasosos. Assim, os resíduos são reelaborados gerando um produto identico ou não ao que lhe deu origem. A reciclagem é o último recurso no reaproveitamento de materiais, pois o processo além de consumir energia, gera resíduo. $\mathrm{O}$ aço, por exemplo, é melhor reutiliza-lo do que recicla-lo, pois seu processo de reciclagem precisa ser industrial, o que consome muita energia e gera impacto ambiental. Já o vidro, sendo também sua reciclagem industrial, não consome tanta energia além de poder ser reciclado quantas vezes forem necessárias. A madeira também pode ser reciclada. A madeira é moída ou transformada em lascas que são prensadas em um novo formato que é chamado de compensado.

Os resíduos mais comuns numa construção são os restou de alvenaria e revestimento sendo geralmente constituído por areia, cimento, concreto, aço, blocos e tijolos. O entulho devidamente reciclado apresenta propriedades físicas tão boas quanto de materiais originais (CORRÊA, 2009).

\subsection{Disperdícios}

Além das demolições, grande parte da produção diária de resíduos vem dos disperdícios de materiais de construção devido a projetos construtivos malfeitos e falta de 


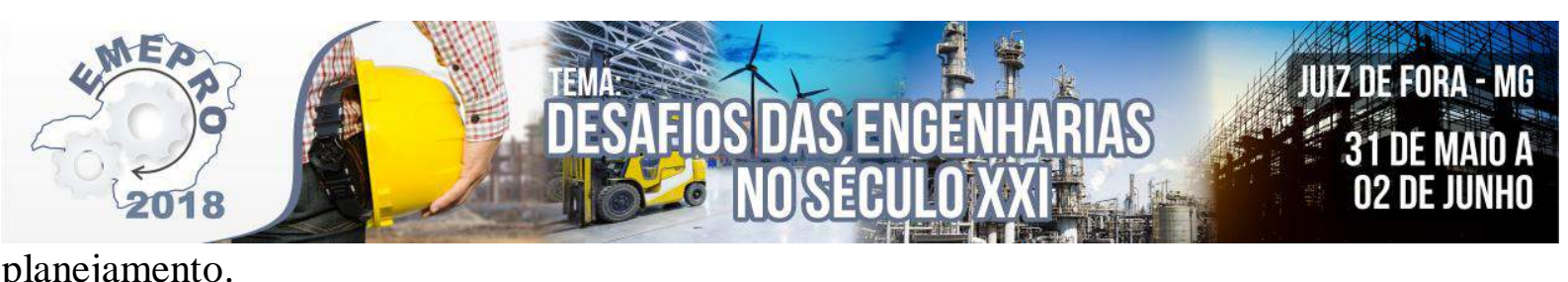

planejamento.

TABELA 1: Taxas de desperdício de materiais de construção no Brasil.

\begin{tabular}{lccc}
\hline & \multicolumn{3}{c}{ Taxas de desperdicio (\%) } \\
\cline { 2 - 4 } Material & Média & Mínima & Máxima \\
\hline Concreto usinodo & 9 & 2 & 23 \\
Aco & 11 & 4 & 16 \\
Blocos e tijolos & 13 & 3 & 48 \\
Plocos cerâmicas & 14 & 2 & 50 \\
Revestimento têxtil & 14 & 14 & 14 \\
Eletrodutos & 15 & 13 & 18 \\
Tubos & 15 & 13 & 18 \\
Tintos & 17 & 8 & 56 \\
Fios & 27 & 14 & 35 \\
Gesso & 30 & 14 & 120 \\
\hline
\end{tabular}

Fonte: (Romanel e Boptista, 2013).

Na tabela 1, temos as taxas de disperdícios de materiais de construção no Brasil em termos de valores mínimos, médios e máximos. Uma construção mal planejada possui grande quantidade de disperdícios, o que faz com que ocorram prejuízos econômicos e geração de resíduos e entulhos além do esperado. Isso produz grandes impactos ambientais.

\section{Conclusão}

Os materiais de construção são componentes indispensáveis da construção civil que geram grandes impactos ambientais. Na busca da sustentabilidade, buscam-se soluções que minimizem tais impactos. Para isso é preciso sempre tentar explorar o mínimo possível dos recursos, tentar facilitar reformas e renovações de uma edificação e pensar na facilitação de desmontagens tanto parcial como total de uma edificação.

Para a escolha dos materiais, priorizam-se os materiais locais que não requerem transportes de longas distâncias. O transporte de materiais geram impactos como a poluição do ar com a queima de combustíveis.

O pensamento sustentável dos materiais de construção deve ser pensado em todas as fases da construção como projeto, construção, manutenção, recuperação e demolição, visto que em todas as etapas eles podem gerar impactos. 


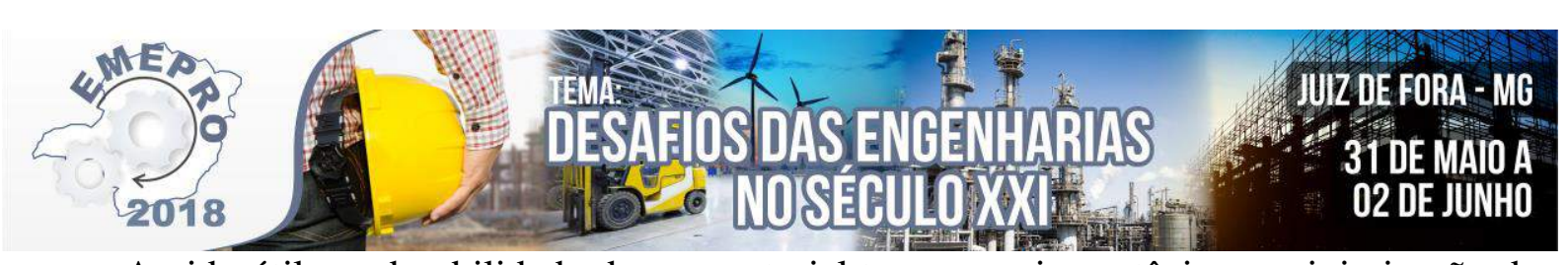

A vida útil e a durabilidade de um material tem suma importâcia na minimização dos impactos ambientais. Ao longo do tempo, o desempenho do material pode ser degradado devido ao ambiente. Desta forma, é preciso conhecer a vida útil do material e o ambiente que será exposto antes de sua escolha, para que garanta uma durabilidade que atenda as expectativas. Quanto maior a durabilidade do material, maior será sua vida útil. A degradação do material deve ser prevista. Existem várias estratégias para a prevenção da degradação, por isso a grande importância de um estudo minucioso na escolha do materia.

Quando não se consegue recusar um material, deve-se buscar a redução de sua utilização. Com a diminuição da utilização do material, reduz-se o lixo gerado. A reutilização do material também é uma boa alternativa. Alguns materiais podem ser reutilizados várias vezes com a utilização da criatividade.

Quando a vida útil de um material acaba, ele pode ser transformado em um novo material através da reciclagem. Desta forma é possível utilizao o material sem o consumo de matéria-prima e sem geração de resíduo. Grande parte dos materiais da contrução civil tem baixo índice de reciclagem, porém outros conseguem ser reciclados várias vezes. Os metais, por exemplo, quase sempre podem ser reciclados. Se o material não puder ser reutilizado, pensa-se então na reciclagem. O aço, por exemplo, vale mais reutiliza-lo do que reciclo-lo, pois seu processo de reciclagem gera impactos ambientais. Já o vidro e a madeira possuem processos de reciclagem que não geram grandes impactos, o que faz com que valha a pena reciclá-los.

Um grande impacto ambiental gerado pelos materias de construção e de fácil solução são os disperdícios. Os disperdícios além de gerar custos desnecessários, geram maiores quantidades de resíduos. Um bom planejamento inicial é essencial para combater esse problema.

Numa visão geral, os impactos ambientais gerados pelos materiais de construção podem, em sua maioria, serem minimizado através de um bom planejamento. Para um bom planejamento, deve-se ter um pensamento sustentável relacionado aos materiais e focar em alguns pontos:

- É preciso conhecer as necessidades da obra;

- Estudar os materiais utilizados;

- Saber se existem materiais alternativos que gerem menos impactos;

- Conhecer a vida útil de cada material;

- Buscar redução;

- Reutilizar materiais sempre que possível;

- Saber se o material pode ser reciclado e se seu processo de reciclagem é apropriado;

- Evitar os disperdícios.

Os pontos citados acimas são pequenas ações que fazem toda a diferença. Para ser sustentável não é preciso construir de forma totalmente sustentável, mas sim começar pelas pequenas ações. Desta forma conseguiremos um mundo melhor. 


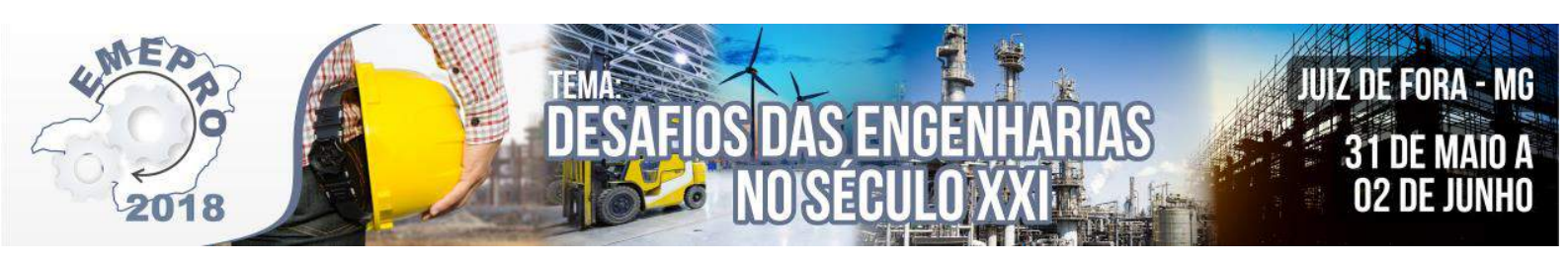

\section{Referências}

BERTOLINI, L. Materiais de construção. [s.l: s.n.].

CORRÊA, L. R. SUSTENTABILIDADE NA CONSTRUÇÃO CIVIL. 2009.

EM, C. D. E. P.; CIVIL, E. UNIVERSIDADE FEDERAL DO RIO GRANDE DO SUL. 2000.

JALALI, S. CONSTRUÇÃO SUSTENTÁVEL. O CASO DOS MATERIAIS DE Materiais “amigos do ambiente". p. 1-10, 2007.

JOHN, V. M.; PAULO, U. D. S. Materiais de Construção e o Meio Ambiente. 2010.

VIEIRA, J.; JUNIOR, B.; ROMANEL, C. Sustentabilidade na indústria da construção: uma logística para reciclagem dos resíduos de pequenas obras. p. 27-37, 2013. 